\title{
Socijalno - filozofski i psihoanalitički pristup (sado)mazohizmu
}

Šokičić, Iva

Doctoral thesis / Disertacija

2021

Degree Grantor / Ustanova koja je dodijelila akademski / stručni stupanj: University of Zagreb, Faculty of Humanities and Social Sciences / Sveučilište u Zagrebu, Filozofski fakultet

https://doi.org/10.17234/diss.2021.133978

Permanent link / Trajna poveznica: https://urn.nsk.hr/urn:nbn:hr:131:834812

Rights / Prava: In copyright/Zaštićeno autorskim pravom.

Download date / Datum preuzimanja: 2023-04-26

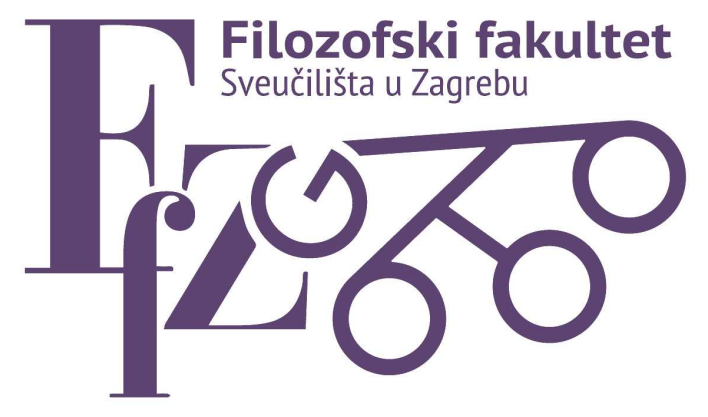

Repository / Repozitorij:

ODRAZ - open repository of the University of Zagreb

Faculty of Humanities and Social Sciences
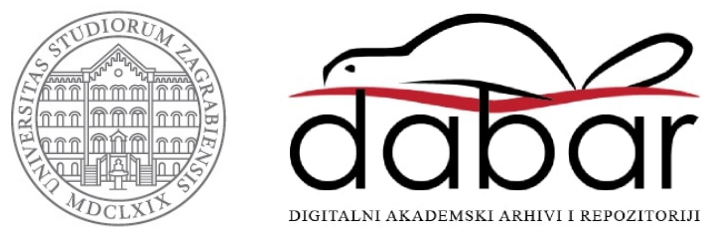
Filozofski fakultet

Iva Šokičić

\title{
SOCIJALNO - FILOZOFSKI \\ I PSIHOANALITIČKI PRISTUP (SADO)MAZOHIZMU
}

\author{
DOKTORSKI RAD
}

Zagreb, 2021. 
Filozofski fakultet

Iva Šokičić

\title{
SOCIJALNO - FILOZOFSKI \\ I PSIHOANALITIČKI PRISTUP (SADO)MAZOHIZMU
}

\author{
DOKTORSKI RAD
}

Mentor: dr.sc. Bernard Harbaš,

izvanredni profesor

Zagreb, 2021. 


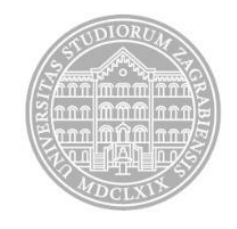

University of Zagreb

Faculty of Humanities and Social Sciences

Iva Šokičić

SOCIO - PHILOSOPHICAL

AND PSYCHOANALYTICAL

APPROACH TO

(SADO)MASOCHISM

DOCTORAL THESIS

Supervisor: Bernard Harbaš,

Associate professor, Ph.D.

Zagreb, 2021 


\section{SAŽETAK}

Osnovni je cilj rada interpretacija sadomazohizma kao relevantne seksualnosti i psihoseksualnog, socijalno - filozofskog i kulturnog fenomena multidisciplinarnim aspektima psihoanalize i socijalne filozofije s težištem na individualnom i društvenom shvaćanju i filozofskoj analizi sadomazohizmate bitnim dilemama o njihovom razumijevanju i adekvatnom pozicioniranju sadizma i mazohizma u domeni seksualnosti.

Kao polazište za elaboraciju teorija sadomazohističke seksualnosti izložila sam povijesni pregled pojma perverzije te interpretacija sadomazohizma u najranijoj psihonalizi Richarda von Krafft - Ebinga i Sigmunda Freuda.

Uslijedit će interpretacija seksualnosti i sadomazohističkih odnosa teorijom konceptualno kategorijalnog sustava Jacquesa Lacana, kao najrelevantnijom za modernu i suvremenu psihoanalitičku filozofiju zbog njegovog drugačijeg pristupa psihoanalizi i razumijevanju seksualnosti i sadomazohizma.

Nastojala sam kritički promisliti sadomazohizam kao specifičnu seksualnost u svojoj praksi, no jednaku svakoj drugoj prema egalitaritarnom principu slobode izbora te filozofskom elaboracijom njene pozicije u kontekstu suvremenih teorija seksualnosti.

Centralne originalne teze su interpretacije ontologije i fenomenologije sadomazohizma $u$ antropologijskoj filozofiji seksualnosti Georgesa Bataillea, njegove naturalističke konceptualizacije kao „nasilne transgresije“, a istovremeno erotskog, senzualnog i ritualnog, transcendirajući seksualnost

Pozicija sadomazohističke seksualnosti u društvenom kontekstu prikazana je historijsko filozofskim pristupom odnosa moći u misli Michela Foucaulta, s naglaskom na njegovu izuzetnu, detaljnu i vjerojatno najprecizniju analizu razvoja misli i znanosti o seksualnosti.

Filozofsko tumačenje Freuda Herberta Marcusea od izrazite je važnosti za objašnjenje refleksije psihičkog u društvenom stanju te široke problematike suvremenog društva i pojedinca kao produkta represivne civilizacije te ideje kao otvorene mogućnosti ozbiljenja nerepresivnog no produktivnog društva. 
Bitan dio rada utemeljen je na teorijama društva i seksualnosti u Foucaultovoj i Deleuzevoj filozofijii, veoma različitoj i snažno kritički suprotstavljenoj psihoanalitičkim pristupima historijske i ,antihumanističke“ analize društvene dinamike koja oblikuju pojedince uvjetujući njihovo ponašanje.

Suvremenim koncepcijama i teorijama sadomazohizma, koje su bile najizraženije u SAD-u od 1990 - ih do danas, razjašnjen je i protumačen osnovne jezični registar BDSM-a, te prikazane prakse ove seksualnosti, koja je, društvenim razvojem, evolvirala od "istinskog" sadomazohizma do popularizacije u mainstream kulturu konzumerističkog društva.

Brojni suvremeni teoretičari sociologije i psihologije, uključujući i psihoterapeute zastupaju pozitivan stav prema sadomahizmu te će biti suprostavljeni „teškim“ argumentima“ radikalnih feminističkih autorica protiv ove seksualne prakse, no važno je napomenuti da su renomirane feminističke teoretičarke zauzele afirmativan stav prema S/M -u i kao praktikantice.

Intencija rada je, nakon filozofskog pregleda fenomena sadomazohizma u teoriji i praksi, tumačenje brojnih teza o fenomenu sadomazohizma te originalna interpretacija i promišljanje još uvijek prisutnih upitnih i problematičnih shvaćanja sadomazohizma - kao poremećaja, perverzije, nasilja, nenormalne seksualnosti odnosno devijacije.

Inovativne interpretacije relevantne literature te mojih osobnih teza vezanih za ontologiju i epistemologiju individuuma, zajednice i društvene cjeline konstituirat će jedinstvenu opoziciju „psihopatologizaciji" sadomazohističke seksualnosti u društvu i individualnoj psihološkoj sferi fenomena sadomazohizma koji iz sociološke, filozofske i psihološke perspektive ima iznimnu ulogu u suvremenom društvu i kulturi.

\section{KLJUČNE RIJEČI:}

društvo, fenomenologija, filozofija, mazohizam, ontologija, sadomazohizam, sadizam seksualnost, perverzija, psihoanaliza, tijelo 


\section{SUMMARY}

The general aim of the thesis is an interpretation of sadomasochism as a relevant sexuality and a psycho - sexual, socio - philosophical and cultural phenomenon, developed by multidisciplinary aspects of psychoanalysis and social philosophy with the focus on the philosophical analysis of the individual and social understanding of sadomasochism and the essential dilemmas about its intelligibility and adequate positioning of sadism and masochism in the domain of sexuality.

I have made the effort of critically rethinking sadomasochism as a specific sexuality in its practice, but equal to every other sexual orientation according to the principle of egalitarian freedom of choice and philosophical elaboration of its position in the context of contemporary theories of sexuality.

As a starting point for understanding the theories of sadomasochistic sexuality, a historical background of the concept of perversion and interpretations of sadomasochism is presented through a detailed overview and analysis of the earliest psychoanalysis of Richard von Krafft Ebing and Sigmund Freud.

The interpretation of sexuality and sadomasochistic relationships in the postpsychoanalytical theory of Jacques Lacan is elaborated as the most relevant for the contemporary psychoanalytical philosophy and understanding of sexuality.

Sadomasochism is explained in terms of Lacan's conceptually - categorial system, as a special and unique relationship of signifiers, intermediated by desire described as the relationship of the other (objet petit a) and the Other (objet grande Autre).

Lacan's structurally - categorial system of subjects, objects and indefinite different possibilities of relationships between individuals and signifiers reveals their both conscious and unconscious desires and therefore is an excellent method of studying and theoretizing sadomasochistic sexuality and interactions in all their varieties and development of the Symbolic, Imaginary and the Real order. 
The central original theses are interpretations of ontology and phenomenology in anthropological philosophy of sexuality of George Bataille and his naturalist conceptualization of sexuaity as a „violent transgression“, and at the same time erotic and sensual, spiritual and ritual, transcendental phenomenon.

Bataille's theory of the essential, inevitable unity of sexuality and violence is strongly antropologically founded, relying on vivid depictions of ancient sexual ritual in comparison with contempory human sexual experience.

According to Bataille, violence and sexuality, as primal animal insticts and human drives, are inseparable and therefore sadomasochism can be understood as a necessary trangression, transcending all taboos and cultural norms.

His exquisite theses on sexuality, based on descriptions of the unity of the physical and the psychological dimensional and explaining the very origin of sadomasochism, are an excellent theoretical framework for the understanding the practice of sadomasochistic sexuality as an equilibrium of the violent, cruel, profane with the sacrificial, ritual and sacred, transcending into the domain of the spiritual.

Bataille's works and thought on sexuality are interpreted as the basis for the ontology of sadomasochism, since transcendentality is the main characteristic of the state of mind caused by intense and unique sensations of the masochistic experience.

Phenomenology of masochism, as the primary and far more complexed sexual predisposition and orientatation than sadism, is best expressed in the thought of Gilles Deleuze, centrally focused and concentrated on distingishing and dividing masochism and sadism into two different entities and forms of existence.

Deleuze's theory of masochism is of great relevance, since he strictly excludes masochism from sadism, as two separate worlds, with his references on Leopold Sacher - Masoch and his notion of masochism as supersensuality.

According to Deleuze, masochism is a world of its own, and the masochistic individual has a unique set of mind, psyche and desires for physical pain, opposite to a sadist, which ontologically differenciates masochists from sadist. 
Jean - Luc Nancy's philosophy of the body is of great significance for understanding sadomasochistic sexuality, since he positioned the body as the central part of the individual's person, selfhood and the realization of sexual identity.

As I have demonstrated, he has developed a conceptual paradigm in which myself is the body and his term „corpus ego“ stands for the unity of body, self and mind.

The unity of body, self and mind and the idea of the body as the self are followed by his understanding of physical sensations as life forces, which are the essential components of sadomasochistic sexuality and lifestyle.

Jean Baudrillard's analysis of the postfuturist and postsexual society and his brilliant depictions of human drives for violent sexuality in comparison with the perception of reality or its simulation plays an extremely important role in explaining the contemporary technological society and specific sexual practices.

Baudrillard has reformulated some of the major Lacan's terms and concept in his own, original and different interpretation of sexuality and violence in terms of seduction, pornography and sexual pleasure by referring to manifestations of extreme sexuality in voyeurism, implying various sadomasochistic practices, reaching the limitless hyperreality of taking pleasure in participating severe accidents and acts of brutality as a response to the exposition and submission to mechanisms of technology.

Herbert Marcuse's philosophical interpretation of Freud is of extreme importance for the explanation of the reflexion of the physical in the social state and the broad problematics of contemporary society and the individual as a product of repressive civilization and repressed sexuality and the idea of an open possibility of realization of an non - repressive, but productive society of the pleasure principle.

The essential part of the thesis is based upon the theories of the society and sexuality in Foucault's and Gilles Deleuze's philosophy, very different and highly critically opposed psychoanalitical approaches - a historical and ,antihumanist“ analysis of social dynamics which shape individuals by conditioning their behaviour.

The position of sadomasochist sexuality in the social context has been demonstrated by the historically - philosophical theory of power relations in the thought of Michel Foucault with an emphasis on his exquisite, detailed and probably most precise analysis of development of thought and science of sexuality. 
I have applied Foucault's theses on social power relations on the hermeneutics of sadomasochistic sexuality, since his main focus was the historical knowledge of sexuality, dating from ancient Greece, its practices and a specific ethics.

Foucault's theory of sexuality was established precisely on societies buit upon the essential relation of power and knowledge which made sexuality a political and scientific issue, including the practice of sadomasochism as the best manifestation of paradoxical power relations, the one of equal individual, both wielding power and submitting to powerlessness, a realtionship beyond power, in search of knowledge through sexual experience and liberation.

Sexuality, as an ultimate form of liberation, is presented with an emphasis on sadomasochistic sexuality as the ultimate form of interpersonal power exchange in the social context of sadomadochistic communities and subcultures and the reception of such practices by the traditional mainstream society.

The final conclusion of Foucault's theses on sexuality is an interpretation of power relations in radical sadomasochistic relationships from the socio - philosophical, political, but also psychological perspective, along with the ethics of sadomasochism as a prescribed conduct regarding safety and consensuality.

Contemporary theories and conceptions od sadomasochism, most expressed in the USA from 1990s to the present day have explained and interpreted the basic linguistic register of BDSM and represented the essential practices of this sexuality, which has, by social development, evolved from „true“ sadomasochism to populizarization and mainstream culture of the postcapitalist consumerist society.

Numerous contemporary sociology and physchology theoreticians, including psychotherapists represent a positive attitude towards sadomasochism and shall be confronted with „heavy“ arguments of radical feminist authors against this sexual practice, but it is important to note that the renowned feminist theoreticians have taken the affirmative attitude towards $\mathrm{S} / \mathrm{M}$ as practioners themselves.

The intention of the thesis, after a philosophical overview of the phenomenon of sadomasochism in theory and practice, is an original interpretation and rethinking of various theories and the still present dubious and problematic understandings of sadomasochistic sexuality - as a psychopathological disorder, perversion, violence, abnormal sexuality or deviation, which should be disregarded and discarded as obsolete misinterpretations. 
Innovative interpretations of the relevant literature and my own personally developed theses in ontology and epistemology of the individual, community and the social totality shall constitute a unique opposition to the psychopatologization of sadomasochist sexuality in the social and the individual psychological sphere of the phenomenon of sadomasochism which, from the socio - philosophical and psychological perspective, has an immense role in contemporary society and culture.

\section{KEY WORDS:}

society, phenomenology, ontology, philosophy, masochism, sadism, body, perversion, psychoanalysis, sexuality, sadomasochism 


\title{
PODACI O MENTORU
}

\author{
Prof. dr.sc. Bernard Harbaš
}

Rođen 1977. godine u Zenici (BiH). Diplomirao filozofiju i sociologiju na Odsjeku za filozofiju i sociologiju na Filozofskom fakultetu Univerziteta u Sarajevu 2004. godine

Doktorirao na temu „Filozofija zajednice Jean-Luca Nancya“ 2011. godine na Filozofskom fakultetu Sveučilišta u Zagrebu. Sudjelovao na većem broju konferencija u zemlji u inozemstvu. Autor je trideset znanstvenih radova iz područja filozofije i sociologije, knjige Zajednica bez zajedništva (Naklada Breza, Zagreb, 2013). kao i Preko CEEPUS i ERASMUS programa održao predavanja na slijedećim sveučilištima: International Hellenic University - Thessaloniki (Grčka), Institut für Philosophie - Graz (Austrija), Univerzitet Novi Sad (Srbija); Univerzitet u Splitu (Hrvatska).

Član je uredništva slijedećih časopisa Eidos (Zenica), Dijalog (Sarajevo) International Dialogue (Omaha, USA). Osim toga, član je Odbora za filozofiju Akademije nauka i umjetnosti BiH.

Radi u zvanju izvanrednog profesora na Filozofskom fakultetu Univerziteta u Zenici (BiH).

\section{IZBOR RADOVA:}

Knjige:

„Zajednica bez zajedništva“, Naklada Breza, Zagreb, 2013.

"Jačanje interkulturalnih i međureligijskih kompetencija", TPO fondacija, Sarajevo,2020.

Izvorni znanstveni radovi :

„Filozofija ili dekonstrukcija”, Scopus - časopis za filozofiju Hrvatskih studija, Zagreb, 2006 „Dekonstrukcija, kozmopolitika, literatura i tonalitet (kratko upućivanje na Kantovo naslijeđe u filozofiji Jacquesa Derride), u: Quorum, Zagreb, 2005. 
„Svijet je mnoštvo glasova“, Motrišta, 2012, Mostar

"Antagonističko, agonističko i singularno pluralno političko" (s Nadom Harbaš) u: Dijalog, 2011

Sarajevo

"Postmoderna kao Aufhebung religije i tijela“, Eidos, Zenica 2017

“Consumption and Production as Forms of Resistance”, Eidos, Zenica, 2018

“Da li je moguća etika u potrošnji?, Dijalog, Sarajevo, 2018

„Consumption and Production as Forms of Resistance“, Eidos, Udruženje za filozofiju i društveno - humanistička istraživanja, Zenica, 2018

„, Sociologija potrošačkog tijela“, BH Ekonomski forum 8, Ekonomski fakultet Univerziteta u Zenici, Zenica, 2018

„Neprijatelj kao konstitutivni drugi svakog prijateljstva“ u Opraštanje i/ili zaboravljanje, Zbornik radova, Centar za emprijska istraživanja religije, Beograd, 2019. 


\section{SADRŽAJ}

1. UVOD U FILOZOFSKO TUMAČENJE POJMA SADOMAZOHIZMA. 1

1.2 Freudova teorija perverzije u komparaciji s Lacanom i Deleuzom

Historija znanosti o perverziji i fetišizmu 7

1.3 Rana psihoanaliza o sadomazohizmu 13

\section{SADOMAZOHIZAM I PSIHA}

2.1 Interpretacija sadomazohističke seksualnosti Lacanovom postpsihoanalitičkom teorijom .39

2.2 Želja i D/drugi u sadomazohističkoj seksualnosti. 72

2.3 Eroticizam i seksualnost. 84

2.4 Problematika destruktivne seksualnosti. 101

\section{ONTOLOGIJA SADOMAZOHIZMA}

3.1 (Sado)mazohistička seksualnost i fenomenologija mazohizma 109

3.2 Ontologijsko - antropologijska interpretacija sadomazohističke seksualnosti u djelu Georgesa Bataillea. 
3.4 Baudrillard i Lotringer o seksualnosti, perverziji i Foucaultu Ideja re-semantizacije sadomazohizma 144

3.5 Baudrillard i zavođenje.

3.6 Zaključak

(Sado)mazohizam kao reziduum Imaginarnog i ontologijski fenomen 166

\section{SADIZAM I MAZOHIZAM U SUVREMENOM SOCIJALNOM KONTEKSTU SOCIO - FILOZOFSKE TEORIJE SADOMAZOHIZMA KAO PSIHOSEKSUALNOG I DRUŠTVENOG FENOMENA}

4.1 Sadomazohistička seksualnost u kontinentalnoj filozofiji

Dinamika i odnosi moći sadomazohizma u relaciji s društvom 177

4.2 Seksualnost i kapitalizam

4.3 Foucaultova teorija seksualnosti i sadomazohizam

Sadomazohizam u kontekstu Foucaultove filozofije seksualnosti.

4.4 Etika konsenzualnosti i moralnost sadomazohizma

Briga o drugome i sebi. .204

4.5 Zaključak

Libertinizam, sadomazohizam i etika. 218 


\section{SUVREMENO RAZUMIJEVANJE SADOMAZOHISTIČKE SEKSUALNOSTI I ODNOSA U DRUŠTVU I PARTIKULARNIM ZAJEDNICAMA}

5.2 Pozicija radikalnog BDSM - a

Radikalna seksualnost i ,nekonsenzualni pristanak“ 245

6. FEMINISTIČKE TEORIJE KAO ŽARIŠTA SUKOBA FEMINIZAM I SADOMAZOHIZAM - PRO ET CONTRA

6.1. Radikalni feminizam protiv sadomazohizma 273

6.2 Feministička obrana mazohizma

Sadomazohizam kao feministička seksualnost 281

7. ZAKLJUČAK .289

8. POPIS LITERATURE 300

9. BIOGRAFIJA AUTORA 306 


\section{UVOD U FILOZOFSKO TUMAČENJE POJMA SADOMAZOHIZMA}

Promišljanju i tumačenju fenomena sadomazohizma potreban je detaljan, oprezan i nadasve stručan multidisciplinarni pristup kao produktivan pokušaj objašnjenja samog pojma sadomazohizma i mogućih odgovora na uvijek otvoreno pitanje: Što je zapravo sadomazohizam u svojoj biti, ontologijskom i socijalnom određenju, svojoj psihologiji i tjelesnosti, socijalno filozofskoj i teoriji i seksualnoj praksi ?

Na samom početku, važno je napomenuti da neovisno što su sadomazohizam u posljednjih pet desetljeća filozofski i sociološki proučavali i istraživali i dalje se konstantno, unutar socijalne filozofije i filozofije seksualnosti brojni autori diljem svijeta, razvijaju nove originalne misli, interpretacije i teorije, čemu je jedan od temeljnih razloga razvoj tehnologije i medija, čijim se posredstvom seksualne prakse i njihovi diskursi, kako je Michel Foucault formulirao, umnažaju i razvijaju bezgranično ${ }^{1}$.

Granica koja se u domeni filozofije mora postaviti je prvenstveno znanstveni kriterij i relevantnost naposljetku motivacija interesa određene teorije i stoga ću prikazati socijalno filozofsku dimenzija sadomazohizma, za razliku od one popularizirane koja je sveprisutna upravo intervencijom medija.

Socijalno - filozofski i psihoanalitički pristup, te ontologijski i epistemološki, omogućit će znanstvenu analizu ovog psihološko - socijalnog fenomena, pri čemu će težište biti na individualnom i društvenom shvaćanju te filozofskoj analizi sadomazohizma.

Prije razumijevanja i prakse sadizma i mazohizma, potrebno je dati uvid u sam pojam perverzije, elementarnog pojma fetiša i osnova shvaćanja fetišizma veoma detaljno razrađenog kod Krafft - Ebinga ${ }^{2}$, Freuda ${ }^{3}$ i Lacana ${ }^{4}$ te kasnije, u suvremenoj psihoanalizi i teorijama socijalne filozofije poststrukturalizma.

Nakon objašnjenja semantičke podloge naslova rada na samome početku bit će iznesen povijesni pregled pojma perverzije te porijekla termina "sadizam" i "mazohizam" i bitne dileme oko njihovog razumijevanja i međusobne povezanosti, a za uvod u filozofski i psihoanalitički pristup sadomazohizmu pojasnit će se semantika naslova, koji „,sado“ upisuje u zagradu.

\footnotetext{
${ }^{1}$ Michel Foucault, Znanje i moć, 1994, Globus, Zagreb

${ }^{2}$ Richard von Krafft - Ebing, Psychopathia Sexualis, 1894, The F. A. Davis Company Publishers, London

${ }^{3}$ Sigmund Freud, Tri eseja o teoriji seksualnosti, Matica Srpska, Beograd, 1981.

${ }^{4}$ Jacques Lacan, Ecrits, W.W. Norton Company, New York, 2006
} 
Sadomazohizam možemo shvaćati kao jednu od seksualnosti, seksualnu praksu koja podrazumijeva specifični psihički ustroj pojedinaca koji je prakticiraju, kao način života unutar $\mathrm{S} / \mathrm{M}$ zajednica, seksualnu orijentaciju, neophodnu preferencu za samoostvarenje pojedinca, te s druge strane, kao psihičku karakternu crtu koja se ne mora uopće svjesno manifestirati, ukoliko je latentna, pri čemu se misli na "psihički" sadizam ili mazohizmu, koji često i rezultira analognom seksualnom sklonošću.

Većina psihoanalitičara koji su se bavili ovim seksualnim fenomenom, smatrali su ne samo da su sadizam i mazohizam u domeni seksualnosti suprotnosti, već štoviše da sadizam kao primarni nagon usmjerava destruktivnu energiju subjekta prema sebi samome, stvarajući nesvjesnim procesima mazohizam, dok su drugi smatrali mazohizam primarnim, čijim posredstvom nastaje sadizam kao podsvjesna manifestacija istog nagona prema drugoj osobi, prvenstveno Jacques Lacan, što će biti detaljno prikazano u daljnjim poglavljima.

Već je Freud utemeljio teoriju da sadizam kao primarni nagon okreće destruktivnu energiju subjekta prema sebi samome i time pobuđuje mazohizam, dok su kasniji psihoanalitičari koji su se bavili ovim psihoseksualnim fenomenom, smatrali da su sadizam i mazohizam u domeni seksualnosti uvijek istodobno prisutni kod iste osobe kao komplementarni nagoni koji se međusobno nadopunjuju.

Intencija rada je konfrontirati i kritički preispitati obje teze, Freudovu i Lacanovu te ispravno pozicionirati i objasniti u domeni seksualnosti obje sklonosti, nazivane perverzijama kao najčešće neovisne jednu o drugoj, premda međusobno psihološki povezane i uvjetovane.

Sadizam i mazohizam najbolje će biti potom objašnjeni u djelima teoretičara i kritičara psihoanalize poput Gillesa Deleuzea ${ }^{5}$, Michela Foucaulta ${ }^{6}$ te Lynn Chancer sa sociološke pozicije $^{7}$, od seksualne prakse do šireg društvenog koncepta.

Kod Foucaulta će biti naglašena njegova izuzetna, detaljna i vjerojatno najpreciznija analiza razvoja misli i znanosti o seksualnosti, znanosti o subjektu kroz povijest te sasvim nov pristup seksualnosti, odbacivanje određenih hipoteza i paradigmi te postavljanje teza koje su daleko bliže realnom društvenom stanju.

Marcuseovo filozofsko tumačenje Freuda bit će relevantno za objašnjenje refleksije psihičkog u društvenom stanju te široke problematike modernog no i suvremenog društva i pojedinca kao

\footnotetext{
${ }^{5}$ Gilles Deleuze, Coldness and Cruelty, Zone Books, New York, 2013

${ }^{6}$ Michel Foucault, Essential Works, Volume 1, 2, The New Press, New York, 1997

${ }^{7}$ Lynn Chancer, Sadomasochism in Everyday Life, The Dynamics of Power and Powerlessness, Rutgers University Press, New Brunswick, New Jersey, 1994
} 
produkta represivne civilizacije te otvorene mogućnosti ili, bolje rečeno, ideje ozbiljenja nerepresivnog no produktivnog društva.

Uslijedit će analiza društva i pojedinca u Foucaultovoj i Deleuzevoj filozofiji, bitno različitoj i u mnogočemu oprečnoj psihološkom pristupu i analize društvenih zbivanja koja oblikuju pojedince i uvjetuju njihovo ponašanje, kao kritiku te dekonstrukciju psihoanalize.

Autori, liječnici i teoretičari društveno - humanističkih znanosti time se, lacanovski rečeno, u velikoj mjeri vraćaju Freudu, pozivajući se na njegove teze kao temelj svojih vlastitih interpretacija seksualnosti, primarno sadizma i mazohizma, koji u psihoanalizi proizlaze iz „,perverznih struktura ličnosti“ te je stoga ,povratak Freudu“ razumljiv i opravdan.

Njegove teze nisu mogle objasniti sadomazohizam na posve adekvatan način iz suvremene perspektive, zbog atmosfere jednog sasvim drugog vremena i činjenica da su on i Krafft - Ebing prvi učinili seksualne perverzije predmetom znanosti u pravome smislu.

Sadomazohizam možemo razumjeti kao spoj sadizma i mazohizma u jednoj ličnosti, a također i kao naziv za obje seksualnosti, koje ne moraju biti te često i nisu dio iste osobe, već tvore odnos sadista i mazohista, dominantne i submisivne osobe te je stoga bitno naglasiti razliku, $\mathrm{u}$ psihologiji i praksi, između sadista i dominantne osobe te mazohista i submisivne.

Za ispravno tumačenje sadomazohizma neophodno je razumjeti da sadist i dominantna osoba nisu sinonimi, no sadist može biti dominantan, no i submisivan, u slučaju kad svoj sadizam okreće prema vlastitoj ličnosti, jednako kao što i mazohistična osoba ne mora biti seksualno submisivna, budući da je to prototipna paradigma, ali u mnogim slučajevima ona preuzima dominantnu ulogu sadističke.

U slučajevima seksualnih neuroza, mazohizam se manifestira sklonošću samoozljeđivanju kao izražavanjem želje za dominantnim drugim, koji joj nedostaje te ga nadomješta „užitkom u boli“, čemu je najčešće razlog želja za samoponiženjem zbog vlastitog osjećaja manje vrijednosti i nezadovoljstva.

Od velikog je interesa razmotriti tradicionalne definicije u suprotnostima i sličnostima sa suvremenim shvaćanjima perverzije slijedeći historiju znanosti o perverziji ili historiju perverzije i komparacije shvaćanja perverzije od Antike, neoklasicizma, viktorijanske ere, sve do početaka psihoanalize, kad započinje razvoj suvremene misli, koja je sinteza i krajnja točka svih dosadašnjih filozofsko - političkih, socioloških i ostalih društveno - seksualnih teorija. 
U navedenim usporedbama vidljivi su veliki napredak, no i velike sličnosti u razumijevanju seksualnosti, što nam govori da brojne davno uspostavljene norme još nisu prevladane i da ih čak niti „revolucionarne“ psihoanalitičke struje od druge polovice 20. stoljeća ni današnje teorije i prakse nisu uspjele prevladati.

Sadomazohizam, kao prvenstveno psihički uvjetovan fenomen nije univerzalan već čini kompleksnu psihologiju u kojoj je individuum kao takav mjerilo, a njegova logika je također partikularna, premda često biva generalizirana.

Racionalnost i imaginacija, nisu stoga uvijek u opoziciji, već često čine spoj jedne kompletne seksualnosti, kao niti Realno i Imaginarno u teoriji Jacquesa Lacana koji su među temeljnim pojmovima u njegovom konceptualnom sustavu koji ću interpretirati u kontekstu sadomazohističke seksualnosti u osnovnim tematskim cjelinama rada.

Sadizam i mazohizam mogu biti shvaćeni kao potpuno različiti i odvojeni, kao kod Gillesa Deleuzea i još mnogih suvremenih mislilaca, i koliko god njihovi argumenti bili relevantni, neophodno je shvatiti njihovu međusobnu vezu i ovisnost.

Pritom su bitne upravo razlike i poveznice Simboličkog i Imaginarnog, o čemu već govore sami počeci proučavanja sadizma i mazohizma u psihoanalizi, tada kao perverzija i psihičkih poremećaja, odnosno ozbiljnih parafilija.

Tvorac svih triju termina - sadizam, mazohizam, te naposljetku - sadomazohizam bio je Richard von Krafft - Ebing, renomirani bečki psihijatar 19. stoljeća i prethodnik psihoanalitičke teorije Sigmunda Freuda.

Sam pojam sadomazohizam složenica je prezimena dvojice kontroverznih književnika i mislioca, od kojih je prvi, „ozloglašeni“ markiz Donatien Alphonse Francois de Sade, bio tokom cijeloga života proganjan zbog svojih životnih i književnih djela, dok je Leopold von Sacher - Masoch, također plemić, no veoma ugledne reputacije, rezulutno odbijao da se njegovo ime dovodi u vezu sa Sadeom.

Za Sadea je najvažnije reći da je prvi renomirani autor koji je u europskoj kulturi literarno izrazio čisti, beskompromisni sadizam i elaborirao ga demonstrativnim racionalizmom ${ }^{8}$, a temeljna odrednica njegove misli je upravo njegov racionalizam, iskrenost $\mathrm{i}$ cinizam $\mathrm{u}$ prikazivanju najbizarnijih sklonosti ljudi te fiktivnog svijeta njegovih protagonista.

\footnotetext{
${ }^{8}$ Gilles Deleuze, Coldness and Cruelty, Zone Books, New York, 2013 str. 29
} 
Sade je koristio eksplicitne lascivne opise izrazito profanim vulgarnim jezik za svoje vrijeme kao osnovu i smisao izvornog naturalizma te je time zauvijek ostao, koliko god neshvaćen i društveno neprihvatljiv, ispred, ne samo svojeg, nego u mnogočemu i današnjeg vremena.

Za razliku od njega, Sacher - Masoch je pisao svojevrsnim romantičarskim stilom i posve drugačijom metodom, izrazito decentnim književnim izričajem. ${ }^{9} \mathrm{i}$ to najbolje objašnjava Gilles Deleuze, u svom djelu "Coldness and Cruelty", detaljno analizirajući bitne distinkcije sadizma i mazohizma te time i enormne razlike dvojice autora, u pogledu filozofskog pristupa, naracije, etičkih normi i jezika samog. ${ }^{10}$

Kod Masocha je najvažnije istaknuti pojam supersenzualnosti, kojim on objašnjava mazohističku sklonost i želju za podložnošću drugoj osobi i užitak u intenzivnoj boli, gdje se zapravo radi i o psihičko - tjelesnoj predispoziciji i o specifičnom položaju subjekta "kojem je potrebna bit mazohizma utjelovljena u prirodi žene koja se odriče svog vlastitog subjektivnog mazohizma; on definitivno nema potrebu za drugim subjektom tj. sadističkim subjektom". ${ }^{11}$

U 20. stoljeću, ponovnim oživljavanjem interesa za djela de Sadea i Masocha, te kultnom knjigom francuske autorice Pauline Reage "L'Histoire d'O" iz 1942. godine, sadomazohizam i u književnosti i shvaćanju seksualnosti zadobiva veliku važnost.

Još mnoga djela te tematike, bila su s jedne strane, smatrana profanom, vulgarnom pornografijom, a s druge strane, budila su interes kod književnih teoretičara i filozofa.

U daljnjim će poglavljima terminologija i praksa sadomazohizma biti razrađena mnogo detaljnije, naročito jezična konceptualizacija te izuzetno relevantni odnosi unutar sadomazohističke seksualnosti u suvremenom kontekstu.

U psihoanalizi i filozofiji seksualnosti mnogo se govori o takozvanoj normalnoj seksualnosti i raznim odstupanjima od nje, odnosno, inverzijama i perverzijama kao „devijacijama“.

Razlozi tomu su kompleksni, no primarni je uzrok inzistiranje na tradicionalnosti poimanja seksualnosti, nadogradnja, umjesto revidiranje i inovacije zastarjelih teorija i metoda psihoanalitičke tradicije koja se nije željela radikalno mijenjati.

Mnogi moderni autori nastojali su upravo to, dekonstruirati i pobiti iz temelja sve dotadašnje teorije, prvenstveno Gilles Deleuze i Felix Guattari, svojom konstrukcijom shizoanalize, koja je pokušaj prevladavanja freudovskog razumijevanja seksualnosti i neuroza.

\footnotetext{
${ }^{9}$ Leopold von Sacher - Masoch, Venus in Furs, 2013, Zone Books, New York

${ }^{10}$ Gilles Deleuze, Coldness and Cruelty, 2013, Zone Books, New York, str. 15 - 47

11 Ibid. str. 43
} 
Dekonstrukcija psihoanalize, posebno tumačenja sadomazohizma bit će detaljno izložena kao jedna od vodećih teorija budući da je neophodna za razumijevanje seksualnosti i preispitivanja i kritike dosadašnjih filozofsko - psihoanalitičkih struja iz suvremene perspektive.

Teorije autora koji zastupaju pozivan stav prema sadomazohizmu bit će suprotstavljeni argumentima glavnih feminističkih autorica protiv ove seksualne prakse, a osobito je važno ukazati na činjenicu da mnoge teoretičarke feminizma zauzimaju afirmativan stav prema dotičnoj seksualnoj praksi.

Relevantnim ću stavovima razviti tematiku sadomazohizma u današnjem kontekstu, a od neizmjerne važnosti će mi pritom biti komparativne historijske poveznice.

Kritičkom analizom svih zastupljenih teza promislit ću sadomazohizam filozofskom elaboracijom pozicije i tumačenja tog fenomena $u$ kontekstu i suvremene psihoanalize i socijalne filozofije kao seksualnu praksu od osobite važnosti.

Razjasnit ću i protumačiti osnovni jezik sadomazohizma odnosno BDSM-a te prikazati osnovne ciljeve ove bitne seksualnosti i njene brojne oblike kojima je prošla i prolazi put od istinskog sadomazohizma do trendova glazbe, mode i filma.

Osnovni je cilj rada suvremena hermeneutika i promišljanje sadomazohizma te kritički pristup pogrešnim razumijevanjima sadomazohističke seksualnosti - kao poremećaja, perverzije, nasilja nenormalne seksualnosti odnosno devijacije.

Obzirom da je sadomazohizam daleko više od seksualnosti same, naglasit ću da je tjelesno i psihički (pred)uvjetovan i referirati se na razne načine kojima ga je moguće konceptualno razumjeti i kategorizirati i stoga ću prikazati bitne poveznice seksualnosti i društva, tjelesnog i psihičkog kod pojedinaca koji prakticiraju ovu seksualnost i naposljetku razlika doživljavanja sadomazohizma na BDSM sceni i u kontekstu suvremenog društva.

Zaključak će se konstituirati kao vrsta opozicije "psihopatologizaciji" i stigmatizaciji sadističke i mazohističke seksualnosti u društvu i psihološkoj sferi, kao inovativan produkt kritike relevantne literature, primjera, te mojih osobnih teza vezanih za ontologiju i epistemologiju individuuma, zajednice i društvene cjeline u pogledu fenomena sadomazohizma. 


\subsection{Freudova teorija perverzije u komparaciji s Lacanom i Deleuzom Historija znanosti o perverziji i fetišizmu}

Znanstveno, medicinsko i psihoanalitičko proučavanje perverzija započeo je za potrebe sudske medicine Richard von Krafft - Ebing u 19. stoljeću, a nastavio ga je Sigmund Freud, utemeljenjem psihoanalize, i to su bili počeci psihologije i psihijatrije seksualnosti, koja se od toga vremena sve više razvijala, preko svoje kulminacije 1930 - ih godina 20. stoljeća do suvremene psihoanalize, koja konstantno iznalazi nove teorije bazirane na kompleksnoj psihološkoj praksi, oslanjajući bitno se na temeljne teorije znanosti o psihi.

Za detaljnije pojašnjenje prikazat će se historijski razvoj definiranja i razumijevanja perverzija i obuhvatiti detaljan pregled dviju temeljnih koje su teme ovoga rada.

Krafft - Ebing u svom opsežnom djelu pisanom za sudsku forenziku i psihijatriju, "Psychopathia Sexualis" iz 1886. godine, detaljno razrađuje dotične pojmove, prikazujući ih kroz brojne kliničke studije slučajeva, i tim analizama iznosi svoje teze i zaključke, a započinje tumačenjem fetiša i fetišizma naglašavajući da je potrebno razumjeti predmete ili njihove dijelove u asocijativnom odnosu s intenzivnim osjećajem koji pobuđuje duboki interes, draž, etimološki iz portugalskog jezika "feitisso"12 i njegova je definicija fetišizma "individualno vrednovanje fetiša, koje ide do granica nerazumljivog entuzijazma u pogođenom, dirnutom individuumu"13.

On nastavlja da je taj fenomen "objašnjiv empiričkim zakonom asocijacije - odnosom partikularnog prema općenitom konceptu, u kojem je bitna stvar emocionalna obojanost partikularnog koncepta koji pruža užitak, a osebujan je indivuduumu". Kao najčešće fetiše navodi one koji pobuđuju erotske osjećaje i zato "erotski fetišizam nalazi svoje psihološke motive u fetišima koji se sastoje od fizičkih ili psihičkih kvaliteta osobe ili samo predmeta koje je osoba koristila" te "oni uvijek bude intenzivne asocijacije ličnosti kao cjeline i uvijek su obojeni živim osjećajem seksualnog zadovoljstva"14.

Tako se s razvojem fizičke ljubavi, zaključuje Krafft - Ebing, "nukleus" uvijek nalazi u individualnom fetišu i po njegovim dosadašnjim uvidima vide se bitne poveznice s Freudom koje će kasnije biti spomenute i objašnjene.

\footnotetext{
${ }^{12}$ Richard von Krafft - Ebing, Psychopathia Sexualis, The F. A. Davis Company Publishers, London, 1894, str. 15 17

13 Ibid. str. 17

14 Ibid. str. 17
} 
On govori da se "emocionalni i vizualni dojmovi prikazuju u asocijativnom odnosu $i$ kako asocijacija jača putem emocija koje bude vizualno pamćenje, obnavljaju seksualno uzbuđenje koje može doseći intenzitet orgazma te u tom slučaju cijela psihička osobnost ima efekt fetiša"15. Fetiš je također shvaćen kao simbol, potpuno individualan i zato su ljubavnici neshvaćeni od drugih, jer u intenzitetu svojih seksualnih težnji, deificiraju i obožavaju osobu koja ima posjeduje određene fetiše, razvijajući kult odanosti i čak idolatrije, idealizirajući tu osobu nerealnim atributima. ${ }^{16}$

Navedenim bi se mislima mogla povući suvremena paralela s aktivnošću role - playa, gdje je pripisivanje nerealnih osobina i obožavanje osnovno polazište i cilj psihičke i seksualne privlačnosti i postizanja zadovoljstva.

Krafft - Ebing se osvrće na dobro poznate preferencije u sferi fetišizma, navodeći primjere najčešćih fetiša - od figure tijela, boje kose, tona glasa, mirisa do ruku, stopala i ostalih dijelova tijela te određenih odjevnih predmeta. ${ }^{17}$

Za daljnji je razvitak njegove teorije važan uviđaj da ruke i stopala te njihovi asocijacijski ekvivalenti - rukavice i cipele, ukazuju na mazohističke i sadističke osjećaje pri odabiru fetiša te upravo to " pokazuje stanje porijekla fetišizma koje se nalazi unutar fizioloških granica" i zato " fetiš može konstantno zadržati svoju važnost a da ne bude patološki ; ali to je moguće samo kad je partikularni koncept razvijen do općeg koncepta; kad rezultirajuća ljubav uzima za svoj objekt cijelu psihičku osobnost"18.

Krafft - Ebing uvodi termine "patologija fetišizma" i patološki fetišizam", čime želi ukazati da kada je objekt ljubavi i želje samo tijelo ili dijelovi tijela osobe, kao jedino što vodi zadovoljstvu senzualnog užitka, riječ je o tranziciji u patološki fetišizam.

Ta je teza veoma radikalna i možda suviše pojednostavljena, danas, naravno, neprihvatljiva, jer "prava ljubav", koju on spominje, ne mora uopće biti cilj.

On u svojoj studiji posvećuje veliku pažnju pojmu perverzije, preciznije, perverziji seksualnog instinkta te se služi sintagmom "paraesthesia seksualnog osjećaja", koja označava poremećaj u seksualnom životu pojedinca, a važno je spomenuti da on, u svom psihoanalitičkom opisu, perverziji implicitno pridaje karakteristike entiteta.

Krafft - Ebing posvećuje veliku pažnju pojmu perverzije, preciznije, perverziji seksualnog instinkta te se služi sintagmom "paraesthesia seksualnog osjećaja", koja označava poremećaj

\footnotetext{
${ }^{15}$ Ibid. str. 18

${ }^{16}$ Ibid. str. 18.

17 Ibid. str. 19 - 21

18 Ibid. str. 19, prijev.a.
} 
u seksualnom životu pojedinca te nadalje zaključuje da se radi o "perverznom emocionalnom shvaćanju seksualnih ideja koje su abnormalne no uzdižu se do osjećaja koji pružaju seksualni užitak, a njihov je izražaj strastven i nekontroliran"19.

Bitno je spomenuti da on perverziji, u svome psihoanalitičkom opisu perverziji suptilno i implicitno pridaje karakteristike entiteta i njegov se negativni pogled na perverzije najbolje vidi iz teze da su "praktični rezultati pervezni činovi ako osjećaji zadovoljstva, uvećani do strastvenog intenziteta, inhibiraju ideje koje se protive odgovarajućim osjećajima odvratnosti ili utjecaj takvih protivljujućih koncepata bude nemoguć zbog odsutstva ili gubitka svih ideja moralnosti, estetike i zakona" 20.

Time on oštro diferencira perverzije od "normalnog seksualnog instinkta" te ukazuje da drugačiji ili „devijantan“ izraz zadovoljenja seksualnog instinkta nije u skladu s prirodom i mora biti smatran perverzijom. ${ }^{21}$

Perverzija je tako u njegovom djelu suviše simplificirano shvaćena kao jednostavno neprirodna, čemu će se Freud kasnije usprotiviti i dosljedno razlučiti tipove perverzija i time nadograditi teoriju seksualnih odstupanja. ${ }^{22}$

Krafft - Ebingova je konstatacija da "konkretan perverzni čin" koliko god "monstruozan", nije određen" i da bi se "diferenciralo između bolesti perverzije i poroka perverzije, potrebno je istražiti cijelu ličnost individuuma i izvorne impulse koji vode perverznom činu i unutar toga će se naći ključ dijagnoze" ${ }^{23}$.

On tako perverziju definira i kao bolest, što se, naravno, odnosi na ekstremne slučajeve nasilja, kojima se bavio u medicini i forenzici, no ako bi se radilo o jednoj te istoj perverziji, s jednakim ishodom, no ciljem užitka i vođenoj senzualnim impulsima, njegovo bi shvaćanje perverzije bilo na sasvim krivome tragu.

Krafft - Ebing nastavlja svoje proučavanje perverzija sadizmom, koji je za njega "udruženost aktivne okrutnosti i nasilja s požudom" te on naglašava činjenicu da se "požuda i okrutnost često zbivaju zajedno" ${ }^{24}$, kako je to odavno bilo poznato u literaturi te je njemu upravo ta veza između požude i okrutnosti od izuzetne važnosti.

On navodi uobičajene slučajeve izrazito razdražljivih osoba, koje u trenucima veoma jake požude ozljeđuju svoj objekt pod utjecajem snažnih impulsa, u stanju egzaltacije, intenzivnog

\footnotetext{
19 Ibid. str. 56

20 Ibid. str. 56

${ }^{21}$ Ibid. str. 56

${ }^{22}$ Sigmund Freud, Tri rasprave o seksualnoj teoriji, Matica srpska, Beograd, 1981.

${ }^{23}$ Richard von Krafft - Ebing, Psychopathia Sexualis, The F. A. Davis Company Publishers, London, 1894, str. 56 57 , prijev.a.

${ }^{24}$ Richard von Krafft - Ebing, Psychopathia Sexualis, The F. A. Davis Company Publishers, London, 1894, str. 57
} 
uzbuđenja cijelog psiho - motoričkog sustava ${ }^{25}$ te izražava da "egzaltacija seksualnih emocija često potiče impuls da se potroši u besmislenim i očito štetnim činovima"26.

Objašnjava da to nije nesvjesno uzbuđenje, već da se radi o žudnji za najintenzivnijim efektom postizanja stimulacije, a to je, naravno, nanošenje boli. ${ }^{27}$

Freudov pristup seksualnim perverzijama u mnogim je stvarima bitno drugačiji, izuzetno inovativan i napredan za njegovo vrijeme i bliži suvremenom shvaćanju upravo zbog toga se on, kao njen začetnik, bavio psihoanalizom i složenom ljudskom ličnošću, psihom i nagonima, za razliku od Krafft - Ebinga, koji je bio više orijentiran na forenzičku medicinu, iz čije je perspektive pristupao čovjekovoj prirodi.

Svoju raspravu o perverzijama on započinje razlučivanjem pojmova i objašnjenjem svojih osnovnih termina te pored vlastite uvedene terminologije, koja je bolje vidljiva u drugim njegovim djelima, služi se već uvriježenim registrom psihijatrije svoga vremena, koja je već predstavljena kod Krafft - Ebinga.

Freud također objašnjava termine "seksualni objekt", koji podrazumijeva "osobu od koje polazi spolna privlačnost" i "seksualni cilj", kao radnju na koju tu osobu tjera nagon i konstatira da u odnosu na ta dva pojma znanstveno iskustvo pokazuje brojne primjere seksualnih perverzija koje zahtijevaju iscrpno istraživanje.

On perverziju definira veoma inkluzivno kao "odstupanje u odnosu na normalni seksualni cilj", pri čemu je "normalni seksualni cilj" shvaćen isključivo kao genitalni spolni odnos.

Perverzija je, strogo rečeno, svako skretanje od tog cilja, no on napominje i da se kod svakog "normalnog" seksualnog odnosa zamjećuju začeci perverzija i tu se dovodi u pitanje njegovo poimanje tog "normalnog" i njegovog razgraničenja s perverznim, a pojašnjenje je da Freud perverzijama smatra sve seksualne aktivnosti kojima jedini cilj nije genitalni akt, a povećavaju uzbuđenje i vode postizanju orgazma.

Bitno je naglasiti da on perverzije ne smatra entitetima, kao mnogo kasnije Lacan, (a već i Krafft - Ebing pridavao takve značajke), već su za njega samo posredne radnje koje prethode genitalnom odnosu i pružaju dodatno zadovoljstvo.

Freudova konačna definicija perverzija je da su one "anatomska prekoračenja oblasti tijela koje su određene za spolno sjedinjenje", referirajući se na preuzimanje drugih dijelova tijela osim genitalija za seksualne ciljeve, prvenstveno usana, usne šupljine, anusa i ostalih dijelova tijela koja nisu uobičajena za seksualnu aktivnost te zadržavanje na posrednim radnjama bez

\footnotetext{
25 Ibid. str. 58 - 59

${ }^{26}$ Ibid. str. 59

27 Ibid. str. 59
} 
prelaženja na genitalni akt. ${ }^{28}$

Za Lacana perverzija nije samo skretanje i zastranjivanje od socijalnih normi poput heteroseksualnog genitalnog odnosa s ciljem reprodukcije, već "nešto drugo u samoj svojoj strukturi" i on perverziju shvaća kao entitet, izrazito kompleksan i elaboriran, te razlikuje "pervezne činove" od "perverzne strukture" koji mogu, ali ne moraju nužno biti udruženi ${ }^{29}$.

Njegova je pozicija da društveno neodobravanje određuje "perverzne činove", no nije bit "perverzne strukture", kojoj je osnovna karakteristika proces poricanja, kao posljedica Edipovog kompleksa.

Perverzija je za Lacana specifičan analogno složen odnos pojedinca prema porivu, u kojem se on postavlja kao objekt poriva, za užitak drugog te je perverzija je tako strukturirana kao neuroza, no pojedinac je svjestan da svojim činovima služi jouissanceu $\operatorname{Drugog}^{30}$ te je važno spomenuti jasnu implikaciju da on, za razliku od Freuda, u psihoanalitičkom liječenju „perverznih“ pojedinaca ne postavlja za cilj eliminaciju perverznih aktivnosti.

Freud detaljno analizira fetišizam, govoreći o seksualnom precjenjivanju, pretjeranom obožavanju cijelog tijela, posebice određenih dijelova koji tada postaju seksualni ciljevi i upravo je to, kao i upotreba usana i usta, osim za fetišizam kojeg Freud smatra "neprikladnom zamjenom seksualnog objekta" izuzetno važno za sadomazohističke seksualne aktivnosti.

Osnovna primjedba bi bila da se u većini slučajeva tu ne radi o zamjeni već o sredstvu dodatnog užitka na putu prema zadovoljenju cilja jer on također kao uobičajene fetiše navodi stopala, kosu te odjeću i donje rublje.

Freud misli na slučajeve kad je fetiš nužan za postizanje seksualnog cilja i zato ga tako obilježava te je za njega perverzno uvijek u kombinaciji s fetišizmom.

Njegova je definicija fetiša kao objekta nužnog za postizanje seksualnog zadovoljstva uvelike preuzeta od Krafft - Ebinga, a fetišizam je već spomenuto precjenjivanje seksualnog objekta, fetiša, njegovih fizičkih atributa i predmeta koje ga označavaju te Freud zaključuje da je fetišizam patološki samo kad se težnja za fetišem postavlja na mjesto „normalnog“ seksualnog cilja i kad se naposljetku fetiš odvoji od ličnosti i postaje jedini seksualni objekt.

Freud sadomazohizam smješta unutar perverzija "fiksiranja privemenih seksualnih ciljeva", kao i voajerizam i egzibicionizam jer dijele zajednički aktivni i pasivni oblik, budući da se on pri tumačenju sadizma i mazohizma poziva na Krafft - Ebingovu definiciju i slaže se da je osnova te sklonosti uživanje u bolu, poniženju i potčinjavaju, ili u aktivnoj ili u pasivnoj ulozi.

\footnotetext{
${ }^{28}$ Sigmund Freud., Tri rasprave o seksualnoj teoriji, Matica Srpska, Beograd, 1981, str. 27 - 30

${ }^{29}$ Jacques Lacan, Ecrits, W.W. Norton \& Company, New York, 2006

${ }^{30}$ Ibid.
} 
Lacan je fetiš smatrao zamjenom za nedostatak falusa kod majke te fetišist poriče taj manjak i nalazi objekt koji je simbolična zamjena za majčin nepostojeći penis.

Bitno je spomenuti da je Lacan kasnije okrenuo i Freudovu i vlastitu teoriju tezom da penis za heteroseksualnu ženu preuzima vrijednost fetiša, i fetiš nije više bio simbolična zamjena za penis, već je penis sam postao fetiš zamjenjujući ženin odsutni simbolički falus ${ }^{31}$.

Ta je nova teza zamijenila i ranija shvaćanja o izuzetnoj rijetkosti fetišizma kod žena i proizvela upravo suprotnu tvrdnju - ako je penis smatran fetišem, fetišizam je kod žena mnogo učestaliji nego kod muškaraca heteroseksualne orijentacije.

Iz Lacanove teorije možemo zaključiti fetiš kao objekt može biti entitet te i druga osoba u kojoj fetišist nalazi ispunjenje svoje želje, naročito u teoriji falocentrizma - kad muškarac postaje fetiš žene, no i kad je žena kao seksualni objekt fetiš muškarcu, naravno, i u istospolnim odnosima, gdje o manjku falusa ne možemo govoriti.

Fetiš tako ne počiva samo na manjku, već i na obožavanju željenog, potrebnog za ispunjenje zadovoljstva, on pored seksualne poprima i društveno uspostavljenu ulogu dominantne osobe i submisivne kao seksualnog objekta.

Gilles Deleuze, u svojoj izvanrednoj filozofsko - psihoanalitičkoj analizi mazohizma”Coldness and Cruelty", razlikuje sadistički i mazohistički fetišizam, već samim time što fetišizam za njega pripada esencijalno mazohizmu, kao poricanje, odgoda ili prekid užitka, dok fetiš u sadizmu ima ritualni značaj nasilja prema fetišu. ${ }^{32}$

Fetiš je za njega svojstven isključivo mazohizmu, kao obožavanju ženskih odjevnih predmeta pri čemu se referira na Masochovu „Veneru u krznu“, a osnovno za mazohistički fetišizam je odgađanje seksualnog užitka, koje je jedan od osnovnih motiva Masochovih romana. ${ }^{33}$

Suspenzija, termin koji Deleuze detaljno elaborira, odnosi se i na prekid užitka podređenoj, mazohističkoj ličnosti, na fizičku suspenziju kao razne načine vezivanja, no i jezičnu figuru koja prikazuje geste dominantne osobe, čime je taj termin „orgazmički“ u mazohističkom kontekstu. ${ }^{34}$

Sadistički fetiš, on zaključuje, uvelike se razlikuje od mazohističkog zbog svoje opscenosti, sirovih opisa koji izražavaju nagon smrti jer fetiš kao objekt mora biti uništen da bi se postigao klimaks koji se ne odgađa, a narativ prelazi u demonstraciju kao aktivan i agresivan proces. ${ }^{35}$

\footnotetext{
${ }^{31}$ Jacques Lacan, Ecrits, W.W. Norton \& Company, New York, 2006, str. 575 - 584.

${ }^{32}$ Gilles Deleuze, Coldness and Cruelty, Zone Books, New York, 2013 str. 32 - 33

${ }^{33}$ Ibid. str. 32 - 33

${ }^{34}$ Ibid. str. 32 - 33

${ }^{35}$ Ibid. str. $34-35$
} 
Upravo zbog pozicioniranja fetiša u sferu mazohizma, Deleuze fetiš naziva protestom protiv Realnog, s obzirom da je za njega baziran na poricanju i odgodi, a mazohizam isključivo prevladava u sferi Imaginarnog. ${ }^{36}$

Freud bi se vjerojatno donekle složio s Deleuzeovom karakterizacijom mazohizma i fetiša kao njegovog osnovnog ,simptoma“, no u posve drugom smjeru, budući da je mazohizam za njega bio izrazito teška perverzija, a mazohist time osoba izvan realiteta, te je njegova je teorija sadizma i mazohizma bila daleko drugačija po svom razumijevanju, porijeklu i gradaciji što je svojstveno ranoj psihoanalizi kao utemeljenju znanosti o „drugačijim“ seksualnostima.

\subsection{Rana psihoanaliza o sadomazohizmu}

U samim počecima psihonalize, Richard von Krafft - Ebing shvaća i definira sadizam kao teški patološki poremećaj, na način opisan u djelima Sadea, sadizam kojem su osnovne komponente teško ozljeđivanje, mutilacija i smrt.

On Sadea naziva čudovištem jer ga je coitus uzbuđivao samo kad bi brutalno ozljeđivao svoje žrtve do krvi i sadizam je tako postavljen kao odnos sadista i žrtve, od kojih je žrtva gotovo uvijek pasivna žena, jer je agresivna, aktivna uloga svojstvena muškarcu ${ }^{37} \mathrm{i}$ to je maskulinizirana vizija "sadizma" unutar diskursa kliničke i sudske prakse 19. stoljeća.

Danas takvo poimanje sadizma nije prihvatljivo, osim u slučajevima nasilja, nikako seksualno konsenzualnog sadizma jer nasilje i BDSM nemaju ništa zajedničko.

On isprva opisuje sadizam kao isključivo maskulin, agresivan, okrutan, nasilan, prvenstveno nad ženama a tek kasnije dolazi i do relevantnih žena s jakim sadističkim sklonostima, dakle, sadizam je ipak donekle univerzalno shvaćen. ${ }^{38}$

Argumenti kojima objašnjava rijetke pojave sadizma kod žena su prvo, sadizam po svojoj prirodi pripada muškom seksualnom karakteru i drugo, žene imaju mnogo veću introjekciju prepreka kod izražavanja svojih instinkata. ${ }^{39}$

\footnotetext{
${ }^{36}$ Ibid. str. 31 - 32

${ }^{37}$ Ibid. str. $70-73$

38 Ibid. str. $59-67,70-82,87-89$

${ }^{39}$ Ibid. str. 87
} 
Seksološki i kulturološki gledano, drugi bi argument bio valjan, dok se prvi ne može dokazati, a pogotovo ne generalizirati, no ono bitno je da je kod Krafft - Ebinga sadizam elaboriran kao ozbiljna psihopatija i teško poremećena vita sexualis, a cilj je takvog agresivnog, sadističkog karaktera "potpuno podčiniti objekt želje, čak ga i uništiti i ubiti"40.

Njegova najegzaktnija definicija sadizma bila bi da je on "pretjerana i monstruozna patološka intenzifikacija fenomena - moguć također, u normalnim uvjetima u rudimentarnim formama koje prate fizičku vitu sexualis" te najvažnije - "udruženje požude i okrutnosti u kojem požudna emocija budi impuls okrutnosti, no $i$ vice versa; okrutne ideje i činove uzrokuju seksualno uzbuđenje i na taj način ih koriste perverzne osobe ${ }^{\prime 41}$.

On tumači i razvoj sadizma, smatrajući najtočnijom tezu da je on urođen i da pojedinci koji dugo vremena inhibiraju svoje instinkte ne postižu zadovoljstvo "normalnim seksualnim činom“, sve dok konačno ne prevladaju etičke zakone ostvarenjem svojih perverzija te diferencira sadističke činove prema seksualnim dispozicijama od kojih su najvažnije libido i sklonost samom seksualnom odnosu. ${ }^{42}$

Napominje da oni variraju od teških zločina do bezazlenih činova perverzne želje koji pružaju samo simboličko zadovoljenje, no, u svim slučajevima, sadizam ostaje perverzija, a hiperstezija podloga za sadističke sklonosti. ${ }^{43}$

Ta se tvrdnja, napretkom psihijatrije, pokazala netočnom, osim u kliničkim i kriminalnim slučajevima koji su i danas veoma važan predmet psihijatrije i forenzike.

Krafft - Ebing opisuje brojne studije slučajeva ubojstva, mutilacije, nekrofilije, koji uvelike podsjećaju na "120 dana Sodome" ${ }^{44}$, dok su kasnije navedeni slučajevi mazohizma koje navodi bliski, logično, Masochovu djelo ${ }^{45}$ te je jasna njegova vizija sadizma kao teškog poremećaja. Opisan je i slučaj ponižavanja u javnosti, koji ima sve karakteristike sadomazohističke prakse, kakvi se i danas konsenzualno prakticiraju i daje poveznice sadizma s mazohizmom kroz još brojne slučajeve muškaraca koji posjećuju prostitutke da budu ponižavani i ozljeđivani.

Krafft - Ebing kompleksno i interesantno inkorporira odnos požude i okrutnosti unutar koncepta koji je sam i razvio, psihološki proučavajući fenomene sadizma i mazohizma, shvaćajući mazohizam neodvojivim od sadizma, uvodeći sintagmu - "udruženje pasivno trpljene

\footnotetext{
${ }^{40}$ Ibid. str. 60

${ }^{41}$ Ibid. str. 60

${ }^{42}$ Ibid str. 61

${ }^{43}$ Ibid. str. 61

${ }^{44}$ Najveće i najopširnije djelo D. A.F. de Sade-a iz 1785. op. a.

${ }^{45}$ Leopold von Sacher - Masoch, Venus Im Pelz (Venera u krznu) iz 1869. op.a.
} 
okrutnosti i nasilja s požudom". 46

Njegovo opsežno shvaćanje mazohizma jest da je on kao "suprotan sadizmu želja za trpljenjem boli i podređenošću sili"47, osebujna perverzija seksualnog života u kojoj je pojedinac u svojim seksualnim osjećajima i mislima zaokupljen idejom da bude potpuno i bezuvjetno podređen volji dominantnoj osobi koja ga tretira kao gospodar - ponižava i iskorištava. ${ }^{48}$

Govori da je "ta ideja obojena požudnim osjećajem; pojedinac živi u mašti, u kojoj kreira situacije te vrste $i$ nastoji ih ostvariti" te tom perverzijom njegov seksualni instinkt je često neosjetljiv na normalni stimulus suprotnog spola, nesposoban je za za normalnu vitu sexualis", čak "fizički impotentan"49.

Ta rigorozna definicija ipak nije strogo određena niti dokazana jer on navodi i slučajeve gdje zajedno s perverzijom postoji i osjetljivost na normalne stimulanse te se spolni odnos odvija "pod normalnim uvjetima" 50 .

Osnovna bi pitanja na ovakvo shvaćanje mazohizma bila : što je "normalni" seksualni život, što "normalni spolni odnos" i zašto Krafft - Ebing ne prihvaća raznolikost stimulansa unutar seksualnosti. U njegovo vrijeme, odgovor bi bio veoma jasan, kao i kod Freuda, a u posljednjem slučaju radi se o striktnom medicinskom pristupu koji ograničava područje nagona $\mathrm{i}$ seksualnosti uopće.

Otvoreni problem koji ostaje je inzistiranje na impotenciji osoba mazohističkih sklonosti, dok je prihvaćanje bilo kakvog perverznog ili "normalnog" odnosa imperativno samo sa suprotnim spolom razumljivo jer Krafft - Ebing homoseksualnost i biseksualnost također smatra perverzijama i poremećajima ${ }^{51}$, što se kod Freuda mijenja, postaje inverzija i upravo se to može se smatrati velikim napretkom u misli početka 20. stoljeća, a Freuda daleko ispred svoga vremena i kulture $^{52}$ jer Krafft - Ebing, osim što i mazohizam smatra psihopatijom, spominje i nasljedne predispozicije kao faktore u razvoju mazohističke ličnosti.

Urođenost, koju je ranije konstatirao, dokazana je u većini slučajeva, no teza o nasljednosti je neodrživa, što su pokazale brojne kasnije studije i opće je prihvaćeno.

On zaključuje da "pojavljuje li se mazohizam udružen s normalnim seksualnim instinktima ili isključivo kontrolira pojedinca, ovisi o stupnju intenziteta perverzije kao $i$ o psihičkoj

\footnotetext{
${ }^{46}$ Richard von Krafft - Ebing, Psychopathia Sexualis, The F. A. Davis Company Publishers, London 1894, str. 89

47 Ibid. str. 89

${ }^{48}$ Ibid. str. 89

49 lbid. str. 89

50 Ibid. Str. 89

51 Ibid. str. 90

${ }^{52}$ Sigmund Freud, Tri rasprave o seksualnoj teoriji, Matica Srpska, Beograd, 1981, str. 13 - 23
} 
organizaciji pojedinca", te ukazuje da je mazohizam suprotstavljen instinktu samoočuvanja jednakim argumentima kojima je obilježio sadizam. ${ }^{53}$

Potpuno je jasno da ovo djelo govori o sadizmu i mazohizmu iz jedne, današnjoj kulturi i subkulturi gotovo nepoznate i odavno prevladane perspektive - one liječnika koji se bavi psihičkim poremećajima, zločinima iz strasti te stoga prihvaća uglavnom samo takvu klasifikaciju ovih seksualnih praksi.

Za svjesne, konsenzualne mazohiste, mazohizam je upravo izvor instinkta samoočuvanja, Freudovom terminologijom, nagona za životom i seksualnog nagona, no Krafft - Ebing navodi svoje studije slučajeva mazohizma kod muškaraca, prvenstveno bičevanja, ponižavanja od žena, gdje spolni odnos nije bitna komponenta ili čak nije uključen u odnos.

Slučajevi su brojni i upravo time donekle pobija svoju raniju tezu da je mazohizam feminin jer su mnogi muškarci oduvijek željeli i ostvarivali podređenost ženi te bili podložni snažnom bičevanju, koje je simboličan čin te čak daje određenu moć mazohistu, jer proizlazi iz obostranog zadovoljstva, ali željom mazohista.

U tome se vidi složenost odnosa moći između podređene i dominantne osobe, mazohist upravlja svojim željama i uživa u ponižavanju i boli te je stoga često veoma teško utvrditi vrstu odnosa te psihofizičku hijerarhiju.

Zato Krafft - Ebing govori da je "mazohizam nešto bitno drugačije od flagelacije i razumljivije" jer "flagelacija je više usputna igra - jedno od mnogih sredstava korištenih za svrhu mazohističkog zadovoljenja u smislu potčinjavanja ženi"54, a budući da je "potčinjavanje mazohistu ono osnovno, a kazna samo izraz tog odnosa kao naintenzivnji efekt" , on sa sigurnošću drži da je mazohizam u svojoj cjelini poremećaj seksualnosti, njegovim riječima, "izvorna anomalija seksualnog osjećaja" ili "paraesthesia sexualis"55.

Općenito je točno da je ono bitno, cilj sam, bol i poniženje i Krafft - Ebing je tako dosljedno obuhvatio bit mazohizma, ono sporno, čemu je potrebno uputiti kritiku je njegova medikalizacija i stigmatizacija mazohizma kao poremećaja, štoviše, psihopatije - ta se riječ može koristiti samo kod slučajeva nasilja.

Opisan je i slučaj koji bi se mogao usporediti s današnjim pojmom sesije ili scene, a to je da nakon fizičkog kažnjavanja poput flagelacije, mazohist ima potrebu stvoriti i izvesti željenu situaciju sa svojom dominantnom osobom, da bude u njenoj moći i sve ostalo što je zamislio da bi postigao zadovoljstvo.

\footnotetext{
${ }^{53}$ Ibid. str. 89 - 90

${ }^{54}$ Ibid. str. $99-100$

${ }^{55}$ Ibid. str. 89 - 90
} 
Krafft - Ebing navodi i analogiju između sadista i mazohista, konstatirajući da sadisti koji nalaze zadovoljstvo u najčešće pokušaju fizičkog ostvarenja sintagme "ubojstvo iz požude" (Lustmord) imaju svoj pandan u mazohizmu, kad mazohizam vodi pojedinca do želje da bude ubijen od dominantne osobe, no to ipak ne biva slučaj zbog instinkta samoočuvanja. Ovo je važno navesti zbog veoma učestalih mazohističkih praksi poput asfiksijacije, iznimno brutalnog konsezualnog bičevanja, vezivanja u iznimno zahtjevnim i opasnim položajima, koji ponekad mogu dovesti i do neželjenih posljedica te on ovu perverziju "vite sexualis" opisuje kao "smještenu u imaginarnu sferu, u unutarnji svijet misli i instikata".

Komentar koji moram uputiti jest da je mazohizam kod aktivnih osoba svjesna želja, svjesna potčinjenost, ali naravno kod mnogih dugo ostaje nesvjesna, samo imaginarna i tu se radi o složenom psiho - seksualnom efektu, koji se razlikuje od osobe do osobe i na koji utječu brojni psiho-socijalni faktori.

Krafft - Ebing i sam priznaje da je "mazohizam neobično česta pojava što pokazuje velik broj slučajeva koji su dotad bili znanstveno proučavani".

On, među poznatim autorima i misliocima mazohističkih sklonosti navodi poznat slučaj Rousseaua koji je u svojoj autobiografiji, "Ispovijestima" opisao svoju mladenačku "podložnost toj perverziji", koja je ubrzo postala latentna, da bi se kasnije pojavila u svome pravom obliku te potom Baudelairea i Zolu, no, naravno, najveću važnost pridaje Sacher - Masochu, prema kome je i formirao ovaj koncept i naposljetku, pored Sadea, svoj centralni pojam.

Referirajući se na Masocha, zaključuje da upravo on u svojim djelima najbolje prikazuje "tipične slike perverznog psihičkog života muškaraca te vrste" te da se "mnogi općinjeni tom perverzijom pozivaju direktno na njega, kao opis svog vlastitog psihičkog stanja".

Kod Masocha, ključan je pojam "supersenzualnosti", koji opisuje psihičko stanje u kojem se autor nalazio i njegovu žudnju za potčinjenosti ženi, život koji je živio i opisao u "Veneri $u$ $k r z n u "$, čime je taj pojam ušao u diskurs o sadomazohizmu, odnoseći se na svaku osobu njegovog psihičkog ustrojstva, osobe kojoj mazohizam postaje fizička i emocionalna stvarnost. Krafft - Ebing se dotiče i simboličnih mazohista, fetišista, koji ne žele fizičko iskorištavanje od žene već obožavanje dijelova tijela i odjevnih predmeta - stopala, ruku, cipela, donjeg rublja i isključivo to su im objekti seksualne želje, oni su kao fetiš zadobili neovisno značenje i važnost. Izuzetno je zanimljivo njegovo konfrontiranje muškog i ženskog mazohizma.

Dok je kod muškaraca riječ o perverziji i psihopatiji, ženski je mazohizam do određenih granica smatran normalnim i pritom se misli na konsenzualni mazohizam jer on konstatira da je "kod žene dragovoljno podređivanje suprotnom spolu fiziološki fenomen".

On objašnjava da je razlog tome pasivna uloga žene u društvu i seksualnim odnosima i da joj 
je ta pasivna uloga "služavke" dana prirodom i samim time instinkte za podređenost muškarcu. Na ovu bi se izjavu moglo navesti gotovo bezbroj kontraargumenata, pogotovo s feminističkog stajališta, s kojima se apsolutno slažem, no reći ću samo da nijednom spolu pasivna uloga nije prirodom dana niti je itko unaprijed predodređen za određenu ulogu rodom samim.

Mazohizam tako on općenito smatra "patološkim porastom specifičnih femininih psihičkih elemenata" i njegov izvor nalazi u "psiho - seksualnom karakteru žene ", a radi li se tu o patologizaciji ženskog karaktera, kakvim ga on opisuje ili o svojevrsnoj "obrani" mazohizma u žena, najbolje će objasniti njegovi stavovi da su kod muškarca takve manifestacije smatrane patološke, a kod žena prirodne i u skladu s običajima budući da on razumije muško - ženske odnose kao odnose moći.

Takvi su stavovi bili već u njegovo vrijeme izloženim žestokim kritikama te prevladani, ne samo od prvih feministkinja već i muških mislioca, poput J. S. Milla, a danas su u zapadnoj civilizaciji odavno znanstveno opovrgnuti i neprihvatliivi.

Konačno, Krafft - Ebing nastoji objasniti mazohizam u domeni psihopatologije, gdje je njemu ona bitna odrednica "neograničeno podređivanje volji druge osobe, praćeno požudnim seksualnim osjećajima do stupnja orgazma".

Međutim, on razlikuje dva izvora mazohizma u sferi normalnih fenomena, prvo, "u stanju požudnog uzbuđenja svaki dojam osobe koja potiče seksualni stimulus je ugodan uzbuđenom pojedincu te dolazi do ekstatičnog stanja" i drugo, "najvažniji izvor mazohizma treba tražiti u raširenom fenomenu koji, premda je izuzetan i abnormalan, ni u kojem se slučaju ne nalazi unutar domene seksualne perverzije".

Primjećuje se da on razlikuje mazohizam kao "normalan" i "perverzan", no tu se uočavaju određeni naizgled nedosljedni stavovi za koje je potreban detaljan uvid u čitavo njegovo medicinsko - psihološko djelo.

Važna je spoznaja da se unutar odnosa veoma često razvija ovisnost jedne osobe o drugoj, sve do potpunog gubitka vlastite volje "koja se razlikuje od normalnog života samo u intenzitetu seksualnog osjećaja i stupnju volje - moći, potrebnog za održavanje ravnoteže" te je "razlika u intenzitetu, ne u kvaliteti, kao u mazohističkim manifestacijama", a takva je vrsta ovisnosti veoma često karakteristična za sadomazohistički odnos, u kojem mazohist postaje ovisan o dominantnoj osobi i stoga ga $u$ tom pogledu ne treba odvajati od uobičajenog odnosa.

Krafft - Ebing koristi termin "seksualni bondage", ne u smislu tjelesne prakse, u kojem se danas koristi, već "bondage" ovdje ima značenje odnosa u kojem "volja vladajućeg pojedinca dominira podređenu osobu, kao gospodar svoga slugu" i time implicira bondage u sadomazohizmu. Takav je seksualni bondage abnormalan fenomen, devijacija od normalnog 
prema stupnju ovisnosti jedne osobe o drugoj, no nije perverzija već se ipak odvija unutar normalnih granica seksualnog života.

On konačno rezimira svoju studiju o seksualnim psihopatijama zaključkom da su sadizam i mazohizam komplementarni na temelju želja i seksualnog zadovoljenja te su obje perverzije iskonske psihopatije kod psihički abnormalnih pojedinaca, koji pate od psihičkog seksualnog poremećaja. Ta je dijagnoza odavno odbačena i u suvremenoj psihijatriji više ne postoji iako je ipak zadržana jednaka medicinska kategorizacija, za sadizam i mazohizam ICD - F65.5, klasificirane su još uvijek kao parafilije, no to je veoma daleko od "psihijatrije" 19. stoljeća.

Krafft - Ebing je u svojim tezama izuzetno radikalan i konzervativan i za njega je osnovni kriterij psihopatije sadizma i mazohizma "činjenica da u seksualnoj emociji, kao popratno psihičko uzbuđenje, nastaje impuls koji utječe na objekt žudnje $i$ s najvećim mogućim intenzitetom postaje impuls za nanošenjem ili uživanjem u boli".

Slučajevima u kojima se sadizam i mazohizam pojavljuju kod iste osobe on potkrepljuje svoju tezu o njihovoj uskoj povezanosti, napominjući da je uvijek jedna perverzija primarna, izvorna i dominirajuća te se iz nje kasnije razvija ona druga i time ukazuje na ono što danas nazivamo "switch", sklonost iste osobe da prakticira i sadističku i mazohističku seksualnost ili mijenja submisivnu i dominantnu ulogu.

Mazohizam i sadizam su tako za njega "fundamentalne forme psiho-seksualne perverzije koja se može pojaviti u bilo kojem momentu domene seksualnog odstupanja ili zastranjivanja" te se uvijek "razvijaju na bazi neuropatske ličnosti".

Freud sadomazohizam smješta unutar perverzija "fiksiranja privemenih seksualnih ciljeva", kao i voajerizam i egzibicionizam jer dijele zajednički aktivni i pasivni oblik te se u svom tumačenju sadizma i mazohizma poziva na Krafft - Ebingovu definiciju i slaže se da je osnova te sklonosti uživanje u bolu, poniženju i potčinjavaju, ili u aktivnoj ili u pasivnoj ulozi.

Kao i njegov prethodnik, Freud porijeklo sadizma vidi u normalnom muškom aktivnom i agresivnom karakteru, odnosno biološkom čimbeniku sklonosti da nadvlada suprotni spol.

On sadizam dijeli prvo na aktivni, potom nasilni stav prema seksualnom objektu i najzad na zlostavljanje i napominje da "strogo uzevši, samo ovaj posljednji, ekstremni slučaj zaslužuje naziv "perverzija".

Mišljenje koje on zastupa, za razliku od Krafft - Ebinga, koji je "psihopatologizirao" cjelokupni fenomen sadomazohizma, izražava apologiju aktivnog, konsenzualnog sadizma, kakvim ga danas shvaćamo, jer on za njega nije perverzija.

Dok je za njega sadizam primarna perverzija sadomazohizma, Lacan smatra mazohizam primarnim, a sadizam izvedenim iz njega, odnosno "poricanjem sadizma". 
Mazohizam je tako pasivni stav u seksualnoj praksi, čiji je najekstremniji oblik doživljavanje zadovoljenja trpljenjem boli od seksualnog objekta i Freud smatra da se on "više udaljuje od normalnog seksualnog cilja" nego sadizam te čak preispituje nastaje li on iz sadizma.

On radikalno nastavlja da je mazohizam nastavak sadizma, autodestruktivna perverzija kojom subjekt sebe doživljava seksualnim objektom te navodi isključivo kliničke slučajeve ekstremnog mazohizma.

Interesantno je da Freud medikalizira mazohizam, smatrajući ga daleko većom perverzijom od sadizma, koji to za njega i ne mora uvijek biti, za razliku od Krafft - Ebinga, koji mazohizam smatra primarnim a oboje, dosljedno, jednako teškim perverzijama.

Razlog Freudovoj tezi derivacije mazohizma iz sadizma bi svakako bila binarna podjela sadomazohizma, na aktivni i maskulini sadizam i pasivni, feminini mazohizam, te prvenstveno njegovo otvoreno priznanje o nedovoljnom poznavanju ženske seksualnosti i stoga davanje prednosti muškoj.

On zaključuje da sadizam i mazohizam zauzimaju posebno mjesto među perverzijama jer je suprotnost aktivnosti i pasivnosti opća karakteristika seksualnog života, a ta je podjela sadomazohizma, naslijeđena od Krafft - Ebinga, površna i samo djelomično točna jer razvijene mazohističke ličnosti nalazimo jednako često kod muškaraca kao i sadističke kod žena.

Freud ponavlja misao da osoba koja uživa nanositi bol, uživa i trpjeti bol u seksualnom odnosu, da je sadist uvijek istovremeno i mazohist, što je generalizacija koja nipošto ne može biti pravilo već samo slučaj kod izvjesnog broja osoba.

Izrazito je važno napomenuti da kategorizacija aktivnosti i pasivnosti $u$ pogledu sadomazohizma nije dovoljno precizno formulirana, jer u odnosu obje strane moraju biti aktivne, pasivnost je tu više simboličke prirode s obzirom da mazohist također aktivno sudjeluje u seksualnom činu, štoviše, veoma često inicira scenu i upravlja njome i zato obje seksualne sklonosti ili ličnosti, moraju biti izjednačene u shvaćanju njihovog intenziteta i ne bi se trebale dijeliti na osnovi rodnih obilježlja niti jednu doživljavati perverzijom, a drugu samo izrazom maskuline seksualnosti.

Za detaljan uvid u psihologijsku dimenziju sadomazohizma, koja je polazište i za razumijevanje i posebice za samu tu seksualnu praksu, osvrnut ću se na temeljne teoretičare psihoanalize koji su analizirali ovaj fenomen s različitih stajališta.

Od osnovnog će značaja biti promisliti i interpretirati presudne psihološke faktore sadomazohističke seksualnosti te međusobne korelacije sadizma i mazohizma. 
Iznimno je važno prikazati tumačenje sadomazohizma u ranoj psihoanalizi kojoj se već odavno može uputiti brojne kritike, no esencijalna je za daljnji razvitak misli u modernoj i suvremenoj psihoanalizi i filozofiji.

Početku psihoanalize, kao što je već prikazano u prethodnome poglavlju potrebno je, nakon odmaka od preko stotinu godina, prilaziti s velikom dozom opreza.

O Freudovom poimanju perverzija bilo je već riječi i jasno je, kako je on i sam ustanovio, da se u njegovo vrijeme gotovo svaka seksualna aktivnost smatrala perverzijom.

Sada će težište biti isključivo na njegovim tezama o sadizmu i mazohizmu opisanih u brojnim njegovim djelima, od kojih sam izdvojila najrelevantnija i najotvorenija za kasnije poveznice sa suvremenim autorima.

Temelj razmatranja Freudove psihoanalize u komparacije sa suvremenom su psihološki aspekti i tjelesne manifestacije, prvenstveno mazohizma u korelaciji sa sadizmom u njegovim djelima. U spisu „Nagoni i njihove sudbine“ iz 1915. godine, Freud izlaže svoje shvaćanje sadizma i mazohizma smatrajući ih pervertiranim seksualnim nagonima.

Razvoju seksualnih nagona on pridaje slijedeće razvojne faze -preokretanje u suprotnost, okretanje protiv vlastite osobe, potiskivanje i sublimaciju“" 56

On sadizam i mazohizam opisuje kao par opreka, kao što je već spomenuto u prethodnome poglavlju - manifestaciju aktivnog i pasivnog cilja nagona i time uspostave relacije subjekta $i$ objekta doživljavanjem i pozicioniranjem vlastitoga Ja, koji je, odstupanjem od genitalnog stadija, izvor svih psihoseksualnih , devijacija“. ${ }^{57}$

Sadizam, definiran infantilnim kompleksima koji uzrokuju želju za nanošenjem boli objektu koji je nesvjesna zamjena, kod Freuda ne zadobiva realnu seksualnu dimenziju, već ostaje na razini ne samo primjerice Edipovog kompleksa već primarne perverzije te nije ni približno dovoljno elaboriran.

Mazohizam, koji je za Freuda, sekundarni i produkt sadizma - sadizam prema vlastitoj osobi, daleko je opsežnije i stručnije koncipiran i njemu je posvetio mnogo istraživanja i utemeljio jednu ipak konzistentnu teoriju.

Od samoga početka Freud mazohizam tumači kao „okretanje nagona od objekta prema Ja“58 tj. „okretanje od Ja prema objektu“ ${ }^{\text {‘59 }}$ i time misli na postavljanje sebe na mjesto objekta.

\footnotetext{
${ }^{56}$ Sigmund Freud, Nagoni i njihove sudbine, Budućnost jedne iluzije i drugi spisi, Naprijed, Zagreb, 1986, str. 180

${ }^{57}$ Ibid, str. 181

${ }^{58}$ Sigmund Freud, Nagoni i njihove sudbine, Budućnost jedne iluzije i drugi spisi, Naprijed, Zagreb, 1986, str. $181-183$

${ }^{59}$ Ibid, str. 182
} 
Time on odlučno naglašava primat sadističkog nagona koji onda pod određenim uvjetima preuzima suprotni smjer i teorija primarnog sadizma prema drugome slijedi Freudovu tezu o izvornom ,zlu“ čovjeka, koja je eksplicitno izražena u mnogim njegovim djelima.

Za psihoanalitičku teoriju sadizma i mazohizma bitno se koncentrirati za konceptualizacije psihoseksualnih fenomena, no i destruktivnih nagona prema drugome i sebi koji će biti detaljnije objašnjeni pri elaboraciji tzv. destruktivne seksualnosti, koja je fundamentalno oprečna fenomenu erotskog sadomazohizma.

Zasad ću se zadržati na usporedbi Freudovog tumačenja seksualnosti i teorija njegovih sljedbenika, sve do moderne psihoanalize i njene filozofske interpretacije.

Freudova korelacija sadizma i mazohizma i njegove ideje istih daleko su pojednostavljeni i bilo bi uistinu naivno polazeći od tih pretpostavki izvoditi zaključke i zauzimati stavove o sadomazohističkoj seksualnosti koji bi bili gotovo jednaki Krafft - Ebingovima.

Danas bi to bilo potpuno neprihvatljivo i netočno budući da u najranijim teorijama sadizma $i$ mazohizma nije bila postavljena razlika između psihopatološkog, forenzičkog i zdravog seksualnog, no to je i razumljivo obzirom na vremensko razdoblje prvih psihijatrijskih pokušaja tumačenja svih „odstupajućih“ seksualnosti, no već je i tada brojnost slučajeva ukazivala na potrebu za daljnjim istraživanjem i drugačijim pristupima, do kojih je protekao dug period.

U djelima „Nagoni $i$ njihove sudbine“, „S onu stranu načela ugode“, „Ja $i$ ono" te „Nesvjesno“ Freud dosljedno razvija svoju ideju o ulozi nesvjesnog u duševnom životu, što se ponajviše manifestira u ,perverzijama“" sadizma i mazohizma.

Već sam njegov polazak od trauma iz djetinjstva i shvaćanje svake ne isključivo genitalne seksualnosti kao perverzije nikada se nije mogao dostatno znanstveno potkrijepiti, a generaliziranje takvih ideja odavno se pokazalo netočnim.

Naravno, uvijek su postojali takvi stereotipni slučajevi, no u znanstvenom se pristupu ne smiju uzimati kao pravila, već samo kao partikularni slučajevi ili skupine slučajeva pod uvjetom iscrpnih kliničkih ili socioloških istraživanja.

Među najboljim primjerima Freudovog razumijevanja sadizma, naročito mazohizma, pored svakako su teze iz spisa „Nagoni i njihove sudbine“ i „S onu stranu načela ugode“, jer u „Tri rasprave o seksualnoj teoriji“ izlaže samo već ranije spomenute polazišne osnove koje kasnije bitno dorađuje i mijenja.

Nagon i njegov cilj kao temelji njegove teorije seksualnosti imaju presudnu ulogu i u sadističkoj i mazohističkoj seksualnosti te on konstatira da je u slučaju sadističke seksualnosti polazna točka „velika suprotnost između nagona života $i$ nagona smrti“ i „objektna ljubav sama nam 
pokazuje drugu takvu polarnost, naime onu između ljubavi (nježnosti) i mržnje (agresije)“60, što se manifestira „u oralnom stadiju organizacije libida, ljubavno ovladavanje objektom još se poklapa s njegovim uništenjem; kasnije se odvaja sadistički nagon“, zakjučujući da je „,sadizam, istisnut iz Ja, pokazao put libidnim komponentama seksualnog nagona“ te se „tamo gdje se izvorni sadizam nije smanjio u ljubavnom životu se stvara ambivalentnost mržnja - ljubav“. ${ }^{61}$

Na taj način, putem odnosa Erosa i Thatanosa, Freud tumači sadističku seksualnost i za njega upravo nagon smrti, Thanatos ima veliku, ako ne i presudnu ulogu u formiranju seksualnosti uopće, naročito u slučajevima sadističkih i mazohističkih tendencija i praksi - on ovladava libidom na (ne)prirodan način.

Freud prvi započinje odnosom subjekta i objekta ${ }^{62}$, kojeg će kasnije usavršiti Lacan, u svom iscrpnom objašnjenju sadizma i mazohizma koje, shvaćajući ih kao par opreka tumači kao zamjene subjekta i objekta, pri čemu cilj uvijek ostaje isti - seksualno zadovoljenje, no „problem“ je u zamjeni subjekta i objekta, ili protiv sebe kod mazohizma, što je već spomenuto, ili protiv druge osobe, kod sadizma. ${ }^{63}$

On svojom paradigmom, polazeći od sadizma kao primarnog, prikazuje redoslijedom sado mazohističke psihičke procese: sadizam kao nasilje nad drugim kao objektom, kojega se tada napušta i zamjenjuje vlastitom osobom i time Ja ili subjekt, zauzimajući mjesto objekta postaje pasivan, okreće nagonski cilj protiv sebe, da bi naposljetku ponovno tražio drugu osobu kao objekt koja zbog promjene nagonskog cilja u pasivni mora preuzeti ulogu subjekta ${ }^{64}$.

Jasno je stoga da je mazohizam presudan u psihoseksualnom razvoju „pervertiranog“, „devijantnog“ individuuma i njegovih psihičkih procesa, duševnog i tjelesnog ustrojstva, koji postaju neodvojivi i neovisni o seksualnoj supremaciji subjekta i ograničeni na genitalnost kao osnovu seksualnog odnosa.

Freud tek posljednju fazu naziva mazohizmom i u početku ga izvodi iz početnog sadizma i fantazije predavanja drugom subjektu te negira izvorni mazohizam. ${ }^{65}$

Očito je, uzevši u obzir njegov opis razvoja mazohizma, da je on već i u počecima svojih istraživanja smatra mazohizam izuzetno važnim jer nadalje elaborira preobrazbu u mazohizam kao poistovjećivanje s objektom i užitak u boli kao mazohistički cilj koji prevladava prvotni sadistički poriv i cilj. ${ }^{66}$

\footnotetext{
${ }^{60}$ Ibid. str. 180 - 183

${ }^{61}$ Ibid. str. 181

${ }^{62}$ Ibid. str. 81 - 85

${ }^{63}$ Ibid.str. 82

${ }^{64}$ Ibid. str. 82

${ }^{65}$ Ibid. str. 82

${ }^{66}$ Ibid. str. 83
} 
U slučaju mazohizma, radi se o komplementarnom nagonu koji usmjerava sadizam protiv vlastitog Ja i Freud pet godina kasnije, u djelu „,S onu stranu načela ugode“ priznaje da bi on mogao biti i primaran, referirajući se na vlastito osporavanje te ideje i svoju raniju isključivost ${ }^{67}$, što je interesantno jer zapravo time pokazuje da ta dva nagona ne moraju biti niti komplementarni niti ih se može objasniti pukom regresijom na ranije stadije razvoja libida, premda oni ipak čine temelj izgradnje psihičkog ustrojstva.

Mazohizam u modernim i suvremenim teorijama seksualnosti ne može biti shvaćen jednostavno kao produkt Thanatosa, kao manifestacija nagona smrti i autodestrukcije kao destruktivnog nagona već ga, kao i sadizam treba promatrati putem tjelesnih senzacija koje su odraz psihe, prvenstveno erotskog užitka u podražaju boli, njenom doživljavanju ili nanošenju iste.

Možemo ponekad smatrati istinitom pretpostavku da u nekim slučajevima postoje psihičke pozadine sadističkih ili mazohističkih tendencija koje potiču osobu na „prisilno“ uživanje u boli ili ozljeđivanju druge osobe, no one nisu izvorno seksualne već su posljedica raznih trauma, ili davnih ili sadašnjih i osoba želi trpiti ili nanositi bol ili kao sadist ili kao mazohist no to su granično patološki slučajevi koji nisu predmet ovoga rada, ali potrebno je na njih skrenuti pažnju da bi ih se moglo radikalno razlikovati od konsenzualne sadomazohističke seksualnosti koja je utemeljena i vođena Erosom.

Kad razmotrimo Freudovo djelo „The Economic Problem of Masochism“, nameće se zaključak da bi usprkos njegovoj prvotnoj tezi, mazohizam ipak morao biti primaran, budući da mu on posvećuje daleko više pažnje, štoviše, detaljno ga analizira, razvijajući teoriju mazohizmu u smjeru mnogih zaključaka.

O njihovoj znanstveno - teoretskoj utemeljenosti mišljenja su uvijek bila podijeljena, no ja ću iznijeti zasada one osnovne kroz vlastitu psihološku - filozofsku prizmu.

Freud započinje iznošenjem svojih generalnih zapažanja o mazohizmu, pridavajući mu atribute, ne samo seksualne perverzije, već i „trenda“, referirajući se na nekolicinu autora svoga vremena, da bi potom započeo ,istraživati poveznicu načela ugode iliti principa užitka s dviju vrsta nagona koje smo već razlikovali - nagone smrti i erotske (libidinalne) životne nagone“. ${ }^{68}$ Njegova tipologija mazohizma dijeli ga na tri vrste, erotogeni, feminini i moralni, od kojih je erotogeni mazohizam najvažniji za tematiku, a karakteriziran je fantazijama osobe da bude prisiljena na bezuvjetnu poslušnost koja izaziva seksualno uzbuđenje, te je osoba izložena praksama vezivanja, bičevanja, čiji je cilj užitak u boli, jednako kao i kod femininog mazohizma, a Freud oba smatra perverzijama infantilnog porijekla.

\footnotetext{
${ }^{67}$ Ibid. str. 182

${ }^{68}$ Sigmund Freud, The Economic Problem of Masochism, Collected Works, str. 274.
} 
On zaključuje da je jedino moralni mazohizam onaj istinski, vrijedan proučavanja jer je baziran na želji za podređivanjem Superegu, štoviše, Freud smatra da je da je „Kantov moralni imperativ ,, nasljednik Superega“. ${ }^{69}$

Moralni je mazohizam izvan sfere seksualnog, u vladavinom načela realita, ne užitka, a osobe ovog tipa zapravo su niskog samopouzdanja i žele biti vođene nekim određenim autoritetom kojeg smatraju vrhovnim gospodarem.

Manifestacije ovog tipa mazohizma su obilježene odnosom mazohizma Ega i sadizmom Superega, a osobe podložne ovom poremećaju žele biti kažnjene i ponižene jer imaju ukorijenjen snažan iracionalan osjećaj krivnje te potrebu za usmjeravanjem od strane kreiranog idealiziranog autoriteta.

Osobe takve psihičke strukture i svijesti destruktivne su i autodestruktivne jer moralni je mazohizam produkt nagona smrti, no ipak, ,ima važnost erotske komponente jer i samouništenje subjekta ne može se dogoditi bez libidinalnog zadovoljenja “.

Moralni mazohist želi patnju i kaznu u kojoj nalazi zadovoljstvo zbog nezadovoljstva vlastitom ličnošću i egzistencijom, koje je indikator ozbiljnog poremećaja psihe.

Erotogeni je mazohizam je ipak, u suvremenom shvaćanju, onaj istinski jer je libidinalni, istovremeno produkt načela užitka i načelom smrti, budući da uključuje bolne prakse koje vode seksualnom zadovoljenju.

Vidimo da Freudovo tumačenje mazohizma, posebice moralnog, otvara brojna pitanja problematike psihe i načina funkcioniranja psihičkog aparata u relacijama sadizma i mazohizma te doživljavanja vlastite osobe.

Njegovim su teorijama oduvijek su bile upućivane oštre kritike, no i mnogi su kasniji, moderni psihoanalitičari zadržali njegove osnovne polazišne teze.

Da bi se izbjegla pogrešna shvaćanja, neophodno je razumjeti razliku između seksualnih i neseksualnih poriva, jer ako govorimo o sadizmu kao želji za povređivanjem drugoga, jasno je da je već od djetinjstva ona prisutna no u jednom sasvim drugom obliku, možda samo posredno seksualne prirode i to vjerujemo li Freudovoj teoriji infantilne seksualnosti.

Stoga ću taj dio zanemariti i usredotočiti se na konsenzualnu sadističku i mazohističku seksualnost te zauzeti kritičko stajalište u pogledu sadizma i mazohizma jer smatram da se ta dva seksualna poriva ne mogu svesti na jednu „bipolarnu perverziju“, niti da bi sadizam mogao biti primarni perverzni seksualni nagon.

${ }^{69}$ Ibid, str. 277 
Naprotiv, temeljem mnogih suvremenih, no i ranijih empirijskih istraživanja, dokazano je da je u domeni seksualnosti u većini slučajeva mazohizam primaran.

Freudovo je tako razumijevanje i tumačenje sadizma i mazohizma kao perverzija koje su posljedica infantilnih faza odavno prevladano, no njegova je teorija bila bitno polazište i kasnije nadogradnje i istraživanja tog područja seksualnosti, u medicini te društvenim znanostima.

Jacques Lacan je također uviđao usku, intimnu povezanost sadizma i mazohizma jer oba proizlaze iz sadomazohističnog nagona, kojeg je nazivao i invokatornim porivom, jer se i sadist i mazohist postavljaju kao objekt istog poriva ili glasa i bitno je shvatiti da su jedno drugome seksualni objekt, da se dominantna i submisivna osoba međusobno nadopunjuju i usmjeruju. Neophodno je te dvije sklonosti promatrati kao kvalitatitivno jednake jer sadomazohizam zbog užitka i ostvarenja seksualnog cilja nije već od Lacanova vremena prikladno smatrati perverzijom. Potrebno je shvatiti složenu dinamiku sadomazohističkog odnosa da bi se moglo razumjeti i Freuda i suvremene teorije i predstavnike ovog fenomena.

U pokušaju da razjasni kliničku sliku sadomazohizma kao pervezne seksualnosti, on psihoneuroze izvodi iz perverznih seksualnih nagona, za njega je "neuroza negativ perverzije", što Lacan kritizira, utvrđujući da su perverzije i neuroze jednako strukturirane.

Freud perverzije svodi na "parcijalne nagone", a te nagone tumači kao psihičke predstavnike izvora draži, i perverzni nagoni tako imaju specifične seksualne ciljeve.

Njegova teorija o nagonima pretpostavlja da tjelesni organi koji pružaju uzbuđenja imaju ulogu erogenih zona, a to su kod perverznih skonosti posebice usne i koža, koja je vjerojatno primarna erogena zona u sadomazohističkoj seksualnosti kao subjekt svih seksualnih aktivnosti.

Kompletna i zdrava seksualnost sastoji se tako od sinestezije nagona, erogenih zona koje vode do seksualnog cilja i tzv. perverzija i genitalnog odnosa.

Slijedeći dugu tradiciju psihoanalize i njene brojne struje, posebno suvremene teoretičare zaključit ću logičnom suvremenom tezom i ujedno vodećom idejom rada, a to je sadomazohizam kao većinom urođena sklonost, fenomen je koji u praksi pruža enormno zadovoljenje, stimulira maštu i kognitivne sposobnosti osoba koje je ostvaruju.

On izgrađuje osobe koje ga prakticiraju, omogućuje im da se tjelesno i psihički realiziraju i sve dok je konsenzualan te služi obostranom užitku, prirodna je i zdrava seksualnost, kao i svaka druga, ukoliko ispunjava zdravstvene i etičke uvjete.

Sadomazohizmu bih stoga mogla dati atribut trancendentalnog koji nadilazi seksualne kategorije, kao što je Judith Butler konstatirala za pojam roda, smještajući ga među 
seksualnostima, ili seksualnim preferencijama ili, kako se dugo smatralo i još u mnogim krugovima smatra, parafilijama ili perverzijama.

Moje bi mišljenje, u odnosu na Freuda i Lacana bilo da je perverzija kao odrednica sadomazohistički orijentirane osobe entitet koji omogućuje egzistenciju osobe koja aktivno prakticira određenu seksualnu aktivnost jer je ona (perverzija) dio bitka te osobe.

Perverzija može stoga biti shvaćena kao entitet, no prije i preciznije kao bitna odrednica i dio entiteta, jer kao entitet mislim prvenstveno osobu koja je prakticira ili je njome aficirana te bih na taj način pokušala uspostaviti definiciju odnosa sadomazohizma i individuuma, sadista ili mazohista, kao odnos subjekta, objekta, njegovog entiteta, bitka i egzistencije unutar sadistikog ili mazohističkog entiteta te njegovog ozbiljenja.

Gilles Deleuze odlučno postavlja fundamentalne razlike između sadizma i mazohizma referirajući se na djela Sadea i Masocha - ,, suprotstavljajući procese negativa i negacije s jedne strane i poricanja i suspenzije s druge “. ${ }^{70}$

Sadizam prikazuje kao baziran na univerzalnoj negativnosti kao aktivnom procesu, negaciji kao ideji čistog razuma, gdje su esencijalne deskripcije i demonstracije kao analitički prikazi nagona smrti, dok mazohizam transcendira u mitski i dijalektički poredak Imaginarnog. ${ }^{71}$

Mazohizam je osnovna tema Deleuzove filozofije seksualnosti upravo zbog uloge suspenzije kao odgađanja seksualnog čina i literarnog odgađanja erotskog i decentnih opisa i implikacija u Masochovim romanima, dijalektike i ideje čiste imaginacije, kao kontrast razumu kod Sadea ${ }^{72}$ i u njegovom je djelo jasno vidljiva ekplicitna supremacija mazohizma kao temeljnog seksualnog poriva koji prethodi svim ostalima.

Psihičko - seksualna praksa mazohizma sadrži upravo te elemente - suspenzije kao vezivanja i motoričko - senzorne deprivacije te odgađanje seksualnog zadovoljenja te dijalektiku i imaginaciju kao poziciju i ulogu mazohističkog subjekta.

Odnosi moći podređene i nadređene osobe dijalektički su proces izmjene moći, odnosno „power exchange" gdje je većini teoretičara mazohizam osnova sadomazohističkog odnosa zbog moći imaginacije i želje zadovoljenja Drugog koju mazohist jasno pokazuje i izražava.

Stoga kada se govori o psihoseksualnoj praksi sadomazohizma, do izražaja dolazi isprepletanje Imaginarnog i Realnog kao neprestana erotska vječna dinamika.

\footnotetext{
${ }^{70}$ Gilles Deleuze, Coldness and Cruelty, Zone Books, New York, 2013, str. 35, prijev.a.

${ }^{71}$ Ibid. str. $34-35$.

${ }^{72}$ Ibid. str. 32 - 35
} 
Na tragu ovih ideja, suvremene psihoanalitičke teorije i uvidi o sadomazohizmu bit će izloženi i kritički protumačeni te komparirani s ranom psihoanalizom, osobito socijalno - filozofskim interpretacijama Freudovih teza.

Freudov sljedbenik i isprva „,vatreni“ nastavljač njegovih teorija, Wilhelm Reich, bečki psihijatar, koji je svojom specijalizacijom u psihoanalizi i psihologiji seksualnosti brzo napredovao kao voditelj seminara na Bečkom psihoanalitičkom institutu i time postao jedna od najutjecajnijih figura bečke psihoanalitičke škole, neophodan je za shvaćanje postfreudovskih teorija, poglavito udaljavanja od „klasične“ psihoanalize i konačno njenog populariziranja raznim ,alternativnim“ pristupima.

Kao nadobudan student, svoju je prvotnu teoriju utemeljio na Freudovim istraživanjima i spisima, no nedugo zatim došao je do raznih „spoznaja“ koje su se potpuno odmaknule od njegovih ideja i time ,zastranio“ u radikalnu simplifikaciju psihoanalitičke teorije te fabriciranje proizvoljnih, znanstveno neutemeljenih teorija.

Reich već 1920-ih postaje „opozicija Freudu“ kritizirajući nedostatnost njegovih teorija da bi nametnuo svoje uske, simplificirane interpretacije seksualnih perverzija i neuroza. Njegove spekulativne teorije seksualne energije dovele konačno do trajnog isključenja iz Bečkog i potom Međunarodnog psihoanalitičkog društva.

U svom djelu „Analiza karaktera“, Reich veoma usko i neinovativno nastavlja na Freudovu teoriju neuroza. Njegovo pojednostavljivanje izvora neuroza bilo je zapaženo i od Freuda samog jer je izvor svih neuroza za Reicha bio u inhibiranoj „orgastičkoj potenciji“ a njihov „lijek“ u genitalnom orgazmu.

On zapravo nije dobro shvaćao bit psihoanalize, ni u teoriji niti u praksi, svodeći sve psihičke poremećaje na jedan nazivnik te je u svim svojim djelima bio suviše konzervativan upravo zbog svog uskog shvaćanja seksualnosti, no činjenica je da su ga kasnije generacije i teoretičara i akteri popularne kulture doživljavali kao „osloboditelja seksualnosti“ jest njegova potpuno neznanstvena teorija orgona, koja će biti detaljnije izložena.

Zasada je važno naglasiti njegovo shvaćanje seksualnih perverzija i neuroza, prvenstveno sadizma i mazohizma, koje on veoma ograničeno, bez imalo originalnosti tumači kao nedostatak genitalnog orgazma ili čak straha od orgazma, što je bilo neprihvatljivo već Freudu, a danas većinom nezamislivo. 
Njegove su ideje, premda bazirane na kliničkim ispitivanjima i proučavanju individualnih slučajeva njegovih pacijenata, uvelike pogrešno izvedeni i pretjerano pojednostavljeni freudovski ,postulati“.

Jedan od najboljih primjera je da Reich mazohizam opisuje kao težak psihički poremećaj, pasivno - feminin po svojim značajkama, koji neupitno zahtjeva liječenje metodom uklanjanja „oklopa“" mazohističkog karaktera. ${ }^{73}$

Važno je napomenuti da je uvijek postojala razlika između kliničkih slučajeva patološkog mazohizma, koje je Reich ispravno zamijetio, no svoje shvaćanje nije proširio na slučajeve mazohističke seksualnosti u kojoj genitalni spolni odnos nije centralno pitanje, niti je riječ o psihičkim poremećajima i stoga tu razliku ili nije razumio ili nije želio prihvatiti.

U „Analizi karaktera“ relevantna je razrada oblikovanja karaktera te teorija seksualnosti kroz elaboraciju oblikovanja karaktera, od kojih ću izdvojiti mazohistički karakter, koji Reich deskriptivno shvaća putem razvoja strukture ličnosti i uspostave genitalnog karaktera, no za njega dobrim dijelom proizlazi iz histeričnih, prisilnih i narcističkih korijena, što je isključivo genitalno ograničeno shvaćanje seksualnosti. ${ }^{74}$

U Reichovoj teoriji najproblematičnija je, pored ostaloga spomenutog, teza da mazohizam nije biološki urođen nagon, eksplicitno izraženo njegovim izvođenjem iz raznih neuroza, što je odavno osporeno, kao i ideja da je on feminino - pasivan što je preuzeo od Freuda no veoma je diletantski nastavljao njegove misli.

Reich spominje i „mazohističku inhibiciju orgazmičke funcije“, što se svakom poznavatelju već desetljećima, pa i stoljećima (uzmemo li u obzir „lascivne autore“ od antike do 20. stoljeća) čini apsurdno i potpuno kontradiktorno, obzirom je upravo bol izvor užitka koji teži orgazmu kao cilju, što je već i Freud s razumijevanjem elaborirao u svojim teorijama seksualnosti.

Reich i sadizam i mazohizam tumači isključivo kao posljedice destruktivnih nagona smrti, ali istovremeno i predavanje istima i strah od njih te polazeći od opreke nagona života i smrti uspostavlja svoju verziju tumačenja sadomazohističke seksualnosti neuropatskom teorijom libida kao želje za kaznom, samoozlijeđivanjem i karakternim poremećajem koji bi se pripisivao osobi niskog samopouzdanja i nerazvijene genitalne seksualnosti, što, naravno, potječe od brojnih bizarnih trauma iz djetinjstva i mladosti, što on slikovito i oprimjeruje. ${ }^{75}$ Već sam termin „oklopljivanje mazohističkog karaktera“ ukazuje na negativan predznak psihički „zarobljenog“ individuuma kojem je potrebno „oslobođenje“ od njegove

\footnotetext{
${ }^{73}$ Wilhelm Reich, Analiza karaktera, Naprijed, Zagreb, 1982. str. 192

74 Ibid. str. 193 - 200

75 Ibid. str. 195 - 203
} 
„mazohističke bolesti“ i uspostavljanje „zdravog“ libida i Reich mazohistične osobe opisuje kao neurotične i sklone tjeskobi, a opet priznaje da iste osobe same tvrde da im bol čini najveću ugodu, čime se ponavljaju njegove kontradikcije i nedostatak znanstvenog pristupa. ${ }^{76}$

On kao temeljne karakteristike mazohista navodi ,trajan subjektivan osjećaj patnje, koji se očituje kao sklonost da se žali; zatim slici mazohističkog karaktera pripadaju trajne sklonosti samopovređivanju $i$ samoponižavanju (,moralni mazohizam“) $i$ jaka strast za mučenjem drugih, od čega mazohist trpi ne manje od svog objekta ". ${ }^{77}$

Takvo shvaćanje mazohističke ličnosti u većini je slučajeva potpuno pogrešno kad se govori o seksualnom mazohizmu, jer sva su suvremena istraživanja (Baldwin, Benjamin, Mains, Moser, Rinella), dokazala da je najčešće upravo suprotno, odnosno, da su mazohisti izrazito jake osobe sa snažnim karakterom i jednako snažnim seksualnim nagonom i upravo im je stoga potrebna ova vrsta stimulacije jer njihovo psihofizičko ustrojstvo zahtjeva više od samog seksualnog odnosa zbog potrebe za endorfinskim podražajima.

Osvrt na pojmove objekta i prijenosa te konačno doživljavanje sebe kao objekta Reich primjećuje putem odnosa ega i superga uspostavljenog u djetinjstvu, što ga iz mogućnosti razumijevanja mazohističkog karaktera vraća na sam početak tumačenja Freudovih teorija.

Mazohizam je stoga kod Reicha pojednostavljen do krajnjih granica, a teorija veze neuroza i seksualnosti najvećim dijelom neznanstvena i neoriginalna.

Reichov život i njegovo subjektivno, veoma kontradiktorno shvaćanje seksualnosti te profesionalno no i aktivističko djelovanje $\mathrm{u}$ tom području neposredno je vezano za razumijevanje njegove teorije seksualnosti.

Bitno je stoga ukazati na njegove najveće kontroverze u shvaćanju pojmova perverzije, neuroze, homoseksualnosti, seksualne slobode i naposljetku seksualne energije koje je tumačio dvosmisleno i proizvoljno, što je dovelo do njegovog razvijanja pseudoznanstvene teorije orgona i orgonskih akumulatora bez ikakvih znanstvenih osnova i dokazanih rezultata, umjesto razvijanja znanstvene psihoterapije pri liječenju seksualnih inhibicija i oslobađanja libidinalne orgazmičke energije $^{78} \mathrm{i}$ on je perverzijama nazivao sklonosti koje to nisu, a pod „,seksualnim oslobođenjem“" nametao je propagandu preskribirane genitalne seksualnosti i time zapravo uskraćivao slobodu izbora svojim pacijentima, no svojim je osebujnim

\footnotetext{
${ }^{76}$ Ibid. str. $201-203$

77 Ibid. str. 203 - 205

${ }^{78}$ Jean Michel Palmier, Wilhelm Reich, Ogled o rođenju frojdomarkizma, Beogradski izdavačko - grafički zavod, Beograd, 1977 str. 171 - 180
} 
„artističkim“" pseudoterapeutskim metodama stekao popularnost, koju je uživao i nakon isključenja iz svih psihoanalitičkih organizacija, a i dugo nakon smrti.

Perverzija je samo inhibirana seksualna fantazija, koja ukoliko se ne ostvari u praksi prerasta u neurozu i opsesiju, a Reich je tu problematiku izokrenuo, polazeći od neuroza do takozvanih perverzija, što je posebno vidljivo u njegom odnosu prema homoseksualnosti, a naročito sadizmu i mazohizmu, koje su za njega, same po sebi, bespogovorne perverzije kao neuroze uzrokovane neostvarenom dominacijom genitalne seksualnosti.

Nakon prethodnih uvida u Reichove teze o sadomazohizmu, potrebno je spomenuti i njegove pozitivne i inovativne doprinose za psihoanalizu i društvene znanosti njegova vremena, no i za općenito stanje svijesti društva prve polovice 20. stoljeća, no i kasnije, kada je od najveće važnosti za socijalnu filozofiju bila njegova marksističko - psihoanalitička misao.

Njegovo zalaganje za seksualnu slobodu i pravo izbora od najveće je važnosti za temu ovoga rada, kao i njegova elaboracija tjelesnih senzacija, seksualne energije i orgazma, no bitno je razlučiti njegove racionalne i znanstvene, rane teorije od kasnijh neznanstvenih spekulativnih, populariziranih ideja.

U svom najvažnijem djelu o seksualnosti, „Funkciji orgazma“, Reich konačno postavlja finalno razgraničenje pojmova „seksualno „, i ,genitalno“ te orgazam shvaća kao ultimativni cilj i imperativ, ukazujući na psihofizički tijek seksualnog nagona.

On detaljno razrađuje i opisuje faze spolnog odnosa i orgazma, te razlikuje „,normalni tijek“ od nimfomanije ili ,prijenosa sa prvobitnog objekta na objekt maštanja“.

Za njega „pravi prijenos“ libidinalne energije označava isključivi realni seksualni doživljaj usmjeren samo prema realnom objektu, odnosno partneru, dok je prijenos seksualne želje prema objektu fantazije iluzorno iskustvo koje uzrokuje seksualno nezadovoljstvo i neurotski poremećaj ${ }^{79}$, jer on konstatira da:

„Kod pravog prijenosa izostaje precjenjivanje realnog objekta;svojstva koja protiurječe prvobitnom objektu pravilno se procijenjuju i toleriraju ; kod nepravog prijenosa idealizacija je isuviše velika i prevladavaju iluzije; negativna svojstva se ne opažaju (potisnuta su), a aktivnost maštanja ne smije se prekinuti, inače bi se izgubila iluzija. "80

Mašta i idealizacija neizostavni su dijelovi seksualnosti i ponekad njihovo dugororočno neostvarenje može dovesti do određenih frustracija, no tada ne bi bilo rješenje pokušaj „preusmjeravanja“ na realni objekt već nastojanje ostvarenja seksualnosti onkraj realnog, prema željama i preferencama individuuma.

\footnotetext{
${ }^{79}$ Wilhelm Reich, Funkcija orgazma, Mladost, Beograd, 1990, str. 29 - 31

${ }^{80}$ Ibid,str. 30 - 31
} 
Seksualnost i realno nisu već odavno u našim kognitivnim sustavima međusobno povezani, već najčešće na potpuno suprotnim polovima i time Reich minorizira važnost mašte u seksualnosti, koja je jedna od elementarnih čimbenika ne samo BDSM seksualnosti, već seksualnosti uopće. Kao što je već utvrđeno, želja i seksualnost zauzimaju mjesto izvan realnog, u imaginarnom, u fantazijama koje je potrebno osvijestiti i realizirati i tome je smislu Reich nastavljač psihoanalitičkog „konzervativizma“ budući da, kao i Freud, nastoji ukloniti simptomatiku nesvjesnog i stoga „maštanja koja ne smiju postati svjesna mogu samo smetati““، ‘81

Elaboraciju faza spolnog odnosa Reich započinje psihomotornim podražajem i ipak ,,nježnom agresivnošću“, te nastavlja penetracijom i kontrakcijom mišića bez „oblika sadističke želje za probadanjem kao što se to događa kod prisilno neurotskih karaktera“ te konačno kulminira obostranim orgazmom pri kojem se „orgastička uzbuđenost raspodjeljuje po cijelome tijelu “ da bi nakon zadovoljenja uslijedilo odsutstvo seksualnog uzbuđenja, koje je i dalje prisutno samo kod nimfomanije. ${ }^{82}$

Ovakvo je pojednostavljeno, opisivanje seksualnog odnosa odavno prevladano, naročito spomenemo li još da je za postizanje istovremenog orgazma potrebna usredotočenost na jedan objekt i pritom se isključuje svjesno maštanje. ${ }^{83}$

Kod većine je osoba upravo maštanje i fantazija ono što inicira seksualno uzbuđenje i upravlja spolnim odnosom Reichovo „precjenjivanje objekta“ i fetišizam za mnoge su neophodni za postizanje orgazma i stoga Reich seksualnost uvelike ograničava.

Drugim riječima, on u svojoj freudovskoj fazi, seksualnost tumači preskriptivno i racionalno, dok je ona u svojoj suštini deskriptivna, raznolika i iracionalna.

Smatram da je ta razlika najbolje uočljiva u sadomazohističkoj seksualnosti jer je seksualno sve samo ne ograničeno na genitalno, štoviše, uopće ne mora biti genitalno da bi se postigao „ultimativni cilj“,dok, naravno, genitalno jest uvijek seksualno kao tek jedan element seksualnosti, no spolni hetero ili homoseksualni odnos nikad ne može ne može činiti potpunu, cjelovitu seksualnost, posebice kad razmatramo submisivnu i dominantnu orijentaciju, kao i brojne druge „netradicionalne“ varijacije unutar BDSM seksualnosti, nestereotipne, negenitalne, nemonogamne, neheteroseksualne - neograničavajuće .

Postavljajući ove opreke stereotipnoj seksualnosti, koja može uključivati povremene blaže „eksperimente“ raznih S/M aktivnosti, no u suštini je , l'art pour l'art “ (sex pour sex) usmjerena

\footnotetext{
${ }^{81}$ Ibid. str. 30

${ }^{82}$ Ibid. str 25 - 29

${ }^{83}$ Ibid. str. 30
} 
u svojoj praksi, najbolje možemo razumjeti psihofizičku egzaltaciju osjetila do orgazma na način kojim ga Reich opisuje primjenjivim u kontekstu sadomazohističkog odnosa.

Zalaganje za seksualnu slobodu i naglašavanje važnosti seksualne energije i orgazma svakako moraju biti smatrani kao pozitivni doprinosi njegovog djela tadašnjem društvu no moramo ih uzimati s mnogo opreza zbog brojnih kontradikcija.

U Reichovoj je teoriji seksualnosti i orgazma uistinu mnogo spornih teza od kojih ću izdvojiti onu temeljnu u „Funkciji orgazma“, a to je samo shvaćanje „orgazmičkog poremećaja“, odnosno anorgazmije i njegovih teorija iste. ${ }^{84}$

Prvo je važno napomenuti da je sam pojam veoma subjektivan i kao takav zapravo u praksi i ne postoji u pravome smislu već je problem u načinu na koji svaka pojedina osoba doživljava i prakticira seksualnost, i tijelom i psihom.

Reich anorgazmiju pri genitalnom spolnom odnosu, bez ustručavanja, smatra čak neurastenijom, a navodi i brojne druge teške poremećaje, analogno im pripisujući „odgovarajuće“" orgazmičke probleme.

Navest ću primjer tzv. „cijepanja orgazma“ koji on objašnjava kao akutnu neurasteniju pod kojom on podrazumijeva svojevrsnu „orgastičku impotenciju“ li „relativnu orgastičku potenciju“ uvjetovanu zadržavanjem iodgađanjem orgazma uslijed prekratkog ili predugog trajanja spolnog odnosa, a popratne pojave ovog „poremećaja“ su „,razdražljivost, osjećaj neugode pri radu, stanje umora, neodređene tjelesne tegobe kao bolovi u leđima itd.“85.

Problem koji je ovdje ponovno vidljiv je Reichova fiksacija na genitalni odnos koji bi, pored svega, morao biti i vremenski normiran.

Ovaj je primjer bitan zbog skretanja pozornosti na intencionalno odgađanje ili „zabranu“ orgazma kao dio S/M odnosa, što je veoma učestala praksa zbog povećanja uzbuđenja i orgastičke potencije, a nipošto njenog smanjivanja.

Odavno je poznato i medicinski jasno na koji način živčani sustav regaira na podražaje i orgazam i kada može biti riječi o eventualnom poremećaju neke funkcije, no danas je to daleko drugačije, u smislu da se anorgazmički i uopće svi seksualni liječe psihoterapijom i osvještavanjem seksualnih preferenca pojedinaca.

Reichovo njegovo tumačenje orgastičke potencije potrebno je ispravno shvatiti jer njegova konstatacija da „neurotičar obolijeva zbog nepotpunog zadovoljenja i da je somatsko i psihičko

\footnotetext{
${ }^{84}$ Wilhelm Reich, Funkcija orgazma, Mladost, Beograd, 1990

${ }^{85}$ Ibid. str. 37
} 
zapriječavanje libida jezgra neuroze ${ }^{\text {“86 }}$ apsolutno je točno, shvatimo li seksualnost ispravno, u suvremenom medicinsko - psihološkom smislu.

Ova se tvrdnja odnosi posebice na sadomazohističku seksualnost jer je osobama sa dotičnim seksualnim preferencama, štoviše, potrebama, veoma često teško pronaći adekvatnog partnera i ostvariti zadovoljenje.

Razlog tome su i međusobna kompatibilnost partnera, no često i društveno uvjetovane prilike, koje još uvijek u mnogim sredinama ne prihvaćaju BDSM egalitarno, kao način života kvalitativno jednak ostalima.

Također, izrazito je važno za sadomazohističku seksualnost istaknuti nepobitnu činjenicu da se orgazam ne može svesti na genitalni spolni odnos, niti isključivo spolni odnos uopće.

Problem je u shvaćanju ove seksualnosti „perverzijom“ i normiranjem seksualnosti kao strogo genitalne, heteroseksualne, a svako odstupanje uvijek je, pa i danas, bilo najjednostavnije svrstati pod „psihički poremećaj“, „,neurozu“ ili samo prolaznu fazu određene životne dobi.

Ukazat ću na komparaciju faze orgazma na način na koji je Reich tumači i u kontekstu seksualnosti BDSM - a.

Reich orgazam tumači putem stadija psihofizičke seksualne egzaltacije i trajanjem seksualnog uzbuđenja, što je uvjetovano živčanim, senzornim i motornim sustavom te usmjerenošću na libidinalnu koncentriranost na genitalno. ${ }^{87}$

Upravo je zato prvi dio „Funkcije orgazma“ važan i pozitivan Reichov doprinos za teoriju seksualnosti i izuzetno je važna za sadomazohističku seksualnost jer Reich svojom teorijom veze psihičkog, tjelesnog i orgazmičkog objašnjava neke elementarne faze orgazma i ono osnovno za psihologiju seksualnosti ranog 20. stoljeća, no danas, naravno, samo neke od tih teza mogu biti smatrane valjanima.

Kod Reicha je stoga neizmjerno važno razlučiti znanstveno od neznanstvene ,popularne teorije“ jer je u jednoj knjizi nalazimo i psihoanalitički relevantne, premda ne osobito inovativne cjeline a i potpuno besmislene ideje koje je on, nažalost, u svojoj kasnijoj fazi, ozbiljno shvaćao i to odlično prikazuje francuski teoretičar Jean Michel Palmier u svojoj knjizi „Wilhelm Reich - Ogled o rođenju frojdomarksizma“ 88

Reichovo opsežno razmatranje seksualnih poremećaja te iznalaženja solucija problematike orgastičke moći i potencije u smjeru liječenja neuroza da bi se, otklanjanjem određenih

\footnotetext{
${ }^{86}$ Ibid. str. 33

${ }^{87}$ Ibid. str. 34 - 100

${ }^{88}$ Jean Michel Palmier, Wilhelm Reich, Ogled o rođenju frojdomarkizma, Beogradski izdavačko - grafički zavod, Beograd, 1977
} 
psihičkih zapreka, postiglo seksualno zadovoljstvo i orgazam također, najrelevantnije su njegove ideje, no samo u slučajevima kad se radi o istinskim poremećajima i adekvatnim psihoanalitičkim metodama.

Kao što sam već napomenula, bitno je odijeliti „pseudoporemećaje“ kao što su konsenzualni užitak u boli - sadizam ili mazohizam od primjerice anorgazmije ili impotencije, što Reich najčešće nije činio.

Za razmatranje sadomazohističke seksualnosti kojoj je psihičko ustrojstvo temeljni izvor i time psihologija mora biti polazište, osvrnut ću se na nekoliko uvriježenih mišljenja i predrasuda u okvirima psihologije i medicine.

U psihijatriji i psihologiji se oduvijek smatralo da su sklonosti sadizmu i/ili mazohizmu posljedice raznih trauma, posebice zlostavljanja u djetinjstvu i pubertetskoj dobi, no premda u nekim slučajevima postoje takve poveznice, sva su recentnija znanstvena istraživanja pokazala da nema nikakvih čvrstih, opravdanih dokaza za generalizaciju takvih zaključaka, tj. da se radi o partikularnim slučajevima.

Uvjerenje koje ovaj rad zastupa, utemeljeno na brojnoj literaturi i studijama slučajeva i pojedinaca i BDSM zajednica, jest da je ta ideja, koja datira od 19. stoljeća, a kulminirala je s Freudom, Ferenczijem, Havelock - Ellisom te još mnogim analitičarima, pojednostavljivanje fenomena sadomazohizma zbog nemogućnosti njegova objašnjenja, drugim riječima, nedovoljnog znanja o seksualnosti i psihi.

Naravno, postoje brojni slučajevi osoba mazohističnih osoba kojima je podsvjesna namjera kažnjavanje sebe zbog osjećaja krivnje kao žrtve zlostavljanja ili manjka samopouzdanja zbog vlastitih neuspjeha i osjećaja bezvrijednosti i svoje traume ispoljavaju ili u pogrešnom sadomazohističkom odnosu i samoozlijeđivanju.

Tada je neupitno riječ o patološkom poremećaju jer se ne radi o (sado)mazohizmu u njegovom iskonskom smislu, u kojem ga ovaj rad opisuje, niti o osobama koje možemo nazvati S/M praktikantima - koje ga suštinski shvaćaju i istinski žive.

U svom opsežnom, političko - seksualnom, manifestno nastrojenom djelu „Spolna revolucija“ iz 1936.godine, Reich nastoji razbiti konvencionalno poimanje seksualnosti koje je ljudima nametnuto od najranije mladosti i time ih čini seksualno nezadovoljnima subjektima društveno - političkog sustava.

Primijenimo li ove teze na BDSM seksualnost, odnosno dotičnu seksualnu predispoziciju, uvidjet ćemo da konflikti s roditeljima ili manjak istih ne može ipak u većini slučajeva biti „uzrok“ ili razlog sadomazohizma, samim time što govorimo o predispoziciji kao dimenziji karaktera s kojom se individuum rađa i postupno ga, od najranije mladosti, otkriva i razvija. 
Za Reicha su sve seksualne prakse svedene na paradigmu „obitelj - pubertetska apstinencija inhibicija - neuroza“, a u psihologiji sadomazohizma je neophodno pobiti i zanemariti takva „pravila“ za težnje ka dominaciji ili submisivnosti.

U „Spolnoj revoluciji“ Reich nas uvodi u jedno specifično „društvo seksa“, Foucaultovim terminom, u kojem nema gotovo nikakvih ustaljenih normi ni pravila, osim jednog - seksualnog zadovoljstva pod svaku cijenu, uz imperative odbacivanja malograđanskog seksualnog morala poput seksualne apstinencije, spolnih odnosa u svrhu reprodukcije, već rezolutnog osvještavanje u pogledu seksualnog užitka i kontracepcije.

Međutim, jedna stvar ostaje upitna i problematična, i to je upravo seksualna submisivnost žena i njihova obveza da budu seksualni objekti muškarcima, jer Reich najnormalnije proklamira da je bit seksualne revolucije i oslobođenja upravo nesputano „,iživljavanje“ spolnog nagona i pritom se referira na prominentnu sovjetsku komunističku političarku, aktivistkinju za ženska prava iz vremena „socijalističko - seksualne“ borbe mladeži u Sovjetskom Savezu 1920 - ih i 30 - ih godina 20. stoljeća, Sofie Smidovič $(1872-1934)^{89}$, koja ,ironizira i prezire spolnu ideologiju " mladeži postrevolucionarne epohe:

„Svaki član komunističkog saveza omladine može i smije iživljavati svoj spolni nagon. Iz nepoznatih razloga to vrijedi kao nepobitan zakon.

Spolna se apstinencija osuđuje kao „,malograđanština“.

Svaka mala komsomolka, ženski član Komunističkog saveza omladine na koju padne izbor ovoga ili onoga momka, mora mu biti podatna, inače je „malograđanka“, ne zavrijeđuje ime proleterske studentice. “

Reich time jasno izražava svoj stav - slaganje sa seksualnim oslobođenjem u Sovjetskom Savezu, no i osviještavanje po pitanju kontracepcije kojim bi se riješili problemi dovođenja u pitanje prikazane ,seksualne ideologije“.

Isti ovaj citat navodi i u „Masovnoj psihologiji fašizma“ i to s afirmativnim stavom, prikazujući seksualnu slobodu proleterske mladeži u odnosu na malograđanski moral, zabrane i ograničenja, prelazeći čak i neke granice seksualne slobode, naime, izvjesnu slobodu izbora u ime seksualnog imperativa, na što ću se još osvrnuti u prikazu destruktivne seksualnosti i etike. Može se reći da bi Reich navedenu seksualnu politiku Sovjetskoga Saveza u potpunosti podržao, no uz disciplinu kontracepcije - kao seksualnu slobodu i društvo na granici Huxleyevog „Vrlog novog svijeta“ i Orwellove „1984“, dakle, jednu „optimalnu“ opciju seksualno oslobođenje uz kontrolu provođenja istoga, kao imperativ društva i tijela pojedinca.

\footnotetext{
${ }^{89}$ Wilhelm Reich, Spolna revolucija, Naprijed, Zagreb, 1985, str. 200 - 234
} 
Jasno je stoga zašto Reich spominje socijalističko - feminističku poziciju koja ne prihvaća seksualnu dominaciju muškaraca - on, izgleda, želi pokazati da se tu zapravo radi o „,normalnom“ seksualnom poretku jer za njega je društveno stanje u kojem je svatko svačiji seksualni objekt, u kojem, Huxlyevim riječima, svatko može i mora imati svakoga, pravo oslobođenje i cilj seksualne revolucije.

Asocijacija koja dolazi na pamet kao paralela ovom poretku jest također onaj u dvorcu Roissy iz "Story of $O$ " - zatvoreno BDSM društvo u kojem svaka žena mora biti podložna i uvijek na raspolaganju svakome muškarcu, tu se radi o bezuvjetnom i neograničenom seksualnom posjedovanju koje će biti jedna od tema četvrtoga poglavlja. Upravo je zbog tih poveznica bilo važno ukazati na ovaj Reichov osvrt koji budi brojne ideje o promišljanjima bitnih znanstvenih i književnih djela o BDSM - u.

Iz njegove opsežne analize seksualne revolucije vidljivo je da seksualnost za Reicha predstavlja elementarno društveno pitanje, no naglašena je i snažna ideološka dimenzija i stoga su ovi navodi bitni za uvid u njegovo poimanje seksualno slobodnog društva, što je uvijek bilo i ostaje područje političkih konflikata.

Kao suvremene paralele, navest ću još uvijek aktualno pitanje prava homo i transseksualnosti u relaciji s BDSM orijentiranim zajednicama i pojedincima te Reichovo društvo seksa možemo shvatiti kao falocentrično, antifeminističko, no iz njega možemo iščitati i neke poveznice s BDSM zajednicama i pripadajuće fikcije.

Pri tome mislim na „pristanak bez pristanka“ ili „,consensual non - consent“, pojam koji će biti još spomenut u kontekstu BDSM - a, a i Reichov imperativ orgazma oba partnera i maksimu seksualnog zadovoljenja.

On je osuđivao sputavanje seksualno - političke revolucije mladeži od strane konzervativne reakcije, no na način koji je opet bio i ostao veoma sporan zbog pretjeranog nametanja „diktature“ pseudopsihoanalitičkih ideja.

O seksualnosti i teoriji orgazma Reich najviše govori u „Funkciji orgazma“, i to, o poremećajima orgazma kao obiteljsko - društveno uvjetovanim neurozama kao posljedicama seksualnih inhibicija i on, pored brojnih generaliziranih spekulacija, ima i ponešto valjanih teza, no osnova njegove teorije su suviše radikalizirane Freudove teorije, potkrepljene poveznicama društveno - političke situacije vremena i partikularnih, ektremnih kliničkih slučajeva.

Bitno se tada usredotočiti na odnos psiha - drušvo - seksualnost i u Reichovom kontekstu razumijevanja seksualnog zadovoljenja i orgazma kao cilja prikazati poveznice sa sadomazohističkom seksualnošću. 
Važne smjernice za drugačiju interpretaciju Reicha, umjesto samo kao nastavak Freudovih teorija prvenstveno je njegova ideja da ukoliko su zadovoljenje i orgazam ciljevi jer tada niti seksualni sadizam i mazohizam nisu perverzije ako vode tim ciljevima.

Reich se time zalaže za obostrano zadovoljstvo partnera i smatra velikim problemom ukoliko jedan od partnera nije zadovoljan u seksualnom odnosu jer bit je da su partneri međusobno duboko psihički povezani i izuzetno kompatibilni te spremni učiniti sve jedno za drugoga, u okvirima zajedničkih želja da bi ostvarili najveće zajedničko zadovoljstvo.

Ta je misao izuzetno važna za BDSM odnos, koji se i temelji na međusobnom razumijevanju i obostranom zadovoljstvu, a nezadovoljsvo jedne osobe je nedopustiva jer je briga i o partneru i o sebi osnovni preduvjet, budući da su u istinskom BDSM - u česte i prakse uskraćivanja orgazma, tzv. ,orgasm denial “ no to je konsenzuana aktivnost koja uzbuđuje submisivnu osobu, i samim time ona u konačnici biva zadovoljena. 


\section{SADOMAZOHIZAM I PSIHA}

\subsection{Interpretacija sadomazohističke seksualnosti Lacanovom postpsihoanalitičkom teorijom}

Jacques Lacan, kao znanstveni utemeljitelj moderne psihonalize, iznimno je relevantan i možda najveći utjecaj suvremenim filozofskim, lingvističkim i književnim teorijama, te je stoga od iznimne važnosti prikazati interpretaciju njegove psihoanalitičke i filozofsko - semantičke teorije seksualnosti i sadomazohizma kao specifičnog odnosa.

Kao inovativan teoretičar nove psihoanalize i strukturalizma razvio je i etablirao sasvim originalan i specifičan koneptualno - strukturalni kategorijalni sustav kojim možemo protumačiti brojne psihološke, društvene i seksualne fenomene.

Nastojat ću ga što pristupačnije pojasniti te oprimjeriti idejama i interpretacijama vezanima za teoriju sadomazohističke seksualnosti i ovo je poglavlje posvećeno prikazu njegove teorije u kontekstu seksualnosti, te mom vlastitom razumijevanju kao originalnoj interpretaciji sadomazohističkih odnosa putem Lacanova sustava.

Lacanova je psihoanalitička filozofija od izrazite važnosti za tumačenje sadomazohističke seksualnosti jer njegovim se kategorijalnim aparatom ili sustavom pojmovlja, najbolje mogu opisati BDSM odnos u svim svojim mogućnostima i varijacijama.

Hermeneutiku psihoseksualnih razvojnih stadija započet ću elaboracijom Lacanovog Imaginarnog, kao esencijalnog, putem kojeg se Simboličko razvija, a u svojoj je strukturi posve drugačije jer Imaginarno je, kao stadij razvoja i poredak, ono prvotno i iskonsko, počevši od najranije dobi, sve do izgradnje i stvaranja ličnosti, što je individualno u svome trajanju i periodima kontinuiteta i diskontinuiteta.

Imaginarno je stoga primarni stadij razvitka još nesvjesnog subjekta obilježen stadijem zrcala koji stremi Simboličkom, osvještavanjem svojih želja, u kojem se razvija slika sebstva, proces spoznavanja i konstruiranja prvotnog, zrcalnog "Idealnog Ja".

Mali drugi, kao objekt i uzrok apsolutne želje, u Imaginarnom teži željenom, postaje svojom željom, procesom identifikacije sa „Ja Idealom“ svojim autoritetom, velikim Drugim i njegovom željom koja se ostvaruje tek prijelazom u slijedeći stadij, a to izuzmemo li Realno, mora biti Simboličko kao ultimativni stadij psihoseksualne samospoznaje. 
Imaginarni stadij kao put prema Simboličkom najbolje je izražen kod submisivnih osoba te mazohističnih, što ne mora biti komplementarno niti u korelaciji, koje se poistovjećuju s amelioriziranom, gotovo perfektnom slikom u zrcalu, odnosno, slikom Drugoga kao željenog. Simbolički poredak kao uspostava sebstva, kao što Lacan i govori, ima ključnu ulogu u psihoseksualnom razvoju pojedinca, te se kao stadij konstituira posredno, izvor je naše želje i same formacije odnosa prema malom drugom i Velikom Drugom.

Unutar Simboličkog stadija odvijaju se procesi kao što su identifikacija, individuacija, i formacija ličnosti te je riječ prvenstveno o odnosu osobe prema sebstvu kao onome što odražava i prikazuje istovremeno i subjektovo istinsko, zrelo "Ja" sebstvo u svome bitku, što ono jest i u svojoj želji i što bi željelo biti.

On je razvojni stadij manifestiran konfliktima unutar vlastite ličnosti, koja postaje osvještena kao isključivo želja za Drugim, za postajanjem Drugim putem utemeljenja i formiranja vlastite seksualnosti kao primarnog dijela ličnosti, koji potom određuje sve ostale životne aspekte i međuodnose.

Drugi je tako na razini označitelja druga osoba no istodobno i vlastiti "imaginarni” ideal kojem drugi teži i podređuje mu se, on u suštini predstavlja brojnost identiteta, pojmova i identiteta, no zasad ću konstatirati da Drugi predstavlja želju i drugost od vlastite ličnosti i identiteta.

Primjerice, osoba koja od najranije dobi biva upoznata i dolazi isprva samo u vizuelni kontakt s BDSM seksualnošću, osvještava je, auditivno - vizuelnim podražajima i na taj način stvara sliku idealnog Ja kao formativa „Ja funkcije“, stvarajući zapravo Velikog Drugog (le grande Autre), dok ona sama "postaje" mali drugi (objet petit a) te se s njime identificira - postaje objekt i uzrok želje ${ }^{90}$, kao što ću pojasniti u objašnjenju pojma želje.

Svi se odnosi u Lacanovoj teoriji uspostavljaju upravo u Simboličkom poretku i zato on naglašava njegov primat, koji brojni psihoanalitičari nisu shvaćali, već su inzistirali na Imaginarnom kao temeljnom razvojnom stadiju ili na "prijelazu u Realno", koje za Lacana nemoguće jer se temelji na prevladavanju nesvjesnog, na osvještavanju želja da bi ih se sublimiralo, no ključan je prijelaz u Simboličko kao ultimativno samoostvarenje - aktivno življenje svoje svjesne želje formacijom svoje istinske ličnosti.

\footnotetext{
${ }^{90}$ Jacques Lacan, Ecrits, The Mirror Stage as the Formative of the I Function, W.W. Norton \& Company, New York, 2005, str. $90-100$
} 
Lacan govori da je "dostatno razumjeti stadij zrcala u ovom kontekstu kao identifikaciju u punom smislu koji analiza daje tom terminu: transformaciju koja se odvija u subjektu kad on zauzima sliku - sliku koja je naizgled predodređena da ima efekt u ovoj fazi”, kao što svjedoči upotreba termina "imago" u analitičkoj teoriji. ${ }^{91}$

Simboličko je, za razliku od subjektivnog Imaginarnog, intersubjektivno, karakterizirano dualnim odnosom između subjekta i objekta ili objekta malog a i velikog A, drugog i Drugog, no i taj odnos može biti ili jednostrano ili obostrano subjektivno shvaćen i doživljen.

Svaki je odnos uvijek dualan, pa i onaj Imaginarni, koji individuum ima sam sa sobom ili "imaginarnim" Drugim, te drugog koji želi postati Drugi (le grande Autre) i tu je riječ o fundamentalnoj fantaziji koja teži Simboličkom kao putu prema samoostvarenju, da bi u Simboličkom poretku temeljan postao odnos prema sebi, doživljen također kao dualan jer osoba sebe simboličkim zakonom jezika doživljava kao drugog (objet petit a).

Imaginarno je stadij procesa razvitka, stadij fantazije kao začetka želje, no još nepotpuno osviještene i neostvarene, dok je Simboličko realizirana egzistencija, uspostavljena želja, svjesno življenje želje i uspostavljen odnos s D/drugim.

Lacan dinamiku Imaginarnog prema Simboličkom izražava na slijedeći način:

“Dovoljno je reći da je stadij zrcala u ovom kontekstu kao identifikacija,

Transformacija koja se odvija u subjektu kad on zauzima sliku - sliku koja je naizgled predodređena pridaje im efekt u ovoj fazi, kao što svjedoči upotreba termina “imago" $u$ analitičkoj teoriji. Pretpostavka njegovoj spekularnoj slici je formirana situacijom simboličke matrice u kojoj je subjekt određen u primordijalnoj formi, prije nego što biva objektiviran u dijalektici identifikacije s Drugim.Ta bi forma morala biti zvana “idealni - ja”, ali ona smješta ego u fikcionalnom smjeru, koji će samo asimptomatično pristupiti subjektovom postajanju, Ja, njegov nesklad s njegovim vlastitim realitetom." 92

\footnotetext{
91 Ibid.

92 Jacques Lacan, Ecrits, The Mirror Stage as Formative of the I Function,W.W. Norton \& Company, New York, 2005, str. 95, prijev.a.
} 
"Idealni Ja" je bitan koncept za razumijevanje Imaginarnog stadija i poretka, kojeg Lacan doživljava i postavlja temeljnim i čak potpuno autonomnim i stoga „Idealni Ja” možemo prevesti u “idealni Drugi” kao ultimativnu težnju malog a.

Također, i drugi i Drugi, odnosno objet petit a i le grande Autre zapravo egzistiraju autonomno, no u konstantnoj međusobnoj korelaciji , koegzistenciji kao subjekt i objekt ili, preciznije, veliki Objekt i mali objekt, isprepleteni u intersubjektivnosti koja je neposredno uvjetovana malim drugim kao polazištem, izvorom želje kao pokretačem njihova odnosa, on je taj "neposredni posrednik", kao Aristotelov nepokretni pokretač, no i daleko više od toga, on je odraz želje, želja sama, kao što je Veliki Drugi cilj želje u i subjekt nadređen malom a kao gospodar robu i oni zajedno čine odnos submisivne i dominantne osobe.

Lacanova je konstrukcija stadija ličnosti i poredaka tropartitna, no svaki bismo od njih mogli sagledati i protumačiti kao autonoman upravo stoga što predstavlja određenu cjelinu ličnosti i vremenski period razvitka psihičkih procesa unutar individuum te odnosa s drugima.

U psihoanalitičkoj interpretaciji Drugog i drugog, Lacan u svim svojim djelima pruža veoma opširne elaboracije njihovih odnosa, pružajući osnove odnosa dominantne i submisivne osobe, referirajući se, između ostalog, na poznat Hegelov paradoks međusobne uvjetovanosti gospodara i roba, koji će kasnijim teoretičarima postati „paradigma“ za tumačenje odnosa dominacije i submisivnosti, čime nastoji prikazati upravo perpetualni međuodnos Drugog i drugog, njegovu kontingenciju u smislu konstantnih izmjena moći i pozicija.

Kao što je prikazano kod Simboličkog i Imaginarnog, posebice prijelaznog stadija zrcala, jasno je da se mali drugi želi i u svojoj imaginaciji uspijeva „transformirati“, u ,idealni Ja“, svoju „sliku“, te naposljetku u velikog Drugog, svoju želju i u svome ostvarenju postaje svojom željom - to je Lacanov istinski paradoks odnosa Drugog i drugog.

Odnos submisivne i dominantne osobe odnos je transgresije Imaginarnog i Simboličkog te svih granica do stadija koje transcendira čak i Simboličko, što je moguće detaljnom analizom iščitati iz Lacanovih djela.

Primjer u sadomazohističkoj seksualnosti, u kojoj podjele sadista i mazohista nisu često ekvivalentne ulogama submisivnosti i dominacije, upravo ta želja i izmjena uloge dolazi do izražaja na način da submisivna osoba, posebice ako je mazohistične orijentacije, zadobiva osjećaj superiornosti svojim položajem i time od malog, submisivnog drugog postaje veliki dominantni Drugi, dominantni mazohist. 
Također, prijelaz od malog a, drugog do Drugog, velikog $A$ kao autoriteta i ultimativnog objekta želje kojem se drugi kao submisivna osoba podređuje da bi se u konačnici s njime identificirala odvija se prvo u stadiju zrcala te konačno realizira u Simboličkom poretku.

Odnos ega s velikim Drugim je identifikacija s istim, uslijed koje ego kao mali drugi doživljava svojevrsno otuđenje, te iživljava narcizam i agresivnost jer pod utjecajem vlastite imaginacije konstituira sebe Drugim i njegovom željom, zamišljenim idealom, realnom osobom, koju doivljava kao nadređenu i stoga mu je dominantna.

Subjekt kao podređen, u svom nastojanju da postane Drugi, konstituira svoj ego narcistički i agresivno, boreći se protiv svoje podređene pozicije, nezadovoljan njome, od nje se otuđuje, a prijelaz od drugog do Drugog, Lacanu, u svom 2. seminaru, „Ego in Freud's Theory and in Technique of Psychoanalysis “ iz 1955. godine, opisuje kao formaciju ega u alter ego, odnosno razvijanje alter ega $u$ egu samom. ${ }^{93}$

Sličnu ideju u pogledu filozofije psihe i tijela nalazimo kasnije kod kod Nancya, no sada je bitno ustanoviti na koji se način prijelazom iz Imaginarnog u Simboličko odvija taj prijelaz od objet petit a do objet grande A.

Kad govorimo o psihofizičkom razvitku prirodno submisivne ili dominantne osobe, $u$ seksualnom i psihičkom aspektu, moramo imati na umu da se ta razvojna faza karaktera odvija veoma postepeno i diskontinuirano.

Upravo je iz tog razloga stadij zrcala od iznimne važnosti, budući da obje osobe isprva „gledaju“ i zamišljaju „sebe“, predočavaju sebi sliku „onoga što žele postati“ i „biti“, nastojeći prevladati ono što toga trena jesu.

Ta snažna aspiracija uspostavljanju novog identiteta temeljna je za razumijevanje sadomazohističke seksualnost budući da je ona upravo ontologijski utemeljena osvještavanju svog istinskog bitka i sebstva, što se samo naizgled čini kao „novi“ identitet“, no riječ je o momentu konflikta subjekta i objekta unutar jednog sebstva koje samo zadobiva i razvija nove modalitatet i karakteristike.

Lacan objašnjava odnos malog a i velikog $A$ opsežnom elaboracijom svoje teorije ega, a najvažnije bih izdvojila primarnu analizu ega u svom bitku i sebstvu, postavljanjem pitanja što znamo o egu te je li on imaginarna konstrukcija ? Što je subjekt, na koji se način odnosi prema sebi te koja je relacija želje, subjekta i ega?

\footnotetext{
93 Jacques Lacan, Seminar 2, Ego in Freud's Theory and in Technique of Psychoanalysis, lacaninireland.com, ur. i prijev. Cormack Gallagher
} 
Lacan detaljno pojašnjava da se:

"Ego pojavljuje u svijetu objekata, kao objekt, no zasigurno privilegiran.

Svijest u čovjeka je po svojoj biti polarna tenzija između ega otuđenog od subjekta i percepcija koja ga fundamentalno izbjegava, čisti percipi.

Ono iznad intersubjektivnog odnosa postiže osobito na imaginarnoj razini.

Subjekt prolazi iznad tog zrcala kojem uvijek vidi, zapleten, svoju vlastitu sliku. Svaka interpozicija između subjekta i svijeta prestaje.

Dobiva se osjećaj da se događa prijelaz u svojesvrsnu a - logiku i tu je zapravo pravi problem. Također je pitanje - do koje mjere simbolički odnos, odnos jezika, zadržava svoju vrijednost iznad subjekta u onome što može biti karakterizirano kao centrirano u egu, egom, za alter ego? Ljudsko znanje $i$ istim znakom sfera odnosa svijesti, sastoji se u određenom odnosu prema toj strukturi koju zovemo ego, oko koje je imaginarni odnos centriran. Potonji nas je naučio da ego nikada nije samo subjekt, da je bitno odnos prema drugom, svi su objekti uzeti u obzir sa stajališta ega.

No svi objekti su zapravo željeni sa stajališta primitivno neskladnog subjekta, subjekta funtamentalno fragmentiranog egom.

Subjekt ne može željeti bez vlastitog razriješenja i bez viđenja, ovdje aludiram na fundamentalni poremećaj instiktualnog života u čovjeku.

A tenzija između subjekta koji ne može željeti bez odvojenosti od objekta, i ego, gdje počinje pogled prema objektu, je polazište za dijalektiku svijesti." 94

Lacan smatra da Imaginarno ne može biti centralno u psihoanalizi, i između ostalih je teza, kritizirao čitavu freudovsku psihoanalizu zbog najvećeg naglaska na Imaginarnom poretku.

Za njega je Imaginarno presudno za formiranje ličnosti i samog ulaska u Simboličko, odnosno, da bi se Simboličko uopće moglo doseći i razumjeti, potrebno je ovladati Imaginarnim kao polazištem, jer Imaginarno, u vidu slika, imaginacija i snova potrebno je prevesti u simbole, $u$ lingvističko - psihologijskom kontekstu interpretacije koji je Lacanova čvrsto utemeljena pozicija.

\footnotetext{
${ }^{94}$ Jacques Lacan, Seminar 2, Ego in Freud's Theory and the Technique of Psychoanalysis, 1954 - 55, ur. i prijev Cormack Gallagher, lacaninireland.com, prijev.a.
} 
Osvrnula bih se na ovu tezu iz drugačije, deduktivne dijametralne perspektive jer apsolutno je logično i neupitno da je Imaginarno primarno, jer je stadij prvotnog razvija određene svijesti o ličnosti samoj, posebice "stadij zrcala", i Imaginarni je poredak "uvertira" u Simbolički poredak kao svojevrsni proces individuacije ličnosti, no je li tu uistinu riječ o "individuaciji"?

U Imaginarnom se poretku i stadiju zrcala (in)dividuum ili radije osoba, obzirom da je ličnost bitno podijeljena, započinje izgrađivati i stvarati isključivo u smjeru želje, vođena željom, prethodno formiranom slikom koju želi vidjeti i stoga pitanje izgradnje ličnosti i individuacije ne može biti egzaktno postavljeno i objašnjeno jednom tezom ili stajalištem već ga je potrebno sagledati pluriperspektivističkim pristupom psihologije i filozofije.

Imaginarno je, s druge strane, naš residuum, sfera fantazije, seksualnosti i stoga od neophodne važnost za BDSM seksualnost jer individuum u Imaginarnom promatra i doživljava sebe posredno, putem Drugog, ne čini to aktivno, već pasivno, sve dok ne učini psihički zaokret i počne aktivno živjeti svoj život, kreirati vlastitu egzistenciju i svoju želju u Simboličkom.

Simbolički poredak možemo prvenstveno razumjeti i tumačiti kao napredak nakon Imaginarnog stadija, kojim je obilježeno životno razdoblje od najranijeg djetinjstva do adolescencije, no on može potrajati i do zrele dobi, ukoliko osoba ne ostvari svoje želje i ambicije, posebice seksualne želje i fantazije i stoga razvija neuroze i nestabilnost ličnosti, koji je zadržavaju u daljnjem razvoju ličnosti i zadržavaju u Imaginarnom i stadiju zrcala, kao temeljnoj manifesticiji ovog stadija.

Iz navedenih razloga veoma je delikatno i često nejasno govoriti koji bi poredak zauzimao centralno mjesto u razvoju ličnosti, obzirom da svaki pojedinac do stadija Simboličkog dolazi drugačijim psihičkim razvojem, a to ovisi o partikularnoj ličnosti, okolnostima, psihičnoj stabilnosti ili nestabilnosti.

U seksualnosti općenito, a posebice sadomazohističkoj, Simbolički upravo je poredak centralan jer je postavljen kao cilj, no Imaginarni je stadij izrazito važan zbog izgradnje ličnosti, brojnih promjena i diskontinuiteta u psihoseksualnom razvoju osobe.

U Lacanovoj je misli bitno je postaviti Imaginarni stadij kao primarnu želju i proces spoznavanja, te potom radikalan ili postupan prijelaz u Simboličko, putem stadija zrcala čijim prevladavanjem osoba izgrađuje svoj novi identitet kao novo sebstvo.

Elaboracija Simboličkog bit će detaljno izložena kao temeljnog koncepta te konačno esencijalnog poretka, najvažnijeg u njegovoj tropartitnoj teoriji psihičkog ustrojstva i ujedno interpersonalnih i društvenih odnosa jer sam pojam Simboličkog se ab principio odnosi na sferu 
i njegovu stvorenu "realnost" u kojoj individuum egzistira određen odnosima vlastitog Ja, želje, Drugog, užitka i jouissancea.

U kontekstu sadomazohističke seksualnosti, možemo dovesti u pitanje ideju Simboličkog kao jedine moguća egzistencija ostvarenja u kategorijama onog željenog, želje kao takve, posebice seksualnosti, koja ipak u Imaginarnome postoji u svome pravome smislu, premda Lacan opravdano dovodi u pitanje značenje i smisao Imaginarnog poretka $u$ tradicionalnom psihoanalitičkom shvaćanju.

Tu je tezu najbolje izložio u seminaru "Love and the Signifier" jer njegova se cjelokupna filozofija i temelji na psihologičkim tumačenjima odnosa stvari i otuda njena kompleksnost i ambiguiteti u shvaćanju njenog značenja, budući da postoje brojne valjane interpretacije.

Postoje veoma široke mogućnosti interpretacije Lacana u kontekstu seksualnosti, posebice tumačenja sadističke i mazohističke seksualnosti njegovom teorijom, što je i mnogim iskusnim teoretičarima zahtjevan zadatak, upravo zbog veoma kompleksnih i izrazito zahtjevnih teza otvorenih pitanja i perspektiva promišljanja.

Elaborirat ću osnovne pojmove i poretke u tumačenju sadomazohističke seksualnosti s ciljem doprinosa razumijevanju Lacanove filozofije i psihologije seksualnosti obzirom da interpretacija sadomazohističke seksualnosti u kontekstu Lacanove tropartitne teorije registara može biti ponešto drugačija svojim tijekom od ustaljenog tijeka poredaka.

Lacanov kategorijalni sustav registara razvojnih stadija psihe i kognitivno - konceptualnog ustroja pojedinca ima svoj logični slijed faza mentalne percepcije, no ti periodi mogu nastupati istovremeno ili isprepleteno, $\mathrm{u}$ diskontinuitetima.

Simbolički poredak, ključni i ultimativni za Lacanovu psihoanalitičku teoriju slijedi nakon što individuum prevlada stadij Imaginarnog te individuacijom kao procesom diferencijacije od drugih ovladavanjem jezikom i osvještavanjem i spoznajom svog sebstva - uma, psihičkog ustrojstva i tjelesnosti.

Imaginarno u sadomazohističkoj seksualnosti možemo interpretirati kao inicijalnu fazu daljnjeg razvoja, budući da se odvija u fantaziji, neposrednom željom, na granici Imaginarnog i Simboličkog jer modusom diskontinuiteta manifestira psihičke odrednice i karakteristike oba poretka, ovisno o partikularnoj psihičkoj strukturi.

Premda osvještavanje i stvaranje sebe, a istodobno i spoznaja drugih započinje u Simboličkom, bitno je ukazati na značenje i važnost Imaginarnog stadija zrcala koji uvodi subjekt u fantaziju, 
identifikacijom sa željenim objektom, velikim Drugim, a potom i u novi poredak, Simbolički, u kojem njegova želja, utemeljena na kognitivnoj realizaciji prijašnje fantazije, postaje želja velikog Drugog kao jedini i krajnji cilj.

Poveznica Imaginarnog i Simboličkog jasna je upravo iz subjektovog odnosa prema velikom Drugom kao samoostvarenju te želji kao i prvotnoj i ultimativnoj motivaciji u psihoseksualnom razvoju ličnosti.

U kontekstu sadomazohističke seksualnosti, Imaginarni stadij ima inicijalnu ulogu, budući da subjekt počinje doživljavati sebe kao objet petit a, malog drugog, u odnosu na objet grande Autre, velikog Drugog, što ostaje temeljno polazište u konceptualnoj, jezično - hijerarhijskoj strukturi Simboličkog poretka.

U stadiju zrcala, slika koju subjekt promatra nije uvijek jednaka, obzirom da ličnost nije formirana, već konstantno želi ili radije ima potrebu postati istovjetna Drugom, premda pojam želje još nije konceptualiziran, no taj Drugi je apstrakcija koja mijenja svoje karakteristike i time se slika u zrcalu psihe subjekta u Imaginarnom stadiju radikalno mijenja, sve do spontane, razvojno uvjetovane inicijacije u Simbolički poredak, uvjetovan jezikom, zakonima te konačno stvaranjem i artikulacijom želje.

Imaginarni stadij psihoseksualnog razvoja pobuđuje submisivne i mazohistične težnje subjekta, njegovom fantazijom da želi postati veliki Drugi, poistovjećujući se s njime, da bi ta fantazija, u kasnijem Simboličkom stadiju postala želja subjekta kao želja Drugog, ultimativna želja kojoj se pojedinac podređuje i kojom se podređuje Drugom simboličkim zakonom jezika da bi finalno i sam postao Drugi, kao aktivni subjekt brojnih odnosa želje, svojeg finalnog ostvarenja, no istovremeno i početka novih odnosa razmjene moći unutar Simboličkog poretka.

Subjekt, doživljavajući sebe kao objet petit a, mali drugi, promatra imaginarnu sliku željenog, velikog Drugog u svom „zrcalu“, što Imaginarnom stadiju pridaje veliku važnost pri razvoju kasnije simboličke želje i njome posredovanih odnosa.

Stadij zrcala Lacan tumači kao prvotni formativ „Ja“ te stoga možemo razumjeti kasniju povezanost Simboličkog s Imaginarnim, no to „Ja“ Imaginarnog je prividno, projicirano, zrcalno „Ja“, dok tek u Simboličkom poretku subjekt razvija svoje istinsko „Ja“, neposrednim djelovanjem želje i odnosa s D/drugim, koje jedino unutar poretka kulture i jezika može ostvariti i održavati.

Imaginarno svojom manifestacijom poistovjećivanja s „Idealnim Ja“, Drugim, doživljavanjem odraza ili idealnog Ja, početak je psihoseksualnog razvoja jer u njemu započinje proces 
kognitivnog osviještavanja psihe i tijela, prvotnom kreacijom fantazije, koja u Simboličkom zadobiva ontologijsku formu i status želje.

Pojedinac proživljava Imaginarni stadij putem kontinuiteta i diskontinuiteta i stoga Imaginarno zapravo nikad potpuno ne prestaje, već prolazi faze latencije, pa čak i kad biva prevladan ulaskom u Simbolički poredak, njegovi su temelji uvijek u podsvijesti psihe pojedinca, u fundamentu njegove želje.

Simbolički je poredak jezika neophodan uvod za spoznavanje i razvitak želje sebstva i identiteta verbalizacijom i artikulacijom, koja potom prelazi u „neizgovorenu“, „nedefiniranu“, već vizualnu i osjetilnu želju novo uspostavljenog, redefiniranog Imaginarnog poretka, koji pripada sadomazohističkoj seksualnosti.

Simbolički poredak, centralan u Lacanovom konceptualnom sustavu, predstavlja stadij kreacije sebstva i formacije ličnosti, budući da ulaskom u poredak jezika individuum može verbalizirati odnosno izraziti sebi i drugima svoje misli i želje riječima, no i govorom tijela kao neverbalnom komunikacijom, koju još možemo smatrati dijelom Imaginarnog i stoga je upravo Simboličko za Lacana esencijalan stadij u razvoju psihe i seksualnosti.

U sadomazohističkoj seksualnosti subjekt često doživljava oba poretka istovremeno, oni nemaju često čak niti striktan redoslijed, već se konstantno interpoliraju kod sadomazohističkih ličnosti, no Simbolički je uvijek presudan i finalan, govorimo li o svjesnom psihoseksualnom razvoju, stvaranju i sazrijevanje želje te samoodređenju psihičkog i seksualnog identiteta.

Simboličko je poredak želje koja je u svijesti subjekta percipirana kao želja velikog Drugog i za Drugim, što je nadovezano na fantaziju o poistovjećivanju s Drugim kao „Idealnim Ja“ u Imaginarnome i u Simboličkom se stadiju ostvaruje formacija istinskog vlastitog identiteta kao ontologijski moment ujedinjenja uma i tijela spoznavanjem vlastite psihe, kreiranjem svog identiteta te i posrednim i neposrednim uspostavljanjem socijalnih i seksualnih odnosa prema sebi, Drugom i drugima.

Identitet i odnosi prozvedeni njime ozbiljuju praksom, odnosno djelovanjem osviještenog, sebstva kao simboličke egzistencije, a najbliži, neposredni odnos je odnos prema sebi, svom sebstvu kao bitku koji napreduje od pozicij drugog, na granici Imaginarnog, do željene pozicije Drugog, da bi se konačno realizirao i pozicionirao kao subjekt vođen željom, čime je u potpunosti podređen Simboličkom poretku i stremi svom potpunom ostvarenju.

Unija umnog, psihičkog i osjetilno - tjelesnog može se ostvariti tek u Simboličkom stadiju, dok je u Imaginarnome izražen samo njen fundament, u fantaziji i spoznavanju vlastite tjelesnosti 
procesom identifikacije s željenim idealom, koji se konstantno dinamički mijenja, ovisno o psihičkoj strukturi koja određuje želju i njen objekt.

Egzistencija subjekta je vođena i upravljana željom koja je podređena Drugom, manifestirajući se i razvijajući kao ostvarenje fantazije subjekta kao drugog, neposrednim odnosom Drugog i drugog, u kojem se fantazijom kreira imaginarno poistovjećivanje jednadžbom , $a=A$ “.

Jasno je da niti jedan stadij ili poredak nije autonoman već je svaki uvjetovan ostalima te se realizira i opstaje isključivo u odnosu s njima i na njih, i to izvjestan period vremena, dok subjekt ne ostvari psihičku zamjenu objekta želje i dok želja ne prevlada trenutni stadij, nalazeći mjesto u slijedećem, pozicionira subjekt iz Imaginarnog u Simboličko, ili ga, uslijed specifičnih psihofizičkih fenomena, vraća u bitne momente Imaginarnog, što je karakteristično za sadomazohističku seksualnost.

U sadomazohističkoj seksualnosti konstantno se izmijenjuju dinamički odnosi između Imaginarnog i Simboličkog, dok je Realno isključeno iz registra kao nepostojeće jer ne posjeduje mogućnost imaginacije, osjetilnog, senzualnog, erotičnog, već je samo suviše stvarno, postvareno, materijalno i time ne pripada ni fantaziji niti želji.

Realno je koncipirana, preskrivna kategorija u kojem egzistiraju samo materijalno utemeljne stvari po sebi i svojoj danoj prirodi, kao konkretni koncepti, stadij koji je kao postvareni materijalni poredak i on je u Lacanovu izvornom smislu prevladan Simboličkim i Imaginarnim kao "ne - željeno" i stoga nemoguće jer se u njemu ne mogu osvijestiti niti fantazije ni želje.

Realno je, kao suviše stvarno te ograničeno zabranama u jeziku i ponašanju, neoizgovorivo i neostvarivo i stoga, paradoksalno, doživljeno kao apstrakcija, neozbiljiva i gotovo nezamisliva budući da želja stremi ,zabranjenom“.

U interpretaciji sadomazohističke seksualnosti Lacanovom filozofijom nikada ne možemo govoriti o Realnom zbog manjka svih navedenih konstituenata seksualnosti - fantazije, želje, seksualnog odnosa te jouissancea unutar jezika i preskribiranog ponašanja, ono nema svoje mjesto u poretku seksualnosti niti odnosima moći kao životu fantazije, želje i opstojnosti i razvoju subjekta i objekta kao D/drugog.

Lacanov tropartitni registar psihoseksualnih stadija konceptualiziran je odnosima međusobne uvjetovanosti, kao u slučaju povezanosti Imaginarnog i Simboličkog te njihovom interakcijom i utjecajima, primjerice Imaginarnog na Simboličkog, ili Realnog na Imaginarni i ti procesi konstantno mijenjaju i oblikuju psihu subjekta. 
Bitak subjekta određen je željom Simboličkog poretka, koja kreira i usmjerava njegove odnose sa sobom i prema sebi, te najzad prema $D /$ drugom i drugima, dok je intersubjektivnost na taj način posredovana Drugim kao izvorom i ciljem želje.

U Simboličkom je poretku Drugi i posrednik i odraz i objekt želje, zauzima poziciju želje same, dok je u Imaginarnom subjekt u svojoj fantaziji drugi samodoživljen kao Drugi, procesom zrcalne identifikacije i time podređen i svom idealu i samome sebi, a prevedeno iz fantazije, nadređen Drugom, igrajući ulogu Drugog, maštajući o njemu kao o svome cilju.

Prototipno opisani odnos subjekta, želje i fantazije unutar dvaju ključnih poredaka analogno karakteriziraju vezu submisivne i dominantne osobe u sadomazohističkom odnosu, i to u dva segmenta, percepciji sebe kao subjekta ili objekta te odnosa prema D/drugome, shodno poziciji i prirodi odnosa.

Tranzicija iz Imaginarnog u Simboličko je bitan moment u psihoseksualnom razvoju ličnosti, no kod sadističke ili mazohističke ličnosti taj se redoslijed stadija izmijenjuje, jer $\mathrm{u}$ Simboličkom uvijek ostaje velik dio Imaginarnog, bez kojeg sadomazohistička seksualna praksa ne bi mogla kao takva postojati te se često Imaginarno ponovno nameće kao primarno, no ipak u strukturi Simboličkog.

U sadomazohističkoj seksualnoj praksi, Imaginarno je neophodno za sve opcije, želje koje su utemeljene na fantazije, uživljavanje u uloge, življenje i iživljavanje svojih fantazija, seksualnih poriva koji su prvotno u Realnom bili zabranjene nesvjesne potrebe da bi postali osviještene fantazije, a naposlijetku, u Simboličkom poprimile oblik artikulirane i aktualizirane želje, njenog izraza i ostvarenja.

Simboličko, reprezentirano ovladavanjem jezikom i time individuacijom i socijalizacijom putem lingvističke simboličke strukture, ultimativno je prevladavanje Realnog, budući da je cjelokupan izraz i egzistencija subjekta, upućena na misaono verbalno, osjetilno i taktilno u svojoj biti strukturirana u konceptualnom sustavu jezika, koji potom preuzima sustav djelovanja u socijalizaciji i seksualizaciji subjekta.

Unija Imaginarnog i Simboličkog osnovna je karakteristika sadomazohističke seksualnosti, pri čemu je Simboličko kao stadij želje centralni stadij formacije ličnosti i seksualnosti obuhvaća subjekt kao život želje koji označuje egzistenciju subjekta vođenu željom, jouissanceom te lingvističkom i bihevioralnom simbolikom. 
Psihičke odrednice i praksa sadomazohističke seksualnosti određene su Simboličkim poretkom, kodificirane specifičnim registrom jezika i govora tijela, što je najbolje izraženo igranjem uloga u sadomazohističkom odnsosu, obuhvaćajući tjelesno kao taktilno, osjetilno, senzualno i psihičko kao prvotno misaono i verbalno.

Kod sadističke ili mazohističke ličnosti Simboličko, nakon prvotnog Imaginarnog najranije dobi, prethodi „novom Imaginarnom“ stadiju, koji subjekt razvija svojom željom prema Drugom, kao transcendentnom objektu svoje želje.

Imaginarno je stoga uvijek i dalje prisutno, no u novome obliku, koji slijedi jednom trajno uspostavljeno Simboličko, kao njegova „fantazijska“ nadopuna i nadogradnja, neophodna za ostvarenje sadomazohističkih fantazija i praksi.

Označila bih taj moment konceptom „reinventirano i redefinirano Imaginarno”, kao stadij identifikacije i spoznavanja te pronalaženja sebe kao „imaginarnog“ identiteta u kontekstu sadomazohističkog odnosa i scene, uživljavanjem u imaginarnu zadanu i željenu ulogu i kontekst kao scenarij sessiona u određenom vremenskom periodu i ta je uloga zamišljena i kreirana i Imaginarnim i Simboličkom, fantazijom i željom.

Razvojni proces sadomazohističke seksualnosti možemo zamisliti shemom prijelaza od stadija Imaginarnog do Simboličkog te potom do "redefiniranog Imaginarnog", koje se razvija i djeluje unutar Simboličko kao njegova psihoseksualna „nadogradnja“

Imaginarno je svojevrsna baza za razvoj Simboličkog koje lingvističkim poretkom postaje temelj za uspostavu „redefiniranog Imaginarnog“ kao ontologijskog momenta u kojem fantazija i identifikacija sa zamišljenom ulogom i stvorenim identitetom nalaze svoju poziciju upravo u Simboličkom poretku, verbalizacijom i kodifikacijom lingvističkog registra, bihevioralnih imperativa i seksualne prakse.

Simboličko je uvijek temeljno za osobnu, psihičku te socijalnu i seksualnu egzistenciju dok je Imaginarno kao njegova baza u sadomazohističkoj seksualnosti uvijek prisutno i kao regresija, no i kao novo uspostavljeni poredak u specifičnoj uniji Simboličkog i Imaginarnog kod sadističkih i mazohističkih ličnosti, njihovog osobnog samoostvarenja te međusobnih odnosa kao ultimativni stupanj realizacije Simboličkog s bitnim odrednicama Imaginarnoga u kojem se dotična seksualna praksa odvija u svjesnoj fantaziji i želji.

U interpretaciji Lacanove teorije psihološkim kontekstom tematike sadomazohizma, Imaginarno i Simboličko nemaju uvijek definiran kontinuiran tijek, već se često na prethodno prikazan način, odvijaju istovremeno, ili se izmijenjuju, varijabilnim diskontinuitetima jer je 
„,novo uspostavljeno“, „redefinirano Imaginarno“ unutar Simboličkog poretka istinska bitna sfera sadomazohističke seksualnosti.

Sadomazohistička seksualnost mora dozvoliti konstantne interferencije Imaginarnog unutar Simboličkog, budući da su one neophodan uvjet za ostvarenje psihoseksualnog odnosa kao jouissancea, u smislu vremenski određene, dugotrajne ili kratkotrajne faze osjetilnog doživljaja te psihičke izgradnje ličnosti.

Život želje kao egzistencija vođena željom Drugoga i za Drugim, svojim „Idealnim Ja“, realizacija je fantazija i želja subjekta i temelj odnosa drugog i Drugog, koji se u prvotnom Imaginarnom vizuelno i fiktivno izjednačuje poistovjećivanjem subjekta s Drugim, a $=A$, dok u redefiniranom Imaginarnom on opstoji kao odnos dvaju različitih, povezanih označitelja sa Simboličkim hijerarhijskim pozicijama i ulogama, diferencijalno i interpersonalno.

Iz Lacanova seminara „Desire and its Interpretation“95 razumljivo je da su u sadomazohizmu Simboličko i Imaginarno uvijek povezani, vezani zajedno, psihološkom definicijom fantazije: „Svaka fantazija je artikulirana načinom na koji subjekt govori imaginanrnom drugom. Zato je ljudska želja prilagođena, ne objektu, već fantaziji.

Perverzija, devijacija, čak $i$ deluzija artikulirane su $u$ objektivaciji koja veže zajedno imaginarno i simboličko." 96

U sadomazohističkom odnosu dominantna i submisivna osoba prolaze analogni tijek razvoja ličnosti, psihe i tjelesnih predispozicija kao odnos Drugog prema drugom, recipročan odnos kojim se međusobno nadopunjuju te zadovoljavaju, postižu jouissance i plaisir, pri čemu želja motivira odnos i želju za D/drugim.

Domena sadomazohističke seksualnosti na taj način postaje locus susretanja i koegzistencije Imaginarnog i Simboličkog, jer je Imaginarno neophodno za prvotnu fantaziju seksualnosti i zamisao te uživljavanje u ulogu i poziciju, a Simboličko za izvedbu scene verbalizacijom naredbe, tjelesnim aktima dominacije i podređivanja, provođenje moći te kodom pravila sadomazohističkog poretka i registra u svrhu užitka.

Upravo je to transcendencija iz Imaginarnog u Simboličko, te slijedeća, iz Simboličkog u „redefinirano Imaginarno“ ili, najbolje rečeno, u istovremeni sadomazohistički poredak Simboličkog i Imaginarnog, u kojem je Simboličkog ipak dominantno jer njime submisivna

\footnotetext{
${ }^{95}$ Jacques lacan, „Desire and its Interpretation”, www. lacaninireland.com, prijev. Cormack Gallagher

${ }^{96}$ Ibid, str. 12, prijev. a.
} 
osoba biva upravljana, podređena velikom Drugom simbolikom rituala pristanka, pregovora, ugovora i vlastite predaje svoje osobe.

Želja za supremacijom dominantne osobe reprezentiranog označiteljem velikog Drugog, cilj je i svrha egzistencije submisivne osobe kao malog drugog, čija je jedina želja ispuniti želju velikog Drugog, ili postati Drugi, transcendirajući pritom vlastiti identitet, što je primjer prijelaza u "redefinirano Imaginarno".

Pored primarne fantazije kao ideje te potom želje, kao pokretača i početka, jouissance zauzima važno mjesto kao bitan konstituent sadomazohističkog odnosa.

Jouissance je u ovome kontekstu potrebno razumjeti i kao užitak i kao bol, odnosno, užitak u boli, manifestaciju seksualnosti kao želje D/drugog u Simboličkom poretku.

Lacanova temeljna formulacija jouissancea kao osjećaja užitka i boli odnosi se na harmoniju i interpolacije Simboličkog i Imaginarnog, unutar kojih Drugi i drugi ostvaruju specifičan odnos međusobnog pružanja užitka i nanošenja boli:

„Što je jouissance? Ovdje se svodi na ništa više nego negativnu instancu, Jouissance je ono što ne služi niti jednoj svrsi. Ništa ne prisiljava nikoga da uživa osim superega. Superego je imperativ jouissancea - Uživaj ! " 97

U sadomazohističkoj seksualnosti u središtu su tijela koja nose obilježja, označitelji užitka i boli jer tijelo je medij koji nosi znakove i tragove svog odnosa, obilježja ljubavi, seksualnog odnosa, potčinjavanja i dominacije.

Tijela koja nose ožiljke bitna su konceptualna odrednica i sintagma interpretacije sadomazohističke seksualnosti tumačene Lacanovom filozofskom psihoanalizom.

Dominantna osoba, kao Veliki Drugi, označuje tijelo malog drugog, koji nosi obilježja, ožiljke kao znakove svoje želje, plaisira i jouissancea i svoje submisivnosti.

Tijelo je medij i predmet odnosa moći, medij na kojem su ispisani znakovi želje, fizički ožiljci kao tragovi boli i užitka i na taj iskustveni način subjekt razumije i doživljava pojam jouissancea tjelesno u kontestu sadomazohizma.

$\mathrm{U}$ interpretaciji sadomazohističkih odnosa jouissance, povezan s plaisirom, predstavlja Simboličko ostvarenje primarnih, iskonskih i isprva neosviještenih želja Imaginarnog, koje

\footnotetext{
${ }^{97}$ Jacques Lacan, On Jouissance Seminar XX, On Feminine Sexuality, W. W. Norton \& Company, New York, 1998, str. 11,12
} 
osviještavanjem zadobivaju svoju formu i dinamiku u Simboličkom, prema Lacanovoj formulaciji:

„Zato je izmišljeno nesvjesno - da bismo shvatili da je čovjekova želja želja drugoga “i da ljubav, dok je strast koja uključuje neznanje o želji, ipak ostavlja želji svoje čitavo značenje, Jouissance. Jouissance tijela Drugog ostaje pitanje jer odgovor koji može konstituirati nije potreban. “

Slijedeći Lacanovu teoriju seksualnosti, možemo zaključiti da je sadomazohistička seksualnost u (dis)balansu Simboličkog i Imaginarnog, pri čemu je Imaginarno uvijek podređeno Simboličkom poretku kao baza za razvoj želje, zadovoljstva i užitka.

Odnos dominantne i submisivne osobe, zasnovan na Imaginarnom, svoj cilj i vrhunac dostiže u Simboličkom, u ravnoteži fantazije, želje, plaisira i jouissancea, te je izvor jouissancea uvijek Drugi, jer se subjekt u Drugome uvijek ostvaruje.

Sadomazohistička je seksualnost na taj način uvijek u domeni i Imaginarnog i Simboličkog, no svoje ostvarenje nalazi u Simboličkom, kao domeni „superega“ dominacije i dinamike odnosa želje, jouissancea te Drugog i drugog.

U sadomazohističkoj seksualnosti postoje brojni modusi prijelaza iz Imaginarnog u Simboličko, od kojih bih kao možda eklatantan i najinteresantniji izdvojila fenomen subspace, kao psihofizičku manifestaciju doživljaja maksimalnog užitka u boli, prvenstveno kod mazohista kao istovremeno submisivnih osoba.

Simboličko je osobno, ultimativno životno ostvarenje u najdubljem psihološkom i seksualnom aspektu, u svome sebstvu, doživljavamo ga i kao sinergiju duhovnog i tjelesnog, pri čemu i jedno i drugo mogu biti primarno, individualno od svake osobe.

Imaginarno je istinska, iskonska egzistencija, dok je Simboličko stadij realizacije te egzistencije, kao najvišeg cilja, osobne esencije i identiteta.

U BDSM seksualnosti, psihičko - spiritualna dimenzija prethodi tjelesnoj i stoga je neophodno najbolje razumjeti upravo Simbolički poredak, kao iskonski i ultimativni "habitat" našeg tijela i uma, ličnosti i senzualnosti.

U sadomazohističkoj seksualnosti sve se ključne psihičke, umne i tjelesne aktivnosti i djelatnosti odvijaju upravo u Simboličkom stadiju i poretku, no inicirane su u Imaginarnom stadiju jer su zasnovane na simboličkoj želji i imaginarnoj fantaziji, koje imaju svoju logiku i neposredan međuodnos u sadomazohističkoj ličnosti. 
Govoreći o logici fantazije, Lacan je naglasio ključnu ulogu i važnost objekta za mišljenje i ozbiljenje koncepta fantazije, budući da fantazija, koliko god se isprva kontradiktorno moglo činiti, ima svoju logiku, što Lacan i elaborira 1966. godine u seminaru „The Logic of Phantasy“, govoreći isprva o objektu fantazije, malom objektu - o, koji je „konstrukt naših želja i fantazija“ te kao takav ,imaginarni objekt" te projekcija sebe kao malog a na veliki A-Drugog i Veliki Drugi je tako projekcija sebstva malog drugog, konstrukcija svih njegovih želja i fantazija te objekta kojeg želi i koji bi želio postati.

O želji on govori kao o onom prvobitnom, to pokreće čitavu egzistenciju subjekta i objekta te upravlja svim ljudskim odnosima i zbog toga je želja možda najvažniji i najbolje elaboriran njegov pojam.

Želja je ono apsolutno što pokreće individuum za svaku misao, djelovanje i odnos te je možemo misliti na bezbroj načina, no u mojoj tematskoj interpretaciji, želja je motivacija za krajnjom realizacijom psihoseksualnih težnji, ono ultimativno, relacija od željenja do cilja postaje sama svojim ostvarenjem - ostvarenjem tijela, psihe i uma u jednom specifičnom i izvanrednom psihoseksualnom odnosu.

Kao najbolji primjer navest ću želju za dominacijom i konstantnim 24/7 odnosom, koji podrazumijeva neprestani "život unutar fantazije" i želja je tada i motiv i cilj, u kojem se jedna osoba svojom željom podređuje drugoj, a druga svojom željom dominira, prvenstveno psihički, željom i u želji, a potom fizički u seksualnoj praksi.

Želja je u svojoj biti kao koncept i bitan entitet inicijator lanca označitelja, ona je faktor i „akter“ koja pokreće sve ostale misli i odnose u Imaginarnom, budući da je ona primarno želja Drugog, želja dominantne osobe.

Odnos desir - plaisir - jouissance je ključan za razumijevanje lacanovske interpretacije seksualnih odnosa i BDSM dinamike te ću ga pojasniti prikazima odnosa subjekta i želje kao želje drugog te primarnog odnosa malog subjekta kao drugog i Drugog kao temeljan, prototipni odnos submisivne i dominantne osobe.

Ne postoji samo jedan objekt želje, dinamika želje je uvijek recipročna objet petit $a$ i želja u svojoj biti kao koncept i kao entitet se konstituira željenjem upravo drugog no i dijametralno, kad je Drugi objekt želje drugog, budući da je on njegov uvjet i kao subjekt želje i identifikacije. Objet petit a ima samo ,privilegiju“ da je i objekt koji pokreće želju i kojem želja stremi, ali i sam njen uzrok, kao aktivni subjekt, iskonska točka Lacanovih odnosa dinamike Drugog i drugog posredstvom želje i svih ostalih kategorija.

Odnos subjekta i želje, kao što je već napomenuto, zasnovan je na želji kao želji Drugog i u tom kontekstu odnos označitelja i označenika su u perpetualnoj koegzistenciji koja je vođena 
željom Drugog, željom gospodara, kao apsolutnog bitka autoriteta prema kome je sva želja usmjerena, dok je želja malog drugog udovoljiti Drugom i, konačno, postati Drugi.

Taj je odnos identifikacija s Drugim koja pripada Imaginarnom, njegova idealizacija i simbolička deifikacija kao iracionalni psihički fenomen.

Nakon što je etablirana u Imaginarnom poretku u obliku fantazije, želja je ta koja formira takav odnos drugog prema Drugom, rukovodeći drugog kao „mali subjekt“ ili objekt te njegov doživljaj i poimanje velikog Drugog u centralnom i u ultimativnom Simboličkom, taj „konfliktni“, no istovremeno i usklađeni odnos kao temeljno polazište sadomazohističke psihoseksualne dinamike.

Referirajući se na Aristotela, Lacan u seminaru o želji konstatira da je ona „,bez sumnje nešto što uspijeva samo u realizaciji identifikacije užitka i dobrog unutar onoga što bih mogao nazvati etikom gospodarenja, nečega što je povezano s gospodarenjem subjekta prema njegovim navikama."

Lacan tu misao smatra nekonzistentnom budući da se sva moralna pitanja dovode u neposrednu vezu s registrom gospodarenja i moraliziranja gospodara, od činjenice da gospodar može disciplinirati, u odnosu na svoje navike, za svoju organizaciju i djelovanje svog ega.

Također, naglašava činjenicu da i želja i gospodarenje moraju imati svoju granicu, što je izuzetno važno za odnos subjekta i objekta, velikog $A$ i malog a u BDSM seksualnosti, što on izražava u svom seminaru iz 1958/59:

„Želje su protjerane iz prikladnog područja čovjeka, ako je činjenica da je čovjek identificiran s realnošću gospodara; u nekim je to prilikama nešto poput perverzija, i štoviše, on tom pogledu ima posebno modernu koncepciju činjenicu da nešto u našem vokabularu može dovoljno dobro izraziti činjenicu da ne može biti smatran odgovornim. ${ }^{98}$

Za detaljnije pojašnjenje relacije jouissancea, plaisira i desira, važno je istaknuti da Lacan tek 1960. uspostavlja i razvija jasnu razliku između jouissancea i plaisira, isprva onu temeljnu, da je jouissance uvijek i samo jouissance Drugog.

Sam pojam jouissancea on koristi u „Ecrits“, već od 1954, referirajući se na jouissance seksualnog objekta i tu se već nazire uloga jouissancea u ulozi moći.

Razlika uživanja i zadovoljstva naizgled se možda ne čini tako značajna, no u Lacanovoj filozofiji, ona je kategorijalna i intersubjektivna instanca.

\footnotetext{
${ }^{98}$ Jacques Lacan, Desire and its Interpretation, lacaninireland.com, prijev. Cormack Gallagher
} 
Koncepti jouissance, desir $i$ plaisir bitno neraskidivo su povezani no njihova je korelacija temeljena i na međusobnoj ovisnosti i na njihovim ontološko - psihologijskim razlikama, temeljnjim distinkcijama desira i plaisira od jouissancea.

Desir i plaisir u sferi su i posjedu drugog, dok je jouissance isključivo „vlasništvo“ i „privilegija“ Drugog i kao takav malom a može biti samo apstraktan i on ga može doživljavati samo kao zadovoljenje Drugog i služenje drugom, no paradoksalno, to postaje njegov krajnji cilj i svrha, sve do presudnog momenta njegove promjene identiteta, transcendencije u Drugog i tek mu tada jouissance postaje dostupan, ,dozvoljen“ i navlastit.

Lacanov jouissance je uistinu mnogoznačan pojam, on je prvenstveno užitak, seksualni užitak, potom svojevrsna igra između subjekta ii objekta, a u seminaru „Jouissance and Transgresion“, referirajući se na Sadea, Lacan zaključuje da je jouissance također patnja i bol i u tome je smislu užitak koji vodi orgazmu, što je jasno implicirano.

Njegova dimenzija orgazma izuzetna je važna za tematiku sadomazohističkog osnosa moći unutar seksualnosti, upravo stoga što se zasniva na služenju Drugom, jouissance je tada temelj odnosa submisivne i dominantne osobe.

U svom seminaru „Ethics in Psychoanalysis“, Lacan propitkuje odnos jouissancea i transgresije, referirajući se na mogućnosti subjektove želje za rizikom upravo prelaženjem granica normi ontologijskim pristupom subjektu i moći, prikazujući time paradoks jouissancea subjekta, zakona i moći:

„,Upoznati smo sa jouissanceom transgresije. No od čega je sadržan?

Ne proizlazi li neprešutno da gaženje svetih zakona, zakoni koji mogu biti direktno dovedeni u pitanje subjektovom savješću, sami potiču određenu formu jouissancea?

Nesumnjivo konstantno vidimo čudan razvoj unutar subjekta koji može biti opisan kao izazivanje bezlične sudbine ili kao rizik koji subjektu, kad ga jednom preživi, na neki način garantira njegovu moć. Ne igra li Zakon kojem se ovdje prkosi ulogu sredstva, očišćenog puta koji vodi ravno do rizika ?No ako je potreban put, što je rizik koji je u pitanju?

Što je cilj koji jouissance traži, ako mora naći podršku u trangresiji da bi ga postigao ?"99

Ova je analitičko - ontologijska misao esencijalna za psihologijsko promišljanje sadomazohističke seksualnosti jer postavlja centralno pitanje koje obuhvaća BDSM odnose, prvenstveno iz perspektive pojedinca, a potom odnosa prema drugom.

Rizik i moć su elementarni pojmovi koje možemo misliti na brojne načine u kontekstu sadomazohističke seksualnosti, no upravo Lacanova filozofija nam svojim ontologičkim

\footnotetext{
99 Jacques Lacan, Seminar VII, "The Ethics of Psychoanalysis", prev. C. Gallagher, lacaninireland.com
} 
pitanjima i dilemama već otvara put brojnim odgovorima i smjernicama za individualnu i kolektivnu psihologiju sadomazohizma.

Nakon elaboracije Simboličkog i Imaginarnog te esencijalnih psihičkih senzacija i pojmova kojima su označeni, izložit ću svoju tezu i objašnjenje razumijevanja Lacanovog Realnog kao poveznicu njegove teorije sa sadomazohističkom seksualnošću i odnosima.

Ideji Realnog i Realnom kao sferi, prostor egzistencije je realitet koji konstituira stvaran život, real life, izvan kojega submisivna ili dominantna osoba ne mogu postojati kao takve, realizirati svoj identitet i stoga je u seksualnosti nepostojeće, te je $\mathrm{u}$ tom aspektu najbolje shvaćena $\mathrm{i}$ mišljena Lacanova teza Realnog kao nemogućeg koje se ne može integrirati u Simboličko niti imaginarno, no i vice versa.

Realno je stoga doživljeno i koncipirano kao „nemoguće“, budući da biva negirano i odbačeno već u Imaginarnom stadiju, kojim započine razvoj individuuma, a posebice u Simboličkom kao željenom, krajnjem cilju i njegovom ultimativnom psihoseksualnom ostvarenju te je izrazito je važno spomenuti i pojasniti i specifične paradigmatske situacije u kojima se Imaginarno i Simboličko mogu integrirati u Realno u BDSM seksualnosti.

Kao primjer ću navesti autore koji se bave znanstvenim istraživanjima o BDSM seksualnosti i njenim praksama i psihoterapeute koji se bave psihoterapeutskim i psihoanalitičkim tretmanom osoba BDSM sklonosti i praktikanata iste, a i sami prakticiraju dotičnu seksualnosti te su često i istaknuti pripadnici $S / M$ scena, posebice u SAD - u, npr. Guy Baldwin, Jack Rinella, Pat Califia, čiji će stavovi biti detaljno izloženi u kasnijim poglavljima.

Možemo tako zaključiti da su psihologija, sociologija, a posebice psihoterapija „idealne“ profesije za osobe koje nastoje uskladiti svoje Imaginarno, Simboličko i Realno u sferi sadomazohističke seksualnosti, pi čemu ne smijemo izostaviti niti umjetnost, koja je vjerojatno i „najslobodnija“ u tom pogledu, vizualna i auditivna umjetnost kao izrazi S/M seksualnosti i kulture, ujedno opredijeljenja, je upravo sfera u kojoj osoba zaista može do izvjesne mjere uvijek i privatno i javno biti ono što uistinu jest.

Ipak, većina BDSM praktikanata je, zbog određenih normi i čak stigmatizacije okoline, primorana u svojoj ličnosti strogo odvojiti, napraviti clear cut između svog identiteta određenog seksualnošću i svog javnog i poslovnog identiteta.

Naposljetku zaključujemo da se pomiriti ili bar približiti Imaginarno i Realno čini isprva „nemoguća misija“, no zapravo, psihička stabilnost i organizacija strukture ličnosti i aktivnosti osobe ključne su i presudne u tom cilju, a taj je prvenstveno razrješenje psihičkih i seksualnih frustracija osoba S/M orijentacije. 
Najvažnijim radovima i seminarima za razumijevanje njegove teorije i moguće nove interpretacije Lacanove teorije smatram „Četiri temeljna pojma psihoanalize“, „The Logic of Phantasy“ i „Desire and its Interpretation“.

Za Lacanovo razumijevanje sadomazohizma, prvenstveno mazohizma, najbolji su izvor bitni dijelovi zbirke seminara „Četiri temeljna pojma psihonalize“, u kojima svojim konceptualnim sustavom objašnjava i sam izvor sadomazohističkog odnosa i njegovu poziciju vlastitim psihoanalitičkim jezikom kojim je i zasnovao svoju cjelokupnu teoriju seksualnosti.

Lacan ima, kao što je već poznato nakon studije i, koliko je to moguće, definiranja njegovih pojmova i kompleksnih korelacija, specifičan pristup i način uspostave tumačenja seksualnosti, posebice sadomazohističke, koja se nadograđuje na njegov temeljni sustav, no moguće su, razne nove interpretacije njegovih misli.

Za inovativna lacanovska tumačenja sadomazohizma primarni je uvjet odlično poznavanje njegova pojmovlja i kategorija te njihovo jasno razumijevanje kao baza za originalnu nadogradnju njegove teorije ili pak opoziciju njegovom shvaćanju.

Nastojat ću, nakon prikaza i referenci na njegove radove, izgraditi zaključke koji će biti jedna pozitivna kritička nadogradnja, suvremena interpretacija teme u Lacanovim terminima.

Njegovo razumijevanje sadomazohističkog odnosa neophodno je započeti tumačenjem njegove terminologije i grafičkih prikaza kružne dinamike međusobnih relacija pojmova koji reprezentiraju osobe, njihove pozicije i stadije.

Ključan je već sam njegov prikaz seksualnosti i odnosa koji su na njoj utemeljeni, upravo zbog njegovog specifičnog psihologijsko - logičkog te konceptualno - kategorijalnog sustava, koji je veoma ambivalentan i upravo je stoga bitno približiti se njegovom razumijevanju za interpretaciju sadomazohističke seksualnosti.

Lacan naziva isprva taj odnos „dijalektikom želje” te elaborira naizgled iznimno kompleksan i kontradiktoran sadomazohistički odnos i ustaljenim psihoanalitičkim i vlastitim uvedenim pojmovima te referirajući se isprva na Freudovu teoriju nagona, uspostavlja vlastiti odnos nagona, koji su neprestano u kružnome toku ${ }^{100}$, te objašnjava esencijalno dijalektične odnose seksualnosti i smrti, putem seksualnih nagona i tijela, kojima je početak i uporište život, a ishodište i konačna točka smrt. ${ }^{101}$

\footnotetext{
${ }^{100}$ Jacques Lacan, Četiri temeljna pojma psihoanalize, Naprijed, Zagreb, 1985, str. 186 - 190

101 Ibid. Str. $188-189$.
} 
Ta je teza, koja će biti kasnije izražena u elaboraciji misli Georgesa Bataillea, centralna je za razumijevanje dinamike sadomazohističkog odnosa u kojoj se osnovna dva nagona, sadizam i mazohizam, manifestiraju kroz odnos drugog - a kao objekta i Drugog - A kao subjekta.

Važno je istaknuti temeljne razlike u poimanju sadomazohizma između Freuda i Lacana, koje su potpuno logične i očekivane, obzirom na veliki napredak u psihonalitičkoj teoriji i praksi od Freudova do Lacanova vremena.

Freud uporno i dosljedno sadizam i mazohizam tretira kao perverzije i nastoji ih adekvatno liječiti, nalazeći njihove uzroke u brojnim infantilnim, no i kasnijim traumama i nesvjesnim fantazijama, no on zaključuje da su i sadizam, a naročito mazohizam dio i Erosa i Thanatosa, da pripadaju i nagonima ugode i zadovoljstva, no i nagonima destrukcije i smrti i stoga time ulazi u kontradikciju, kao što je često i slučaj sa svim njegovim teorijama.

Freud je, izgleda, želio istovremeno i „liječiti” od ugode, od sklonosti povođenja za načelom, od užitka, a opet, s druge strane, poticao je „, slobodnu, zdravu, zadovoljavajuću” seksualnost, no ona je „morala” biti genitalna, „oslobođena” od perverzija. Naravno, kao što je jasno iz njegovih spisa, on se ne uspijeva pomiriti s činjenicom da ukoliko su sadizam i mazohizam komponente načela ugode, odnosno, pružaju seksualno zadovoljstvo, ne bi trebale biti predmet patologije, koju je nužno odvojiti od seksualnih preferenci, no u tome ni mnogo kasniji Freudovi sljedbenici, pa i suvremeni kritičari, nisu potpuno uspjeli.

Lacan je upravo iz tog razloga bitna iznimka i najvažniji teoretičar ove teme, promišljamo li prvo njen psihoseksualni aspekt, koji i jest osnova ovog rada, a potom i psihologijske lingvističke odrednice međuljudskih odnosa koje on objašnjava svojim psiho - ontologičkim sustavom pružajući uvid u brojne korelacije osoba kao označitelja, ne donoseći pritom medicinsko - etičke sudove o seksualnosti.

Premda i on i sadizam, a posebno mazohizam smatra perverzijama, njegov je pristup potpuno drugačiji, jer za razliku od Freuda koji cjelokupnu seksualnost, a naročito perverzije svodi isključivo na vlastitu proizvoljnu teoriju nesvjesnog, Lacan nesvjesno objašnjava upravo jezikom koji je osnova svih psihičkih procesa te shodno tome i „seksualne perverzije” interpretira vlastitom sustavnom analitičkom psihologijom utemeljenim metajezikom.

Lacanov "povratak Freudu” bio je mišljen kao kritička dekonstrukcija Freudovih teza, no također ga je potrebno shvatiti i figurativno, kao utemeljenje jedne nove psihoanalize, što je i bio njegov cilj koji je maksimalno postigao, razmotrimo li brojne suvremene interpretacije 
raznih aspekata Lacanove psihologije i filozofije, od kojih su odabrane poveznice tematski zastupljene $\mathrm{i}$ interpretirane $\mathrm{u}$ svim dijelovima rada.

Cijelu jednu „novu struju“ poststrukturalizma potaknuo je upravo Lacan, čije je djelo bilo osnovno polazište brojnim suvremenim autorima za proširivanje i unapređenje područja psihoanalize, lingvistike, socijalne filozofije i epistemologije novim intepretacijama i primjenama Lacanovih teorija.

Rezultat je utemeljenje novih psihoanalitičkih i socio - filozofskih teorija jer njegov sustav logike i metajezika čini bitan okvir suvremene psihologije i filozofije seksualnosti i stoga je proučavanje i razumijevanje njegove filozofije i psihologije nezaobilazan i "vječan" temelj suvremene filozofsko - psihoanalitičke misli.

Lacan je svojim konceptualnim sustavom, odnosno, kategorijalnim aparatom nastojao prikazati i protumačiti gotovo sve temeljne odnose među ljudima, unutar individuuma samoga i to kao semiotičke odnose označitelja i označenika.

On je nastojao psihologijski i hermeneutički obuhvatiti odnos osoba kao označitelja, a odnose je tumačio kao složene koncepte ili kategorije.

Najbolji je primjer njegova teza iz četvrtog dijela opsežne knjige seminara „On Feminine Sexuality”, „Love and the Signifier“, a to je „Il n'y a pas de rapport sexuel“ (Ne postoji seksualni odnos, op.a.), u kojem on objašnjava odnos muškog i ženskog spola/roda kao dvije drugosti, a odnos među njima je odnos dvaju označitelja ${ }^{102}$ i stoga seksualni odnos postaje apstrakcija koja u bi bila kontradiktorna i "nemoguća” u psihologičkome smislu.

Time on podrazumijeva odnose između dva suprotna spola koji su oba označitelji i želi ukazati da „drugim “ ili „Drugim“ mora biti na suprotan spol - ,, Označitelj je karakteriziran činjenicom da predstavlja subjekt drugome označitelju “ 103

Na semiotičkoj i semantičkoj razini, između dva označitelja, konkretno muškog i ženskog, ne može u jezičnom smislu biti seksualnog odnosa jer se radi, u Lacanovu smislu, o jezično logičkoj konstrukciji jer sam pojam „seksualni odnos“ je znak ili označenik, a subjekti tada ostaju na razini označitelja.

Naravno, to je samo elementarni uvod jer ostaju brojna pitanja koja Lacan dalje razrađuje, a to su, pozicija subjekta, drugog spola, i njihova korelacija sa jouissanceom, koji jest manifestacija seksualnog odnosa jer je on kao kao veza dva označitelja kompleksno psihoanalitičko pitanje i

\footnotetext{
102 Jacques Lacan, On Feminine Sexuality, Love and the signifier, str. 49 - 50

${ }^{103}$ Ibid. str. 50
} 
Lacan zapravo ovim logičkim analizama želi prikazati brojna shvaćanja intersubjektivnih odnosa i razumijevanje seksualnosti same.

Njegova konceptualna sistematizacija odnosa označitelja izuzetna je inovativna je upravo zbog mogućnosti tumačenja neograničenih varijacija svih odnosa, bili oni odnosi prema sebi, interpersonalni, seksualni, odnosi jednakosti ili nejednakosti.

Seksualni je odnos u Lacanovim seminarima tumačen putem njegovih temeljnih pojmova i bitno je naglasiti da je utemeljen upravo na oprekama, nejednakostima i težnjama za identifikacijom s drugačijim, oprečnim ili Drugim, a njegova je centralna misao koja zaokružuje dinamiku seksualnog odnosa:

"U ljubavi cilj subjekt, subjekt kao takav, sve dok je pretpostavljen u artikuliranoj rečenici, u nečemu što je organizirano ili može biti organizirano na osnovi čitavog života. Subjekt, kao takav, nema mnogo veze sa jouissanceom. Ali, s druge strane, njegov znak je sposoban pobuditi želju. U tome leži osnovno polazište ljubavi." 104

Rapport je kod Lacana igra riječi - odnos i diskurzivni izričaj, izvještaj, jezični diskurs u logičkom i matematičkom smislu i time on otvara problematiku odnosa prema drugom/Drugom i razmatra mogućnosti takvog odnosa.

Kad se sjetimo da "jouissance Drugog nije znak ljubavi”, imamo još jednu zanimljivu logičku “jednadžbu” jer obzirom da je Drugi označitelj ne može biti znak i to je logička igra, kao i spomenuta logička teza o seksualnom odnosu. ${ }^{105}$

Lacan govori istovremeno i u psihologičkim terminima i metaforama, kao što se može iščitati iz ovog osebujnog seminara, a "Il n'y a pas de rapport sexuel" temeljna je psihologijska metafora na kojoj on gradi odnose između dvije osobe, formulirana i mišljena kao "logička apstrakcija", o Lacanovom promišljanju odnosa kroz jezik i strukturiranja odnosa putem logike jezika kao temelja psihologije.

Referirajući se na njegov koncept jouissancea u smislu seksualnog odnosa i užitka u istome, uviđa se bitna poveznica sa sadomazohističkim odnosom i to upravo u odnosu drugog i Drugog budući da je odnos između dominantne i submisivne osobe u mnogočemu analogan Lacanovom opisu u ,Love and the Signifier“.

Kao primjer navodim tezu “Jouissance Drugog nije znak ljubavi”, koja će kasnije biti detaljnije pojašnjena, no zasad ću naglasiti da se $D / s$ (dominant/submissive) odnos temelji na dominaciji

\footnotetext{
${ }^{104}$ Lacan, J, Seminar XX, Love And The Signifier, W.W. Norton \& Company, New York, 1998, prijev.a. 105 Ibid.
} 
i da je "zadaća" submisivne osobe pružiti jouissance, ne samo zbog zadovoljenja dominantne, već i zbog vlastitog plaisira, i tu se ne može govoriti o "klasičnoj ljubavnoj vezi”, premda ljubav može biti vrsta nagrade li naprosto spontani osjećaj koji će se razviti napredovanjem takvog specifičnog odnosa.

Za razumijevanja Lacana općenito, a naročito reprezentacije seksualnosti u njegovoj teorije, potrebna je ozbiljna studija Lacana, posebno $u$ formuliranju nove interpretativne teorije lacanovske psihologije sadomazohističke seksualnosti i stoga je važno napomenuti da su značenja i pozicije njegovih pojmova i kategorija veoma varijabilne te otvorene brojnim novim tumačenjima i spoznajama.

Lacan sve interpersonalne odnose, pa tako i seksualne „perverzije”, promatra kao relacije označitelja s pojmovima ili konceptualnim strukturama, a osnova je odnos malog a/drugog (objet petit a, le petit autre) kao submisivne osobe i velikog A/Drugog (le grande Autre) u odnosu na želju kao posrednu odrednicu svakoga odnosa u Imaginarnom poretku.

Sadomazohistička se seksualnost odvija i u Imaginarnom i Simboličkom poretku, pri čemu simbolički stadij obuhvaća stadij izgradnje osobe, a primarni Imaginarni označava neostvarenu želja, drugim riječima, reprezentira neostvaren bitak i egzistencija osobe i stoga je izvan dosega želje i jouissancea.

Želja (desir) je aktivni agens koji određuje poziciju individuuma, kao što ću prikazati kasnijim referencama i idejama suvremenih teoretičara psihoanalize i feminizma, no pored želje, bitno je razlikovati i pojasniti pojmove plaisir, jouissance, fantaziju unutar i onkraj kategorija Imaginarnog, Simboličkog i Realnog.

Želja uspostavlja odnos $a$ prema $A$, i to na način da, $a$, tj. drugi bivstvuje kao podređen želji Drugog - A, cilj mu je da služi njegovoj želji, želja drugog nije njegova, već on živi za želju Drugog, i do do mjere da se konačno identificira s njime kroz svoju potčinjenost $i$ to je polazišna točka sadomazohističkog odnosa, koji se dalje razvija shodno dijalektičkim procesima i dinamici koju proizvode dominantna (A, S) i submisivna (a, o) osoba u međusobnoj interakciji. Dijalektička dinamika subjekta i objekta konstituira sadomazohistički odnos u kojem subjekt egzistira kao potčinjen, drugi, objekt je želje Drugog jer on se s jedne strane identificira s drugim i time istovremeno i njegova želja postaje želja Drugog, on se odricanjem od svoje vlastite želje odriče i svog identiteta te zadobiva novi identitet kroz prizmu stadija zrcala.

Slika (image) koju u zrcalu vidi submisivna osoba jest slika Drugog, odnosno slika dominantne osobe kojoj ona stremi s kojom se se ona želi poistovjetiti ili joj se što više približiti da bi i 
sama mogla sudjelovati u razmjeni želje i moći, koja pripada samo Drugom. Način kojim će to postići jest da joj se potpuno podređuje služeći želji Drugog, izjednačavajući svoju želju sa željom Drugog i pružanjem plaisira kao užitka i zadovoljstva.

Drugim riječima, odricanjem od sebe, submisivna osoba kao $a$ i objekt odricanjem od sebe i svoje želje uspostavlja i ostvaruje sebe, proživljava svojevrsnu simboličku anihilaciju i doživljava "ponovno rođenje" svoga sebstva.

Pojasnit ću taj proces putem Imaginarnog poretka u kojem se odvija stadij zrcala, a odličan primjer, na koji ću se referirati je već ranije spomenuti književni klasik „Story of $O$ “, u kojem su brojni eksplicitni erotski opisi sadrže duboke psihološke analize.

Submisivna osoba „vidi u zrcalu“ dominantnu osobu, kojoj je ona objekt, svoju želju, no ona zapravo istovremeno gleda $\mathrm{u}$ dva zrcala, jer u prvome, gledajući dominantnu osobu i sama to postaje, kao O u dotičnome romanu ili pak postaje sve više podložna, dok u drugome zrcalu vidi izmijenjenu sebe - svoj novi identitet, svoju drugo sebstvo koje jedva prepoznaje i ta se dva odraza međusobno preklapaju i time ona putem stadija zrcala zadržava svoju opstojnost kroz psihičku metamorfozu na razini fantazije i njena opstojnost kao osobe ili ostaje u Imaginarnom ili prelazi u Simboličko, ovisno o dinamici želje i odnosa prema Drugom.

Kod Lacana nalazimo brojne igre riječi, koje prikazuju dijalektiku odnosa Drugog i drugog kao primjer navest ću najvažniju "Maitre - mon etre" ${ }^{106}$, koja prikazuje identifikaciju malog drugog (a) s Drugim (A) i time je polažište ontološke pozicije i psihičke dinamike sadomazohizma.

Lacan govori o dva nagona, sadističkom i mazohističkom, koji predstavljaju dva pola - mučiti i biti mučen čine kružni tok i time uvodi i treći nagon - novi Subjekt, koji predstavlja povratak u kružni tok, a to bi značilo ujedinjenje tih dvaju nagona ili pak njihovo poništavanje, povratkom na početnu točku kruga. ${ }^{107}$

Ta je njegova misao inspirirana Freudom, no ipak on zahvaća nagone bitno dublje te treći nagon kao subjekt, prikazuje kao figure drugog:

“Taj subjekt, koji je upravo drugi, pojavljuje se utoliko što je nagon mogao zatvoriti svoj kružni tok. Samo njegovom pojavom na razini drugoga, može se ostvariti odnos što pripada funkciji nagona.",108

\footnotetext{
106 franc. Maitre - gospodar, mon etre - moj bitak, tj. gospodar = moj bitak

107 Jacques Lacan, Četiri temeljna pojma psihoanalize, Naprijed, Zagreb, 1985, str. 189 - 190

108 Ibid. str. 189.
} 
"Novi subjekt” ili „novi drugi” bio bi impersonacija transformacije i transcendencije dominantne i submisivne osobe kroz njihovu novu egzistencijalnu poziciju što podrazumijeva sadistički i mazohistički karakter, no oni međusobno ne moraju biti komplementarni u klasičnom, uvriježenom smislu, već sadist može biti podređen, a mazohist dominantan jer ono što određuju pozicije Drugog i drugog jest upravljanje željom i njenim ostvarenjem.

Za razumijevanje Lacanovih stadija od velikog su značaja pojmovi užitak i zadovoljstvo (jouissance $i$ plaisir), a njihova se razlika najbolje može objasniti putem pojma fantazije. Fantazija je, kao što Lacan tumači kod stadija zrcala, maštanje subjekta da postaje objekt Drugom, poticaj želje za ostvarenjem plaisira i jouissancea.

Pritom jouissance nije samo užitak već je kod Lacana kompleksan pojam koji obuhvaća isprepletenost užitka, igre i zadovoljstva, kao jedan cilj kojemu svi odnosi teže, no također i kao posredna faza u realizaciji odnosa.

$\mathrm{S}$ lingvističko - semantičke strane, napominjem da su u francusko - engleskom riječniku značenja riječi jouissance sljedeća - enjoyment, pleasure, fruitition, possession ${ }^{109}$, od kojih je zanimljiv upravo posljednji - posjedovanje jer implicira posjedovanje objekta uživanja ili odnos “posjedovanja” između subjekta i objekta u sadomazohističkom odnosu.

Samo uspostavljanje odnosa i uloga nije jasno postavljeno u Lacanovom opusu, upravo iz razloga što se ono etablira na brojne načine, u raznolikim uvjetima i psihičkim ustrojstvima osoba te ih nije moguće jednostavno klasificirati kao u ranim psihoanalitičkim teorijama.

Osnovni cilj Lacanove teorije jest prikazati i objasniti dinamiku nagona te odnose subjekta i objekta, kojima on dolazi do problematike kategorije spola kao razlikovnog elementa ${ }^{110}$, što je najbolje elaborirano u seminaru „Love and the Signifier“", gdje je međusobni odnos suprotnih spolova postavljen kao odnos označitelja, kompleksan odnos koji, suprotno tradicionalnom mišljenju, ne vodi „ljubavi“ prema Drugom, već je odnos dvaju ili više označitelja postavljen hijerarhijski, a osnovne su mu karakteristike želja, jouissance, zadovoljstvo, dok se temelji na hegemoniji i dominaciji subjekta nad objektom. ${ }^{111}$

On ustanovljuje da "jouissance drugog nije znak ljubavi", a Drugi je reprezentiran tijelom pod time on podrazumijeva da je on isljučivo drugi spol, koji pretpostavlja jouissance kao seksualni odnos, no kroz razlikovnu ulogu falusa i njegovog manjka.

\footnotetext{
${ }^{109}$ uživanje, užitak, ostvarenje, posjedovanje, op.a.

${ }^{110}$ Ibid. str. 188

${ }^{111}$ Op.a. vezano za Lacanovu terminologiju
} 
Želja kao centralni pojam i ključni aktivni agens u Lacanovoj misli određuje i usmjerava svaki, koliko god kompleksan odnos dvaju subjekata, od kojih jedan postaje objekt, no istovremeno, "sub - jectum" je podređen Drugome ili drugome.

Osnovno je psihološkim i filozofskim kategorijama smjestiti subjekt i objekt unutar sfere Simboličkog, te naglasiti važnost prethodnog napuštanja Imaginarnog.

Bitno je napomenuti da je za njega želja uvijek izvan ili onkraj Realnog, a plaisir kao zadovoljstvo se ostvaruje upravo predstavljanjem i pružanjem plaisira malog drugog velikom Drugom putem želje i fantazije.

Lacanova psihoanalitička teorija polazi od toga da se libido zasniva na psihičkoj energiji želje, pa ću se referirati na njegov seminar "Desire and Its Interpretation" u kojem on napominje da su upravo mehanizmi želje, kao erotizirani simptomi, predmet psihoanalize, konstatirajući da "psihoanalitičari interveniraju u razne realitete fenomena sve dok oni dovode želju u igru”"112

Lacan izlaže tezu energije želje kao proširenje i preciznije objašnjenje ideje libida te napreduje od Freudove teorije definirajući želju kao identifikaciju sa željom gospodara, i time svojevrsnu perverziju, koju etablira kao punopravan entitet, dok su je raniji analitičari nastojali ukloniti iz psihičkog aparata individuuma.

On tumači želju i kao entitet i kao odnos “subjekt - objekt" u kojem je želja - želja Drugog, dok se odnos temelji na koegzistenciji označitelja i označenika pri čemu je želja gospodara zapravo želja drugog ja, uzvišenog Drugog - želja drugog da zadovolji i postane, uspostavljajući novi identitet unutar domene želje.

Njegovo revolucionarno multiperspektivističko poimanje želje najbolje je izraženo u etabliranoj frazi "Che Vuoi", ${ }^{113}$ koje je ishodište i geneza želje te svakog odnosa subjekta i objekta, kojji je zasnovan na želji Drugog, gospodara, no ujedno i želji drugog koji je samim postavljanjem pitanja ispunjava.

Kao primjer elaboracije Lacanove teorije u kontekstu sadomazohističke seksualnosti, objasnit ću odnose dominantne i submisivne osobe na slijedeće načine:

1) Temeljni odnos A - a u kojem želja posreduje odnos malog drugog prema velikom Drugom - drugi je sveden na objekt kojem je cilj da transformacijom svoje želje u želju Drugog, postigne

\footnotetext{
112 Ibid. str. 1

${ }^{113}$ Pitanje „Che Vuoi“ je Lacan preuzeo iz Cazotteovog djela „Le Diable amoreux“, u kojem se Drugi manifestira kao superego, a superego prvi puta susreće želju kao želju Drugog
} 
međusobni jouissance i time neprestanu dinamiku odnosa u kojem je ključna psihička dominacija Drugog nad drugim koji to prihvaća i nalazi u tome svoje zadovoljstvo.

2) Odnos dvaju subjekata S - s ili S - S u kojem je S/m odnos između dvaju jednakih osoba, dakle, shvaćen kao povremena, vremensi limitirana igra ili kao konstantna dinamika postavljenih uloga no uz međusobnu jednakost.

Takav odnos ne isključuje ništa iz prvonavedenog, već je daleko širi i psihološki raznolikiji u smislu izmjene moći, seksualnih praksi, kontrole i predanosti te samim time dugotrajniji.

3) Odnos S- o, koji u današnjim BDSM zajednicama i nije smatran reprezentativnim odnosom jer se ne temelji na jednakosti već na isključivnoj objektifikaciji submisivne osobe, koja je shvaćena i tretirana kao puki objekt.

Takav odnos može nekim osobama biti interesantan, no dugotrajno, on može biti i neprikladan te štetan za psihičku stabilnost submisivnih osoba, a često i destruktivan odnos u kojem jedna osoba iskorištava drugu ili autodestruktivan kod nestabilne submisivne osobe.

Postoje još brojne varijacije sadomazohističkih odnosa, no ovo su tri osnovne sheme Lacanove teorije prema kojima se potom sve ostale mogućnosti izgrađuju ili postojeće modificiraju.

Obuhvatiti sve opcije i kombinacije pojmova i kategorija Lacanova sustava nije jednostavno moguće, obzirom da su bezgranične, no one osnovne daju uvid u složenost ove problematike i cilj je njihovog prikaza uvod u daljnju filozofijsku razradu fenomena sadomazohizma, za koju je Lacanova filozofija odlična baza i samim time budi veliki interes za razvijanjem novih teza. Za psihoanalitičko - hermeneutičko proučavanje sadomazohizma u okvirima Lacanove misli potrebno je postaviti temeljno pitanje: Što je suština S/M odnosa dviju osoba, kakva je njegova priroda, je li to odnos subjekta i objekta ili dvaju subjekata te koji ga primjeri najbolje opisuju?

Budući da se ovo promišljanje ne može svesti niti na isključivo na psihoalizu, niti socijalnu filozofiju, prikazat ću sadomazohizam kao neograničeno inkluzivan psihoseksualno - filozofski fenomen i bitno je stoga, pored teoretskih mogućnosti predočiti najbolje reprezentativne primjere Lacanovim konceptima i mogućnostima njihovih relacija.

Ako govorimo o subjektu i objektu (S - o), nadređenoj i podređenoj osobi (A - a) i to je jedna mogućnost, a kad govorimo o dvaju subjekata tada bi se BDSM odnos opisao kao S- s li S - s, Drugi i drugi su shvaćeni kao uloge u "igri Imaginarnog”, pri čemu Realno uvijek ostaje nadvladano od Imaginarnog i Simboličkog i stoga predstavljeno kao nemoguće i to je želja i subjekta i objekta kao aktera odnosa. 
Međutim, ono što određuje o kojem se tipu odnosa radi, važno je uspostaviti ulogu želje, zadovoljstva i jouissancea - tko njima upravlja, u kojem smjeru ti pojmovi kao psihičke i tjelesne senzacije usmjeravaju odnos.

Subjekt, osoba mazohističkih sklonosti svoju želju predaje Drugome, štoviše, postaje djelomično ili potpuno podređena volji Drugog, dok sadistički subjekt provodi svoju želju nad drugim, pružajući mu pritom zadovoljstvo, dakle, također se podređuje želji mazohista.

Želja ima kompleksne, perpetualne, kružne tokove kojima neprestano stvara nove relacije, ona podređuje drugog, no istovremeno mu daje novi identitet, uspostavlja Drugog, čija je egzistencija stvorena i određena željom drugog.

Lacanovim riječima, "upravo subjekt koji je preuzeo ulogu predmeta podržava realitet situacije onoga što nazivamo sado - mazohističkim nagonom, i koji postoji samo u jednoj točki-u samoj mazohističkoj situaciji. Sado - mazohistički nagon se zatvara i konstituira zbog toga što subjekt postaje predmetom druge volje." 114

Objektivacija ili popredmećenje ${ }^{115}$ osobe uvijek je polazišna točka dinamike sadomazohističkog odnosa kao fantazija da se ostvari svoja želja zadovoljenjem sebe postajanjem objekta D/drugom.

U odnosu sadista i mazohista ili dominantne i submisivne osobe nema striktne, jasne podjele jer "sadist sam zauzima mjesto predmeta, ali ne znajući to, za dobitak drugoga, za čije uživanje on obavlja svoju radnju perverzno - sadističku'. ${ }^{116}$

Subjekt za Lacana faktički ne egzistira u domeni Realnog, koje za njega predstavlja nemoguće, preostaje mu život u Imaginarnog ili na granici Imaginarnog i Simboličkog poretka, gdje su moguća ozbiljenja svih zamislivih odnosa i upravo zato, možemo Lacanov sustav i nazvati psihologičkim, štoviše, metalogičkim i metasemantičkim.

Jezik i odnosi koji se njime konstituiraju, bitni su za objašnjenja svih intersubjektivnih odnosa, podrazumijevaći i derivirani odnos Subjekt - objekt i Drugi - drugi, koji mogu biti čak gotovo jednaki u svojoj semantici, psihologiji i praksi.

Subjekt ili individuum zapravo nije svjestan Realnog, ne može jer ne želi osvijestiti poredak koji bi ga sputavao, u smislu Freudovog Relitätsprinzipa, već reziduum nalazi u Lustprinzipu

\footnotetext{
114 Jacques Lacan, Četiri temeljna pojma psihoanalize, Naprijed, Zagreb, 1985, str. 196 - 197.

115 Popredmećenje kao nova riječ koju uvodim za objektivaciju, engl. objectification, op.a.

${ }^{116}$ Jacques Lacan, Četiri temeljna pojma psihoanalize, Naprijed, Zagreb, 1985 str. 197
} 
jer samo se, nakon Imaginarnog, u Simboličkom može približiti želji, upravljati njome i ostvarivati svoj plaisir i jouissance.

Najveći nedostatak Freudove teorije bio je upravo nedostatak pojam Drugog, priznavanje raznolike psihoseksualnosti u širemu smislu, pored, naravno, uvođenja termina djelomičnih nagona kao pokazatelj njegovog nerazumijevanja sadomazohizma kao psihoseksualne prakse. Za odnos pojedinca prema sebi i Drugome kod mazohističkog psihičkog ustrojstva i za međusobni odnos pojedinaca u sadomazohističkom odnosu, Lacanov je doprinos neizmjerno važan, upravo stoga što razlikuje tipove objekata.

Nema jasne granice između pozicije subjekta i objekta, jer Drugi može biti također objekt ili oboje istovremeno, kao što i drugi preuzima ulogu dominantnog subjekta, no kao što je već spomenuto, etimološki je subjekt taj koji je potčinjen pa bismo objekt stoga trebali doživljavati, ne samo kao predmet želje, već sam njen izvor, a time je on izvorni i dominantni akter odnosa. Želja potječe od “objekta”, od submisivne osobe, ona započinje dinamiku sadomazohističkog odnosa i njime upravlja, veoma kompleksno, perfidno, logički, dok se Drugi kao dominantan najzad mora potčiniti njenoj želji da bi zadovoljio vlastitu, oni konstantno zamjenjuju mjesta, igraju dvostruku igru želje i dominacije.

Koliko god bila istinita teza da drugi preuzima želju Drugog kao vlastitu, želja se u osobi subjekta kao Drugog se javlja posredstvom promatranja objekta, i time objekt postaje želja subjekta, pojmovi drugi i Drugi naposljetku gube svoja originalna značenja, a poprimaju nova značenja - dvaju jednakih subjekata.

U Lacanovoj teoriji, kao što se moglo vidjeti iz ranije prikazanog, mazohizam zaista, njegovim riječima, zauzima posebno mjesto i to se najbolje može razumjeti iz njegovog odnosa svih njegovih kategorija i koncepata, prvenstveno Drugog i drugog, no posebno objekta i subjekta te njihove pozicije u relacijskim strukturama želje, fantazije, (desir), zadovoljstva (plaisir), Imaginarnog i stadija zrcala.

Prvo je bitno spomenuti da on u svom seminaru „The Logic of Phantasy“117 polazi od objekta, raščlanjujući O i o, veliki i mali objekt, da bi objasno upravu poziciju sličnu onoj Drugog i $\operatorname{drugog}(\mathrm{A}-\mathrm{a})$.

Mali je objekt samo izraz želje Subjekta i on govori Drugome: „,Moja želja je tvoja želja“, „Moja želja je biti Ti“ “ $i$,Ja sam tvoja želja“ i u tome je izražena korelacija malog drugog kao potčinjenog i velikog Drugog kao Gospodara.

117 Jacques Lacan, The Logic of Phantasy, prijev. Cormac Gallagher, lacaninireland.com 
Međutim, kao što Lacan i uviđa, samim time upravo mali drugi uvjetuje želju i moć velikog Drugog, dijalektički, hegelijanski no i psihoanalitički.

Fantazija tako postaje realitet i tada Imaginarno isključuje Realno kao nemoguće, postavljujući se kao primaran i gotovo apsolutan poredaka fantazija postaje centralni koncept $u$ Lacanovoj teoriji za razumijevanje sadomazohističke seksualnosti.

Ona je presudna za sam doživljaj psihoseksualnih senzacija, osobito u mazohističkoj orijentaciji, jer na njoj se putem psihe zasnivaju sve tjelesne manifestacije

Njome počinje sama seksualnost mazohizma, budući da Lacan polazi od objekta i upravo je to presudno za za fenomen mazohizma.

Osobe mazohističkog psihičkog ustrojstva u fantaziji nalaze svoj jouissance i svoj plaisir, a pritom ispunjavaju užitak i zadovoljstvo Drugog.

Sama mogućnost ozbiljenja seksualnosti započinje upravo zamišljanjem, maštanjem o ostvarenju koje prelazi u realitet, realitet Imaginarnog.

Kad govorimo o fantaziji, u poziciji smo antiracionalizma, u kojem je i esencija i egzistencija u sferi Imaginarnog, no to "antiracionalno" i iracionalno ima ipak svoju logiku jer iracionalno je utemeljeno samo sa stajališta racionalnog i Realnog.

U BDSM odnosu fantazija je ono primarno i bitan dio apsolutnog, bitak i smisao odnosa koji se odvija između dvije osobe nema postavljenih granica ratia.

Fantazija o dominiranju druge osobe, posjedovanju iste, fantazija o potčinjavanju i bivanju posjedovanim su centralne iz kojih proizlaze sve sadomazohističke seksualne prakse, no njihovo uporište, alfa u umu, a tjelesna omega može biti samo privremeno i fiktivno jer je ličnost osobe u realitetu sasvim drugačija.

Upravo zbog takvog shvaćanja fantazijske i simboličke psihičke i fizičke dominacije i submisivosti, veoma je teško, ako ne i nemoguće većini razumjeti ovako duboku duhovno tjelesnu egzistenciju i upravo joj to daje onaj naizgled mističan atribut.

Fantazija je doživljena kao skrivena, tajna, a opet onima koji su otvoreni razumijevanju psihologije sadomazohizma, toliko prirodno i samorazumljivo i u tome je zapravo važnost ove seksualnosti, koja je odlično prikazana Lacanovim tumačenjem fantazije.

Upustimo li se u promišljanje ili praksu sadomazohističke seksualnosti, Imaginarni objekt je konstrukt naših želja i fantazija, što Lacan jasno izriče u svome seminaru „,The Logic of Phantasy" i taj odnos prema D/drugome imaju na gotovo jednak način i dominantna i submisivna osoba. 
Dominantna osoba odnosi se prema svom objektu želje jednako „opsesivno brižno“ kao i submisivna osoba prema svome, odvija se međusobna objektifikacija koj je cilj užitak i zadovoljstvo D/drugog.

Razlika je jedino u orijentaciji ili ulozi, koje se često i mijenjaju, dakle, ne možemo govoriti o isključivom sadizmu ni mazohizmu u ovome kontekstu, već o istovremenoj dominaciji i submisivnosti koje se isprepliću u unikatnom, ekskluzivnom odnosu dvaju subjekata koji jedno drugo objektificiraju - iz užitka, želje, pa i ljubavi.

Vratit ću se na Lacanovu logičku konstrukciju da ,jouissance Drugog nije znak ljubavi“ jer on nije znak - on je reprezentacija i manifestacija specifične ljubavi.

Lacan jasno prikazuje odnos osobe prema samoj sebi posredstvom D/drugog, jer mali objekt postaje velikim ispunjavanjem želje Drugog, a istim načinom i naizgled dominantni subjekt može postati Drugi samo u međuodnosu s o/Objektom.

Fantaziju je stoga neophodno promatrati uvijek u korelaciji o/O i s/Subjekta, što Lacan i prikazuje u svojim izuzetno interesantnim psihologičkim dijagramima koji su usmjereni na već spomenuto pitanje „Che vuoi“, a svi su pojmovi i kategorije povezani lancem označitelja koji određuje želja, no fantazija je njeno uporište.

Možemo reći da fantazija u svojim bezbrojnim oblicima stvara, uspostavlja i usmjerava želju i stoga, bez obzira što nije jasno označena u dijagramima, ona implicitno stoji iza riječi ,želja“ u svakome prikazanom odnosu.

Tome prethodi ona prvotna izgradnja sebstva, ovisna o partikularnoj orijentaciji osobe, koja je dinamična, nikada statična jer se pozicije subjekta i objekta, Drugog i drugog mijenjaju već napuštanjem stadija zrcala, a konačnu svoju formu za daljnji razvitak i međusobne korelacije postižu dinamikom želje kao počela te razmjenom moći putem plaisira i jouissancea.

Lacanovo postavljanje objekta kao polazišta pa i centra presudan je za teoriju mazohizma, kojoj će biti posvećeno mnogo više pozornosti nego sadističkoj orijentaciji, obzirom da je ona i kod najvažnijih teoretičara, a i s mog stajališta smatrana primarnom i daleko kompleksnijom i stoga pruža daleko više materijala za filozofsko - psihološku studiju, a time i veći interes za promišljanje fenomena sadomazohističke teorije i prakse. 


\section{Želja i D/drugi u sadomazohističkoj seksualnosti}

Korelacija želje i D/drugog polazište su za elementarnu uspostavu sadomazohističkog odnosa, kao što je Lacan već objasnio u seminaru „On Feminine Sexuality“ i taj je odnos daleko od idealizma ili romanticizma, već je logički, dinamički i zasnovan na moći i dominaciji.

U seminarima o želji, „Desire and its Interpretation“, te možda najrelevantnijim za tumačenje odnosa pojmova „Četiri temeljna pojma psihoanalize“, razjasnio je problematiku relacije želje i D/drugoga i logika je slijedeća: želja je uvijek želja Drugog, moja želja je želja mog Gospodara i ja sam je dužna ispuniti da zauzmem svoje mjesto u dijagramu odnosa.

U sadomazohističkom odnosu relacija želje i jouissancea su moj zadatak da udovoljim Drugome, a njegov plaisir i jouissance su ujedno i moji jer stvaraju i održavaju moju pozicije i identitet, pri čemu je moja želja je samo refleksija želje Drugog, želja drugog je refleksija želje Drugog, projekcija na velikog Drugog, koji je razlog mog opstanka u odnosu moći.

Podsjetimo se Lacanovog temeljnog metaforičkog pitanja „, Che vuoi?“" - ono je sada isključivo i eksplicitno - „Que veut mon Maitre?“ - što želi Drugi kao moj Gospodar - to je upravo na pitanje što želim ja, to i samo to može biti moja želja.

$D / s$ odnos je recipročan i komutativan - ja sam samo objet a i ostvarujem želju i jouissance Drugog samo na način da ispunim svoju vlastitu želju, dok Drugi ostvaruje svoj jouissance samo ostvarenjem mojeg i zbog toga je međusobna kompatibilnost, inkluzija i koncentričnost neophodna, kao što je i prikazano u Lacanovim brojnim dijagramima.

Na psihološke i etičke dileme sadomazohističkog odnosa možemo jednostavno odgovoriti da se radi o odnosu dvije jednake osobe, no može se uvijek zapitati na koji način Drugi kao gospodar doživljava drugog, kao naizgled podređenog i tko zapravo određuje želju ?

Odgovor bi mogao biti da je želja konstruirana obostrano jer za Drugog sam ja kao drugi također doživljena kao veliki Drugi $-A-A^{\prime}$ i to je već objašnjena suština odnosa.

Način na koji Drugi doživljava mene određen je jednakim uvjetima pod kojima i ja doživljavam njega jer dominantna i submisivna osoba čine jednu specifičnu cjelinu, no u smislu Deleuzeovog tumačenja mazohizma, a suprotno Freudovoj psihoanalizi. 
Relacija S/m odnosa stoga može biti shvaćena i jednostavno i kompleksno, ovisno o prirodi odnosa, a ponajprije o ličnostima koje ga sačinjavaju i razvijaju.

U sadomazohističkom odnosu bitno je naglasiti ontološku dimenziju, u pogledu identiteta i uloga, koja je od iznimne važnosti i time razjasniti osnovne moguće pozicije individuuma i njegove egzsistencijalne, ontologijske izgradnje.

Sintagma „ontologija sadomazohizma“ nosi kompleksno značenje razlučivanja pozicije dominantne i submisivne osobe i njihovog odnosa, prvenstveno psihološko - lingvističkog te potom seksualnog kroz filozofsku interpretaciju.

Moderne i suvremene teorije filozofije seksualnosti i psihologije koje nasljeđuju temelje proučavanja fenomena sadomazohizma, označit ću, ne samo kao poststrukturalističke, već i kao kao postpsihoanalitičke.

Lacanovu filozofiju i kasnije teoretičare seksualnosti inspirirane njegovom teorijom potrebno je sagledati i interpretirati u kroz nova značenja i time ih proširiti na područje u kojem do sada nisu bile eksplicitno i potpuno izgrađene.

Lacan je bio na najboljem tragu razumijevanja psihoseksualnosti sadomazohizma pa ću stoga izložiti vlastitu interpretaciju njegove psihoanalitičko - semantičke misli, primijenjenu na izrazito složene odnose sadomazohističke seksualnosti.

Možemo ga stoga nazvati začetnikom postpsihoanalize s naznakama antiracionalizma, budući da se kod njega svi psihički procesi i odnosi odvijaju u Imaginarnom i Simboličkom poretku, dok Realni poredak predstavlja autonegaciju.

Simboličko je strukturirano i doživljeno kao istinska egzistencija i bitak, dok je Realno nemoguće, nebitak, ,neželja“ u tome shvaćamo Lacanov zaokret od racionalističke freudovske psihoanalize te posve drugačiji, psihologički pristup seksualnosti.

D/s odnos, tj. odnos dominantne i submisivne osobe zasniva se na doživljavanju sebe u nadređenom ili podređenom položaju u psiho - seksualnom odnosu, no psihički je aspekt primaran, iz kojeg se razvija cjelokupan odnos prema sebstvu te prema drugoj osobi kao drugobitku, koji producira perpetualnu dinamiku potrebnu za održavanje egzistencije te vrste. Već u pisanju riječi „Dominantan“, „,submisivan“, „Gospodar/ica, „rob/inja“ vidimo hijerarhiju odnosa unutar jezika, kao i u obraćanju dominantnoj osobi na „Vi“, „Gospodaru/ice“ i slično. Iz perspektive submisivne osobe, to bi značilo - odnos sebe kao podređenoj Drugome, jer mazohizam je velikim dijelom u imaginarnoj sferi i njen odnos prema dominantnoj osobi, kojoj 
se predaje psihički i tjelesno, kao objekt, objektivizirani individuum, koji u svrhu S/M prakse, prestaje biti samostalan i slobodan, no kroz svoju submisivnost i snagu koju ona zahtjeva zadobiva novu, drugačiju vrstu slobode putem novoostvarenog identiteta.

O tome je osobito stručnu i detaljnu teoriju izgradila suvremena američka psihoanalitičarka Jessica Benjamin, koja, uz brojne neofreudističke i lacanovske teze, uvodi brojne nove pojmove u znanosti o sadomazohističkoj seksualnosti.

Suština BDSM - a je dominacija nad - i submisivnost tijelom i psihom jer mazohistički subjekt transcendira u objekt Drugog, Dominantnog, kojem želi podrediti svoje tijelo, psihu, misli i konačno um, sebe bezuvjetno i bezgranično.

Najbolji primjer u literaturi za ovu praksu je protagonistica romana „Story of $O$ “, koja odjednom spoznaje u sebi svoju iskonsku seksualnost i podređuje se osobama i radnjama koje bi i većini današnjih $\mathrm{S} / \mathrm{M}$ praktikanata bile nezamislive. ${ }^{118}$

Osnovni koncepti koje je potrebno objasniti su teorija intersubjektivnost, koja se odnosi na interakciju sebe $\mathrm{i}$ drugoga, te se $\mathrm{u}$ tom pogledu individuum razvija $\mathrm{u}$ odnosu $\mathrm{s}$ drugim subjektima, i intrapshička teorija koja drži da subjekt počiva na nesvjesnom, no ta dva shvaćanja psihe su međusobno povezana, a ne suprotstavljena. ${ }^{119}$

Koncept dinamičkog nesvjesnog, kao utjecaj Freuda, Benjamin uvodi kao poveznicu te dvije teorije jer ,bez intrapsihičkog koncepta nesvjesnog, intersubjektivna teorija postaje jednodimenzionalna "120, a poziciju individuuma ona tumači intersubjektivnom teorijom jer se fenomen sadomazohizma jedino i može razumjeti kroz odnos sa i prema drugome.

Mazohizam autorica tumači u kontekstu intersubjektivnosi kao želju i potrebu za priznanjem Drugog, koje je najviši cilj submisivne osobe, a smješteno je iznad ili onkraj senzacija moći i nemoćnosti ${ }^{121}$ jer ona konstatira da je ,žudnja za priznanjem proces koji objašnjava na koji način naše najdublje želje za slobodom $i$ zajedništvom postaju implicirane u kontroli $i$ submisivnosti te se ,iz tih želja stvaraju veze ljubavi“. ${ }^{122}$

\footnotetext{
118 Pauline Reage, Story of O, Corgi Books, London, 1994

119 Jessica Benjamin, The Bonds of Love - Psychoanalysis, Feminism and the Problem of Domination, Pantheon

Books, New York, 1988, str. 15 - 25

120 Ibid. str. 21

121 lbid. str. $82-84$.

122 Ibid. str. 84
} 
Benjamin piše iz feminističke pozicije u kojoj je žena uvijek submisivna i teži podređenosti, a muškarac dominantan, što se najbolje vidi u njenom promišljanju objektivizacije žene kao osobe i njenog tijela i njena bitna referenca na Freuda jest da je falus iskonski simbol želje.

Žena je svedena samo na objekt čija je želja biti željena, ona nije subjekt vlastite želje već je u ulozi objekta zadovoljstva muškarca, ona čak niti nema vlastitu želju, koju samo muškarac može posjedovati, kao i ženu samu, poput objekta koji služi njemu kao Drugom. ${ }^{123}$

Ove bi se tvrdnje mogle shvatiti "radikalno feministički", no intencija autorice je kritičko promišljanje rodnih odnosa u sadomazohističkom odnosu, a pravo im je značenje upravo obostrana želja žene i muškarca za dominacijom i submisivnošću, erotska dominacija u kojoj su partneri drugačiji no jednaki.

Ženin „manjak želje“ njeno je vlastito, svjesno davanje kontrole nad sobom i svojim tijelom Drugom, mazohizam je u tome smislu njeno psihičko i seksualno oslobođenje.

Ona se kao podređena ostvaruje i ispunjava i time objektivacija submisivne žene postaje njen bitak, kao što i njena „nepostojeća“ želja postaje njena istinska želja i na taj način ostvaruje erotsku zajednicu s dominantnim muškarcem.

Submisivna osoba ima duboke mazohističke težnje jer agresija je, kao što i Benjamin uviđa, neophodan dio seksualnosti, i u tome smjeru možemo razumjeti intenzivne psihoseksualne orgazmičke doživljaje kao što su „subspace“ i „topspace“, specifična euforična stanja uma nakon intenzivne sesije, najčešće „edge playa“, u kojem se prelaze granice boli, a stanje zadovoljstva može potrajati satima.

Benjamin u svojoj knjizi kroz analizu izmjene moći "power exhange“ i pozicije rodnih identiteta u BDSM praksi implicira tu jednakost užitka Drugog i objekta kroz paradoks dominacije i submisivnosti, odnosno Hegelov paradoks gospodara i roba, koji su u analizi sadomazohizma koristili gotovo svi autori tog područja.

Ona ga tumači kao odnos sebstva, subjekta, objekta i Drugog, kao borbu između ,neovisnosti $i$ ovisnosti o samosvijesti“", u smislu da subjekt nastoji očuvati sebstvo pokušavajući se postaviti kao neovisni entitet, no potreban mu je Drugi ili drugi, subjekt ili objekt da bi kao on mogao egzistirati - kontrolirati drugoga kao objekt ili biti podređen kontroli Drugoga kao objekt. ${ }^{124}$

\footnotetext{
123 Ibid. str $88-89$

124 Ibid. str. 31 - 34
} 
Benjamin objašnjava polarizaciju rodnog identiteta prvo kroz maskulinizaciju sadizma i feminizaciju mazohizma, utemeljenu u Freudovim djelima koju rezolutno odbija te piše iz feminističke pozicije, sugerirajući da je u pogledu dominacije i rodne razlike žena uvijek objekt Drugog i jednakost još uvijek nije postignuta zbog porijekla sadomazohistčkih uloga, u kojima je originalno muškarac imao moć nad ženom, kao objektom koji ima zadovoljstvo biti željenim. ${ }^{125}$

Već i davno prije njenog vremena, to nije bio slučaj u praksi, a u suvremenom shvaćanju sadomazohizma od 1960 -ih do danas, uloge i ontološke pozicije su izjednačene ovisno o seksualnoj sklonosti, neovisno o spolu i rodu.

Stoga bi se moglo zaklljučiti da je seksualna diferencijacija uspješno i logično prevladana, jer odnos objeta $A$ i objeta petit a nisu uvjetovani rodom, već dominantnom ili submisivnom seksualnošću individuuma.

Nije li submisivni muškarac na jednak način samo objekt podređen dominatnoj ženi i ne uživa li submisivna žena u svojoj podređenosti, koja joj je često i jedini uvjet zadovoljenja, jednakim intenzitetom kao i muškarac?

Žene i muškarci su stoga u sadomazohističkom kontekstu prema svojoj psihičkoj i seksualnoj poziciji jednakopravni, i kao dominantni i kao submisivni, bez obzira što većina teoretičara još uvijek smatra da je podređena uloga svojstvena, odnosno nametnuta ženi.

Govoreći o problematici dominacije, Benjamin razlikuje Eros kao fantaziju za dominacijom i perverziju kao pravu, istinsku dominaciju ${ }^{126}$, što je izrazito važno razumijevati i razlikovati u sferi S/M - a, jer fantazija za erotskom dominacijom utjelovljuje i želju za neovisnošću i želju za priznanjem drugog ${ }^{127}$

Erotska dominacija ima duboko značenje, počevši od muške separacije od ženskog drugog kao objekta, podsvjesno podređene majke, gdje se još vidi velik utjecaj Freuda, no ono bitno za ovaj rad je dominacija kao erotizacija razlike, kontrole, transgresija dominantne osobe kao gospodara i time objektifikacije žene. ${ }^{128}$

\footnotetext{
125 Ibid. str. 81 - 91

126 Ibid. str. $73-74$

127 Ibid. str. $52-53$

128 Ibid. str. $75-79$
} 
Benjaminina formulacija glasi: „Upravo ta objektivacija, kombinirana s održavanjem apsolutne razlike i kontrole objavljuje gospodarevu transgresiju. “129

Ona govori i o ,povredi ženskosti“, no bitno je naglasiti njen odmak od radikalnog feminizma te činjenicu da submisivna žena sama pristaje na svoj manjak subjektivnosti ${ }^{130}$, predajući sebe vlastitom voljom za vlastiti užitak moći gospodara kao jednakopravna u odnosu i time, odričući se sebe, predaje i svoju subjektivnost te konačno i volju samu.

Kao što je i Freud utvrdio, sadist je seksualni objekt mazohistu i tu se odražava egalitarnost i uzajamna povezanost sadizma i mazohizma, što se može povezati i s Deleuzeovim tezama, naročito analizi Masochovog djela.

Sadistička i mazohistička tjelesnost i seksualnost ne bi smjeli biti shvaćene kao nagoni za destrukcijom ili autodestrukcijom, što je često u medicinskoj praksi, već kao težnja za užitkom i oslobođenjem tijela i uma.

Između Benjamin i Lacana nalazimo brojne poveznice, kao osnovnu navest ću simbolički poredak Drugog i drugog, te monopol falusa u reprezentaciji želje, u kojem je žena stavljena u poziciju drugog koji je obilježen manjkom i nastoji služiti Drugome, podrediti mu svoju želju i egzistenciju, a krajnja je točka takvog odnosa asimilacija vlastitog sebstva s drugim. ${ }^{131}$

U svojoj knjizi „Bonds of Love, Psychoanalysis, Feminism, and the Problem of Domination“ ona govori upravo o problematici odnosa Drugog i drugog i samim time o rodnim razlikama, pri čemu najveći naglasak stavlja na pojam želje i njeno (ne)ozbiljenje u ženskoj egzistenciji i seksualnosti koja je suprotstavljena muškoj, dominantnoj poziciji. ${ }^{132}$

Benjamin prikazuje izuzetno važnu problematiku za sadomazohistički odnos, a to je odnos subjekta i objekta, drugog i Drugog, koji se može, prema Lacanu, dijalektički tumačiti, no feministički je pristup ovdje drugačiji.

U izvornom tumačenju Lacana, primaran je koncept želje, koji određuje i bitak i poziciju osobe, a Benjaminin je pristup da u odnosu submisivne i dominantne osobe nema dijalektike niti mogućnosti recipročnog ili egalitarnog odnosa, jer samo dominantna osoba ima i posjeduje želju i moć, a egzistencija submisivne jest da služi želji dominantne, dok vlastite želje nema.

\footnotetext{
${ }^{129}$ Ibid. 77 prijev. a.

130 lbid. str. 77 - 80

131 Ibid. str .67, 86 - 90

132 Jessica Benjamin, The Bonds of Love - Psychoanalysis, Feminism and the Problem of Domination, Pantheon Books, New York, 1988, str. 86 - 90
} 
Već prvu kritiku moram uputiti njenom ograničavanju na odnos podređene žene i dominantnog muškarca i interpretaciji takvog odnosa odviše neofreudovski, budući da je i cjeli njen znanstveni rad baziran na feminističkom pristupu cjelokupnom Freudovom djelu. ${ }^{133}$

Benjamin je koncentrirana na fenomen ženske submisivnosti i želje za muškom dominacijom, na odnosu submisivne žene prema dominantnom muškarcu kao idealiziranom ocu, kao Drugom, što oprimjeruje vlastitom feminističkom interpretacijom Freudove teorije.

Ona propitkuje "hegemoniju falusa" - poredak u kojem je žena objet petit a, a muškarac objet $A$ te smatra da bez obzira na rodnu polarizaciju samo jedinstvo sumisivne i dominantne sobe mogu činiti cjelinu. ${ }^{134}$

Njeno se djelo, koliko god opširno i bogato razrađeno, ne udaljava od ekskluzivno ženskog mazohizma i ženske submisivnosti i stoga sagledava stvar isključivo s feminističkog stajališta, no ipak se znatno separira od tradicionalnih feministkinja koje su oštre oponentice sadomazohizma per se.

Putem brojnih vlastitih feminističkih interpretacija Freudovih teza autorica zapada u problematiku oprečnosti - govori li o sadomazohizmu iz suvremene perspektive ili se vraća zastarjelim teorijama poput supremacije oca, prezira prema deseksualiziranoj majci i manjka falusa kroz suvremeni feminizam?

Ona pritom navodi i vlastitu studiju slučaja uspješne žene kojoj je imanentna podređenost muškarcu kao reprezentaciji oca, i daleko više, reprezentaciji nje same kao objekta želje, a to je motiv koji nalazimo i u romanima Pata Califie, od kojih ona navodi "Jessie” koja je kao submisivna "potpuno neovisna žena koja opisuje da je erotska violacija konačno oslobađa “mjehurića sebstva, zatvora uma”. 135

Iz navedenog, mazohist je nezavisna osoba koja uživa u submisivnosti kao u svome oslobođenju, slobodnom voljom i vlastitim pristankom te seksualnost bez D/s odnosa joj je neispunjavajuća, nezadovoljavajuća i stoga joj je S/M praksa neophodna za postizanje sreće i užitka, a rodno nametanje uloga u sadomazohističkom odnosu je pretjerano.

\footnotetext{
133 Pritom mislim prvenstveno na Benjaminine knjige "The Shadow of the Other" $\mathrm{i}$ „Beyond Doer and Done to Recognition Theory, Intersubjectivity and the Third", op.a.

134 Ibid. str. 86 - 90

135 Ibid. str. 83
} 
Benjamin tako upućuje kritike brojnim feminističkim teoretičarkama koje su bile, po mome mišljenju, oštre protivnice ženskog mazohizma iz razloga što ga jednostavno nisu mogle razumjeti pa su se postavile prema njemu kao prema "opresivnoj" praksi.

O feminističkim zagovornicama i oponenticama sadomazohizma bit će riječi u petome poglavlju, a u "Bonds of Love" je jedini "problem" što sagledava i razmatra samo i isključivo žensku mazohističku i submisivnu poziciju te suviše podržava Freudove teorije, poput želje za ocem kao “uzroke” težnji za submisivnošću žena.

Kritika koju je nužno uputiti svim interpretacijama Freuda, pa tako i ovoj jest naizgled nepremostivi paradoks da žena uvijek ima potrebu biti seksuani objekt figure oca - u slučaju kad je polje označitelja oca prazan - kad otac ne postoji već je manjak ona ga mora fiktivno "stvoriti", no naročito kad je otac oduvijek njena centralna figura i kad borbu za njegovu podsvjesno seksualnu naklonost prenosi na partnera.

Ta je teza upravo opreka njenom psihoanalitičkom opažanju da žena nema svoje želje i bitno je razlučiti feminističke teorije od psihoanalitičkog uvida u sadomazohistički odnos, što brojne autorice ne čine dovoljno jasno ili uopće.

Poveznica s Lacanovom teorijom, pored odnosa prema Drugom, jest ideja da je falus univerzalni simbol želje en generale, a žena zbog vlasttitog manjka falusa podilazi Drugom, i uvijek mu služi bez vlastite želje, no uviđamo još jedan bitan manjak - manjak želje i žena ima dva osnovna manjka, te joj je, prema psihoanalitičkoj teoriji, submisivna uloga neizbježna i jedina moguća opcija.

Paradoksalna teza koju uviđamo u „Bonds of Love“ je da se oslobođenje žene zbiva u momentu kad ona postaje seksualni objekt, suprotnost „tradicionalnoj“ figuri ,žene - majke“ koja je deseksualizirana, već je žena seksualizirana, u službi želje Drugog i to je njen iskonski i istinski bitak koji mora dostići.

Možemo stoga zaključiti da je osoba, kao praktikantica BDSM -a , neovisno koje orijentacije ili u kojoj poziciji, oslobođena društveno nametnutih uloga i stvara unutar sebe te između sebe i D/drugog harmoniju Simboličkog i Imaginarnog.

Takvom erotskom unijom dvaju ili više osoba postže se sklad uma, psihe i sebstva kod svake osobe unutar odnosa i to je cilj i submisivnosti i dominacije i Benjaminin rad može biti shvaćen kao eksplicitna psihoanalitička kritika rodnih odnosa, no fokus će ipak biti na njenim osnovnim tezama o sadomazohizmu. 
Kad govorimo o rodnim odnosima i naizglednim oprekama dominantnih muškaraca i submisivnih žena, moramo se prisjetiti Lacanovog seminara "Love and the Signifier", u kojem svojim jezikom govori upravo o toj problematici.

Drugi kao drugi spol, jouissance Drugog koji nije znak ljubavi te "nemogućnost seksualnog odnosa" osnovne su njegove implikacije kojima želi ukazati upravo na paradoksalnost rodne i seksualne problematike.

Kao što je već poznato, odnosi Drugog i drugog, dominantne i submisivne osobe sve su samo ne oprečni i deseksuallizirani - oni su vođeni perpetualnom dinamikom želje i seksualnosti, u terminima plaisira i jouissancea, i stoga Lacan mazohizam postavlja na početnu točku, a jouissanceom označava upravo seksualni odnos.

Benjamin možda suviše inzistira na odnosu subjekt - objekt, no ipak ne zanemaruje dinamiku D/s odnosa i jednakopravni status osoba i njena je centralna teza da su dominacija i želja Drugog i biološki i kulturno uvjetovani, no ne zanemaruje niti psihološku dimenziju potrebe za submisivnošću, no, kao što sam već napomenula, previše se oslanja na freudovsko objašnjenje ženske submisivnosti.

Ipak, brojne njene ideje su izuzetno relevantne kao originalna suvremena psihoanalitička tumačenja, posebice njena teorija mazohizma i submisivnost kao oslobođenje sebstva kao osnovni leitmotiv knjige od centralne su važnosti jer upravo mazohizam kao odnos prema drugom temeljna je poveznica s Lacanovom filozofijom jer je Drugi neophodan za ostvarenje i oslobođenje sebe.

Od teza koje sam istaknula u nekoliko poglavlja rada, izdvojila bih njeno tumačenje erotske dominacije, dijalektiku kontrole, tumačenje Batailleva djela, te elaboraciju "Story of $O$ " kao relevantne za ovu tematiku, a naravno i njene misli koje se u mnogočemu nadovezuju na Lacanovu teoriju.

U svojoj analizi dotičnog romana, Benjamin predstavlja osnovnu psihologiju i dinamiku sadomazohizma, nazivajući je sadomazohistčkom fantazijom o erotskoj dominaciji, jer vrstu dominacije i submisivnosti u kojima je riječ shvaća trangresijom tjelesnog i psihičkog podređene osobe. ${ }^{136}$

\footnotetext{
136 Jessica Benjamin, The Bonds of Love - Psychoanalysis, Feminism and the Problem of Domination, Pantheon Books, New York, 1988, str. 55
} 
Važno je napomenuti da ovdje pojam „fantazije“ treba shvatiti metaforički, jer roman opisuje jednu realnu situaciju, pogotovo u suvremenoj praksi BDSM - a.

Potpuno, bezuvjetno, podređenost i poslušnost i odricanje od vlastitog subjektiviteta, kao što je već spomenuto, dio su 24/7 odnosa, u kojem submisivna osoba prolazi kroz gubitak svog prvotnog identiteta da bi zadobila novi identitet koji joj omogućuje i novu egzistenciju koja joj je dotad bila svjesna ili nesvjesna fantazija.

Podređivanje drugome je tako ujedno i prvenstveno podređivanje sebi i svojim željama, što Benjamin i napominje $\mathrm{e}^{137}$, a prvotni manjak subjektivnosti i negiranje sebe, neophodan su dio procesa koji vodi transformaciji - zadovoljenju dominatne osobe kao cilju i zadovoljstvu koje pritom doživljava submisivna.

Dijalektika kontrole, koju njeno djelo elaborira, utemeljena je na erotskoj submisivnosti, strahu od gospodareve moći, a održava se disciplinom, služenjem i poslušnošću i na taj se način otklanjaju svi strahovi te uspostavlja veza ${ }^{138}$.

Erotska je dominacija na taj način oslobođenje u kojem gospodar nad robinjom ima potpunu kontrolu, tretira je kao objekt jer njegov je cilj prosvijetljenje robinje ${ }^{139}$, kojim je dovodi na viši nivo svijesti za obostrano zadovoljstvo.

Argument koji Benjamin iznosi jest da su kontrola i submisivnost, uz čežnju za priznanjem drugog, najdublje želje za slobodom i zajedništvom ${ }^{140}$, koje je potrebno osvijestiti i ona podsjeća da su žene tih predispozicija samostalne žene koje uživaju u svojoj submisivnosti kao oslobođenju od nametnutih normi i nametnutog $\mathrm{Ja}^{141}$ :

„Mazohizam, stoga možemo promatrati, ne samo kao strategiju bježanja od samoće, već također kao potragu sa samoćom s drugim: dozvoljavanjem drugim da zadrži kontrolu, mazohist se nada naći „siguran“ otvoreni prostor u kojem će napustiti zaštititni lažni Ja i dopustiti urođenom, skrivenom Ja da izroni" 142 .

U ovoj je misli uvelike sadržana bit mazohizma, koja perpetualnom ontološkom dinamikom omogućuje realizaciju sadizma, diferencijacije, a time ravnoteže i komplementarne povezanosti

\footnotetext{
137 Ibid. str.

138 Ibid. str. $55-79$

139 Ibid. str. $55-63$

140 Ibid. str. $83-84$

141 lbid. str. 82 - 84

142 Ibid. str. 72, prijev. a.
} 
Erosa i Thanatosa ostvarenjem najdubljih želja - užitka tjelesnih senzacija boli i psihičke dominacije i submisivnosti življenjem fantazije.

Benjaminina analiza djela „Story of $O^{“}$ je veoma zanimljiva, jer ona polazi upravo od već spomenute samosvjesne submisivne žene u kontekstu feminizma.

Osnova odnosa O s Drugima kao submisivne žene koja traži i formira svoj identitet svojevrsnom anihilacijom utemeljena je na sadomazohističkoj fantaziji - fantaziji o erotskoj dominaciji $^{143}$ koja, kao najdublji oblik potpunog predavanja sebe Drugome, postaje novouspostavljeni apsolutni modus vivendi.

Teorija submisivnosti za Benjamin predstavlja želju za psihičkim i seksualnim oslobođenjem, koje se realizira potčinjenošću Drugome, svojevrsnim „prosvijetljenjem“ i izgradnjom nove ličnosti budući da submisivna žena tako također slijedi svoju logiku, komplementarnu logici Drugog kao dominantne osobe ili gospodara i na taj način ponovno zadobiva vlastitu želju.

O tako prolazi proces individuacije i voljnom submisivnošću postaje „nova žena“, jer prvotnu negaciju vlastitog identiteta zamjenjuje stvaranjem svog novog subjektiviteta i time prevladava granice stereotipiziranih submisivnih žena. ${ }^{144}$

Pozicija O u Roissyu dualistična je jer s jedne strane, poredak kojem je podvrgnuta je stroga racionalistička disciplina u stilu Sadeovih djela, ali cilj ovakve dugotrajne discipline je prevladavanje psihičkih granica i zadobivanje priznanja putem nemoći i podređenosti, da bi protagonistica i sama postala dominantna, sadistička ličnost i naučila uživati dvostruki identitet koji je morala zaslužiti - submisivne robinje i gospodarice, no prvi joj, kao iskonski i bitni ostaje primarni.

Benjamin kostatira: „,Veza dominacije je asimetrična. Može se preokrenuti kad O preuzima ulogu mučitelja, ali nikad ne može postati recipročna ili jednaka.

Identifikacija je važan dio ove promjenjive veze, ali uvijek stipulacijom da mazohist zadobiva svoj identitet kroz gospodarevu moć. " 145

Relevantan je i interesantan njen osvrt na Bataillea, čija će misao kasnije biti detaljno razrađena, kao i usporedba s Freudovom teorijom vezanu za koncepte erotizma, seksualnosti i destrukcije

\footnotetext{
143 Jessica Benjamin, The Bonds of Love - Psychoanalysis, Feminism and the Problem of Domination, Pantheon Books, New York, 1988, str. $55-63$.

144 Ibid. 55 - 65, 83

145 Ibid. str. 62, prijev.a.
} 
jer u poveznici s Freudom, Benjamin naglašava da je za njega seksualna dominacija neizbježna jer bi se inače instinkt smrti okrenuo unutra i uništio život sam.

Život i smrt su uvijek povezani, a „,najbolje mjesto za analizu spajanja života i smrti su upravo erotski život sadizam i mazohizam kao manifestacije destruktivnog nagona, snažno udruženog s erotizmom". 146

Referirajući se na Bataillea, ona konstatira da je on „direktno primijenio Hegelovu dijalektiku na erotsku violaciju “ 147 te da je za njega individualna egzistencija stanje separacije i izolacije“ jer smo povezani i odvojeni idejom smrti.

Benjamin zamjećuje bitne odrednice Batailleve filozofije seksualnosti kao što su tijelo koje reprezentira individualnost i život, shvaćene kao granice koje, po njegovom mišljenju moramo prijeći i prekršiti jer je ,, violacija tijela transgresija granice između života i smrti “i to je upravo ono što čine i sadistička i mazohistična osoba.

Rezimirano, i submisivna i dominantna osoba doživljavaju ultimativno uzbuđenje u činu nasilja, submisivna uživa u „gubitku sebe“ primanjem boli, a dominantna u kontroli nanošenjem boli, a dinamika rezultira „protektivnom moći i autoritetom“ sadista i voljnom podređenošću mazohista čime se postiže njihov zajednički užitak.

Zaključno, najvažnije kod Jessice Benjamin je njena teorija samosvjesne želje koja svoju seksualnu submisivnost doživljava i prakticira kao oslobođenje, oslobođenje od svih društvenih normi, svojevrstan reziduum ustaljenom, svakodnevnom životu koji je ne ispunjava, to ispunjenje submisivna žena ili osoba, nalazi upravo u podređenosti Drugome, u tome je njeno zadovoljstvo i njena želja.

Sadomazohizam je neophodno sagledati i promisliti kao psihosocijalni konstrukt, u smislu stereotipizacije i $\mathrm{S} / \mathrm{M}$ odnosa i pojma samoga te se tim putem približiti prvim pokušajima teorijama dekonstrukcije koje već nalazimo u samim počecima poststrukturalizma, kojeg je Lacan zapravo i bio začetnik.

\footnotetext{
146 Ibid. str. 66, prijev.a.

147 Ibid. str. 63. prijev.a.
} 


\subsection{Erotizam i seksualnost}

Kao najrelevantniju za fundamentalno razumijevanje sadomazohističke dijalektike i prakse prikazat ću eksplicitnu teoriju erotizma Georgesa Bataillea.

Bataille je nezaobilazan autor i teoretičar za izuzetno široko razumijevanje sadomazohizma, od njegove filozofije, književnih djela, te antropoloških i umjetničkih osvrta.

Njegova teorija obuhvaća cjelinu ljudske psihe i seksualnosti, od filozofskog, duboko psihološkog, duhovno - religijskog i umjetničkog uvida u aspekte erotizma koji čine ljudsku egzistenciju, povezani u konceptima erotskog, života i smrti.

Njegovo najvažnije djelo „Erotizam“ iz 1957. izvanredan je poststrukturalno - antropologijski pristup adekvatnom, primjerenom, no i nadasve kontroverznom razumijevanju erotskog $\mathrm{i}$ seksualnog, s eksplicitnim pristupom sadomazohističkoj seksualnosti, a elaboraciju njegovog temeljnog djela započet ću relevantnim tezama za fenomen mazohizma.

On detaljno elaborira inicijalan prijelaz od primitivnog čovjeka koji je još vladan životinjskim nagonima te instinktivno čini nasilje, do razumnog, civiliziranog čovjeka, koji se bio primoran odreći najprimitivnijih nagona u svrhu, koji ipak, koliko god represirani kulturom, ostaju u njegovoj podsvijesti a manifestiraju se u seksualnosti.

Međutim, jedino je razuman, racionalan čovjek sposoban svjesno djelovati i iracionalno prema svojim željama te je sposoban za transgresiju normi i psihičku i seksualnu transcendenciju.

U tome je sadržana bitna razlika između ,čovjeka - životinje“ i civiliziranog čovjeka koji može postati okrutni sadist i uzvišeno biće u svome subjektivitetu, no zajedničko im ostaje nasilje kao mogućnost i težnja.

Bataille i napominje da erotizam posjeduje samo čovjek kao civilizirano ljudsko biće, a samim time i činovi nasilja bivaju „racionalni“ - ritualni i osmišljeni, logički.

Između seksualnosti i erotizma on postavlja rezolutnu razliku - seksualnost je bitan dio našeg života, no eroticizam je nešto sublimno, što nadilazi seksualnost samu i u toj je misli sadržana bit sadomazohizma kao sublimnog unutarnjeg iskustva, kojem je neophodni preduvjet razumijevanje veze seksualnog, erotskog, psihičkog, ritualnog i destruktivnog.

U Batailleovoj misli, mazohizam je usko vezan za sadizam, obzirom da on anakrono sinkronistički objašnjava historijski razvoj sadizma analogno s mazohizmom od najnižeg, iskonskog poput rituala žrtvovanja, spiritualnog i religije, sve do suvremenog shvaćanja sadomazohizma kao tjelesno - sublimnog fenomena. 
Najeksplicitnije su njegove izrazito vividne deskripcije tjelesnih senzacija boli i nanošenja boli, a mazohizam je kao užitak i postizanje vrhunca u boli najuzvišenija tjelesna i psihička senzacija koja, budući da potječe od religijskih rituala, ima status spiritualne egzaltacije, te je time i seksualnost sama shvaćena ritualno, što je i slučaj u BDSM - u.

Mazohizam u BDSM zauzima posebno mjesto kao pokretač cjelokupne dinamike, a posebice važnu ulogu ima u konstituiranju identiteta i bitka mazohističke, submisivne no i dominantne, sadističke osobe, koja se mora ravnati po logici mazohizma.

Naravno da sadizam i dominacija, kao niti mazohizam i submisivnost ne moraju biti u odnosu korelacije, no kod Bataillea stječemo taj dojam jer su odnos tijela i psihe te dimenzija spiritualnog i ritualnog u sadomazohističkoj seksualnosti centralni u njegovoj filozofsko antropologijskim studijama o seksualnosti kao životnom djelu.

Mazohizam ćemo u suvremenom kontekstu razumjeti kao voljan, konsenzualan, a tada ćemo zaključiti da psiha usmjerava tijelo, ali um ipak ima glavnu riječ kao temelj misli, a psiha kao projekcija uma podliježe ostvarenju nagona i seksualnim transgresijama, Freudovom Idu, dok bi um sam upravljao Egom i Superegom.

Kod Bataillea bi ipak psihičko nagonsko i nesvjesno vodilo tijelo, psiha bi, bez obzira ili u odnosu na ratio u potpunosti upravljala djelovanjem individuuma, bez obzira koliko moralno upitni ili „subverzivni““ oni bili, u sadeovskom smislu.

Tijelo je doživljeno kao sveto, predmet štovanja i fetišističkog, totemskog obožavanja, no samim time istovremeno postaje i objekt želje uništenja, jer mora se oskvrnuti i destruirati sveto da bi se od njega učinilo profano i to je jedna od vodećih ideja Batailleve filozofije $\mathrm{s}$ psihologijsko - antropologijskim utemeljenjem.

Tijelo ima atribut polubožanstva, u svojoj ljepoti i čistoći, i zato je njegova desekracija tabu koji se mora prevladati violacijom, silovanjem, nasilnom destrukcijom, ono mora biti degradirano, oskvrnuto kao profani predmet seksualnog iživljavanja i ritualnog nasilja, kao elementarna demonstracija i sam iskon erotizma.

U ritualnim praksama BDSM - a submisivna je osoba obožavana kao seksualni objekt no ponižavanjem i nanošenjem boli je jednako tako "degradirana i silovana”, prisiljena na poslušnost, vezana, označena ožiljcima boli koji su znakovi njene neprocijenjive vrijednosti, no, naravno, u samorazumljivom imaginarnoj sceni koja je izraz pružanja užitka.

Podređena osoba je doživljena kao sublimna i stoga mora biti simbolički tretirana kao poniženi predmet samovolje dominantne osobe, jer ona to traži i to joj pruža maksimalno zadovoljstvo, često i daleko veće nego dominantnoj osobi, a i submisivna osoba samo tada, prelazeći tu granicu može ostvariti svoje istinsko sebstvo i svoj bitak, transformacijom putem užitka u boli. 
Transcendencijom od profanog do sublimnog postiže se svijest o tijelu u svom punom smislu te realizacija erotskog i seksualnog na granici života i smrti jer podređeni seksualni objekt mora podleći praksama koje su na doslovno na toj granici, primjerice hard bondage, asfikcijacija i slično, i stoga je BDSM područje u kojem Batailleva misao doživljava svoj misaoni vrhunac i u teoriji i u praksi.

Bataille je bio pod velikim utjecajem Sadea, kao najboljeg primjera u književnosti i filozofiji naturalističke seksualnosti, neovisno o činjenici da je Sade bio zagovornik nasilja bez pristanka i opravdanja, nasilja kao prirodnog i svojstvenog čovjeku te užitka per se - zato ga je Bataille “štovao" jer je poticao ono istovremeno i najniže i najviše, iskonsko ljudsko i stoga:

"U orgiji slavlje napreduje s preplavljujućom silom koja otklanja u stranu sve pepreke. Sama u sebi, ta gozba je u sebi posao uskraćivanja životnih granica, ali ta orgija okreće sve obrnuto. Nije slučaj da se "društveni poredak običavao okretati tokom saturnalija gospodar je služio roba, i takvi su "ekscesi" proistekli iz pradavne veze između senzualnog zadovoljstava $i$ seksualne egzaltacije." 148

On se i osvrće na komparaciju Sadeovog suverenog čovjeka kao opoziciju „normalnom“ čovjeku i zaključuje da je on beskupulozni libertin, koji potpuno zanemaruje interes i dobrobit svoje "žrtve” i djeluje u skladu sa svojom željom, koja mu je jedini cilj i jedina granica, dakle, granice nema:

"Sade čini svoje heroje unikatno usredotočenima na sebe; partnerima su potpuno uskraćena sva prava: to je ključ njegovog sistema.

Čovjek koji nije podređen nikakvim ograničenjima nasrće na svoje žrtve s prodirućim bijesom zlog psa." 149

Sadeov je "suvereni čovjek" vođen samo svojom sebičnom samovoljom, težeći isključivo vlastitom zadovoljstvu, uživajući u iskorištavanju i povređivanju drugih.

Bataille pojašnjava da je “seksualna unija fundamentalno kompromis, kuća na pola puta između života i smrti. Zajednica između participanata je ograničavajući faktor i mora biti prekinut prije no što istinska nasilna priroda erotizma bude vidljiva, čiji prijevod u praksu odgovara pojmu suverenog čovjeka. ${ }^{150}$

Sadeovo seksualizirano nasilje i profani jezik bili su ritualizirano i otuda njegova vrijednost $\mathrm{u}$ književnosti i kulturi, ne samo BDSM - a već i "subkulturi” jednog izuzetno relevantnog

\footnotetext{
${ }^{148}$ Georges Bataille, Eroticism, Marion Boyard Publishers Ltd., London, 2006, str. 112

${ }^{149}$ Ibid. str. 167, prijev.a.

${ }^{150}$ Ibid. str. 167 , prijev.a.
} 
historijskog razdoblja, no i u suvremenom bezvremenskom kontekstu i iz tog razloga nikad neće izgubiti svoju važnost $\mathrm{i}$ interes.

"Božanstveno nije nimalo manje paradoksalno od zlog $i$ opakog", govori Bataille, pojašnjavajući svoju životnu filozofiju:

"Riječi "božanstveno" $i$ "sveto" nosile su prizvuke unutarnje tajne animacije, duboko ukorijenjenog ludila, nasilnog dohvaćanja objekta, konzumirajući ga kao vatra, vodeći ga naglo do uništenja." 151

Taj nasilan i poguban aspekt božanstva manifestirao se općenito u obredima žrtvovanja, takve činjenice imaju jednu prednost pred Sadeovim fantazijama : nitko ih ne može smatrati prihvatljivima ali će svaka razumna osoba priznati da one na neki način odgovaraju potrebama čovječanstva; uzmemo li u obzir prošlost, teško je poreći univerzalnu i suverenu prirodu ove potrebe; a s druge strane, sluge ovih okrutnih bogova su s namjerom bili oprezni u postavljanju granice svojih razora." 152

Ovaj zaključak pokazuje racionalnost čovjeka u činovima nasilja - strast za ritualnim no ipak i određenu "granicu" transgresije, što kod Sadea ne nalazimo.

Koliko god njegova diskurzivna obrazloženja i libertinska "fillozofija" imaju racionalnih točaka, njegovo književno ni osobno djelo nije imalo granica i zato jedino za njega možemo reći da je živio transgresiju u pravome njenome smislu.

O Sadeovim fantazijama i ikonografiji Bataille ipak zaključuje da one ne mogu "nadmašiti" predantičke, antičke niti krščanske ritualne obrede, niti po svojoj okrutnosti, niti kulturološkoj relevantnosti, koliko god im se činile bliske.

On teoretski objašnjava sadomazohističke fenomene, no postavlja im određene granice, i premda u njegovim djelima nalazimo "devijantne" seksualne prakse, nikad nije deklarativno "zakoračio" u Sadeovu sferu, već se znanstveno i književno zadržao na granici racionalnog i iracionalnog te imaginarnog.

Sade i Bataille imaju ipak, kao što možemo vidjeti u glavnim tezama "Erotizma", mnogo zajedničkog, prvenstveno jasno izražen i eksponiran naglasak na vezu seksualnosti i destrukcije, te agresivnu, nasilnu seksualnost, čiji je orgazam na granici života i smrti, no dok Sade eksplicitno izriče "racionalne" riječi nasilja iz svoje "moralno pervertirane" perspektive, Bataille svoje teze elaborira iz rafinirane, psihološko - antropološke.

Kao najbolji primjer navest ću Bataillevo poglavlje o ljepoti, u kojem on logikom "agresivne" seksualnosti objašnjava tijek zajedničkog razvoja nagonskog i estetskog, umjetničkog, što je

151 Ibid. str. 180, prijev.a.
152 Ibid. str. 181, prijev.a. 
bit erotizma kao opreke vulgarizirane sadeovske "životinjske" seksualnosti, koju on ne osporava, no ne ostaje pri simplificiranoj seksualnoj destrukciji kao manifestaciji prirodnih nagona već inzistira na estetskom i misaonom razvoju od seksualnog do erotskog. Erotizam za njega polazi od objekta i on konstatira:

"U našem vlastitom svijetu, onkraj orgije razlike su očite, i kako su pojedinci njima nejednako opremljeni, prema svojim talentima, stanju uma i bogatstvu, naglašavaju razlike.

Razvitak tih znakova ima sljedeću posljedicu: erotizam kao fuziju koja premješta interes od $i$ iznad osobe $i$ njenih granica i svejedno je izražena objektom. Suočeni smo s paradoksom objekta koji implicira ukidanje granica svih objekata, erotskog objekta" 153

Ljepota je upravo jedan od temeljnih pojmova kojima on potkrepljuje svoje teze i to u smislu prvotnog divljenja i obožavanja ljepote, lijepog tijela, a potom desekracije i uništavanja istog nasilnim seksualnim činom koji je estetski doživljen kao "ružan".

Želja koju se nastoji ostvariti je trangresija čistoće, nevinosti ljepote same kao i ljepote određenog tijela, individuuma, kod Bataillea je to, kao i kod Sadea - žena, koja je prvotno, u svojoj suštini, tjelesno i misaono čista i nevina, u svojoj ljepoti, no da bi postala seksualni objekt, te osobine moraju biti prevladane, prvo, nasilnom seksualnošću, a zatim eroticizmom kao obožavanjem tijela u njegovoj golotinji i iskonskoj, ljudskoj - životinjskoj seksualnosti ${ }^{154}$. "Ljepota ima kardinalnu važnost, jer ružnoća se ne može oštetiti, a uništenje je esencija eroticizma. Ljudskost implicira tabue, a u erotizmu su i ona i oni prekoračeni.

Ljudskost je prekoračena, učinjena profanom i uprljanom.

Što je ljepota veća, to je više okaljana. "155

Ova je misao jedna od Bataillevih sličnosti sa Sadeom, no samo u okviru teoretskog razumijevanja seksualnosti i erotskog, jer Bataille upućuje da "diviti se Sadeu jest umanjiti snagu njegovih ideja"156 kao i da je "konačni smisao eroticizma je smrt"157 i Bataille ovom mišlju započinje sadeovsku elaboraciju doživljavanja objekata ljepote i želje da bi ih se ponizilo do profanog, misao koja se provlači kroz čitavo njegovo djelo formulacijom:

"U žrtvovanju, žrtva je izabrana tako da njeno savršenstvo daje puni smisao brutalnosti smrti. "158

\footnotetext{
153 Ibid. str. 130, prijev.a.

154 Ibid. str. 140 - 146

155 Ibid. str. 145, prijev.a.

156 Ibid. str. 179, prijev.a.

157 Ibid. str. 144, prijev.a.

158 Ibid. str. 144, prijev.a.
} 
Ljepotu Bataille razumije u kontekstu erotizma i umjetnosti - stvaranja i razaranja te upravo u ljepoti on nalazi kontrast čistoće kao čednosti, koja je kulturno konstruirana i nečistoće kao poročnosti, koja je svojstvena ljudskoj prirodi.

Bataille tom poretku izlaže ženu kao "privilegirani objekt požude", premda ne smatra da žene posjeduju veću ljepotu od muškaraca no ipak, ženu prikazuje kao podređenu “žrtvu sadističkog rituala”, kao prostitucije što vidimo iz slijedećeg:

“Muškarci imaju inicijativu, a žene imaju moć pobuđivanja želje kod muškaraca.

Žene nisu poželjnije, ali se otvoreno postavljaju da bivaju željene.

Sve dok je žena privlačna, ona je plijen želje muškaraca.

Osim ako u potpunosti odbije jer želi ostati čedna, pitanje je pod koju cijenu i pod kojim uvjetima će se predati. Ali ako su uvjeti ispunjeni, ona će uvijek ponuditi sebe kao objekt. Žena smatra sebe objektom uvijek nastojeći privući pozornost muškaraca. Slično, svuče li se do gola, otkriva objekt želje muškaraca." 159

Poveznica sa Sadeom je veoma očita jer su sve njegove protagonistice bile bezgranično "razvratne" žene ili također prostitutke, koje su uživale u podavanju sebe kao objektificiranom tijelu, što im je bio osnovni osnovni identitet, a životna "filozofija" im je bio užitak pod svaku cijenu, a tjelesno je u njihovoj egzistenciji imalo ulogu (i) ratia, što znači da su promišljale umom koji je bio vođen tijelom.

Jasna je poveznica s BDSM praksama podavanje sebe kao objekta, ali također kao submisivne žene koja pristankom biva "prostituirana" nalogom svog gospodara, a budući da je to veoma česta praksa, postoje brojna oprečna mišljenja između BDSM praktikanata i radikalne feminističke pozicije, no bitno je iznova naglasiti da je uvijek riječ o užitku iste te žene koja sebe objektificira te da su sve prakse isključivo i samo uz njen pristanak.

Sade uništava krepost i ljepotu brutalnom i okrutnom torturom i seksualnim iskorištavanjem no protuprirodno - nekonsenzualno, vulgarno i "nehumano" dok Bataille razumije "seksualno nasilje" bitno drugačije, erotski i ritualno te u duhu filozofije sadomazohizma.

On nam u svom ogledu o Sadeu daje jasne odgovore na pitanje što znači razumijevanje njegove filozofije užitka pod svaku cijenu, užitka u nasilju i negaciji svakog morala te odbacivanja humanosti i empatije kao slabosti.

Bataillev je erotizam, kao što je već naglašeno, i uz brojne poveznice, bitno različit i u mnogočemu opozicija de Sadeovoj iracionalnoj životnoj filozofiji, koja ipak napreduje do elaborirane logike užitka - njena je racionalnost u njegovoj antietičkim principima i negaciji

159 Ibid. str. 130, prijev.a. 
svih emocija te shvaćanju suverenosti kao ignoriranju i povređivanju želja i prava drugih, uključujući i najbrutalnje zločine kao izvore vlastitog užitka. ${ }^{160}$

Što više iščitavamo i promišljamo Bataillea, to više poveznica sa Sadeom uočavamo, kao i bitne razlike, kao najvažniji ću istaknuti relaciju života, seksualnosti i smrti.

Bataille je doživljava deskriptivno, kao životni ciklus te religijsko - umjetnički koncept i manifestaciju, koja se najbolje očitava u erotskom kao najuzvišenijem obliku, dok je Sadeu najveće dostignuće uništenje svih vrijednosti, i premda ritualan, njegov je diskurs zavodljivo lascivan, toliko provokativan i obavijen suviše snažnim strastima za "najporočnijim" užicima da mu je teško "odoljeti" i sigurno je to, pored moralnog licemjerja, bio temeljan osude zabrana i uništavanja njegovih djela.

Zanimljivo je spomenuti podatak da su u SAD - u prva izdanja Sadeovih djela objavljena tek 1960 - ih godina, nakon što je već odavno ušao u povijest svjetske književnosti transgresijom literarnog izričaja i specifičnom naturalističkom životnom filozofijom.

Bataillev erotizam i Sadeova antihumanistička, gruba "pornografija", koja i danas ima svoje ekvivalente u porno - snuff subkulturi te individualnim patološkim slučajevima

Sadeova preliminarna opsesija jest uništenje ljepote silovanjem i zlostavljanjem, no Bataille postavlja poredak sasvim drugačije, naime, on ljepotu prikazuje kao objekt želje i za seksualnim odnosom kao simboličkim uništenjem.

Ovo je razmišljanje na odličnom tragu razvitka sadomazohističke psihoseksualne prakse, jer upravo ponižavanje submisivne osobe i njena objektivacija, najgrublja i najbrutalnija, naravno, na njenu želju i pristanak jest mnogima najvažnija komponenta S/M seksualnosti.

Bataille prikazuje tradicionalnu paradigmu sadomazohističkog odnosa, u kojem je žena podređena muškarcu, što čine i suvremeni autori koje sam prikazala, posebice feminističke teoretičarke psihoanalize i filozofije seksualnosti, što daje Batailleu dodatne otvorene mogućnosti suvremenog tumačenja obzirom na njegovo vrijeme i antropološki opus.

Osvrnemo li se na klasike, takav je poredak čvrsto etabliran, naravno, uz brojne iznimke.

Sjetimo li se Sadea ili Pauline Reage, žena je uvijek podređena i objekt najokrutnijih sadističkih praksi, kod Sadea nalazimo i okrutno iživljavanje i samosvjesne žene, a kod Reage naizgled samovoljnu ženu, no ipak psihički nestabilnu i mazohistički ovisnu.

Bataille je tako zaista svestran u svom promišljanju uske veze seksualnosti, nasilja i umjetnosti, erotizma jer obuhvaća izuzetno iscrpan prikaz antropologijskog razvitka čovjeka u aspektu seksualnosti, psihe i religije te razvija vlastitu teoriju iskonskog čovjeka koji nije ni čovjek

160 Ibid. str. $164-173$ 
civilizacije, ali niti Sadeov suvereni čovjek, već čovjek erotizma - "rastrgan” između svojih sirovih prirođenih seksualnih i nasilnih poriva kulture koja mu omogućuje da realizira svoje želje i potencijale, u seksualnosti, mišljenju i djelovanju.

Važnost Batailleve ideje čovjeka je od izuzetne važnosti za sadomazohističku seksualnost jer jedino takva vrsta osobe svojim psihičkim predispozicijama može realizirati svoje najdublje želje potrebnim transgresijama seksualnosti i perverzije, uz jasno određene granice koje je vežu, a to su granice života i smrti.

Ljepota je sklad s prirodom i tu, pored brojnih ostalih kategorija poput etike, dolazi do bitnog razlaza Sadea sa sadomazohizmom konstatacijom da se "Sadeovi izopačeni libertini upuštaju u duge razgovore, jednako često kao i ne, vjeruju da se pokoravaju diktatima Prirode.

Hvale se da su oni jedini ljudi koji žive u skladu s njenim pravilima."

Bataille napominje esencijalnu Sadeovu kontradikciju prirode i ljudske samovolje i devijacije od "normi ljudskosti”" te i od prirode same:

"No iako njihova mišljenja odgovaraju Sadeovoj filozofiji, uzeta kao cjelina, nemaju nikakve koherencije. Nekad su uzburkana mržnjom prema Prirodi.

U svakom slučaju, oni inzistiraju na pretjeranoj vrijednosti nasilja, ekscesa, zločina i torture, nedostaje im duboka tišina neoubičajena nasilju, jer nasilje nikad ne deklarira niti svoju egzistenciju niti svoje pravo na postojanje; jednostavno postoji." ${ }^{161}$

Iz navedenog evidentno je da se Bataille svojom teorijom erotizma ograđuje od Sadeove ideje nasilja, ne samo zbog užitka već zbog nasilja samog te svoju ideju erotskog i sadomazohističkog konfrontira Sadeovoj filozofiji nekonsenzualnog tjelesnog i seksualnog nasilja, a jedino što možemo razumjeti kao bitne poveznice dvaju autora su neka zajednička shvaćanja veze prirode, čovjeka, seksualnosti, života i smrti.

Da bih to ilustrirala, referirat ću se na Bataillevo razumijevanje ljepote i libertinstva te uništenja i smrti kao krajnjeg ishoda erotizma, no važno je reći da je većinu Bataillevih naizgled radikalnih i kontroverznih teza potrebno interpretirati metaforički.

Najbolji primjer tome je njegova elaboracija veze između "seksualne plethore" i smrti, pri čemu on govori zapravo o uspostavljanju harmonije između čovjekovih bestijalnih poriva i imanentno ljudskom erotizmu, kao o njihovom pomirenju i međusobnoj ovisnosti, no potpuno se ograđujući od Sadeove ideje čovjeka kao „racionalne, okrutne životinje“ koja slijedi nagone zadovoljenja tijela destrukcijom drugog tijela, jer psihička i spiritualna dimenzija su upravo ono

${ }^{161}$ Ibid. str. 188, prijev.a. 
što čovjeka (a može se odnositi samo na inteligentne osobe koje su na višem stupnju od pukih „stvorenja navika“") diferencira i omogućuje mu doživljaj ne samo seksualnosti već erotizma: "Erotizam uzet kao cjelina je infrakcija tabua: on je ljudska aktivnost. No, premda počinje tamo gdje čista životinjska priroda završava, njegov temelj je svejedno životinjski. Ljudska se priroda s užasom okreće od tog temelja, no istovremeno mu dozvoljava da opstaje, $i$ to tako učinkovito da je izraz "bestijalan" neprestano povezan s erotizmom."162

On priznaje i pridaje veliki značaj i životinjskoj ljudskoj seksualnosti jer kao što je već prikazano, ona je iskon i ishodište ljudske egzistencije:

„Pogrešno je misliti da kršenje seksualnih tabua znači povratak prirodi kao što je primjer kod životinja, a ipak ponašanje zabranjeno tabuima je kao životinjsko.

Fizička seksualnost, koja uvijek popraćuje erotizam, njemu je ono što je mozak umu; fiziologija ostaje materijalna baza misli na upravo jednak način.

Moramo uključiti seksualnu funkciju životinje s ostalim činjenicama ako ćemo staviti naše unutarnje iskustvo erotizma na njegovo pravo mjesto u objektivnoj realnosti i čak mu dati svoju primarnu pozornost.

Uistinu, seksualne funkcije životinja imaju aspekte koji nas približavaju unutarnjem iskustvu uzimamo li ih pozorno u obzir. "163

Bataille niti najmanje ne zapostavlja životinjsku stranu čovjeka, naprotiv, na prvi se pogled čini da je preintenzivno naglašava, no čini to s motivom fenomenološkog prikaza transcendencije čovjekovih životinjskih, nasilnih seksualnih poriva u uzvišeno erotsko seksualno iskustvo i u tome je neizmjerna relevantnost njegovog djela.

On objašnjava da erotizam egzistira i djeluje kao iskrivljena stvarnost životinjske seksualnosti kojoj je cilj smrt, a sredstvo "plethorički poremećaj", što bi značilo pretjerano nasilna seksualnost, dok je s druge strane, u ljudskoj prirodi da seksualnost prakticira putem nasilja koje ima značenje smrti no i otvara um i sferu spiritualnog osobama koji ga doživljavaju ${ }^{164}$ :

"Nasilje smrti i seksualno nasilje, kad su međusobno povezani, imaju dualno značenje.

Erotska aktivnost nije uvijek slom u sustavu, ali potajno i na najdubljoj razini slom intimno pripada ljudskoj senzualnosti i izvor je zadovoljstva.

U načelu, erotizam se na prvi pogled čini suprotan ovom užasavajućem paradoksu.

On je plethora genitalnih organa. Životinjski impuls u nama je uzrok krize.

\footnotetext{
162 Ibid. str. 94

163 Ibid. str. 94

164 Ibid. str. 104
} 
Ali organi ne ulaze slobodno u to slučajno stanje. To se ne može dogoditi bez pristanka naše volje. Ustvari, individuum se razdijeljuje i njegovo jedinstvo je poremećeno od prve instance seksualne krize. Upravo tada plethorički život tijela ustaje protiv otpora uma."165

Bataille razvija tezu čovjekovog vječnog unutarnjeg konflikta između agresivnog i bestijalnog elementa i onog spiritualnog te "civiliziranog", racionalnog u svojoj biti te dovodi u pitanje i mogućnost harmonije tih dviju strana ljudske prirode i zaključuje da "čak niti naizgledna harmonija nije dovoljna“ jer „,onkraj pristanka, konvulzije tijela zahtijevaju tišinu i odsutsvo duha. Fizički poriv je zagonetno stran ljudskom životu. Biće koje se predaje tom porivu nije više ljudsko, već kao zvijeri, plijen slijepih sila u akciji, beskonačan opći tabu je postavljen protiv nasilja, nama poznat direktno, putem subjektivnog znanja da je njegova priroda nepomiriva s našom osnovnom humanošću. "166

Upravo je zbog navedenih spoznaja i interpretacija seksualnosti i ljudske prirode Batailleva misao temeljna i nezaobilazna za razumijevanje sadomazohizma, budući da se jasno otkriva da je svojevrstan nasilan poriv neophodan ne samo za prakticiranje već i samo doživljavanje seksualnosti i horizonata užitaka.

U njegovoj filozofsko - antropološkoj teorijii u sadomazohističkoj seksualnosti jedna je stvar sigurna, a to je da su nasilni poriv, psiha i um u vječitom odnosu uspostavljanja ravnoteže putem bihevioralnih i seksualnih transgresija te da je to perpetualan proces koji je esencijalan za istraživanje seksualnosti, no primarno osobnosti, vlastite i ljudske općenito.

Za sadomazohističku seksualnost, pri čemu podrazumijevam isključivo konsenzualnu praksu željenog „seksualnog nasilja“ od velike je važnosti Batailleva konstatacija da je:

„Poriv prvo od svega prirodan, ali ne može mu se dati slobodna vlast bez rušenja granica, toliko da prirodni poriv i uništene zapreke zbunjuju um.

Prirodan poriv znači uništena zapreka, a uništena zapreka znači prirodni poriv.

Uništene zapreke nisu jednake kao smrt, ali jednako kao što nasilje smrti nepovratno preokreće strukturu života, tako privremeno i djelomično to čini seksualno nasilje.

Neizbježno povezano s momentom klimaksa postoji manji prekid koji navještava smrt; $i$ obratno, ideja smrti igra ulogu u pokretanju senzualnosti.

To se uglavnom nadovezuje na smisao transgresije opasne za opću stabilnost i očuvanje života, a bez koje instinkti ne bi mogli nesmetano voditi svoj tijek.

Ali transgresija nije samo objektivno potrebna njihovoj slobodi, jer može se dogoditi da ukoliko ne vidimo da se transgresija odvija, više ne možemo imati osjećaj slobode koju zahtjeva

\footnotetext{
165 Ibid str. 105

166 Ibid. str. 105
} 
potpuno ispunjenje seksualnog čina, tako da je delikatna situacija ponekad nužna pojedincu da dosegne vrhunac užitka.

Mnoge žene ne mogu doživjeti orgazam bez pretvaranja sebi da bivaju silovane.

No duboko unutar značajnog prekida nalazi se bezgranično nasilje. "167

Ova duboka misao predstavlja zapravo Bataillevu najužu vezu sa sadomazohizmom, jer, prvo, objašnjava prirodu seksualnih nagona, i drugo, još važnije, implicira relevantnost želje za nasiljem, mazohizma, koji se u BDSM praksi manifestira kao „rape play“i još brojne aktivnosti koji zahtijevaju nasilne prakse.

Bataille o sadomazohističkim praksama ne govori direktno, već putem psihičkog i ritualnog, no jasno se mogu iščitati suvremene ideje koje pronalazimo u S/M praksama i upravo stoga je na njegovo djelo stavljen možda najveći naglasak.

Upravo je to temelj sadomazohizma, pomicanje i rušenje granica te analogno tome svojevrsna transformacija uma da bi postigao harmoniju sa željama tijela.

No želje tijela su uvijek, često i nesvjesno, prvenstveno želje uma i psihe kao njegove najizraženije projekcije, dakle, nesklad je samo svjestan privid koji je potrebno razumjeti i kao vlastite inhibicije i one kulturološki nametnute.

Dokazano je i poznato je da upravo inhibicije seksualnosti, posebice one sadomazohističke pobuđuju patološke tendencije pravome nasilju, koje je protivno temeljnom stavu konsenzualnog sadomazohizma i ideji mog rada.

Iz tog razloga Bataille govori o ,najmračnijim“ fantazijama i seksualnim ostvarenjima, s namjerom da ih osvijesti te ukaže na njihovu važnost za zdrav seksualni razvoj i priznavanje vlastite prirode, jer koliko god snažna bila ta problematika, njeno savladavanje je ona transgresija koja, suočavajući se sa nasiljem i idejama smrti, nadilazi sve negativno i vodi u esenciju erotskog života te zadovoljstvo individuuma.

Fundamentalni i finalni cilj je stoga i osnovni motiv odbacivanje i rušenje svih mogućih granica, nadilaženje tabua da bi se približilo ideji i ontološki i egstencijalno obuhvatilo praksu seksualnog oslobođenja te Bataille uviđa ,paradoks generalnog tabua o seksualnoj slobodi ako ne i seksualnosti općenito“, prikazujući iznova usku, neraskidivu vezu seksualnosti, transgresije, užitka i zabrane.

On razvija tezu da zabrane i represija imaju zapravo paradoksalno značenje i, analogno tome, kontradiktoran učinak - oni su samo naizgled tabui i transgresije, no udubimo li se u prirodu

167 Ibid. str. $106-107$, prijev.a. 
ljudske psihoseksualnosti i društvenih odnosa, uvidjet ćemo da su isključivo tzv. „,zabranjene“ prakse one imanentne ljudskoj prirodi, nama najbliže i neraskidive s našim životom.

Kad govorim o ljudskom životu, mislim na njegovu paradigmu života kao veze eroticizma, seksualnosti, života i smrti, a slične je termine koristio i Foucault, samo u socijalno filozofskom i političkom kontekstu, dok je kod Bataillea riječ isključivo o psihologiji, antropologiji i filozofiji seksualnosti, koje, naravno, čine i značajan dio svih u ovome radu obuhvaćenih autora, od Freuda, nezaobilaznih Deleuza i Foucaulta, pa sve do suvremenih teoretičara psihe, društva i seksualnosti.

Filozofija tijela i seksualnosti esencijalna je za razumijevanje sadomazohizma, osobito mazohizma u okvirima Batailleve misli i stoga ću navesti i protumačiti slijedeće važne misli kojima bismo se mogli približiti osnovnim zaključcima o mazohističkoj seksualnosti i time ovoga poglavlja:

„Izuzetna stvar glede seksualnog tabua jest da je potpuno vidljiv u transgresiji.

Tabu je otkriven direktno potajnim i isprva djelomičnim istraživanjem zabranjenog teritorija. Pristupamo znanju užitka u kojem je ideja užitka pomiješana s tajnom, sugestivnom tabuu koji istovremeno i potiče i osuđuje užitak. "168

Bataille ovim zaključkom govori o „otkriću putem transgresije“:

„Naša seksualna aktivnost se zaklinje na tajnost i svugdje, premda do varijabilnog stupnja, čini se suprotno našem dignitetu tako da se bit erotizma nalazi u zamršenoj konfuziji seksualnog užitka i tabua.

Transgresija pripada ljudskosti. Erotizam kao cjelina je organizirana aktivnost.“169

Sadizam i mazohizam u korelaciji čine jednu cjelinu, kojoj je Bataille posvetio čitav svoj opus s intencijom da prikaže ljudsku prirodu i seksualnost antropološki i filozofski, no i s velikom dozom umjetničkog senzibiliteta.

Njegov je cilj bio uspostaviti svojevrsnu metafizičku filozofiju seksualnosti kojom prikazuje seksualnost kao neophodno nasilnu, no kao iskonsku, predcivilizacijsku karakteristiku koja se danas manifestira u seksualnom životu na sasvim drugi način - transgresijom kao oslobođenjem užitaka te sublimnom transcendencijom u sferu ritualnog i umjetničkog i to je osnovna granica koja ga razdvaja od Sadea, kome je deskriptivna, konfesionalna nasilna seksualnost bila osnovni izričaj filozofije života.

Premda je Sade razvio vlastitu diskurzivnu filozofiju seksualnosti, nije nikad zahvatio ontologijski pojam tijela i seksualnosti, već se zadržao isključivo na repeticiji ritualnog mučenja

\footnotetext{
168 Ibid. str. 107, prijev.a.

169 Ibid, str. 108, prijev.a.
} 
u svrhu zadovoljstva samo sadističkog subjekta te ispovijesti kao narativa, dok je tijelo drugog bilo mišljeno kao stvar, objekt i instrument degradacije tjelesnosti i osobnosti, budući da piše isključivo iz Sadističke perspektive.

Njegova djela nisu samo vulgarna pornografija, već svojevrsna filozofska antietička erotika s jasnim porukama i "savjetima” za libertinski život bez etičkih načela bez ijedne jasne granice. Bataille je s druge strane, svoje životno djelo posvetio studiji seksualnosti od iskonskog životinjskog, na kojemu Sade čak i uz filozofsku dimenziju uvelike ostaje, do uzvišenog, vrhovnog načela seksualnosti kao unutrašnjeg iskustva i čitajući Bataillea, postaje nam jasno da je svaka transgresija napredak u ostvarenju transcendencije, štoviše, često je i sama transgresija izravan put upravo do transcendentalnog iskustva i s njime se izjednačava.

U svojim spisima o nadrealizmu "The Absence of Myth", Bataille detaljno ulazi u Sadeovu književno - filozofsko djelo i temeljne odrednice njegovih misli o seksualnosti posredstvom eklatantnih autora, Malcolma de Chazala i Mauricea Blanchota, obzirom da su njihova djela bitne poveznice za interpretacije sadeovske filozofije time što su evoluirala do istinske teorije erotizma i seksualnosti, a njihova izgradnja književnog paralelno s filozofskim u rafiniranoj umjetničkoj formi bitno nadilazi Sadea, koji je bio brojnim autorima polazište i inspiracija.

Bataillevi rani romani te brojne novele erotske su pa i pornografske u blažem smislu, no one se ne mogu razumijevati na jednak način kao Sadeova djela.

Bataille je stoga izložio svoj uvid u poveznice Sadeovog života i književnih radova, nastojeći spojiti "lik i djelo", koji su kod Sadea uistinu komplementarni, no Bataillev je prikaz ipak drugačiji i to ga čini osobito interesantnim i relevantnim za razumijevanje filozofije i književnosti seksualnosti i upravo u "The Absence of Myth" analizira sadeovski pojam ekscesa kojima je cilj nasilje i smrt izričući:

“Tko bi se konačno usudio ne prepoznati u sebi ukus za senzualne užitke koji nalaze svoje ekstremne kontinuacije u degradiranju i poniženju, odbiti senzualnost, vrijednost s kojom se interesi razuma ne mogu nadmetati, odbiti vidjeti u senzualnosti silovanje bez kojeg božanstveno (uznemirujuće, okrutno i negacija čovjeka) ne bi moglo biti zamišljeno. " 170

On navodi da je Sadeovo djelo i književno - filozofski izričaj, koji je označen kao racionalističko - antietički, odraz njegovog života, no ipak, još mnogo više.

Za Sadea objekt želje, koji mora biti oskvrnut predstavlja zapravo koncept i ideju negaciju, jednako kao i sam čin brutalnog silovanja ili sadističkog odnošenja prema objektu kao sredstvu koje je kao osoba anihilirano.

\footnotetext{
${ }^{170}$ Georges Bataille, The Absence of Myth, Verso, London, 2006, str. 200, prijev.a.
} 
Međutim, Bataille ističe, ,postoji ključna razlika između univerzuma koji Sade prikazuje $i$ svijeta koji mi doživljavamo. Kao pravilo, seksualna aktivnost ujedinjuje bića, dok je Sade definira - u svom djelu, ako ne životu - kao negaciju partnera. "171

On promišlja seksualnu uniju partnera kao kompromis u svojoj suštini, koji vrijednost nalazi samo između života i smrti te je stoga "separiran od tog zajedništva koje ga limitira samo zato da seksualnost može slobodno manifestirati potrebu u svom temelju." ${ }^{172}$ i time ukazuje da je za seksualni partnerski odnos potrebno daleko više te da je Sadeovo poimanje isključivo egocentrično i nedostatno, naročito promislimo li odnose dominacije i submisivnosti u suvremenom kontekstu jer:

"Sadeov stvarni život dozvoljava element hvalisanja da bi se pojavila negacija, ali to hvaljenje samo bilo je potrebno za elaboraciju misli čija probitačnost ne prihvaća servilne principe, ne prihvaća principe u kojima su korist, uzajamna pomoć i dobrota značajniji od zavođenja." 173 Navedene su misli od iznimne važnosti za istinski sadomazohistički odnos, koji, osim seksulanosti, mora biti utemeljen na međusobnom razumijevanju i valoriziranju partnera, dok su sadeovska negacija i sebičnost neprihvatljivi.

Promislimo li problematiku ekscesa ili pretjerivanja unutar seksualnih praksi, posebice u Sadovom djelu, po tom pitanju je Bataille dosta kontrakditoran, no ipak jasan jer u "Erotizmu” navodi eksces kao neophodnu, višeznačnu transgresiju:

"Eksces vodi do momenta kad transcedentni užitak nije više ograničen na osjetila, kad je ono što se osjeća putem osjetila zanemarivo i mišljeno, mentalni mehanizam koji vlada užitkom preuzima cijelo biće. Bez tog ekscesa uskraćivanja užitak je potajna, prezirna stvar, nemoćna da zadrži svoje pravo mjesto, najviše mjesto." 174

Batailleva je ideja da premda seksualno zadovoljstvo ima toliko zajedničkog s destrukcijom, da orgazam nazivamo "mala smrt” a seksualni objekti su uvijek izloženi nekoj vrsti poremećaja, ipak mnogo toga se zahtijeva od nas da bismo postigli to zadovoljenje ${ }^{175}$, jer ono ne može i ne smije biti jednostrano i destruktivno, već koliko god seksualnost bila povezana s nasiljem i smrću, erotizam uvijek mora težiti životu i obostranom zadovoljstvu.

Možemo stoga zaključiti Bataillev konačan odmak i razlaz od Sadea, jer premda Bataille navodi da "općenito, strastvena destrukcija ima moć da nas uvede u svijet seksa" ${ }^{176}$, on kroz svoja dva

\footnotetext{
${ }^{171}$ Ibid, 205, prijev.a.

172 Ibid, str. 201, prijev.a.

${ }^{173}$ Ibid, str. 201, prijev.a.

174 Georges Bataille, Eroticism, Marion Boyars Publishers Ltd, London, 2006, str. 173

175 Ibid, str. 203

176 Ibid, str. 203, prijev.a.
} 
djela koja sam analizirala u radu, zagovara eroticizam kao transcendentalnu nadseksualnost kao filozofsku kategoriju.

Taj“ sirovi, grubi, nasilni“ erotizam i pripadajuća mu seksualnost inspiracija su brojnim umjetničkim djelima, a potom i suvremenim suvremenim subkulturama i seksualnostima, od kojih je naglasak isključivo na BDSM - u kao orijentaciji, životnom stilu i subkulturi.

Proučimo li Bataillevo djelo, ne samo filozofsko već njegov književni opus, romane poput „Story of the Eye“ i „Blue of Noon“, shvatit ćemo da je on i sam jedan od relevantnih „opskurnih“ autora sadomazohističke seksualnosti i samim time, njegovu perspektivu ćemo shvatiti ozbiljnije, a poebice uzmemo li u obzir da se radi o autobiografskim djelima, jasno je da je na djelu i njegov ratio i njegova fantazija.

On govori o međuljudskim odnosima u kontekstu nasilja, seksualnosti i smrti, no antropologijski te erotsko - umjetnički, za razliku od destruktivnog i ,vulgarno pornografskog“, premda racionalnog antietičnog Sadea.

Bataille racionalno uviđa imanentnu Sadeov značaj za razumijevanje ne samo ljudske seksualnosti, već i iskonske prirode čovjeka:

"Tek danas uviđamo da bez Sadeove okrutnosti nikad ne bismo s takvom lakoćom pronikli u jednom nepristupačnu domenu gdje leže skrivene najbolnije istine.

Nije tako lako prijeći od znanja o znatiželjnim vjerovanjima i ponašanju čovječanstva u područje religije, sada povezano s našim znanjem o tabuu i transgresiji, do znanja o čudnovatosti njegovog seksualnog ponašanja.

I ako danas prosječan čovjek ima duboki uvid u ono što trangresija za njega znači, de Sade je bio taj koji mu je pripremio put.

Sada prosječan čovjek zna da mora postati svjestan stvari koje ga najnasilnije odbijaju - one stvari koje nas najviše odbijaju dio su naše vlastite prirode." ${ }^{177}$

Premda je dekonstrukcija sadomazohizma leitmotiv cjelokupnog rada, ukazat ću da već kod Bataillea nalazimo dekonstrukciju kulture i civilizacije, idejama da je čovjek biće nagona no istovremeno i razuma te da životinjski nagoni i sublimirane djelatnosti tvore individuum, njegov život i erotizam, a nasilje kao transgresija kulturnih normi je sredstvo za postizanje submlimnog u kojem se čovjek ostvaruje kao uzvišeno biće.

Za Bataillea je ključna poveznica tijela kao instrumenta nasilja koje je nerazdvojivo od seksualnosti i to kroz koncepte povrijeđivanja i žrtvovanja kao ritualnog, što prethodi erotizmu koje je „unutarnje iskustvo“, psihičko i duhovno, budući da je upravo unutarnje iskustvo

177 Ibid. str. 196, prijev.a. 
erotizma ono je što nas izdiže iznad surove životinjske seksualnosti, no i dalje je čvrsto za nju vezano željom i seksualnom plethorom odnosno obiljem seksualnih odnosa.

Želja je izlaganje, degradacija i poniženje, pa i prostitucija, pri čemu on razlikuje „nisku“ i „,visoku“ prostituciju, a samo ona visoka je dostojna erotizma.

U BDSM - u nalazimo situacije posuđivanja submisivne osobe ili roba/inje drugoj dominantnoj osobi ili Gospodaru ili naredbu seksualnog čina s drugom osobom pri čemu dominant gleda svoju submisivnu osobu.

Dominant ili Gospodar je tada i promatra i participant jer on i naređuje i vodi submisivnu osobu kroz seksuani akt s drugim/a naređujući joj i upućujući je što da radi zbog svog užitka promatranja i posrednog užitka u seksualnom činu.

Možemo se podsjetiti Bataillevog romana „Story of the Eye“ da bi nam stvari bile jasnije promatranje seksualnog čina također je aktivno sudjelovanje u njemu.

Bol i nasilje su esencijalni za seksualno zadovoljstvo i klimaks istoga, budući da su seksualnost i smrt usko povezani, isprepleteni u seksualnom odnosu.

Bataille to oprimjeruje uvidima u religijska žrtvovanja $\mathrm{i}$ tu nalazimo bitnu poveznicu sa sadomazohističkom seksualnošću, jer je u Master/slave odnosu veoma česta praksa iznajmljivanje submisivne osobe, pa čak i za novac, koji ima simboličku ulogu te izvedbe striptiza, kao ritualnog služenja drugome što možemo povezati s religijskom prostitucijom u hramu u egipatskoj, rimskoj i još mnogim davnim religijama.

Bit je u izlaganju svog tijela kao vlasništva svog Gospodara te bezuvjetna poniznost i poslušnost - seksualno služenje koje ima simboličku i spiritualnu dimenziju.

Najvažnija je, naravno violacija tijela kao svetog, što nalazimo u praksi rape playa $i$ to je odličan primjer granice između BDSM - a i nasilja, jer je mnogima još uvijek nejasna sama činjenica da brojne osobe imaju fantazije silovanja.

Te fantazije formirane kao integralni dio ličnosti su već od rane predpubertetskke dobi i s godinama one jačaju, dok se ne počnu ozbiljavati i jedino tada dosežu svoje zadovoljenje i transcendiraju potencijale i želje psihe i tijela.

Konsenzualne „nasilne“ prakse mogu biti zamjena za seksualnosti odnos, ali najčešće su njegova „nadopuna“ bez koje on kao takav, ne može pružati dostatno zadovoljstvo.

Već je odavno dokazano u psihologiji i neuroznanostima da nasilni i grubi činovi dovode do orgazma kao egzaltacije svih osjetila, no uvijek je potrebno podsjetiti da se u BDSM - u sve mora biti konsenzualno, dogovoreno ili ugovoreno. 
U vezi između psihičkog, seksualnog kao osjetilnog, Bataille ne čini velike razlike, već ističe poveznicu seksualnosti i smrti kao baze za nadogradnju sadomazohističke seksualnosti kao cilja i osnovne implicirane teme.

Bol i nasilje su na taj način u službi zadovoljenja, užitka i klimaksa, kao kod religijskog žrtvovanja, jer BDSM istinski praktikanti i doživljavaju kao svojevrsnu ,religiju“.

$\mathrm{S}$ jedne strane osjetilno, senzualno, tjelesno, a s druge psihičko, i nagonsko uspostavljaju naizgled nemoguću sinergiju kojom se uspostavljaju sadomazohistički odnosi i upravo ti snažni kontrasti čine i održavaju njihove dinamike, zato je važno shvatiti tanku liniju između životu i smrti te seksualnosti i smrti koje čine okosnicu Batailleve filozofije seksualnosti.

Psihičko i spiritualno zajedno s tjelesnim i instinktivnim čine jedinstvo u sadomazohističkoj seksualnosti kojoj su ekstremne senzacije imanentne, od najjednostavnijih, do najintenzivnijih senzacija boli koje su neophodne za ostvarenje seksualnog i psihičkog zadovoljstva, no i emotivnog ostvarenja.

Osobama takve psihoseksualne predispozicije je mazohistička pozicija odrednica njihovog ontološkog statusa, ona je egzistencija koja održava njihov bitak.

Reifikacija eroticizma i seksualnosti ostvaruje se putem transgresije kao prijelaza kultuloroloških i biologijskih granica i time poprimaju dimenziju imaginarnog kao nadrealnog, egzistencije onkraj seksualnog i ljudskog.

Mazohizam je, u svom najizraženijim manifestacijama, trangresija psihičkog i biološki zadanog i tu se događa transcedencija životinjsko - nagonsko - ljudsko - Imaginarno kao nadljudsko putem ostvarenja fantazija i želja, kao što Bataille izriče „Transgresija ne uskraćuje tabu već ga transcendira i ispunjava. “178

Veze Erosa i Thanatosa uspostavljaju harmonija psihičkog i tjelesnog u mazohizmu jer Eros se manifestira u užitku u boli, nasilju i transgresiji, kao i Thanatos.

178 Bataille,G, Eroticism,Marion Boyars Publishers Ltd, London, 2006, str.63, prev.a. 


\subsection{Problematika destruktivne seksualnosti}

O pojmu destrukcije i destruktivnim nagonima osnovne je teze već odavno postavio Freud, a ja ću nastojati prikazati i rastumačiti razumijevanje odnosa seksualnosti i destrukcije i njihove mogućnosti i poziciju u seksualnoj praksi.

S jedne strane, agresija kao neophodna komponenta seksualnosti, mora biti odijeljena od destrukcije, koliko god tanka linija ih razdvajala, kao što će biti prikazano već Freudovim, a potom Bataillevim, te suvremenim teorijama seksualnosti, no ona je istovremeno dio jedne drugačije vrste destrukcije, one koja prethodi seksualnom zadovoljenju i preustrojem psihe i tjelesnih granica, kao što je to slučaj u sadomazohističkom seksualnom odnosu.

Seksualnost i destrukcija mogu biti i djelovati kao potpune opreke, ekskluzivne i strogo odvojene, a mogu biti i međusobno jedno drugom imanentne, kao kod Sadea, a također, seksualnost može biti nedestruktivna, no samo s početnim uzbuđujućim sadističkim ili destruktivnim fantazijama, no bez njihovog ostvarenja, kako su to i Freud i Reich već ustanovili. U istinskoj sadomazohističkoj seksualnosti, samo posljednja dva slučaja mogu biti smatrani prihvatljivima, no bitno je razraditi i „destruktivnu seksualnost“, upravo zbog jasnog postavljanja razlike između destrukcije i ,,agresivne“ seksualnosti.

Freudovo shvaćanje sadizma i mazohizma kao produkata nagona smrti, odnosno nagona destrukcije, apsolvirano je i prevladano, no ipak ostaju brojna otvorena pitanja, kao na primjer - gdje je zapravo „granica graničnih slučajeva“, no to će pitanje uvijek ostati otvoreno, obzirom na brojne mogućnosti konsenzualne sadomazohističke prakse, koja nema granica i samim time možemo je okarakterizirati i kao transgresiju i transcendenciju.

Kao što su već konstatirali i Freud i Lacan, a posebice Bataille, agresija i nasilje su neophodne komponente seksualnosti, što je najizraženije u sadomazohizmu, one, kao konsenzualne odrednice seksualnih praksi sačinjavaju odnose sadizma i mazohizma, dominacije i submisivnosti, odnosno BDSM praksi.

Nasilje i seksualnost, dva su naličja istog pojma i prakse, budući da, kako je Bataille konstatirao, ne postoji seksualnost bez nasilja, no to u suvremenom tumačenju ne možemo shvaćati doslovno, već u smislu da je seksualnost prožeta osjećajem boli i nasilnim praksama, isključivo konsenzualno i u svrhu užitka.

Kod Bataillea je bitno shvatiti razliku između njegove historijske deskripcije arhaičnih religijskih kultova i rituala i seksualnosti kakvu danas poznajemo, koja, iako sadrži tragove mitskih, ritualnih kultura, mora biti usmjerena užitku, nipošto nasilju. 
Želimo li komparirati Batailleve teze i pojam „destruktivne seksualnosti“ s Lacanovom teorijom, prisjetit ćemo se identificiranja s velikim Drugim kao dominantnim i tada je transgresija u tome da je užitak Drugog uvjet opstanka submisivne.

Kad govorimo o autodestrukciji u ekstremnom mazohizmu, Lacan je razradio anihilaciju sebstva i stvaranje lažnog ,ja“ kao novog identiteta kod submisivnih osoba, što je već ranije spomenuto u kontekstu analize kultnog BDSM romana.

Sličnu formulaciju nalazimo i kod Bataillea - seksualni užitak, ekstaza, orgazam kao nadvladavanje smrti, a kao druga strana istoga destrukcija.

Erotski odnos dominantne i submisivne osobe, u tom je smislu odnos koji se uspostavlja nadvladavanjem sebe i drugoga da bi se postigao vrhunac i transcendenciju seksualnosti $u$ obliku erotizma:

„Smatram erotizam kao neravnotežu u kojoj biće svjesno dovodi u pitanje vlastitu egzistenciju. Ujednom smislu, biće gubi sebe namjerno, ali tada je subjekt identificiran s objektom gubeći svoj identitet. Ako je potrebno, mogu reći u erotizmu : Ja gubim sebe. Nije privilegirana situacija, bez sumnje. Ali, namjerni gubitak sebe u eroticizmu je manifest ; to je neupitno. "179

Erich Fromm, jedan od ključnih psihoanalitičara i filozofa ima veoma rezolutno, podosta rigorozno stajališe o seksualnosti, užicima, a posebno sadomazohizmu.

U svom djelu „Čovjek za sebe“ Fromm kategozira mazohizam i kao perverziju i kao neurozu te joj pripisuje negativne učinke za psihu, tretirajući je kao autodestrukciju.

„Sve mazohističke želje mogu se opisati kao žudnja za onim što je štetno za čitavu ličnost. U svojim izrazitijim formama mazohizam je težnja za fizičkim bolom i istovremenim uživanjem $u$ tom bolu. Kao perverzija, mazohizam je povezan sa seksualnim uzbuđenjem i zadovoljenjem, pri čemu je želja za bolom svjesna. " 180

Njegov je stav kategorički pogrešan, govorimo li o konsenzualnom, erotskom mazohizmu jer nezadovoljenje je izvor neuroza, a zadovoljstvo koje osoba nalazi i ostvaruje u mazohizmu prevenira nastanak neuroza.

Fromm ipak priznaje da je mazohizam svjesna želja za uživanjem u boli i ne svrstava ga pod nesvjesno, što je isprva pozitivan napredak od Freuda.

\footnotetext{
179 Georges Bataille, Eroticism, Marion Boyars Publishers Ltd, London 2006, str. 31, prijev.a.

${ }^{180}$ Erich Fromm, Čovjek za sebe, Naprijed, Zagreb, 1984, str. 162
} 
Međutim, budući da je neuroza produkt inhibirane seksualnosti, a za Fromma je destrukcija ,posljedica neiživljenog života“181, on nedosljedno govori o mazohizmu jer tada voljni mazohizam ne može biti neuroza niti perverzija u strogom smislu jer:

„Mazohističke pojave, međutim, samo su naročito napadan primjer nesvjesnih želja koje su objektivno štetne; sve se neuroze mogu shvatiti kao izraz nesvjesnih težnji koje tendiraju da povrijede rast ličnosti " 182

Potonja Frommova teza danas nam se može činiti potpuno neutemeljenom i paradoksalnom, poznajemo li psihološke i sociologijske teorije sadomazohističke seksualnosti, no premda su i u Frommovo vrijeme, pa i stoljećima prije pojedinci prakticirali dotičnu seksualnost, on je se nije trudio adekvatno razraditi.

Perverzija je korištenje nečega ili nekoga na krivi način, suprotno ispravnom te potpuno skretanje od cilja. Stoga, ako je cilj zadovoljstvo koje nikoga ne povređuje, mazohizam u svrhu užitka ne može po definiciji biti perverzija, kao ni bilo koja seksualna sklonost ili aktivnost koja postiže svoju svrhu - užitak i zadovoljstvo.

Perverzija može biti samo nešto pogrešno, npr. sadizam koji uključuje prisilu, svaki oblik seksualnog nasilja, no i autodestruktivni mazohizam kod psihičkih poremećaja kada osoba samu sebe fizički i psihički povređuje.

Za razliku od suvremene psihoanalize koja sadomazohizam smatra zdravom seksualnošću, pa i s terapeutskim učinkom, što ćemo vidjeti kod Roya Baumeistera, Fromm je još na tragu Freudove škole koja „brani“ mnoge užitke u korist supremacije Superega i sublimacije, a Id, nakon osvještavanja zanemaruje kao ,štetan“.

O užitku Fromm ima zanimljivih misli, dijeleći užitke na korisne i produktivne i one neproduktivne i nepoželjne za društveni napredak.

Međutim, užitak se ne može ni pod kojim uvjetim promišljati kroz kategoriju objektivnog, on je subjektivan u svojoj suštini, samim time što pripada subjektu.

On je osobno i intimno iskustvo i ne može se svoditi na etički „objektivno“ kao što Fromm pokušava dokazati, niti pod subjektivnim kategoriziranjima „štetnog“ ili „korisnog“ jer užitak je pojam za sebe, kao što je i čovjek za sebe i tu on zapada u kontradikciju, bez obzira što je zastupnik konzervativne „humanističke etike“.

U sadomazohizmu se radi upravo o ostvarenju sebe, koje Fromm jasno promiče, no tada nije prikladno zadirati u sferu i vrste užitaka, koji su u svojoj biti onkraj tradicionalne etičke teorije, ali imaju svoju vlastitu jasno izraženu etiku.

\footnotetext{
181 Ibid. str. 193

182 Ibid. str. 163
} 
U sadomazohističkom užitku postoje jasna temeljna pravila, počevši od „Safe, Sane and Consensual“, kojima se upravo spriječava bilo koji štetan učinak ili posljedica, i time se razumije da zdravoj osobi ne postoje ograničenja užitka.

Zaključak je stoga da je užitak kategorija koja nema pravila, niti je podložna objektivaciji te se može interpretirati na bezbrojne načine, ovisno o teoretskom okviru i orijentaciji, no kad se sjetimo Lacanovog plaisira i jouissancea, jasno je da je užitak jedan od temeljnih faktora svake vrijedne egzistencije i odnosa.

Frommova se cjelokupna filozofija i psihologija zasniva na podjeli karaktera i to na produktivne i neproduktivne, pri čemu on sadiste i mazohiste svrstava u neproduktivne karaktere, budući da su „perverzni“, „,invertirani“ i prema njegovu mišljenju destruktivni, a produktivna je samo nesebična ljubav.

Kad usporedimo ovakve ideje s mislima o užitku, jasna nam je neprofesionalnost ovakvog površnog, generaliziranog kategoriziranja ličnosti jer ako osoba postiže svoj užitak kao cilj, bez činjenja štete drugome, to može biti jedino i isključivo produktivan čin, a užitak nikada ne može biti nesebičan.

Zbog ovakvih nedovoljno promišljenih „teza“, čitav Frommov opus možemo znastveno propitkivati, a mnoga njegova djela svrstati pod ,popularnu psihologiju“.

Slijedeći tradicionalnu psihoanalizu, on gotovo sve tjelesne užitke, a posebice sadomazohizam svrstava pod poremećaje i bolesti, pa se postavlja pitanje tko bi uopće bio „zdrav i normalan“: „,Mazohistička perverzija je primjer svjesnog užitka iz neurotske žudnje, a žudjeti za onim što je štetno,prava je suština mentalnog oboljenja “. ${ }^{183}$

On izrazito negativno stigmatizira seksualni sadizam i mazohizam, što je suviše pristrano za sljedbenika psihoanalize, $\mathrm{u}$ smislu da se pored tolikih dosad navedenih paradoksa $\mathrm{i}$ kontradikcija i time neznastvenih pristupa dovodi u pitanje kredibilitet njegovih misli i čak se može razmišljati o pseudopsihoanalizi.

Ipak, Fromm je bio relevantan zastupnik humanističke etike i stoga zauzima stavove koji su isključivo i neupitno u svim slučajevima etički ispravni, a područje seksualnosti to ne može biti, već zahtjeva izrazito duboku razradu.

Ne treba možda ,prestrogo“ kritizirati Fromma, uzmemo li u obzir njegovo cjelokupno živono djelo koje je od izuzetne važnosti, a posebice vrijeme kad filozofija seksualnosti još kao takva nije bila službeno utemeljena, ali ipak, bilo je autora i mislilaca koji su sadomazohizmu i svim „perverzijama“ pristupali sasvim prirodno, bez prenaglih zaključaka i stigmatizacije.

183 Ibid. str. 163 
O destrukciji Fromm govori da je ,etika prvenstveno zaokupljena problemom iracionalne mržnje, strašću što uništava ili osakaćuje život. Ona je upravljena isto toliko protiv drugih koliko i protiv sebe, premda smo češće svjesni da mrzimo druge nego da mrzimo sebe "184, što je realan, bezvremenski prikaz destruktivne mržnje ili mržnjom uzrokovane destrukcije i tu ideju možemo smatrati istinitom.

Kad razmislimo o Frommovoj tezi da je "destrukcija posljedica neiživljenog života" 185 vidjet ćemo da je ta tvrdnja točna u samo oko 50 \% slučajeva, dok se u ostalima radi o upravo suprotnome - o ekscesivnom iživljavanju, pretjeranom "de sadeovskom hedonizmu", odnosno poremečaju ličnosti uzrokovanom iživljavanjem na drugima i sebi te ne - svijesti o vlastitoj ličnosti i dobrobiti sebi i drugih.

Naravno, postoje i brojni patološki slučajevi iz područja kriminalistike, te je Fromm donekle bopravdao svoje stavove, jer je destrukcija ipak jedno od temeljnih pitanja humanističke etike te on veoma etično govori o ljudskom ostvarenju, no ako je nekim osobama to ostvarenje $u$ konsenzualnom sadomazohističkom odnosu, ne bi bilo potrebno to osuđivati niti patologizirati. Osnovno je razjasniti što bi uopće bila „destruktivna seksualnost“, a što ona nije i to u kontekstu sadomazohizma, jer postoje mnogi ,grey zone“ slučajevi kod kojih je teško razlučiti granicu pristanka, i to je predmet brojnih diskusija.

Odgovor je u suštini veoma jasan - svaka prisila, nanošenje fizičke ili psihičke povrede tj. uskraćivanje dobrobiti i užitka destruktivni su za osobu koja je takvom nasilju izložena i to nije BDSM seksualnost, već destruktivna.

Svaka osoba, posebice submisivna koja se upušta u takav odnos mora znati jasno postaviti svoje granice, a dominantna osoba ih mora odgovorno poštivati.

Obostrana želja i pristanak su produktivni čimbenici seksualnosti i samim time antidestruktivni, već pozitivni te kao takvi čine istinsku $\mathrm{S} / \mathrm{M}$ seksualnost, a i svaku drugu, kao i svaki međuljudski odnos općenito.

Stoga, kad govorimo o BDSM seksualnosti, moramo ukloniti stigmu „destruktivne seksualnosti“ i tradicionalne psihoanalize, koja erotski mazohizam i sadizam doživljava kao destruktivne, psihičke poremećaje i „moralno loše“ prema samome sebi ili drugome, već se okrenuti suvremenom shvaćanju seksualnosti i odnosa izmjene moći u svrhu produktivnog i ugodnog užitka sa svrhom psihoseksualnog ostvarenja i izgradnje identiteta.

\footnotetext{
184 Ibid. Str. 192

185 Ibid. str.
} 
Odličan primjer destruktivne seksualnosti nalazimo u filmu Nagise Oshime „U carstvu čula“ iz 1976. godine, prema istinitoj priči, biografiji Sade Abe ${ }^{186}$, japanske gejše 1930 - ih godina, o čijem se životu mnogo pisalo, i biografskih knjiga i znanstvenih članaka, a i sama je objavila vlastitu autobiografiju 1948. godine, nakon odsluženja šestogodišnje zatvorske kazne za teško ubojstvo i sakaćenje tijela.

Veoma blaga kazna bila je rezultat pomilovanja uslijed političkih prilika - dolaska novog cara i proslave 2600. mitskog utemeljenja Japana.

Istinita priča Sade Abe uistinu je impresivna i šokantna, ona je primjer strastvene veze bivše prostitutke i geishe i njenog gospodara u bordelu, koja od samoga početka svojim intezitetom stremi destrukciji, a u najtežoj destrukciji i završava.

Destruktivni osjećaji i činovi prisutni kroz čitav film, čitavu njenu vezu, a najbolji su primjeri potpuno sadeovski činovi ,slobodne seksualnosti“ bez ikakvih pravila i granica, od „divljeg“ opsesivnog seksa pa sve do silovanja žena, bespogovornog posuđivanja partnera „u ime bezuvjetne ljubavi““ jer Abe je svog ljubavnika poticala da siluje druge žene, uživajući u promatranju i osjećaju nadmoći.

Najbolja paralela sa Sadeom je upravo tijelo kao javno dobro unutar određene skupine ljudi, seksualni odnosi u javnosti, pred skupinom poznatih i nepoznatih osoba, bez imalo osjećaja stida, štoviše to je bilo sasvim „normalno“, a istovremeno fascinantno za vremensko razdoblje u kojem se priča događala.

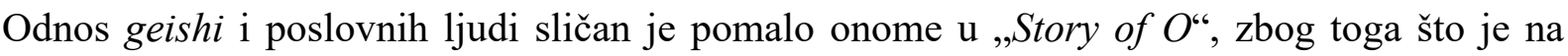
svojstven način „svatko svakoga seksualno posjedovao“ kad bi poželio i to je bilo nepisano pravilo koje se nije kulturološki niti moralno dovodilo u pitanje.

Seksualnost i osjetila djelovala su bez imalo razuma, znanja, etike, potpuno iracionalno, bezumno kao u Freudovom „,prirodno seksuanom stanju“, no ipak vođeni svojom specifičnom, imanentnom logikom - logikom libertinske seksualnosti.

Iz psihoanalitičke prizme, ovo je eklatantan primjer infantilne seksualnosti, jer se Sada Abe u početku svog odnosa s gospodarom i ljubavnikom ponašala zaista djetinje naivno, kao da ne razumije uistinu ništa o temeljnim pitanjima seksualnosti, pa je cjelokupna situacija veoma zbunjuća, gledatelj se konstantno pita do koje je mjere psihički poremećena, a do koje opsesivna, perfidna manipulatorica te sadistička ličnost.

Ona svome ljubavniku prijeti ubojstvom bude li imao spolne odnose sa svojom suprugom, želi ga samo za sebe i njeni se osjećaji pretvaraju u potpuno ludilo - paranoidno shizofreno stanje

${ }^{186}$ Nagisa Oshima, „Dans Le Empire de les Senses“, 1976, 
koje nije ni moglo završiti drugačije već nasiljem i postaje jasno da se radi o poremećenoj seksualnosti, iskrivljenom shvaćanju posjedovanja i prakticiranja sadističkih rituala.

Sada Abe patila je od psihopatološke infantilne neuroze, opsesivne ljubomore i bolesne želje za posjedovanjem svog ljubavnika, koji nije shvaćao ozbiljnost i poasnost njenih želja i namjera. „U carstvu čula“ daje stoga pravi primjer opozicije destruktivne seksualnosti i konsenzualnog sadomazohizma, jer bez obzira što Ishida, Sadin ljubavnik pristaje na međusobnu asfikcijaciju i šamaranje kao sadomazohističke prakse, bitna je razlika između takvog odnosa i nepatološkog sadomazohizma, u prirodi odnosa i konačno, ishodu, koji je bio senzacija u čitavome svijetu. BDSM je ozbiljna seksualna praksa i u njemu nema mjesta psihopatologiji već je njegovo osnovno obilježje intenzivna seksualnost koja uključuje rizične prakse i eksperimente zahtjeva zrele, izrazito mentalno zdrave osobe koje znaju što čine te cijene i štite vlastito i tuđe tijelo i psihu, i jedino pod tim uvjetima opasno može biti normalno.

Priča o Sadi Abe je stoga primjer ekstremno destruktivne seksualnosti koja zbog svog enormne seksualne energije patološkog naboja vodi uništenju, a nikada nije niti bila zdrav odnos prema paradigmi i kodesku BDSM - a.

Sam kraj pruža nam izvrstan „školski primjer“ Freudovog psihopatološkog fetišizma Sada nekoliko dana nosi sa sobom u svom kimonu odsječene genitalije svog ljubavnika, nakon „strastvenog“ ubojstva asfikcijacijom, jer ona je „obožavala“ njegov falus te se sama se predaje s potpunim ispovijednim priznanjem krivnje, a kasnije i piše svoje memoare tog razdoblja prikazujući detaljno čitav događaj.

Sadu Abe tako možemo smatrati utjelovljenjem nekim od de Sadeovih likova, što je najbolje vidljivo u njenom deskriptivnom i demonstrativnom narativu tj. sadističkom diskursu, gdje ona „govori riječima žrtve“, na način kojim je Deleuze okarakterizirao de Sadeov svjetonazorski izričaj i književni stil.

Njena je priča zaista teatralna, no to pokazuje složenost ličnosti Sade Abe, koja je bila opsesivno posesivna prema svome ljubavniku i time pokazivala svoju patološku kliničku sliku, i iz tog je razloga ostala kontroverzna ličnost svoga vremena, koja je obilježila znanost o psihopatologiji, seksualnosti, no i prikazala „mračnu“ destruktivnu stranu seksualnosti, kojoj je od samoga početka nesvjesno težila.

Baudrillard se također referira na fenomen seksualnosti u „Carstvu čula“ i hiperrealnu vezu seksualnosti i „ludila“ prikazanu u ovom provokativnom i kontroverznom filmskom klasiku, elaborirajući praksu i senzibilitet „ekstremne seksualnosti“ logikom zavođenja i ciljem užitka, „Agonističke logika, logike rituala i zavođenja, snažnije su od seksa. 
Kao moć, seks nikad nema posljednju riječ.

U carstvu čula“, film koji je od kraja do kraja zaokupljen seksualnim činom, potonji, svojom vlastitom upornošću, biva zaposjednut logikom drugog poretka.

Film je, nerazumljiv u terminima seksa, za seksualno zadovoljstvo, po sebi, vodi svemu osim smrti. No ludilo koje obuzima par (ludilo samo za nas, u realitetu je to rigorozna logika), gura ih do esktrema, gdje : značenje više nema smisla i provođenje osjetila nije nimalo senzualno. Niti je razumljivo u terminima misticizma ili metafizike.

Ili preciznije, ključni događaj je prijelaz od logike užitka na početku, kad muškarac vodi igru, do logike izazova i smrti, koja se odvija porivom žene - koja time postaje gospodarica igre, premda je isprva bila samo seksualni objekt. Feminini princip je taj koji dovodi do obrata seks/vrijednost u agonističku logiku zavođenja. Nema nikakve perverzije niti morbidnog nagona, nikakve interpretacije izvučene iz naših psihoseksualnih granica, nikakvog „,afiniteta“ Erosa za Thanatos, niti ikakve ambivalencije želje.

Nije pitanje seksa, niti nesvjesnog. Seksualni čin je promatran kao ritualni čin, ceremonijalni ili nalik na ratni, za koji je smrt obvezatan ishod, emblematska forma ispunjenja izazova. "187

Ukazala sam na elementarne, a time i najvažnije distinkcije između sadomazohističke seksualnosti, sadističkih i mazohističkih erotskih nagona i s druge strane destruktivnih nagona, čina destrukcije, autodestrukcije i destruktivne seksualnosti. Oni mogu među međusobno biti u konstantnom inkluzivnom, koncentrinom odnosu, a mogu se biti potpune opozicije, suprotnosti koje jedna drugu međusobno isključuju da bi bile ozbiljive.

Studijski gledano, izuzetno su interesantni primjeri proučavanja ektremne situacije preklapanja i prožimanja sadomazohističke seksualnosti s destruktivnim nagonima, te zajedno s njima destruktivne $\mathrm{i}$ autodestruktivne osobe, koje nemaju definiranih granica osim vlastitog zadovoljstva uz vlastitu i tuđu bol, do najveće moguće mjere.

No, u realitetu i praksi, možda su ipak psihički zdravije i dugotrajnije zadovoljne osobe s manjim oscilacijama između boli, užitka i destrukcije.

Na kraju, BDSM je seksualnost koja podrazumijeva odgovornost, psihičko zdravlje, bol prema mjeri užitka uz obvezatan pristanak i dogovor osoba u odnosu, a autodestrukcija i destrukcija su apsolutne granice - transgresije u Bataillevom smislu.

\footnotetext{
${ }^{187}$ Jean Baudrillard, Seduction, New world Perspectives, New York, 1990, str. 45 - 46, prijev.a.
} 


\section{ONTOLOGIJA BDSM - A}

\section{1. (Sado)mazohistička seksualnost i fenomenologija mazohizma}

Sintagma koju uvodim, „ontologija sadomazohizma“, zahtjeva objašnjenje i opravdanje ovog ozbiljnog filozofskog statusa, drugim riječima, pitanje što je to ontologija sadomazohizma i koje su uopće njene temeljne odrednice.

Ontologija jest filozofija bitka i biti, bitan dio metafizike, pitanje osnovnih određenja i karakteristika nekog pojma ili fenomena te njegove opstojnosti pa će filozofski pristup imanentan ontologiji biti primijenjen na fenomen sadomazohizma.

Suvremena je filozofija odavno prevladala metafiziku i tradicionalna shvaćanja pojma ontologije te danas filozofija bitka govori prvenstveno o identitetima i opredijeljenjima, životnim stilovima, seksualnim orijentacijama i preferencama.

Ontologija je danas suvremeno široko shvaćanje pojedinca i njegovih određujućih karakteristika i time daleko širi i obuhvatniji pojam nego ranije jer upravo je identitet individuuma temeljno polazište ontologije.

U kontekstu BDSM - a identitet je apsolutno najvažnija odrednica, zbog svog multipliciteta i pluriperspektivizma jer sadomazohistička seksualnost je bitna odrednica identiteta mnogih osoba, no ona najčešće ostaje u sferi privatnog, osim u razvijenim društvima i kod autora i teoretičara koji su ujedno i praktikanti BDSM - a.

Možemo se zapitati na koji je način BDSM seksualnost, seksualna orijentacija, preferencija, životni stil, i koja sve značenja pojedina kategorija može obuhvaćati i prema kojim kriterijima određujemo što je seksualnost i može li neka praksa uopće biti kategorizirana kao seksualnost te što zapravo racionalno i znanstveno određuje i definira pojam seksualnosti ?

Kod BDSM - a pokušaji kategorizacije uistinu su kompleksni i često neproduktivni, no pokušamo li filozofski promisliti, konceptualizacijom raznih sadomazohističkih praksi dominacije i submisivnosti koje izazivaju seksualno zadovoljenje, a ne uključuju nužno seksualni odnos kao obvezatan, nameće se dilema možemo li BDSM smatrati seksualnošću jer on može biti shvaćen i kao „seksualnost bez seksa“. 
Možemo se opravdano zapitati se je li BDSM uopće i samo seksualnost, no ustanovili smo već prikazom brojnih autora i izvedenim zaključcima da transcendira sam pojam seksualnosti, a sada ću pokušati pojasniti zašto je možda prije svega seksualnost.

Osnovni kriteriji za definiranje seksualnosti bili bi seksualno uzbuđenje doživljajem boli, brojni intenzivni tjelesni podražaji, seksualni užitak što uz brojne sadomazohističke prakse ne mora uključivati seksualni odnos i upravo ću u tom smjeru približiti naizgled kompleksan status BDSM seksualnosti.

Ontologijski status BDSM - a kao seksualnosti može veoma biti naizgled upitan jer mnogi praktikanti ne uključuju seksualni odnos u sessionima iz raznih razloga, poput nezainteresiranosti za vanilla seksualni odnos, dok neki to čine povremeno, a neki uvijek kao pravilo ili nagradu za poslušnost submisivnog partnera.

Raznolikost u doživljavanju seksualnog odnosa ne znači da određene osobe BDSM ne doživljavaju kao seksualnost, već suprotno, sve BDSM aktivnosti kao što su bondage, flagelacija, razne vrste nanošenja boli, naređivanje, ponižavanje, role play, senzorna deprivacija i ostale dovode do seksualnog zadovoljstva i orgazma i bez seksualnog odnosa, a mogu ili ne moraju prethoditi seksualnom odnosu.

Naravno, postoje prakse kod kojih je seksualni odnos nephodan, a najbolji primjer je rape play, no to je praksa koja zahtijeva izrazitu psihičku stabilnost participanata.

Osnovni kriterij koji BDSM kategorizira kao seksualnost bio bi seksualni užitak u S/M praksama i aktivnostima, od kojih ne moraju sve uključivati intenzivnu bol, no elementarna odrednica je erotizacija boli u praksama gdje su multipliciranje boli i prelazak vlastitih granica analogni multicipliranju užitka i zadovoljenja.

Također, odnos moći između dominantne i submisivne osobe svojom manifestacijom u role play aktivnostima, imaginarnom igranju uloga i time se postiže erotizacija moći koja snažno privlači osobe za daljnje istraživanje preferenca i granica, pri čemu seksualni odnos, ukoliko je dio sessiona, ima posebno ritualno značenje, no nije sam po sebi ni polazište niti cilj.

Upravo u tome je temeljna razlika BDSM seksualnosti od gotovo svih ostalih jer prema raznim istraživanjima, seksualni odnos tokom sessiona prakticira aproksimativno $60 \%$ praktikanata, ovisno o raznim faktorima, primjerice jesu li u stalnom ili povremenom odnosu. 
Kad se radi o povremenim ili jednokratnim sessionima, seks često nije dio istoga kao imperativ, no to ne znači da ostale prakse nisu seksualne, već naprotiv, S/M aktivnosti su visoko seksualizirane i većini praktikanata daleko uzbudljivije i važnije od samog spolnog odnosa te možemo stoga konstatirati da je $\mathrm{S} / \mathrm{M}$ „,seksualnost koja to nije“ jer ona to ne mora biti $\mathrm{u}$ tradicionalnom shvaćanju riječi, ali u svim slučajevima nadilazi pojam seksualnosti.

Obzirom da je za većinu praktikanata, seks jedna od komponenta BDSM - a, možemo postaviti možda nepotrebno pitanje, što je primarno, seks ili S/M aktivnosti?

Naravno da nema univerzalnog odgovora, no ipak, logično je, i prema pisanim iskustvima brojnih autorima, kao i izjavama S/M participanata iz cijeloga svijeta, brojne aktivnosti dominacije, kontrole i boli su ključne i preduvjet za seksualni odnos.

Postoje neki već ranije navedeni kriteriji no bitno je naglasiti da su oni subjektivni, relativni i varijabilni zato što postoje razne varijacije BDSM odnosa te je potrebna analiza pojedinaca $\mathrm{i}$ njihovih odnosa, prvenstveno radi li se o povremenim scenama, dugotrajnom D/s odnosu ili najradikalnijem 24/7 Master/slave odnosu.

Ne postoje univerzalni parametri prema kojima bismo mogli pozicionirati BDSM unutar kategorije seksualnosti, samo parametri preferencija unutar BDSM - a kojima možemo „kategorizirati“ osobu prema njenoj orijentaciji.

Orgazam u BDSM - u možemo analizirati kao određujuću komponentu seksualnosti jer on ne mora biti postignut seksualnim odnosom već raznim drugim aktivnostima, primjerice asfiksijacijom, flagelacijom i intenzivnim podražajima S/M opremom.

Možemo ga razumjeti kao određujući moment vrhunca seksualnog uzbuđenja, i stoga, bez obzira na seksualni odnos, BDSM možemo bez većih dilema kategorizirati kao seksualnost budući da se putem boli i raznolikih praksi postiže seksualno zadovoljstvo, pa i bez seksualnog odnosa, erotizacijom i seksualizacijom boli uspostavlja se novi pojam seksualne prakse i orgazma, a samim je time BDSM bez sumnje seksualnost.

Za sadomazohističku teoriju seksualnosti presudno značenje imaju imaginacija, želja i imaginarni odnos moći, koji sačinjavaju sasvim drugačije razumijevanje seksualnosti uopće, a unutar BDSM zajednica stvaraju diskurs teorije orgazma bez seksualnog odnosa, erotizacijom boli kao tjelesno - spiritualnim iskustvom, možemo do jedne mjere usporediti s tantričkom seksualnošću. 
Ne postoje univerzalna pravila prema kojima bismo BDSM seksualnost mogli „strogo znanstveno" definirati, budući da je ona iznad svega subjektivan doživljaj i svaki će participant izložiti subjektivnu perspektivu, a one se uvelike razlikuju, prema preferencama i orijentacijama - kao i kod svake druge seksualnosti.

Jedini istinski kriteriji kojima se možemo voditi u deskripciji i razumijevanju BDSM seksualnosti su želja i užitak, no oni su, naravno, subjektivne kategorije, no seksualnost je uvijek i jedino subjektivna i intimna, kako najbolje izražava Pat Califia u svom predgovoru „SlaveCraftu“ Guya Baldwina, na koga ću se detaljno referirati u poglavlju o radikalnom BDSM - u: "S/M je umjetnost, ne znanost. Postoje mnogi pristupi S/M seksu i vezama: ljudi ulaze u to carstvo s ciljevima i metodama unikatnima poput njihove individualnosti. "188

Uvod u sintagmu ,fenomenologija mazohizma“ započet ću retoričkim pitanjem zašto i čime (sado)mazohizam zaslužuje tako snažan atribut?

Izložit ću svoje relevantno objašnjenje opravdanosti upotrebe termina „fenomenologije“ u kontekstu tumačenja sadomazohističke seksualnosti.

Fenomenologija je teorija i praksa proučavanja fenomena te njenu konceptualnu konotaciju upotrebljavam, idejom transcendencije (ne u Hegelovu niti Husserlovu smislu, premda su i oni tumačili transcendenciju u svojim temeljnim teorijama fenomenologije), u Bataillevoj antropologijskoj filozofiji i Foucaultovim historijsko - socijalnim proučavanjem fenomena te brojnih relevantnih modernih i suvremenih teoretičara društva i seksualnosti.

Sadomazohizam je filozofijski, psihologijski, sociologijski i medicinski fenomen, a nadasve bitan predmet proučavanja suvremene filozofije i stoga svojim multidisciplinarnim statusom zauzima važno mjesto u suvremenoj fenomenologiji.

Znanstveni kriterij za kategorizaciju sadomazohizma i sadomazohističke seksualnosti kao fenomenologije te materijalno korektnu i opravdanu upotrebu pojma opravdavam i potkrepljujem činjenicom važnosti dotičnog fenomena u filozofiji tijela, antropologiji i socijalnoj filozofiji u mislima i djelima autora počevši od Sartrea pa sve do modernih i postmodernih teoretičara od kojih izdvajam Deleuza i Foucaulta, koji su sadomazohizmu posvetili velik dio svog filozofskog znanstvenog opusa.

Posljednjih se desetljeća suvremena filozofija, kao i sve ostale društvene znanosti, od sociologije, antropologije i etnologije do komparativne književnosti, stručnim teorijama i

${ }^{188}$ Guy Baldwin, SlaveCraft, Daedalus Publishing Company, Los Angeles, 2004, str. 20 
kritičkim stajalištima razvijaju teorije i elaboracije sadomazohizma u kontekstu određenog područja i time je status fenomenologije sadomazohizma nedvojbeno postao iznimno relevantan dio znanstvenog diskursa.

Znanstvenu poziciju sadomazohističke seksualnosti strukturirat ću objašnjenjem da je mazohizam kao koncept i svojoj praksi daleko iznad same seksualne pozicije ili orijentacije, dakle, fenomen koji je odraz iznimne psihičke snage i time mnogo kompleksniji od sadizma. Fenomenologija, kao filozofija određenog fenomena, proučava i tumači određenu konceptualnu strukturu i to je upravo ono što ću fenomenologijom mazohizma pokušati prikazati jer sadomazohizam je fenomen koji zahtijeva duboko filozofsko, psihološko i sociološko promišljanje obzirom na brojne interpretacije i teorije.

I sadizam i mazohizam moraju biti doživljeni kao fenomeni jer obuhvaćaju veoma širok spektar pojmova, od osjetilnog, psihičkog, seksualnog do individualnog životnog stila te jedne čitave suvremene kulture zajednica, manifestacija, umjetnosti i ,ppopularne kulture“.

Fenomenologija mazohizma je stoga iscrpno, multidisciplinarno proučavanje teorija i prakse fenomena mazohizma i svih njegovih komponenta i praksi u modernim i suvremenim interpretacijama, pri čemu ću prednost dati afirmativnima.

Mazohizam je kod većine teoretičara shvaćen kao specifičan poriv i fenomen u korelaciji sa sadističkim nagonom i zato ću ga posebno razmotriti i analizirati psihoanalitičkim i psihologijskim pristupom, a bitno će mjesto zauzeti i etika u filozofiji seksualnosti, no prvenstveno problematika psihičkog mazohizma i pojma moralnosti u ovome kontekstu.

Najveća će pažnja konačno biti usmjerena na filozofsko - umjetničko razumijevanje seksualne egzaltacije pojedinca u mazohističkoj seksualnosti

Vlastitim refleksijama na temeljne psihoanalitičke teorije, zaključujem da mazohizam može biti derivativno primaran pojam, u mnogim se slučajevima on razvija iz prvotnog sadizma, od najranijeg djetinjstva, no iz suvremene perspektive porijeklo mazohizma znanstveno je prihvaćeno kao psihofizička predispozicija za bol kao uvjetom seksualnog užitka te psihičkog zadovoljstva i ravnoteže.

Zauzimam i zastupam afirmativno shvaćanje sadomazohizma kao produktivnog odnosa, i erotskog mazohizma kao zdrave seksualnosti s pozitivnim učincima, istraživanja vlastitih granice, ne samo u seksualnosti, već jačanja ličnosti u cjelokupnoj egzistenciji i raznim ekstremnim životnim situacijama.

Naravno, postoje i slučajevi ekstremnog mazohizma, za koji je sadomazohizam uopće potrebno razumjeti u širem kontekstu, onkraj seksualnog, tjelesnog i psihičkog, misaonog, što ću detaljno pojasniti, a kao primjer navest ću konstantnu želju i čak opsesiju pojedinca za osjećajem boli, 
boli koju mu nanosi druga osoba ili nanošenje boli samome sebi, sve do teškoga samoozljeđivanja, koje je sasvim oprečno ideji sadomazohizma.

Bitno je stoga shvatiti velike razlike između ovakvog mazohizma i zdravog, prirodno uvjetovanog psihoseksualnog mazohizma, budući da je postavljena je esencijalna razlika između tradicionalne i moderne te suvremene psihoanalize - seksualno „zdrav“, nepatološki mazohizam nasuprot freudovskom invertiranom sadizmu prema sebi.

U sociologijskim teorijama mazohizam je, kao i sadomazohizam kategoriziran kao edgework emocionalno intenzivno rizično ponašanje na rubu granice prihvaćenog dopustivog, a i tu postoji podjela. ${ }^{189}$, obzirom da edgework može biti voljno rizično ponašanje u svrhu užitka $i$ zabave, a opet može biti opasno, hazardersko destruktivno ponašanje s ciljem istraživanja transgresije kulturnih te psihofizičkih granica, smatrano „,negativnim“.

Relacije užitak u boli i užitak $i$ bol su u posebnome odnosu reciprociteta te samo naizgled i u nekim slučajevima eventualno borba ili pomirenje Erosa i Thanatosa.

Mazohizam, na tragu Lacana, opravdano možemo smatrati primarnim nagonom, jer je taj atribut neupitno „zaslužio“ jer kao prvotna sklonost, on je izvoran kod tvorenice termina „sadomazohizam“ jer mazohizam je fundament sadomazohističke seksualnosti, a često je početak oblikovanja elementarne seksualne orijentacije kod sadistički nastrojenih osoba.

Separacija kao jasna distinkcija i distanca sadizma i mazohizma kao nipošto nužno ovisnih poriva i orijentacija ili dvije strane iste sklonosti i nagona početak je filozofsko - psihološkog istraživanja ovog područja seksualnosti.

Iz tog je razloga već i u samome naslovu rada „sado“ naznačeno u zagradi jer polazim od mazohizma i intencija je naglasiti da „samorazumljiva“ interpolacija sadizma i mazohizma kod jednog individuuma nije ni opravdana niti utemeljena.

Takve su generalizacije nažalost često ustaljena medicinsko - psihološka praksa no njima se izvodi velika materijalna greška i stoga bi moderna znanost o tijelu i psihi trebala ustrajati u prevladavanju površnih kategorizacija već pristupati individualistički i uistinu stručno.

Mazohizmu je u mom radu pridana daleko veća pozornost upravo stoga što je daleko kompleksniji i s psihološkog i etičkog stajališta, i pravno je vrijednosno mnogo jasniji, dok su kod sadizma uvijek prisutne određene sumnje, nekada i opravdane, no veoma često neutemeljene i netočne upravo zbog nerazumijevanja te je stoga sadizam izuzetno teško jasno definirati i prepoznati clear cut između patološkog poremećaja i konsenzualne dominacije. Već su i najraniji teoretičari kao Krafft - Ebing i Freud bili na dobrome tragu po tom pitanju, izuzev

189 Vidi: Stephen Lyng, Edgework: The Sociology of Risk Taking, 2004 
njihove strogo parafilijske kategorizacije sadomazohističke seksualnosti, ali od Lacana nadalje, pitanje sadizma i mazohizma dobilo je, psihološki i seksološki svoj pravi smisao i značenje te mjesto u psihoanalitičkoj teoriji, filozofiji i sociologiji.

Stjecanjem znanja o sadizmu i mazohizmu u njihovoj korelaciji te poznavanje pravila BDSM a pruža nam mogućnost da jasno odijelimo erotski sadizam i dominaciju od nasilja i nekonsenzualnih radnji bilo koje vrste.

Mazohizam je opravdano prikazan kao primarni nagon i sklonost, elementarna seksualnost kod možda ne uvijek prikladne tvorenice „sadomazohizam“, on je izvoran jer mazohist je zapravo taj koji dominira, upravlja, pa i „manipulira“ i ta će teza biti oprimjerena stručnom literaturom te mojim vlastitim opažanjima i zaključcima iz relevantnih djela jer govoreći o sadomazohizmu, mislim prvenstveno o mazohizmu kao pokretaču ove ekstremno dinamične i dijalektičke psihoseksualne dinamike $s$ težištem na suvremeno shvaćanje mazohizma kao specifičnog psihoseksualnog ustrojstva i prakse.

Gilles Deleuze u svom već spomenutom i najvažnijem djelu o mazohizmu dekonstruira dotadašnje shvaćanje sadomazohizma, dajući prvenstvo mazohizmu kao posebnom fenomenu, daleko drugačijem i separiranim od sadizma, te logici mazohizma i problemu njegovog shvaćanja u suvremenoj filozofskoj teoriji, u što nas on najbolje uvodi, zauzimajući pristup suprotan psihoanalizi, pridajući gotovo svu pažnju elaboraciji mazohizma.

Mazohizam kao senzualni fenomen, Deleuzovim terminom - supersenzualnost, on prikazuje kao bipolaran, a najbolji mu je primjer pritom Sacher - Masochova "Venera u krznu”, u kojoj je protagonist mazohist izrazito submisivan, no imamo i žensku dominantnu ličnost koja je naizgled isprva sadistična, no kasnije se otkriva kao submisivna, istovremeno i mazohistična, a nadasve manipulativna.

U odnosu mazohista i sadista, pitamo se tko zapravo vodi dinamiku pozicije se konstantno mijenjaju, jer i jedni i drugi prolaze kroz brojne psihičke promjene koje rezultiraju novim spoznajama i izmjenama ličnosti tko će se u konačnici pokazati kao dominantan, no to Deleuze ipak jasno implicira svojom karakterizacijom mazohizma.

Mazohizam je za Deleuza sam sebi baza, samostalan je, nije mu potreban sadizam za utemeljenje i razvoj, sam sadrži svoju bit, za razliku od sadizma koji bit traži u drugom i zato nipošto ne može biti freudovski smatran "sadizmom prema sebi", ${ }^{190}$

${ }^{190}$ Gilles Deleuze, Coldness and Cruelty, Zone Books, New York, 2013 
Mazohizam je jedinstven i zbog relacije kazne i užitka, koji su prema Deleuzeu mazohistu potrebni zbog ugovorom utemeljenih uloga gospodara i roba, i kompletnog zaokreta rodnih uloga, statusa muškaraca i žena jer kod njega je žena gospodarica i sadistkinja, po uzoru na Masochovu Wandu.

Mazohist je inicijator odnosa kojim i upravlja svojim inteligentnim humorom jer ,bit mazohizma leži u tome da je isti zakon koji zabranjuje zadovoljenje želje pod prijetnjom kazne pretvoren u onaj koji zahtjeva prvo kaznu, a tada naređuje da zadovoljenje želje nužno slijedi nakon kazne. "191

Deleuze zaključuje da mazohist ipak u većini slučajeva upravlja odnosom, pretvara ga u svoju igru i „,mazohist je drzak u svojoj ulagivačkoj poniznosti, buntovan u svojoj submisivnosti; ukratko, on je humorist, logičar posljedica, kao što je ironični sadist logičar principa. "192

Mazohističku primjenu fantazije Deleuze opisuje kao suprotnu sadističkoj, ona se ,sastoji od neutraliziranja stvarnog $i$ sadržavanja ideala unutar fantazije “193, budući da mazohisti čekaju i odgađaju zadovoljstvo u očekivanju boli kao primarne želje.

On objašnjenjem paradoksa mazohizma pokazuje da sadisti i mazohisti ne mogu biti kompatibilni niti povezani jer pripadaju drugačijim svjetovima.

Za mazohista je dominantna osoba ili gospodar „mazohistička fantazija“ koja pripada njegovom „mazohističkom svijetu“, a „,sadistički svijet“ ima sasvim drugu logiku, destrukcije fetiša i objekta želje.

Filozofsko postavljanje problema fenomenologije mazohizma postavljam kao predmet ontologijskog i psihoanalitičkog promišljanja partikularne i univerzalne analize karaktera i psihičke strukture ličnosti.

Deleuzova radikalna separacija sadističkog i mazohističkog svijeta najbolji je primjer mazohizma kao fenomena samoopstojnosti, samodostatnosti i samosvijesti jer on kod njega nema etabliranu korelaciju sa sadizmom, već jedino ekstrinzičan ne - odnos, te stoga on detaljno promišlja mazohizam kao kontrafenomen sadizmu. ${ }^{194}$

Njegova fenomenologija svojevrsna je opozicija Freudovoj teoriji međusobne uvjetovanosti mazohizma sadizmom kao primarnim porivom upravo teorijom mazohističkog svijeta fantazije

\footnotetext{
191 Ibid. str. $88-89$, prijev.a.

192 Ibid. str. 89, prijev.a.

193 Ibid. str. 73, prijev.a.

194 Gilles Deleuze, Coldness and Cruelty, Zone Books, New York, 2013, str. 37 - 45
} 
u kojem je supersenzualnost, kao temeljno obilježje i osobe koja uživa u boli i podređenosti i „sadista“ koji, bez obzira što uživa u nanošenju boli, mučenju i degradaciji svog objekta, pripada isključivo mazohističkom svijetu i svojim odnosom s mazohistom slijedi logiku mazohizma jer pripadaju istom svijetu, bitku ili entitetu perverzije. ${ }^{195}$

U Deleuzevoj teoriji mazohizma, koja je eklatantan primjer tumačenja mazohizma putem psihologije književnih narativa Sadea i Masocha, samo mazohisti međusobno mogu zajedno činiti uspješan odnos jer njihov se način razmišljanja i doživljavanja tijela,, seksualnosti i želje bitno razlikuje od sadističkih.

Sadist i mazohist, smatra Deleuze, no i mnogi njegovi suvremeni sljedbenici, prema etabliranom no ne uvijek istinitom mišljenju, nikada ne mogu postojati kao par niti ostvariti uniju, obzirom da mazohisti žele sasvim drugačiju vrstu zadovoljstva, senzualni užitak u boli, umjesto agresivnosti i destrukcije, te svojom supersenzualnom prirodom nadilaze naturalizam sadista i sadistički poredak.

Mazohisti žude za osobom jednakog psihičkog ustrojstva koja će im biti dominantna igrati prividnu ulogu sadista i zato su samo dva mazohista kompatibilan par.

Promišljajući Deleuzeovu teoriju, dolazimo do svojevrsnog poznatog paradoksa mazohizma te pritom možemo opravdano dovesti u pitanje egzistenciju istinskog, esencijalnog mazohizma i njegove navlastite fenomenologije, a razjašnjenju tog paradoksa pristupit ću osnovnom Masochovom karakteristikom mazohizma, supersezualnošću, koja izražava želju za užitkom u boli jer supersenzualnost mazohizma očituje se u „mazohističkoj upotrebi fantazije“, „ona se sastoji u neutralizaciji realnog i zadržavanju ideala unutar fantazije“, a „konstitucija fetiša u mazohizmu ukazuje na unutarnju silu fantazije, njenu karakteristiku strpljivog čekanja i načina na koji su idealno i realno zajedno pounutreni njome. “196

Mazohizam kao supersenzualnost odražava se psihičkom praksom iščekivanja užitka u boli, „,mazohist čeka užitak i očekuje bol kao uvjet koji će naposljetku osigurati (i fizički i moralno) dolazak užitka“ te ,zbog toga odgađa zadovoljstvo u iščekivanju boli koja će omogućiti zadovoljenje“ - njegov je psihoseksualni modus operandi „,beskrajno iščekivanje užitka $i$ intenzivno očekivanje boli“ ${ }^{197}$

\footnotetext{
195 Ibid, str. 42 - 43

196 Ibid, str. 73, prijev.a.

197 Ibid, str. 71, prijev.a.
} 
Prihvaćam i podržavam Deluzeovu teoriju ekskluzije dvaju svjetova, mazohističkog i sadističkog te zasebne dinamike mazohizma zbog njegovog esencijalno suprotnog psihoseksualnog ustrojstva, no želim istaknuti i njihovu neizbježnu korelaciju.

Mazohizam se u samome početku razvija kao samostalni entitet, bitak i samosvijest, u formi misli i djelovanja mazohističkog subjekta, samostalan i jedinstven fenomen te u svojoj daleko kompleksnijoj esenciji od sadizma može biti samodostatan.

Kao nastavak na Deleuzovu tezu, bitno je naglasiti da mazohizam u određenom momentu dolazi u korelaciju sa sadističkim svijetom, putem sadističkog subjekta i time se uspostavlja

odnos moći, doživljen kao odnos, Hegelovim terminom, dvaju samosvijesti koje stvaraju ili međusobni konflikt ili skladnu uniju dvaju ili više različitih osoba, protagonista razliitih ili suprotstavljenih svjetova.

To je fenomenološki moment transcendencije vlastitog svijeta, za mazohističku osobu u drugačiji, suprotni poredak, kao i za sadističku, no obzirom da je mazohizam daleko kompleksnija karakteristika i predispozicija, prijelaz je daleko obuhvatniji jer mazohistična se osoba može kao mazohistična uživjeti i u ulogu sadista i dominantne osobe, dok sadistička zadržava svoju težnju prema „,nasilju“ nad objektom, nevisno o novo zauzetoj ulozi.

Mazohisti vole dominirati, no u svrhu vlastitog užitka u boli, nastojeći pridobiti prvo mazohističnu dominantnu osobu da im ispunjava želju užitka nanošenja boli, a potom prijelazom u sadistički svijet, eksponiraju svoju mazohističku stranu kao pokušaj realizacije sadističke žrtve, no ipak, bol koju će zadobiti često neće biti njihovo ,mazohistično iskustvo užitka“, već samo „,sirova“ i „gruba“ sadistička ,,igra“ bez mazohističkog supersenzualnog doživljaja i zadovoljenja.

Deleuze ističe da dominantna osoba u odnosu s mazohistom ne može biti sadist jer se nalazi u mazohističnoj situaciji, ona je realizacija mazohistične fantazije i pripada tom svijetu ${ }^{198}$ svijetu obožavanja fetiša kao objekta želje i stoga u BDSM - u možemo govoriti o $D / s$ odnosu kao o odnosu dominatnog i submisivnog mazohista.

Teorija mazohizma prezentirana $\mathrm{u}$ „Coldness and Cruelty“ neophodna je za suvremeno filozofsko promišljanje $\mathrm{S} / \mathrm{M}$ odnosa, jer je utemeljen na novom shvaćanju te pobija tradicionalnu percepciju sadomazohističke seksualnosti i karaktera.

198 Ibid. str. $40-41$ 
Od relevantnih i interesantnih suvremenih primjera referirat ću se na američkog teoretičara Roya Baumeistera, priznatog američkog socijalnog psihologa, koji je izuzetno stručno razvio cjelokupnu teoriju mazohizma kao pobornik njegovog primata, no istovremeno i dosljedan kritičar sa stajališta svoje psihologije seksualnosti uz brojne primjere znanstvenih empirijskih istraživanja i vlastitih teza.

Osnovno je istaknuti Baumeisterovo objašnjenje mazohizma kao primarnog iz razloga što ga on dosljedno i anakrono - sinkronijski elaborira izuzetno edukativnom perspektivom primjerenom suvremenom shvaćanju ovog fenomena .

Mazohizam kao elementarni nagon i praksa Baumeister istovremeno tumači i kao prvo, negaciju sebstva i odricanje od vlastite volje, potom kao profilirani seksualni užitak u boli te konačno prezentira terapeutske učinke mazohizma.

Zašto i čime je mazohizam zaslužio toliko važnosti stekao i dobio toliko prostora u filozofskim, psihološkim i sociološkim teorijama?

Brojne odgovore nalazimo u Baumeisterovoj studiji “Masochism and the Self” iz 1989. godine, u kojoj je najvažnije istaknuti detaljnu elaboraciju cjelokupnog mazohističkog psihičkog ustrojstva te mazohističke želje i potrebe za osjećajem boli.

On polazi od same percepcije boli i naglašava da mazohisti većinom imaju određenu granicu tolerancije i analogno tome žele određen stupanj boli, a budući da postoje brojne razine i stupnjevi boli neizmjerno je važno da dominantna osoba bude svjesna do koje granice može nanositi bol submisivnoj.

Mnogi mazohisti žele prijeći granicu kao dokaz svoje psihičke snage i tjelesne izdržljivosti, a dominantne osobe imaju želju testirati granice, što je uistinu bitna odrednica sadomazohističke prakse te Baumeister zaključuje da su fantazija i iluzija bitni faktori mazohizma i zato mazohist želi prijeći svoju granicu, a dominant hotimično prelazi granicu jer ako prestane s određenom aktivnošću nanošenja boli, fantazija mazohizma i submisivnosti gubi svoju čar jer tada mazohist dobiva privid dominacije i užitak prestaje. ${ }^{199}$

Najbolje je ipak objašnjenje dominantnih osoba da transgresijom dogovorenih limita i ignoriranjem znaka za prestanak, safeworda, proširuju horizont i užitak submisivne osobe i pomaže joj da otkrije svoje istinske granice jer dokazano je da svatko može podnijeti mnogo više boli nego što to subjektivno misli. ${ }^{200}$

\footnotetext{
${ }^{199}$ Roy F. Baumeister, Masochism and the Self, Psychology Press, New York, 2014, str. 65

200 Ibid. str. 65 - 66
} 
Bol je tako senzacija koju ne možemo kategorizirati, no opisati je i proučavati možemo brojnim teoretskim pristupima, od kojih je Baumeisterov izvrstan jer polazeći od osnova, dolazi do kompleksnih dilema mazohizma, doživljavanja sebstva u odnosu s dominantnom osobom te spoznavanja vlastite ličnosti.

Baumeister ipak ima jednu diskutabilnu tezu, a to je da je transformacija boli u užitak fantazija mazohista i za to daje nekolicinu primjera, no tu se radi o partikularnim slučajevima i takve osobe ne možemo nazivati mazohistima.

Mazohisti uistinu doživljavaju određene vrste boli kao ugodu i duboku psihičku praksu i treba ih diferencirati od znatiželjnih osoba koje samo žele „eksperimentirati“ te ostaju neugodno iznađene raznim $\mathrm{S} / \mathrm{M}$ iskustvima.

To još više potkrepljuje tezu da su mazohisti uistinu jake ličnosti koje znaju što žele i samouvjereno pristupaju svim sadomazohističkim aktivnostima te se u prepuštanju svim užicima, uvijek rukovode razumu i brizi o sebi.

Također, veoma važno objašnjenje jest bol kao simbol submisivnosti i poslušnosti dominantnom partneru, kao što Baumeister navodi - prihvaćanje boli bez razloga, bez protesta podređujući se arbitrarnoj kazni kao dokaz submisivnosti i odanosti. ${ }^{201}$

Veoma problematično pitanje je je li mazohizam također ispaštanje i kazna za vlastiti osjećaj krivnje zbog svojih djela, nedjela, propusta, nezadovoljstvom samim sobom.

Baumeister konstatira da izlažući se mazohističkoj praksi, kažnjavanjem od dominantne osobe, mazohist se, iako se ne može iskupiti, oslobađa bar momentalno svoje krivnje, uspijeva pobjeći od sebe i svoga realiteta. ${ }^{202}$

Stoga nas samoozljeđivanje, koliko god bilo opravdano medikalizirano, ne smije nimalo začuđivati, ali mazohizam iz takvih pobuda nije istinski mazohizam.

Kazna, samo ako je simbolička i unutar sessiona, može biti opravdan razlog mazohizma, ali prvenstveno je to „,bol u kontekstu fantazije igranja uloga i seksualne stimulacije koja može biti moćan bijeg od svakodnevnog svijeta “. ${ }^{203}$

Osnovno je zadovoljenje koje mazohistična osoba nalazi u aktivnostima boli, poniženja, podređivanja drugoj osobi i tu je jednostavno riječ o seksualnoj orijentaciji koja je u službi

\footnotetext{
201 Ibid, str. 66

202 Ibid, str. 70

203 Ibid. str. 100
} 
užitka - ekstaza u otklanjanju samosvijesti može biti izvor direktnog, intenzivnog užitka“"204 $\mathrm{i}$ ta je ideja apsolutno točna kod istinskih mazohista.

Naravno, to je samo početak jer intenzivni užici stvaraju sve jaču mazohističku želju, ne samo za konstantnom repeticijom istih, već za transformacije svojih iskustava na još snažnije i moćnije prakse.

Konačno, možda najkontroverznija teza koje se Baumeister oprezno dotiče jest terapeutski učinak mazohizma, pri kojoj se on poziva na autore poput Pata Califie, koji zagovaraju teze da uče bolje prihvaćati sebe i osjećati se bolje prihvaćajući bol te da mazohističke prakse otklanjaju njihove probleme pri čemu on citira Califiu:

\section{„Dobra scena ne završava orgazmom - završava katarzom. “}

Baumeister zauzima prilično konzervativan stav - za njega mazohizam nije terapija i on upućuje kritike takvim shvaćanjima smatrajući ih pogrešnima i arbitrarnim mazohističnim izgovorima i afirmativnim opravdanjima za prakticiranje sadomazohizma, što je i očekivano za psihologa koji nije specijalist tog područja.

On smatra da je ,teško zamisliti kako je biti vezan, udaran, vrijeđan može uzrokovati da ljudi sebe bolje razumiju. Ipak, možda ljudi nauče da mogu uživati novi oblik devijantnog seksa, ali čini da ima malo osim toga što bi obećalo poboljšanje samospoznavanja. Pisci iz mojih primjera doživjeli su zadovoljstvo, užitak i čak osobno ispunjenje. Ali nisu tvrdili da su naučili ništa o samima sebi, osim da uživaju u mazohističkom seksu. "205

Baumeisterov je stav veoma uzak i limitiran pa ga ne možemo smatrati potpuno valjanim zaključkom, već prejudiciranim subjektivnim mišljenjem.

Da bi se došlo do istinskih zaključaka, potrebno je promišljati duboko ispod same površine i nastojati proučavati fenomen mazohizma od samog korijena do suvremene perspektive i prakse, znanstvenim metodama, s istraživanjem na ispitanicima kao što će biti prikazano kod Charlesa Mosera i Peggy Kleinplatz. ${ }^{206}$

Teza koju nastojim predstaviti je da mazohizam treba razumijevati i doživljavati kao svojevrsnu moćnu terapiju, u smislu oslobođenja sebe i pročišćenja sebe od vlastitih negativnih stavova o sebi, svojih shvaćanja i percepcije svijeta, naročito boli i užitka.

\footnotetext{
204 Ibid. str. 101

205 Ibid. str. 102

${ }^{206}$ Charles Moser, Peggy Kleinplatz, Sadomasochism, Powerful Pleasures, Routledge, New York, 2006
} 
Naravno da je navedeno mišljenje do jedne mjere subjektivno, no gotovo sve teorije seksualnosti su neizbježno subjektivne, što ne umanjuje njihovu vrijednost, a posebice vrijednost njihovog znanstvenog statusa, jer vjerojatno ne bi bile vrijedne promišljanja kad im se ne bi mogle uputiti kritike i preispitati ih iz raznih perspektiva?

Renomirana američka sociologinja i profesorica na Hunter Collegeu u New Yorku, Lynn Chancer u svojoj knjizi „Sadomasochism in Everyday Life, the Dynamics of Power and Powerlessness" izrazito detaljno i stručno analizira seksualnu i interpersonalnu dinamiku dominantnih i submisivnih osoba multidisciplinarnim sociološko - filozofskim pristupom sadomazohističkoj seksualnosti.

Njena najveća fascinacija je mazohizam i „mazohistična anologna dilema, kojom ona prikazuje mazohista kao samo prividno podređenog, a ustvari superiornog, onog koji „vodi igru“ i upravlja dinamikom sadomazohističkog odnosa.

Pojmovi moći i nemoći te dominacije i potpune podređenosti ključni su u njenom djelu i najbolje oprimjereni vječnim romanom „Story of $O$ “ $\mathrm{u}$ kojem nalazi inspiraciju za primjer sadomazohizma u svom istinskom obliku, no naravno, u okvirima Simboličkog i Imaginarnog, jer riječ je o izuzetnom odnosu, koji prelaskom u Realno prestaje postojati, a tada se može govoriti o nadređenosti i podređenosti u društvenoj sferi, što također ima određene poveznice s erotskim Dominant/submissive odnosom.

Premda sadist ima iznimnu potrebu za kontrolom i ponižavanjem mazohista, on negira svoju ovisnost o njemu i time dugoročno odražava svoju nesigurnost i veliku ovisnost o mazohistu, submisivnoj osobi kao neophodnoj za opstojnost svoje pozicije i tako je, kao što Chancer konstatira, „sadomazohistička dinamika karakterizirana ideološkim mitom neovisnosti sadista dok, u realitetu, čak više ovisan o mazohistu nego mazohist o sadistu“. ${ }^{207}$

Možemo jasno zaključiti, na temelju Chancerinog djela i svih ostalih relevantnih autora i participanata S/M seksualnosti, u duhu Deleuzea, da je mazohist zapravo „dominantan“, a mazohizam causa prima sadomazohističke dinamike izmjene moći, obzirom da želja za moći i za priznanjem D/drugog postoji i kod sadista i kod mazohista.

Kod sadista, to je moć za apsolutnom kontrolom i nesvjesni egocentrizam, no kod mazohista nalazimo nešto još daleko ekscesivnije - opsesivnu želju za privlačenjem pozornosti svojom „neposlušnošću“ da bi se zaslužila kazna u smislu nanošenja boli kojom mazohist sebi uzima

${ }^{207}$ Chancer, L., Sadomasochism in Everyday Life, the Dynamics of Power and Powerlessness, Rutgers University Press, New Jersey, 1992, str. 47 
monopol nad željom i zadovoljstvom i preuzima kontrolu u cjelokupnoj dinamici, dok sadist toga još nije niti svjestan, već smatra da je on taj koji kontrolira.

Želja i kontrola su i svjesne i nesvjesne i upravo zato ova psihologija mazohizma uvijek ostaje održiva i sadomazohistički odnos je moguć samo priznamo li ovu činjenicu manipulacije i kontrole mazohista, nad sadistom i nad vlastitim tijelom, za doživljaj priznanja i samopriznanja. Chancer također smatra da je osnovna težnja mazohista priznanje Drugog, sadista, Gospodara, no najveći naglasak stavlja na Hegelovu dijalektiku i međusobne potrebe sadista i mazohista, iako daje i implikacije o suprotnim pozicijama i logici sadista i mazohista u seksualnoj dinamici te svojevremenom sadistovom gubitku kontrole ${ }^{208}$, jer izmjena moći i kontrole uvjetuju pozicije moći i time su i baza i ishod same dinamike.

Ona navodi primjere iz „Story of $O$ “ u kojima se protagonistica razvija u ,podijeljenu ličnost“", prvo ovisnu o Gospodaru i nestabilnu ženu koja udovoljava svom ljubavniku, pristajući na dugoročan sadeovski „odgojni tretman“ u dvorcu Samois, da bi spoznala užitak u boli i najtežim oblicima podređivanja, te naposljetku preusmjerila svoju želju prema jačem gospodaru, Sir Stephenu, oblikujući se opet u ovisnu mazohisticu, no postepeno razvijajući i ekstremnu sadističku seksualnost s drugim ženama.

Na početku romana početak romana O je ponosna i po dolasku u Samois ne želi se predati i sama testira svoje granice, ona je svojevoljni mazohist i ne čini to zbog dokazivanja Reneu već sebi i ostalima želi pokazati da je jača ličnost od sadista kao dominantnih, i time dokazuje da je mazohistička osoba daleko ekstremnija od sadističke, jer izdržavanje najvećih boli i uživanje u njima jest snaga.

Konačno, Chancer zaključuje da sadomazohistička dinamika konačno dolazi do svog kraja jer „, niti san mazohista da bude potpuno kontroliran, niti san sadista da ima potpunu kontrolu nisu mogući“ jer „mazohist ne može pobjeći od svoje snage i neovisnosti, a sadist od svoje stvarne ovisnosti"209 i tako odnos prestaje kao nemoguć osviještavanjem Realnog kao ideje da neograničena moć ne može biti provedena nad mazohistom, da sadist ne može ispuniti očekivanja mazohista - čarolija Imaginarnog prestaje i nastupa ponovno traženje sebe u Simboličkom stadiju do ponovnog uspostavljanje nove, uspješnije sadomazohističke dinamike. „Story of $O$ “ je samo naizgled paradigma bespogovornog radikalnog sadomazohističkog odnosa, no dubljom analizom vidimo da takav odnos fantazije postoji u iznimnim slučajevima, no i tada se uvijek može prekinuti raskidom ugovora, što će biti i izloženo.

Zaključna pitanja mazohizma koje bih ja postavila su:

\footnotetext{
208 Ibid. str. 52 - 65

209 lbid. str. 66 - 67
} 
Do koje granice je mazohistična osoba spremna izložiti sebe i žrtvujući svoje tijelo i psihu dokazati sebi svoju snagu i supremaciju ? U kojem je momentu je „dovoljno“?

Može li se on uopće odrediti unutar svijesti? Postoji li granica?

To su fundamentalna pitanja koja ostaju svakom individuumu za vlastito promišljanje.

Prethodnim uvidima u relevantne autore i teorije jasno je da je jedan od osnovnih ciljeva ovog rada prikazati suvremeno afirmativno razumijevanje mazohizma.

Primarni je fokus analize mazohizma suvremeno, pozitivno i koliko je moguće objektivno shvaćanje erotskog mazohizma kao specifičnog psihoseksualnog ustrojstva i prakse koje je osnova sadomazohističkog odnosa.

Konačno ću zaključiti osnovne podjele i dileme unutar sadomazohističke seksualnosti da bih pojasnila zašto je mazohistička seksualnost zauzela toliko mjesta u ovome radu, dok je sadistička stavljena u drugi plan, kao njena nadogradnja.

Osnovno je razlučiti, diferencirati i zaključiti razlike i podjele između dominantnih osoba i sadista te submisivnih i sadista budući da postoje brojne kombinacije, koje se čak isprva ne moraju činiti smislene, no ipak imaju svoju duboku psihologiku.

Kao primjer, navest ću dominantne mazohiste, osobe koje žele da im se nanosi bol i svojstvenim načinom to „naređuju“ partneru, zahtijevaju od njega da ih dominira nanoseći im bol koja ih dovodi do vrhunca.

Kod ovakve mazohistične osobe, najčešće je primaran užitak u boli, a „submisivni sadist“ joj je objekt koji služi njenom seksualnom zadovoljenju.

Razjasnila sam već na koje elementarne načine bol, posredstvom tijela, utječe na psihu, kao oslobođenje, pročišćenje, „bijeg“ od realiteta i stoga mazohizam ima zaista mnogo složeniju psihologiju od sadizma.

Mazohizam je stoga daleko kompleksniji psihoseksualni fenomen i praksa jer je utemeljen na specifičnom psihičkom ustrojstvu i tjelesnim manifestacijama, koje su sadistima ili „,vanilla“ osobama ili nezamislive ili nedoživljive.

Komponente mazohističkog identiteta koje ću navesti su psihičko, misaono, tjelesno i seksualno i unutar njih se ostvaruje psihička i fizička snaga najsnažnije izražena u mazohističke submisivne osobe jer joj je neophodna da bi mogla ostvariti svoje zadovoljenje i pružiti isto dominantnoj osobi.

Sve dosad navedene teze relevantnih autora i moji zaključci u ovome poglavlju bili su pokušaj objašnjenja i opravdanja statusa fenomenologije mazohizma, te indikator na koje je sve načine moguće taj fenomen formulirati daljnja pitanja, a posebice generirati nove teze i konkluzije. 


\section{3}

\section{Ontogijsko - antropologijska interpretacija sadomazohističke seksualnosti u djelu}

Georgesa Bataillea

Ontologija sadomazohizma nezamisliva je bez Batailleve misli budući da se cijeli njegov „Erotizam“ temelji upravo na poveznici seksualnosti, erotizma i destruktivnih nagona koji se transformiraju u sublimnu, ritualnu tjelesnu i psihičku praksu.

Polazeći od antropologijskih teorija, prvo predcivilizacijskog stanja, potom predantičkih i antičkih religija, sve do kršćanstva, Bataille uspijeva „ogoliti“ čovjeka do njegovih elementarnih nagona, seksualnih nagona samoodržanja, koji uključuju i produktivne i destruktivne komponente jer su ujedno i nagoni i života i nagoni smrti.

Promišljanjem njegove teorije seksualnosti možemo razumjeti da nagoni za samoodržanjem te očuvanjem života mogu biti istovremeno, prakticiranjem ritualnih orgija i oni za njegovim uništenjem ili za doživljavanjem i prakticiranjem ritualnih mučenja i žrtvovanja.

Život, seksualnost i smrt za Bataillea su konceptualno „sveto trojstvo“ koje sačinjava ljudski bitak, od prapovijesti do suvremene ere i stoga nagon za destrukcijom, kao sadistički nagon te nasilje nad tijelom također pripada nagonu za samoodržanjem jer amplificira svijest o povezanosti života i smrti harmonijom Erosa i Thanatosa te potiče sve veće obilje ili plethoru prakticiranja „,nasilne“, nietzscheanski rečeno, „odviše ljudske“ seksualnosti, jer seksualnost je život, no istovremeno, u svom iskonskom, nasilnom obliku, i opozicija životu i put prema smrti kao svojevrsnom vrhuncu, klimaksu života i seksualnog užitka.

Nagoni smrti tako usmjeravaju nagone za životom, a ljudska je priroda ustrojena upravo na način da „balansira“ između ekstrema, što je ključno za razumijevanje Batailleve misli kao komparativne analize razvoja čovjeka od samih njegovih početaka u primitivnim zajednicama, kao okrutne životinju sa sposobnošću za ritualno i magijsko te njegove nagone koje ga je kultura primorala eliminirati u dubine podsvijesti, no upravo nagoni za nasiljem i jednakom takvom seksualnošću, esencijalne su, prvotne i iskonske ljudske odrednice.

Napominjem da riječ „ljudski“ ne znači ,humani“ jer pojam humanosti je etički konstrukt i ne nalazimo ga u Bataillevoj filozofiji, a niti u etici ne mogu biti sinonimi.

Bataille prvenstveno naglašava da je čovjeku nasilje imanentno i o tome govori kroz prizmu vječnog ciklusa života, seksualnosti i smrti, ističući pritom u poglavljima „Seksualna plethora i smrt" i „Transgresija“ ono najvažnije vezano za tabu i transgresiju istoga i time izražava 
najvažnije misli erotizma, a osnovni koncepti kojima utemeljuje svoju teoriju erotizma su transgresija i tabu koji je objekt iste - tabu je zabranjeno tijelo ili čin koji se transgresijom kulturno seksualnih normi mora oskrvrnuti:

„, Tijelo je ekstravagancija u nama postavljena protiv zakona pristojnosti.

Ako tabu postoji, to je, po mom mišljenju, tabu nekog elementarnog nasilja.

To nasilje pripada tijelu, tijelu odgovornom za nagone reproduktivnih organa.

Putem objektivnog razmatranja aktivnosti tih organa pokušat ću doći do unutrašnjeg iskustva koje transcendira tijelo. Prvo ću skrenuti pozornost na unutrašnje iskustvo plethore za koju sam rekao da se otkriva u smrti ritualne žrtve. Podloga erotizma je osjećaj nečeg gorućeg, nasilja koje popraćuje eksploziju“" 210

Za filozofsko i psihološko tumačenje sadomazohističke seksualnosti Bataillevom filozofijom pojasnit ću temeljne relacije njegovih osnovnih pojmova i njihovih interpretacija u kontekstu seksualnosti i sadomazohizma.

Bataille govori o temeljnim senzacijama sadomazohističkog odnosa, tjelesnog odnosa kao žrtvovanja i ritualnog nasilja u kontekstu erotskog odnosa svojevrsnog obožavanja tijela objekta ili žrtve te prakticiranja nasilnih činova u svrhu i tjelesnog užitka i spiritualne egzaltacije kao psihičke trascendencije sekksualnosti.

Najvažnije koncepte erotizma, seksualnost, život i smrt potrebno je protumačiti u kontekstu sadomazohističke seksualnosti jer Bataille je mislilac čija je teorija neophodna za njeno antropologijsko razumijevanje budući da je utemeljio svojstvenu filozofiju i psihologiju seksualnosti sa sasvim drugačijim poretkom stvari i odnosa od dotadašnjih teoretičara, a u mnogim stvarima suprotnu mnogim suvremenim autorima.

Njegova je teorija seksualnosti kao iskonski nasilne zapravo izraz njegovog shvaćanja psihologije čovjeka putem njegova razvitka, a svoje bitno ostvarenje nalazi, kao što je prikazano, pored antropologije, u književnosti i umjetnosti.

Važno je istaknuti njegove poveznice sadističkog elementa koji prožima sferu produktivnog elementa u seksualnosti da bismo mogli razumjeti sadomazohističku seksualnost kao harmoniju naizgled nasilnog i destruktivnog poriva konstruktivnog, transcendentalnog odnosa i rezultirajućeg užitka.

BDSM je nadasve produktivan odnos, no stadiji i faze intenzivnog sadizma i mazohizma neophodne su za ostvarenje istoga, u smislu destrukcije jednog sustava vrijednosti i identiteta u svrhu uspostave željenog drugog.

${ }^{210}$ Georges Bataille, Eroticism, Marion Boyars Publisher Ltd, London, 2006, str. 92, 93 
Sadomazohistički odnos možemo sagledati kao istovremeno i destruktivan i produktivan jer tada ćemo ga shvatiti kao jedan od iskonsko ljudskih društveno - seksualnih odnosa koji se temelji na ciklusu života, seksualnosti i smrti.

Taj „vječni krug“ erotizma čine, pored transgresije i tabua, žrtvovanje objekta kao simbola ljepote, želja za seksualnim činom kao simboličkim uništenjem seksualnog objekta, kod Bataillea uvijek ženskog, a kraj ili „,nepostojeća“ granica je uvijek smrt:

„Uobičajeni je posao žrtve da dovede život i smrt u harmoniju, da smrti daje uspon života, životu značaj, momentalnost $i$ vertigo smrti otvarajući se nepoznatom. Tu je život pomiješan sa smrću, ali smrt je simultano znak života, put u beskonačno. Danas je je žrtva izvan područja našeg iskustva i imaginacija mora nadomjestiti pravu stvar" 211 i tada ,, inverzija ima značenje uzmemo i sada u obzir sličnosti između ljubavnog čina $i$ žrtve. " 212

Batailleva sinergija žrtvovanja kao nasilnog seksualnog čina i ljubavnog odnosa jedna je od temeljnih teza za BDSM seksualnost jer ona kao takva započinje upravo na tim temeljima, a dalje se razvija u imaginarne ritualne uloge i prakse nanošenja boli, užitka i kažnjavanja te sve tjelesne prakse ove seksualnosti proizlaze iz veze žrtvovanja i seksualnosti - nasilne seksualnosti u kojoj orgazam i smrt slijede istu liniju.

Žrtvovanje sebe u svrhu služenja drugome i obostranih erotskih senzacija užitka i zadovoljenja temelj su S/M seksualnosti i stoga Batailleve misli o tijelu i seksualnoj slobodi odlično opisuju poziciju individuuma u takvome odnosu:

„Primarna patnja povezana sa seksualnom uznemirenošću znači smrt.

Nasilje te uznemirenosti otvara se ponovno u umu osobe koja ga doživljava koja i zna što je smrt, bezdan koji je smrt otkrila.

Nasilje smrti i seksualno nasilje, povezani zajedno, imaju dualno značenje.

S jedne strane, konvulzije tijela su akutnije kad su bliže nesvijesti, a s druge, nesvijest, čini fizički užitak izvrsnijim.

Erotska aktivnost nije uvijek tako razorna, nije uvijek slom sustava, no potajno, na najdubljoj razini, slom intimno pripada ljudskoj senzualnosti i glavni je izvor užitka. “213

Mogućnosti interpretacije Batailleve teorije ne prestaju već tek počinju razmislimo li samo o transgresiji koja će biti polazni pojam seksualnoj plethori, obilju seksualnih odnosa i što sve ta transgresija znači za Bataillea i njegovu teoriju erotizma?

\footnotetext{
211 Ibid. str. 91, prijev.a.

212 lbid. str. 92, prijev.a.

213 Ibid. str. 104 - 105
} 
Ona je savladavanje tabua i uživanje u njemu, stvaranje erotskog od svetog i nevinog, bilo kao lijepo i puteno, bilo kao vulgarno i opsceno, ona je sveopća orgija, no i sveopća desekracija svetog da bi se transcendiralo u ,,profani okrutni ljudski sadeovski poredak“, ili ipak nešto drugo - spiritualna dimenzija tjelesnosti imanentna samo hipersenzibilnima poput autora samog i praktikanata $\mathrm{S} / \mathrm{M}$ seksualnosti?

Ritualne prakse žrtvovanja su put do transcendencije transgresijama seksualnih normi i tijela samog te ulogama sadista i žrtve, ,predstavom“ iskonskog životinjsko - ljudskog erotizma, da bi se praksama nasilja postigla transcendencija u sublimno, promjenom svijesti kao moment transcendentnalnog i ekstatičnog.

Za Bataillea perverzija ne postoji i u tome leži osnovna transgresija već u samoj misli i to je temeljna razlika njega i svih ostalih autora ove tematike, obzirom da su u njegovom djelu elaborirane eklatantne teze kao smjernice $\mathrm{i}$ reference za ontologijsko istraživanje sadomazohističke seksualnost te upravo zbog njegove „transgresije“ deskriptivnog narativa, eksplicitna teorija sadomazohističke seksualnosti veoma je jasna.

Destrukcija je za njega samo jedna komponenta koju ne treba shvatiti doslovno, već kao transgresiju normi i u tome je osnovna poveznica s BDSM seksualnošću, kao transgresija tradicionalne kulture i morala i povratak iskonskom, no istovremeno nadilaženje ljudsko životinjskog kroz praksu istoga, što zahtijeva duboko promišljanje ritualnog i transcendentalnog u čitavom Bataillevom životnom djelu.

U BSDM praksi najveću ulogu ima upravo ritualno, transcendentalno i naizgled anakrone prakse „mučenje“, žrtvovanja, prisile, dominacije, podređivanje, okrutnog iživljavanja nad objektom žrtve kao konsenzualne upravo su ono što nam možda Bataille upravo čitavo vrijeme antropologijsko - psihologijski implicira jer sve teorije i deskriptivne prakse, a posebice njegova terminologija nezaobilazni su za ozbiljnu filozofsku studiju sadomazohizma, kao seksualnosti i kao psihičkog fenomena, pristupa i promišljanja njegovog filozofsko - psihologijskog sustava. On čitatelje time inicira u ovaj psihoseksualni i antropološki fenomen, a ostalo ostavlja brojnim mogućim interpretacijama $\mathrm{i}$ osvrnemo li se na suvremene prakse sadomazohističke seksualnosti, nalazimo sve ono, naravno, i daleko više, o čemu Bataille piše u čitavome svome filozofskom i literarnom opusu kao neizostavnom djelu BDSM seksualnosti i kulture.

U zbirci eseja „The Absence of Myth“ Bataille ističe relevantnost temeljne razlike između seksualnog ponašanja i svakodnevnog života jer su međusobno ekskluzivni i ,postoje dva inkompatibilna načina: jedan u kojem se odvija erotski čin, drugi u kojem se odvijaju djelovanja 
društvenog života“214, i time on opisuje upravo život BDSM praktikanata koji, ne samo zbog stigme i diskriminativnih društvenih mehanizama, u svojoj seksualnosti uživaju privatno te svoju orijentaciju i preference drže u tajnosti.

Primarni je razlog tome, posebno u razvijenim društvima, osnovno načelo da privatno i javno moraju biti odvojeno, privatno mora biti privilegirano, kao ono voljeno i štovano, naš izvor užitka, i zato ih svaka osoba može dijeliti samo s najbližim osobama iz svoje privatne sfere ili zajednice, neovisno govorimo li o klubu ljubitelja ekstremne glazbe ili BDSM zajednici, a posebice partnerski odnos dvoje ili više osoba - privatno mora biti privatno, da bi opstalo, a to uključuje i javne manifestacije BDSM kulture koje pripadaju određenoj zajednici.

U Bataillevom djelu nalazimo brojne esencijalne komponente sadomazohističke seksualnosti jer nalazimo toliko građe o sadomazohističkim praksama budući da on razvija antropološko filozofsku teoriju seksualnosti i erotizma, a kao najbolji primjer navela bih njegovu konstantnu zaokupljenost raznim ritualnim praksama mučenja, žrtvovanja i silovanja koje imaju svoje veoma eksplicitne pandane u suvremenim BDSM praksama.

Razmislimo li prvenstveno o bondageu i svim zaista raznovrsnim oblicima vezivanja, uvidjet ćemo da ta praksa svoj korijen nalazi upravo u ritualima žrtvovanja koje Batailleu navodi, a kad tek razmislimo o još ekstremnijim aktivnostima poput flagelacije, ona svoje podrijetlo nalazi u religijskim praksama, koje opstaju i danas.

Kombinacija ,hard bondagea“ i flagelacije je upravo žrtvovanje kakvo Bataille opisuje, a pored tjelesnih senzacija, koje sežu do orgazma, ima izuzetnu spiritualnu dimenziju i iz tog razloga mnogi radikalni BDSM praktikanti svoju seksualnost i način života opravdano poistovjećuju s religijom, jer, i sama latinska riječ „re - ligio“ ima značenje biti vezan, obuzdan, podređen.

Sacrificijalni objekt je podložan i mučenju i silovanju, koje je izuzetno važno mnogima koji prakticiraju rape play, koji ne uključuje samo tjelesnu praksu, već često i razrađen „scenarij“, dakle, sve preduvjete za BDSM scenu, a granice moraju biti ili osjetilne, u smislu da se radi o dugotrajnim partnerima koji poznaju tijelo drugoga ili unaprijed dogovorene.

U aktu ,simulacijskog silovanja“ tj. rape playa nalazimo i ono famoznu desekraciju ljepote ponižavanjem i nasilnim seksualnim činom i stoga se submisivna osoba koja se upušta u bilo koju od navedenih praksi mora ponašati u skladu s pravilima i biti shodno tome (ne)odjevena, i zato je S/M outfit osebujan i prilagođen svakoj ulozi, svakoj aktivnosti, senzibilitetu, od fetišizma kao obožavanja seksualnog objekta, do prigodnosti za određene aktivnosti.

${ }^{214}$ Georges Bataille, The Absence of Myth, Verso, London, 2006, str. 200, prijev.a. 
O golotinji Bataille govori da utjelovljuje princip nepravilnosti i to iz civilizacijskih razloga koji su nam propisali ne samo odjeću, već određene odjevne predmete kao prihvatljive, a neke su označili kao neprihvatljive zajedno $s$ našim seksualnim ponašanjem $u$ suprotnosti $s$ društvenim normama, upravo iz razloga što kao i golotinja odražavaju našu prirodnost $\mathrm{i}$ seksualnost, što je bit golotinje. ${ }^{215}$

BDSM je kao što uviđamo dubljim promišljanjem, ne samo igra tijela i psihe, već prvenstveno, nesvjesna igra kao mimesis praiskonskog što možemo razumjeti vlastitim zapažanjima o vizuelnom i podražajnom, pa sve do egzaltacije mazohističkog užitka u boli kao ekstaze, odvajanja od sebe i, finalno, transcendiranja sebstva.

Kad govorimo o sadomazohizmu kao esencijalnoj praksi za postizanje seksualnog vrhunca, polazimo od vizuelne scene, odnosno psihičke dimenzije, koja je ritualna reprezentacijom odjeće ili golotinje, vezivanja u točno zamišljenom ili zadanom položaju, da bi uslijedio prijelaz na tjelesno, taktilne tjelesne podražaje boli, od kojih su najbolji primjeri već navedena flagelacija i rape play, Bataillevo ritualno i religijsko mučenje žrtve i silovanje njene ljepote i „oduzimanje njene osobnosti““.

Fenomen BDSM - a podrazumijeva prakse koje su u kategoriji visokog rizika, i s psihičkog i fizičkog aspekta jer pripadaju seksualnosti koja je u svojoj biti, posredstvom psihoseksualnog, na granici užitka i smrti, užitak je postavljen na samu granicu, a transgresijom, prelaženjem granice doživljava se „unutrašnje iskustvo“, transgresija seksualnosti, kulture, svijeta, vlastitog bitka, identiteta i konačno sebstva.

Ekstaza koju nastojim povezati u kontekstu suvremene BDSM prakse i Batailleve filozofije je kulminacija boli, užitka, svijesti o životu i smrti i stoga je „Erotizam“ kvalitativno i fenomenološki, sadržajno i stilski najzastupljenije djelo ovoga poglavlja te sam nastojala protumačiti sadomazohističku seksualnost Bataillevom antropološko - filozofskom teorijom seksualnosti koja je uistinu dokazala svoju izvrsnost i bezvremenost, kao što se može zamijetiti kod brojnih suvremenih autora koji daju svoje interpretacije Batailleva djela.

Interpretaciju fenomena sadomazohističke psihologije i tjelesne prakse koju je Bataille pružio cjelokupnim svojim opusom filozofije seksualnosti jedan je od presudnih za obuhvaćenu tematiku, a koncepcija osnovnih elemenata sadomazohizma je misao o ,tijelu u žrtvovanju $i$ ljubavi“ kojom on tumači postizanje harmonije života i smrti, izjednačavanjem senzacija nasilnog žrtovanja i ljubavnog čina, erotske konvulzije organa, ,nasiljem koje je izvan kontrole razuma $i$ volje“, pri čemu je „,ijelo ekstravagancija postavljena protiv zakona pristojnosti “. 216

\footnotetext{
${ }^{215}$ Georges Bataille, The Absence of Myth, Verso, London, 2006, str. 199

${ }^{216}$ Bataille, G, Eroticism, Marion Boyars Publishers Ltd, London, 2006, str. 91 - 92, prev.a.
} 
Uspostavimo li smislenu relaciju navedenih ideja sa suvremenom konceptualizacijom sadomazohističke seksualnosti i imanentne joj filozofske ontologije, nametnut će nam se brojna pitanja u našoj vlastitoj prirodi, seksualnosti, svjesnim i podsvjesnim željama, odnosima prema sebi i drugima i seksualnosti, što je upravo bila i namjera prema cilju spoznavanja i sadomazohizma kao specifične seksualnosti i mogućih odnosa pojedinaca, iz pozicije participanata, ili iz prizme teoretičara kao istraživača.

\section{4}

\section{Transcendentnost sadomazohističkog iskustva}

Kao što sam već izložila u poglavlju o fenomenologiji mazohizma, transcendentnost sadomazohističke seksualnosti je kontekstualno razumljena kao prijelaz iz tjelesnog $\mathrm{u}$ psihičkog, seksualnog u ritualno psihičkim i tjelesnim procesima ovladavanja sobom i drugim, ovladavanje tijelom i podređivanjem tijela, što je svojevrsna umjetnost jer tijela su tada $u$ specifičnom dvostrukom odnosu - kao samostalna prema sebi i podređena sebi te kao podređena ili nadređena drugome tijelu.

Prema brojnim autorima, to je vrsta spiritualnog „,magičnog iskustva“ jer je u takvim odnosima seksualnost nadvladana - ona je uzdignuta na jedan viši nivo, koji samo hipersenzibilne osobe mogu doseći i doživjeti, dok ga većina ljudi može izrazito teško konceptualno pojmiti.

U filozofiji sadomazohističke seksualnosti, interpretacijom mog rada, sadistička i mazohistička tendencija i praksa su shvaćene i prikazane kao antidestruktivne težnje za užitkom i oslobođenjem tijela, psihe i uma, što je bit psihoseksualnosti dominacije i submisivnosti.

Osnovno je polazište nadvladavanje vlastitog tijela i savladavanje sve veće boli, što je psihički uvjetovano, a individualni cilj je tim povezivanjem tjelesnog i psihičkog, postizanje vrhunca u prevladavanju sve većih vlastitih granica, što se kao subjektivan pojam individualno razlikuje, no može se univerzalno primijeniti na svakog pojedinca koji sudjeluje u BDSM praksama, naravno, što je viši stupanj submisivnosti ili dominacije u smislu vrste odnosa, to je veći i teži zadatak postavljen i pred dominantnu i pred submisivnu osobu. 
Primjerice, osoba koja neobavezno ili povremeno prakticira S/M sessione i aktivnosti, nije niti približno u jednakoj mjeri psihički uvjetovana istim kao osoba koja je u 24/7 odnosu ili striktnom dogovorenom, ugovornom odnosu s Gospodarem ili robom i S/M seksualnost joj je primarna odrednica identiteta.

Fundament je odnos tjelesnog i psihičkog, boli i užitak u odnosu sa sobom i odnosu s drugim, svojim tijelom i tijelom drugoga za upuštanje u promišljanje i razumijevanje odnosa prema vlastitome tijelu, prvo, u interakciji sa sobom, a potom s drugima, referirat ću se na „Corpus“, Jeana - Luca Nancya i njegovo promišljanje i doživljavanje samoga pojma tjelesnosti, istančano razrađenog te općenito tijela kao vlastitog tijela i tijela drugog. ${ }^{217}$

Nancyjeva je filozofija tijela fenomenološka i to u smislu da ulazi u dubinu shvaćanja tijela, tjelesnosti, osobnosti i seksualnosti na osebujan način.

„Corpus“ je stoga izuzetno važno i upečatljivo djelo kompleksne filozofije tijela u relaciji s psihom, koje iznosi teoriju shvaćanja tijela kategorijama ega, altera, svijeta tijela, dodira, interakcija te statusa i pozicija tijela kao jastva, sebstva i drugosti.

Za Nancyja tijelo nije niti označitelj niti označenik, već je deskriptivno pozicioniran kao „,izlagajuće“, „ono koje se izlaže“ ili „,izloženo“ (exposant/exposé), kao ekstenzija egzistencije i upravo je takav pristup esencijalan za tumačenje tijela u kontekstu dominacije i submisivnosti jer je manifestacija izražaja tjelesnih i psihičkih praksi koje sadomazohistička seksualnost proklamira, podrazumijeva i kojima djeluje.

Nancyjev pojam ega, kako ga on tumači, proizlazi iz Descarteove filozofije, no za njega je ego nešto daleko više jer on sastavlja sintagmu „,corpus ego“, umjesto izraza „moje tijelo“, iz razloga što „corpus ego “ sadrži i tijelo i misao i svijest o egzistenciji, čime se on izravno referira na Descartesa, podsjećajući da „ego“ ima smisao jedino kada je njegov smisao identičan egzistenciji (ego sum, ego existo) ${ }^{218}$, budući da se ta svijest o egzistencije zbiva u umu, mišlju i izjavom i Nancy na taj način nastoji izraziti doživljaj tijela, kao ekstenzije cogito i bitka samog. Ukazujući da je u kartezijanskoj misli artikulacija ega uvijek tijelo, izjednačeno s umom, ne tijelo ega, već „corpus ego“, a ego jest ego samo kad je artikuliran kao raspon ili flekcija:

„Izražavanje , ega“ nije samo zauzimanje mjesta, zbivanje. Naprotiv, on jest mjesto, ego = ovdje, ako je lokaliziran. “ ${ }^{219}$, Nancy elaborira „,corpus ego“ kao omniinkluzivan konglomerat tijela, tjelesnosti, uma, egzistencije i seksualnosti, i možemo stoga reći da je taj pojam prava

\footnotetext{
217 Jean - Luc Nancy, Corpus, Fordham University Press, New York, 2008.

218 Ibid. str. 25

219 Ibid. str. 25
} 
pozicija tijela, u smislu da ga ne samo filozofski sagledava i opisuje, već mu priznaje sve atribute i mogućnosti koje posjeduje u svojem potencijalu.

U tom smislu, „corpus ego“ bio bi svijest spoznaje koja govori „Ja sam tijelo“, i time bi imao značenje jastva kao tjelesnosti, no, kao što sam već navela, ne samo uma, već korelacije i jedinstva uma i tijela, egzistencije kao mišljenja i djelovanja i tjelesnosti kao doživljavanja vlastitoga tijela u odnosu sa samim sobom i s drugim tijelima:

„, Svijet tijela je neprobojan svijet, svijet koji nije inicijalno podređen kompaktnosti prostora, već je svijet u kojem tijela inicijalno artikuliraju prostor.

Svijet je razmještanje u prostoru, tenzija prostora, gdje tijela nisu u prostoru, već prostor $u$ tijelima.“220, zaključuje Nancy.

Od izrazite je važnosti za razumijevanje odnosa svog tijela s drugim i tijelom drugog pojam „alter, koji Nancy objašnjava putem razumijevanja ega.

On konstatira da „ego formira apsolutnu prepreku tijelu“ jer ,izražen, izgovoren ego je trenutno odvojen od izražavajućeg, izgovarajućeg ega, upravo zato što je isti, i stoga ego: to je povučeni identitet, identificiran kao povučen.

Povlači se u točki svoje vlastite suprotnosti: gdjegod se corpus deklarira kao „ego “, ego ulazi u proturječje, bivajući suprotstavljen sobom koje se suprotstavlja svojem sebstvu, a corpus postaje materija - prepreka toj suprotnosti: Ob - jektna materija subjekta.

Zato ne postoji ,, vlastito tijelo, samo rekonstrukcija.

To je ili samo „proširivanje istoga“ i prerano za „,vlastito“, ili je već uhvaćeno u suprotnosti, već prekasno. No corpus nikada nije vlastito ja. “ 221

Vidimo koliko duboko Nancy analizira poziciju ega i njegovu egzistenciju ustanovljujući ontologijske razlike ega i „corpusa“ te njihov kompleksan odnos jer „corpus ego“ je shvaćen kao najviša instanca individuuma, svojevrstan vlastiti, imanentni apsolut.

Ego kao i ja i jastvo zajedno s tijelom i tjelesnošću izražava i predstavlja identitet te je esencija i egzistencija individuuma i zato Nancy govori da je tijelo „uvijek objekt, tijelo - ob - jektno upravo spram tvrdnje bivanja tijelom - subjekt ili subjekt - $u$ - tijelu“ i „Tijelo je uvijek objektirano (objectè, usprotivljeno, op.a.) izvana, meni li nekome drugome.

Tijela su prva i uvijek druga - kao što su drugi prvi i uvijek tijela. “222

\footnotetext{
220 Ibid. str. 27, prijev.a.

221 lbid. str. 29, prijev.a.

222 Ibid. str. 29, prijev.a.
} 
To bi značilo da su ja kao jastvo i tijelo kao komponenta sebstva uvijek u određenom konfliktu i bitno ih je kao takve razumjeti, iako se uvijek nastoje uskladiti jer su dio jednog - „corpus ega“ kao inkoherentne cjeline, kao što je već prikazano.

Za Nancyja seksualnost, kao i za Bataillea, nema samo tjelesnu već iznad svega psihičku i metafizičku dimenziju, koja dolazi do izražaja upravo u „Corpusu“, budući da njegova zapažanja i teze čine jednu izuzetnu filozofiju tijela.

Promišljajući tijela i njihove pozicije, on možda najveću pažnju posvećuje fenomenu dodira jer je upravo on esencijalan za doživljaj i stimuluse tijela te nadalje fenomene inkarnacije $\mathrm{i}$ inskripcije koji su izuzetno važni za tematiku sadomazohističke seksualnosti jer njene su i polazne točke intenzivne i delikatne taktilne senzacije:

„Ob-jekcija (protivljenje, op.a.) dodiruje. Ovo tijelo, ovo obilježje, ova zona ovog tijela me dodiruje (dodiruje "moje“ tijelo“). To mi godi ili mi ne godi, protivi mi ili mi ne protivi, interesira me ili me ne intersira, doima me se ili me ostavlja hladnim, uzbuđuje me ili mi se gadi. To će uvijek doći u samome dolaženju drugog.

Drugi će doći prvi, iz najdaljeg, najudaljenijeg mjesta, corpus obilježja, konačno identificiran s , „njim “ - no ostajući u sebi neidentificiran: jer su sva ta obilježja strana jedno drugome, ova ruka i ova brada, ova kosa i ovi kukovi, i ovaj glas, svi dolaze zajedno i bivaju dislocirani $u$ jedno i isto vrijeme. " 223

Dodiri tijela, tijela kao međusobno bliska i strana, spojena i otuđena esencijalna su za tumačenje korelacije i društvenih i seksualnih odnosa, upravo tijelo kao istovremeno poznato i nepoznato, a dijelovi tijela kao posebni objekti čijim posredstvom diferenciramo jedno tijelo od drugoga jednu osobu od druge i Nancy zaključuje da se ta interakcija odvija beskonačno ,sve dok ne postane jasno da drugi čak nije ni prava riječ, samo „tijelo“.

Svijet u kojem sam rođen, umirem, postojim, nije svijet „,drugih“, budući da je „moj“ koliko i bilo čiji drugi. To je svijet tijela. Svijet suprotnosti.

Ogroman, beskrajan susret: svako tijelo, svaka masa uzeta iz tijela je ogromna, što znači nemjerljiva, vječnost ponuđena za dosezanje, dodirivanje, gledanje. "224

Nancy daje uvid u ekspoziciju, izlaganje tijela, što je od enormne važnosti za temu ovoga rada $\mathrm{i}$ to veoma domišljatom riječju ,expeausition“225, odnosno, ,izlaganje kože“ i time lingvističkom igrom dočarava smisao najdubljeg i najintimnijeg sloja tijela, ispod površine kože, a to je tijelo pozicionirano i doivljeno kao subjekt, osobnost.

\footnotetext{
223 Ibid, str.31, prijev.a.

224 Ibid. str.31, prijev.a.

225 peau, koža, exposition, franc. izlaganje, op.a.
} 
Koža je površinski sloj tijela, ono puteno, i kao takva primarni senzualni organ čija je uloga u seksualnosti izrazito velika zbog svih podražaja koje prima, ožiljaka koje nosi, koža je ono prvo vidljivo, ona je medij sebstva i seksualnosti osobe, kao ono prvo osjetilno.

Ona nosi sva obilježja osobe, ogledalo je sebstva, a u BDSM - u je izrazito važna upravo zbog navedenih svojstava jer ima prvenstvo u svim tjelesnim praksama no i kao objekt ekspozicije, kako Nancy objašnjava „expeausiotion “ te bih skrenula pozornost na veoma čestu mazohističku praksu ozlijeđivanja kože, nanošenja ožiljaka, pa i trajnih poput brandinga ili manje ekstremnog scarificationa u kojima osobe uživaju i deklariraju svoj identitet.

Osim užitka, ekspozicijom kože osobe izražavaju i svoje negativne emocije kao što su neprihvaćanje sebe i nezadovoljstvo sobom i tada je samoozljeđivanje svojevrstan poremećaj koji ukazuje na psihičke poremećaje ličnosti, i takve su manifestacije kože, tijela i psihe prisutne, ne samo, kao što se smatra, u mladoj dobi, već i kod starijih osoba, koje se okreću autodestrukciji zbog prekida veze između sebstva i tijela.

Način na koji izlažemo i odnosimo se prema svojoj koži ukazuje na naš odnos prema sebi jer tijelo je subjekt života i užitka, i osjećati svoje tijelo znači poistovjećivati se s njima na način na koji Nancy to elaborira jer tijelo je ključan, primarni organ našeg života, ljubavi prema životu. Ono otkriva našu osobnost, izražava naše misli i našu seksualnost.

Svoju ideju izlaganja tijela, „exposition“, objašnjava sljedećim riječima:

„Intimnost tijela izlaže čisto ne - sebstvo, ne - sebstvo kao ne ja.

„Ekspozicija“ " ne znači da je intimnost izostavljena iz svog povlačenja i stavljena na prikaz. Jer tada bi tijelo bilo ekspozicija , sebstva“. Ekspozicija, naprotiv, znači, da je izraz sam intimnost i povlačenje. " 226

Nancy govori o jukstapoziciji intimnosti i izloženosti i njihovoj povezanosti jer tijelo kao intimno postaje izloženo u svijetu tijela - društvu medija i seksualnosti no i privatno unutar odnosa postaje izloženo drugome, no ono mora zadržati svoju temeljnu intimnost, bez obzira što je konstantno u interakciji s drugim tijelima, jer u protivnome dolazi u konflikt s psihom, sa sebstvom, i osoba tada gubi svoj identitete u vidu „corpus ega“.

Misao o tijelu je koncept kojem on pristupa s velikom pažnjom, naglašavajući međusobno dodirivanje tijela, koje je za njega početak i vrhunac egzistencije, jer izražava užitak, tugu ili bol, te on uspostavlja pojmovnu kombinaciju „tijelo - misao - užitak - bol“227, koju možemo direktno paradigmatski povezati sa senzacijama u sadomazohističkom odnosu.

\footnotetext{
226 Ibid, str.33, prijev.a.

227 Ibid, str. 37
} 
Tu kognitivno - tjelesnu konceptualnu relaciju on naziva „seks“, misleći time na moment ili fenomen dodirivanja u samoj ekspoziciji jer:

„Seks dodiruje nedodirljivo. „Moj“ seks nije cijelo vrijeme jedna stvar; on je diskretan, nasumični, događajni kontakt zona ,,mojega“ tijela, jednako kao i drugih - moje tijelo postaje drugi, dodirujući sebe tamo, bivano dodirivano tamo, postajući isto, više apsolutno, više odvojeno nego ikada, više identificirano.

Od (a)faličnog do (a)cefaličnog, razina, glatko, pluralno, zasjenjeno, dodirivano tijelo.

Nećemo ga zvati ,,žena“ ili „,muškarac“: ta imena nas ostavljaju previše među fantazijama $i$ funkcijama. Umjesto toga ćemo reći : da jedno neodređeno/određeno, indiskretno/diskretno tijelo je seksulizirani bljesak tijela, kližući od od tijela do tijela, ravno u intimnost-bljeskanje, u efektu - granice na kojoj se dodiruju se zaokreću. "228

Na taj način Nancy prikazuje odnos tijela i svoju ontologijsku konceptualizaciju seksa koje je veoma blisko shvaćanju BDSM prakse i psihologije i stoga upravo njegove misli odlično odražavaju shvaćanje seksa i tijela u okviru filozofije sadomazohističke seksualnosti:

„Iz toga slijede razne posljedice: zakon najviše površnosti, gdje se tijelo računa apsolutno kao koža, s niti jednim dubljim organom ili penetracijom (seksualizirana tijela su neranjiva, vječna); povezani zakon prema kojem ne postoji seks bez minimalne mjere ljubavi, kao što nema ljubavi bez seksa; konačno seks kao zakon, imperativ dirati, jebati - nešto zašto ni instinkt niti „libido“ mogu biti odgovorni.

Jer taj imperativ nema objekt za cilj-samoužitak/bol diranja sebe.

Orgazam je dijastola bez sistole u srcu dijalektike: to srce je tijelo. “229

U sadomazohističkoj seksualnosti tijelo se od intimnog transformira u izloženo, ali time još intimnije, dodirima i nanošenjem boli ono zadobiva novo određenje - podređeno ili nadređeno, pozicija ili ekspozicija, a koža nosi tragove koje tijelo proživljava, ona je neposredni receptor svih podražaja užitka i boli.

Tijelo i psiha kao „corpus ego, putem raznih (i)racionalnih djela doživljavaju svoju modifikaciju i osim osjetilnih manifestacija, poprimaju novi identitet, kroz užitak i bol te pulsirajući orgazam kao metafora za psihofizičke senzacije tijela.

Pored elaborirane Nancyjeve filozofije tijela u „Corpusu“, detaljnije ću interpretirati poveznice drugog dijela njegovog opusa o seksualnosti teorijom tijela i njegovih odnosa i interakcija $u$ kontekstu sadomazohističke seksualnosti.

\footnotetext{
228 Ibid, str. 37, prijev.a.

${ }^{229}$ Georges Bataille, Eroticism, Marion boyars Publishers, London, 2006, str. 39, prijev.a.
} 
Tijelo kao medij dekonstrukcije seksualnosti prikazujem vlastitom tematskom interpretacijom Nancyjevog "Corpusa", konstatirajući sam da je sam pojam i doživljaj tijela subjektivan i transcendentalan i time neposredno vezan za shvaćanje tijela u sadomazohističkoj seksualnosti. Tijelo je polazište seksualnosti a priori, a raznovrsni doživljaji tijela i tjelesne senzacije, psihičke promjene $\mathrm{u}$ vlastitom poimanju tijela temeljni su za teoretski pristup sadomazohističkoj seksualnosti, kao i interpretaciji njene prakse.

Referirajući se na dobro poznatu i ranije objašnjenu Lacanovu formulaciju da ne postoji seksualni odnos (,Il n'y a pas de rapport sexuel“), u semantičkom smislu, Nancy razvija svoju tezu o postojanju i uvjetima seksualnog odnosa.

Svojom lingvističko - filozofijskom elaboracijom on detaljno promišlja i ustanovljuje tezu da seksualni odnos postoji, no potrebno je definirati što je odnos te na koji ga način tijelo, putem svoje seksualnosti doživljava i ostvaruje.

Nancy Lacanovu tezu i razumije kao provokaciju i poziv na promišljanje:

“Kad počinjemo pokušati razumjeti, otkrivamo da se provokacija u odnosu na empirijsko iskustvo (na činjenicu da odnos postoji svakoga dana) ispostavlja da nije esencijalna poanta. Moguće je jedino sredstvima druge provokacije ili svojevrsnog nametanja jezika.

"Ne postoji odnos" rečeno je na način na koji bi se reklo "nema ulja u vrelu".

To pretpostavlja da je ,odnos “ neka stvar. To nije neposredno dano u jeziku.

Riječ „odnos“ navodi nas da mislimo na djelovanje, ne supstancu.

Ona ne designira ni substancu, niti sredstvo.

Odnos sensu stricto ne designira niti jednu stvar. U dodatku, u praksi izraz , seksualni odnos “ nije onaj koji koristimo da izrečemo taj događaj “230

Poimanje tijela, seksualnosti i odnosa temelji se na jeziku, na konceptualnim strukturama semantike koje oblikuju našu percepciju vlastite tjelesnosti i seksualnosti u odnosu sa tijelima drugih i Nancyjev pristup tijelu zaista je blizak, ako ne i ekvivalentan sadomazohističkom razumijevanju tijela i seksualnog odnosa.

230 Jean Luc Nancy, Corpus 2, Fordham University Press, New York, 2013, str. 4, prijev.a. 
S/M odnos u svojoj biti i praksi je aktivan, tjelesno - psihički seksualni fenomen, nije supstancijalan, a ponajmanje pasivan, dok apstraktan nije niti u fantazijama jer i one su imaginacija koja čeka svoju materijalizaciju kao tjelesno ostvarenje:

"Ako slijedimo odnos iz ugla "nečega", možemo reći da ne postoji odnos seksualnog ili da seksualno ne povezuje ništa. Možda je to ono što Lacan želi indicirati kad kaže da odnos piše sebe, a da seksualno ne piše sebe, pod čime moramo razumjeti da je pisanje stvar povjeravanja i prenošenja prije nego označivanja, stvar grafa ili algoritma, prije nego književnosti. Možda je pitanje ovo: Što postoji od seksualnog odnosa u cjelokupnoj književnosti, poebno poeziji (no možda također - tko zna - u cjelokupnoj filozofiji)? “231

Nancy o odnosima govori u deskriptivnom, tjelesnom, no i metaforičkom i ontologijskom kontekstu i registru, pri čemu je bitno istaknuti upravo njegovo promišljanje Lacanove teorije i njegovu vlastitu interpretaciju seksualnog odnosa kao odnosa tijela u ulozi „instrumenta“ osjetila i osjetilnog podražaja, odnosa iznad stvarnosti i jezične logike označitelja.

U Nancyjevu djelu možemo jasno predočiti tijelo kao cjelinu, ono je, nakon svoje ontologijske pozicije kao „corpus ego“, misaono i psihičko, subjekt senzacija užitka, boli, vizualnog, taktilnog i auditivnog posredstvom odnosa, koji su elaborirani i postpsihoanalitičkom semantikom i filozofijom jezika.

Interpretacija Nancyjeve filozofije tijela kroz prizmu sadomazohističke seksualnosti svojevrsna je dekonstrukcija filozofije seksualnosti, no njegova je teorija izrazito bliska i u većini stvari komplementarna suvremenim S/M teorijama tijela.

Tijelo i seksualnost kao subjekti, akteri i instrumenti odnosa moći koji se provode senzornim i senzacijskim praksama tjelesnih podražaja užitka i boli temeljni su predmet Nanyjceva djela u kontekstu teme sadomazohizma jer je tijelo užitka prvenstveno tijelo boli, samostvoreno, bezgranično u svojoj energiji samoostvarivanja i želji za daljnjim uzbuđenjima i u svojoj esenciji i svojom egzistencijom življenja užitaka, nadilazi granice tijela kao sebstva.

Nancyjev koncept tijela, kao "corpus ega", cjeline psihičkog, fizičkog, podražajnog i nadasve senzualnog i seksualnog, individualnog, no u međuodnosu s drugim tijelima, kao podređeno ili nadređeno biće, što njegovoj misli daje novi smisao, razlog i poticaj za čitanje njegove filozofije tijela jer svojim tezama jasno implicira poimanje tijela u kontekstu teorije sadomazohizma.

${ }^{231}$ Ibid, str. 5, prijev.a. 
Tijelo je hermeneutički zahvaćeno kao ja, jastvo, sebstvo, subjekt, tijelo je izloženo i podređeno tjelesnim senzacijama ugode, suptilnima, nježnima, no i bolnima neposrednim odnosom $\mathrm{s}$ drugim tijelima i tijelima drugih.

Interpretacija odnosa tijela u Nancyjevoj misli polazi od tijela koje reprezentira osobu kao ego i “corpus ego" koji svoje psihofizičko ostvarenje nalazi u seksualnom odnosu izmjene doživljaja i podražaja boli i užitka te u tom kontekstu nalazimo karakteristike sadistične i mazohistične te dominantne i submisivne osobe.

Nancyjeva filozofija tijela ima originalan pristup konceptu odnosa, referencom i nadogradnjom na Lacanovu tezu o "nemogućnosti” seksualnog odnosa, konstatacijom da je odnos nepostvariv, nematerijaliziran te on zaključuje da odnos nije moguće doživljavati kao stvar, supstancu, već aktivno djelovanje te ga se ne može opisivati, prepričavati niti mjeriti kao "stvar" u formi reificiranog označitelja.

Njegova ontologija tijela kao bitka svoje tumačenje centrira na tjelesne senzacije, dodire i stimulacije kože i svih dijelova tijela kao erogenih zona, što je bitna odrednica sadomazohističke seksualnosti i „kontrateorija“ psihoanalitičkim teorijama koje su stavljale naglasak na spolne organe kao isključive erogene zone i seksualne ciljeve.

Međutim, za suvremenu postpsihoanalizi Nanyceva teorija od velike je važnosti jer erogene zone i erotski stimulansi mogu biti baš sve - ne samo dijelovi tijela poput lica, ruku, kose (koji su tradicionalni bili smatrani fetišima), već i audio - vizualne karakteristike osobe - boja glasa, držanje tijela, izraz lica ili pogled.

Jouissance je za Nancya bitan konstituent seksualnosti kao poveznica tijela s užitkom, a odnosi se na tjelesnost $\mathrm{i}$ fizičke senzacije $\mathrm{u}$ relevantnom za sadomazohističku seksualnost $\mathrm{i}$ on prikazuje svoje razumijevanje Lacanova jouissancea kao bitnog konstituenta odnosa tijela i seksualnosti vlastitom konceptualizacijom užitka:

"Jouissance nije jouissance seksa, kao neka vrsta dobra koja bi se mogla posjedovati, i nije jouisssance seksom, da bi davao pristup posjedovanju nekog dobra.

U tom kontekstu, korištenje jezika subjekta i objekta je izrazito opasno jer implicira, barem u filozofskom diskursu, konstituciju $i$ reprezentaciju objekta od $i$ za subjekt. Ali seks niti konstituira niti reprezentira ni jednu takvu stvar; on razlikuje i odgađa sam sebe, tako da nije ni njegov subjekt niti objekt.

Jouissance je činjenica ili bitak seksa utoliko što razlikuje i odgađa sebe. 
Reprezentacija fuzije, bilo izvorna ili terminalna, reprezentira ekstinkciju jouissancea.

Cijela historija erotizma, od Platona do Henrya Millera, ista historija svjedoči da užitak ne postoji bez dodirivanja patnje i radosti muke : taj dodir sam ne postoji, kao što bi trebao, bez odmaka i diferencijacije." 232

Tijelo kao ego i sebstvo uživa posredstvom senzacija odgađanja seksualnog odnosa, čime doživljava svojevrstan užitak svoje fantazije:

"Jouissance je upravo simultanost otpuštanja i ekscesa tenzije. Možemo to opisati kao „,nemoguće” ako želimo, ne u smislu u kojem bismo morali priznati fantaziju fuzije kao impasse, već u smislu da je impasse u pitanju upravo ono što otvara put - čemu? Beskonačnosti želje - užitka koja je beskonačnost odgađana seksa i razlikovanja sebe.

Želja - užitak mora biti shvaćena kao nezadovoljstvo: iznad zadovoljstva." 233

Nancyjeva filozofija tijela $\mathrm{u}$ odnosu na sadomazohizam i sadomazohističku seksualnost najbolje je interpretirana upravo njegovim teorijama o jouissanceu i (bes)konačnosti seksualnosti u odnosu na uzbuđenje, dodir, bol i seks u specifičnom značenju:

"Konačnost odnosa ili jouissancea mora biti shvaćena kao ono što završvava seksualnu beskonačnost. To beskonačno je dobro ili stvarno beskonačno - to je beskonačnost u stvarnosti čina samog ukolio je čin prekoračenja sebe.

Seks esencijalno prekoračuje i nadmašuje sebe zbog čega je esencijalno uzbudljiv.

Jer da bi se povezalo sebe, u smislu u kojem sam rekao, je uzbuditi sebe, ispuniti se, ostvariti se izvan. Zaista, želja nije ugašena kad je zadovoljena; dosezanjem točke ostvarenja ponovno se prekoračuje. Užitak opisan kao "terminalan” je samo kraj sekvence unutar pokreta koji je u pravilu beskrajan. Štoviše, taj užitak nadmašuje zadovoljstvo identično: na vanjskim granicama nezadovoljstva postoji iscrpljenost u dva smisla riječi, gotovo uzdisaj, ponekad molba, preklinjanje." 234

Sadomazohistički je odnos upravo najbolji primjer beskonačnog uzbuđenja i "beskonačne konačnosti" vremenskog perioda, izvan vremena i prostora, izvan dosega svijesti i svakodnevnog života, što ga čini ekstatičnim i transcendentalnim.

\footnotetext{
232 Ibid, str. 13, prijev.a.

${ }^{233}$ Ibid, str. 13 - 14, prijev.a.

234 Ibid, str. 15, prijev.a.
} 
Stanje svijeti izazvano tjelesnim senzacijama i psihičkom kontrolom, naizraženije u mazohističnih i submisivnih osoba, zaista je razumijevanje sebe kao tijela užitka i boli, manifestacijom ekstaze kao "izlaska" iz svog tijela, svog uma i psihe, svog ega te uspostavljanje doživljaja imaginanrog ,novog tijela” i novog alter ega vođenog energijom iskušavanja granica beskonačnog uzbuđenja i iskustva:

„,Tijelo izranja iz svoje forme. Njegovo srce više ne udara u ritmu pumpe krvi, već u ritmu divlje panike; njegova pluća više ne dišu već uzdišu, čak se guše u pokušaju da udahnu dah koji bi bio suspenzija daha i uskraćivanje zraka.

Njegovi udovi i organi nisu više udovi i organi već su deformirani i reformirani u zonama ili dezorijentiranim kontinentima čija se čitava geografija širi ili kontrahira sukladno ekscitacijama koje u svakom trenutku podižu mogućnost potpune rekompozicije, tijela koje bi se ponovno uzdiglo.

U seksu, tijela svjedoče pozivu da sebe učine beskonačnima iznad svih sekundarnih odrednica danog poreka. Zato je seks mjesto stvaranja. Tijelo užitka (i njegova opreka, tijelo boli) čine tijelo bezgraničnim. To je njegova transcendencija. “235

Nancy jasno prikazuje tjelesno iskustvo sadomazohističkog doživljaja koje zapravo izuzetno realno opisuje egzaltaciju tijela u ekstremnim i rizičnim praksama, u kojima su tijelo užitka i tijelo boli jedno te nadilaze stanje uma i svijesti:

„Seks kao tjelesna odrednica - "seksualnost" ili „,seksuacija“ je upuštanje tijela u odnos. Tijelo je po sebi upuštanje u odnos; uvijek je već u odnosu utoliko što je esencijalno ekpozicija, ektraverzija, a seks je determinizam ekspozicije zbog sebe, bez ijednog drugog kraja i stoga beskrajno, apsolutno. “236

Tijelo užitka, pored strukturiranosti vlastitom organizacijom, neovisno o vanjskom svijetu, podređeno seksualnom užitku kao odnosu razmjene, Nancy opisuje kao:

“tijelo kao kapacitet za transformiranje sebe, reformiranja sebe, ili možda informiranja i čak eksformiranja sebe, prelazeći od usklađivanja, čak i sklada, reguliranih skupom društvenih, kulturnih i tehnologijskih praksi, do forme koja je sebstvo uvijek u procesu formacije. "237

\footnotetext{
235 Ibid, str. 96, prijev.a.

236 Ibid, str. 101, prijev.a.

237 Ibid, str. 94, prijev.a.
} 
Nancyjev pojam eksformiranja sebe vjerojatno je mišljen u smislu odvajanja sebe od vanjskog svijeta, usmjeravajući se isključivo na sebe kao bitak, svoj odnos sa sobom, s drugim i svoj užitak, bez konformizma s društvenom sferom:

„,To tijelo otkriva i osmišlja sebe, ponovno sastavlja, ponovno odigrava sebe.

Ono reformira sebe i gotovo eks - formira sebe, uistinu de -formira sebe na način da sada nije više nešto nego ta ekspozicija sebe; tijelo kao koža koja biva dirana i koja dira, kao modulacija pristupa koji uvijek počinje iz pravilne granice tijela.

Ono doseže svoju granicu, prelazi svoju granicu, čini sebe bezgraničnim. “238

U tumačenju njegove misli, tijelo je mišljeno i kao esencija, uvijek aktivna, a istovremeno i egzistencija sebe, dok je seksualnost, kao bitak i egzistencija tijela uvijek u neposrednom odnosu s tijelom, kao njegov esencijalni i egzistencijalni dio.

Nancy promišlja tijelo kao bitak, kao subjekt koji se poistovjećuje s psihom te postaje komplementaran s umom jer tijelo, psiha i um se međusobno uvjetuju i konstantno nadopunjuju, a tijelo često ima primarnu ulogu nad ostalim konstituentima osobe.

No tijelo nije upravljano uvijek i isključivo psihom, već i sobom kao aktivnim bitkom, koji se manifestira reakcijama na podražaje kao osjećaje kojima upravlja.

Tijelo, kao istovremeno i subjekt i objekt, temeljno je za tumačenje sadističkih i mazohističkih praksi i senzacija jer je pozicionirano kao centralni pojam svih odnosa, seksualnosti sadomazohizma i cjelokupne egzistencije.

Psiha i erotika tijela najvažniji su aspekti tumačenja sadomazohističke seksualnosti jer njima se uspostavlja ravnoteža senzualnog i misaonog koji zajedno stvaraju i ostvaruju želju - tijelo užitka i tijelo boli koji zajedno čine tijelo energije:

„,Tijelo užitka stremi bezgraničnosti, kao da višse uopće nije tijelo već čista duša.

Na jednak način, suprotni pokret, bol, nastoji reducirati tijelo koje pati na dušu koja pati koja koncentrira sebe u izgaranju i svom odbijanju istoga ili, preciznije, u tom izgaranju tako da ono sebe odbija. Užitak $i$ bol su kao dva načina gorenja: gorenje koje se hrani samim sobom $i$ ono koje se odupire i odbija sebe.

Postoje dva modusa ekscitacije: ekscitacija je pokret poziva od i odgovra vanjskom agensu. Ekscitabilnost je elementarno vlasništvo živih bića.

238 Ibid, str. 94, prijev.a. 
Živa bića su iznad svega uzbuđena, pozvana da odgovore izvanjskom.

U užitku i boli, ekscitacija je shvaćena za sebe, ne odnosi se i nije upravljana prema izvanjskom ostatku svijeta kad je stvar percepcije, primanja i komuniciranja, ponašanja.

Ali vani je tijelo samo ili ništa ili drugo tijelo kao ponovni beskonačni kontakt s totalitetom tijela, u svijetu; kontakt se odnosi, u dubljem smislu do najdaljih granica svijeta, njegovog stvaranja i kraja. “239

Naravno, psiha i um su elementarni, no tijelo u jednom momentu preuzima dominantnu poziciju u dinamičkoj strukturi individuuma, seksualnost zadobiva primarnu ulogu u formaciji corpus ega, tijela kao medija receptora i centra užitka.

Nancyevo je razumijevanje tijela izrazito važno za tumačenje sadomazohističke seksualnosti, jer iako je psiha inicijalni, primarni medij fantazije i želje, tijelo je u praksi ultimativni bitak i moment ostvarenja želje i seksualnosti, putem transformacije sebstva u sferi bezgraničnosti, onkraj pojma prostora i vremena - svijeta kao ograničenja.

239 Ibid, str. 94 - 95, prijev.a. 


\subsection{Baudrillard i Lotringer o seksualnosti, perverziji i Foucaultu}

\section{Ideja re-semantizacije sadomazohizma}

O suvremenim proučavanjima perverzija najstručnije piše Sylvere Lotringer u svojoj izvanrednoj studiji „Overexposed - Perverting Perversions“, uvodeći prvo u seksualnost u suvremenom društvu, te potom predstavljajući kognitivno - bihevioralnu terapiju u liječenju ozbiljnih seksualnih poremećaja detaljno prikazao što su uistinu postmoderne perverzije. ${ }^{240}$

Lotringer je svojim dovođenjem perverzije do apsurda dao velik doprinos novom shvaćanju toga pojma, apelirajući na paradoksalnost proučavanja perverzije.

Njegova je teorija, zasnovana na metodologiji prikaza devijantnog ponašanja, perverzija i seksualnosti uopće na temelju transkripata i intervjua sa stvarnim seksualnim prijestupnicima u američkim kaznenim ustanovama.

On time nije samo objasnio razumijevanje neprihvatljivog i nedozvoljenog ponašanja, perverzija i seksualnosti u suvremenom društvu, već je njegov ultimativni zaključak da društvo u cjelini, osobito mjerodavne institucije i stručnjaci svojom pretjeranom zaokupljenošću proučavanjem perverzije stvaraju perverziju od ljudskog života samog.

Kao najbolje primjere takvoga stanja u znanosti, on govori o poticanju perverzija, pozitivnog pristupa devijacijama, u kojemu nema zabrana već je terapija govor, vizualizacija i ispovijed najvećih, najokrutnijih djela i opsesivnih fantazija. ${ }^{241}$

Zločini, silovanja i razni oblici sadizma glavni su subjekti medicinske znanosti i verbalizacija njihovih čini je baza studije o perverzijama, što Lotringer naziva kopernikanskom revolucijom u svijetu terapije ${ }^{242}$.

Za razliku od dotadašnjih terapijskih metoda, nova bihevioralna terapija 1980 - ih godina u SAD - u inzistirala je na govoru, riječima o „neizgovorenom“, zabranjenom kojemu su se ukinule sve zabrane, kako Lotringer govori, ,ono je bilo kažnjavano sada je ohrabrivano “ $\mathrm{i}$ to je bio radikalan zaokret u pristupu i metodi. ${ }^{243}$

\footnotetext{
${ }^{240}$ Sylvere Lotringer, Overexposed, Perverting Perversions, Semiotext(e), Los Angeles 2007, str. 13 - 31

241 Ibid. str. 16 - 20

242 Ibid. str. $15-17$.

243 Ibid. str. 16, prijev.a.
} 
Sam naslov djela „Pervertiranje perverzije“ implicira da devijantnost prestaje postojati kad se znanost služi jednakim metodama - medicina i sama postaje perverzijom inicirajući kontroverzne diskurse koji osvještavaju perverziju.

„Devijacija sama je postala lijek“,on zaključuje i ,jednom odobrena, devijacija gubi svoje značenje“244 jer i sama riječ znači „okrenuti““,,izokrenuti““ i time Lotringer pokazuje da je medicina kao znanost izlaganjem i nametanjem perverzija nastojala stvoriti društvo seksa, kako je to Foucault formulirao, a time i ukinula originalni pojam perverzije.

Lotringer se referira i na suvremene psihologe Reichove struje koji „orgazam smatraju moralnom dužnošću, kategoričkim imperativom i neotuđivim pravom upisanim u našu biološku konstituciju“"245, konstatirajući da je seks je sve dalje od represije, što je očita poveznica s Foucaultovim tezama o poticanju bezbrojnih diskursa o seksu kao centru suvremene znanosti o subjektu i života $\operatorname{samog}^{246}$.

Od izrazite je važnosti referenca na Foucaulta i problematiku moralnosti u drugome djelu

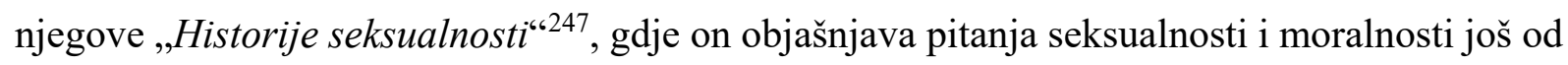
vremena Antike i uspoređuje ga s današnjim razumijevanjem etike seksualnosti.

On pokušava odgovoriti na složeno pitanje o moralnosti samoj i o moralnosti unutar seksualnosti, karakterizirajući je kao „skup vrijednosti i pravila djelovanja preporučenih pojedincima neposrednim preskriptivnim agensima kao što su obitelj, obrazovne institucije, crkva itd. “, no „,moralnost se također odnosi i na realno ponašanje pojedinaca u odnosu na pravila $i$ vrijednosti" 248 i tu je vidljivo da deskriptivno ima prednost nad propisanim, zamišljenim ,moralnim kodom“.

Foucault naglašava da se „u proučavanju ovog aspekta moralnosti mora odlučiti kako se i s kojim marginama varijacija transgresije pojedinci ili grupe ponašaju u odnosu na preskriptivni sistem koji je eksplicitno ili implicitno operativan u njihovoj kulturi i kojega su više ili manje svjesni“ i , taj nivo fenomena možemo nazivati „,moralnost ponašanja“. 249

Svojim tezama Foucault ukazuje da norme i moralnost nikad nisu i ne mogu biti ozbiljivi i da ostaju uvijek samo na razini preskriptivnog, nikad realnog stanja.

\footnotetext{
244 Ibid, str. 17 prev.a.

245 Ibid, str. 37, prev.a.

${ }^{246}$ Michel Foucault, Znanje i moć, Globus, Zagreb, 1994

${ }^{247}$ Michel Foucault, History of Sexuality 2, The Care of the Self, Random House, New York, 1986.

248 Ibid. str. $39-40$

249 Ibid, str. $40-43$
} 
Budući da je predmet velikog dijela njegovog opusa upravo tumačenje seksualnosti $u$ historijskom kontekstu, bitno je razumijevanje njegovog određenja rođenja perverzije $u$ suvremenim diskursima filozofije, društvenih znanosti i medicine.

Djelo Jeana Baudrillarda s Lotringerovim opsežnim uvodom te intervjuom s Baudrillardom, „Forget Foucault“, prvi put objavljeno u Francuskoj 1977. godine pod nazivom „Oublier Foucault", promišlja i kritizira Foucaultove teze o seksualnosti, relacijama s vremenom i, najvažnije, društveno - produktivnim odnosima.

Lotringer, uvodeći u Foucaultovu misao, polazi od njegove filozofije politike i društva, da bi došao do njegovih osnovnih teza o seksualnosti, navodeći kao najvažniju njegovu elaboraciju da je ,, seks bio navika na koju svijest dugo vremena nije bila prilagođena “ i time ,, bitno različit od seksualnosti koja je bila fluidna konfiguracija mišljena da se spremno prilagodi raznim društvenim pritiscima i historijskim situacijama “. ${ }^{250}$

On podsjeća da je Foucault odbacio Freudovu i Reichovu „hipotezu o represiji“ pitajući se „do koje su mjere raznolike skupine seksualnosti bile preuzete seksom“ ${ }^{251}$ te je uvidio „upornu naredbu“ za izražavanjem seksa, zahtjev da ga svatko razotkrije do zadnjeg detalja ${ }^{252}$, što je bitno za promišljanje odnosa unutar i prema raznolikim, „specifičnim“ seksualnostima.

Kao primjer navest ću ,izlazak u javnost“ i okupljanja grupa raznih seksualnih oprijedjeljenja, posebice sadomazohističkog, što je posljednjih destljeća poprimilo velike razmjere, iz razloga da se demonstrira pravo na jednako valoriziranje svake seksualnosti i destigmatizaciju.

Lotringer napominje da dok je prema Foucaultovu modelu ,, socijalna difrakcija moći zamjenila transcedentnu moć “ i tu se nameće seksualno poticanje, za Baudrillarda „novi „plutajući“ status seksa ga postavlja na jednaku bazu kao kapital i kao posljedica, „oslobađanje“ seksa može značiti jedino njegovu eksterminaciju“. 253

On ističe da Baudrillard, ,postavlja pitanje nije li Foucault govorio tako dobro o moći samo zato jer je moć mrtva te da je izbjegavao koristiti pojam ,,̌̌elja“ zbog Lacanove konotacije ovisnosti želje o manjku, već ju je zamijenio „užitkom“ kao neutralnim, gotovo lišenim značenja"254 i tim bitnim smjernicama Lotringer uvodi u Baudrillardovo promišljanje Foucaultove misli te filozofije društva i seksualnosti.

\footnotetext{
250 Baudrillard, J, Lotringer, S, Forget Foucault, Semiotext(e), Los Angeles, 2007, str. 18, prev.a.

251 Ibid, str. 18, prijev.a.

252 Ibid, str. 18

253 Ibid. str. 19

254 Ibid. str. 19 - 20
} 
Baudrillard se prema Foucaultovoj filozofiji seksualnosti odnosio i afirmativno i kritički, preispitujući je i analizirajući sa svoje poststrukturalističke pozicije.

Na samome početku odaje velike pohvale Foucaultovom životnom djelu, karakterizirajući njegovu filozofiju kao savršenu, u pogledu razumijevanja i prikazivanja diskursa moći, posebice moći $u$ i nad tijelima i seksualnosti, da bi potom kritički elaborirao Foucaultov pristup moći i seksualnosti.

Baudrillard navodi na razmišljanje pitanjem, ,što ako nam je Foucault govorio tako dobro o seksualnosti samo zato što je njena forma, ta velika produkcija naše kulture, bila, kao ona moći, u procesu nestajanja? "255

On time dotiče Foucaultov socijalno - historijski pojam trajanja - privremenosti, nastavljajući da „seks, kao čovjek ili kao kategorija društvenog, može trajati samo neko vrijeme“ " te „što ako je efekt stvarnosti seksa počeo radikalno iščezavati, dajući prednost drugim simulakrama $i$ povlačeći za sobom velike referente želje, tijela i nesvjesnog“, budući da „Foucaultova hipoteza sama sugerira koliko je seks smrtan, prije ili kasnije“, dok ,psihoanaliza prividno inaugurira milenij seksa i želje, ona u određenom načinu zaustavlja seks $i$ želju“256.

Dotičnim formulacijama Baudrillard promišljeno ukazuje na cijeli niz faktora koje je potrebno razumjeti u pristupu Foucaultovoj filozofiji i filozofiji seksualnosti općenito jer napominje da Foucault ostaje unutar klasične semiurgije ${ }^{257}$ seksa i moći, čime želi kritički ukazati na upitnost Foucaultove teorije odnosa moći, seksa i seksualnosti. ${ }^{258}$

On konstatira da kod Foucaulta moć ,,pročešljava“ i prožima mjesto želje, ona je uvijek prisutna i na taj se način postavlja na mjesto koje želja ima kod Deleuzea i Lyotarda, koji su razvili drugačije shizoidne i libidinalne teorije zasnovane na želji kao beskonačnoj mreži, sustavu u kojem se zbivaju i seksualne neuroze i perverzije. ${ }^{259}$

Baudrillard kao „nedostajuću spiralu“ u Foucaultovoj filozofiji navodi svoj temeljni pojam simulacije i njegovu primjenu u seksualnosti, govoreći o hiperrealnosti seksa kao fenomenu paradoksa „oslobođene seksualnosti“ u kojoj pod krilaticom „sve je seksualnost“" seks kao takav zapravo nestaje, prelazi u područje simulacije, što je najbolje vidljivo u pornografiji. ${ }^{260}$

\footnotetext{
255 Ibid, str. $27-28$, prijev.a.

256 Ibid. str. $27-28$, prijev.a.

257 semiurgija - franc. semiurgie, termin stvoren 1970-ih u poststrukturalističkoj filozofiji - proizvodnja novih značenja putem stvaranja novih znakova i time proširavanje semiosfere

258 Jean Baudrillard, Sylvere Lotringer, Forget Foucault, Semiotext(e), Los Angeles, 2007, str. 33 - 35

259 Ibid. str. 35

260 Ibid. str. 32
} 
Baudrillard se kritički postavlja spram „Foucaultove spirale“ moć/znanje/zadovoljstvo čime on ostaje unutar „klasične formule“ seksa i moći te ne priznaje termin ,želja“ već umjesto njega samo „Zadovoljstvo“261, smatrajući da Foucaultu nedostaje poveznica s brojnim novim značenjima i odnosima unutar seksualnosti da bi stigao na trag spirale seksualne simulacije. ${ }^{262}$ Materijalni je razlog tome što ,želja“ nosi psihoanalitičko, lacanovsko i strukturalističko značenje i stoga ne bi odgovarala Foucaultovu socijalno - političkom disciplinarnom modelu seksualnosti i moći jer Foucault zbog psihoanalitičke konotacije „izbjegava“ pojam „želje“, dosljedno inzistirajući na tumačenju seksualnosti kao odnosa moći terminima moći i seksa.

Sadomazohistička seksualnost se u velikoj mjeri može tumačiti u sferi simulakruma, odnosa moći i želje jer ona bitnim dijelom i odražava upravo simulacijskim transcendiranjem seksualnosti u vizuelno, imaginarno - hiperrealnost seksa koji više nije „seks“ u klasičnome smislu riječi, već posredovan i obilježen novim simboličkim modelima odnosa moći i novom semiotikom, elementarnima za njeno ostvarenje.

Međutim, Foucaultova paradigma seksualnosti i zadovoljstva, posebice produkcija seksa i discipline posredstvom moći te transparencija, nadzor i simbolična kazna u kontekstu seksualnosti su temeljni za određenje sadomazohističkih odnosa.

Bitna Baudrillardova interpretacija Foucaultove misli jest da je „seksualnost, kako o njoj čujemo i kako „ona govori“ i kako „id govori“, samo simulakrum koje je iskustvo odavno prevladalo, te da koherencija i transparencija homo sexualisa nikad nije imala više stvarnosti od one homo oeconomicusa “ ${ }^{263}$ te je psihičko, seksualno i „druga strana „, fantazije, psihička energija kao „halucinacija“ seksualne substance ustanovljena dugotrajnim procesom i u toj simulaciji on nalazi temelje psihoanalize. ${ }^{264}$

Ipak, on osnovnim smatra analizu odnosa zavođenja, produkcije i moći u poretku i diskursima o seksualnosti, i to mišlju da je zavođenje jače i od produkcije i od seksualnosti, dok je seksualno pak forma zavođenja ograničena na želju. ${ }^{265}$

Baudrillard stoga upućuje da proizvodnja nastoji ukinuti zavođenje da bi uspostavila svoj vladajući ekonomski poredak, a seks želi prevladati zavođenje da bi uspostavio svoj vladajući poredak želje te o ovim odnosima moći zaključuje:

\footnotetext{
261 lbid. str. $32-34$

262 Ibid. str. 33 - 35

263 Ibid. str. 43

264 Ibid. str. 43

265 Ibid. str. 54
} 
„Ako je horizont produkcije nestao, tada horizont govora, seksualnosti, želje može još uvijek nastaviti;uvijek će biti nešto za osloboditi, uživati, razmijeniti s drugima kroz riječi:to je stvarno, to je substancijalno, to je perspektivna vrijednost. To je moć. “266

Baudrillard naglašava upravo Foucaultovo „deskriptivistički preskriptivno““267, pluriperspektivističko, shvaćanje seksualnosti, vrstu diktirane panseksualnosti, kakvo je najbolje demonstrirano u pornografiji.

Osnova takve paradigme seksualnosti je upravo proizvodnja odnosno produkcija kojoj je zapravo značenje činjenje vidljivim, pokazivanje, prezentiranje i time transformacija poretka tajnosti i zavođenja u materijalistički poredak. ${ }^{268}$

Zavođenje je moment opozicije produkciji i Baudrillard naglašava ovu Foucaultovu interpretaciju kao društveni imperativ „neka sve bude proizvedeno, čitano, postane realno, vidljivo, označeno znakom efektivnosti, označeno odnosima sile, u konceptualne sisteme, neka sve bude rečeno, prikupljeno i registrirano : tako se seks pojavljuje u pornografiji, no to je više generalno produkt cijele naše kulture, čije je prirodno stanje „opscenost“ “269

Ideja pornografije važna je upravo da bi se prikazalo suvremeno mišljenje o poretku stvari unutar seksualnosti i njenom promišljanju, pri čemu je ono fundamentalno simulacija te ,luda opsesija realnim“, kao ono „opsceno“, točka u kojoj seksualnost u svome pravome smislu nestaje, granica seksualnosti koja je rezultat njene materijalizacije i instrumentalizacije. ${ }^{270}$

Razumljivo je tako da je zapadna kultura ona demonstracije, ispovijesti, neprestane produkcije i „prisiljene“ seksualnosti, bez zavođenja, već je ,seksualno postalo isključivo aktualizacija želje u momentu užitka “ 271

Ove su misli od neizmjerne važnosti za tematiku sadomazohističke seksualnosti jer upravo se u njenoj recepciji očitava konstantno promatranje, proučavanje i želja za novim spoznajam, foucaultovski rečeno, proizvodnjom znanja o njoj i to je ono „društvo u kojem ne postoji seks“, već sami isprepleteni diskursi, pozitivne i negativne evaluacije i kritike, društvo kontrole nad seksom i seksualnošću.

\footnotetext{
${ }^{266}$ Ibid. str. 54 prijev.a.

${ }^{267}$ Ovim sam naizgled kontradiktornim terminom željela objasniti Foucaultovu tendenciju opisivanja društveno propisanih normi i imperativa. Oba termina koje sam spojila su inače svojstvena kognitivnim znanostima, prvenstveno filozofije i lingvistike.

${ }^{268}$ Jean Baudrillard, Sylvere Lotringer, Forget Foucault, Semiotext(e) 2007, str. 37 - 38

${ }^{269}$ Ibid. str. 37, prijev.a.

${ }^{270}$ Ibid. str. 38

${ }^{271}$ Ibid. str. 39, prijev.a.
} 
Baudrillardova konstatacija o karakteristikama naše kulture je stoga od velike važnosti kod pristupa seksualnosti, posebice onoj „drugačijoj“ od „ustaljene“, jer kad se iz perspektive promatrača sagledava način na koji se društvo odnosi prema seksualnostima, jasno je da ih ono istovremeno odmjerava, preispituje te istovremeno i stigmatizira i komercijalno propagira.

Kad razmatramo Foucaulta i Baudrillarda sa znanstvenog stajališta, očigledna je opozicija „disciplinarnog“ društva i istinskog društva seksualnih sloboda bez intervencija ustanova, politike, medicine i pojedinaca u sferu privatnog.

U našem „društvu seksa“ sve mora biti predmetom javne intervencije, izloženo „bezobzirnom voajerizmu“" političkih ustanova, društva u cjelini i pojedinaca samih, koje žele promatrati i time ,živjeti“ simulaciju tuđega života - naša se egzistencija pa tako i seksualnost pretvorila istovremeno u laboratorij i u groteskni reality show.

Upravo to Baudrillard primjećuje, konstatirajući da danas kulturom upravlja „seksualni imperativ“ koji nas usmjerava prema nesvjesnom, „,naturalizaciji želje vezane za nagone, no iznad svega za imaginarni poredak represije i oslobođenja“ i time psihoanalizi:

„,U današnje vrijeme nitko više ne kaže: „Imaš dušu, moraš je spasiti. “, već „Imaš seksualnu prirodu, moraš saznati kako je dobro koristiti. “

Ili „, Imaš nesvjesno i moraš naučiti kako ga osloboditi., „Imaš tijelo, moraš naučiti uživati u njemu. “, „,Imaš libido, moraš ga naučiti koristiti. “ etc. ${ }^{272}$

$\mathrm{Tu}$ „obavezu“ prema psihičkom i seksualnom on uspoređuje sa silom koja upravlja ekonomskom tržišnom vrijednošću, naglašavajući da pri takvom načinu materijalizacije seksualnog tijela bivaju svedena na formu kapitala i seksualnost je tada model vrijednosti i kapitala na razini tijela. ${ }^{273}$

Ovaj kontekst suvremene ,prisilne seksualizacije“ psihe i tijela u svrhe komercijalizacije psihoanalitičke prakse, promidžbe te naposljetku znanstvenog proučavanja može se veoma dobro shvatiti iz današnjeg odnosa društva u cjelini, medija te „popularnih znanosti““, seksualnost postaje predmet tržišta, promidžbe te popularne umjetnosti.

Međutim, navedeni citat bi se mogao i drugačije protumačiti - jednostavno tragom izlaženja seksualnosti u sferu javnosti, i medijskim diskursima i promoviranjem psihoanalitičkog pristupa po američkom modelu.

\footnotetext{
272 Ibid. str. 39, prijev. a.

273 Ibid. str. $39-40$
} 
Pripadnici svih seksualnosti i seksualnih orijentacija ovdje mogu naći pozitivan put za svoje društveno prihvaćanje i razumijevanje, kao i za psihoanalitički pristup svojim dvojbama vezanima za seksualni identitet ili preference.

S druge strane, važno je da svi pri promišljanju seksualnosti, oprezno i selektivno pristupaju informacijama koje svakodnevno primaju te da, slijedeći svoj razum i svoje želje, izgrađuju svoje znanje o brojnim seksualnostima, da bi što bolje upoznali vlastitu i svoje spoznaje tokom cijeloga života nadograđivali.

U Lotringerovu djelu nalazimo brojne teze veoma bliske Foucaultovim i Baudrillardovim, čak se može reći da dijele gotovo zajednički pogled na poziciju seksa i seksualnosti u društvu, naročito perverznog seksualnog ponašanja, njegovog uzroka, deskripcija i teoretskog tumačenja oprimjerenih empirijskim proučavanjem .

Perverzije su za njega prvenstveno samo nasilni, involuntarni činovi koji su ujedno i kriminalni, a time su devijanti ili kao ,pervertiti“ ili kao oni koji odstupaju od društvenih normi, silovatelji, pedofili i eksplicitni voajeri s fantazijama koje uključuju nasilje prema odabranom objektu. ${ }^{274}$ Međutim, govoreći o perverzijama općenito, on se referira na Foucaultovu tezu da je „,moderno društvo perverzno“", na što se već i Baudrillard referirao, te ističe svoju tezu da su devijanti, u ovom slučaju nenasilni, „maksimalisti želje u društvu koje smješta seks svugdje osim u seksualnost“, oni „,ne konzumiraju seks metaforički kao oni „normalni“, već „poduzimaju mjeru da iskuse život doslovno u seksualnim uvjetima, namećući svojim ponašanjem čisto seksualnu prirodu seksualnosti “. ${ }^{275}$

On zaključuje da nas seksualni devijanti poput zagonetke izazivaju da dešifriramo njihove opsesije i to postavlja kao svoje centralno pitanje i forma znanja koju je nastojao razotkriti svojom studijom. ${ }^{276}$

U pogledu Foucaultove izjave o „perverznom“ društvu i Baudrillardove ideje „opscenog“ on svoj pristup ingeniozno i vrlo inteligibilno rezimira:

"Overexposed" proučava generaliziranu opscenost kulture u kojoj živimo, gdje se sve, a ne samo seks, izlaže svjetlosti dana samo da bi brzo potonulo u potpuno indiferentnost. U tom pogledu, biheviorizam se pokazuje boljim vodičem nego što su to bile freudovske dubine. Barem

\footnotetext{
${ }^{274}$ Sylvere Lotringer, Overexposed, Perverting Perversions, Semiotext(e), Los Angeles 2007

275 Ibid. str. 52

276 Ibid. str. 53
} 
ne gaji iluzije o suvremenom čovjeku i tretira ga kao životinju, čistu i jednostavnu. Ostavljam čitatelju da prosudi daje li mu čak i ovo previše kredita. “277

Izlažući temelje svog proučavanja, polazi od same etimologije latinske riječi deviare zastranjivanje s pravoga puta, odstupanje od etabliranih društvenih normi i podsjeća nas na cijelu historiju ovog termina i perioda ,perverznih“ tendencija, od grčkih dionizija, preko Sadeove filozofije do LGTBQ subkultura te napominje je danas riječ devijacija eufemizam za nekadašnju osuđujuću riječ ,,perverzija“‘. ${ }^{278}$

Referirajući se na Freudovu tezu da su perverzne tendencije prisutne u svakome, ,pervertiti mogu biti smatrani , uspješnim neurotičarima “i prema Lacanu je ,perverzija negativna strana neuroze budući da uspijeva nadopuniti želje koje vrebaju na pragu inhibirane svijesti “. ${ }^{279}$

Time Lotringer želi ukazati da bi se svakoga od nas moglo opisati kao devijanta ili pervertita, no u pozitivnom smislu jer smo osvještavanjem i ostvarenjem svojim ,„perverzijama“ na putu prevladavanja inhibicija i liječenja neuroza.

On se osvrće i na Sadea, njegovo promicanje najperverznijeg i najvažnije, njegovo odbacivanje svakog pokušaja utemeljenja znanosti o seksualnosti, što se odmah može povezati s Foucaultovom elaboracijom zapadne scientie sexualis. ${ }^{280}$

Bitna konstatacija je da seksualnost ne može jednostavno biti racionalizirana jer je „,povezana s mračnim silama koje često eruptiraju iznad ičije kontrole “281, čime dolazi do Bataillea kao „perverznog mistika“ koji je ustanovio poveznicu erotizma, seksualnosti, ritualnog nasilja i smrti te antropološko - filozofski deskriptivno definirao transgresiju seksa i oslobođenog libida koji svoju granicu nalazi jedino u nagonu smrti. ${ }^{282}$

O Bataillevoj tezi da seksualnost ne bi mogla preživjeti bez žrtvenog nasilja, i samoj ideji uske povezanosti seksa i nasilja, Lotringer govori o primjeni tog načela u funkciji sadomazohizma, nazivajući ga ,ritualističkom formom socijalne terapije“283

On objašnjava da gospodar, podređujući svog roba erotističkom nasilju, obećaje mu više od zadovoljstva, oslobađa ga inhibicija koje ga sprečavaju od preuzimanja odgovornosti za vlastitu

\footnotetext{
277 Ibid. str. 31, prijev.a.

278 Ibid. str. $41-42$

279 Ibid. str. 43, prijev.a.

280 Ibid. str. 45

281 Ibid. str. 46, prijev.a.

282 Ibid. str. $45-46$.

283 Ibid. str. 46
} 
egzistenciju $^{284}$ i stoga je cilj sadomazohizma ponovno rođenje, a ne smrt u doslovnom bataillevskom smislu, kao što je i nasilje erotsko i simboličko, a ne „,̌isto“, životinjsko, kao kod devijanata ili pervertita.

Sadomazohizam je doživljen kao devijacija samo zbog svoje „neuobičajene“ seksualnosti, konfrontaciji nasilja i senzualnog, egzibiciji, umjesto egzibiciji seksa te na taj način prevladavanja društvenih normi kao uzroka neuroza.

Lotringer konstatira da mazohist odstupa od norme jer je pretjerano „normalan“ i moralan u smislu svoje predanosti gospodaru da jedino putem tog odnosa može ponovno uspostaviti sebe i sve svoje potrebe za prihvaćenošću obzirom da gospodara obožava kao boga i bezuvjetno mu je poslušan, ali gospodar je potpuno odgovoran za svoje postupke - u slučaju da pogrešno procijeni psihičke i fizičke granice submisivne osobe ili roba, njegova moć prestaje. ${ }^{285}$

Ovom konciznom i stručnom prikazu psihičke ravnoteže sadomazohizma i liječenja inhibicija predajom drugome s bezgraničnim povjerenjem Lotringer još dodaje da „to objašnjava zašto mazohista ima na tisuće, a istinskih sadista (kao distinkcija od psihopata) samo na desetke "286 On izričito napominje da sadomazohizam „,nastoji izbjeći Hegelovu dijalektiku gospodara i roba koja u ,stvarnom svijetu“ pervertira svu energiju u sumnjivim konfrontacijama“, jer je „,cilj sadomazohističkog ugovora osigurati da moć nikad nije u pitanju, submisivna se osoba ne natječe s gospodarem, već nastoji uz njegovu pomoć izazvati svoje granice i te se dvije različite konfiguracije preklapaju da bi svaka postigla svoju singularnost “. ${ }^{287}$

Dominantna osoba sadističke orijentacije ili gospodar tako može činiti jednake stvari na samo naizgled jednak način kao psihopat, silovatelj, a bit je upravo u dimenziji simulacije, kao npr. rape play te je poredak simulakruma temeljan za sadomazohističku praksu, kroz njega ona postaje stvarnost i zato je ta seksualnost smještena između Realnog i Imaginarnog i granica je uistinu veoma tanka.

Sve što se odvija unutar sadomazohističke „sesije“ je scenarij koji se odigrava konsenzualno, pa nekada čak i spontano, no uz prethodno utvrđene granice i maksimalno poštivanje želje druge osobe, pogotovo submisivne.

\footnotetext{
284 Ibid. str. 46

285 Ibid. str. 51

286 lbid. str $51-52$, prijev.a.

287 Ibid. str. 52, prijev.a.
} 
Dogovoreni scenariji su situacije veoma česte među osobama koje prakticiraju hard BDSM jer predstavljaju maksimalnu dominaciju i zahtijevaju ultimativnu poslušnost i zato se može zaključiti da model discipline i poredak simulakruma moraju u tome smislu biti povezani, tvoriti svojevrsnu harmoniju i ne bi trebali biti shvaćeni ni kao opreke niti u ontologijskoj suprotnosti. Sadomazohizam, kao fenomen već u svojoj biti sačinjen od dvije naizgledne suprotnosti, neophodno je proučavati kroz prizme i Foucaultovog i Baudrillardovog modela, a posebice kroz suvremene sociološke i psihoanalitičke teorije da bi ga se moglo obuhvatiti iz svih aspekata i dobiti najbolji filozofski prikaz ove seksualnosti.

Osnovno je polazište, eksplicitno izraženo kod svih postmodernih autora, ponajviše Lotringera, da je sadomazohizam potrebno konceptualizirati pozitivno, bez negativne konotacije perverzije, jer ona nastaje upravo pogrešnim razumijevanjem istoga, njegovim pervertiranjem.

Nakon ovih bitnih uvida u korelacije seksualnosti i perverzija, vidljivo je da kod svih navedenih autora ostaje otvoreno pitanje paradigme „normalne“ seksualnosti i one „devijantne“, shvaćene kao aberacije ili perverzije jer kad se zapitamo: „Što je zapravo „normalna“ seksualnost, a što „devijantna“? potrebno je usporediti razumijevanje tih pojmova kroz povijest sa suvremenima. Riječ „normalno“ zapravo je višesmislena, jer označava norme, koje su se mijenjale u svakom povijesnom razdoblju, a danas, kad je društvo bitno evoluiralo i odmaklo se i od postmodernog stanja ekspanzije znanja o kojem je J.F. Lyotard već krajem 70 - ih godina 20. stoljeća govorio, nalazimo se u situaciji da su norme uvelike varijabilne i kao takve, jedan skup pravila, koja potječu iz raznih razdoblja historije.

Paradigma „normalne seksualnosti“ stoga postaje paradoksalna, jer je određena i pojedinom društvenom sredinom i stoga kao univerzalna ne postoji.

„Normalno“ je shvaćeno kao zakon, no nikad nije i ne može biti jasno što ono označava i u tome je paradoks jedne zastarjele sintagme.

„Normalna“ i „devijantna“ seksualnost ili aberacija su arbitrarne konstrukcije koje se ne mogu definirati jer se odnose isključivo na subjektivno, a sve dosadašnje pokušaje njihovog univerzalnog shvaćanja bilo bi racionalno i potrebno svesti samo na sferu kriminaliteta, nanošenja štete i povrede drugome.

Nakon izloženih teza i obrazloženja, jasno je da više nema smisla postavljati pitanje što je to „,normalna“ seksualnost jer ta sintagma u filozofskom tumačenju nema značenja.

Ona se mogla i može još koristiti kad želimo preskriptivno prikazati prosječan seksualni život, prosječne osobe, statističke brojke, no kad želimo promišljati i tumačiti psihoseksualne fenomene njoj nema mjesta. 
Potrebno je naglasiti da je neophodno govoriti o historiji perverzije i suvremenom poimanju rođenja perverzije, seksualnosti koja mora biti vrednovana kao i svaka druga, no kvalitativno i substancijalno, socio - ontološki je unikatna u svojoj biti, svojoj transcendentnosti, kojom psihički, intelektualno i tjelesno nadilazi ostale seksualnosti, naročito „tradicionalnu“, seksualnost koja je seksualnost po sebi i ne prelazi granice seksualnih odnosa i uvriježenog pojma zadovoljstva.

U tom se smislu može zaključiti da je sadomazohistička seksualnost specifična transgresija, koju je potrebno realno i pozitivno razumjeti, što je i jedna od osnovnih misli ovog filozofskog promišljanja sadomazohizma jer sadomazohizam se nalazi i ozbiljava u posebnoj dimenziji, stranoj ostalim seksualnostima i uvod u tu sferu obilježen je primarno analizom perverzije.

Da bih potkrijepila i oprijemjerila ranije navedene temeljne teze znanosti o perverzijama $\mathrm{i}$ sadomazohizmu, prikazat ću misli i teorije suvremenih autora te predstaviti i mnoge manje poznate na našim prostorima, no veoma relevantne $u$ američkoj i europskoj filozofiji seksualnosti i psihoanalitičkoj praksi.

Kao relevantan primjer najšireg, općeg shvaćanja sadizma i mazohizma navodim Oxfordski rječnik u kojoj su prve definicije sadizma i mazohizma seksualne, dok ostale definicije tek slijede nakon kao sekundarne, mazohizam je tako primarno definiran kao ,praksa postizanja seksualnog zadovoljstva bivanjem fizičkim ozlijeđenim“288, a sadizam kao „potreba za ozljeđivanjem nekoga za postizanje seksualnog zadovoljstva“‘289

To je bitan pokazatelj da današnje društvo doživljava seksualnost sadizma i mazohizma, koja je veoma očito izražena u suvremenoj kulturi i znanosti.

No, realno, radi li se o seksualnosti kojoj je cilj sve ostalo osim reproduktivnog i koja odstupa od genitalnog kao ultimativnog, sve je perverzija, odnosno, perverzije zapravo ne postoje, osim kad se radi o fizičkom ili psihičkom povređivanju druge osobe kao što su silovanje, pedofilija ili voajeristička povreda privatnosti.

Perverzija jest, već po definiciji, etimološki, ono izokrenuto, izopačeno, naopako, pa ću se stoga držati Lotringerovih primjera perverzije, u kojima se radi o kliničkim slučajevima situacija teških zločina, povreda koje su predmet suvremene znanosti forenzičke psihijatrije.

Stoga ako se prihvati da je ono izopačeno, perverzno povreda fizičkog i psihičkog zdravlja te integriteta ličnosti druge osobe, jasno je da sadomazohizam u svojoj ispravnoj praksi nije i ne može biti perverzija, budući da više niti u medicini nije ako je konsenzualna praksa bez

\footnotetext{
288 Oxford Advanced Learner's Dictionary, Oxford University Press, London, 2011

289 lbid.
} 
nanošenja štete već joj je svrha užitak, a o perverziji se radi samo u slučaju bilo kakve prisile ili u slučaju osjećaja krivnje kod psihički nestabilnih osoba koje nisu svjesne svojih postupaka. Sadomazohizam, u svome pravome smislu, kada ga konsenzualno prakticiraju svjesne i zrele osobe koje se znaju odnositi prema svome tijelu i psihi i tijelu i psihi drugoga te koje su rođene s tim ustrojstvom psihe, koje ,po prirodi“ imaju tu sklonost ili su je razvile bilo već u najranijoj dobi, bilo da su je osvijestile kasnije, nakon faze latencije uzrokovane podsvjesnom supresijom čemu je razlog nametanje društvenih normi i „normalne“, „,neinventivne“ seksualnosti.

Sadomazohizam je bitan dio ličnosti, daleko više od same sklonosti i time kvaliteta esencije i egzistencije jer čini užitak, proizvodi jouissance i unutar dogovorenih želja i pravila, te je time neupitno zdrava i „normalna“ seksualnost koliko i ostale što će biti detaljno elaborirano.

Kao istinska kvaliteta i bitna odrednica ličnosti, izvan je medikalizacije u već navedenim uvjetima, a ne bi bila niti „kontra - ponašanje“, kako bi je Foucault ocrtao u društvenim okvirima diskursa moći ${ }^{290}$, niti puka simulacija, a struktura joj je suprotna strukturi neurozi, ako i samo ako uspije nadići sve inhibicije.

Može se stoga reći da je, Foucaultovim terminom, pozitivno produktivna ili, mojim riječima, bitno osjetilna do krajnjih granica psihe i tijela, sintestezija i interakcija misaonog i tjelesnog jer se inicira u mozgu, a potom slijede tjelesne senzacije kao reakcije tijela upravljanog specifičnim psihičkim podražajima.

Izložene misli bitno pripadaju psihologiji ove seksualnosti koja će biti prikazana i detaljnije suvremenim psihoanalitičkim teorijama.

290 Michel Foucault, Security, Teritory Population, str. 191 - 215 


\subsection{Baudrillard i zavođenje}

Poststrukturalističko tumačenje jouissancea i zavođenja, koju možemo interpretirati kao kulminaciju erotskog u seksualnosti, posebice sadomazohističkoj, nalazimo kod Jeana Baudrillarda u djelu „Seduction“ o seksualnoj ekonomiji, kognitivnim i tjelesnim procesima seksualnosti u kojem podrazumijeva načine na koji se seksualnost ozbiljava i doživljava.

Pokušamo li tumačiti sadomazohističku seksualnost putem Baudrillardove filozofije, stvari će biti veoma jasne jer upravo se on najviše približio njenoj logici a tu je presudna razmjena moći kao temeljni faktor uspostave i održavanja sadomazohističkog odnosa.

U njegovoj izvanrednoj studiji suvremenog društva temelj je postmoderno utemeljenje seksualnosti kao hiperrealne simulacije, što je od velike važnosti za razumijevanje raznih pozicija sadomazohističke psihologije i prakse i stoga je Baudrillardova filozofija iznimno dobro polazište za dekonstrukciju seksualnosti, i na svojstven eklatantan način i od velike važnosti za dekonstrukciju sadomazohizma.

On pojašnjava da objekt zadobiva vrijednost na četiri načina i to su funkcija, razmjena, simbolika i znak i upravo je time zastupljen - svojom funkcijom submisivne osobe, predajom moći dominantnoj osobi, simbolikom uloge podređene osobe i pripadajućim joj znakom.

Koncept hiperrealnost, kao najbolji primjer funkcioniranja suvremenog postmodernog društva, sadržava sve bitne elemente za tumačenje sadomazohističke seksualnosti i zato se njegova teorija u brojnim aspektima može primijeniti na tumačenje sadomazohističke seksualnosti jer Baudrillard je tim terminom objasnio stanje u kojem je nemoguća distinkcija svijesti između realiteta i simulacije ili fikcije i time simulacija postaje stvarnost, a granica nije razlučiva.

U BDSM odnosima i scenama, esencijalan je upravo taj „gubitak svijesti o realitetu“ koji je i cilj sadomazohističkog odnosa, no postaje i cilj svojevrsne egzistencije, u smislu da se osobe u takvom odnosu oslobađaju realiteta da bi postigle zadovoljstvo i jouissance.

Baudrillard govori o „eklipsi seksa“, a time misli da je danas seksualnost hiperrealna i postoji samo kao simulacija te zbog toga on konstatira da je i želja samo želja simulacije, toliko je izvjesna da je hiperrealna, a istovremeno imaginarna i realna.

Zavođenje je inicijalna praksa, posebice važna za sadomazohističku seksualnost, upravo zbog svoje diskurzivne, performativne moći - ona sama zavodi kao želja te je zavođenje je jače od 
produkcije i seksualnosti te posjeduje određenu moć da prevlada sve poretke i vlada „simboličkim svemirom“.

Baudrillardove misli uvelike su povezane s Foucaultovom teorijom moći i seksualnosti, no on ide još mnogo dalje, svojom poststrukturalističkom i hiperrealističkom teorijom, proširujući moć zavođenje na sve sfere života.

Za njega su simulacija i zavođenje polazište kompletne dekonstrukcije seksualnosti, a time i sadomazohizma kao seksualne, ali i društveno - političke kategorije.

U tom kontekstu on govori o omniprezentnosti seksualnosti putem produkcije pornografije kao simulacije seksualnosti i o zavođenju kao temeljnoj uspostavi moći.

Sadomazohizam je ipak prvenstveno psihoseksualni fenomen, ali zavođenjem poprima oblik simulacije jer više nema granica niti zabrana - sve je dozvoljeno i seksualnost je jedini realitet. Baudrillard govori o slici u zrcalu, no radi bitnu distinkciju od Lacanovog stadija zrcala, u kojem se subjekt uspostavlja u Simboličkom, naglašavajući dominantno Imaginarno simulacije i nemogućnost razlikovanja Istog i Drugog, oni su jedno, što je formulirano već u naslovu poglavlja „I'll be Your Mirror“ - subjekt biva zaveden svojom slikom u zrcalu:

„Zavođenje je nemoguće reprezentirati.“, , „Ja ću biti tvoje ogledalo“ ne znači „Ja ću biti tvoja refleksija“ "već „Ja ću biti tvoja obmana.“

Zavesti jest umrijeti kao realitet i rekonstituirati se kao iluzija.

To jest biti uvučen vlastitom iluzijom i prijeći u začarani svijet.

To je moć zavodljive žene koja zamijenjuje sebe za svoju vlastitu želju i užitke u samoobmani u koje će drugi svojevremeno biti uhvaćeni.

Strategija zavođenja je ona obmane "291

Zavođenje i hiperrealnost su inicijalne prakse sadomazohističke seksualnosti jer se u njoj stvaraju prividi izazivanjem i negiranjem granicama realnosti.

Baudrillard propitkuje: „A što ako se sve, obratno nego što izgleda - ustvari odvija sukladno tajnom pravilu privida - ako se sve pokreće na osnovi zavođenja: trenutak zavođenja, napetost zavođenja, neizvjesnost zavođenja, zgoda zavođenja, zanos zavođenja, odmor zavođenja. "292

\footnotetext{
291 Jean Baudrillard, Seduction, New World Perspectives, New York, 1990, str. 72

${ }^{292}$ Jean Baudrillard, Simulacija i zbilja, Jesenski i Turk, 2001, Zagreb
} 
U njegovim djelima zaista nalazimo mnogo materijala za tumačenje sadomazohizma kao hiperrealne egzistencije, drugačije seksualnosti, posebice u smislu dekonstrukcije - stanju nakon orgije, gdje polazimo od kraja, kako on navodi u svojim memoarima „Cool Memories“: „,Tijekom snimanja porno filma, jedna od djevojaka, prolazi kroz sve raznolike činove bez promjene izraza lica. Njena indiferencija je zavodljiva. Usred pijanke, muškarac šapuće u ženino uho: Što radiš nakon orgije? Nije tajnovita zavodljiva figura zavođenja, već figura subjekta mučenog vlastitom željom svoje vlastite slike. "293

Baudrillard pokazuje da zavođenje i seksualnost djeluju u sferi hiperrealnosti - imamo samo sliku o njima, a zapravo nemamo vezu s realitetom te za gubitak veze s realitetom u S/M seksualnosti imaginacija i gluma imaju veliku ulogu, te on zaključuje:

„Bolje od onih žena koje doživljavaju orgazam su one koje daju dojam da ga doživljavaju, ali održavaju vrstu distance $i$ nevinosti ispod pretenzije užitka jer nas obavezuju ponudom silovanja“"294

U ovoj je misli vidljiva ironična spoznaja o imaginaciji, igri izvan realnosti koja postaje realna u našoj svijesti, što je eklatantan primjer S/M scene, igre i simulacije uloga.

Naravno, u ,real life“ ili ,full time“ $\mathrm{S} / \mathrm{M}$ - u, granice između imaginarnog, hiperrealnog i realnog gotovo i nema i upravo je po tome zasebna kategorija kojoj će biti posvećeno mnogo stranica jer govorimo li o ozbiljnom odnosu, hiperrealnost prelazi granicu istinske, stvarne realnosti, uloge postaju identiteti, a igra život.

Promišljajući brojne Baudrillardove teorije društva i seksualnosti, prikazat ću interpretaciju njegovih bitnih misli u kontekstu sadomazohističke seksualnosti, u djelima „Seduction“, „The Transparency of Evil, Essays on Extreme Phenomena “ i ,Simulacra and Simulation“.

Baudrillardova je teorija simulacije i hiperrealnosti velikim dijelom imanentna prikazu doživljaja i razumijevanja sadomazohističke seksualnosti te ću je putem njegove filozofije i terminologije interpretirati i kao specifičnu ,simulaciju“ i kao hiperrealnu.

Sadomazohistička seksualna praksa zasnovana je prvo na zavođenju, što sam već prikazala, da bi dobila formu simulacije postavljanjem i zauzimanjem uloga i pozicija koje, iako nisu „realne“, u danom kontekstu i dogovorenoj ili spontanoj situaciji postaju hiperrealne, svojim intenzitetom proživljavanja iskustva tjelesnih senzacija.

\footnotetext{
293 Jean Baudrillard, Cool Memories, 1980 - 1985., Verso, New York 1990 , str. 5, prijev.a.

294 Ibid. str. 5, prijev.a.
} 
Pojam simulacije u Baudrillardovoj misli obuhvaća više značenja, ovisno o kontekstu pojedinog djela i tematike, no njeno je izvorno značenje djelovanje prema poretku simulakruma koji nadilazi lingvistički koncept znaka i time uspostavlja i uključuje ostale temeljne konceptualizirane cjeline, prvenstveno hiperrealno i virtualno.

Simulacija je imaginacija i produkcija realnog i konačno hiperrealnog, na način da putem poretka simboličke vrijednosti simulakruma te ideje određene situacije stvaramo i doživljavamo hiperrealno, kao ultimativni modus egzistencije, koja slijedi nakon realnog, a vodi nas virtualnom, finalnom poretku u kojem danas živimo, a već ga je Baudrillard opisao izrazito napredno u kontekstu svoga vremena.

Njegovom idejom virtualne stvarnosti možemo interpretirati suvremene i društvene i seksualne odnose, koji su okarakterizirani zavođenjem u poredak simulakruma, imaginarnog realiteta, a potom uvode pojedince u sferu hiperrealnog, ,realiteta koji to nije“, upravo stoga što je suviše stvaran za našu percepciju:

„Kao što je sve postalo seksualno, sve može biti objekt želje : moć, znanje - sve je interpretirano u terminima fantazije, u terminima represije, a seksualna stereotipija vlada u svakom zadnjem uglu. Jednako tako, sada je sve estetizirano: seks u reklamama i pornografiji i svim vrstama aktivnosti u kojima se na njega konvencionalno referira.

Kad je sve seksualno, ništa više nije seksualno i seks gubi svoje odrednice.

Više ne postoji avantgarda, politika, seksualna ili umjetnička, koja utjelovljuje kapacitet za anticipaciju; a time ne postoji niti mogućnost bilo koje radikalne kritike - bilo u ime želje, revolucije ili oslobođenja formi. “ 295

Hiperrealno, koliko god se činio isprva drugo i oprečno od simulacije, zapravo je njen bitan konstitutivni dio, u smislu suviše naglašenog i ekscesno iživljenog realnog, što je eklatantno prikazano i izloženo u sadomazohističkom poretku kao izmjena moći putem simulirano nasilnih seksualnih praksi.

Na taj je način sadomazohistička seksualnost i u svojoj psihičkoj i u seksualnoj dimenziji konstituirana i zavođenjem te finalno istovremeno simulacijom i hiperrealnim, pri čemu je važno istaknuti Baudrillardovo promišljanje suvremenog poimanja tijela i seksualnosti:

„Jedno je vrijeme tijelo bilo metafora za dušu, potom je postalo metafora za seks.

\footnotetext{
295 Jean Baudrillard, The Transparency of Evil, Essays on Extreme Phenomena, Verso, New York, 1993, str. 9 -
} 10 
Danas više nije metafora ni za što uopće, samo lokus metastaze, veze nalik na stroj između svih njegovih procesa, beskrajnog programiranja lišenog svake simboličke organizacije ili glavne svrhe: tijeloje tako predano čistom promiskuitetu svog odnosa prema sebi - istom promiskuitetu koji karakterizira mreže i integrirane krugove.

To je aspekt opće tendencije prema transseksualnosti koja se proteže daleko iznad seksa“, obzirom da Baudrillard konstatira, ,, seks više nije lociran u seksu samom, već drugdje - svugdje drugdje zapravo. " 296

Za razliku od hiperrealnog za mase, koje je Baudrillard najviše promišlja u kontekstu suvremenog poretka, sadomazohistička seksualnost egzistira i gradi svoje odnose na hiperrealnom kao „ekstremno realnom“, naizgled „nezamislivom“ većini populacije te je stoga izvan dohvata razumijevanja i doživljaja većine u svome pravome smislu, izuzmemo li popularizirane romane i komercijalne filmske prikaze te je kao takva jedan od najboljih primjera iskonske, direktne veze simulacije i hiperrealnog u praksi.

Poveznicu simulacije i hiperrealnog u Baudrillardovoj misli, primijenjenu na sadomazohističku praksu možemo razumjeti kao istovremeno imaginarno uživljavanje i aktivno djelovanje na simboličkoj, simuliranoj platformi, zamišljanjem i uživljavanjem u zadanu ulogu ili poziciju te ponašanje i djelovanje isključivo prema pravilima ili scenariju, kao psihološku igru koja testira granice seksualnosti, kao cjeline tijela, psihe i sposobnosti imaginacije.

Sadomazohističku seksualnost doživljavamo kao hiperrealnu manifestaciju simulacijskog, te je bitno pokušati pojasniti poveznice i moguće granice pojmova hiperrealnog, simulacije, realiteta i virtualnog realiteta.

U kontekstu sadomazohističke seksualnosti, hiperrealno je fizičko, doživljeno fizičkim senzacijama, sadističkim i mazohističkim manifestacijama, ono je sirova seksualnost kao ozbiljenje simulacijske fantazije i želje:

„Seksualnom je tijelu sada dodijeljena svojevrsna umjetna sudbina.

Ta sudbina je transseksualnost - „transseksualno“ ne u anatomskom smislu, već radije u generalnom smislu transvetizma, o igranju komutabilnošću znakova spola - i igranju, $u$ suprotnosti s prijašnjim načinom igranja spolnim razlikama, o spolnoj indiferencij : o manjku razlikovanja između seksualnih polova, i o indiferenciji prema seksu kao užitku.

\footnotetext{
${ }^{296}$ Jean Baudrillard, The Transparency of Evil, Essays on Extreme Phenomena, Verso, Ney York, 1993, str. 7 8 , prijev.a.
} 
Seksualnost je poduprijeta užitkom, jouissanceom (letmotivom seksualnog oslobođenja); transesksualnost je poduprijeta artefaktom - bio to artefakt stvarne promjene spola ili artefakt transvestita koji igra morfološke ili gestikularne znakove spola.

Dovoljno je logično da je naš model seksualnosti trebao postati transseksualnost $i$ da je transseksualnost svuda postala lokus zavođenja. ““297

U sferi hiperrealnog sadomazohizma simulacijsko i hiperrealno zajedno čine aktivno sudjelovanje, S/M odnos i transgresivni seksualni čin koji je upravo prerealan i stoga ekstatičan u smislu transcendencije realnog do domene hiperealnog.

Koncept simulacije moramo razumjeti i kao fantaziju i njeno realno, performativno življenje, kao privid realnog, kad se referiramo na seksualnost primjerice dogovoreni „scenarij“ ili ,igru“ u sadomazohističkoj praksi, simulaciju i hiperrealno se povezuju fantazijom i uživljavanjem u želju i zadanu situaciju.

Virtualno kao „hipersimulacijsko“ predstavlja psihičku dimenziju, no prvenstveno kibernetičku komunikaciju i interakciju u kojoj se fantaziji može realizirati isključivo u misli i ideji, u virtualnom realitetu koji isključuje taktilnost i fizički kontakt.

Sadomazohistički odnos sačinjen je od neraskidive veze simulacije, hiperrealnog i virtualnog pri čemu simulacija kao uživljavanje u sadomazohistički odnos predstavlja transcendenciju realnog i time uvjetuje hiperrealno kao ultimativno u sadomazohizmu, prvenstveno fizički intenzivno da nadilazi svako poimanje realnog, a istovremeno i psihičko ustrojstvo uloge ili orijentacije čine $\mathrm{S} / \mathrm{M}$ scenu kao hiperrealnu.

Tumačenje sadomazohističke seksualnosti Baudillardovom teorijom simulakruma najbolje je prikazati poveznicom užitka kao hiperrealnog doživljaja boli uvjetovanog simuliranim nasiljem, pa i destrukcijom.

Seks, simulirano nasilje i hiperrealni doživljaj užitka Baudrillard je najbolje opisao interpretacijom romana „Crash", J.G. Ballarda u djelu „Simulations and Simulacra“, referirajući se na nasilnu i ekstremnu seksualnost u kojoj se seksualno uzbuđenje i konačno orgazam postižu promatranjem i sudjelovanjem u fatalnim automobilskim nesrećama, kao metaforu za sadizam i mazohizam, budući da protagonist romana uživa i u promatranju i u samoozlijeđivanju. ${ }^{298}$ :

\footnotetext{
297 Jean Baudrillard, The Transparency of Evil, Essays on Extreme Phenomena, Verso, New York, 1993, str. 20, prijev.a.

298 Jean Baudrillard, „Simulations and Simulacra“, University of Michigan Press, Michigan, 1995, str. 75 - 77
} 
„,U apokaliptičnoj verziji „Crasha“, tehnologija je smrtonosna dekonstrukcija tijela - ne više funkcionalnog medija, već ekstenzije smrti - raskomadanja i rezanja na komade, ne u pejorativnoj iluziji izgubljene unije subjekta, već u eksplozivnoj viziji tijela dostavljenoj „, simboličkim ranama“, tijela zbunjenog tehnologijom u svojoj nasilničkoj i nasilnoj dimenziji, u divljoj i kontinuiranoj operaciji koju nasije provodi : rezovi, izrezi, scarifikacije, ponori tijela, kojih su seksualne rane i tjelesni užici samo partikularni slučaj - tijelo bez organa ili užitka organa, potpuno podređeno ožiljku, rezanju, tehničkom ožiljku - ispod blistavog znaka seksualnosti bez referencijalnosti i bez granica. “299

Sadomazohizam kao simulirano nasilje možemo direktno komparirati s navedenom ekstremnom praksom, jer, premda u svojoj biti nije destruktivna s ciljem uništenja u svrhu užitka, već konstruktivna, u smislu da potiče uzbuđenje bez nanošenja ozbiljnih i opasnih povreda, ipak je utemeljena na radikalnim i rizičnim praksama.

Osnovna je razlika u pristanku dviju ili više involviranih strana, konsenzualnosti kao scenariju simulacije te „umjerenoj“ hiperrealnosti koja ne ostavlja i ne smije ostavljati fatalne posljedice niti po jednu osobu i time je simulirano nasilje u sadomazohističkoj praksi posve različito od Ballardove seksualne opsesije koju Baudrillard prikazuje, no ima i bitne slične ili jednake faktore, simulirano nasilje, hiperrealni užitak i virtualnu stvarnost:

„Disfunkcija više nije moguća u univerzumu nesreće stoga nije niti perverzija.

Nesreća, kao smrt, nije više u poretku neurotičnog, obuzdanog, rezidualnog ili transgresivnog, ona je poticatelj novog načina neperverznog užitka (suprotno samom autoru, koji uvodi u novu perverznu logiku, moramo odoljeti moralnom iskušenju čitanja „Crasha“ kao perverzije), strategijske organizacije života koji počinje smrću.

Smrt, rane, mutilacije nisu više metafore kastracije, upravo suprotno - čak niti suprotno. Samo fetišistička metafora je perverzna, zavođenje putem modela, putem nametnutog fetiša ili putem medija jezika. Ovdje su smrt i seks čitani na istoj razini kao tijelo, bez fantazama, bez metafora, bez rečenica, zavodljivi jer su ogoljeni od značenja, a tijela i tehnologija su kombinirani, zavedeni, zamršeni “. 300

U sadomazohističkoj seksualnosti užitak je pozicioniran kao ultimativni, hiperrealni doživljaj boli i simulacije ponižavanja uživljavanjem u dogovorenu ulogu, ozlijeđivanja kao destrukcije

\footnotetext{
299 Jean Baudrillard, Simulation and Simulacra, University of Michigan Press, Michigan, 1995, str. 74 - 75, prijev.a.

300 Jean Baudrillard, Simulation and Simulacra, University of Michigan Press, Michigan, 1995, str. 76 - 77
} 
te uključuje faktore iznenađenja kao ostvarenja najdubljih fantazija te voljno nadmašivanje vlastitih granica rizika, boli i sigurnosti.

Sadomazohizam možemo iz navedenih argumenata razumjeti kao dekonstrukciju „preskribirane“, „konzervativne“ seksualnosti, uživljavanjem u simulakrum, proživljavanjem hiperrealnog ,nasilja“ te ultimativnog vrhunca u maksimalnoj boli.

U radikalnom sadomazohizmu, tijelo je doživljeno kao „tijelo boli“, a seksualnost onkraj svog izvornog značenja već označava simulacijsku brutalnost, „seksualni odnos“ kao užitak u hiperrealnom nasilju.

Tijelo kao tijelo boli te seksualnost tijela u ekstremnim praksama boli osnovna su obilježja sadomazohističke seksualnosti kao svojevrsne perverzije seksualnosti u boli koja je svojim bitnim karakteristikama hiperrealna seksualnost, a Baudrillardov je fokus elaboracija tijela i nasilja sredstvima moći tehnologije te razlikovanje sadomazohizma od tehnologijske prakse nasilja opisanog u ,Crashu“:

„Tehnologija nikad nije zahvaćena osim u nesreći, u nasilju učinjenom tehnologiji samoj $i$ nasilju učinjenom tijelu. Svaki šok, svaki udarac, svaki udar može se čitati u semiurgiji tijela ni u anatomiji niti fizilogiji, već semiurgiji kontuzija, ožiljaka, mutilacija, rana kojih je toliko mnogo da su se u tijelu otvorili novi seksualni organi.

Dovidenja „erogenim zonama“: sve postaje rupa koja se nudi refleksu ejakulacije.

Ali iznad svega, čitavo tijelo postaje znak koji se nudi razmjeni tjelesnih znakova.

Tijelo i tehnologija međusobno razlažu difrakcijom svoje zavedene znakove kao karnalnu apstrakciju, bez afekta, bez psihologije, želje, libida ili nagona smrti.

Naravno, smrt je implicirana u neograničenom istraživanju mogućeg nasilja učinjenom tijelu, ali to nikada nije, kao u sadizmu i mazohizmu, s izrazom i perverznim ciljem nasilja, distorzije značenja i seksa. “301

Dekonstrukcija seksualnosti najbolje je opisana analizom pornografije u „Transparency of Evil“, putem korelacija hiperrealnog i virtualnog pri čemu je hiperrealno je iznad i onkraj realnog te prethodi virtualnom kao krajnjem poretku stereo - porno produkcije seksualnosti ${ }^{302}$

\footnotetext{
301 Ibid, str. 75 - 76, prijev.a.

302 Jean Baudrillard, Seduction, New world Perspectives, New York, 1990, str. 28 - 31
} 
Pornografija je bitna simulacija seksualnosti, no istovremeno hiperrealna seksualnost, hiperrealnost zadovoljenja suvremenog društva u kojem seksualnost više nije seks, već simulirana hiperprodukcija virtualne seksualnosti.

Taktilna i senzualna seksualna zadovoljenja zamijenjena su vizualnim putem slika, snimaka, virtualno putem imaginacije zamjenjuje realno.

Hiperrealnost i vezu seksualnosti i pornografije Baudrillard promišlja naglašavajući da „pornografija dodaje dimenziju prostoru seksa, čini seks realnijim od realnog - i to doprinosi njegovom odsutstvu zavođenja “ i stoga:

„Nema potrebe tražiti fantazije koje proganjaju pornografiju (fetišizam, perverzije, istinske scene itd.) jer one su ogoljene ekscesom ,,realnosti“.

Opscenost sama gori i konzumira svoj objekt. Iz blizine se vidi ono što se nikad prije nije vidjelo: nitko nikad nije video nečije genitalije iz te blizine, niti po tom pitanju, iz tako generalne perspective. Sve je to previse istinito, preblizu da bi bilo istinito.

To je ono fascinantno, taj eksces realnosti, ta hiperrealnost stvari.

Jedina fantazija je pornografija ako fantazija postoji, i tada to nije fantazija seksa već realnosti i njenog absorbcije u nešto drugo od realnog, u hiperrealno.

Pornografski voajerizam nije seksualni voajerizam, već voajerizam reprezentacije $i$ njena gubitka, vrtoglavice stvorene gubitkom scene i prekidom opscenog.

Konsekventno anatomskom povećanju slike, dimenzija realnog je ukinuta, udaljenost implicirana pogledom daje prednost trenutnoj reprezentaciji, reprezentaciji seksa u svom čistom stanju, ogoljenom ne samo od svakog zavođenja, već i od potencijalnosti vlastite slike.

Seks tako blizu da se spaja s vlastitom reprezentacijom : kraj perspektivnog prostora, $i$ stoga, kraj imaginarnog i fantazije - kraj scene, kraj iluzije. “303

Zavođenje kao polazišna točka seksualnosti općenito, a posebice sadomazohističke, možemo interpretirati odnosom sadizma, mazohizma i voajerizma, kao sveobuhvatne pornografije, gledanja, promatranja, ekspozicije, egzibicionizma i voajerizma u svrhu uzbuđenja, no i cilja seksualnog zadovoljstva.

Pornografija je simulacija seksualnosti koja je svoju najveću važnost poprimila upravo u simuliranju, „glumljenju“, sadomazohističkih praksi, a posebice njihovom gledanošću, gledanjem s pozicije pasivnog promatrača s osjećajem aktivnog subjekta, „življenjem“ virtualne stvarnosti na ekranu egzaltacijom osjetila doživljajem hiperrealnosti seksualnosti.

${ }^{303}$ Jean Baudrillard, „Seduction“, New World Perpectives, 1990, str. 28 - 29, prije.a. 
Simulacija seksualnosti postaje na taj način hiperrealnost seksualnosti i zadovoljenja, jer pojedinci simulacijskim vizualnim podražajima doživljaju prakse koje u realnom možda nikad ne bi mogli ili željeli provesti, dok virtualna atmosfera, stvorena poretkom simulakruma, proizvodi njihovu željenu seksualnu realnost kao moguću, ostvarivu i ostvarenu hiperrealnost. Perspektivom suvremenog društva računalne tehnologije postavlja se problematika istovremenog potpunog otuđenja od vlastite osobe i od drugih te se pornografija prikazuje kao ,jedina fantazija“ postaje ,residuum“ pojedinaca od realnog.

Pornografija je hiperrealnost društva u kojem seksualnost više nije seks, već simulirana hiperprodukcija virtualne seksualnosti, a i „realna“ seksualnost postaje hiperrealna stvaranjem većih želja, hiperrealnih ekstremnih seksualnih praksi, što se prvenstveno odnosi na depikcije sadomazohističke seksualnosti - od umjetničkih filmova i performansa do pornografije je najdostupnije simulacijsko zadovoljenje.

Pornografija i voajerizam, prema Baudrillardovom tumačenju, nekad imaju svoje uporište u sferi erotike i seksualnosti i tada ih možemo smatrati transcendentnom hiperrealnošću, no kad su u službi konzumerizma i komercijalizacije sadomazohističke seksualnosti putem, govorimo o masovnoj kulturi koja može biti samo jednostavna, potrošna simulacija i ništa više od toga.

Internetska tehnologija, od društvenih mreža do raznih foruma, mogu biti i prilika osobama S/M opredijeljenja za međusobno upoznavanje i pronalazak partnera, no i mogućnost za kreiranje virtualnih identiteta, koji su u suprotnosti s njihovim realnim identitetom, što dovodi u sukob realno i hiperrealno budući da brojne osobe na internetskim mrežama prikazuju život koje bi željele živjeti, a sebe osobama koje bi željele biti, no gdje je onda granica simulacije, hiperrealnog i virtualnog, a postoji li realno?

Upoznavanje strane osobe s internetskog prostora i upuštanje u sadomazohističke aktivnosti može biti adrenalinski doživljaj, doživljen slično sudaru automobila, zbog faktora uzbuđenja i rizika te istovremene moguće opasnosti i upravo ta dimenzija virtualnom svijetu interneta daje status hiperrealnog. 


\subsection{Zaključak}

\section{(Sado)mazohizam kao reziduum Imaginarnog i ontologijski fenomen}

Nakon detaljne filozofsko - psihološke elaboracije sadomazohizma, jasno je da je on kao psihoseksualna praksa pozicioniran, lacanovski rečeno, između Imaginarnog i Simboličkog, a cilj mu je psihičko i tjelesno oslobođenje.

BDSM je daleko više od samo ,jedne od mnogih seksualnosti“ jer se razvija iz najdubljeg, najsenzibilnijeg psihičkog prema tjelesnoj želji i manifestaciji, a pritom neophodna je bezgranična imaginativnost osobe.

Sadomazohizam svojom psihologijom, logikom i dinamikom nadilazi i koncept seksualne prakse jer psihički sadizam i mazohizam uvijek uvjetuju i prate tjelesni.

U socijalno - ontološkoj sferi, pozicija osoba koje prakticiraju BDSM u odnosu na društvo veoma je složena obzirom da je poznato da dotična seksualnost još uvijek nije do kraja društveno prihvaćena, osim u državama sjeverne i zapadne Europe, no neovisno o tome, odnos društva prema BDSM - u je vrlo složen iz dva razloga: prvo, kao i svako mišljenje i stav, individualan je i ne može ga se generalizirati i konačno, ljudi su nedovoljno, a često i izrazito pogrešno upućeni u značenje i praksu ove bitno kompleksne seksualnosti.

Govoriti o sadomazohizmu kao o jednoj od ,,alternativnih seksualnosti”, što je već desetljećima uvriježeno, potpuno je besmisleno i neutemeljeno, ne samo zbog materijalne ontološko logičke pogreške, već i stoga što je u multiplicitetu seksualnosti jedino ispravno sve vrijednosno promatrati kao jednake, a kvalitativno svaku protumačiti u ontološko - socijalnom smislu.

Sadomazohizam svojom psihologijom, logikom i dinamikom nadilazi i koncept seksualne prakse jer psihički sadizam i mazohizam uvijek prate tjelesni pri čemu je osnovno istovremeno ovladavanje tijelom i podređivanje tijela, svojevrsna umjetnost, igra tijelima koja se isprepliću u sferi Imaginarnog.

Esencija sadomazohizma jest, iz filozofskog tumačenja navedenih autora, dominacija i submisivnost tijela i psihe, a egzistencijalni aspekt sadomazohističke seksualnosti je kontrola nad drugim, kojoj prethodi prvenstveno kontrola nad sobom, i kod submisivnih i kod dominantnih osoba, naravno, u drugačijim psihološkim i ontološkim pozicijama ili uloga, ovisno o prirodi i dubini odnosa. 
Najbolji su primjeri urođeni seksualni sadizam i mazohizam, dominacija i submisivnost kao uvjet i jedina mogućnost seksualnog života, jedina praksa koja osobu može zadovoljiti i kojom se ličnost osobe može razviti i ostvariti.

Kod svih je teoretičara sadomazohistička seksualnost doživljena kao nešto drugačije, čak nadnaravno, jer su tijela kao takva u specifičnom odnosu gdje je seksualnost nešto daleko više od seksa, sasvim drugo od onoga što je pod tim pojmom generalno mišljeno.

Riječ je o stanju svijesti, karakterističnima za doživljaj užitka u podnošenju i zadavanju boli, od kojih su neki već spomenuti, poput „sub/top spacea“, jer radi se o hipersenzibilnim osobama s lučenjem endorfina isključivo prilikom podražaja boli, u sadističkom ili mazohističkom obliku, ili oba istovremeno.

Referirajući se na Wilhelma Reicha, može se ustanoviti poveznica između njegove teorije energije koja rezultira orgazmom ${ }^{304} \mathrm{~s}$ endorfinskom energijom sadizma i mazohizma, potrebnom i neophodnom za orgazam supersenzualnih osoba kojima je bol u raznim oblicima i ulogama neophodna za orgazam.

Povezanost seksualnosti, orgazma i destrukcije veoma je jaka kod Bataillea, jer erotizam je aspekt unutrašnjeg života čovjeka, no čovjek konstantno traži izvanjski objekt koji odgovara unutrašnjosti želje te on nastavlja da kad se govori o erotizmu uopće, to unutrašnje iskustvo ne bi bilo moguće kad ne bi bila jasno definirana ravnoteža između zabrana i trangresija. ${ }^{305}$

Znanje o erotizmu zahtjeva osobno iskustvo zabrana i transgresija $i$ tu se dolazi do tabua $\mathrm{i}$ Bataille naglašava da upravo transgresija nadilazi tabu - zaustavlja ga ali ga ne potiskuje jer „, ako trangresija nije fundamentalna, tada žrtva i ljubavni čin nemaju ništa zajedničko “, ${ }^{306}$ on konstatira te ,ako je transgresija intencionalna, žrtva je namjerni čin“, čija je svrha smrt. ${ }^{307}$ Bataille formulira da je „Čin nasilja koji lišava stvorenje, tj. osobu njene partikularnosti $i$ stavlja je u bezgraničnu prirodu svetih stvari - intencionalni akt ,,

Primjer koji daje je muškarac koji žudi i želi penetrirati svoju žrtvu, odnosno ,ljubavnik lišava svoju ljubavnicu njenog identiteta “. 308

Njegova formulacija "seksualna plethora i smrt" označavaju krv i smrt simbolima erotizma i zato on uspoređuje simboliku i ikonografiju religije i erotike te naglašava sličnost ljubavnog čina i žrtvovanja.

\footnotetext{
${ }^{304}$ Wilhelm Reich, Funkcija orgazma, Mladost, Beograd, 1990

${ }^{305}$ Bataille, Eroticism, Marion Boyard Publishers, London, 2006

306 Ibid.

307 Ibid.

${ }^{308} \mathrm{lbid}$.
} 
Pritom navodi tjelesne manifestacije prilikom žrtvovanja i seksualnog čina - konvulzije i promjene $\mathrm{u}$ organima te s psihičke strane poništavanje ili gubljenje identiteta čime tjelesni nagoni nadjačavaju volju i tjelesnost je nastrojena protiv tradicionalnih zakona normi pristojnosti, a nasilje tako pripada tjelesnosti jer se vezom seksa i nasilja njime dolazi do fundamentalnog unutrašnjeg iskustva koje nadilazi tijelo i tjelesnost, uspoređeno s magijskim i religioznim iskustvom.

Foucault za razumijevanje cjelokupne problematike seksualnosti eksplicitno govori da je potrebno odrediti i razumjeti poredak moć - znanje - užitak, kojim se bavi diskurs o ljudskoj seksualnosti, dakle, analizirati sve faktore koji o njemu govore.

On napominje da je ,važno spoznati kroz koje diskurse moć dospijeva do najustrajnijih $i$ najindividualnijih ponašanja, kako zahvaća i kontrolira svakodnevni užitak-dakle polimorfne tehnike moći". ${ }^{309}$

Slijedeći Foucaulta u kontekstu sadomazohističke seksualnosti, svi negativni elementi represija i zabrane, odbacivanja, cenzure, poricanja nisu temeljni momenti povijesti seksualnosti, već su samo dijelovi s ograničenom ulogom u oblikovanju diskursa o seksualnosti, tehnike moći i volje za znanjem.

Oni pripadaju njegovoj hipotezi o represiji, dok tehnike moći koje djeluju na seks svojom ekspanzijom stvaraju polimorfne seksualnosti, a volja za znanjem se nije zaustavila pred tabuom već konstantno stvara znanost o seksualnosti, pozicionirajući seks u središte zahtjeva za znanjem putem analize društva i odnosa moći. ${ }^{310}$

Osnovno je razumjeti odnos seksualnost - tijelo - moć, te Foucault konstatira:

„,Mi smo danas u društvu ,,seksa“ “ili, bolje rečeno, usmjerenog ka ,,seksualnosti “: mehanizmi moći obraćaju se tijelu, životu. “311

Seks je tako središnja meta moći za upravljanje životom - ono sveto i zabranjeno, i predmet i meta moći i društvenih ciljeva, a iznad svega, on zaključuje, seks je visoka instanca, koja do stanovite mjere prožima naš život, a naše tijelo mu je osnovno uporište, vrijedan je smrti i prožet je nagonom smrti što se može povezati s psihoanaličkom teorijom i ranijim Bataillevim tezama.

Ovim se argumentima jasno može zaključiti da su tijelo i pojam tjelesnosti vječno upravljani seksualnošću samom ili diskursima kojima moć na njih djeluje.

Sadistička i mazohistička tjelesnost i seksualnost ne bi smjele biti shvaćene kao nagoni za

\footnotetext{
${ }^{309}$ Foucault, Znanje i moć, 1984, Globus, Zagreb

310 Ibid.

311 Ibid.
} 
destrukcijom ili autodestrukcijom, već kao težnja za užitkom i oslobođenjem tijela i psihe, što je uostalom i bit seksualnosti i slobodnog izbora, kao što je Foucault rezimirao:

„,Seksualnost je dio našeg ponašanja. Dio je naše svjetske slobode. Seksualnost je nešto što mi sami stvaramo - naša je vlastita kreacija i mnogo više od otkrića tajne strane naše želje. Moramo razumjeti da s našim željama, kroz naše želje, dolaze novi oblici veza, novi oblici ljubavi, novi oblici stvaranja. Seks nije fatalitet : on je mogućnost za kreativan život "312 Nastavit ću osvrtom na problematiku odnosa sadista i mazohista, o kojoj su govorili i koju su proučavali brojni autori, o kompatibilnosti, odnosno nekompatibilnosti međusobnog odnosa sadista i mazohista jer već je Deleuze govorio da sadisti i mazohisti nemaju apsolutno ništa zajedničko jer mazohisti pripadaju mazohističkome svijetu, a sadisti sadističkome svijetu.

U svojoj analizi Wande iz Masochove "Venere u krznu", ustanovio je da ona pripada sadističkom svijetu i tada Severin kao njen rob također pripada sadističkom svijetu, a jednako bi se moglo reći za komparacije Sadeovih Juliette i Justine.

Osoba koja je objekt, odnosno subjekt kao "sub - jectum", podređena sadistu, "žrtva sadista" pripada sadističkom svijetu i iz te perspektive nije mazohist, jer to ontološki ne može biti, bez obzira što prima bol, često i voli da joj se nanosi bol, uživa u boli, podložna je svim oblicima boli kao seksualni objekt sadista, i to etablira njenu poziciju u sadističkom svijetu.

Naravno, radi se o konsenzualnom mazohizmu, koji je i predmet ovoga rada i osoba koja voli biti izložena intenzivnoj boli jer u njoj nalazi seksualno zadovoljenje.

Prema definiciji, mazohist je osoba koja doživljava seksualni užitak u boli, te uživa u boli i fizički i psihički, međutim ako sadist i mazohist ne mogu ostvariti zajednički odnos jer pripadaju različitim svjetovima, i nemaju jednak ukus niti jednak način izražavanja seksualnosti, niti izražavanja misli, imaju potpuno različita psihička ustrojstva. Sadistična i mazohistična osoba predstavljaju stoga, prema teorijama poststrukturalističke perspektive, opoziciju kao međusobno ekskluzivni.

Mazohistična bi osoba tada trebala također mazohističnu osobu, ali nadređenu, dominantnu mazohističnu osobu koja će toj osobi nanositi bol, a možda će zauzvrat tražiti od submisivne osobe da preuzme dominantnu ulogu, jer radi se o izmjeni moći između dvaju mazohista.

${ }^{312}$ Foucault, Sex, Power and the Politics of Identity, Advocate, August, 1984, Ethics : Subjectivity and Truth, 1997 
To je Deleuzeva ideja razmjene moći između dvije mazohistične osobe, jedne submisivne, druge dominantne, koje pružaju zadovoljstvo jedno drugome, upravo jer se mogu međusobno razumjeti zbog jednake orijentacije, samo drugačijih uloga u mazohističkom kontekstu.

U sadističkom svijetu nalazimo sadista kao osobu koja uživa u nanošenju boli drugome, i samim time naizgled logično uživa u dominaciji, no psihički život nije tako jednostavan jer postoje $\mathrm{i}$ brojni sadisti koji nisu dominantni, već submisivni, Deleuze to najbolje elaborira, a od suvremenih autora Lynn Chancer,

Deleuze je za elaboraciju te razlike najrelevantniji i na njegovu u se teoriju razlike sadista $\mathrm{i}$ mazohista i na njega ću se stoga referirati, jer on je prvi u svom djelu "Coldness and Cruelty" ukazao na radikalno odvajanje mazohizma od sadizma, oni nikada ne mogu biti komplementarni, to su dva različita svijeta, dva načina razmišljanja i parovi, vrste osoba.

Unutar njih postoje podjele, kod mazohista, mazohističnih ličnosti, dominantni i submisivni, mazohisti koji aktivno i "agresivno" inzistiraju na vlastitom ponižavanju i mole za nanošenje boli, kao Masochov Severin i oni kojima je poslušnost i potpuna submisivnost jedina želja.

Kod sadista, podjele su slične jer postoje čak i submisivni sadisti koji nanose bol jer to od njih traži njihova dominantna osoba koja je dominantni sadist te voli i da se njoj nanosi bol - voli upravljati odnosom i ima izraženu dominantnu osobnost, i u privatnoj i seksualnoj sfreri, no i u životnoj i poslovnoj.

Mazohizam je ipak mnogo kompleksniji jer u mazohističkom svijetu, osoba može kao dominantni mazohist zahtijevati, naređivati da joj se nanosi bol, voli nekada i sama sebi nanositi bol kao želju kontrole nad sobom, koja joj je primarna i neophodna da bi bila sposobna uspostaviti kontrolu nad partnerom.

Ona prvenstveno inicira scenu, motivirajući partnera, naređuje partneru i točno artikulira i izgovara svoje želje, na koji način želi da je partner tretira, upravlja scenom - dominira i precizno izriče što točno želi da joj partner radi i time ga postavlja u podređen položaj, ostvarujući odnos dvaju mazohista, dominantnog i submisivnog, a u veoma bliskom odnosu dovoljna je samo implikacija.

U svakome dominantno - submisivnom, odnosu osobe su ili obje mazohisti ili obje sadisti, BDSM je odnos je u kojem je neophodno da su partneri kompatibilni, u istome svijetu i jednaki u esencijalnim odrednicama ličnosti i seksualnih preferenca. 
Podjelu ću još detaljnije razraditi, na koji se način odvija odnos dvaju sadista ili dvaju mazohista no pokušajmo zamisliti situaciju, je li ona uopće moguće i koliko dugotrajno, kad bismo imali odnos sadista i mazohista.

Na prvi pogled uvijek se činilo da su sadist i mazohist samorazumljiv par no ipak prema relevantnim psihološko - filozofskim teorijama, oni se međusobno negiraju budući da se radi s jedne strane o mazohističkoj, a s druge strane o sadističkoj logici, koje se uvelike razlikuje te stoga se postavlja pitanje na koji način bi onda mogli sadist i mazohist zajedno funkcionirati $u$ jednoj uniji, D/s odnosu koji je specifičan već u samoj svojoj orijentacijskoj odrednici.

Takav odnos može opstati u početku, kao baziran na suprotnim polovima koji se međusobno privlače, no trajao bi veoma kratko zbog fundamentalnih, esencijalnih razlika između sadista $i$ mazohista, na koje, inspirirana i Deleuzeovom no i Lacanovom teorijom, nastojim ukazati i osvijestiti, što zapravo znače sadistička i mazohistička orijentacija, a potom dominacija i submisivnost kao preference i sklonosti i u tome je osnovna razlika.

Osobe sa sadističkim psihičkim predispozicijama i one mazohističnih sklonosti koja imaju sasvim drugačiji način razmišljanja, a prevelike, štoviše, ekstremne razlike dovele bi do ekscesa kakve vidimo kod Sadea, a posebice je važno spomenuti djelo Pauline Reage, koje govori upravo o sukobu sadističke i mazohističke orijentacije.

U "Story of $O$ " u samome početku odnosi nisu posve jasni, no ubrzo shvaćamo da se ne radi o odnosu sadista i mazohista već je postavljen isprva odnos dvaju mazohista jer njen je ljubavnik, također esencijalno mazohist, želeći postati njen gospodar, odvodi u Roissy da bi je sadisti naučili disciplini i podređenosti, da bi kasnije O bila uvedena u sadistički svijet.

To je djelo veoma ambivalentno, jer O ipak, sagledamo li dubljom psihoanalizom, uvijek ostaje u mazohističkom svijetu, kao mazohistička ličnost, samo postaje dominantna, no ona nikada zapravo i ne ulazi u sadistički poredak.

Kod Sacher - Masocha imamo slučaj da protagonist kao mazohistička ličnost postaje od submisivne dominantna osoba i tu govorimo isključivo o mazohističkom svijetu, dok su u "Story of $O$ " ta dva svijeta čitavo vrijeme međusobno isprepletena i u konstantnom konfliktu s fatalnim, misterioznim ishodom ostavljenim interpretaciji čitatelja.

Ishod je naime, gubitak sebstva, podsvjesni gubitak identiteta, koji je prvo svjestan kao prihvaćanje novog identiteta u smislu discipline i temporalne izmjene ličnosti, no posljedice bivaju daleko ozbiljnije i složenije. 
"Story of $O$ " možemo veoma jasno i najbolje tumačiti Lacanovom teorijom kojom objet petit a u želji da dosegne svoj ideal, objet grande A, procesom identifikacije naizgled u svom zrcalu postaje A, no prividno, a psihičke odrednice postaju problematične jer identitet jednostavno iščezava - identitet postaje manjak.

Osvrnut ću se na osnovnu podjelu kategorija, orijentacija, preferenci i uloga sadizma i mazohizma, te dominacije i submisivnosti, unutar kojih postoje još brojne "role play" uloge, no one su varijabilne no ovaj je rad usredotočen na osnovne kategorijalne podjele, njihove dileme i kontradikcije budući da bez obzira na mijenjanje uloga, moramo biti jasni s podjelama orijentacija i uloga, prvo, sadist i mazohist kao orijentacije i ličnosti, a potom uloge ili preference, dominantan ili submisivan jer moramo znati bar približno, ako ne egzaktno, kad govorimo o sadističkome, a kad o mazohističkom svijetu.

U mazohističkom svijetu, uloge dominacije i submisivnosti nisu konstantne no imaju kompleksniju psihologiju upravo jer nemaju strogo definiranu logiku, mnogo više uranjaju u imaginarno umjesto deklarativno - deskriptivnog i upravo to je temelj deklarativne nepremostive razlike psihe i misli između sadista i mazohista.

U sadističkom kontekstu orijentacijske su uloge konstantne i racionalnije, premda su neki teoretičari izvorni sadizam suprotstavljali razumu i to nisu samo uloge već orijentacije, možemo ih nazvati i tradicionalno, karakterima ili orijentacijskim ulogama moramo tu biti veoma oprezni u samome pristupu diferencijaciji sadizma i mazohizma.

Odavno je prihvaćeno da je seksualno psihička struktura i seksualna orijentacija svake osobe biseksualna, pri čemu se kod većine heteroseksualna strana svjesno i aktivno manifestira dok homoseksualna ostaje nesvjesna ili latentna.

Uzrok tome je kulturoloroški, no i kod kulturološki slobodnih i neinhibiranih osoba, homoseksualnost i biseksualnost imaju svoje mjesto, ili kao njihova osnovna orijentacija, ili kao uvijek otvorene opcije zasnovane na ljudskoj prirodi.

U sadomazohističkoj seksualnosti, možemo konstatirati da gotovo svaka osoba ima i sadističku i mazohističku stranu, dominantne i submisivne elemente, no koja će od njih doći do izražaja i izboriti se za svoje mjesto u seksualnom životu pojedinca, ovisi o nizu faktora, no osnovni su motivacija i želja za istraživanjem i zadovoljenjem. 
Deleuze se referira na Freudovu tezu da ,sadistu nikad ne bi palo na pamet da nalazi užitak $u$ boli drugih da nije sam prvo prošao mazohističko iskustvo veze između boli i užitka "313 i ta teza ima svoje značenje obzirom da mnogi sadisti ili dominantne osobe u svom psihoseksualnom razvoju „eksperimentiraju“ prvo sa svojom mazohističkom i/ili submisivnom stranom, proživljavaju mazohističku poziciju ili submisivnu ulogu, od kojih nekih u njoj ostaju, dok drugi prelaze u sadistički svijet.

U suvremenoj psihoanalizi i filozofiji tijela i seksualnosti, koncepti dominacije i submisivnosti ne mora uopće biti komplementarno sa relacijama sadizma i mazohizma, oslanjamo li se na Deluzea i suvremene teoretičare sadomazohizma.

U analizi mazohizma, isključivo mazohistični partneri su u svome odnosu submisivna i dominantna osoba, kao što Deleuze ilustrira u opširnoj analizi Masochovog djela, argumentima da jedino mazohisti zbog jednakog načina doživljaja (sado)mazohističke prakse, mogu doživljavati jednake senzacije.

Mazohizam je fenomen psihe i tijela koji se može realizirati unutar svog specifičnog, naizgled separiranog svijeta, no stvaranjem odnosa moći, submisivnosti i dominacije, on ima svoj krucijalan moment inkluzije u sadistički svijet, kao i „dozvolu“ konekcije sadističkih osoba s mazohističkim, primarno iz razloga potpunog seksualnog zadovoljenja te ekspanzije horizonata sadomazohističke psihoseksualne prakse.

Sa stajališta psihoanalize, mazohizam i sadizam su uvijek u konstantnom dinamičkom odnosu budući da su međusobno uvjetovani te mazohistična osoba uvijek ima i izražene sadističke porive, nesvjesne i svjesne.

Freudova teza da je mazohizam invertirani sadizam prema sebi, no istovremeno i prema drugome može naći svoje opravdanje u partikularnim analizama osoba, no tradicionalna psihoanalitička teorija odavno je ili prevladana ili nadograđena u modernoj psihoanalizi i psihologiji raznovrsnim mogućnostima odnosa između mazohista i sadista u širokom spektru sadomazohističke seksualnosti.

Ukoliko postoji, obzirom na odnose moći, seksualnost, psihu i društvo, mazohizam za sebe, primaran kao seksualni užitak u boli i stoga mnoge osobe ostaju unutar „mazohističkog svijeta“, no često se događa i moment korelacije i ostvarenja unije sa sadističkim svijetom, kao ekspanziju i „revoluciju“ sebstva - vlastite psihe i tijela.

\footnotetext{
313 Ibid, str. 43, prijev.a.
} 
Bitno je razlikovati fiziološki uvjetovani ili psihofizički od psihičkog, psihoseksualnog mazohizma, premda nisu međusobno isključivi, već uvijek duboko povezani, jer paradigmatski odnosi - tijelo i um, psiha i tijelo, tijelo i drugi, sebstvo i društvo uvijek su polazište za sve teorije fenomena sadomazohizma.

Primarno fiziološki mazohizam je, s medicinski dokazano, urođen strukturom podražaja neuroreceptora koji su kod brojnih osoba izrazito osjetljivi na bol koja ih vodi užitku, te je time fizički mazohizam neupitno realan i znanstveno dokazan.

Psihički odnosno psihoseksualni mazohizam doživio je brojne interpretacije u nastojanjima da ga se objasni psihologijskim i sociologijskim tezama, kao produkt relacija i utjecaja psihe $\mathrm{i}$ društva kao temeljnih odrednica.

Od Freudove teze urođenog i primarnog sadizma, koji ostaje „sadizam prema sebi“ do psiholoških teorija nezadovoljstva i ,mržnje“ prema sebi kao rezultata disfunkcionalne obitelji ili okruženja, pokušaji da se mazohizam neadekvatno i pogrešno definira prisutni kroz čitavu povijest medicine i društvenih znanosti.

Bitno je podsjetiti da većina mazohističnih osoba, istovremeno i submisivnih, razvijaju svoju sadomazohističku seksualnost od užitka u mazohizmu, izloženosti i određenosti ekstremnim senzacijama boli i psihičkom ponižavanju u kontekstu scene, da bi kasnije razvili i eksponirali snažnu sklonost dominaciji i sadizmu.

Zaključak je, kao što većina suvremenih teoretičara i praktikanata sadomazohističke seksualnosti i govori iz vlastitog iskustva, da je primarni mazohizam i podređenost svojevrsna uvertira učenjem novog, jer da bi osoba znala dominirati i pružati užitak drugome nanošenjem boli, mora spoznati i doživjeti mazohističko iskustvo.

Psihoanaliza i socijalna filozofija tijela i seksualnosti na taj se način susreću u mišljenjima i tezama jer mazohizam je izuzetno kompleksan psihoseksualni fenomen kojemu je potreban multidisciplinarni pristup za formulaciju stručnog razumijevanja.

Razumijevanje mazohizma, kao iti jedne druge seksualnosti ili društvenog fenomena nikada ne može biti egzaktno, mora biti deskriptivno, tumačeno putem teorija no i istraživanja praktikanata, što je najbolji uvid u pitanjima seksualnosti.

U okviru teorija filozofije zapitat ćemo se može li mazohizam biti fenomen za sebe, jedinstven kao u Deleuzeovoj misli ili ipak usko povezan sa sadizmom ili čak njegov produkt kao u Freudovim tezama? 
Kao to sam već prikazala, mazohizam nije sasvim samostalan niti može biti izdvojen fenomen u Deleuzevom smislu, kad dosegne svoj optimalni stupanj razvoja, no još je manje uvjetovan sadizmom ili o njemu ovisan putem seksualne inverzije.

Mogli bismo se sada opravdano zapitati, obzirom na sve navedene teze, postoji li mazohizam kao takav uopće, ili taj termin samo označava koncept užitka u boli, koji zapravo i nema neko stabilno utemeljenje u psihičkoj strukturi, pa niti varijabilnom tjelesnom užitku koji mijenja svoje erogene zone i seksualne prakse.

Mišljenje koje osobno zastupam, referencama na Deleuzovu teoriju je da je mazohizam isprva, u svom radiksu samostalan i naizgled samodostatan, te da dva mazohista mogu imati odnos submisivne i dominantne osobe.

Sa sigurnošću možemo ustanoviti da već sama riječ „sadomazohizam“ upućuje na duboku povezanost dva naizgled psihički različita svijeta te da su mazohistične osobe, svojim psihičkim i tjelesnim ustrojstvom, željom za znanjem putem stjecanja iskustva i ekspanzijom svoje seksualnosti upućeni na domenu sadizma.

Ne postoji univerzalan odgovor o temeljnoj, realnoj egzistenciji mazohizma, samostalnosti i utemeljenosti iskonskog, „čistog“ mazohizma, on je predmet individualnog iskustva i afirmativnih teorija, paradoks i upitnost egzistencije istinskog, esencijalnog mazohizma $u$ odnosu na sadizam uvijek će ostati otvoreno pitanje. 


\section{SADIZAM I MAZOHIZAM U SUVREMENOM SOCIJALNOM KONTEKSTU SOCIO - FILOZOFSKE TEORIJE SADOMAZOHIZMA KAO PSIHOSEKSUALNOG I DRUŠTVENOG FENOMENA}

\subsection{Sadomazohistička seksualnost u kontinentalnoj filozofiji \\ Dinamika i odnosi moći sadomazohizma u relaciji s društvom}

Najistaknutiji i temeljni teoretičari socijalne filozofije pružili su nam detaljne elaboracije pozicija sadomazohističke seksualnosti i psihe individuuma u odnosu s društvom i njen status u odnosu na društveni poredak uvidima u bitne etablirane vrijednosti, i tradicionalne društveno ukorijenjene i subkulturne, seksološke i psihologijske, imanentne mnogobrojnim pojedincima i zajednicama BDSM orijentacije.

Njihovim teorijama će se uspostaviti razumijevanje međusobnog odnosa i pojedinaca unutar BDSM zajednica ili jednostavno privatnih odnosa te vrste, s naglaskom na odnose moći u dinamici sadomazohizma, no također njihov odnos s društvom, koje provodi svoje odnose moći implikacijom preskriptivnih pravila.

Psihičko ustrojstvo i seksualna orijentacija bitni su faktori u odredbi pozicije sadomazohistički orijentiranih osoba u društvu, putem kojih se pojmovima drugi $i$ drugačiji doživljavaju odrednice identiteta i stvaranja slike o BDSM praktikantima.

Kao i u svim ostalim opredjeljenjiima, primjerice, ukusu u glazbi, odijevanju, etičkim normama, političkoj orijentaciji, društvo je oduvijek zasnovano na oprekama „mi - oni“ i različitostima koji ga ustvari obogaćuju i unapređuju u pogledu znanja i razumijevanja diverziteta i ne bi smjele izazivati negativne kritike niti animozitete.

Diverziteti odražavaju otvorenost multikulturnosti i postkapitalističkom multiorijentacijskom društvu, koje bi danas moralo u svakoj demokratskoj državi biti samorazumljivo budući da je izlazak iz konzervativno - kapitalističkog okvira u javnom prostoru prisutan već čitavo jedno stoljeće i ta je promjena, od suptilne, postala radikalnom sredinom 20. stoljeće, obuhvativši društvo u svome totalitetu.

U suvremenom je društvu potrebno razvijati znanja za, ne samo toleranciju, već integraciju raznolikosti u pogledu seksualnosti kao univerzalno ispravnu konceptualizaciju seksualnosti, a ta su znanja i razvijanje svijesti u početku bile izražene prvo u umjetnosti, no kasnije, posebice 
u današnje vrijeme, svoju su realizaciju dobile u čitavom društveno - državnoj sferi, od odgoja i obrazovanja, javnih i privatnih društvenih odnosa do pravosuđa i politike.

Referirat ću se stoga na relevantne teze Herberta Marcusea iz njegovog vjerojatno najvažnijeg djela „Eros $i$ civilizacija, jer svaka društvena misao i ideološka praksa, društveno uređenje i djelovanje neodvojivo su povezani sa seksualnošću.

Promišljajući BDSM kao društveni fenomen, možemo ga razumjeti i tumačiti kao dekonstrukciju Freudove „edipovske“ psihoanalize kao paradigme teorije društva i seksualnosti, koju su predstavili Gilles Deleuze i Felix Guattari, i u tome kontekstu kao svojevrsni manifest i čin dekonstrukcije seksualnosti same.

Istovremeno se odvija i dekonstrukcija koncepta i prakse sadomazohizma, paralelno sa svim ostalim društvenim promjenama koje pobuđuju psihičke promjene unutar svijesti pojedinaca te preokret ustrojstva racionalnog i iracionalnog djelovanja, psihe, svjesnog i nesvjesnog, osvještavanje i racionalizaciju seksualnosti.

To „seksualno oslobođenje“ manifestira se slobodom za izražavanjem i ostvarivanjem vlastitih želja, njihovom izlasku iz nesvjesnog, čime sloboda seksualnosti i seksualnih praksi zadobiva status odrednice identiteta pojedinca i njegovog temeljnog prava.

Izjednačavanje preferenca i želja s ljudskim pravima svojstveno je kraju 20. stoljeća kao radikalan preokret u ljudskoj misli i socijalnoj praksi te se svi društveni i seksualni fenomeni sve snažnije razvijaju vođeni novom logikom dekonstrukcije čime napreduju svojem ultimativnom ostvarenju.

Fundament „nove misli“ je razumijevanje i analiza pojedinca i partikularnih skupina, sve većim odmakom od kolektivnih društvenih ideologija, s naglaskom na autonomiji pojedinca za i od društva, koje više kao takvo nije baza, već nadogradnja pojedinačnih osoba i praksi.

Nukleus „,novog društva“ je, možemo zaključiti, pojedinac i njegovo ponašanje, a seksualnost, kao jedna od bitnih odrednica pojedinca i skupina, poprima, novom semantikom, značenje izraza, stava i realizacije individuuma kao označitelja, a njegovog ponašanja i psihoseksualnih karakteristika kao označenog.

Za uvod u poziciju psihe i seksualnosti individuuma neophodno je uzeti u obzir društvene čimbenike i sagledati relaciju psiha - seksualnost - društvo, bolje rečeno, na koji način životni stil i seksualnost pojedinca utječu na njegovu poziciju u društvu. 
Pritom ću se osvrnuti na Marcuseove bitne teze, u djelu „Eros i civilizacija“ koje obuhvaća brojne relevantne ideje o utjecaju društva na seksualnost, prije svega shvaćanju odnosa suvremenog društva prema seksualnim praksama i pojedincu. ${ }^{314}$

U kojoj smo vrsti odnosa s društvom ukoliko imamo određene preference ili prakticiramo „drugačije“ i životne i seksualne prakse?

Marcuseova je osnovna teza da nas kapitalističko, konzumerističko društvo nastoji učiniti međusobno što sličnijima te nam nametnuti nam obrazac života koji najbolje odgovara potrebama konstantnog rada i produkcije, a s njime i stvorene potrebe, te je danas kad je sve, pa tako i „alternativni lifestyle“ roba i business, veoma teško razlučiti što je zapravo naše navlastito a što nam je kulturološki nametnuto u svrhu potrošnje i kontrolirane zabave.

Marcuse u „Erosu i civilizaciji“ objašnjava represivne civilizacijske mehanizme ograničavanja seksualnosti, od represivnih metoda do pokušaja deseksualizacije tijela u korist rada, pa sve do „prisilne desublimacije“, kojoj je svrha kontrola i znanje o seksualnosti pojedinaca, što ima određene poveznice s Foucaultovom filozofijom, no Marcuseova je teorija prvenstveno interpretacija psihoanalize u društveno - seksualnom kontekstu.

Odnos pojedinac - društvo - seksualnost Marcuse tumači putem načela užitka i (ne)mogućnosti njegova ostvarenja u kapitalističkom društvu svoga vremena, pri čemu primijećujemo da današnja situacija u svom načelu i praksi nije bitno drugačija, obzirom da je jedna od temeljnih manifestacija postkapitalizma sveopća komercijalizacija seksualnih orijentacija i praksi, posebice one koja je i predmet moje studije.

Represija i ograničenje nagona uvjetovano je načelom zbiljnosti, koje Marcuse poistovjećuje s načelom održanja industrijskog društva, koje bi već prema Freudu, utjecajima neobuzdanih nagona, bilo uništeno.

Seksualnost je bitno društveno određena i Marcuse naglašava da se prvo odvija deseksualizacija tijela u korist rada te da „ograničenje nagona u vlasti načela zbiljnosti djeluje na životni nagon kao i na nagon smrti; ali se razvoj ovog drugog može u potpunosti razumjeti samo u svjetlu razvoja represivne organizacije spolnosti ${ }^{315 “}$ te su ,spolni nagoni izloženi silini načela zbiljnosti“, a „taj proces sadržava odvraćanje libida od vlastitog tijela u pravcu stranog objekta suprotnog spola, a zadovoljavanje sporednih nagona zabranjuje se kao perverzija, sublimira ili pretvara u dopunu prokreacijske spolnosti “. 316

\footnotetext{
${ }^{314}$ Herbert Marcuse, Eros i civilizacija, Naprijed, Zagreb, 1985.

315 Ibid str. 46

316 Ibid. str. $46-47$
} 
Marcuse ulazi u dublju analizu kao psihološko - filozofsku polemiku između tijela kao pored primarno čulnog, osjetilnog bitka i, s druge strane, društveno - ekonomskog subjekta te konstatira da je temeljni problem zapadne civilizacije „skretanje nagonske energije prouzrokovano održavanjem monogamno - patrijarhalne obitelji ili hijerarhijskom podjelom rada ili javnim nadzorom nad privatnom egzistencijom pojedinca“317_

Za razliku od Freuda, on to ne smatra neophodnim, niti pozitivnim, već nastoji promisliti alternativu kulturi koja „Zabranjuje“ užitak već tijelo i seksualnost čini radnim oruđem ili kontroliranom „zabavom“, koja se može uživati samo pod stalnim nadzorom, ne bi li se „zloupotrijebila“ raznim „devijacijama“.

Marcuse je u Freudovoj teoriji nalazio temeljno uporište razvoja vlastite filozofske hermeneutike, kao svojevrsne nadogradnje i unapređenja psihoanalitičke teorije seksualnosti i društva, no u mnogočemu je distanciran od Freudovih psiholoških „dogmatskih aksioma“, već tumači seksualnost postfreudovski i neomarksistički - filozofskim pristupom psihoanalizi.

Njegova se alternativa Freudu najbolje razumije njegovim postavljanjem mogućnosti nerepresivne civilizacije i tumačenjem desublimacije te daleko širom analizom seksualnosti u društvenom kontesktu.

Sadomazohistička je seksualnost posljednjih desetljeća poprimila upravo obilježja i status Marcuseove „prisilne desublimacije“ i njegove ideje nerepresivne sublimacije te promišljanje mogućnosti nerepresivne kulture svojstvene kapitalističkom društvu, ne samo njenim korištenjem u komercijalne svrhe marketinga, show businessa, zabave, porno te seks industrijom i masovnom prodajom S/M opreme, već i aparatom stjecanja socioloških i psiholoških ispitivanja seksualnih preferenci i aktivnosti pojedinaca.

Ukoliko se ta znanja stječu metodama ispitivanja kao predmet istraživanja u kojima su praktikanti BDSM - a svojevoljno participirali u znanstvene svrhe, govorimo o znanstvenom pristupu na kojem su utemeljene i brojne renomirane knjige i studije.

U slučejevima kad se „propaganda“ S/M kulture i seksualnosti putem popularne kulture koristi kao svojevrstan „nadzor“ i kontrola seksualnosti, riječ je o pravno i etički neprihvatljivom zadiranju u privatnost imanentne seksualnosti te nametanju preskribiranih normi BDSM - $\mathrm{u}$, što možemo okarakterizirati kao „represivnu desublimaciju“"318 kapitalističkog društva.

Pojam „represivne desublimacije“ možemo tumačiti putem Marcuseove političko - ekonomske kritike kapitalističkog poretka koja uvjetuje „represivnu organizaciju spolnosti““, koja isprva

\footnotetext{
317 Ibid, str. 44

${ }^{318}$ Herbert Marcuse, Čovjek jedne dimenzije, Naprijed, Zagreb, 1983, str. 67 - 75
} 
djeluje $\mathrm{u}$ formi deseksualizacije tijela te određene zabrane neprokreativnih seksualnih aktivnosti, proklamirajući ih perverzijama. ${ }^{319}$

Nadalje, kao što zamjećujemo u suvremenom društvu, „represivna desublimacija“ se manifestira na način da je seksualnost svedena na razinu robe, komoditeta, a pojedinci su samo konzumenti koji je „uživaju“ pod kontrolom društvenog aparata.

Najbolje poznati primjeri takve konzumerističke seksualnosti su, pored porno industrije prilagođene svim preferencama, svima dostupni striptiz klubovi, specijalizirane trgovine (sex shopovi), a ponajviše pristupačna legalna „niska“ i „elitna“ prostitucija u brojnim državama koja pruža sve seksualne usluge u obliku raznovrsnih klubova seks industrije, od kojih se posebice izdvajaju usluge profesionalne dominacije kao najunosnije.

BDSM klubove za članove također možemo promatrati kroz ovu prizmu, jer, koliko god bili zasnovani na zajednicama i zajedničkim interesima $\mathrm{S} / \mathrm{M}$ praktikanata, oni su „komercijalna“ mjesta seksualne slobode, prakticiranja i izmjenjivanja užitaka, no njihovi su članovi većinom osobe koje seksualnost doživljavaju na suptilan način, kao intimni užitak koji nam je navlastit, no slobodni smo ga prakticirati u skladu s vlastitim preferencama i dijeliti s kime želimo uz obvezatna pravila BDSM zajednica, prvenstveno konsenzualnosti.

BDSM seksualnost je tako veoma profitabilna „skupa roba“ za rafinirane konzumente, čime seksualnost gubi svoju apstraktnu bit i značenje, te postaje opredmećena, konceptualizirana i prakticirana kao predmet koji ima svoju namjenu i cijenu - užitak i zabavu za koju je potrebno izdvojiti određenu svotu novca i koja ima svoja fleksibilna, no ipak jasna pravila.

U privatnoj sferi, između intimnih, duboko povezanih partnera, BDSM je pod izvjesnim utjecajem medija i seks industrije pa i naizgled „neovisni“ pojedinci postaju podređeni kapitalističkoj društvenoj strukturi koja ovladava njihovom seksualnošću, što radikalno mijenja njihov bitak, identitet i odnos i BDSM praksa tada postaje preskriptivna, određena seks industrijom i time komercijalizirana, a odnos partnera prestaje biti seksualni odnos između osoba, već postaje odnos opredmećenih i popredmećeni entiteta, koji „materijalizacijom nematerijalnog“ zaboravljaju svoj istinski identitet i osobnost te podliježu paradigmatskom ponašanju liberalističkog društva.

Komercijalizirana seksualnost je već po sebi ontologijska materijalna pogreška, no i svojevrsna dijalektika društveno - seksualnih odnosa, u određenim momentima logički analogna kupovno - prodajnim ugovornim odnosima, i time je možemo komparirati s Marxovom društveno ekonomskom teorijom.

\footnotetext{
${ }^{319}$ Herbert Marcuse, Eros i civilizacija, Naprijed, Zagreb, 1985, str. 46 - 48
} 
Neizmjerno je važno pritom imati na umu, da je Marxova filozofija, kao jedna od temeljnih Marcuseovih utjecaja, bila i bitan predmet njegove kritike, te da je Marcuse razvio zasebnu postmarksističku teoriju primjerenu svojem vremenu i filozofskim strujama tadašnje kontinentalne filozofije od kojih su najvažniji prvenstveno psihoanaliza te socijalna filozofija frankfurtskog kruga i poststrukturalizma.

Marcuse o seksualnosti govori prvenstveno tumačenjem psihoanalize $u$ kontekstu konzumerizma te nam svojim tezama implicira određene zaključke.

Identitet pojedinca u modernom i suvremenom društvu konstruira se isključivo posredstvom materijalnih dobara, materijalno postaje personificirano, dok nematerijalno, tjelesno i duhovno opredmećenjem poprima status materijalnog.

Kad tijelo i seksualnost postaju „materijalna dobra“, „predmeti“ i „kontrolirana zabava“, tada shvaćamo pravo značenje industrijalizacije i materijalizacije seksualnosti, te Freudovog antagonizma slobodnog Erosa i represivnoj civilizaciji, koja, sputavajući ga, stvara destruktivne nagone i time ,zapada u razornu dijalektiku“320 seksa i tijela kao dotada transcedentne kategorije obzirom da:

„Ljudi ne žive svojim vlastitim životima, libido se skreće u smjeru društveno korisnih izvedbi $^{\text {‘321 }}$, a kontrola slobodnog vremena i seksualnosti je konstantna i omniprezentna, odnosno „pojedinac se ne smije ostaviti da bude sam“, da se njegov libido ne bi kojim slučajem odao željama i užicima, te društvo zahtijeva da ,slobodno vrijeme bude pasivna relaksacija $i$ rekreacija energije za rad $^{\text {‘322 }}$.

Centralna teza o seksualnosti Marcuseove misli jest da ona postala oblik društvene kontrole jer: „Koncept o kontroliranju desublimacije bi uključivao mogućnost simultanog otpuštanja potisnutog seksusa i agresivnosti. Prema Freudu bi jačanje seksualnosti (libido) nužno uključivalo slabljenje agresivnosti $i$ vice versa. No, ako bi društveno dozvoljeno i podržavano opuštanje libida bilo oslobođenje parcijalnog i lokaliziranog seksualiteta, ono bi bilo jednoznačno sa stvarnim potiskivanjem erotičke energije, pa bi ovakva desublimacija bila kompatibilna s rastom kako sublimiranih, tako i nesublimiranih formi agresivnosti.

Agresivnost je na djelu u cijelom suvremenom industrijskom društvu. “323

„Ego užitka“ ipak nalazi svoj residuum i pobunu u perverzijama te Marcuse pojašnjava da „u ime načela užitka, perverzije pokazuju duboko srodstvo s fantazijom“, koju Marcuse objašnjava

\footnotetext{
320 lbid, str. $47-49$

321 Ibid. str. 50

322 Ibid. str .52

323 Ibid, str. 85
} 
freudovski kao područje autonomije užitka i mašte i perverzije su stoga djelatnosti u kojima je seksualnost cilj sebi samoj, „pružaju „promesse de bonheure“ veće nego što je obećanje „,normalne seksualnosti“ kao,,manifestacije užitka kao fleurs du mal, simbol razorne istovjetnosti slobode i sreće “. 324

Govoreći o seksualnosti kao komoditetu posredstvom dostupnosti robnih sredstava za omniprezentnost seksualnosti i njenih manifestacija u svim društvenim odnosima, Marcuse promišlja i tumači u njegovo vrijeme novi fenomen izlaganja tijela i eksplicitnog izražavanja seksualnosti u javnome prostoru, u društvenim i radnim odnosima kao imanentnu desublimaciju i time razvija svoju misao o seksualnosti kao „masovnoj kulturi“‘

„Razvijena industrijska civilizacija operira s ovećim stupnjem seksualne slobode - ,operira “ $u$ tom smislu što ova postaje tržišna vrijednost i faktor društvenog ponašanja.

Tijelu je dozvoljeno da izloži svoja seksualna obilježja u svakodnevnom svijetu rada i radnim odnosima. To je jedno od vanrednih ostvarenja industrijske civilizacije. Ono je omogućeno reduciranjem teškog i prljavog fizičkog rada, dostupnošću jeftine, privlačne odjeće, kozmetike i fizičke higijene. " 325

Seksualnost je na taj način instrumentalizirana kao „društvena stabilnost“, no ona, svedena na tržišne odnose vrijednosti, gubi svoju esencijalnu erotsku dimenziju i time biva lišena svoje senzualne, transcendentalne biti i prirode.

Promišljajući seks kao tjelesno - psihički akt i represiju BDSM seksualnosti, uviđamo enormnu stigmatizaciju seksualnosti nametnutim društveno prihvatljivim obrascima ponašanja kojima je temelj neodobravanje tzv. „marginalnim“ i ,devijantnim“ seksualnim praksama iz razloga što su označene kao „društveno neproduktivne“ i time seksualnost postaje preskriptivna kategorija, preskribirana seksualnost koja putem kontrole određuje poredak moći i pozicije u društvu.

Seksualnost u društvu poretka moći s jedne strane i poredak moći u seksualnom odnosu postale su time dvije strane u međusobnom odnosu konstantnog diskontinuiteta,

konzervativno društvo koje provodi moć nad seksualnošću i privatnošću nasuprot sadomazohističke seksualnosti u kojoj su odnosi moći nerepresivni, a kontrola simbolička i konsenzualna.

To je konfliktna situacija represivne civilizacije kojoj je cilj i svrha kontrola seksualnosti i slobode pojedinaca, a kao svoja sredstva koristi represivnu sublimaciju i desublimaciju, no postoje li zaista trajno ozbiljiva alternativa?

\footnotetext{
324 Ibid, str.53 - 54

325 Herbert Marcuse, Čovjek jedne dimenzije, Naprijed, Zagreb, 1983, str. 82
} 
Marcuse zaključuje da ,libido prelazi neposredne erotogene zone - to je proces nerepresivne sublimacije.“, ali usprkos tome „mehanizirana okolina blokira takvo samotranscendiranje libida“ te "libido postaje manje „polimorfan“, manje sposoban za erotiziranje preko lokaliziranog seksualiteta, pa je ovaj intenziviran“ te se „tako umanjuje erotska, a intenzivira seksualna energija, tehnološka stvarnost limitira djelokrug sublimacije“. ${ }^{326}$

Marcuseova teorija ima i svoju drugu perspektivu, a ta je sublimacija fetišizirane seksualnosti u sferu privilegije, koja potom konačno postaje dostupna i širim krugovima pojedinaca $\mathrm{i}$ skupina, fetišiziranjem ljudskih odnosa i proizvoda:

„, Seksualno privlačne činovnice i prodavačice, muška ljepota pomoćnika direktora $i$ šefa odjela uvelike su podobne robe, a posjedovanje prikladne ljubavnice - nekad privilegija kraljeva, prinčeva i lordova - olakšava karijeru čak i manje istaknutih redova u zajednici biznisa “. 327

Sadomazohistička seksualnost kao psihološko - društveni fenomen i praksa može se u svojoj osnovi deskriptivno iščitati i elaborirati iz Marcuseove teorije seksualnosti.

Sadomazohizam je prvenstveno doživljen kao sublimacija seksualnosti, no također, u svojim ekstremnim praksama kao eklatantan primjer nerepresivne desublimacije i seksualnog oslobođenja koje je ključno za bitak i ostvarenje individuuma.

Pored nerepresivne desublimacije, Marcuseova teorija jasno implicira mogućnost seksualno ispunjavajuće sublimacije, koja bi uslijedila nakon prvo, imperativa industrijske sublimacije i potom kontrolirajuće i konzumentske desublimacije, koja seksualnost transformira putem popularne kulture u preskribiranu društvenu aktivnost i formu, bez seksualnosti same.

Sadomazohistička seksualnost je sublimacija time što nadilazi seksualnost per se te svojim psihičkim egzaltacijama i momentima te fizičkim senzacijama transcendira $u$ domenu umjetnosti, ona postaje umjetnost i time je esencijalno sublimna.

BDSM kao seksualnost i lifestyle postala je tako par excellence, premda je pretežito uvijek i bila, ,privilegija“ višeg društvenog sloja, pojedinaca i grupa višeg socijalnog i obrazovno kulturalnog statusa, s razvijenim smislom i ukusom za umjetnost i estetiku, što su odlike sublimirane seksualnosti i posredovana tim eksplicitnim uvjetima i karakteristikama ona transcendira u sublimnu dimenziju.

Prikazana teza je najbolji primjer nerepresivne sublimacije, no istovremeno i nerepresivne desublimacije, gdje one nisu postavljene kao međusobni kontrast niti u opoziciji već kao jedna cjelina, jedna alternativa, istinski slobodna seksualnost.

\footnotetext{
${ }^{326}$ Ibid, str. 81

327 lbid, str. 82
} 
U tom smislu možemo razumjeti Marcuseovo tumačenje Erosa, kao produktivne, nerepresivne, nenasilne sile odnosno nagona, koji se protivi svakoj represiji seksualnosti, bilo nametnutoj sublimaciji ili desublimaciji u korist industrijskog društva i zbog toga je njegova teorija, primijenjena na sadomazohističku seksualnost, vjerodostojna paradigma nerepresivnog društva i civilizacije, koja se neprestano razvija te postaje ozbiljiva mogućnost slobodne ljudske egzistencije.

BDSM seksualnost je još uvijek, u širem društvenom kontekstu, smatrana „devijantnom“ ili bar drugačijom te iz tog razloga društvo nad njom želi uspostaviti i zadržati određeni stupanj kontrole, kao što su nadzor pojedinaca u vidu raznih psiholoških, medicinskih i socioloških te seksoloških istraživanja, da bi je se „spoznalo“, steklo znanje o njoj u svrhu kontrole, što će biti prikazano kod Foucaulta.

Zakonske odredbe koje proizlaze iz tradicionalnih, konzervativnih društvenih normi, koje, iako nisu primjerene današnjem vremenu niti shvaćanju seksualnosti, ipak uspijevaju opstati u svojoj kontroli i primorati S/M praktikante da svoju orijentaciju i seksualnost smatraju stigmatiziranom i neprihvaćenom.

Takve represivne i diskriminatorne prakse nastoje i često uspijevaju „zabraniti“ užitak i slobodu seksualnog oprijedijeljenja i pretvoriti pojedince u radnike i konzumente kojima to „mora“ biti jedina svrha egzistencije, i uvelike u tome uspijevaju, introjiciranjem tzv. „društvene odgovornosti“, krinke malograđanskog morala, što ću prikazati u kasnijem osvrtu na Nietzscheovu misao.

Osnovna pretpostavka za mogućnost ozbiljenja nerepresivnog društva u domeni BDSM seksualnosti i svih ostale društvenih i seksualnih fenomena, praksi, i lifestyleova je društvo s minimalno nasilja i nasilnih tendencija ili destruktivnih nagona, što je, kao i Marxova teorija, „fantastična utopija“ koja izuzima temeljni ljudski faktor, primarni nagon za destrukcijom, što je najbolje tumačio Freud, kao i brojni politički filozofi poput Machiavellia i Hobbesa.

Slobodna će seksualnost uvijek ostati „,siva zona“ u kojoj je granica nasilja i užitka veoma tanka i do velike mjere nerazjašnjiva i nepojmljiva, a time granica između pristanka i prisile biva neprestano područje manipulacije tijelima i psihom.

Želimo li se Marcuseovom hermeneutikom približiti razumijevanju BDSM seksualnosti, njegovu filozofiju moramo shvatiti i kao refleksiju na društveno i stanje, no i kao pokušaj elaboracije residuuma, alternative kao slobode pojedinaca.

Represivno društvo potpuno pogrešno pristupa osobama BDSM orijentacija i stoga je potrebno postići pomirenje konzervativnog, industrijskog društva i nerepresivnih zajednica kao osobne privatne sfere slobode na slijedeći način. 
BDSM praktikanti, pojedinci koji prakticiraju sadomazohističke aktivnosti, bilo kao članovi scene, bilo zasebno u $D / s$ paru ili društvu, u trajnom BDSM odnosu, uklapaju se u Marcuseovu teoriju represivnog društva, prvo, time što su su svoj „dug“ heteroseksualno - patrijarhalnom, prokreativnom društvu ,ispunili““ time što su roditelji te jesu ili su bili u bračnom odnosu ili dugotrajnoj vezi s osobom suprotnog spola.

Naravno, i osobe u istospolnim vezama smatraju se „stabilnima“ po svojoj monogamnoj ili roditeljskoj preferenci, samom činjenicom da su „vezane“, dok su meta kritike jednodimenzionalnog društva konzervativnih svjetonazora ponajviše „slobodne“ osobe, koje nemaju sklonost monogamiji ili zaziru od iste, već žele isključivo osobnu i seksualnu slobodu. U BDSM - u također postoji ta tendencija, koja stremi partnerstvu dvaju osoba ili ekskluzivan Master/slave ili Dom/sub odnos, koji može povremeno ili konstantno uključivati i druge osobe, no samo s ciljem dodatnog užitka ili dokazivanja odanosti dominantnoj osobi, dok su temelj odnosa međusobna ozbiljna obaveza, predanost, a često i ugovor kao svojevrsna analogija bračnom ugovoru ili zajednici.

Druga relevantna premisa koja osobama BDSM sklonosti pridaje jednak status kao i ostalima jest činjenica da se bave društveno korisnim zanimanjima i profesijama te stoga njihovo slobodno vrijeme i privatnost mora biti slobodna od svake interferencije društva, a njihova seksualnost ne smije ni pod koju cijenu biti predmetom diskriminacije ili javnog interesa, što je zasad ostvareno samo u razvijenim društvima.

Osobe koje žive drugačije od tradicionalnih standarda, primjerice samci zaposleni kao freelanceri ili umjetnici, jednaki su jer svakom pojedincu mora biti zajamčena individualna sloboda i pravo na slobodan izbor te su time svi jednakopravni i u svome načinu života, zanimanju i seksualnoj orijentaciji budući da je sloboda temeljno ljudsko pravo.

Možemo stoga zaključiti da $u$ današnjem društvu naziremo to pomirenje represivnog $\mathrm{i}$ nerepresivnog, nadzora i kontrole sjedne, i oslobođenja, s druge strane.

Osobe koje prakticiraju bilo koju formu BDSM - a, po ostalim se odrednicama identiteta ne razlikuju bitno od ostalih, zaokupljeni su raznolikim konstruktivnim i kreativnim poslovima, raznih su obrazovanja, ukusa, stilova, imaju jednake životne dileme kao i ostatak populacije, a jedino što ih separira od ostalih i međusobno ujedinjuje je njihova specifična seksualnost i ona također mora biti shvaćena kao normalna odrednica identiteta i životnog stila pojedinaca kao temeljno ljudsko pravo na samoodređenje i američkom formulacijom ,pursuit of happiness “. Na taj je način disolucija sukoba represivnog i slobodnog, o kojem Marcuse govori, moguća i ozbiljiva u onoj mjeri u kojoj su pojedinci zreli i spremni spoznati i živjeti međusobnu 
toleranciju i prihvaćanje, svjesni da svatko ima elementarno pravo i dužnost na samoostvarenje i slobodu, u javnom i posebice privatnom prostoru, unutar vlastitog subjektiviteta.

\subsection{Seksualnost i kapitalizam}

Djelo Gillesa Deleuzea u koautorstvu s Felixom Guattarijem “Anti - Edip, Kapitalizam i shizofrenija bilo je "revolucionarni" poduhvat rekonstrukcije teorije društva i seksualnosti te utjecaj na suvremenu dekonstrukciju seksualnosti kojem je osnovna tema i cilj prevladavanje i prevrednovanje tradicionalnog psihoanalitičkog shvaćanja seksualnosti ${ }^{328}$ za novo razumijevanje karaktera i seksualnosti.

Njihov "nietzscheanski" poduhvat izuzetno je važan za novo tumačenje i razumijevanje seksualnosti jer oni elariciraju cjelokupni poredak freudovskih kompleksa, tzv. "svete obitelji" i njihov utjecaj na seksualni razvoj pojedinca.

Mazohistična osoba ne bi tada bila podložna figuri oca, što čak i do danas psihoanalitičke škole nisu prihvatile, a Deleuze i Guattari su svojevremeno naišli na brojne negativne kritike, a njihova teorija "shizoanalize" nije potpuno prihvaćena niti danas, kad bi trebalo biti neophodno imati pluralistički pogled na psihoseksualne fenomene i njihov razvoj.

Shizoanaliza pobija cjelokupnu Freudovu psihoanalitičku teoriju u temelju i gradi novi, konstruktivan pristup uspostavi identiteta individuuma i društva.

Slijedimo li Deleuzea i Guattaria, pojedinac više ne može ,prebacivati krivnju“ za svoje seksualne inhibicije i neuroze na roditelje (osim u ekstremnim traumatičnim situacijama) već pristupamo individualistički i egzistencijalistički izgradnji vlastite ličnosti te seksualne orijentacije i podsvjesnih želja, koje osvještavamo da bismo ih ostvarili, a ne zatomljivali niti stigmatizirali te je stoga njihova teorija uvelike relevantna za sadomazohističku seksualnost jer je ona u tom smjeru shvaćena kao naša vlastita, a ne produkt „konfliktne obitelji“, društvenih okolnosti i ostalog.

${ }^{328}$ Gilles Deleuze, Felix Guattari, Anti - Oedipus, Capitalism and Schizophrenia, Continuum, London, 2003. 
Osnovno je istaknuti da je cilj shizoanalize osobno preuzimanje odgovornosti za svoje želje, postupke i probleme na sebe umjesto traženja odgovora u proizvoljnim psihološkim konstrukcijama utjecaja obitelji i društva.

Jasno je da su obitelj i društvo do izvjesno mjere faktori koji utječu na razvoj pojedinca, no samo parcijalno, u adolescenciji, pa i ranije, taj utjecaj slabi da bi konačno sazrijevanjem nestao i tada pojedinac oblikuje i stvara svoju egzistenciju.

Anti - psihoanaliza je tako dekonstrukcija i sadomazohističke seksualnosti jer sadomazohizam više ne razumijevamo u kontekstu odnosa s roditeljima, što je u tradicionalnoj, pa i suvremenoj psihoanalizi duboko ukorijenjeno i nezaobilazno.

Paradigma psihoanalize kod tretmana osoba sa sadističkim ili mazohističkim seksualnim sklonostima neprestano traži uzroke njihovih sklonosti u „svetoj obitelji“, prividnoj želji žene za seksualnim odnosom s ocem i sina s majkom, što je suviše pojednostavljeno i dovedeno do apsurda te stoga shizoanaliza pruža jedno široko shvaćanje razvoja pojedinca unutar suvremene kapitalističke kulture, u kojoj je seksualnost shvaćena kao psihički otpor, borba za oslobođenjem pojedinca od društvenih imperativa i konzervativnog, samo naizgled slobodnog razvitka i poretka.

Stoga nas ne treba nimalo čuditi što je za Deleuzea i Guattaria upravo ta konzumeristička kultura represivna i opasna za mentalno zdravlje pojedinca, ona je izvor kolektivne shizofrenije, a seksualnost je kreativna i voljna sloboda pojedinca.

Paradigma „antiedipovske shizoanalize“ kao eklatantna opozicija tradicionalnoj psihoanalizi, svojim prikazom neraskidive veze kapitalističkog društva i psihičkih poremećaja, predstavlja egzistencijalističku struju u poststrukturalističkoj filozofiji.

Naravno da je i BDSM kultura, kao i sve druge, pod velikim utjecajem kapitalizma i konzumerizma, no naglasak je na negaciji i prevladavanju freudovskih simplificiranja „perverzija“ i „neuroza“ te traženja uzroka u „esenciji“ i pozadini pojedinca, a ključ je egzistencija, život individuuma, kojem prethodi osobna želja i volja, a u BDSM seksualnosti upravo su ti momenti presudni za formaciju ličnosti:

„Objektivni bitak želje je Realno u i po sebi. Ne postoji partikularna forma egzistencije koja može biti obilježena kao ,psihička realnost“. 
Želja nije opterećena potrebama, već upravo suprotno; potrebe su derivirane iz želje, one su kontraprodukti unutar realnog koje želja proizvodi, a manjak je kontraefekt želje, distribuiran unutar realnog koje je prirodno i društveno.“329

Deleuze i Guattari stavljaju težište na dijalektiku želju i pojedince kao svjesne subjekte želje i realnog, što je iznimno važno za temu sadomazohističke dinamike, no i želje kao do izvjesne mjere samostalnog faktora i agensa realiteta:

„Ako želja proizvodi, njen proizvod je stvaran. Ako je želja produktivnost, može biti produktivna samo u stvarnom svijetu i može proizvoditi samo realitet.

Želja nema manjak ničega; nema manjak svog objekta. ${ }^{330}$

Autori putem želje objašnjavaju i odnos subjekta i represije te utjecajem Lacana, sintagmom „želećeg stroja“ kao realnog, a ne stroja fantazije li sna (desiring - machine) i u tom kontekstu tumače relaciju subjekta, želje i realiteta:

„Subjekt nedostaje u želji, ili želji nedostaje fiksan subjekt; nema fiksnog subjekta ukoliko nema represije. Želja i njen objekt su jedno i ista stvar: stroj, kao stroj stroja. Želja je stroj, a objekt želje je drugi stroj spojena na nju. “331

Deleuzeovo i Guattarijevo tumačenje želje i želećeg subjekta kao strojeva u realnom poretku možemo razumjeti kao njihovu interpretaciju društva i seksualnosti u kojima subjekt ima aktivnu ulogu, jednako kao i želja, njegova želja i želja kojom je upravljan, svjesno, realno, izvan područja fantazije i Imaginarnog:

„Realno nije nemoguće; sasvim suprotno, unutar realnog sve je moguće, sve postaje moguće. Želja ne izražava manjak unutar subjekta, već organizacija lišava želju njenog objektivnog bitka. Revolucionari i umjetnici su zadovoljni da budu objektivni, samo objektivni: znaju da želja zahvaća život u svom moćnom produktivnom zagrljaju i reproducira ga na sve intenzivniji način. "332

Seksualnost je upravljana odnosom želje i kapitalističkih mehanizama, pri čemu je želja određena kapitalističkom produkcijom seksualnosti, prijelazom iz svoje apstraktne biti u materijaliziranu „stvar“, a odnos želje i kapitalizma izuzetno je važan za postmoderno razumijevanje seksualnosti, a kompleksan obzirom na moguće kontekstualne interpretacije.

\footnotetext{
329 Ibid, str. 28, prijev.a.

$330 \mathrm{lbid}$, str. 28, prijev.a.

$331 \mathrm{Ibid}$, str. 28, prijev.a.

332 Ibid, str. 29, prijev.a.
} 
Osvrnut ću se na temeljne odrednice materijalizacije želje posredstvom tehnologije i medija, referencama na Deleuzevu i Guattarijevu teoriju tijela, želje i seksualnosti, u kojoj je seksualnost produkcija želje putem materijalizacije tijela, a tijela kao ,želeći strojevi“ stvaraju svojevrsnu ,kolektivnu shizofreniju“.

Autori svojom dekonstrukcijom psihoanalize uspostavljaju društvene i seksualne odnose putem „želećih strojeva“ i „proizvodećih strojeva“, koji su primarni i finalni agenti formacije seksualnosti u kapitalističkom poretku.

„Želeći strojevi“ i „proizvodeći strojevi““ su postkapitalistički realitet za individuum psihe i tijela, koji zauzimaju čitavo područje seksualnosti putem želje koja proizvodi realitet i to je i njen uvjet postojanja i njen cilj.

Produkcija želje stvorena je društvenim odnosima želećih strojeva i kapitalističkog stvaranja sfere umjetnog, imaginarnog kao postvarenog da bi preusmjerile pojedince od apstraknog i nematerijalnog doživljaja društva i seksualnosti. ${ }^{333}$

Želja i realno imaju specifičan međuodnos, proizvodno - konzumeristički, želja je lišena imaginarne i simboličke dimenzije te uspostavljena produkcijom realnog:

„Ako je želja manjak realnog objekta, sama njena priroda kao realnog entiteta ovisi o „, biti manjka“ koji proizvodi fantazijski objekt, želja stvorena kao produkcija fantazija, želja intrinzično proizvodi imaginarni objekt koji funkcionira kao duplicitet realiteta. " Ako želja proizvodi, njen proizvod je realan. Ako je želja produktivna, može biti produktivna samo u realnom svijetu i može proizvoditi samo realitet. "334

Kapitalizam i seksualnost, odnos želje i kapitalizma usredotočen je svim svojim sredstvima i mehanizmima na produkciju želje i seksualnosti, pri čemu su tijela strojevi, želeći, budući da su upravljani stvorenom konzumerističkom željom i proizvodeći jer su podređeni poretku hiperprodukcije seksualnosti, tijela kao strojevi proizvode novi seksualni realitet, Deleuze i Guattari pojašnjavaju:

„Objektivni bitak želje je Realno u sebi i po sebi. Ne postoji niti jedna partikularna forma egzistencije koja može biti označena kao „psihički realitet“.

\footnotetext{
333 lbid, str. $28-32$

334 Ibid, str. $27-28$, prijev.a.
} 
Želja nije potaknuta potrebama, već radije suprotno; potrebe su derivirane iz želje: one su kontraprodukti unutar realnog kojeg želja proizvodi. “335

U kontekstu sadomazohističke seksualnosti, možemo zaključiti da je želja stvorena kapitalističkim poretkom koji oblikuje seksualnost kao imperativ produkcije i ,shizofreničnog“ stanja svijesti, kao efekta ekskluzivnog, ekscesivnog realnog.

Sadomazohistička seksualnost kao proizvedena i proizvodna, postala je, u domeni postkapitalističkog realnog, putem fetišističkih predmeta kao objekata želje, proizvod stvorene i nametnute potrebe i želje s arbitrarnom tržišnom vrijednošću, a posebice njena ikonografija predstavljena je kao proizvodnja želje upravljane strojevima, želećim i proizvodećim i to je temeljno obilježje kapitalističkog ovladavanja i upravljanja seksualnošću.

Kao najbolji primjer kapitalističke proizvodnje sadomazohističke seksualnosti, koji možemo iščitati iz Deleuzeove i Guattarieve teorije odnosa želje i kapitalizma, navela bih pornografiju, kao hiperprodukciju konzumerizma i manifestaciju kreirane želje koja stvara potrebe i oblikuje seksualne potrebe i afinitete pojedinaca.

Tehnologija kapitalizma proizvodi odnose i diskurse u sadomazohističkoj seksualnosti, koji ikonografijom i marketingom, kao odrazima kreirane želje, pridonose enormnom profitu brojnih industrija, no prvenstveno direktno ili indirektno podsvjesno diktiraju pojedincima određene stilove, koristeći pojmove „subverzivnost“ i „alternativne seksualnosti“ kao označitelje statusnog simbola jedne kompleksne i „zahtjevne“ seksualnosti, koja zahtijeva maksimalnu intervenciju kapitalističkih mehanizama te je kao takva ultimativna forma produkcije želje i seksualnosti.

335 Ibid, str. 28, prijev.a. 


\section{3}

\section{Foucaultova teorija seksualnosti i sadomazohizam \\ Sadomazohizam u kontekstu Foucaultove filozofije seksualnosti}

Filozofski najrelevantnije i najstručnije tumačenje seksualnosti i sadomazohizma u socijalnoj filozofiji nalazimo u Foucaultovom bogatom historijsko - epistemološkom opusu, u kojem on temu seksualnosti proširuje na društveno i političko područje, sve do pitanja etike u svojoj fascinantnoj i nenadmašivoj „Historiji seksualnosti“, posebice prvome dijelu, „Znanje i moć“ Foucault u svim svojim djelima duboko promišlja te razvija originalne teze o seksualnosti iz razloga što je seksualnost bitan konstituirajući faktor i individuuma kao subjekta i svih privatnih i javnih društvenih odnosa kao intersubjektivnih i stoga je, kao predmet historijsko filozofijskog proučavanja, integrirana u sve socijalno - političke odnose.

U djelu „Znanje i moć“, Foucault objašnjava logiku moći i njeno omnipotentno djelovanje u politici, društvu i seksualnosti, na makro i mikro razinama, ona prožima sve društvene odnose analogno, imanentnim mehanizmima - kontrolom, nadzorom, znanjem o pojedinom društvenom ili seksualnom fenomenu te stoga univerzalni i partikularni odnosi tjelesnog i društvenog na individualnim i kolektivnim razinama čine predmet socijalne epistemologije. Politika intervenira u seksualnost kontrolom nad tijelom jer:

„Seks je istodobno pristup životu tijela i životu vrste. On služi kao matrica discipliniranja i kao načelo regulacije. Stoga se u 19. stoljeću seksualnost i pretražuje do najsitnijih pojedinosti u životu ljudi, hvatu ju se u snovima, ona postaje šifrom individualnosti.

No također uočavamo da ona postaje temom političkih operacija, ekonomskih intervencija, ideoloških kampanja moralizacije ili podizanja odgovornosti: ona se vrednuje kao pokazatelj snage jednoga društva. “336

Društveno su preskribirane „normalne“ seksualne prakse i njihova distinkcija od „perverznih“ jer „normalno“ je ono što služi političkom i društvenom poretku, a pojedinci ili skupine koji ne slijede nametnuta pravila smatrani su svojevrsnim „diverzantima“ te se njihov moral, pa i mentalno zdravlje dovodi u pitanje.

Foucaultovim historijskim prikazom uviđamo da se i današnje društvo nije mnogo odmaklo od pravila 19. stoljeća, naravno, uz razdoblja seksualnog oslobođenja, i to su upravo oni

\footnotetext{
${ }^{336}$ Michel Foucault, Znanje i moć, Globus, Zagreb, 1994, str. 101
} 
diskontinuiteti o kojima Foucault čitavo vrijeme govori - društvene promjene jedno vrijeme teže napretku, da bi se ponovno vratile konzervativnom poretku i staroj logici moći.

Naravno, on ne priznaje teze „mračnih konzervativnih vremena“ po pitanju diskursa o seksualnosti, jer upravo su u tim razdobljima - prosvjetiteljstvu i viktorijanskom dobu nastala najlascivnija djela koja su i producirala sam koncept i praksu sadomazohističke seksualnosti. Ona su morala biti držana u tajnosti, bila su oštro osuđivana i stoga se o njima nije moglo govoriti na način na koji to možemo od druge polovice 20. stoljeća, a naročito danas kad sve možemo i „smijemo“ artikulirati, a neizrecivo više ne postoji, no što nam to zapravo govori? Uvedeni smo u privid slobodnog društva, društva bez diskriminacije, no realitet je bitno drugačiji i također, moramo biti svjesni da mi danas zapravo proučavamo historiju s modernog aspekta i historijsko znanje primjenjujemo na današnji život i seksualnost.

U Foucaultovoj socijalno - historijskoj studiji seksualnosti, kojoj je posvetio gotovo čitav svoj opus, budući da je ili glavna tema ili leitmotiv svih njegovih djela, od najveće je važnosti poredak moć/znanje/volja/seksualnost te paradigma diskursa moći, kontrole i discipline te nadzora i kazne i on konstantno opisuje sve društvene promjene putem tih modela, naglašavajući pritom omniprezentnost potrebe za znanjem da bi se uspostavila moć nad pojedincem i čitavim društvom.

U kontekstu seksualnosti, posebice manjinskih seksualnih orijentacija o kojima on govori, homoseksualne zajednice i $S / M$ leather subkultura, to je, posebice u njegovo vrijeme značilo istražiti, doći do znanja da bi se s jedne strane, stigmatiziralo i nastojalo eradicirati, a s druge, njegove strane, potaći proizvodnju pozitivnih društveno - seksualnih odnosa u tim sferama, čemu je on čitavog svog života težio i zbog istoga često dolazio u nezavidne situacije zbog nerazumijevanja okoline. ${ }^{337}$

Do koje je mjere je seksualnost bitna odrednica identiteta važna govori nam Foucaultova misao da „svatko ustvari mora proći kroz seks, tu imaginarnu točku ustanovljenu mehanizmom seksualnosti, da bi imao pristup vlastitoj pojmljivosti (jer seks je istovremeno skriveni element i tvoračko načelo smisla), cjelini svoga tijela (jer seks je njegov stvarni i ugroženi dio), svome identitetu (jer on snazi jednog poriva dodaje osobitost jedne povijesti).“338

Za razumijevanje sadomazohističke seksualnosti osobito su važne Foucaultove teze o poimanju seksualnosti u relacijama života i smrti, koje sam ranije prikazala u Bataillevoj misli jer Foucault S/M prakse također karakterizira kao „elaborirane $i$ razvijene putem mitskih

\footnotetext{
337 Vidi - David Macey, Critical Lives, Michel Foucault, veoma opsežna i precizna biografija M. Foucaulta

${ }^{338}$ Michel Foucault, Znanje i moć, Globus, Zagreb, 1994, str. 108, prijev.a.
} 
odnosa“ i, najvažnije: „S/M nije veza između nje ili njega koji pati i nje ili njega koji nanosi patnju već između gospodara i onoga nad kojim on provodi svoju moć.

Ono što interesira praktikante $S / M$ - a je to da je veza istovremena regulirana i otvorena. "339 Iskonska veza života i smrti u kontekstu sadomazohizma je najbolje izrečena u misli: „Faustovska pogodba, čiji je mehanizam seksualnosti u nas usadio iskušenje, od sada glasi: život u cijelosti zamijeniti za sam seks, za istinu o suverenosti seksa.

Seks je vrijedan smrti. Upravo je u tom, ali kao što vidimo strogo povijesnom smislu, seks danas prožet nagonom smrti. “340

Sadomazohistički je odnos rafinirana manifestacija praksi života i smrti, no prvenstveno spoznaje sebe, svog identiteta i znanja o vlastitoj seksualnosti te disciplina vlastite psihe i psihe drugoga i stoga je uvijek neophodna sinergija znanja, istine, moći i discipline.

Niti jedan sadomazohistički odnos ne može postojati bez tih esencijalnih elemenata, a kad govorimo o „radikalnom“ ili „ekstremnom“ sadomazohizmu, neophodno je razumijevanje kompletne Foucaultove konceptualizacije seksualnosti.

Pritom mislim na njegove osnovne odnose pojmova kao socijalno - seksualnih kategorija i to prvenstveno njegovo tumačenje relacije znanje - istina - moć - kontrola - seksualnost, kao temeljnu paradigmu sadomazohističke seksualnosti na koju se nadograđuje njegovo cjelokupno tumačenje sadomazohizma koje je najbolje objasnio u svojim intervjuima.

Njegova osnovna teza o esenciji S/M subkulture i psihičkog ustrojstva te o sadomazohizmu kao nenasilnoj praksi, jer on u intervjuuu „Sex, Power and the Politics of Identity “, referirajući se pritom i na istaknutu pro S/M feminističku teoretičarku Gayle Rubin govori:

„Mislim da želimo govoriti upravo o inovacijama koje te prakse impliciraju.

Na primjer, kako bi inzistirala naša dobra prijateljica Gayle Rubin.

Ne mislim da taj pokret seksualnih praksi ima išta s razotkrivanjem S/M sklonosti duboko unutar našeg nesvjesnog. Mislim da je S/m mnogo više od toga; on je realna kreacija novih mogućnosti užitka, o kojima ljudi ranije nisu imali pojma.

Ideja da je $S / M$ povezan s dubokim nasiljem, da je prakticiranje $S / M$ - a način oslobađanja tog nasilja, te agresije, je glupa.

Foucaultovo je stajalište veoma jasno, on je u potpunosti mogao razumjeti važnost sadomazohističke seksualnosti, ne samo iz osobne perspektive kao praktikant i kasnije

\footnotetext{
${ }^{339}$ Michel Foucault, Essential Works 1, Ethics: Subjectivity and Truth, New Press, New York, 1997, str. 151, prijev.a.

${ }^{340}$ Michel Foucault, Znanje i moć, Globus, Zagreb, 1994, str.108
} 
pripadnik S/M leather scene, već utemeljenjem socijalno - filozofske i historijske znanstvene teorije razvoja seksualnosti:

„Mi vrlo dobro znamo da ono što svi ti ljudi rade nije agresivno; oni pronalaze nove mogućnosti užitka sa neobičnim dijelovima tijela putem erotizacije tijela.

Mislim da je to vrsta stvaranja, kreativni poduhvat, kojem je jedno od glavnih obilježja ono što ja zovem deseksualizacija zadovoljstva.

Ideja da tjelesno zadovoljstvo uvijek treba dolaziti od seksualnog zadovoljstva kao korijen svega našeg mogućeg zadovoljstva, mislim da je to nešto potpuno pogrešno.

Te prakse inzistiraju da možemo proizvoditi užitak s veoma čudnim stvarima, veoma čudnim dijelovima našeg tijela, u veoma neuobičajenim situacijama.“341

Njegova je polazna teza ispitivanje i istraživanje historije ljudske prirode putem civilizacijskih sustava i njima nametnutih modela, a zaključci, kao teorije djelovanja mehanizama moći, su zapravo smjernice, štoviše, imperativi za daljnje proučavanje, stjecanje znanja o društvu, međuljudskim i odnosima i seksualnosti koja nema granice, kao niti znanje samo, posebice znanje o seksualnosti i njenoj moći.

Stoga nas on govoreći o poznavanju tijela svojom retorikom podsjeća:

„,Mogućnost korištenja naših tijela kao mogućih izvora veoma brojnih užitaka je nešto veoma važno. Kao primjer, ako pogledate tradicionalnu konstrukciju užitka, vidite da da su tjelesno zadovoljstvo, ili tjelesni užici, uvijek piti, jesti i jebati.

I to se čini da je granica razumijevanja našeg tijela, naših užitaka"342

Posljednja misao podsjeća nas na poznatu misao vodilju „božanstvenog“ markiza de Sadea koji je užitak svodio isključivo na piće, hranu i seks, naravno, uz uživanje u krvoproliću i brutalnom nasilju, čime je čovjek predstavljen kao nadmoćna životinja.

Sadeova ideja izražava ogoljenu prirodu čovjeka i to je ono što Foucault pokušava ironično objasniti, da bi ukazao na relevantnost istraživanja seksualnosti i novih seksualnih praksi, konstatirajući time da je združivanje užitka i seksa slomljeno, da je je prekinuto njihovo spajanje $u$ jednu cjelinu.

O sadomazohističkoj seksualnosti kao jednom sveobuhvatnom konceptu koji, pored seksualne orijentacije i praksi, neophodno podrazumijeva i uključuje način života, razmišljanja i svojevrsnu subkulturu, Foucault nam govori o odnosu moći, užitka u kontekstu S/M praksi: „Može se reći da je S/M erotizacija moći, erotizacija strategijskih odnosa.

\footnotetext{
${ }^{341}$ Michel Foucault, Sex, Power and the Politics of Identity Essential Works 1, Ethics : Subjectivity and Truth, New Press, New York, 1997, str. 165, prijev.a.

$342 \mathrm{lbid}$, str. 165 , prijev.a.
} 
Ono što mi privlači pažnju u pitanju S/M - a je kako se razlikuje od društvene moći.

Ono što karakterizira moć je činjenica da je ona strategijska relacija koja je stabilizirana putem institucija. Tako je je mobilnost u odnosima moći limitirana, i postoje snažna uporišta koja je vrlo, vrlo teško potisnuti zato što su institucionalizirana i sada su veoma raširena na sudovima, u kodeksima i tako dalje.

Sve to znači da su strategijski odnosi ljudi učinjeni rigidnima.

U tom smislu, S/M igra je veoma interesantna jer je strategijski odnos, no uvijek fluidna. Naravno, postoje uloge ali svi jako dobro znaju da se te uloge mogu preokrenuti.

Ponekad scena počinje s gospodarem i robom, a na kraju rob postaje gospodar.

Ili, čak kad su uloge i stabilne, veoma dobro znate da je to uvijek igra.

Ili su pravila prekoračena, ili postoji sporazum, ili eksplicitan ili prešutan, koji ih čini svjesnima određenih granica. Ta strategijska igra kao izvor tjelesnog užitka je vrlo zanimljiva. Ali ne bih rekao da je to reprodukcija struktura moći unutar erotske veze-

To je izigravanje struktura moći strategijskom igrom koja je sposobna pružiti seksualno zadovoljstvo ili tjelesni užitak."343

Foucault objašnjava i na koji se način strategijski odnos S/M - a razlikuje od odnosa moći, u socijalno - historijskom kontekstu:

„Praksa S/M - a je kreacija užitka i s tom kreacijom postoji identitet.

Zbog toga je S/M stvarno subkultura. To je proces invencije. S/M je korištenje strategijskog odnosa kao izvora užitka (fizičkog užitka).

To nije prvi puta da ljudi koriste strategijske odnose kao izvor užitka.

Na primjer, u srednjem vijeku bila je institucija „udvaračke ljubavi“, trubadur, institucije ljubavi između dame i ljubavnika itd. To je također bio strategijski odnos.

To čak nalazimo između momaka i djevojaka kad plešu subotom navečer.

Oni provode strategijske odnose. Ono što je zanimljivo jest da, u heteroseksualnom životu, ti strategijski odnosi dolaze prije seksa. To je strategijski odnos u službi pridobivanja seksa.

A u S/M - u ti strategijski odnosi su unutar seksa, kao konvencija užitka unutar partikularne situacije. U jednom slučaju, strategijski odnosi su čisto društveni odnosi i uključeno je samo naše društveno biće ; dok u drugom slučaju, uključeno je naše tijelo.

I taj transfer strategijskih odnosa od (u)dvora do seksa je ono vrlo interesantno. "344

\footnotetext{
343 Ibid, str. $169-170$

344 Ibid, str. $169-170$, prijev.a.
} 
Nadalje, Foucault pojašnjava na koji se način S/M odnosi mogu razumjeti u suvremenom kontekstu kao društveni odnosi unutar uma i psihe pojedinca samog na individualnoj razini te u njegovoj relaciji sa širim pojmom društva kao cjeline.

Pojedinac svoju društvenu i seksualnu orijentaciju poima kao ono navlastito i subjektivno, ona je njegova subjektivnost, dok njegov odnos s naizglednom apstrakcijom društva doživljava često kao animozitet u smislu preskriptivnih normi.

Foucault konstantno naglašava da bi odnos pojedinca i društva trebao težiti postajanju pozitivnim, produktivnim odnosom, a to se postiže upravo nivelacijom međusobnih diferencija pojedinaca i njihovim usklađivanjem, iako i njihove suprotnosti proizvode pozitivne odnose moći, koji oblikuju i pojedinca kao osobu za djelovanje i društvo kao konglomerat sačinjen od naizgled nepomirljivih raznolikosti.

Kao najbolji suvremeni primjer tome navela bih upravo današnje društvo 2010/20-ih godina, u kojemu ponovno nailazimo na opreke i represije o kojima Foucault govori, s jedne strane „novi puritanizam“ ili „novi konzervativizam“, a s druge tzv. alternativne životne stilove, poput brojnih glazbenih pravaca, filozofskih i političkih teorija, pa sve do BDSM - a, koji bismo mogli razumjeti kao svojevrstan produkt brojnih ostalih životnih stilova, njihov izraz.

Kad promišljamo razne „ekstremne“ prakse - ekstremne sportove, tattoo, piercing $i$ body modification kulturu, fetish - goth modu, metal glazbu, sve njih nalazimo u BDSM - u, samo u jednom rafiniranom obliku, gdje se one ističu samo svojim najsenzualnijim svojstvima i na taj način BDSM ne možemo smatrati samo netipičnom, alternativnom seksualnošću, već kompletnim i kompleksnim životnim stilom u opreci s „,normalnim“, ustaljenim društvenim normama s kojima se konformira većina populacije.

Seksualnost moramo razumjeti kao kreaciju, svjetsku slobodu, upozorava nas Foucault, kao što, pored njega, i brojni S/M praktikanti konstatiraju da je BDSM seksualnost koja je sve samo ne seks, u smislu da je seks samo jedan dio, a bit je sve ostalo, psihička dimenzija, elementarne osobine i kvalitete koje submisivna i dominantna osoba moraju imati da bi uopće mogle biti u određenoj, željenoj poziciji.

Pored kreacije i slobode, osobito bih naglasila kreativnost i izrazitu psihološku - kognitivnu imaginativnost, jer BDSM seksualnost u najvećoj mjeri oblikuje i razvija sposobnost zapažanja, imaginacije, mišljenja i stvaranja putem fantazije i njene realizacije.

Sam identitet individuuma se neposredno konstruira njegovim seksualnim preferencama i seksualnim praksama te je stoga S/M bitan konstituent identiteta, u osobnom, interpersonalnom, psihološkom te naposljetku društvenom kontekstu. 
Na pitanje u kojoj je mjeri važno da se identiteti formiraju novim seksualnim praksama poput S/M - a i, bez obzira koliko omogućuju istraživanje tih praksi, jesu li također ograničavajući u pogledu mogućnosti pojedinaca, Foucault odgovara:

„Ako je identitet samo igra, ako je samo procedura ostvarivanja odnosa, društvenih i odnosa seksualnog užitka koji stvaraju nova prijateljstva, koristan je.

No ako identitet postane problem seksualne egzistencije, i ako ljudi moraju , razotkriti“ svoj „, vlastiti identitet“, i ako njihov vlastiti identitet mora postati zakon, princip, kod njihove egzistencije; ako je vječito pitanje koje postavljaju:

„Da li ovo odgovara mom identitetu? “, tada mislim da će se okrenuti vrsti etike bliskoj staroj heteroseksualnoj muževnosti.

Ako smo upitani da se povežemo s pitanjem identiteta, to mora biti identitet nama unikatnim sebstvima. Ali veze koje imamo sa sobom nisu one identiteta, radije moraju biti veze diferencijacije, kreacije, inovacije. Biti jednak je zaista dosadno. Ne smijemo isključiti identitet ako ljudi nalaze zadovoljstvo putem tog identiteta, ali ne smijemo misliti o tom identitetu kao o etičkom, univerzalnom pravilu. "345

O odnosima moći kao pozitivnima u društvenoj i seksualnoj domeni, posebice sadomazohističkima, Foucault pojašnjava svoje misli o intervencijama politike i ekonomije te osjećajima „zarobljenosti“ u kontekstu otpora za slobodu:

„Uvijek smo u takvoj vrsti situacije. To znači da uvijek imamo mogućnosti, uvijek postoje mogućnosti mijenjanja situacije. Ne možemo iskočiti izvan situacije i nema točke gdje smo slobodni od svih odnosa moći.

Ali uvijek to možemo promijeniti. Stoga ono što sam rekao ne znači da smo uvijek zarobljeni, već da smo uvijek sposobni za slobodu, da uvijek postoji mogućnost promjene. “346

Foucault želi reći da je upravo otpor, prema društvu i institucionaliziranim, političko ekonomskim normama ponašanja, neophodan za poimanje odnosa moći te cjelokupne dinamike pojedinca u odnosu s drugima i na druge te seksualne prakse koje se smatraju neprikladnima jer ugrožavaju ustaljeni poredak:

„,Kad ne bi bilo otpora, ne bi bilo odnosa moći. Zato što bi to bilo jednostavno stvar poslušnosti. Moramo koristiti odnose moći za referiranje na situacije u kojima ne činimo ono što želimo. Stoga otpor dolazi prvi, i otpor ostaje superioran silama procesa ; odnosi moći su se primorani mijenjati s otporom.

\footnotetext{
345 Ibid, str. 166, prijev.a.

346 Ibid, str. 167, prijev.a.
} 
Stoga mislim da je otpor glavna riječ, ključna riječ u ovoj dinamici. “347

Foucault se dotiče i tada veoma aktualnog pitanja S/M zajednica u kontekstu društva i moći te navodi poveznice seksualnosti pojedinca sa širim zajednicama koje ga i određuju, no i uvelike kontroliraju njegov modus vivendi.

Zanimljiv je upit o tendenciji i želji da seksualne prakse budu prakse otpora u političkom i društvenom smislu, na koji je način moguće da se takvima postave obzirom da kontrola može biti provođena stimulacijom užitka i možemo li biti sigurni da novi užici neće biti eksploatirani u komercijalne i disciplinarne svrhe kao sredstva kontrole društva, na koji Foucault odgovara: „Nikad ne možemo biti sigurni. Zapravo, uvijek možemo biti sigurno da će se to dogoditi, i da sve što je bio stvoreno ili stečeno, svaka osnova kojoj je bila dana volja, može u određenom trenutku biti upotrebljena na takav način.

To je način na koji živimo, način na koji se borimo, to je način ljudske povijesti.

I ne mislim da postoji prigovor svim tim pokretima ili svim tim situacijama.

Ali potpuno ste u pravu naglašavajući da uvijek moramo biti dosta svjesni činjenice da moramo krenuti nečemu drugome, da imamo također i druge potrebe.

S/M geto u San Franciscu je dobar primjer zajednice koja je eksperimentirala s, i formirala identitet oko zadovoljstva. Ta getoizacija, ta identifikacija, ta procedura eksluzije i sve ostalo što imaju također je proizvelo njihove kontraefekte.

Ne usuđujem se upotrijebiti riječ dijalektika, no veoma je blizu tome." ${ }^{\text {348 }}$

On svojim uvidima želi naglasiti važnost volje pojedinca u oblikovanju spoznaje vlastite seksualnosti kao aktivan subjekt koji promišlja svoja djela te stječe potrebno znanje o samome sebi i društvu mišljenom, ne kao apstraktnom pojmu, već kao konkretnom agensu odnosa moći i na taj se način u njemu pozicionira u skladu sa svojim stvarnim željama i potrebama.

Drugim riječima, pojedinac kao cjelina za sebe i dio društva mora biti taj koji određuje svoje vlastite uvjete egzistencije i svoju ulogu u društvenim odnosima moći, posebice unutar seksualnosti, a to je najintenzivnije izraženo u sadomazohističkoj seksualnosti, koja je izgrađena upravo na specifičnim odnosima moći.

U zbirci odabranih intervjua iz perioda 1972 - 77.,"Power / Knowledge“, Foucault objašnjava svoje tumačenje i shvaćanje seksualnosti kroz povijest u svojim najvažnijim djelima, posebice u intervjuuu „History of Sexuality“ ${ }^{349}$, pojašnjava na što je zapravo želio ukazati pod

\footnotetext{
347 Ibid, str. 167, prijev.a.

${ }^{348}$ Michel Foucault, Sex, Power and the Politics of Identity Essential Works 1, Ethics : Subjectivity and Truth, New Press, New York, 1997, str. 166

${ }^{349}$ Ibid, str. 167
} 
pojmovima represije seksualnosti te istovremeno njene diskurzivne moći kao produktivne, napominjući da je razvoj misli o seksualnosti potrebno historijski promatrati s aspekta opozicija „dozvoljeno ili zabranjeno“, „,normalno ili abnormalno“, „žensko ili muško“, da bi se mogla shvatiti poveznica s anksioznošću koju je seksualnost izazivala u medicini uslijed neznanje i nastojanja ovladavanja i kontrole nad veoma dugo prilično nepoznatim područjem. Iz tog razloga „aberantnu“ seksualnost prikazuje u komparaciji s ludilom da bi pojasnio izvore i razloge potrebe za znanošću o seksualnosti i njenom medikalizacijom, nadzorom te konstantnim ispitivanjem u svrhu stjecanja znanja te konačno uspostavom kontrole nad njome. Foucault u svim svojim djelima naglašava da je seksualnost je oduvijek bila od izuzetne važnosti kao preduvjet odnosa moći i stoga je znanje i moć nad njome predstavljala moć nad životom samim, kontrolom populacije, društveno prihvatljivog ponašanja, ekonomije i politike: „Vjerujem da postoji serija historijskih relacija između ludila i seksualnosti koje su važne, a kojih sigurno nisam bio svjestan kad sam pisao „Madness and Civilization“.

U to sam vrijeme imao na umu napisati dvije paralelne historije : s jedne strane historiju isključenosti ludila i opozicija koje su iz toga proizlazile, s druge, historiju raznih formi upisivanja koje su se provodile unutar područja seksualnosti (oblika seksualnosti koja su kažnjiva ili zabranjena, normalna ili abnormalna, muška ili ženska, dječja ili odrasla) : mislio sam o čitavoj seriji binarnih opozicija od kojih se svaka zasnivala na velikoj opoziciji između razuma i nerazuma.

No ne mislim da će to biti dostatno: dok je ludilo bilo, barem jedno stoljeće esencijalno objekt negativnih operacija, seksualnost je tijekom istog tog perioda postala domena veoma preciznih i pozitivnih ulaganja.

U 19. stoljeću, pojavio se apsolutno fundamentalni fenomen: ispreplitanje dvaju velikih tehnologija moći: jedna koja je proizvodila seksualnost, druga koja je izdvajala ludilo, tehnologija se promijenila od negativne ka pozitivnoj, od bivanja binarnom do bivanja kompleksnom i multiformnom.

Nastala je široka tehnologija psihe, koja je postala karakteristika 19. i 20. stoljeća, ona je odmah pretvorila seks u stvarnost, skrivenu iza racionalne svijesti i razuma." ${ }^{\text {350 }}$

Svojim promišljanjem razumijevanja seksualnosti i ludila analognom diskurzivnom praksom i metodom, Foucault nam daje do znanja da su određene seksualne prakse uvijek imale važnu ulogu, shodno određenom vremenskom razdoblju, budući da je i sam znanstveno proučavanje sadomazohizma započelo svoj razvoj u 19. stoljeću.

\footnotetext{
350 Michel Foucault, Colin Gordon, Power/Knowlegde, Selected Interviews, Pantheon Books, New York, 1980, str. $184-185$
} 
U zbirci predavanja na College de Franceu iz 1981. godine „Subjektivnost $i$ istina“, on iznosi esencijalne, presudne teze o historijskom razvoju društva i ulozi seksualnosti i etike, prikazujući ih svojim tumačenjem seksualnosti elaboracijom odnosa istine i subjekta te osvrtom na prirodu seksualnosti i psihoanalizu. ${ }^{351}$

Već sam naslov „Subjektivnost $i$ istina“ upućuje na osnovne pojmove seksualnosti, posebice hermeneutike sadomazohističke prakse, jer istinu poimamo kao znanje o sebi i drugome kao znanje o tijelu i psihi te povjerenje u drugu osobu.

To podrazumijeva produktivan odnos koji započinje željom, a ostvaruje se užitkom i oslobođenjem seksualnosti, posredstvom odnosa moći, što je bit i temelj sadomazohističkog odnosa u subjektivnosti osobe prema sebi i drugome.

Subjektivnost možemo shvatiti kao subjektivitet osobe, razmjene moći i dominacije u S/M odnosu jer Foucault napominje, referirajući se na podsvjesne, inhibirane seksualne fantazije u obliku seksualnih snova da:

„Iluzija zbog koje je subjekt očaran i koja se sama oslobađa spontanim pokretom buđenja, ta iluzija bi u većini kultura morala reći istinu o tom subjektu“ i stoga je bitno za ono što nazivamo,,uspostava znanja sa znanstvenim statusom “ u historijsko - filozofskom promišljanju zapadne kulture ,,ponovno ocijeniti mehanizam uspostave odnosa između istine i subjektivnosti, istine i subjekta. ${ }^{352}$

U tom psihoanalitičko - hermeneutičkom odnosu subjekta i istine, snovi su od velikog značaja, kao simboličke manifestacije izričaja istine o seksualnosti.

Istina o seksualnosti i želji uspostavlja se relacijom subjekt - san - seksualnost - istina jer naše želje i koncepti izraženi u snovima kao neposredni doživljaji, govore nam istinu o našoj seksualnosti, istinu koju često ne možemo potpuno razumjeti.

U BDSM seksualnosti, polazišna je točka upravo san kao fantazija i stoga je san odraz želje subjekta i svojevrstan putokaz njegovom djelovanju i razvijanju vlastite seksualnosti, u osobnoj i društvenoj sferi.

Mnoge osobe BDSM orijentacije uspijevaju samo u stanju sna ili psihoanalitičkom imaginarnom stadiju doživjeti svoje želje i spoznati sebe kao subjekt, spoznavanjem svoje seksualnosti kao vlastitog subjektiviteta i seksualnosti.

Foucault preispituje pitanje istine i subjekta psihoanalitičkom perspektivom:

\footnotetext{
${ }^{351}$ Michel Foucault, Subjektivnost $i$ istina, Sandorf \& Mizantrop, Zagreb, 2019

352 Ibid, str. 51
} 
„Što ako je istina istinita samo na temelju ukorijenjenosti nečega što je kao iluzija i san? Što ako je istina naposljetku samo moment nečega što je samo san ?,, 353

te napominje važnost shvaćanja „odnosa subjektivnosti - istine kod Freuda : kako možemo znati istinu o subjektu samom, koja je situacija s istinom subjekta i i ne bi li se ono što je u subjektu najočitije iluzorno izreklo ono što je najtajnija istina subjekta?“, da bi o problematici uspostave istine subjekta i sna zaključio:

„Eksplicitno ili potiho, pitanje sna se širilo duž cijele povijesti odnosa između subjektivnosti $i$ istine, s posebnim snažnim trenucima u kojima su se ti odnosi između subjektivnosti i istine reorganizirali i modificirali svoj zajednički mehanizam.,, 354

Nadalje, Foucault govori o „umijeću življenja“ kao o „studiji odnosa između subjektivnosti $i$ istine“, ističući da nam se upravo u snovima predočava naša

subjektivna, donekle iluzorna istina, dok je to umijeće pronaći način „u budni život integrirati dati smisao i vrijednost sanjalačkom subjektu. “

Foucaultova osebujna hermeneutika seksualnosti veoma je kompleksna jer ona, kao prvenstveno historijsko - filozofijska, ipak zadire i u psihoanalitičko područje.

Koncept žudnje imanentne egzistenciji i seksualnosti subjekta najbolji je primjer za tematiku sadomazohističke seksualnosti, jer u upravo u njoj subjekt je motiviran snovima, iluzijama, a nadasve žudnjom za ostvarenjem svojeg seksualnog nadmoćnog subjektiviteta, kao želje i fantazije u Lacanovoj filozofiji.

U pojam i smisao žudnje Foucault nas uvodi naznakama o njenoj ulozi u samoostvarenju subjekta spoznavanjem i kreiranjem svoje istine u seksualnosti:

„Trebalo bi pokazati kao je žudnja daleko od toga da je potisnuta nešto što je malo pomalo bilo izdvajano i izronilo je iz jedne ekonomije užitaka i tijela, kako je doista bila izdvojena iz nje, kako su se i na koji način oko i o njoj kristalirizirali svi zahvati i sve pozitivne i negativne vrijednosti koje se tiču seksa. “ 355

Foucaultove nas misli o žudnji pružaju mnogo materijala za interpretaciju i nalaženje teza i zaključaka o sadomazohističkoj seksualnosti.

Žudnja je predstavljena kao temeljni aktivni faktor seksualnosti i upravo je iz tog razloga morala biti potiskivana i sputavana u BDSM seksualnosti, jer ekonomija BDSM seksualnosti zahtjeva upravo maksimalnu prisutnost i involviranost žudnje, užitaka i tijela u netipičnim seksualnim i ostalim praksama kojima su i sredstva i cilj.

\footnotetext{
353 Ibid, str. 52

354 Ibid, str. 52

355 Ibid, str. 266
} 
Društvo koje je, s jedne strane propagiralo i nametalo konzervativizam seksualnosti, a s druge je koristilo sadomazohističku seksualnost kao predmet istraživanja kao diskursa društvenih i prirodnih znanosti te ikonografije u marketingu, prikazujući je kao negativno obilježenu, kad je riječ o „građanskom odgoju“, i kao izazov kad je korištena u svrhu marketinga metodama poticanja konzumentskog apetita, reklamnim i medijskim agitiranjem podsvjesnih želja kod potencijalnih subjekata masovne potrošnje, neophodnima za održanje i rast ekonomije.

Sad je paradoks ,potisnute žudnje“, kao i seksualnosti, veoma jasan jer se odnosi posebice na drugačije seksualnosti, te i apelira na praktikante istih.

Žudnja je, pored, pokretača seksualnosti, temeljni koncept za tumačenje subjekta i seksualnosti o kojem Foucault zaključuje:

„Žudnja je je uistinu ono što bi nazvao povijesnim transcendentalnim od kojega možemo $i$ moramo promišljati povijest seksualnosti.

Valja, na temelju povijesti tehnologija sebstva, na temelju povijesti upravljanja -vladanja sobom i drugima - pokazati kako je moment žudnje bio izdvojen i uzdignut i kako se iz toga formirala izvjesna vrsta relacije sebe sa sobom koja je sama podnijela određeni broj transformacija, jer smo vidjeli kako se razvija, organizira, dijeli u sustavu koji je najprije bio sustav puti, prije nego što je mnogo kasnije postao sustav seksualnosti.

Žudnja je ta koja je, sama na koncu zaplijenila sve što se nekoć nalazilo ujedinjen u to jedinstvu žudnji, zadovoljstava i tijela. I tako je iskrsnulo ono temeljno pitanje žudnje i subjekta žudnje, zato što je žudnja doista oblik, u kojem je bio objektiviran i subjektiviran, problem aphrodisia, to jest seksualnih činova."356

${ }^{356}$ Ibid, str. 266 


\subsection{ETIKA KONSENZUALNOSTI I MORALNOST SADOMAZOHIZMA BRIGA O DRUGOME I SEBI}

Suvremena sadomazohistička seksualnost razvila je svoju specifičnu etiku, etiku konsenzualnosti te etičku odgovornosti i, pored brige o sebi, prvenstvo ima briga o drugome, što je razlikuje od svih ostalih etičkih sustava i seksualnosti.

Općepoznati imperativ i moto „Safe, Sane and Consensual“ samo je pojednostavljen izraz etičke i moralne odgovornosti u BDSM praksama.

U sadomazohističkim odnosima i praksama osnovni je moralni imperativ briga o drugome, koja je ispred brige o sebi, što podrazumijeva poštivanje ne samo pristanka i želja druge osobe, već i brige o njoj u svrhu očuvanja njenog fizičkog i psihičkog zdravlja i upravo se time ona izdvaja od brojnih drugih međuljudskih odnosa i seksualnosti, u kojima je primarna briga o sebi, dok druga osoba biva zanemarena.

U istinskom BDSM - u to nikada ne smije biti slučaj jer su konsenzualnost i briga o tijelu i psihi partnera su prerogative u svim vrstama odnosa, praksi i aktivnosti koje S/M seksualnost uključuje, neovisno radi li odnosu dominantne i submisivne osobe, mazohističke i sadističke ili gospodara i roba, a briga dominantne osobe o submisivnoj je od najveće važnosti, no i vice versa, briga submisivne o dominantnoj, za obostrani užitak, i na taj način oba partnera, brinući jedno o drugome, dobrobiti drugog, njegovoj dobrobiti, sigurnosti i užitku, istodobno doživljavaju vlastito zadovoljstvo brinući jedno o drugome.

Briga o sebi postaje tada relacija i odnosa sebe i drugog i odnosa ja prema sebi jer brinući i pružajući užitak drugome, adekvatno pravilima svoje pozicije ja individuuma brine bespogovorno i bezuvjetno i o sebi i ta briga stvara elementarnu dinamiku.

Naravno, što je odnos ozbiljniji i intenzivniji, ta briga je time veća i tako u 24/7 Master/slave odnosu briga gospodara/ice prema robu/inji je neograničena, no i briga roba/inje prema gospodaru/i je izrazito zahtjevna i podrazumijeva udovoljavanje i ispunjavanje svih želja i pružanje svih užitaka koje se zahtijevaju.

Briga o submisivnoj osobi mora biti na prvome mjestu dominantnoj, a submisivnoj osobi, pored brige o sebi, bezgranično povjerenje u dominantnu, i time obveza da poštuje dogovorene naredbe i zadatke $\mathrm{i}$ to je njena briga o dominantnoj osobi i njenom užitku da bi njime posredovala svoj vlastiti to je meritum etičkih načela sadomazohističke seksualnosti.

Etika konsenzualnosti te briga o drugome i sebi temelji su užitka i zadovoljstva u BDSM - u te se razumiju se i uspostavljaju na dva elementarna načina, prvo, kod dominantne osobe, kao 
briga o submisivnoj na prvome mjestu, a kod submisivne poslušnost ili „služenje“ i zadovoljavanje dominantne osobe i briga o sebi i takav odnos rezultira međusobnim psihičkim i seksualnim ispunjenjem i razvitkom.

Umjerenost je bitan faktor zadovoljstva i etičkog postupanja i prema drugome i prema sebi, obzirom da je ona kod ekstremnih seksualnih praksi zaista potrebna, naročito u početku uspostavljanja odnosa prema drugome i razvijanja odnosa prema vlastitoj osobi te Foucault, inspiriran grčkom misli zaključuje:

„Strategija je omogućila ravnotežu u dinamici užitka i želje: obuzdala je dinamiku da ne postane ekscesivna, postavljanjem zadovoljenja potrebe kao unutarnju granicu jer je omogućila samo ono što je potrebno tijelu, namjerom prirode i ništa više.

Istovremeno, osposobila je pojedinca da izbjegava neumjerenost, ponašanje koje nema svoju bazu u prirodi. Postojala je neumjerenost koja se mogla nazvati neumjerenost „plethore“ ili „ispunjenja“. ${ }^{357}$ Shvaćena na taj način, umjerenost nije mogla poprimiti oblik poslušnosti sistemu zakona ili kodifikacije ponašanja, niti služiti kao princip poništavanja užitaka; bila je umjetnost, praksa užitaka, sposobna za samoograničenje putem „upotrebe“ onih užitaka koji su bili bazirani na potrebi.“358

Foucault je etici seksualnosti posvetio čitav opus, od „Historije seksualnosti“ do brojnih radova i intervjua, objavljenih u zbirkama „Essential Works“, kojima je ukazao na centralnu problematiku odnosa subjekta, seksualnosti i etike, a fundamentalna problematika je stoga etika intersubjektivnih odnosa u kontekstu tumačenja S/M seksualnosti i praksi.

Izrazito je detaljno proučavao i izložio historijske modele seksualnosti, od Antike do 20. stoljeća, koje je primijenio na moderno i suvremeno filozofsko tumačenje seksualnosti i odnosa moći, a najvažnije je naglasiti etiku sadomazohističke seksualnosti, koju Foucault, u svim svojim djelima, implicira diskursima odnosi moći i seksualnosti.

Za suvremenu hermeneutiku sadomazohističke seksualnosti ključan je odnos i moguće relacije pojmova „subjekt - objekt - seksualnost - užitak - etika“, koje Foucault seksualnost tumači putem grčke filozofije, od senzualnih i tjelesnih senzacija do duhovnih i etičkih načela, referirajući se na pojam aphrodisie, objašnjavajući dinamiku užitaka:

„Kad su (užici) bili predmeti ispitivanja, pitanje nije bila forma koju su zauzimali, bila je to aktivnost koju su manifestirali, njihova dinamika.

\footnotetext{
${ }^{357}$ Pojam ,plethora“, koji je već spomenut kod Bataillea ima prvenstveno značenje „,izobilja“ ili „,pretjeranosti“”, no kod Foucaulta je u engleskome prijevodu riječ „fulfillment“ kao „ispunjenje“, jer se radi o širokome, višeznačnome pojmu, ovisno o kontekstu, op.a.

${ }^{358}$ Michel Foucault, The History of Sexuality 2, The Care of the Self, Vintage Books, New York, 1990, str. 57
} 
Ta dinamika bila je definirana pokretom koji je povezivao aphrodisiu s užitkom, privlačnost potaknuta užitkom i silom želje usmjerene prema njoj konstituirale su, zajedno s djelovanjem aphrodisie same, stabilnu uniju - karakteristike etike tjelesnosti i poimanja seksualnosti.

Etičko pitanje koje se postavljalo nije bio koje želje ? koji čini? koji užici?, već s kojom silom je osoba transportirana užicima i željama?

Ontologija na koju se odnosila ta etika seksualnog ponašanja bila je ontologija sile koja je spajala čine, užitke $i$ želje. Ta dinamička veza, konstituirala je ono što bi se moglo nazvati teksturom etičkog iskustva aphrodisie.“359

Jasno je razumljivo do koje je mjere seksualni identitet važan, često i bitan konstituent izgradnje etičkog promišljanja i djelovanja pojedinca, obzirom da je u sadomazohističkoj seksualnosti sastavni dio seksualne prakse same, ali prvenstveno jedan od osnovnih dijelova ličnosti i odnos subjekta sa seksualnim identitetom Foucault pojašnjava na slijedeći način:

„Ako identitet postane problem seksualne egzistencije, $i$ ako ljudi misle da njihov vlastiti identitet mora postati zakon, princip, kod njihove egzistencije; mislim da će se oni vratiti vrsti etike veoma bliskoj staroj heteroseksualnoj muževnosti. Ne smijemo isključiti identitet ako ljudi nalaze svoje zadovoljstvo kroz taj identitet, ali ne smijemo misliti o tom identitetu kao o etičkom univerzalnom pravilu. “360

Sadomazohistička seksualnost bez etike kao moralnog načela konsenzualnosti i brige o drugome i sebi ne može postojati jer manjkom etike i izgrađene, samosvjesne ličnosti ili je simulacija ili oblik nasilja.

Vladanje sobom u kontekstu već spomenutog grčkog pojma „enkrateia“, pravilne upotrebe, temeljene na umjerenosti i ispravnim djelovanjem, da bi se moglo uspostaviti vlast nad drugom osobom u sadomazohističkom odnosu znači uspostaviti odnos samokontrole i prvenstveno, razvoj ovladavanja nad svojim željama i užicima.

Foucault takav odnos prema sebi i drugome objašnjava kao svojevrsnu pobjedu koja je „definirana postavljanjem solidnog $i$ stabilnog stanja vladavine sebe nad sobom; intenzitet želja i užitaka nije nestao, već ga je umjereni subjekt kontrolirao dovoljno dobro da nikad ne podilazi nasilju. “ 361 , što je izuzetno relevantno za temeljnu etiku S/M prakse u „sigurnom, zdravom i konsenzualnom“ jer, on nastavlja, posljedice mogu biti:

\footnotetext{
359 Ibid, str. $42-43$

360 Michel Foucault, Sex, Power and the Politics of Identity Essential Works 1, Ethics : Subjectivity and Truth, New Press, New York, 1997, str 166

${ }^{361}$ Michel Foucault, The History of Sexuality 2, The Care of the Self, Vintage Books, New York, 1990, str. 69
} 
„uživanje (akolasia), u kojem osoba lako izgubi sebe u svojim užicima i, ekstremno rijetko, neosjetljivosti (anaisthesia), u kojoj ne osjeća zadovoljstva“, dok za razliku od toga ,umjereni pojedinac nije onaj koji nema želja već onaj koji želi ,, samo do umjerenog stupnja, ne više nego što bi trebao, niti tada kad ne bi trebao".

U domeni zadovoljstava, vrlina nije bila koncipirana kao stanje integriteta, već kao odnos dominacije, odnos gospodarenja, ,vladaj željama i užicima“, „provodi moć nad njima“, „upravljaj njima“ (kratein, archein).

Drugim riječima, da bi formirao sebe kao kreposnog i umjerenog subjekta u načinu upotrebe užitaka, pojedinac mora konstruirati sa sobom odnos koji je tipa „,dominacija - submisivnost“", „zapovijed-poslušnost“ $i$,,gospodarenje - docilnost ${ }^{\text {"362 }}$

O ljudskim pravima u pogledu seksualne orijentacija i izbora, Foucault naglašava:

„,Važno je, prvo, imati mogućnost i pravo izabrati svoju vlastitu seksualnost.

Ljudska prava u pitanjima seksualnosti su važna $i$ još uvijek nisu poštovana na mnogim mjestima. Ne bismo trebali smatrati da su takvi problemi sada riješeni.

Potpuno je istinito da je postojalo istinsko oslobođenje u ranim sedamdesetima.

Taj je proces bio veoma dobar i u skladu sa situacijom is mišljenjima, no situacija se definitivno nije stabilizirala. Ipak, mislim da moramo otići korak dalje.

Mislim da će jedan od faktora stabilizacije biti stvaranje novih formi života, odnosa, prijateljstava u društvu, umjetnosti, kulturi i tako dalje kroz naše seksualne, etičke i političke izbore. Ne samo da moramo braniti sebe, ne samo priznavati sebe kao identitet već kao stvaralačku silu. “363

Konstantno proučavanje i „nadziranje“ seksualnosti u razne svrhe jedna od osnovnih tema Foucaultova proučavanja te on dolazi do raznih, često kontradiktornih zaključaka, posebice kad promišlja represiju i odnose moći.

No u pogledu proučavanja i vrednovanja seksualnog ponašanja i morala on implikativno potiče naše promišljanje ostavljajući otvorena pitanja:

„Zašto je seksualno ponašanje, zašto su te aktivnosti i užici koji su im privrženi objekt moralne brige? Zašto ta etička briga, koja se u nekim vremenima, u određenim društvima i skupinama, čini važnija od moralne pozornosti fokusirane na područja individualnog ili kolektivnog života kao što je ispunjenje građanskih dužnosti ? Odgovor odmah dolazi na pamet, znam da su bile predmet fundamentalnih interdikcija, a transgresija istih je smatrana ozbiljnim kaznenim

\footnotetext{
362 Ibid, str. 70

${ }^{363}$ Michel Foucault, Sex, Power and the Politics of Identity Essential Works 1, Ethics : Subjectivity and Truth, New Press, New York, 1997, str 164, prijev.a.
} 
djelom. No to pokazuje neuspjeh prepoznavanja da etička briga nije, u svom intenzitetu i formi, uvijek direktno vezana za sistem interdikcija.

Često je slučaj da je moralna brižnost snažna upravo tamo gdje nema niti obaveze niti prohibicije. Drugim riječima, interdikcija je jedna stvar, a moralna problematizacija je druga stvar. Činilo mi se da je pitanje koje bi trebalo voditi moje ispitivanje slijedeće:

Kako, zašto i u kojim formama je seksualnost bila konstituirana kao moralna domena? Zašto ta etička zabrinutost koja je bila toliko uporna ? Zašto ta „problematizacija“?

No, nakon svega, to je bila prikladna zadaća historije misli, pored protiv historije ponašanja $i$ reprezentacija : definirati uvjete u kojima ljudi ,,problematiziraju“ ono što jesu, što rade i svijet u kojem žive. "364

Kao najveća historijska, kulturološka i filozofska opozicija normativnoj, preskribiranoj seksualnoj etici, a naročito suvremenoj etici sadomazohizma, ,prosvjetiteljska“ je misao je i djelo i „božanstvenog“ i ,ozloglašenog“ markiza de Sadea.

Njegov je „sustav etike“, odnosno antietika, spomenuta kod Beauvoir i Lacana ${ }^{365}$, utemeljena na naturalističkoj filozofiji, prirodnim porivima kao jedinim normama bez limitacija te libertinskom načinu života i nekonsenzualnom sadizmu s ciljem užitka.

Ipak, njegova je filozofsko i književno djelo obilježeno racionalizmom, „hladnim“ i „okrutnim“, suprotstavljenom etici, no njegov racionalizam ima svoju duboku logiku.

Temeljna obilježja Sadeove racionalističke antietike je prosvjetiteljstvo povratka prirodi negiranjem zakona i morala, te je zakon prirode i svojevrstan naturalizam postavljen kao temelj njegove racionalističke ,etike“.

Prema Sadeu, priroda čovjeku ne postavlja niti nameće ograničenja, već je pojedinac slobodan prepustiti se samovolji i užitku, pa makar i štetio drugome, ukoliko u tome nalazi zadovoljstvo, koje je i temeljna maksima njegove antietike.

Kao što je neposredno jasno iz Sadeovih djela, ona su pisani kao libertinski antietički odgoj, poučavajući razvratu, zločinu te protestirajući protiv suosjećajnosti, obazrivosti i brige o drugome - imperativ je isključivo briga o sebi i vlastiti užitak, pa i pod cijenu najvećih zločina, jer, životna logika nalaže da, budući da je čovjek za sve te čine sposoban, oni nisu protuprirodni, već u skladu s njegovom iskonskom prirodom.

Racionalizam i antietika, sirovi naturalizam kao racionalizam, sintagme su koje imaju smisao, međutim, kao povratak prirodi bez zakona, kulture i humanističke etike nisu ozbiljive zbog

\footnotetext{
${ }^{364}$ Michel Foucault, The History of Sexuality 2, The Care of the Self, Vintage Books, New York, 1990, str. 10, prijev.a.

${ }^{365}$ Vidi Jacques Lacan, Kant With Sade i Simone de Beauvoir, Must We Burn Sade, op.a.
} 
opstanka civilizacije i stoga nedopustive, te je stoga i autor istih ideja cijeloga života podlijegao najstrožim sankcijama, i zbog svojih djela, no i svojih pisanih djela.

Sadeov radikalni, revolucionarni obrat, koji je do današnjeg vremena smatran podjednako etički blasfemičnim, no opet iznimno odvažnim, bilo je upravo uvođenje antimoralističkog kategoričkog imperativa kao modusa vivendi u obliku logički - sistematičnog načina razmišljanja kao sustava pravila promišljanja ljudskog djelovanja, ponašanja i nadasve, egoističnog i egocentričnog libertinizma, koje se najbolje manifestiraju u njegovim napucima o ophođenju prema drugima postizanju osobnog zadovoljstva i supremacije.

Osnova sadeovske racionalističke antietike je ono vitalno i prirodno, u skladu s ljudskom prirodom u njenom izvornom obliku, životu koji ne podliježe kulturi i njenim normama, za razliku od moralno - asketskih „neprirodnih“ Kantovih ideala.

Lacan govori upravo o tome u svom eseju "Kant with Sade", ističući jasne paralele između Sadeove misli i racionalizma Immanuela Kanta, pri čemu se referira na Kantovu tezu čistoga uma te s njime komparira Sadeov racionalizam ${ }^{366}$, baziran na jedinstvenom lascivnom demonstrativnom i nadasve deskriptivnom narativu, što je kasnije najdetaljnije elaborirao Deleuze u svojoj iznimnoj studiji o mazohizmu. ${ }^{367}$

On smisleno konfrontira Sadeovu univerzalnu negaciju kao ideju čistog razuma ${ }^{368}$ s Kantovim konstatacijama kategoričkog imperativa i ideje Dobra, kojemu razum mora težiti, kao prethodan tjelesnom, podređujući tijelo moralnim zakonima.

Lacan time usporedno suprotstavlja Kantovu maksimu razumskog i ćudorednog sa Sadeovim imperativom joussaincea, kao imperativu tijela i paradoksa u kojem smo mi kao subjekt Drugi, objet $A^{369}$ te je važno istaknuti da već na samome početku naglašava ulogu Sadeovog "budoara" kao mjesta svojevrsnog učenja, uspoređujući ga sa školama i licejima i u tome mu smislu daje veliku važnost za razdoblje neoklasicizma i racionalizma. ${ }^{370}$

Sadeova logika i relacija želje i Drugog specifični su te onkraj svakog, pa i suvremenog etičkog i estetičkog shvaćanja jer za njega je bitak ili vrhovno biće koje postavlja na mjesto nepostojećeg boga, "Biti / Biće - Nadmoćan - U - Pokvarenosti",371, u destruktivnom zadovoljenju želje.

\footnotetext{
${ }^{366}$ Jacques Lacan, Kant With Sade, Ecrits, W.W. Norton \& Company, New York, 2006

367 Gilles Deleuze, Coldness and Cruelty, 2000, Zone Books, New York, 2013

368 Ibid, str. 29, 35

369 Jacques Lacan, Kant With Sade, Ecrits, W.W. Norton \& Company, New York, 2006, str. 646 - 650

370 Ibid. str. 645.

371 Ibid. str. 652, prijev.a.
} 
Budući da je on kao subjekt Drugi, želja se za njega može shvatiti kao želja za jouissanceom, no taj je odnos daleko složeniji jer je osnovni zakon podređenost užitku i time dolazi do podijeljenosti i subjekta i objekta u sferi fantazije ${ }^{372}$ te je Sadeova fantazija relacija želje, praktičnog uma, sirovog subjekta užitka i njegovog objekta koji je žrtva nadmoćnog subjekta kao Drugog. ${ }^{373}$

U tome se upravo vidi racionalnost Sadeove "antietike", koja postavlja vlastite norme, protivne i svemu humanističkom, a naročito hipokrizijama kršćanstva i društva svoga vremena. Jouissance kao zadovoljenje najokrutnijih želja na granici ratia i fantazije, želja je želja Drugog, odnosno moja, objekt, samo sredstvo mog užitka, a subjekt tada sam postaje vrhovno biće bez ograničenja i slijedi samo vlastite zakone na putu do potpunog zadovoljenja, koji nikad ne prestaje, već samo mijenja cilj svoje želje i želju samu.

Simone de Beauvoir, u svom opsežnom kritičkom eseju "Must We Burn Sade”, ,staje u obranu” Sadea, zaključkom da je on od svoje seksualnosti stvorio svoju etiku te da se upravo u tome manifestira njegova originalnost misli i argumentima kojima opravdava svoje principe i njima spontano inspirane seksualne aberacije. ${ }^{374}$

On je "podredio svoju egzistenciju svom eroticizmu jer mu se eroticizam činio jedinim mogućim ispunjenjem njegove egzistencije" 375 i upravo je stoga i utemeljio vlastiti sustav vrijednosti, prevladavanjem tadašnjeg malograđanskog morala inzistiranjem na vladavini iskonske ljudske prirode, koliko god ona okrutna bila.

Beauvoir uviđa da je Sade izabrao život u Imaginarnom i zbog toga se osjećao nadmoćnim nad drugima, izvan svih granica i utemeljenih pravila ${ }^{376}$ te je njena vizija Sadeovog djela veoma široka, s najvećim naglaskom na logičnom, racionalnom opravdanju "libertinske filozofije života" i cilj je njenog eseja analizirati upravo njegovu filozofsku misao, premda ga je u kontekstu literature smatrala prilično osrednjim, čak lošim autorom u pogledu stila i jezika. ${ }^{377}$ Sade je tako bio od iznimnog interesa i važnosti mnogim velikim teoretičarima, od Nietzschea, potom Freuda i kasnijih generacija psihoanalitičara te brojnim feminističkim autoricama, upravo zbog svojih višeslojnih aspekata ocrtavanja i filozofiranja ljudske prirode i zastupanja

\footnotetext{
372 Ibid. str. $652-653$.

373 Ibid. str. $652-653$.

${ }^{374}$ Simone de Beauvoir, Must We Burn Sade, 1966, Grove Press, New York, str. 3 - 9.

375 Ibid. str. $14-15$, prijev. a.

376 Ibid. str. $14-18$.

377 Ibid. str. $3-6$.
} 
principa užitka i pod cijenu činjenja zla, što i jeste njegova etika, u kontrastu s Kantovim moralnim imperativom, no opet racionalnog promišljenih čini i obrazloženja.

Sade kao antiidealist glorificira sve ljudsko, odviše ljudsko, nietzscheanski formulirano, postavljajući pravila prirode kao osnovna i jedina koja slobodan čovjek mora slijediti, a priroda dozvoljava apsolutno sve i ne poznaje ni inhibicije niti restrikcije i time libertinski naturalizam poznaje samo antietiku.

Kulturna ograničenja produkt su ljudske civilizacije, te uzrok nezadovoljstva, što je najbolje opisao Freud u svom spisu „Nelagoda u kulturi“, no neophodna za opstanak ljudske vrste i napredak, međutim, za Sadea, ali i Nietzschea, ona su refleksije malograđanskog morala, nametnutog ponašanja morala protivnog ljudskim instinktima, koje je potrebno prevladati $u$ svrhu vlastite slobode i zadovoljstva.

Elementarno pitanje u kontekstu sadomazohističke seksualnosti kao načina života i svojevrsne Sadeove filozofije, jest do koje mjere može i smije sezati sloboda i vladavina ljudske prirode i nasilnih poriva, ima li ona uopće granica te koje njene granice mogu i moraju biti ?

Sadeov odgovor znamo i upravo iz njegovih lascivnih, pornografskih deskripcija čitamo proklamaciju njegovog manifesta „slobode“ i filozofije života.

Predmet Sadeove kritike i osude prvenstveno je kršćanski moral, a „kršćanski grijeh“ razvrata i sadizma te brojni moralni prijestupi srž su Sadeove filozofije, prikazane i oprimjerene konkretnim mislima i činovima, naturalističkom formom i vulgarnim stilom, zbog koje je i bio proglašavan lošim pornografskim autorom, i u svoje vrijeme i u 20. stoljeću.

Kao što sam već pojasnila, iza njegove pornografske, naizgled „,isprazne“ forme, krije se duboka filozofija racionalističkog naturalizma, estetike ružnoće i antietike koja je gotovo jednako sustavno razrađena kao Kantova etika.

Zbog svoje radikalne misli je i postao priznat i cijenjen te nezaobilazan autor teorijama književnosti, a najbolji dokaz da je autor od presudne kulturološke i filozofske važnosti upravo je činjenica da se suvremeni teoretičari danas njime bave više nego ikada ranije.

Njegova filozofija libertinskog života i razumijevanje sadističke seksualnosti protivno je i svjetovnoj etici, budući da je njegov imperativ individuuma činiti što ga je volja, odati se isključivo užicima ne uzimajući u obzir niti štetu nanesenu drugima, ni društvene norme, niti vlastitu reputaciju, što je izvrsno opisano u „Juliette or the Misfortunes of Virtue“““, koja takav odgoj stječe i postupno prihvaća kao mlada djevojka u samostanu, „učenica“ „beskrupulozne“ i „razvratne“, nadasve racionalne Madame Delbene:

„Fundamentalno pravilo moje filozofije je prezir prema javnom mišljenju. 
Ne možeš zamisliti do koje sam mjere prezirno indiferentna prema svemu što bi se o meni moglo reći. I kakav koristan ili drugi utjecaj može mišljenje vulgarnih budala imati na našu sreću? Samo naša prenježna osjetljivost dopušta da nas pogađa, ali ako čvrstim i bistrim razmišljanjem uspijemu u umrtvljavanju ovih osjetljivosti, s vremenom dosežući stadij kad je efekt tih mišljenja prema nama ništavan, čak i kad su u pitanju stvari koje nas najintimnije dotiču, tada postaje potpuno nezamislivo da dobro ili loše mišljenje drugih ima ikakvog utjecaja na našu sreću. Mi sami možemo stvaramo svoje osobno blagostanje, hoćemo li biti sretni ili nesretni, ovisi isključivo o nama, o našoj savjesti $i$ možda čak mnogo više o našim stavovima koji sami dopunjuju čvrstu podlogu inspiracije naše savjesti.,, 378

Sadeova životna filozofija vođena imperativom užitka, antietika argumentirana „prirodnim“ težnjama za nasiljem i seksualnim užitkom u istome ima nadasve interesantne refleksije o savjesti, koja ima brojne poveznice s Nietzscheovim tezama savjesti, posebice „loše savjesti“ te distinkcije ,dobrog“" i ,lošeg“":

„, Savjest je čisto i jednostavna konstrukcija ili predrasuda koje su insinuirane u nas ili etičkih principa koje mi sami osmišljamo sa svoje strane.

Istinito je da je potpuno moguće, ako za materijalne upotrijebimo osjećajne principe, stvoriti savjest koja će nas proganjati i gristi, pogađati nas najranjivije u svakoj prilici - da se nađemo zaposjednuti savješću tako tiranskom da za svoje senzualno zadovoljstvo, ne uspijevamo izvesti niti jedan zabavan plan do njegovog potpunog, najbogatijeg detalja, niti one zlobne, pretjerano kriminalne. "379

Naizgled nepremostive i kontroverzne opozicije potpuno suprotnih perspektiva Sadea i Kanta zbog najkonzistentnije je objasniti tumačenjem kategoričkog imperativa, koji zaista može biti interpretiran i u Sadeovom duhu.

Samim time što je kategorički, on ne podrazumijeva nužno određenu etiku i može se logički primijeniti na bilo koji etički sustav ili neetički sustav vrijednosti.

Kantova formulacija kategoričkog imperativa jest:

„Kategorični imperativ, koji općenito izriče samo ono što je obvezatno glasi:

Djeluj prema maksimi koja ujedno može vrijediti kao opći zakon.

Svoja djelovanja moraš prvo promotriti sa stajališta njihova subjektivna načela; no je li to načelo i objektivno valjano, to možeš razabrati samo po tome da li se ono kvalificira za opće

\footnotetext{
378 Donatien Alphonse Francois de Sade, Juliette, Grove Press, New York, 1968 str. 15, prijev.a.

379 Ibid, str. 18, prijev.a.
} 
zakonodavstvo, jer tvoj ga um podvrgava kušnji u kojoj sebe zamišljaš kao općeg zakonodavca." 380

Evidentno je i jasno da je Kant imperativ djelovanja doživljavao kao subjektivan, apstraktan pojam jer govori:

„,Maksima je subjektivni princip djelovanja koji subjekt sam sebi postavlja kao pravilo (kako naime hoće djelovati iz volje proizlaze zakone, iz htijenja maksima. "381

Možemo li tada etiku i Kantove ideje moralnosti i legaliteta staviti pod zajednički nazivnik ? Možda je, između ostaloga, i to jedan od razloga zbog koji Lacan nalazi brojne sličnosti Kantu i Sadeu, pored poučavateljskog pristupa čitatelju ?

Sade i Kant, kao što Lacan i ističe u svom eseju „Kant avec Sade“ imaju zajedničke odrednice filozofske misli, pored enormnih razlika u filozofiji života, načinu života i poimanja moralnost, no obojica imaju etički sustav i dosljedan pristup istome.

Njihova je najveća zajednička karakteristika upravo činjenica, da, kao dva suprotna pola, ne promišljaju toliko pojam etike, već je Kant zaokupljen pitanjima moralnosti i ćudoređa u čemu je jednako ekstreman koliko i Sade u svom inzistiranju na negaciji i anihilaciji svih utemeljenih kulturnih moralnih vrijednosti.

Kategorički je imperativ stoga problematičan u svome razumijevanju, jer budući da je subjektivan, svatko ga može tumačiti prema vlastitoj želji i volji i shodno tome, postaviti kao maksimu svoje nemoralno ili neetičko djelovanje.

Tradicionalni problem razumijevanja etike nalazimo stoga upravo u Kantovom imperativu, jer ako djelovanje pojedinca mora biti usmjereno prema njegovim idejama koje bi sam postavio za univerzalni moralni zakon, tada kategorički imperativ, gotovo koliko i Sadeova priroda, implicira slobodu odlučivanja.

Do koje mjere Kantov kategorički imperativ dozvoljava subjektivnost i slobodu pojedinca ?

Što je tada etika, na koji je način uopće možemo odrediti, jer ona je, kod Kanta apstraktan pojam, od Sadea konkretniji, no uvijek eksplicitno subjektivan i u tom kontekstu o njoj u suvremenoj filozofiji ne možemo smisleno ni govoriti.

I Sade i Kant imaju argumentirane stavove, no Kant uvodi istovremeno inkluzivne i razlikovne pojmove moralnog i legalnog i time ne postavlja dovoljno jasnu etiku pitanjima tjelesnih užitaka, u kojima je restriktivan do mjere apsurda.

Etika ne smije biti postavljena subjektivno i arbitrarno, s prevelikom slobodom interpretacije, no Kant ipak postavlja zakon, racionalnost, kritički um kao vrhovne odrednice moralnosti

\footnotetext{
380 Immanuel Kant, Metafizika ćudoređa, Matica hrvatska, Zagreb, 1999, str. 22

381 Ibid, str. 23
} 
ljudskog djelovanja, a Sade oslobađa ono Nietzscheovo „dionizijsko“ u svom najsurovijem obliku, postavljajući užitak za kategorički imperativ.

Sadeova je ,etika seksualnosti“ nasilni, nekonsenzualni sadizam, užitak u povređivanju drugih, no obraća pozornost i na mazohiste, koji, postajući žrtve, dolaze do spoznaje svijeta i sreće jedino pod uvjetima preskribiranom ,libertinskom antietikom“, jer samo je ona u skladu s prirodom i kao takva ispravna.

Kantova je „etika“ moralnost i legalnost, a Sadeova odanost poroku, libertinstvo i razvrat, zločin, nasilje bez granica - priroda kao jedini „moralni“ zakon:

„Da bi opravdali bilo koje ekstremno ponašanje, prava mudrost mora nas savjetovati da usvojimo racionalnu, umjerenu poziciju između ekstravaganca i pričina i da razvijemo stavove koje će se dokazati simultano kompatibilni s napucima koje smo individualno primili od Prirode i zakone zemlje u kojoj živimo; sve su to stavovi iz kojih moramo razviti svoju savjest.

I zbog toga što prije počnemo raditi na usvajanju filozofije kojom namjeravamo biti vođeni, time bolje, jer ta nam filozofija pribavlja svoju formu u savjest, a naša savjest je odgovorna za vladanje i upravljanje svim djelima koje činimo u životu. "382

Sadeova antietika sadržana je od filozofskih teza koje opravdaju i propagiraju antimoralno i protuzakonito djelovanje, a njegova subjektivna maksima je vlastiti užitak, dok su razvrat, nasilje i zločin najveće vrline njegove misli:

„Ne osjećamo li da Vrlina, koliko god predivna, postaje najgori od svih stavova kad se pokaže preslabom da se natječe s Porokom, i da je, u potpuno pokvarenom dobu, najsigurniji smjer slijediti druge? Oni bolje upućeni, zloupotrebljavajući stečeno koje su stekli, neće li reći, da nema zla tamo odakle se nije rodilo neko dobro?

I neće li izjaviti, da se u tom slučaju mogu odati zlu, jer zaista, ono je jedno od načina proizvođenja dobra? Neće li dodati, da nema razlike za opći plan je li netko, bio kakav god, po svojoj preferenci dobar ili loš, da ako jad progoni vrlinu, a prosperitet prati zločin, one stvari koje bivaju kao jedno u pogledu Prirode, daleko je bolje pridružiti se zlima koji cvjetaju, nego biti ubrojen među kreposne koji propadaju ?“383

Etika užitka kao cilja te briga samo o sebi povezuje nas s Nietzscheovom filozofijom „slobodnog duha“ i „,višeg čovjeka“, i s njima će biti izložena neophodna komparacija.

U Nietzschovoj odlučnoj i nadasve ,antikantovskoj“ teoriji prevrednovanja zastarjelih i „,neprimjerenih“ moralnih vrijednosti izraženima eksplicitnim tezama o zabludama morala te

\footnotetext{
382 Ibid, str. 15, prev.a.

383 Donatien Alphonse Francois de Sade, Justine, Grove Press, New York, 1968, str. 452 - 453, prev.a.
} 
postavljanjem novih imperativa odvažnom i slobodnom čovjeku, nalazimo bitne misli uspostave modernih, pluriperspektivističkih sustava vrijednosti:

„Opreznim sam prstom ukazao na sve veće produhovljenje $i$ „obogotvorenje“ okrutnosti koja se provlači kroz cijelu povijest više kulture.

Gledati patnju pruža zadovoljstvo, nanositi patnju pruža još veće zadovoljstvo - to je opor stavak, ali suviše moćan, ljudski - odviše - ljudski temeljni stavak.

Nema svečanosti bez okrutnosti : tomu nas uči najstarija, najduža čovjekova povijest - a i u kazni je toliko svečanog!

Treba izričito posvjedočiti da je u ono vrijeme kad se čovjek još nije stidio svoje okrutnosti život bio vedriji nego sad...bolesno raznježenje i postajanje moralnim, pomoću kojih zvjerka „čovjek“ uči na posljetku stidjeti se svojih instinkata. “384

Premda Nietzschea ne možemo nipošto nazvati humanistom u normativnom smislu, jer odbacuje upravo ono tradicionalno kulturno uvjetovano ljudsko kao „moral stada“, a njegova temeljna ideja novog modusa vivendi kao pluriperspektivistička teorija formulirana je istovremeno $\mathrm{u}$ duhu povratka historijskim idealima $\mathrm{u}$ harmoniji $\mathrm{s}$ dekonstrukcijom kulture njegova vremena i stoga može opravdano biti smatrana inovativnom humanističkom etikom: „,Moralni pojmovni svijet „krivnja“, ,savjest“, ,,dužnost“ ima svoje podrijetlo - njihov je početak bio dugo i temeljito zalijevan krvlju.

I ne bi li se smjelo dodati da taj svijet u osnovi nikad više nije izgubio stanoviti vonj krvi $i$ mučenja ? Čak i u staroga Kanta: kategorički imperativ odiše okrutnošću.

Tu je prvi put isprepleten onaj jezivi splet ideja „,krivnja i patnja“. Upitajmo još jednom u kojoj mjeri patnja može biti izravnanje „,dugovanja“? Onoj mjeri u kojoj je nanošenje patnje drugome bilo najveće zadovoljstvo, u onoj mjeri u kojoj je oštećeni gubitak, uračunajavajući $i$ neugodu zbog gubitka, se zamijenio za jedno izvanredno protivno uživanje : za nanošenje patnje - jedna prava svečanost. “385

Transformacija u novu vrstu čovjeka za Nietzschea je značila povratak prirodnom, ali istovremeno nadilaženje većinskog morala i etike prijelazom u višu kulturu, te otuda i njegov koncept „nadčovjeka“, kao uspostava nove etike volje i moći, za one slobodne, duhovno najsnažnije, sposobne za stvaranje vlastitih vrijednosti:

„Taj oslobođen, taj gospodar slobodne volje, taj suveren, koliko povjerenja, koliko strahopoštovanja pobuđuje - on ih „zaslužuje. Slobodan“ čovjek, posjednik ustrajne,

\footnotetext{
${ }^{384}$ Friedrich Nietzsche, Uz genealogiju morala, AGM, Zagreb, 2004, str. 59

${ }^{385}$ Friedrich Nietzsche, Uz genealogiju morala, AGM, Zagreb, 2004, str. 59 - 60
} 
nesalomljive volje ima u tom posjedu i svoje mjerilo vrijednosti : polazeći od sebe $i$ odatle, gledajući na druge, poštuje ih ili prezire. "386

Prevladavanje (do)tadašnjeg čovjeka za njega je značilo transcendenciju u „višeg“ čovjeka, slobodnog čovjeka, koji ima hrabrosti za slobodu, bivajući sam sebi mjerilo, postavljajući i slijedeći vlastite vrijednosti i norme, to je Nietzscheov „slobodni duh“, u kome vidimo bliskost Sadeovoj teoriji slobodnog i suverenog čovjeka:

„Čovjek je pomoću ćudorednosti ćudoređa i socijalne luđačke košulje doista učinjen proračunljivim. Postavimo se sad na kraj tog dugotrajnog procesa...naći ćemo suvremeni individuum koji je samo sebi jednak, koji se ponovno oslobodio ćudorednosti ćudoređa, autonomni, nadobičajni individuum (jer se „,autonoman “ $i$,ćudoredan “ uzajamno isključuju). Ukratko, naći ćemo čovjeka vlastite, neovisne i ustrajne volje i u njemu pravu svijest o moći $i$ slobodi. "387

Relevantnost Nietzscheove filozofije za sadomazohističku seksualnost je upravo njegova centralna teza o „novim“, slobodnim ljudima.

Samo slobodne osobe iznimno snažne volje, odvažne, samosvjesne i bezgranično samopouzdane mogu se upustiti u BDSM odnose jer su sposobni promišljati postavljati vlastite norme i granice i živjeti u skladu s njima, sa sobom.

Odvažne osobe se izgrađuju čitavog života i iskustvo koje stječu upoznavanjem svoje sekualnosti i manjim i većim ,transgresijama“ kulturnih normi pomaže im u izgradnji vlastite ličnosti te poštovanje prema sebi i drugima.

Možemo ih zamisliti kao Nietzscheove ,slobodne duhove“ - visoke i duhovno snažne uspješne, a nadasve psihički stabilne, uspješne i odvažne.

Sadeova racionalistička filozofija elaborirana je hladnim i okrutnim argumentima, ona je naturalistički - racionalno nastrojena antietika užitka u okrutnosti.

U današnjem promišljanju etike i moralnosti sadomazohističke seksualnosti, i Kantovo i Sadeovo stajalište bila bi potpuno neprihvatljiva, budući da je temeljni naglasak na humanosti, konsenzualnosti i brizi o drugome i sebi, kao preliminarni uvjet same seksualne prakse i užitka. U Sadeovim djelima nalazimo deskripcije najnasilnijih seksualno nasilnih praksi i oblika ponašanja koje danas možemo pronaći kod ektremnih sadista i mazohista, no uz pristanak, dok Sade svoje nekonsenzualno tjelesno i seksualno „opravdava“ tezom da su žene prirodno predisponirane kao seksualni objekt muškarcima, no ipak, da ih ne mogu posjedovati kao robove u svom djelu.

\footnotetext{
${ }^{386}$ Ibid, str. $59-60$

387 Ibid, str. 60 - 61
} 
Žene kao isprva nevine žrtve postaju Sadeovim naukom ,prisilni mazohisti“ te nauče prihvaćati svoju nametnutu ulogu i do izvjesne mjere pronaći u njoj užitak, no time pronalaze i vlastitu sadističku stranu i zbog toga je Sadeova je pozicija o seksualnosti složena je i kontradiktorna. Mnoge izrazito seksualno lascivne i nezasitne žene, kao Madam Dolmance u „Filozofiji budoara“ priznaju vlastiti užitak u svojoj podređenosti razvratnim muškarcima i stoga Sadeov opus nalazi i danas ushićenje mazohističnih osoba. ${ }^{388}$

Individuum je svojim bitkom hedonistički subjekt neumjerenog nasilja, silovanja, teških povreda drugoj osobi u čemu nalazi najveći užitak libertinstva, no njegovi osnovni protagonisti su žene, koje su, s jedne strane, seksualni objekti, a s druge, učiteljice životne filozofije te okrutne, razvratne vladarice svog života.

Njegov naizgled deterministički falocentrizam povezan je s ženskom supremacijom u brojnim djelima i to nam dokazuje širinu njegove misli te shvaćanja sebstva i seksualnosti te međusobni odnos sadizma i mazohizma u njihovim najprirodnijim, najsurovijim oblicima, koji ne prestaju biti motivi suvremenih $\mathrm{S} / \mathrm{M}$ praksi.

Nanošenje boli, povređivanje i okrutnost, samo kao konsenzualne prakse unutar scenarija ili scene, prihvatljive su i mogu se prakticirati u sadomazohističkoj seksualnosti, kao što je i shvaćanje libertinstva danas nešto posve bezazleno:

„, Kad se upustimo u malo prljave igre, koliko god okrutne, zadovoljstvo koje ona pruža, ili dobit koju pruža, je dovoljno jaka utjeha za nevolju, koliko god silovitu i oštru, koju naše zabavljanje može donijeti našim drugovima.

Prije nego počnimo djelo, ne predviđamo li jasno sve nezgode koje će uzrokovati drugima? Naravno, i ta misao, radije nego da nas zaustavlja, potiče nas i pobuđuje; i bez prolijevanja suvišne suze zbog nečeg što ne možemo urediti drugačije, pokrenimo sav trud da nam slijedećeg puta ne nedostaje takta, okrenimo tu nezgodu u svoju korist i steknimo iskustvo potrebno da poboljšamo svoje metode, tako ćemo osigurati svoju nekažnjenost, zavijemo li svoju svoje nepravilnosti u deblje velove i potpunu tamu. Ali, ne domišljajmo se, besmislenim žaljenjem, iskorjenjivanju zdravih principa; jer to loše ponašanje, ti zlobni, kriminalni i odvratni hirovi, dragocjeni su atributi, pronašli su nam užitak, oduševili su nas i onaj tko se lišava onoga u čemu uživa nije mudar.

Istinita mudrost ne sastoji se od represije poroka, jer poroci konstituiraju, čitavu sreću koja nam je u životu dana, pa učiniti to, bilo bi zauzeti ulogu vlastitog krvnika. Istinit i odobren

\footnotetext{
${ }^{388}$ Donatien Alphonse Francois de Sade, Justine, Philosophy in the Bedroom and Other Writings, Grove Press, New York, 1968
} 
način je predati se porocima, prakticirati ih do najveće mjere, ali s dovoljno brige i opreza da budemo osigurani protiv opasnosti ili iznenađenja. "389

Svojim provokativnim i ,inspirativnim“, no uvelike promišljenim filozofskim djelima, Sade vremenom sve više zaokuplja veliku pažnju teoretičara književnosti, filozofa te zauzima važno mjesto na policama ljubitelja erotske literature BDSM praktikanata.

Razlog tome je što njegova proza „govori“ čitatelju, „poučava“ ga užitku, potiče imaginaciju i fantaziju, no istinski BDSM praktikanti znaju razliku između zdrave i sigurne seksualnosti i „ekscesivnih“ Sadeovih činova koje možemo interpretirati i metaforički, jer, vjerojatno, niti jedna „zdrava“ ili većina SM orijentiranih osoba neće u realnosti prakticirati većinu radnji i iz „120 dana Sodome“, dok neke mogu biti jako zanimljiv poticaj imaginaciji za neke mnogo „blaži““ eksperimente.

Važno je uspostaviti distinkciju između imaginacije i realiteta, jer istinske, etički dopustive želje nalaze se istovremeno i u fantaziji i u realitetu i kao takve su ozbiljive kao konsenzualne, prakse kojima je cilj tjelesni užitak i psihičko zadovoljsvo.

389 Ibid, str. 22, prijev.a. 


\subsection{ZAKLJUČAK}

\section{Libertinizam, sadomazohizam i etika}

BDSM i libertinizam kao uživanje u seksualnim praksama moraju biti čvrsta opozicija „,izvornom“ shvaćanju sadomazohizma, Sadeovoj antietici, u kojoj je izvor užitka sadističko postupanje s podređenom osobom, psihičko zlostavljanje štetno za psihu, teškog fizičkog ozlijeđivanja, odnosno nanošenje tjelesnih povreda te povrede prava pristanka i stoga je neophodno naglasiti ovu distinkciju BDSM - a i nasilja, koja je i danas predmet brojnih polemika zbog nerazumijevanja i pogrešnih pristupa uzrokovanih manjkom edukacije i tolerancije prema „drugačijim“ seksualnostima.

BDSM je stoga potpuno kontrariran praksama iz Sadeovih djela, dakle, svome „službenom“ književnom početku, iako su i prije Sadea izvjesni autori od 15. do 18. stoljeća (od P. Della Mirandole do Rousseaua), opisivali eksplicitni, no konsenzualni, mazohizam kod muškaraca, dok je prvi književni mazohizam u korelaciji sa sadizmom u ženskoj perspektivi oživio tek u 20. stoljeću kod Pauline Reage.

Upravo je tada definiran „,ugovor o posjedovanju“, koji je i danas temelj takvog fascinantnog odnosa i osnovno je naglasiti da je S/M ugovor, bio on Master/slave ili Dom/sub specifičan primarno zbog međusobnog odnosa poštovanja između dviju osoba i temelji se i odražava obavezom te brigom prema partneru.

Iz tog razloga u nekim stvarima ima izvjesnih sličnosti s bračnim ugovorom, premda, naravno, zahtijeva od ugovornih strana daleko više od bračnih obaveza te je u svojoj suštini mišljen kao opozicija, „kontraugovor“ u odnosu na tradicionalnom braku ili zajednici, subverzija same koncepcije bračnog ugovora.

Njegova „subverzivnost“ je u slobodi kao osnovnom polazištu, a istovremeno, pristanku na ekstremnu vrstu posjedovanja, koje može biti shvaćeno i formulirano metaforički, ali često i doslovno, sve dok jedna strana ne odluči raskinuti ugovor.

Ugovor je temeljen na slobodi kao opozicija tradicionalnim ugovorima kojima se ustanovljuju institucije društva kao što su brak i legitimne zajednice, već je utemeljen na etici slobode te izbora načina života i seksualnosti.

Takav oblik ugovorne formulirane zajednice ne uključuje samo seksualne BDSM prakse, već obuhvaća cjelokupan modus vivendi, kao što su poslušnost, pravila ponašanja u svakoj pojedinoj situaciji, aktivnosti i dnevne obaveze o kojima se submisivna osoba ima pravo i 
obvezu izjasniti, a dominantna joj osoba mora prilagoditi svoje zahtjeve te garantirati optimalne uvjete i sigurnost, o čemu moraju detaljno i racionalno „pregovarati“" te konačno ugovoriti. Predaja sebe uz bezuvjetno povjerenje i pristanak na podređivanje načina vlastitog života $u$ gotovo svakoj ili svim sferama kontroli dominantne osobe velika je odgovornost, a dominacija još veća jer zahtijeva, pored preuzimanja potpune kontrole maksimalnu brigu o partneru i stoga obje pozicije moraju biti ozbiljno, voljno i svjesno shvaćene za realizaciju uspješnog odnosa obostranog zadovoljstva.

U sadomazohističkoj seksualnosti osnovna je etika egalitarnosti koja je jedino u takvom odnosu istinski ostvariva zbog same prirode BDSM odnosa, koji mora biti temeljen na međusobnom poštovanju, brizi i svojevrsnom „obožavanju“ drugog.

BDSM seksualnost i praksa je slobodna od rodno - društveno nametnutih uloga i normi, već svaki pojedinac oblikuje svoj karakter, analogno urođenoj predispoziciji i iskustvenoj preferenci te svome partneru pruža nešto doista drugačije i posebno, ostvarujući senzacije i psihičke doživljaje kakve tradicionalna „,vanilla“, patrijarhalna seksualnost gotovo nikada neće moći ponuditi niti dopustiti.

Upotrebu užitaka u Foucaultovom u drugom dijelu „Historije seksualnosti“, možemo misliti kao seksualnu disciplinu, vladanje užitkom i podređivanje istom, što podrazumijeva pozicije dominacije i submisivnosti, jer ,upotreba“ ima značenje i upotreba drugog u svrhu užitka, upotreba sebe i vlastitog tijela.

Kao osnovu i cilj upotrebe užitka morali bismo razumjeti sigurno i konsenzualno postupanje s partnerom prema etičkim načelima brige o drugome i brige o sebi u svrhu užitka i stvaranja slobodne i unikatne seksualne zajednice.

Sadomazohistička seksualnost ima svoju naizgled ,paradoksalnu“ logiku, u kojoj se ekstremne, „grube“ prakse provode s maksimalnom brigom i afekcijom, poštovanjem, senzuanim osjećajima i ljubavlja i to je suština istinskom BDSM - a između ozbiljnih, posebice stalnih, dugotrajnih partnera.

Naravno, i povremeni, part time, casual partneri, tijekom privatnih sessiona, a naročito u S/M klubovima moraju slijediti pravila konsenzualnosti i sigurnosti, osim što je jasna elementarna razlika u dubini i granicama odnosa.

Od perpetualne korelacije subjekt - briga - seksualnost - užitak, koncipirana je i upravljana dinamika sadomazohističke seksualnosti, na psihičkoj i tjelesnoj razini.

Svrha i korištenje užitaka određeno je etičkim djelovanjem i brigom, svojevrsnom umjerenošću, odnosno pravilima te je BDSM praksa, ujedno i veoma kompleksan ali iskusnim participantima ili veoma prirodna jer odražava njihovo oslobođenje. 
Foucault detaljno objašnjava na koji način provođenje praksi slobode zahtijevaju društveno i seksualno oslobođenje:

„Moramo uvesti koncept dominacije. Analize koje pokušavam provesti esencijalno se oslanjaju na odnose moći. Time mislim nešto drugačije od stanja dominacije.

Odnosi moći su izuzetno rašireni u ljudskim odnosima.

Analiza odnosa moći je izuzetno kompleksno područje; nekad se susrećete s onim što bi se moglo nazvati stanjem dominacije u kojima odnosi moći, umjesto da budu mobilni, dozvoljavaju raznim sudionicima da usvoje strategije koje ih modificiraju da ostaju blokirani, zamrznuti. Slažem se da je je oslobođenje ponekad političko ili historijsko stanje za praksu slobode, uzmimo seksualnost kao primjer.

Ali to oslobođenje ne daje povoda sretnom ljudskom biću prožetom seksualnošću putem kojeg bi subjekt mogao postići potpun i zadovoljavajuć odnos.

Oslobođenje utire put za nove odnose moći koji moraju biti kontrolirani praksama slobode.

Postoje situacije u kojima su oslobođenje i borba za oslobođenjem nezamijenjivi za praksu slobode. Jer što je etika ako ne praksa slobode, svjesna praksa slobode?

Sloboda je ontologijski uvjet za etiku. A i etika je smatrana formom koju sloboda poprima kad je upoznata s refleksijom. “390

U društvenom kontekstu i prostoru, subjektivnost i seksualnost moramo promatrati kao elementarne sile koje proizvode odnose znanja i moći u cjelini multikulturnosti, no i partikularnim BDSM zajednicama te konačno u sferi privatnog interpersonalnog odnosa u sadomazohističkoj seksualnosti.

Komparacija i međudjelovanje sfera ,javnog“ i ,privatnog“ BDSM - a, utemeljeni su na odnosu „žudnja - subjekt - seksualnost - etika“, kojeg Foucault promatra u historijskim relacijama, konstatirajući da:

„Govoriti o seksualnosti kao historijski singularnom iskustvu podrazumijevalo je:

1) formaciju znanosti (savoirs) koje se na nju odnose, 2) sisteme moći koji regulirau njene prakse i 3) forme unutar kojih su individualci sposobni i primorani prepoznati sebe kao subjekte seksualnosti. “391

O pogledu individuuma kao subjekta seksualnosti i istovremeno subjekta etike, koji stvarajući svoju seksualnost i sustav, no pritom biva predmet proučavanja znanstvenih i disciplinarnih

\footnotetext{
${ }^{390}$ Michel Foucault, Essential Works 1, The Ethics of a Concern for Self as a Practice of Freedom, New Press, New York, 1997, str. 283 - 285

${ }^{391}$ Michel Foucault, The History of Sexuality 2, The Care of the Self, Vintage Books, New York, 1990 str 4 , prev.a.
} 
mehanizama moći Foucault napominje da je ,,analiza diskurzivnih praksi omogućila ulaženje u trag formacijama disciplina (savoirs) izbjegavši dilemu znanosti protiv idelogije, analiza odnosa moći gledanje istih kao otvorenih strategija, izbjegnuvši alternativu moći stvorenu kao dominaciju ili izloženu kao simulakrum“. 392

Subjekt kao subjekt seksualnosti je tako doživljen je kao „seksualni subjekt, želeći subjekt, općepriznat kao teoretska tema“, te je „iskustvo seksualnosti, kao singularna historijska formulacija dominirano principom želećeg čovjeka“"393.

Jasno je Foucault elaborira subjekt kao centar odnosa moći i znanja o seksualnosti te njezine prakse, vlastite spoznaje o sebi kao subjektu koji želi putem ,historijske i kritičke studije želje iželećeg subjekta“ uspostaviti znanje ,,analizirajući prakse kojima individualci fokusiraju svoju pozornost na sebe, da dešifriraju, prepoznaju i priznaju sebe kao subjekte želje, dovodeći u međusobnu igru određenu vezu koja im dopušta da otkrivaju u želji istinu svog bitka“. 394

Istraživanjima i ispitivanjem historijskih teza grčke filozofije, Foucault nastoji otkriti metode spoznavanja istine subjekata „o sebi i drugima, hermeneutiku želje, hermeneutiku prema kojoj je njihovo seksualno ponašanje bilo u nekim prilikama upitno“ i „da bi se razumjelo kako moderni individualac može doživjeti sebe kao subjekta seksualnosti, esencijalno je bilo prvo odrediti kako je zapadni čovjek naučio prepoznavati sebe kao subjekta želje“. 395

Bitno polazište za približavanje istini, da bi subjekt bio sposoban razviti i razumjeti vlastitu etiku i etiku vlastite seksualnosti je misao ,studije igara istine u odnosu sebe sa sebstvom $i$ formiranje sebe kao subjekta, historijom želećeg čovjeka“. 396

Seksualnost i etika subjekta razvijaju se i putem moći, neposredno putem individualne psihe i društva, koji imaju iznimnu ulogu u formaciji individuuma i manifestacije njegove seksualnosti i etičkog ponašanja jer BDSM odnos se ostvaruje korelacijom znanja i moći, njihovom razmjenom među partnerima, što Foucault naglašava u svojim djelima, esejima i intervjuima. U intervjuu iz 1982. godine, ,Sexual Choice, Sexual Act“, kasnije objavljenom u američkom i engleskom izdanju „Subjektivnosti $i$ istine“, Foucault karakterizira sadomazohizam kao izuzetno „iznenađujući fenomen“, a S/M odnos „ne kao odnos između osobe koja pati i one koja nanosi patnju, već između gospodara i onoga na kome provodi svoju vlast““ 397

\footnotetext{
392 Ibid, str. 4, prijev. a.

${ }^{393}$ Ibid, str.4 - 5, prijev.a.

394 Ibid, str. 5, prijev.a.

395 Ibid, str. 5, prijev.a.

396 Ibid, str. 6, prijev.a.

${ }^{397}$ Michel Foucault, Sexual Choice, Sexual Act, Essential Works Vol. 1, Ethics, Subjectivity and Truth, New Press, New York, 1997
} 
On naglašava da "osobe koje prakticiraju S/M interesira da je odnos istovremeno i reguliran $i$ otvoren, da sliči igri šaha u kojoj svatko može pobijediti ili izgubiti”, ${ }^{398}$

Dijalektika sadomazohističkog odnosa sadržana je u odnosu u kojem "gospodar može izgubiti ako shvati da nije u mogućnosti ispuniti potrebe i pokušaje svoje žrtve i obratno, sluga može izgubiti ako ne uspije ili ne može podnijeti izazove koje mu gospodar postavlja” i “ta mješavina pravila i otvorenosti ima efekt intenzifikacije seksualnih odnosa uvođenjem neprestanih novosti i neprestane tenzije i neprestane neizvjesnosti, koja nedostaje jednostavnoj konzumaciji čina" i “ideja je također da se svaki dio tijela iskoristi kao seksualni instrument”. 399

U Foucaultovom shvaćanju sadomazohizma jasno je da on, kao i u svim društveno produktivnim odnosima, inzistira na odnosima moći, odnosno načinima na koji se moć kao takva provodi. U sadomazohističkoj seksualnosti, bitan je element akt neizvjesnosti i aspekt igre - seksualnost u oslobađajućoj, samo naizgled disciplinarnoj ulozi te upravo zbog toga Foucault ograđuje a i odvaja sadizam od Sadeovih originalnih ideja, racionalnim socijalno političkim argumentima da je njegova ideja seksualnosti u svemu disciplinarna, tijelo je ustrojeno u obrnutoj hijerarhiji od klasične - od spolnog organa do glave te konstatira da je "Sade formulirao erotizam prikladan za disciplinarno društvo: regulirano, anatomsko, hijerarhijsko društvo, karakterizirano poslušnošću i nadzorom". ${ }^{400}$

Bitna je upravo ta distanca, hiatus i distinkcija u suvremenom shvaćanju sadizma, pa time i mazohizma, koji su shvaćeni kao pozitivni međusobni odnosi pojedinaca unutar njihovih uloga, psihe i tijela - diskursi i produktivni odnosi proširenja njihovih seksualnih horizonata, jer kao što Foucault govori, "može postojati Sade bez sadizma i sadizam bez Sadea" ${ }^{401}$, pri čemu se misli na filozofski pristup s jedne strane teoriji, a s druge, BDSM seksualnosti.

\footnotetext{
398 Ibid.prijev.a.

399 Ibid. prijev. a.

${ }^{400}$ Michel Foucault, Sade: Seargeant of Sex, Essential Works Vol 2, New Press, New York, 1998, prev.a.

401 Ibid. prijev.a.
} 


\section{SUVREMENO RAZUMIJEVANJE SADOMAZOHISTIČKE SEKSUALNOSTI I ODNOSA U DRUŠTVU I PARTIKULARNIM ZAJEDNICAMA}

Suvremeno tumačenje koncepta sadomazohizma, odnosno, BDSM - a, koje je započelo 60 - ih godina 20. stoljeća u SAD - u i zapadnoj Europi te se do danas razvilo do krajnjih granica, ima razne varijacije, ovisno o seksualnim orijentacijama, preferencama, subkulturama, kulturi određene države, no ono osnovno shvaćanje pojma je uglavnom zajedničko.

Pojasnit ću stoga najuvriježenija, na neki način univerzalna terminologija sadomazohizma, pojmovlje i jezik koji se koristi unutar BDSM subkultura i pojedinaca koji prakticiraju sadomazohističku seksualnost.

U odnosu na psihopatologizaciju sadomazohizma u ranoj psihijatriji, u suvremenoj medicini još uvijek postoji kategorizacija sadizma i mazohizma kao seksualnih poremećaja, u dijagnostičkom i statističkom priručniku „American Psychiatric Association“, pod klasifikacijom DSM - 5, ICD - 10, F65.5, i za sadistički i mazohistički poremećaj. ${ }^{402}$

Bitno je spomenuti da je da trenutna, najnovija verzija priručnika American Psychiatric Association izbacila konsenzualni sadizam i mazohizam iz kategorizacije psihičkih poremećaja, dok se o poremećaju se dakle radi samo kod patološkog sadizma i mazohizma kojima je cilj ozljeđivanje sebe ili druge osobe s namjerom povrijeđivanja i nanošenja tjelesnih i psihičkih povreda s ciljem zlostavljanja.

U Europi, prve države koje su, na inicijativu građana, prve potpuno ukinule medikalizaciju S/M-a iz medicinskih priručnika su Danska (1995), Švedska (2009), Norveška (2010) i Finska (2011), obzirom da su statistička istraživanja pokazala da između 5 i $25 \%$ populacije prakticira BDSM odnose, tj. seksualnu praksu uživanja u boli kroz dominaciju i submisivnost.

Ti su podaci bitni pokazatelji da je sadomazohizam u suvremenoj medicini klasificiran kao "normalna", zdrava seksualnost kao i svaka druga i da se u današnje vrijeme, ukoliko je konsenzualna, ne smije medikalizirati te mora postojati jasna granica između BDSM -a i nasilja.

U sjevernoeuropskim, kao i brojnim zapadnim državama, sadomazohizam je doživio novu interpretaciju u medicinskoj praksi radikalnom revizijom osnovnog zdravstveno - pravnog dokumenta, ICD - 11, kojim je Svjetska zdravstvena organizacija u lipnju 2018. godin, ukinula

\footnotetext{
402 Diagnostic and Statistic Manual, International Classification of Diseases, American Psychiatric Association
} 
sadomazohizam i fetišizam kao psihijatrijske dijagnoze, a diskriminaciju BSM praktikanata obilježila kao kršenje ljudskih prava na temeljnu slobodu pojedinca.

Revizija i preokret se tako sastoji u pomaku od modela psihopatologizacije do modela seksualnog ponašanja koje teži seksualnoj slobodi i zadovoljstvu te promiče seksualnu dobrobit, a protivi se te patologizira isključivo ograničenje ili izostanak pristanka, odnosno, seksualno nasilje, koje je strogo ograđeno od BDSM praksi.

ICD - 11 klasificira sadomazohizam, prema suvremenoj medicinskoj definiciji, kao varijantu seksualnog uzbuđenja koja pripada isključivo privatnoj sferi pojedinca te ne smije biti izložena stigmatizaciji javnosti niti podliježe psihijatrijskoj dijagnozi.

Temeljna odrednica novog shvaćanja sadomazohističke seksualnosti je poštovanje prava pojedninaca čije je atipično seksualno ponašanje potpuno konsenzualno.

Većina autora ne razlikuju semantičke niti ontologijske podjele osnovnih uloga ili identiteta u BDSM odnosima i stoga je važno detaljnije pojasniti suvremenu medicinsku i forenzičku klasifikaciju sadista i mazohista.

Unutar ove široke definicije ipak postoje psihologijske klasifikacije sadizma i mazohizma, odnosno podjele sadista i mazohista prema preferencama i karakterima, utemeljene na istraživanjima seksualnih praksi u forenzičkoj znanosti.

Mazohisti su tako opisani od onih s podjednakim mazohističkim i sadističkim težnjama, koji vole mijenjati submisivnu i dominantnu ulogu do „ekstremnih“ mazohista kojima su submisivnost, bol i poniženje neophodni za seksualni užitak.

S druge strane, sadisti su podijeljeni na umjerene, koji prakticiraju svoje sadističke fantazije s konsenzualnim osobama, potom na one koje provode svoje sadističke porive na „žrtvama“ koje na to ne pristaju, no bez teškog ozlijeđivanju, te najzad na sadiste koji svojim žrtvama bez pristanka nanose teške ozlijede i oduzimaju život, što je jednako ili daleko ozbiljnije od silovanja, no kategorizirani su jednako.

Iz ove kategorički i kriterijski nejednake podjele i razlikovanja mazohista i sadista, vidimo da još uvijek sam pojam sadizma nosi konotaciju i konceptualizaciju književnosti 18. stoljeća, no evidentno je da pojmovi submisivnosti i mazohizma, a posebice dominacije i sadizma nipošto nisu niti sinonimi a niti komplementarni.

Naravno, ova je podjela suviše radikalna i ni u kojem slučaju ne može biti pravilo niti relevantna BDSM praktikantima, budući da se tiče pravne prakse, forenzičke, sudske medicine i stoga je 
konkluzija da BDSM moramo razumijevati, pored generalnih pravila i sadomazohističke seksualnosti per se, individualnim pristupom, temeljem partikularne situacije, ličnosti, preferenci i konsenzualnosti.

To je ujedno i leitmotiv socijalno - filozofskog pristupa, kao i cjelokupne znanosti o sadomazohističkoj seksualnosti, medicinske, psihološke, sociološke, filozofske te svih ostalih područja koja se bave tom neiscrpnom tematikom.

Suvremenom psihologijskom tumačenju i analizi sadizma i mazohizma psihijatrijska i psihologijska struka, no i sociologija pristupa uzimajući u obzir novu, adekvatnu, bitno izmijenjenu medicinsku klasifikaciju sadomazohizma.

Takva ekspertiza i znanost o seksualnosti daleko je od zastarjele medikalizacije, koja je bila u primjeni još do 80 - ih godina 20. stoljeća, neovisno o formiranju S/M subkulture 1960 -ih godina te postojanju i brojnih BDSM zajednica te ekspanziji diskursa o sadomazohističkim praksama u seksualnosti i postavljanju S/M ikonografije u mainstream umjetnosti.

U kontekstu nove medicinsko - psihološke perspektive bitno je razjasniti BDSM, prvo, kao seksualnu praksu i, konačno, klasifikaciju sadista i mazohista te uvođenje sadomazohizma u društveni i kulturni diskurs.

Neophodno je napomenuti da su sve moguće klasifikacije dostupne u literaturi uvijek aproksimativne i uvelike subjektivne, ovisne u autoru te uzorku subjekata istraživanja i stoga one mogu poslužiti kao opća orijentacija, jer pravila, kad su u pitanju uvelike subjektivni, intimni psihoseksualni fenomeni ne mogu postojati.

Nastojat ću približiti temeljne pojmove i prakse S/M seksualnosti, iz vlastite filozofsko psihologijske perspektive, uz neophodne reference na bitne autore i njihovu literaturu o dotičnoj tematici, od kojih su neka djela pisana iz osobnog iskustva, dok su druga rezultati dugotrajnih istraživanja BDSM scene i praktikanata.

Autori na koje ću se referirati veoma detaljno elaboriraju S/M odnose i to s posebnim naglaskom na psihičke senzacije izazvane i uživljavanjem u ulogu ili življenjem identiteta, ovisno radi li se o $\mathrm{D} / \mathrm{s}$ ili Master/slave odnosu, kao i iznimnu važnost konsenzualnosti te konstantnog ,pregovaranja“ granica dominacije i submisivnosti.

Iz profesionalnog i osobnog iskustva tematiku izuzetno opširno tumače Geoff Mains, Guy Baldwin, Jack Rinella i Phillip Miller i Molly Devon dok Charles Moser i Peggy Kleinplatz pristupaju iz perspektive psihoterapeuta, teoretičara i istraživača sadomazohističke seksualnosti temeljem iscrpnih analiza, intervjua i anketiranja pripadnika BDSM scene u SAD - u. 
Referencama na spomenute autore, protumačit ću BDSM seksualnosti u interpersonalnom i društvenom kontekstu teoretskim okvirom koji će ga prikazati kao koncept seksualne orijentacije, lifestylea, zajednice, subkulture te svojevrsne životne filozofije.

Temeljni termin "BDSM", kombinacija je kratica koje znače sljedeće - "Bondage and Discipline", "Dominance and submission" te "Sadism and Masochism", dakle obuhvaća elementarne odnose dominacije i submisivnosti, discipline, sadizma i mazohizma, u bezbrojnim mogućnostima kombinacija scena ili "sessiona", od fiksnih uloga, zatim "switch", zamjena uloga pa sve do "total power exchange" odnosa.

Želim istaknuti svojevrsnu fenomenološku vrstu seksualnog ili ljubavnog odnosa, koji je svojstven upravo S/M odnosu i koji bi u svojoj psihologiji i praksi, bio najdublji od svih mogućih partnerskih odnosa, upravo stoga što zahtijeva najveću vrstu predanosti i povjerenja.

BDSM je, unutar svojih mogućnosti odnosa i praksi, seksualnost bez granica, toliko opsežna, da ju do sada nitko nije niti mogao u potpunosti definirati, jer kao takva i ontološki i seksološki, nadilazi koncept koji može biti obuhvaćen definicijom, već može samo sadržavati svoje pojmovlje i njihove međusobne odnose,

Osnova odnosa su razlike u ulogama ili pozicijama te udjelu moći, koji je presudan za svakog pojedinca i njegov identitet unutar S/M seksualnosti.

Kad govorimo o S/M odnosu, naizgled je razumljivo da dominantna osoba raspolaže gotovo svim udjelom moći, no prisjetimo li se podjele sadista i mazohista te razlike između $D / s$ i Master/slave odnosa, uvidjet ćemo da se pitanja odnosa moći ne mogu prototipno simplificirati, već da svaki partikularan odnos ima svoj individualan modus operandi, uvjetovan preferencama i dogovorom partnera te samo na taj način možemo shvatiti načine izmjene moći $u$ sadomazohističkoj seksualnosti.

Izložit ću i naglasiti bitna vlastite uvide o tim pitanjima i zaključke koje sam donijela temeljem literature i promišljanja ove kompleksne tematike.

Sadomazohizam je u svojoj biti dinamički proces zasnovan na pozicijama i međusobnim odnosima individuuma koji ima svoj tijek, faze te kontinuitet, koji su varijabilni i stoga se nikada ne mogu univerzalno, strogo znanstveno definirati.

Najbolje je stoga započeti prototipnim prikazima BDSM odnosa i prakse, od kojih se kasnije možemo osvrnuti na specifične situacije potkrepljene konkretnim primjerima. 
Odnos dominantne i submisivne osobe znatno se razlikuje od Master/slave odnosa, i to upravo u samoj svojoj biti, a to je provođenje moći postavljanjem uloga i identiteta koji tvore odnos moći, što je već prethodno spomenuto, određen je i limitiran vremenom i situacijama, i samim time je udio moći daleko manji, a $\mathrm{S} / \mathrm{M}$ prakse daleko manje zahtjevne nego što je to $\mathrm{u}$ radikalnom Master/slave odnosu.

Dominantna i submisivna osoba mogu to biti u jednokratnom susretu u S/M ili fetish klubu, kao povremeni ili stalni partneri, koji, pored „vanilla“ seksualnosti, prakticiraju BDSM samo u određenim situacijama, ili isključivi $D / s$ partneri koji prakticiraju dotične aktivnosti prema dogovoru, sukladno svom slobodnom vremenu, neovisno od svog „drugog“ života, nevezanog za S/M seksualnost.

Za optimalno razumijevanje raznih mogućnosti BDSM odnosa među partnerima, no u širem kontekstu zadane društvene cjeline, bitno je razmotriti društveni aspekt sadomazohizma $u$ terminima mogućnosti ozbiljenja različitih vrsta odnosa.

Proučavajući i promišljajući odnos sadomazohizma i društva, pri čemu društvo kao najširi pojam obuhvaća i BDSM praktikante, kao zasebne pojedince ili pripadnike zajednica ili klubova, i sve ostale osobe koje nisu involvirane ili upućene u S/M seksualnost te sadomazohističku seksualnost u korelaciji s društvom moramo tumačiti putem raznolikih sadomazohističkih odnosa i njihovih temeljnih odrednica.

Determinirajući faktori sadomazohističkih odnosa su interpersonalni odnosi kao najintimniji, odnosi unutar BDSM zajednica i skupina, koji su temeljeni na imaginarnom i simboličkom u seksualnim praksama i stoga ekskluzivni i privatni.

U javnoj sferi, odnosi $u$ i prema društvu određeni su u dinamičkom, multikulturnom totalitetu, konkretnom i realnom, koje uključuje brojne kulture i subkulture, načine života, seksualnosti i preference, $\mathrm{tj}$. sve pojedince koji u njemu aktivno sudjeluju.

Na koji način S/M seksualnost utječe na društvo, a na koji način društvo kao većinski tradicionalna cjelina, koja se vremenom ipak mijenja, utječe na odnose unutar S/M seksualnosti, njenih praktikanata, zajednica i klubova te S/M seksualnost kao takvu?

Iz sociologijskih, filozofijsko - političkih te psihologijskih perspektiva možemo izgraditi brojne teze i zaključke, utemeljene na teorijama najrelevantnijih mislilaca obuhvaćenih u cjelokupnom radu, a ponajviše filozofske pristupe i interpretacije. 
Osvrnut ću se na pozicioniranje sadomazohističkih odnosa u još uvijek dominantnoj društvenoj paradigmi monogamnih, heteroseksualnih, no i istospolnih zajednica ili brakova, koji još uvijek u brojnim društvima počivaju na patrijarhalnom, konzervativnom modelu, no napredna ga društva sve radikalnije napuštaju.

Obzirom da ljudska bića nisu prirodno monogamna, niti vlastitom željom zadovoljna represivnom strukturom braka ili legitimnih zajednica, već im je isto nametnuto kulturom, opcija otvorenih, slobodnih odnosa, veza, zajednica te brakova trebala bi biti residuum u svim seksualnim opredijeljenjima, posebice u sadomazohističkoj, gdje je otvoreni odnos ponekad izričito pravilo, a ponekad zaslužena privilegija.

Kao primjer navodim radikalni Master/slave odnos, u kojem submisivna osoba u konzensualnoj ulozi ili identitetu roba mora poštovati monogamni odnos, osim ukoliko joj gospodar kao dominantna osoba i njen ,ugovorni vlasnik“ ne naredi ili dozvoli drugačije, u svrhu obostranog užitka i proširivanja horizonata $\mathrm{i}$ istraživanja vlastite seksualnosti i seksualnosti partnera.

S druge strane, nešto „liberalniji“ i otvoreniji Dominant/submissive odnos u pravilu ne nalaže monogamiju budući da ne uključuje potpunu predanost submisivne osobe niti vlasništvo dominantne nad njome i stoga je vrsta odnosa stvar želja i dogovora prema preferencama partnera, a otvorenost odnosa i sloboda izbora ima značenje odnosa dviju ili više osoba sa slobodom jednakih ili sličnih odnosa s drugima, a posebice povremeno ili stalno uključivanje drugih osoba u njihov zajednički odnos.

Obostrane želje $D / s$ partnera i njihovo poštovanje kreiraju i modificiraju svaki odnos, te njime upravljaju, unaprijeđujući ga, neovisno radi li se o „striktnom“ Master/slave ili Dom/sub odnosu jer želje i pristanak su temelj svake kvalitetne razmjene moći.

Brojni su slučajevi kad partneri konsenzualno i voljno odabiru monogamni odnos, koji je izvorno kulturni konstrukt, no njihovom željom on postaje njihov vlastiti a razlog je tome težnja svakoga od njih da se u potpunosti posvete izgradnji dugotrajnog odnosa s jednom, odabranom, kompatibilnom, ,idealnom“ osobom, odnos na kojem je potrebno i vrijedno raditi.

Kategorizacija vrste odnosa ili veze dovodi do pitanja koji je termin najprikladnije koristiti u kojoj situaciji, budući da veza i zajednica impliciraju obavezu i određeni stupanj odgovornosti prema partneru, pa smatram optimalni staviti u fokus pojam odnosa kao najinkluzivnijeg, od povremenog $D / s$ odnosa koji ne zahtjeva visok stupanj obaveze i dozvoljava mnoge dogovorene granice, do stalnog odnosa izrazito kompatibilnih dominantnih i submisivnih osoba, te 
radikalne Master/slave veze ili zajednica koja obuhvaća potpunu kontrolu i izmjenu moći s minimalnim granicama.

Razlike su značajne, no dogovoreni odnosi s otvorenim mogućnosti i izrazitom dinamikom najrelevantniji su oblik S/M interakcije, premda su i dugotrajne veze i zajednice izrazito ispunjavajuće, poticajne i uspješne osobama koje zadovoljavaju uvjete visoke međusobne kompatibilnosti te su voljne i sposobne uskaditi sve svoje želje sa željama partnera ne zanemarujući pritom niti svoju već uspostavljenu osobnu životnu sferu, profesiju, karijeru, slobodno vrijeme i socijalni život.

Većina S/M praktikanata nalazi socijalne kontakte i stvara prijateljstva međusobno, unutar S/M scene ili putem poznanstava stvorenih zajedničkim seksualnih preferencama, budući da, pored S/M seksualnosti imaju brojne ostale zajedničke interese i izbore kao što su umjetnički i glazbeni ukus, stil, način odijevanja kao cjelokupan izričaj specifične subkulture, no i mnogo više - posebnu poveznicu u smislu osjećaja pripadnosti i razumijevanja.

Prijateljstvo je temelj svakog uspješnog i obostrano zadovoljavajućeg sadomazohističkog odnosa, polazeći od konstatacije da je svaki intimni odnos prvenstveno prijateljski odnos, budući da se suvremena društva, a posebno subkulture strogo separiraju od tradicionalne društvene strukture konzervativne seksualnosti i monogamne, heteroseksualne veze i braka.

Prijateljstvo je centralni pojam, u čijoj se lingvističkoj kategorizaciji S/M odnosi nalaze možda daleko od prototipnog primjera, no ono je njihova polazišna točka, koja nekad prethodi seksualnoj želji i požudi, no možda se ipak konkretnije nakon nje razvija međusobnim povjerenjem i poštovanjem koje $\mathrm{S} / \mathrm{M}$ odnos zahtijeva.

Zajedničke želje i dijeljenje najintimnijih fantazija i prakticiranje ekstremnih aktivnosti uz maksimalnu brigu o partneru temelj su koji održava odnos postojanim i ispunjavajućim i u psihičkom i seksualnom aspektu, posebice u odnosu koji uključuje rizične seksualne prakse.

Uobičajeni „preskriptivni“ početak svakog BDSM odnosa odvija se neophodnim upoznavanjem psihe i tijela druge osobe, njenih iskustava, želja i trenutnih granica, pri čemu je neophodan ozbiljan razgovor, u kojem obje illi više strana moraju svjesno izraziti svoje želje.

Dom/sub partneri s intencijom dugotrajnog odnosa običavaju ispuniti checklistu brojnih aktivnosti i razgovarati o svojim željama i preferencama prethodno upuštanju u iste, što je od neizmjerne važnosti za obostrani užitak i sigurnost. 
Ukoliko i kad uslijedi prijelaz na neke S/M aktivnosti i prakse zaista moglo približiti stadiju „osjećaja“ i razumijevanja druge osobe te naučiti poštovati njenu psihu i tijelo, kao neophodan put prema ispitivanju i spoznavanju međusobne kompatibilnosti, koja, ukoliko postoji, vodi ostvarenju i razvijanju daljnjeg odnosa.

U većini slučajeva dominantna osoba daje naredbu ili upute submisivnoj o izboru odjeće, ponašanju i ostalome, s obzirom ili bez na mjesto i okolnosti, ovisno o prethodnom dogovoru, koji će u cijelosti biti pojašnjen. ${ }^{403}$

Konsenzualnost je od jednake važnosti i u $D /$ s i u Master/slave odnosu, s jedinom razlikom da su s jačanjem udjela i predavanja moći, granice sve manje, što tada dovodi do naizglednog izostanka traženja pristanka slave osobe, no ona je ipak morala dati svoj potpuni ili djelomični pristanak na vlastito potpuno predavanje.

Pravila ponašanja moraju biti strogo utvrđena i dogovorena, naravno, to je neophodno $u$ Master/slave, 24/7 odnosu, dok je u $D / s$ odnosu varijabilno i ograničeno na scenu i susrete partnere te njihovu svojevrsnu ,simulaciju““.

No radi li se u BDSM - U o simulaciji ili stvarnoj izmjeni moći ?

Odgovore na to pitanje možemo elaborirati upravo vrstom i prirodom odnosa, koji se uvelike razlikuju o udjleu izmjene moći, pri čemu možemo diferencirati ili suprotstaviti ne samo $\mathrm{D} / \mathrm{s}$ i Master/slave odnose, već stupnjevati razne tipove $D / s$, kao Master/slave odnosa i veza.

Presudno je koliko je pojedini odnos intenzivan, blizak i ozbiljan u BDSM kriterijima, drugim riječima, kolika je dominacija jedne sobe nad drugom, do koje se mjere submisivna osoba predaje i kolike granice postavlja.

$D / s$ odnos može biti biti izrazito intenzivan i većina $\mathrm{S} / \mathrm{M}$ praktikanata i ne odlazi dalje od toga, obzirom na faktor egzistencijalne nemogućnosti 24/7 Master/slave odnosa, no i psihičke (ne)spremnosti na takav odnos, što je i sasvim razumljivo obzirom na njegovu izrazitu i zahtjevnost i težinu ostvarenja.

Odnos dominantne i submisivne osobe je fundament BDSM - a i stoga je bitno pokušati što dublje i detaljnije razumjeti psihoseksualnu dinamiku realne izmjene moći u kombinaciji sa simulacijskim igranjem uloga kao izmjene moći na simboličkoj razini, što bi predstavljalo „početnu fazu“ S/M seksualnosti i odnosa.

\footnotetext{
403 Diagnostic and Statistic Manual, International Classification of Diseases, American Psychiatric Association
} 
Budući da je i u psihologijskim i sociologijskim teorijama sadomazohizma i u istraživanjima te znanstvenim radovima samih praktikanata, submisivna osoba primarna i presudna za razvoj i usmjeravanje dinamike odnosa, sagledat ću i prikazati D/s odnos iz upravo te pozicije.

Svakoj je samosvjesnoj submisivnoj osobi koja se voljno podređuje drugome kao dominantnoj osobi ili gospodaru, jasno da takav odnos u koji sama sebe postavlja, zahtjeva izuzetne veliku psihičku snagu za veliki trud i odricanja zbog isprva naizgled nesavladivih izazova i očekivanja, te upravo iz navedenog, većina ljudi ne može razumjeti zbog čega bi se uopće osobe upuštale u takvu vrstu seksualnosti, odnosno života.

Osobe koje svoju submisivnu poziciju doživljavaju kao imanentnu egzistenciju, upravo to podređivanje i izazove doživljavaju kao primarni poticaj koji ih vodi ostvarenju užitka, time što će pružiti užitak svom partneru, a time istovremeno i sebi te doživljavaju sve izazove i zahtjeve dominantne osobe kao konstruktivne i prihvaćaju ih s velikim zadovoljstvom.

Dominantne pak osobe, imaju daleko veću odgovornost, brigu o submisivnoj osobi, koja im se predaje, što će biti detaljnije elaborirano, a nadasve, obvezu da ne iznevjere često visoka očekivanja submisivne osobe, $\mathrm{i}$ to $\mathrm{u}$ aspektima $\mathrm{S} / \mathrm{M}$ praksi, psihoseksualne performanse $\mathrm{i}$ vlastite snage ličnosti.

Možemo stoga, govoreći o skladnom BDSM odnosu, zaključiti da obje strane moraju uložiti svoj maksimalni potencijal i energiju u stvaranje i održavanje sadomazohističke dinamike i u smislu odnosa moći i u međusobnom razumijevanju i doživljavanjem vlastitog zadovoljstva i užitka isključivo pružanjem istoga drugome.

Američki seksualni psihoterapeuti i teoretičari BDSM seksualnosti Charles Moser i Peggy Kleinplatz pokušavajući promisliti pristup $\mathrm{S} / \mathrm{M}$ seksualnosti nameću pitanje samog uvod u definiciju pojma i tko bi ga uopće trebao definirati.

Bi li to trebali biti stručnjaci kao što su liječnici i psihoterapeuti koji rade s S/M praktikantima ili pravnici i i odvjetnici koji određuju granice ponašanja ili možda teoretičari koji istražuju BDSM koji prikupljaju podatke?

Najbliža istini i najkorektnija je možda teza da bi to trebali biti praktikanti sami, no budući da postoje brojne podgrupe i zajednice među njima, ostaje dvojba na koji bi se način moglo uspostaviti „univerzalno“ znanje o S/M seksualnosti, budući da se radi o raznovrsnim taksonomijama, od najjednostavniji - žene vs. muškarci, hetero vs. homoseksualci, već prvenstveno grupe koje se temelje na određenoj vrsti prakticiranja BDSM - a. 
Moser i Kleinplatz pritom navode razlikovne skupine onih kojima su povremeni S/M susreti inkorporirane $\mathrm{u}$ konvencionalniju seksualnost te one kojima svaki seksualni čin mora uključivati S/M. Također, ističu važnost prepoznavanja ravnoteže između fizičkog užitka i boli i psihičkih manifestacija dominacije i submisivnosti pri čemu neki praktikanti preferiraju isključive fizičke prakse poput bondagea i flagelacije, dok drugi daleko više uživaju u eksperimentiraju u daleko većem rasponu praksi i aktivnosti.

Elementarno je pitanje je trebamo li i do koje mjere razlikovati BDSM praktikante i što je uopće $\mathrm{S} / \mathrm{M}$, te autori zaključuju da je lakše napomenuti što nije - nasilje niti bilo nekonsenzualna praksa bilo koje vrste. ${ }^{404}$

Napomenula bih da unutar BDSM seksualnosti i postoje zamjetne razlike u njenom poimanju i praksi od kojih su najvažnije razlike između praktikanata koji slijede sva preskribirana pravila BDSM scene i onih koji ne priznaju nikakva pravila, već preferiraju djelovati spontano i senzualno, no ipak poštuju konsenzualnost drugih osoba, te konačno razlike između onih kojima je presudan fizički dio uživanja u boli kao sadist ili mazohist od onih kojima je daleko važniji psihički čin ponižavanja, kao submisivna i dominantna osoba.

Već spomenuta američka sociologinja Lynn Chancer sadomazohizam analizira kroz odnose moći i njihovu dinamiku, s glavnim težištem na prvo, analizu seksualnog sadomazohizma, naročito mazohizma kod žena, te potom na odnose moći s obzirom na održavanje dinamike unutar S/M odnosa i međusobne odnose sadističkih i mazohističkih osoba. ${ }^{405}$

Poznati paradoks dominantne i submisivne osobe i ona tumači u pomoću dobro poznatog Hegelovog paradoksa gospodara i roba, prema kojem rob uvjetuje gospodara i time mu daje vlast, a u sadomazohističkom odnosu submisivna osoba na taj način „vodi igru“ i to je shvaćeno kao osnova dinamike sadomazohizma. ${ }^{406}$

Korištenju Hegelovog paradoksa u kontekstu sadomazohističkog odnosa potrebno je uputiti kritiku budući da odnos gospodara i roba kod Hegela u materijalno - ontologijskom smislu nije prikladan za interpretaciju S/M odnosa, pa time ni za paradigmu izmjene moći, ,power exchangea" u sadomazohizmu.

\footnotetext{
${ }^{404}$ Charles Moser, Peggy Kleinplatz, Sadomasoschism/Powerful Pleasures“, Routledge, New York, 2006, str. 13

${ }^{405}$ Lynn Chancer Sadomasochism in Everyday Life, The Dynamics of Power and Powerlessness, 1994, Rutgers University Press, New Brunswick, New Jersey, str. 43 - 67

${ }^{406}$ Ibid, str. 63, 66
} 
Temeljna je stvar u tome da nitko nikoga ne uvjetuje kao takvog, već su partneri jednaki u svojim različitim ulogama, što najbolje opisuje termin „different equals“, koji se već desetljećima koristi unutar BDSM kulture.

Osnovno je da se partneri međusobno sporazumno odnose s poštovanjem jedno prema drugome i svatko može u bilo kojem trenutku prekinuti scenu, dogovor ili ugovor, dakle, oboje su jednako slobodni, u tjelesnoj i duhovnoj sferi.

Cilj je obostrani užitak, a ne potčinjavanje prema tradicionalnom disciplinarnom modelu, ranije spomenutom kod Foucaulta i stoga je bitno kritički preispitati komparaciju Hegelovog paradoksa koji je originalno mišljen u jednom sasvim drugačijem značenju, sa suvremenim teorijama sadomazohizma, i postaviti jasan odmak u tumačenju odnosa moći i prakse u sadomazohističkom odnosu.

Hegel u svojoj „Fenomenologiji duha“ iscrpno razrađuje paradoks gospodara i roba govoreći o istovremenoj samostalnosti i nesamostalnosti te samosvijesti i ostvarenju samobitka kao ultimativnog cilja autoreflekije:

„Za samosvijest je neka druga samosvijest, ona je izišla izvan sebe, prvo, ona je samu sebe izgubila jer je našla neku drugu bit ; drugo, ona je ukinula ono drugo jer ni ne vidi to drugo kao bit nego samu sebe u drugome i ona mora ukinuti taj svoj drugobitak, ona mora ići za tim da bi ukinula onu drugu samostalnu bit, da bi time postala svjesna sebe kao biti, ona ide tako za time, da ukine samu sebe, jer to je drugo ona sama. " 407

Hegel konstatira da je bitak i čista samosvijest odnos u kojemu se odnose dvije svijesti - ona roba i ona gospodara, a međusobno se uvjetuju i to na način da je gospodar samostalna svijest, a rob nesamostalna i doživljen kao predmet.

Gospodar svojom moći nad bitkom roba pridaje mu važnost drugog bitka kao posrednika i time stvara neposredan odnos u kojem svijest roba postaje istina i time samostalna svijest - je on obrađuje stvari za gospodara - uvjetuje njegov bitak i pretvara se u samostalni bitak. ${ }^{408}$

Rob tako uvjetuje gospodara jer mu omogućuje da uživa u stvarima i užitku stvarima - čini bit njegova gospodstva te stoga prikaz Hegelove dijalektike pomaže u ilustraciji odnosa dominantne i submisivne osobe i stoga je on ipak od velike važnosti.

Iz tog razloga, Chancer uvodi relevantne psihologijski - filozofske paradokse sadomazohizma, bitne za održavanje konstantne dinamike u odnosu sadista i mazohista, koji su opet dijalektički. Najvažnija je pretpostavka da sadist želi potpuno poslušnog mazohističkog partnera nad kojim

\footnotetext{
407 Georg Friedrich Wilhelm Hegel, Fenomenologija duha, Naklada Ljevak, Zagreb, 200., str. 121 - 122

408 Ibid. str. 125 - 127
} 
će provoditi svoju dominaciju i kontrolu.

Njen je argument da u tom slučaju ne bilo moguće održavati dinamiku odnosa jer sadist ne bi mogao obnavljati svoje zadovoljstvo budući da bi sam proces postao statičan, a ograničeni mazohist pod potpunom kontrolom ne bi više predstavljao izazov sadistu i dovodio bi u pitanje njegovu poziciju i zato se „može očekivati da sadist potiče $i$ da je uzbuđen obrtanjem uloga u kojem mazohist izaziva njihovu hijerarhijsku poziciju“. 409

Sadist, koliko god se čini željan kontrole, žudi za otporom mazohista, jer mu upravo taj otpor i neposlušnost donosi izazov za novim nametanjem moći i vlastitog autoriteta i time neprestano obnovljeni užitak. ${ }^{410}$

Dominantna osoba zato mora konstantno postavljati sve zahtjevnije i teže zadatke submisivnoj, ispitujući njene granice sve većim podređivanjem i „mučenjem“ s ciljem da bi submisivna osoba napredovala i pokazala svoju ljubav prema dominantnoj.

U neprestanom smišljanju novih i težih zadatke, dominantna osoba mora koristiti imaginaciju i inovativnost da podređenoj osobi postavlja stalno nove izazove, a submisivna osoba, izazovima i otporom, pruža dominantnoj nove izazove i prepreke koje mora savladati. ${ }^{411}$ i to je bit seksualne dinamike i progresa sadomazohističke veze, veliki uzajamni trud uz doživljavanje i iskazivanje zadovoljstva, užitka i emocija.

Chancer ilustrira da „vezani mazohist koji više ne pruža otpor predstavlja Pirovu pobjedu za sadista „, , ,slično, mazohist koji se odupro do točke odbijanja sveukupne dinamike, također je izmakao sadistovom dohvatu“412

Od velike je važnosti paradoks neovisnosti, odnosno pitanje ovisnosti mazohista o sadistu i vice versa, koji je strukturalno baziran na suprotnostima i razlikama.

Sadist za mazohista predstavlja utjelovljenje samopouzdanja i neovisnosti, no on je, premda provodi moć zapravo sasvim suprotno od toga, mazohistički partner mu je nužan za samoafirmaciju, premda on to u svojoj ulozi poriče.

Pozicija mazohista je drugačija - za razliku od sadistovog poricanja ovisnosti o drugom, on je svoju ovisnost psihološki primoran pokazati i izraziti kroz svoju odanost pristanak na poslušnost i zato Chancer govori o „mazohističkoj dilemi“ jer pred mazohističkom osobom stoje brojne odluke i zadaci koje mora izvršiti da bi se dokazala dominantnom partneru i zbog toga se pričinjava ovisnom o njemu, unutar odnosa moći i nemoći.

\footnotetext{
409 Lynn Chancer, Sadomasochism in Everyday Life, The Dynamics of Power and Powerlessness, 1994, Rutgers University Press, New Brunswick, New Jersey, str. 55 - 60

410 Ibid. str. 55

411 Ibid. str. 56

412 Ibid. str. 56, prev. a.
} 
Upravo svojim djelima, mazohist pokazuje svoju snagu i neovisnost, a bitna razlika je u tome da „dok sadist ne može pristati da treba drugoga, mazohist ne može pristati ne trebati drugoga “, te tako sadist prikriva svoju ovisnost i potrebu, a mazohist je naučen da prikriva svoju relativno veću snagu, da se ponaša kao da je slab i ovisan . ${ }^{413}$

Ove su spoznaje neophodne za razumijevanje povezanosti moći i snage te osjećaja boli i užitka unutar dinamike sadomazohizma.

Chancer izlaže i odlično dosljednu konceptualizaciju podjele sadista i mazohista u smislu dominacije i podređenosti, prikladnu vrlo širokom tumačenju, od socijalnih statusa do seksualnih određenja koja su u ovome radu primarna.

Ona započinje referencama na odnose u kapitalističkom društvu te prelazi na sferu seksualnosti, u kojoj se sadisti i mazohisti analogno dijele na podređene, submisivne i nadređene, odnosno dominantne i to u raznovrsnim kombinacijama ličnosti. ${ }^{414}$

Dominantni bi sadist tako bio onaj koji je dominantan u svakom aspektu svog života, ne isključivo u seksualnom BDSM odnosu, a dominantni mazohist, mazohist koji ima podređenu ulogu u životu, primjerice radnom mjestu i ima istu seksualnu tendenciju.

Čini se da kod Chancer „dominantan“ ima značenje prevladavajuće crte ličnosti, odnosno, komplementarnost socijalne i seksualne pozicije osobe, no ova podjela nije tako jednostavna, već je veoma kompleksna.

Osoba koja je dominantna na radnom mjestu može biti i podređeni mazohist, jednako kao i dominantni sadist, isto tako, podređena osoba može imati jake sadističke sklonosti, što je čini podređenim sadistom. ${ }^{415}$

Te su socijalne i seksualne pozicije ekstremno isprepletene i uvijek relativne i u odnosu na druge i s obzirom na ličnost određene osobe.

Sadomazohizam je stoga, i u socijalnom i u seksualnom kontekstu simbioza u kojoj ni sadist, bez podređenog drugog niti mazohist bez nadređenog Drugog ne mogu biti. ${ }^{416}$, čime problematika odnosa moći zadobiva ontologijsku dimenziju.

Najpristupačniji uvod i detaljna objašnjenja terminologije i prakse BDSM- a može se pronaći u nadasve opsežnoj i eksponiranoj popularno - znanstvenoj knjizi Phillipa Millera i Molly Devon "Screw the Roses, Send Me the Thorns, The Romance and Sexual Sorcery of Sadomasochism", prvi put objavljenoj 1995. godine, u kojoj autori započinju općim, temeljnim

\footnotetext{
413 Ibid. str. 47 - 60

414 Ibid. str. 97 - 102

415 Ibid. str. 96 - 100

416 Ibid. str. 48
} 
definicijama, da bi kasnije razvili bogato oprimjerene preglede i analize najkompleksnijih segmenata sadomazohističke prakse ${ }^{417}$, kao iskusni BDSM praktikanti i edukativni teoretičari. Budući da sada bavim društvenim aspektom, bitno je spomenuti da su autori ovim naslovom imali intenciju ukazati da je S/M odnos, sa svim svojim ekstremnim, grubim praksama, romantičan i magičan i daleko više nego „klasični“, ,,vanilla“ seksualni i ljubavni odnosi i to je možda najopravdaniji i najrazumljiviji razlog osnovnoj tezi - da je jedini prihvatljiv i dopustiv kriterij vrednovanja i komparacije različitih seksualnosti i opredijeljenja je taj da ih nije niti primjereno, niti moguće komparativno vrednovati.

Relevantnost i „težinu“ te knjige potvrdio je, među ostalim osvrtima na početku predgovora, tadašnji predsjednik Američkog odbora za seksologiju, dr. William Granzig, riječima : „, $S / M$ nije za svakoga, posebno ne za one koji su uvrijeđeni seksualnom otvorenošću i istraživanjem s okom za traženje granica svoje seksualnosti. No ipak, i tim bih ljudima preporučio drugo poglavlje knjige, kao prolog za kreativno mišljenje o bilo kojoj vrsti seksualne aktivnosti“ ${ }^{418}$

Terminologija i koncepti kojima su posredovani BDSM odnosi univerzalna je u generalnom tumačenju, no ima svoje raznolike varijante, ovisno o određenom društvu i sceni, okruženju u kojem se pojedinci prakticiraju svoju seksualnost ili možda određene klupske performanse, no prvenstveno načinu shvaćanja određenih uloga i odnosa, što može zaista izuzetno individualno. Upravo pojam scena višeznačan je i potrebno je stoga pojasniti osnovna značenja da bi se dobio uvid u društveni aspekt BDSM seksualnosti te ću konceptualno, započeti univezalnim, pri čemu scena označava ekskluzivni milje ili zajednicu S/M praktikanata koji imaju svoje privatne klubove ili provode vrijeme $\mathrm{u}$ fetish ili /S/M klubu otvorenog tipa koji održavaju popularizirane fetish partye, no ipak najčešće za članove uz određenu diskreciju.

Fetiš i fetišizam, objašnjeni ranije kroz prizmu psihoanalize od iznimne su važnosti u praksi BDSM - a. "Fetish dress code" je uglavnom obavezan kako u privatnim scenama ili seansama, a posebno u S/M klubovima u Europi i SAD-u, koji su posebno namješteni za sve vrste $\mathrm{S} / \mathrm{M}$ aktivnosti, od otvorenih performansa do privatnih "dungeona" za članove.

"S/M Outfit" je uistinu raznolik i, ovisno o preferencijama "scene", od "klasičnih" kombinacija - kože, latexa, laka, stiletta, posebnog rublja, do raznih uniformi za "role play", igre uloga

\footnotetext{
417 Phillip Miller, Molly Devon, Screw the Roses, Send Me the Thorns, The Romance and Sexual Sorcery of Sadomasochism, Mystic Rose Books, Connecticut, 2010.

418 Ibid, str.
} 
dominantnih i submisivnih partnera, primjerice catsuita" "french maid", "schoolgirl", "pet play” i još brojnih drugih koji su shvaćeni kao estetski i erotski izrazi fantazije. ${ }^{419}$

Pripadnici scene provode vrijeme zajedno i u drugim svakodnevnim prilikama, upoznavajući se međusobno, predstavljajući nove članove i organizirajući razne događaje, od tematskih tribina do privatnih sessiona za odabran, međusobno blizak, uzak krug ljudi koji čine ekskluzivnu zajednicu.

Brojnim S/M praktikantima od izuzetne je važnost pripadanje i sudjelovanje u sceni, zbog vlastitog osjećaja pripadnosti jednakim ili sličnim pojedincima, skupini u kojoj mogu živjeti svoj identitete, biti ono što jesu, dok s druge strane, mnogi ne pridaju tome veliku važnost te preferiraju osobna druženja i sessione s partnerima, isključivo privatno i ne osjećaju potrebu za javnim coming out -om.

Pojam scene stoga nije esencijalan za S/M praksu, jer kao i u svemu ostalome, postoje ljudi koji su skloniji druženju i dijeljenju iskustava, kao i oni koji su samozatajni, individualistički nastrojeni ili ne osjećaju potrebu za time ili se možda ne mogu pronaći u većim skupinama i zajednicama.

Miller i Devon objašnjavaju scenu također kao prvo, predstavljajući pojam playera, odnosno, svih osoba koje participiraju u BDSM odnosima, neovisno o vrsti odnosa, orijentaciji ili ulozi, da bi potom pojasnili osnovnu terminologiju, odnosno koncepte kojima su posredovani S/M odnosi - dominant, submissive, top, bottom, no ne rade između njih bitne materijalne ili ontološke razlike. ${ }^{420}$

Osnovne karakteristike koje pripisuju dominantnoj osobi su prihvaćanje kontrole koje joj predaje submisivna, a za poslušnost, povjerenje i moć koje time dobiva obavezuje se brinuti o submisivnoj osobi i postupati na obostrano zadovoljstvo.

Submisivna osoba, analogno tome, predaje kontrolu nad sobom dominantnoj, i to, ponekad uz dogovorene scenarije i želje, dok mnoge osobe vole ,riskirati opasnost“ kao dokaz moći osobe

\footnotetext{
${ }^{419} \mathrm{~S} / \mathrm{M}$ dress code i pravila ponašanja veoma su dobro objašnjeni u radovima Guya Baldwina i kolumnama i erotskoj prozi Pata Califie, naročito Baldwin, Ties That Bind, Slavecraft te Califia, Public Sex - The Culture of Radical Sex, Macho Sluts te Melting Point i također raznim online riječnicima BDSM terminologije, primjerice xeromag.com, SMil Norge - ww.smil-norge.no te mnogim drugima, op.a.

${ }^{420}$ Phillip Miller,Molly Devon, Screw the Roses, Send Me the Thorns, The Romance and Sexual Sorcery of Sadomasochism, Mystic Rose Books, Connecticut, 2010.
} 
kojoj se predaju. ${ }^{421}$ jer sadisti i mazohisti, naglašavaju autori, ne moraju uopće biti unutar podjela submisivnosti i dominacije, već im je primaran užitak u boli.

Sadist, u suvremenom smislu, osoba je koja uživa u nanošenju boli koja je mazohističnoj osobi seksualno ugodna i potrebna za zadovoljstvo, pružajući joj takvom erotskom stimulacijom bezgraničan užitak, dok mazohist doživljava seksualni užitak u primanju boli, dominaciji, ponižavanju, isključivo u erotskom kontekstu. ${ }^{422}$

BDSM kao deskriptivni koncept seksualnosti, Miller i Devon tumače kao praksu bondagea koji podrazumijeva „blaže“ aktivnosti poput vezivanja, služenja, raznih senzornih senzacija, tjelesnog kažnjavanja kao što je hard bondage i flagelacija. ${ }^{423}$

Izrazito je važno objasniti osobe označene kao „natural submissive“ - osoba koja ima snažnu urođenu potrebu i želju da se podredi i zadovoljava dominantnu osobu, dok ,natural dominant“ ima instinktivnu težnju za kontrolom nad seksualnim partnerom, da podređuje i kontrolira submisivnu osobu, pružajući joj pritom zadovoljstvo i upravo su te odrednice primjer prirodnosti S/M seksualnosti.

Autori naglašavaju razlike uloga u udjelu moći koja se razmjenjuju tijekom scene i ona je najveća u D/s odnosu, dok su top i bottom osobe podjednako angažirane i zainteresirane i za dominaciju i submisivnost, izmjenjuju uloge, odnosno, prakticiraju S/M u switch poziciji. ${ }^{424}$

Pojam scene pojašnjen je prvo, kao cjelokupna skupina ili zajednica osoba koje čine BDSM scenu, ostvaruju međusobne odnose, posjećuju zajedničke, privatne S/M i fetish klubove, a drugo i najvažnije značenje je scena kao session - zajednički erotski susret koji uključuje sve aktivnosti u kojima partneri ili više osoba sudjeluju, a to može biti „,heavy“ ili ,light „, scena, ovisno o razmjeni moći i „težini““ aktivnosti, odnosno stupnju izdržljivosti, boli i iskustvu. ${ }^{425}$ Kao „heavy“ scene autori navode dugotrajni bondage, flagelaciju, a kao light, blaže oblike vezivanja i sve ostale aktivnosti, no presudna je sklonost boli i fiziološki faktor, što je individualno kod svake osobe.

\footnotetext{
421 Ibid, str. 26 - 28

422 Ibid, str. 27

423 Ibid, str. 26

424 Ibid, str. 28 - 31

425 Ibid, str. 25
} 
Najvažnija ideja i motiv cjelokupne koje autori prikazuju te tumače u svim elementima S/m praksi je duboko razumijevanje sadomazohističke seksualnosti kao istovremeno tjelesne, seksualne, romantične i spiritualne.

Miller i Devon u svojoj opsežnoj knjizi, kao svojevrsnom „vodiču“ u BDSM seksualnost i odnose, koliko god interesantan, iskustveno oprimjeren i pristupačan on bio, ipak imaju određenih nedoumica u prikazu pozicija i uloga u S/M odnosu.

Pored detaljnih i akuratnih generalnih opisa i elaboracija BDSM uloga, orijentacija i praksi, autori ipak pomalo površno, ako uopće, razlikuju pozicije i kompleksnost samih razlika između uloga i orijentacija, čemu pristupaju suviše površno i subjektivno iz razloga jednostavnijeg razumijevanja i pristupačnosti širem krugu čitatelja, interesenata i S/M praktikanata.

Autori gotovo čitavo vrijeme govore isključivo o dominantnoj i submisivnoj osobi, od kojih je prva uvijek muškog, a druga ženskog roda, što je velika materijalna pogreška, obzirom na broj submisivnih muškaraca koji je gotovo jednak broju submisivnih žena, i zbog toga je jasno da, govore prvenstveno o vlastitom, subjektivnom odnosu.

Velik problem predstavlja i njihovo izjednačavanje „Dominant/submissive“ uloge s „Master/slave“ pozicijama, koje su za njih samo proširene verzije dominantnih i submisivnih uloga, nazivajući ih ,D/s lifestylerima“. ${ }^{426}$

Između $D / s$ i Master/slave odnosa iznimno je velika razlika već u samome shvaćanju, doživljavanju vlastite pozicije i partnera i to na način da slave osoba svoju poziciju doživljava isključivo posredno svojim odnosom prema Gospodaru, njena je primarna želja biti posjedovana i upravljana, a taj se odnos manifestira već samim obraćanjem, ponašanjem, koje prethodi svakoj drugoj S/M ili seksualnoj aktivnosti.

Master/slave odnos obuhvaća sve aspekte života partnera, njihovu cjelokupnu egzistenciju, osoba u slave poziciji predaje svu svoju moć i povjerenje Gospodaru, koji njome upravlja samo $\mathrm{u}$ najboljem zajedničkom interesu, s posebnim naglaskom na brigu o svom robu/inji, i to isključivo uz pristanak koji biva stipuliran ugovorom, a može uključivati bezuvjetnu, bezgraničnu predaju ili uz određene uvjete ili granice.

Najveću pažnju potrebno je stoga posvetiti proučavanju i tumačenju psihološkog i socijalnog konteksta BDSM odnosa i praksi, da bi se moglo razumjeti sadomazohističku seksualnost kroz prizmu psihe i društva.

426 Ibid, str. 26 
Društveni odnosi i BDSM predmet su znanja o odnosima moći, te obuhvaćaju daleko više od S/M seksualne prakse, pružaju nam uvid u jedan čitav ,,svijet“" seksualnosti koji, Foucaultovim riječima, proizvodi i replicira pozitivne i produktivne odnose.

Ranije spomenuti istaknuti američki psihoterapeut, savjetnik i autor Charles Moser, specijalist za područje sadomazohističke seksualnosti u svojoj knjizi „Bound to be Free“, iz 1996. godine, $\mathrm{u}$ koautorstvu s JJ Madeson (eksponiranom participanticom BDSM scene), razrađuje sadomazohizam u samoj njegovoj praksi, kroz brojne primjere iz života osoba s BDSM scene i ostalih praktikanata s kojima je surađivao, koji su na prvome mjesto u ovom izrazito interesantnom i relevantnom djelu. ${ }^{427}$

Njihov deskriptivni real life pristup razlikuje njegovu interpretaciju BDSM seksualnosti jer je razlikuje od brojnih drugih teoretičara i terapeuta koji su bili usredotočeni na isključivo medicinske teorije, zanemarujući pritom ono najvažnije.

O S/M seksualnosti Moser, sa znanstvenog stajališta psihoterapeuta i s ciljem približavanja i demistifikacije S/M seksualnosti govori:

,$S / m$ je vjerojatno najmanje razumljeno i najzastrašujuće seksualno ponašanje, no $S / m$ je sigurna seksualna igra, to je igranje uloga u seksualnoj areni i ono što je smatrano čudnim $i$ nastranim te rijetkim fenomenom, zapravo to nije.

Moj osobni pogled znanstvenih podataka upućuje da je S/M samo još jedna valjana seksualna varijacija i nije patološka. “428

Moser i Madeson u prvi plan postavljaju društveno - psihološku dimenziju jer upravo je ona temeljna za razumijevanje sadomazohističke seksualnosti, u svojoj psihologiji i tjelesnoj praksi, te je stoga njegova pozicija ona prikladna za tumačenje psihologije individualnog i društvenog aspekta sadomazohizma.

Autori objašnjavaju istinske BDSM odnose stručno, prema BDSM pravilima prema kojima scena i pojedinačni odnosi funkcioniraju.

Uloge dominantnih i submisivnih osoba te aktivnosti koje prakticiraju ili se žele upustiti, napominju autori, moraju biti jasno dogovorene i tu raznolikost S/M praksi i pojedinaca autori opisuju izvrsnom formulacijom:

\footnotetext{
${ }^{427}$ Charles Moser, JJ Madeson, Bound to be Free, The S/M Experience, Continuum, New York, 1996

428 Ibid, str. 20, prijev.a.
} 
"U BDSM svijetu je beskrajan diverzitet ljudi, stilova i mogućih aktivnosti koje radimo, način na koji ih učimo činiti, a što dobivamo radeći ih limitirano je samo našom imaginacijom: virtualno bezgranično. “429, pojašnjava JJ Madeson.

Tumačenje sadomazohističke seksualnosti od samih fundamenata, autori započinju distinkcijom upotrebe samih termina ,sadomazohizam, koji se koristi u znanstvenim i profesionalnim zajednicama, dok S/M, kolokvijalni pojam participanata iste seksualnosti, no denotativno imaju isto značenje.

Kod slučajeva dominantnih i submisivnih osoba, i, s druge strane, sadista i mazohista, te Master/slave odnosa slučaj je bitno drugačiji.

Kao što je više puta naglašeno, podjele uloga i pozicija, orijentacija i preferenca ne mogu se univerzalno kategorizirati, već su varijabilne i subjektivne, ovisno o konceptualnom sustavu pojedinog teoretičara, praktikanta, pojedinca koji promišlja ili prakticira S/M seksualnost.

Moser i Madeson nastoje pružiti što preciznije objašnjenje uloga i odnosa te opisuju dominaciju i submisivnost kao ,namjerni prijenos psihološke $i$ seksualne kontrole jednoga partnera drugome" na način iživljavanja scenarija bondagea i discipline uz raznolike aktivnosti poput fizičkih ograničenja i svladavanja vezivanjem, bičevanjem, senzornim deprivacijama, ovisno o intenzitetu. ${ }^{430}$ jer bol je izuzetno jaka seksualna stimulacija koja mazohistične osobe dovodi do orgazma i psihičke katarze.

Psihička dimenzija S/M - a sastoji se u uživljavanju u potpunu disciplinu, ponižavanje kao užitak pripadanja i kažnjavanja, i u tom se momentu isprepliću psihičko i tjelesno, kao temeljna razlika submisivnih osoba i mazohista.

Submisivne osobe nalaze užitak prvenstveno u verbalnom i fizičkom ponižavanju i kontroli i naredbama na „degradirajuće“ izvedbe te potpunoj predaji, dok mazohisti doživljaju erotsko zadovoljstvo i orgazam isključivo putem senzacije boli, a u ,idealnom“ slučaju tjelesna žudnja za boli i psihička za poniženjem i podređenošću se preklapaju.

Jednako je i kod sadističkih i dominantnih osoba, zadovoljstvo u nanošenju boli partneru, svjesno uz obostrani pristanak i užitak u kontroli, ponižavanju i dominaciji nad drugim ne moraju uvijek biti dio iste osobe, no obično su komplentarni.

Moser i Madeson razvijaju odlične elaboracije S/M seksualnosti scene, opisujući i detaljno pojašnjavajući BDSM scenu putem opisa uloga praksi i aktivnosti, no najvažnijim smatram analizu intervjua $\mathrm{S} / \mathrm{M}$ praktikanata s psihološkog i seksualnog aspekta, koji govore o svojim

\footnotetext{
429 Ibid, str. 91, prijev.a.

430 lbid, str. 25 - 32
} 
doživljajima spiritualnih senzacija uzrokovanih intenzivnim tjelesnim podražajima boli, submisivnosti ili kontrole i dominacije.

Užitak i seksualno zadovoljstvo izuzetno su vezani za bol kao „ekskvizitnu agoniju“, koncept harmonije psihičke submisivnosti predavanja kontrole i moći partneru i tjelesnog mazohizma, koji se manifestira senzacijama boli kao neizmjernog užitka.

Jedan od početnih i najvažnijih momenata BDSM - a je življenje svojih fantazija, od kojih je najzastupljenija fantazija silovanja, rape fantasy, za koju autori napominju da je:

„Fantazija silovanja“ konsenzualna ,, seksualna igra“ dogovorena unaprijed ili scenarijem ili raspravom o aktivnostima koje su željene ili dozvoljene i psihološkim i fiziološkim granicama koje mogu biti istražene.

Snažno bismo naglasili da premda je istina da su mnogim ženama fantazije o silovanje vrlo erotske, pravo silovanje nije željeno. Silovanje je čin nasije, S/M aktivnosti su prirodno seksualne. S/M fantazija može dozvoliti iskustvo grube seksualnosti i bespomoćnosti, koje su glavne komponente erotizma silovanja i konsenzualno igranje te fantazije može biti zabavno $i$ sigurno, priznavanjem da smo izabrali svog partnera jer fantazije su prirodni $i$ normalni produkti imaginacije. " 431

Najvažnija deskriptivna konkluzija o sadomazohističkoj seksualnosti najbolje je izražena u deskriptivnoj konstataciji Charlesa Mosera:

„Istraživačke studije niti podržavaju niti negiraju razvojni uzrok za S/m ponašanje.

To znači da istraživanje nije bilo u mogućnosti izdvojiti niti jedan bihevioralni pokazatelj koji bi indicirao da će određena osoba postati sadomazohist.

Dok će istraživanja nesumnjivo nastaviti u tom području, sudeći prema neizmjernom diverzitetu individualaca uključenih u $S / M$, ne čini se izgledno da će se takve indikacije pronaći. "432

Budući da „raspravljajući o seksualnim uspomenama i fantazijama iz djetinjstva vidimo da većina takvim upamćenih iskustava prije nastoje ukazati stupanj dominacije ili submisivnosti, nego na želju za samim $S / M$ - om. “433

Jedini utjecaj i razlog želje za ili Dom/sub odnosom ili sadizmom i mazohizmom nalazimo možda u pitanju o ranim fantazijama:

„Od onih koji svojevremeno usvoje $S / M$ kao ,sexstyle“ odgovaraju li uloge dominacije $i$ submisivnosti u kojima se osjećaju najugodnije na bilo koji način razvojnim dominantnim ili submisivnim ponašanjima u njihovim ranim godinama?

\footnotetext{
431 Ibid, str. $141-142$, prijev.a.

432 lbid, str. 41, prijev.a.

433 Ibid, str. 41, prijev.a.
} 
Jesu li njihovi mladenački snovi i fantazije bili indikativni seksualnoj ulozi koju su usvojili kao odrasli ?"“434

Želimo li zaista shvatiti BDSM seksualnost kao iznimnu i vrijednu proučavanja, individualističku i nadasve interesantnu, vrijednu psihološkog i filozofskog promišljanja bitno je uzeti u obzir važnost življenja fantazije i dinamike moći:

„Budući da je S/M iskustvo izraz, dijeljenje i provedba seksualnih fantazija koje se najčešće fokusiraju na kontrolu jedne osobe nad drugom, imperativ je da istinska jednakost partnera bude zamijenjena za vrieme igre, iluzijom nejednakosti.

Ta iluzija formira bazu međuigre partnera i najefektivnije je karakterizirana kao „power exchange“ „izmjena moći“, gdje je moć kontrola i odgovornost za, u kojoj odricanje osobne moći jedne osobe i preuzimanje te moći druge stvara dvije nove persone : dominantnu $i$ submisivnu. "435

${ }^{434} \mathrm{Ibid}$, str. 41, prijev.a.

${ }^{435} \mathrm{Ibid}$, str. 93, prijev.a. 


\subsection{Pozicija radikalnog BDSM - a}

\section{Radikalna seksualnost i ,nekonsenzualni pristanak“}

U socijalno - ontološkoj sferi, pozicija osoba koje prakticiraju BDSM u odnosu na društvo je veoma složena, obzirom da u većini slučajeva, ta seksualnost još uvijek nije do kraja društveno prihvaćena, osim u državama sjeverne i zapadne Europe, no neovisno o tome, odnos društva prema BDSM - u je vrlo složen i pluriperspektivistički.

BDSM, kao i svaka druga seksualna ili životna praksa, individualan je i ne može ga se generalizirati i konačno, ljudi su nedovoljno, a često i izrazito pogrešno upućeni u značenje i praksu ove bitne seksualnosti.

Kao što je već spomenuto u prethodnome poglavlju, radikalni BDSM se odvija isključivo vođen temeljnim motom „Safe, Sane and Consensual“ i niti jedna strana ne smije naštetiti drugoj, manipulirati njome na neprikladan način, fizički ili psihički.

Odnos 24/7 total power exchange već je pojašnjen iz ontologijske pozicije osobe kao vlasništva i poprimanja novog identiteta, no kakav je zaista odnos između BDSM praktikanata obzirom na njihovu poziciju, prvo na osobnoj razini između dvije ili više osoba, na BDSM sceni kao široj zajednici, a potom u društvu?

Dotična se problematika može pojasniti s više stajališta, ovisno o tumačenju ili doživljaju određenog praktikanta i/ili autora o razmjeni moći.

Razmjena moći i $D / s$ te Master/slave odnos općenito može se promatrati kao kompletan i ekskluzivan, i tada govorimo o konceptu „total power exchange“, odnosno, potpunom predavanju moći jedne i provođenju apsolutne moći druge.

Za što stručnije tumačenje BDSM odnosa bitno je, pored razumijevanja terminologije i razlike između erotske i totalne izmjene moći, razumjeti odnose prema i samoj biti ulogama, bitku osoba koji sačinjava njihovu ulogu i egzistenciju vođenu predispozicijom i subjektivnom željom individuuma.

Bitno je jasno razumjeti koncepte dominacije i submisivnosti u relacijama boli i užitka da bismo mogli shvatiti vrste i tipove sadizma i mazohima jer mazohizam i submisivnost ne moraju biti uopće u međusobnoj korelaciji kao neophodno interinkluzivni i uvjetovani, štoviše postoje mogućnosti potpunih oprečnosti u karakteru osobe, primjerice, mazohist može biti izrazito 
dominantna, pa i abuzivna osoba, koja prvo, prekoračuje granice svoje prvotne orijentacije, a time ne može pripadati BDSM praksi zbog neetičkog postupanja.

Zadržat ću se na nekim uobičajenijih primjera, sličnih onima koje je razradila Lynn Chancer dominantni mazohisti i submisivni sadisti, budući da su sadizam i dominacija u složenom odnosu jer osoba sadističkih sklonosti ne mora biti i dominantnog karaktera.

Mazohist ne mora biti submisivna osoba, a jednako tako submisivna osoba ne mora uopće uživati u boli već recimo, u verbalnom ponižavanju i ulozi sluge/služavke te uživati tako još u brojnim aktivnostima koje ne uključuju bol, čak niti seksualni odnos.

Submisivnost kao takva može obuhvaćati i bottom i slave pozicije, no ako se radi o prvom stupnju, recimo bottom ili submissive, osoba ne mora uopće biti mazohistična.

Stupnjevanje pozicija submisivnosti određuje se mjerom koliko vlasti nad sobom submisivna osoba daje dominantnoj, koliko vlastite slobode predaje Drugom.

Također, bitno je razjasniti i pitanje boli jer postoje brojne BDSM prakse koje ne uključuju bol ili tek neznatnu bol, prmjerice bondage, poniženje, služenje, razne vrste naređivanje te psihička kontrola kao ultimativna praksa moći.

Centralna je praksa stoga power exchange ili izmjena moći, i prema njoj možemo donekle kategorizirati osobe po njihovoj orijentaciji unutar submisivnosti i dominacije i važno je napomenuti i da svaka osoba ima svoju individualnu percepciju boli, užitka, podčinjenosti, želje za dominacijom te afinitete premaodređenim praksama.

Ne postoje univerzalni obrasci $D / s$ odnosa jer na kraju, sve bi trebalo biti ili stvar dogovora ili pak spontanog istraživanja vlastite i partnerove psihe i seksualnosti i njihovih granica, a to podrazumijeva ravnopravnost partnera jer Dom/sub ili Master/slave su konsenzualne uloge koje proizlaze iz orijentacije i želje.

I sadisti i mazohisti dijele „sebičnu“, no u istinskom BDSM - u, naravno, uvijek konsenzualnu potrebu za D/drugim kao seksualnim objektom, drugom osobom kao ,predmetom“ svojih seksualnih želja i fantazija - objektom svoje želje.

Gotovo jednako kao dominantna, sadistički nastrojena osoba, tako i mazohistički predisponirana i orijentirana osoba dožvljava drugog - kao uvjet za ostvarenje svog zadovoljenja, naravno iz drugačije pozicije i perspektive.

Izuzetno je relevantno razumjeti kategorijalne razlike, i to ne samo sadist - mazohist i submisivna - dominantna osoba, već i one neoprečne kao što su sadist - dominant ili gospodar 
budući da mazohist ne mora uopće biti submisivna osoba već dominantna, a sadist submisivan, i to indicira da u domeni psihoseksualnosti ne postoje striktna pravila, već individualne preference uslijed stjecanja iskustva.

Kao primjer navest ću slučajeve kad mazohistična osoba u potpunosti ima glavnu riječ i zahtjeva bol i određene radnje od sadista i analogno, kad sadist čini mazohističnoj osobi ono što ona želi, no sve se odvija uz uzajamni dogovor i užitak.

Kad govorimo o dominantnim mazohistima, upravo je bol i želja faktor koji određuje i usmjerava relaciju dominacije i submisivnosti i stoga je površno izjednačavati mazohizam sa submisivnošću, što većina autora ipak čini.

Mnogo je manje slučajeva submisivnih sadista i stoga je mazohizam shvaćen kao centralan za filozofiju i praksu sadomazohističke seksualnosti.

Dominantni je mazohist egocentrična osoba koja uživa u boli, vodi $D / s$ odnos te objektivira sadista - doživljava ga kao objekt svoje želje, kao drugog koji se mora podrediti njenim željama $\mathrm{i}$ ispuniti njene fantazije.

Razumijevanje ove dinamike bitno je za malo drugačije poimanje mazohizma u korelacije sa sadizmom, a također i za diferencijaciju mazohizma od samorazumljive submisivnosti i sadizma od neizbježne dominacije.

Za razumijevanje načina života, egzistencije kao takve, u kojoj je sadomazohistički odnos neophodan za ozbiljenje ne samo seksualnog zadovoljenja već seksualnosti uopće, bitno je pokušati shvatiti veoma kompleksnu psihologiju sadomazohizma, na razini osobe, zajednice i refleksije u društvu.

Činjenica je da je brojnim osobama uistinu nemoguće zamisliti drugačiju seksualnost i način života, bilo u odnosu s partnerom ili na sceni BDSM zajednica te ako, prema ranije spomenutim statistikama, između 5 i $25 \%$ populacije zapadno europskih zemalja prakticira neki oblik BDSM odnosa ili aktivnosti, ne bi trebalo biti teško prihvatiti da među njima postoje i osobe kojima je sadomazohistička seksualnost, conditio sina qua non, ne samo užitka već njihovog bitka i egzistencije.

Drugim riječima, nemoguće im je živjeti i ostvariti sebe u supresiji svoje seksualnosti, bez S/M odnosa koji ih čini onim što jesu, razvijajući njihovu psihu i pružajući im neprestano nova iskustva koja, kroz usavršavanje već proživljenih, bivaju uvijek i iznova neponovljiva i za njih su odnos dominacije i submisivnosti jedina moguća i zadovoljavajuća seksualnost. 
S/M je ponekad doživljen u tom smislu kao revolt protiv nametanja takozvanog „mainstream“, konzervativne seksualnosti, no prvenstveno kao iskonski poriv koji osoba nosi u sebi, a inhibicijom istoga pati od teških frustracija i neuroza, pa nerijetko postaje krajnje neuravnotežena, depresivna i autodepresivna jer se protiv svoje volje bori protiv sebe i tada njena seksualnost postaje patološkom.

Ovim se argumentima nastoji ukazati na činjenicu da je $\mathrm{S} / \mathrm{M}$ je nezamisliv način života velikom broju ljudi koji ne samo odbijaju, već ne mogu zamisliti prakticiranje isključivo „vanilla“ odnose, drugim riječima, odnose koji su fokusirani na „tradicionalno“ shvaćanje i prakticiranje seksualnosti, te gotovo nikada ne uključuju BDSM elemente, osim ponekad neke blage aktivnosti kao povremene ,igre“.

Važno je naglasiti da je BDSM, već kao jezična konstrukcija, psihološka sintagma i time je praksu sadizma i mazohizma, dominacije i submisivnosti neophodno shvaćati simbiotički jer se međusobno uvjetuju u svakome odnosu, te i unutar jedne ličnosti, koja izražava obje sklonosti i zato ranije objašnjeno Deleuzovo radikalno odvajanje sadizma od mazohizma nosi brojne dileme i konsekvence za razumijevanje sadomazohističke seksualnosti.

Budući da on inzistira na tezi o dvije sasvim različite seksualnosti, potkrepljujući to uistinu valjanom filozofskom elaboracijom, ostavlja velik problem razumijevanja odnosa sadista i mazohista, s obzirom da on sadomazohističku seksualnost postavlja isključivo kao odnos dvaju mazohista, neovisno o tome što je jedan u apsolutno dominantnoj, a drugi submisivnoj ulozi. ${ }^{436}$ Polazište i razlog njegove teorije su utemeljen na shvaćanju mazohizma kao primarnog, što sadizam istovremeno i odvaja od njega i čini ga, može se reći, ,pervertiranim“ produktom mazohizma, a za filozofiju i psihologiju sadomazohizma izrazito je važno je do krajnjih granica razjasniti poziciju submisivne osobe u odnosu na dominantnu i vice versa.

Dosad je bilo riječi o osnovama BDSM odnosa, o objektivizaciji submisivne osobe, no sada će se objasniti koncept submisivne osobe kao vlasništva dominantne.

Takav odnos, kao najekstremniji oblik BDSM odnosa, temelji se na bezuvjetnom pristajanju bivanjem vlasništvom d(D)rugog ili rob dominantnoj osobi kao Gospodaru, odričući se svih vlastitih prava ugovorom, osim prava potpunog prekidanja ugovora.

${ }^{436}$ Gilles Deleuze, Coldness and Cruelty, Zone Books, New York, 2013 str. 40 - 46! 
Osnova koja proizlazi iz osobne psihičke tendencije, jest $D / s$ odnos, tj. odnos dominantne i submisivne osobe, čije će elementarne varijacije i uvjeti biti detaljnije elaborirani i otvoreni za promišljanje bezbrojnih horizonata BDSM seksualnosti.

Primarni uvjet sina qua non je konsenzualnost, pristanak obje osobe, pogotovo submisivne, na aktivnosti koje želi prakticirati, koje je voljna pokušati i aktivnosti koje trenutno ili permanentno ne dolaze u obzir, tzv. "hard limiti", granice koje submisivna osoba ne želi ili ne može prijeći, što, naravno, isto vrijedi i za dominantnu osobu, ako u nekim aktivnostima nema još dovoljnog iskustva ili prema njima jednostavno ne osjeća nikakav afinitet, što je varijabilan pojam, ovisan o iskustvenom vremenu.

Izrazito je važno naglasiti da istinski BDSM odnos mora egzistirati na potpunom međusobnom povjerenju, naročito kad govorimo o trajnoj vezi ili 24/7 odnosu, u kome je submisivna osoba $\mathrm{u}$ bilo koje vrijeme na raspolaganju dominantnoj, jer se ona ili on tada u potpunosti predaje svim željama i naredbama svog Dom partnera ili Gospodara, ovisno na koji je način veza semantički konceptualizirana.

Tu razliku će se pojasniti - „Dom“ ili „Domme“, kao ženska inačica, ne mora nužno biti Gospodar, Gospodar implicira potpunu vlast nad submisivnom osobom, čak i situacije da je ona njegovo vlasništvo, naravno, vlastitom stipulacijom međusobnog ugovora, koji je bitan dio ekstremnog BDSM-a, a ide čak do označavanja "roba" ili "robinje" tetovažom ili "brandingom" tj. žigosanjem inicijala Gospodara.

Mnogi parovi ili povremeni "play partneri" običavaju ispuniti "checklist" aktivnosti i na taj način im je najjasnije u kojem smjeru će se odnos i scene dalje odvijati.

Submisivna osoba ima gotovo uvijek pravo prekinuti ili ublažiti pojedinu aktivnost korištenjem "safeworda", riječi koje označavaju stupnjeve boli, ili znakova, ovisno o sceni tj. aktivnostima koje se u danom momentu odvijaju i mogućnosti izražavanja.

U "hard BDSM-u" često nema "safeworda" i prakticiraju se intenzivne aktivnosti do krajnjih granica, što se naziva "edge play", poput teške asfikcijacije rukama, užetom ili raznim opremom za tu namjenu, snažnog dugotrajnog bičevanja, vezivanja i suspenzije u veoma zahtjevnim položajima i upravo je tada osnovno iskustvo i znanje dominantne osobe i bezgranično povjerenje submisivne.

Bitno je spomenuti da se granice pa i ,hard limiti“ gotovo uvijek s vremenom pomiču, pozicije submisivnosti i dominacije evoluiraju, što je znak razvijanja obje osobe i u njihovoj izvornoj S/M poziciji i kao ličnosti u psihološko - ontološkom smislu te svaka promjena znači 
savladavanje novog iskustva, izazova, koji se prije smatrao nedostižnim, čak nezamislivim pa je stoga BDSM područje konstantnog učenja i usavršavanja. ${ }^{437}$

O vlasništvu dominantne osobe kao Gospodara nad submisivnom kao robom, referirat ću te na Kantovu teoriju ugovora $s$ i vlasništva nad drugom osobom.

Kant u svojoj teoriji vlasništva u „Metafizici ćudoređa“ razrađuje pitanje na koji način nešto može biti nečije vlasništvo i zaključuje da je to moguće jedino introjekcijom, da ga se pravnim ugovorom učini svojim, vlastitim i u tom kontekstu možemo tumačiti i introjekciju druge osobe kao vlasništva putem ugovora.

Za njega je polazište ,posjedovanje nečijeg htijenja kao moć da ga svojim vlastitim htijenjem po zakonima slobode navedem na neki čin ${ }^{“ 438}$ i to je ,jedno od prava (kojih spram iste osobe ili spram drugih mogu imati više); ali sustav zakona po kojima to htijenje mogu posjedovati jest osobno pravo koje je samo jedno jedino “439 i shvaćeno je kao inteligibilno pravo, međusobnim sporazumom i Kant tako konstatira da je ,čin sjedinjenog htijenja dviju osoba kojime vlastito jednoga uopće prelazi drugome jest ugovor. “440

Bitno je napomenuto da je kod Kanta svaki ugovor intelektualni i pravni odnos posjedovanja između dvaju jednakopravnih osoba, prema zakonima slobode, obzirom da on ima jasne stavove pravnih mogućnosti ozbiljenja vlasništva nad drugom osobom - ugovorom koji za njega obavezuje na korištenje tijela druge osobe.

Radi se o spolnoj zajednici koja je ,uzajamna uporaba spolnih organa i sposobnosti ${ }^{\star 441}$, a kao prirodna može biti ili ,puke životinjske naravi ili zakonita -brak tj. Veza dviju osoba različita spola radi doživotna uzajamnog posjedovanja svojih spolnih svojstava “, a „prirodna uporaba spolnih organa drugoga jest užitak radi kojega se jedan spol podaje drugome. U tom činu čovjek sam od sebe čini stvar i to je moguće samo pod jedinim uvjetom da neku osobu, koja drugu stječe poput stvari, ta druga pak stječe zauzvrat ; jer tako opet zadobiva samu sebe $i$ ponovno uspostavlja svoju osobnost. ${ }^{\text {(442. }}$.

\footnotetext{
${ }^{437}$ Ovaj osnovni uvod u BDSM praksu ili lifestyle pišem iz vlastitog općeg znanja o ovoj sferi seksualnosti, no također, reference svega navedenog nalaze se u knjizi Phillipa Millera i Molly Devon, Screw the Roses, Send Me the Thorns, The Romance and Sexual Sorcery of Sadomasochism, Mystic Rose Books, Connecticut, 2010.

${ }^{438}$ Immanue Kant, Metafizika Ćudoređa, Matica Hrvatska, Zagreb, 1999, str. 65

${ }^{439}$ Ibid. str. 65

440 lbid.str. 65

441 Ibid. str. 70 - 71

442 Ibid. str. 71
} 
Na temelju Kantove ideje stvarnog i osobnog prava, možemo povući paralele sa specifičnim položajem osobe kao vlasništva drugog, poimanjem i tretiranjem submisivne osobe kao konsenzualnog ,vlasništva“.

Takvom odnosu prethodi ugovor i konačni pristanak obje strane na sve stavke navedene u istome, a može biti dogovoran ili u nekim državama legitiman.

Njime se definira specifična zajednica, dogovoreni način ophođenja koji tada zadobiva ontološku - socijalnu dimenziju jer submisivna kao „rob“ postaje objekt drugome no međusobnom ugovornom obavezom objektificira dominantnu osobu gospodara i identitet osobe se ponovno uspostavlja.

Postoje brojne verzije takvih legitimnih ugovora, sastavljenih od strane odvjetnika, primjerice u SAD - u i oni su zapravo znak potpune konsenzualne podređenosti, što je većini veoma teško razumjeti, No, ako je riječ i o simboličkom pisanom ugovoru, koji je najčešće u obliku knjižice koji obje osobe ispunjavaju i potpisuju, on se prema pravilima BDSM zajednice mora poštivati, a o izmjenama se uvijek može iznova razgovarati i pregovarati.

Najradikalniji izraz i oznaka takve vrste vlasništva je, već spomenuta tetovaža $\mathrm{s}$ inicijalima Gospodara /vlasnika ili branding, žigosanje na određeni dio tijela i Gospodar u tom slučaju s robom može činiti što god ga je volja, izlagati ga najkontroverznijim naredbama koje je dužan ispuniti, posuđivati ga drugim gospodarima, bez safeworda, ograničenja, naravno, sve dok rob ne prekine ugovor.

Uvijek odličan primjer takvog odnosa je roman Pauline Reage „Story of $O$ “, u kojem mlada žena biva uvedena u odnos potpune potčinjenosti i postaje vlasništvo svog ljubavnika, te njegovom željem robinja brojnih drugih muškaraca.

U njenom djelu osnovna je ideja postajanje submisivnom, potpunom robinjom u kojem $\mathrm{O}$ otkriva sebe i više joj drugačija egzistencija nije zamisliva i ne želi je prihvatiti, jer mora „biti željena“, „biti objekt"“ i stoga autorica na kraju ostavlja otvoreno pitanje je li protagonistica izabrala „odbačenost“ Gospodara ili smrt.

Na sličan način na koji je Simone de Beauvoir definirala postajanje ženom, kao rodni identitet s kojim se ne rađamo, već ga stvaramo, moglo bi se objasniti postajanje submisivnom osobom, međutim, de Beauvoirina postavka ne bi bila u mnogočemu točna kad bi se shvaćala doslovno, kao što niti postojanje i bivanje submisivnom ili dominantnom osobom nije nešto što se postaje, već je urođeno te se od najranije dobi nadalje nadograđuje. 
Dotična predispozicija se u BDSM terminologiji naziva „natural submissive“ ili „,natural

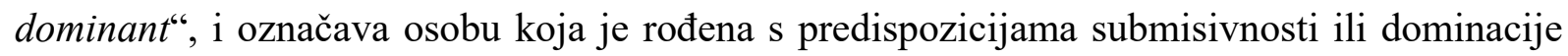
koje dalje razvija. ${ }^{443}$

Znanstveni pristup sadomazohizmu zahtjeva razumijevanje i samog koncepta relacija dominacije i submisivnosti, no pored toga i na koje sve načine takav odnos mogu doživljavati osobe koje ga prakticiraju.

Radikalni sadomazohizam u društvenom i interpesonalnom kontesktu bit će detaljnije razrađen u narednom poglavlju, od samih temelja, terminologije, odnosa i prakse i to perspektivama suvremenih autora, istraživača i BDSM praktikanata.

Za bolji uvid u dotičnu problematiku, osvrnut ću se na neke segmente tipologije i kategorizacije sadomazohističke prakse u općem, prototipnom obliku.

Kao prvi oblik navest ću slučajeve insceniranih slučajeva s specifičnim, dogovorenim ili spontanim, no ipak, konsenzualnim scenarijem koji se odvijaju se tako i privatno i u javnosti, a najbolji, prototipni primjeri takvih „scena“ su simulirane otmice ili rape play, popraćenih „,nesporazumima javnosti““ kakve navodi kanadska teoretičarka sadomazohizma i pornografije Ingrid Olson u svojim brojnim radovima i studija, od kojih navodim njen rad ,Abduction in the Public Sphere: Sadomasochism, Surveillance and Governmentality“ iz 2016. godine u kojem je izložila studiju slučaja insinuirane otmice kao realno izveden, osmišljeni scenarij S/M scenarij u sadomazohističkom role playu.

Olson opisuje slučaj u kojem je osoba konsenzualno bila oteta na javnom mjestu, odvedena na siguno mjesto te ,podređena fizičkoj i seksualnoj agresiji: grupnom silovanju“4444 a nekolicina građana koji su svjedočili „otmici“ i percipirali je kao kriminalnu radnju promatrali su i željeli pozvati policiju, dok im participanti nisu „objasnili situaciju“, što je zahtijevalo dulje vrijeme. Olson ovu konkretnu situaciju tumači kao „,nenormativnu seksualnost u javnom prostoru“, te Foucaultovom sintagmom „sexual counter - conduct“, tj.,,seksualno kontraponašanje“ te postavlja pitanja „koja su ograničenja seksualnog ponašanja u javnoj sferi “. ${ }^{445}$, nastavljajući bitnim razlikovanjem nasilnog čina otmice i silovanja i scenarija istoga u kontekstu BDSM - u, koji je simbolički i konsenzualan .

\footnotetext{
443 Phillip Miller, Molly Devon, Screw the Roses, Send Me the Thorns, The Romance and Sexual Sorcery of Sadomasochism, Mystic Rose Books, Connecticut, 2010

${ }^{444}$ Ingrid Olson, „Abduction in Public Sphere : Sadomasochism, Surveillance and Governmentality“, 2016,

Conference Presentation, American Association of Geographers, 2016

445 Ibid.
} 
Ona naglašava da je osobama koje nisu S/M praktikanti veoma teško zamislive i prihvatljive javne S/M aktivnosti, te naglašava termin „consensual non - consent“ ili „konsenzualni ne pristanak“, koji ima značenje ekstremnih seksualnih praksi, čije prakticiranje u javnosti pojačava stimulaciju i seksualno uzbuđenje participanata.

Olson čitav realni scenarij tumači referencama na Foucaulta, naglašavajući seksualnost kao strategijski dispozitiv te problematiku nadziranja seksualnosti, provođenja moći nad tijelom te hermeneutike subjekata koji provode moć seksualnim kontraponašanjem, pozicioniranjem sebe izvan tehnika normalizacije. 446

Konačno je relevantno i interesantno spomenuti da je Olson i sama bila jedna od participanata „otmičara“ i da je ocijenila čitav scenarij, uz detaljne opise, veoma uspješnim, što izražava suvremeni otvoreni, ouvert pristup znanosti o $\mathrm{S} / \mathrm{M}-\mathrm{u}$.

S druge strane, Jack Rinella opisuje iz osobnog iskustva veoma apsurdnu situaciju inscenirane otmice, prisjećajući se vlastite epizode započete korespondencijom s jednim muškarcem koji mu je izrazio želju da bude otet, na što je on i pristao učiniti, te ga je oteo odmah u zračnoj luci, stavio mu lisice u automobilu, te ga odveo svojoj kući i s povezom ga odveo u svoj dungeon. Međutim, morao je izići poslom i kad se vratio, njegov „zatvorenik“ je nestao, ostavivši poruku da mu zahvaljuje na dobrom provodu.

Rinella želi prikazati neuspjeli scenarij da bi prikazao osobu koja ne zna što želi i nije ozbiljna u svojim namjerama, što je veliki nedostatak u S/M praksi. ${ }^{447}$, a ono najvažnije što želi istaknuti je problem brojnih osoba koje imaju fantazije da budu „zatočene“, obrazloženo pretpostavljajući da žele samo fantaziju i bijeg od realnosti, a ne BDSM:

„Zabavno vrijeme u dungeonu $i$ dobar seks može nam pomoći da nakratko pobjegnemo, no bijeg će biti vrlo kratak. Zdravi životi građeni su na suočavanju s problemima i njihovom rješavanju i sama priroda S/M - a nastoji dovesti realitet u jasniji fokus: povećanu svijest o našim tijelima, povišena intimnost i nešto u vezi boli, užitka i seksa se udružuje ih da učine realitet više stvarnijim, ne manje. " 448

Iznimno je važno pridati važnost fenomenima javnog ponižavanja u kojem submisivne i mazohistične osobe nalaze ultimativno zadovoljstvo, a takvih primjera je zaista mnogo $u$ BDSM praksi u stvarnome životu te kod autora od 18. do danas, od erotske književnosti do teorije seksualnosti.

\footnotetext{
446 Ibid

447 Jack Rinella, Partners in Power, Living in Kinky Relationships, Greenery Press, Oakland, California, 2003, str.37

448 Ibid, str. 36
} 
Kao eklatantne primjere izdvojila bih Sacher - Masocha, P. Reage te P. Califiu, od kojih je posljednji kao transgender osoba bila i feministička teoretičarka, BDSM praktikantica i autorica teorije i ,provokativne“ autobiografske erotske proze.

Sacher - Masoch je vjerojatno prvi autor koji je prikazao estetsku dimenziju erotske submisivnosti i seksualnog užitka u ponižavanju, dok kod Reage, koja je također izuzetno zastupljena u ovom radu, nalazimo elemente i estetskog i naturalističkog.

O recepciji njene „Story of $O$ “ rečeno je zaista mnogo, od psihoanalitičkih analiza mazohizma, do „ozloglašenosti“ u nekim feminističkim pristupima, dok je Sacher - Masoch, kao što je već spomenuto bio predmet temeljnih komparativnih analiza mazohizma u odnosu na sadizam kod Deleuzea, ali i brojnih suvremenih teoretičara književnosti i filozofije seksualnosti.

Obzirom da su sva navedeni autori i prakse izložene u njihovim djelima detaljno objašnjenje, bitno ih je razumjeti u suvremenoj BDSM praksi, da bismo uvidjeli da se njihova suština nije bitno promijenila, budući da su još uvijek kao najzastupljenije prakse predmeti brojnih rasprava o pitanjima psihičke stabilnosti, pristanka, samosvijesti i izmijenjene svijesti.

Možemo zaključiti da je istim seksualnim praksama uvijek potrebno pristupiti individualno, no primarno s psihološkog stajališta, i ukoliko pružaju određenu vrstu užitka participantima uz potpunu, svjesnu konsenzualnost, nepristrano pokušajima etičkog vrednovanja kroz prizmu konzervativnih seksualnih normi.

Razumljivo je da je većini ljudi teško zamisliti da su osobe koje doživljavaju seksualno uzbuđenje i užitak putem ponižavanja u privatnoj ili tek javnoj sferi i upravo tu nalazimo paradoks mazohizma promišljamo li da osobe koje uživaju u dotičnoj praksi upravu putem tog čina postižu svojim zadovoljenjem psihičku stabilnost, izmjenom moći, bivajući svedene na objekt intenzificira se njihov osjećaj vlastite snage i osjećaj pripadnosti drugome.

Ponižavanje u javnosti, na potajan, neupadljiv način, prepoznatljiv samo involviranim osobama i ostalim prisutnim S/M praktikantima, još je od većeg zadovoljstva osobama koje su i submisivne i psihički mazohisti, ali vole prakticirati i otvoreno, vidljivo ponižavanje, koje je zakonski dozvoljeno isključivo u S/M i fetish klubovima, i leather barovima te je često bilo izloženo zakonskim sankcijama.

Navedene prakse najbolje prikazuju Jack Rinella, Guy Baldwin i Pat Califia te još mnogi participanti S/M scene San Francisca od njena početka 60 - ih i 70 - ih godina 20. stoljeća, njena vrhunca 1980 i 90 - ih - ih do današnjeg vremena.

Ponižavanje na javnom mjestu u odnosu na privatan prostor daje još daleko veći adrenalinski poticaj i stimulaciju i submisivnim i dominantnim osobama jer je udio moći koja se izmjenjuje izrazito velik, i premda su neki takvi oblici ponašanja ipak kulturološki ograničeni, istinski S/M 
praktikanti uvijek će pronaći način kojim neće izazvati ničiji mogući osjećaj nelagode ili negativne konfliktne reakcije.

Konačno, najeksplicitniji oblik scene su ,open sessioni“ u S/M klubovima, koje mogu gledati svi prisutni članovi kluba i prema želji i dogovoru se uključiti.

U tu skupinu pripadaju i veći grupni sessioni, u kojima se izmijenjuju partneri i uloge, dominantne osobe ili gospodari ,posuđuju“ svog submisivnog partnera drugom dominantu ili gospodaru, u svrhu „treninga poslušnosti i demonstracije upravljanja svojim „,vlasništvom“ i time se sfera S/M seksualnosti proširuje i razvija s ciljem stecanja novih iskustava i užitaka.

Važno je spomenuti i S/M performanse koji se održavaju, pored umjetničkog izraza i užitka participanata, prvenstveno kao svojevrsni manifesti i statementi, ponajviše u privatnim klubovima, no također $\mathrm{u}$ javnosti, na velikim trgovima ili parkovima $\mathrm{u}$ a među njih se mogu svrstati S/m prideovi koji se održavaju u brojnim europskim i svjetskim metropolama, što najbolje pokazuje prijelaz $\mathrm{S} / \mathrm{M}$ subkulture i seksualnosti iz privatne u javnu sferu i njeno partikularno i univerzalno društveno usklađivanje.

Geoff Mains (1947 - 1989), američki autor i pripadnik gay leather scene čija je knjiga „Urban Aboriginals" uvrštena u suvremene psihološko - kulturološke BDSM klasike od strane najvećih teoretičara i psihoterapeuta sadomazohističke seksualnosti, poput Gayle Rubin, Guya Baldwina, Charlesa Mosera i Jacka Rinelle.

„Urban Aboriginals“ je djelo hvaljeno i ocijenjeno izvrsnim kritikama renomiranih antropologa i teoretičara seksualnosti, dok je na S/M sceni smatrano nezaobilaznim klasikom, a sam Mains je bio prvenstveno doktor biokemije, $\mathrm{s}$ bogatim iskustvom u području ekologije te bogatim znanjem antropologije, da bi se kasnije kao freelance inžinjer involvirao u leather scenu San Francisca te biokemijsku teoriju primijenio na kulturu i psihološku dimenziju S/M seksualnosti, prakse i zajednica.

Osvrnut ću se na njegovo djelo za stručno objašnjenje iskustvo boli i stanja svijesti u praksi BDSM - a, budući da je osnova rada filozofsko - psihološki aspekt istoga pa bi neka medicinska literatura skrenula ovaj rad u drugome smjeru.

Kad govori o psihofizičkom osjećaju boli, Mains nas podsjeća na koji način funkcioniraju receptori i neurotransmiteri „odgovorni“ za podražaj boli koji su kod nekih osoba daleko osjetljiviji i proizvode opioide i endorfine.

Mains u poglavlju „, The Flowers of Pain“ odlično i biologijski oprimjereno objašnjava senzaciju boli, polazeći od primarnih nervnih podražaja koji prethode osjećaju boli: 
„Ispod kože se nalazi nježna mreža mehaničkih receptora koji reagiraju na rastezanje, drhtanje i udaranje. Druga mreža termoreceptora percipira promjene topline $i$ hladnoće i još jedna mreža nocireceptora odgovara a ono što zovemo bolnim stimulusima.“449

Nadalje, ,aktivacija tih receptora unutra kroz odgovarajuće nervne kanale prema kralježnici $i$ dalje se živcima prenose do mozga." ${ }^{\text {450 }}$

Na taj način osjećamo bol, a upravo je koža primarni organ prožet živcima koji primaju podražaje na razne načine kod pojedinih osoba.

Iz tog razloga mnoge osobe intenzivnije reagiraju na bol jer se radi o biološko - fiziološkoj predispoziciji i takve osobe osjećaju bol kao ugodu.

Osjet „bol - ugoda“ ne doživljava se odmah, ti procesi traju određeno vrijeme od samoga podražaja boli, Mains kao primjere navodi ruke i bradavice kao jedne od najreaktivnijih dijelova tijela na osjećaj ,ugodne boli““.

Osnovna je razlika u tome je što takve senzacije boli, za razliku od onih neugodnih, poput raznih ozljeda traju duže i odvijaju se u fazama, od izrazito jake boli, do manje intenzivne i izrazito ugodne, no mnogima i ona najintenzivnija, najsnažnija čini ugodu.

Mains pojašnjava ugodu u boli uvodeći nas u „sveprisutne opioide“, kemijske supstance najsličnije narkoticima poput, koje mozak proizvodi te izazivaju osjećaj euforije koju slijedi zadovoljenje nagona.

Tijelo ima svoj unutarnji sistem kontrole boli i djelovanjem opioida proizvodi endorfine, čije lučenje izaziva enormno seksualno zadovoljstvo.

Kod osoba koje prakticiraju BDSM, ,percepcija boli je izmijenjena i kapacitet tijela smatra bol užitkom u kontekstu rituala uz povjerenje i poštovanje granica, a takvi individualci su tolerantniji na na inicijalne i surove oblike boli koje prethode ekstatičnoj igri. “451

Vidimo da je senzacija boli specifično stanje svijesti jer Mains daje uistinu detaljan prikaz tjelesnog i psihičkog iskustva boli te reakcije na određene stimulacije:

„U scenama koje uključuju role play, djeluju instinkti dominacije i submisivnosti su uključeni. Um se relaksira i uživa u potisnutim ili skrivenim sposobnostima: oduševljenje u boli-užitku bičevanja; miru ograničenjem u vezivanju, ili preplavljujućem užitku. Realitet postaje zvučna ploča za izvršenje fantazije, u u tom stanju svijesti, izvanjska stvarnost gotovo potpuno prestaje postojati. " 452

\footnotetext{
${ }^{449}$ Geoff Mains, Urban Aboriginals, Daedalus Press, Los Angeles, 2002, str. 57, prijev.a.

450 Ibid. Str. 57, prijev.a.

451 Ibid. str. 65, prijev.a.

452 Ibid. str. 107, prijev.a.
} 
Ovim je mislima izražena bit mazohizma, koja perpetualnom psihološkom dinamikom omogućuje realizaciju sadizma, a time ravnoteže i komplementarne povezanosti Erosa i Thanatosa ostvarenjem najdubljih želja - užitka tjelesnih senzacija boli i psihičke dominacije i submisivnosti kad fantazija postaje realitet.

U ovom izuzetno interesantnom djelu autor ulazi u psihološko - spiritualnu dimenziju BDSM a i zbog tog osjećaja duhovnog knjiga i nosi naziv „Urban Aboriginals“ jer su izložene poveznice urbane underground kulture s drevnim indijanskim religijama.

Psiha i tijelo su doboko povezani, a osjećaj sadomazohističkih praksi autor naziva „bljeskom raja“ zbog specifičnih psihičkih senzacija koje proizlaze iz fizičkih.

Stanje uma i svijesti u S/M sessionu putem jake boli i orgazma doseže ekstatično oslobođenje tijela i uma i time se postiže unutarnji mir.

Mains to naziva „spiritualnom euforijom“ jer su takva ,izmijenjena stanja svijesti su opisana $u$ terminima kozmičkih, univerzalnih kvaliteta $i$ u svojim najintenzivnijim formama, te su transformacije magične i spiritualne. “453

Sadomazohistička seksualnost doživljena je kao gotovo nadnaravan psihofizički fenomen kojem je centar um, a tijelo je tada najmoćniji medij, a Mains je primijenio biologijske kemijske fenomene reakcija u mozgu na sadomazohističku praksu.

Ukratko, kod hipersenzibilnih osoba, prilikom doživljaja boli, posredno putem medija kože, podražaji neurotransmiterima prenosi u mozak izazivajući reakciju lučenja endorfina i time osoba doživljava izrazitu ugodu.

Neuroreceptori za bol nisu do te mjere razvijeni kod svih i stoga osobe takve predispozicije možemo nazvati „rođenim mazohistima“ ili se zadržati na Masochovoj „supersenzualnosti“, kao najboljeg opisa strukture ličnosti koja uživa u ekstremnoj boli i ponižavanju, uzdižući se pritom na višu razinu svijesti:

„Dosljedno, ta izmijenjena stanja svijesti su opisana terminima kozmičkih, univerzalnih kvaliteta. Transcendencija se postiže erotskom ekstazom.

U svojim najintenzivnijim oblicima, te su transformacije ujedno i magične i spiritualne.

Ne dosežu sve scene takve visine, no ipak velik dio njih je začinjeno blažim nijansama transformacija i odvijaju se u potpuno drukčijem stanju uma od uobičajenog.

${ }^{453}$ Ibid. str. 97, pijrev.a. 
Razina iskustva, intenzivna predanost i usredotočenost, zahtjevi su za provođenje takvih scena, potaknut će um da se pokrene putem takvih poduhvata, a mnogi su pojedinci i predisponirani za upuštanje u takve odiseje “. ${ }^{454}$

Danas je medicinsko tumačenje doživljaja senzacije boli, premda veoma kasno istraženo, u svi razvijenim državama općeprihvaćeno te se i dalje razvija brojnim istraživanjima, no u Mainsovo vrijeme, 70 -i ih i 80 - ih godina 20. stoljeća, bilo je još u svojim počecima razvitka suvremene teorije.

Mains je u tom smislu dao velik doprinos modernom, širem biologijskom, psihologijskom i antropologijskom shvaćanju fenomena sadomazohizma svojim izvrsnim prikazima stvarnog života BDSM praktikanata, njihove psihofizičke uvjetovanosti i kulturološke pozadine.

Postignuće i vrijednost njegovog rada je izvrsna elaboracija neuroloških kemijskih procesa $u$ kombinaciji s psihičkim ustrojstvom kao reakcije na tjelesne podražaje te, konačno, postavljanje ove problematike uma u odnos s društvenim poretkom.

On zaključuje da je osnovni problem zapadne kulture formacija uma kao isključivo racionalnog i produktivnog uz maksimalnu represiju senzualnog i imaginativnog, a nadasve prirodnog, što je bio osnovni poticaj za razvoj društveno - seksualnih fenomena i subkultura, posebice $S M$ leather subkulture.

Društvo i psiha, u svojim dihotomijama, osnovna je problematika koju Mains sagledava kroz prizmu psihofizičkih fenomena i senzaciji u BDSM praksi te svoje teze o sadomazohističkoj seksualnosti objašnjava biologijski - antropologijskim pristupom koje potkrepljuje brojnim mislima i primjerima.

S/M subkultura za Mainsa je prvenstveno življenje svojih iskonskih seksualnih nagona u skladu sa svojom prirodom, a tada novotvoreni pojam „radical sex“ označava upravo neobuzdanu seksualnost koja uključuje „ekstremne“ prakse te se udaljava od „,preskribirane“ seksualnosti nametnute dominantnom kulturom.

Veoma je uočljiva poveznica s Freudovom „Nelagodom u kulturi“, samim time što Mains kritizira zapadnu kulturu zbog njene represije nagona i drugačije seksualnosti i inzistiranja na racionalnom djelovanju kao ekonomski produktivnom.

Naravno, za razliku od Freuda koji je represiju nagona smatrao nužno za opstanak kulture, Mains je, kao i istu tu kulturu, smatra pogubnom za um i psihu individuuma jer ona nije u skladu s njegovom prirodom.

${ }^{454}$ Ibid, str. 97, prijev.a. 
Dok je Freud bio pobornik obuzdavanja nagona i perverzija, Mains smatra da nas upravo oni čine prirodnim ljudima i održavaju našu egzistenciju kvalitetnom i ispunjenom, za njega sreća i prosperitet nije materijalističko zapadna kultura već alternativa i revolt protiv njenih represivnih aparata kao povratak prirodnom.

Represijom seksualnosti kao bitnim oblikom restrikcije osobne slobode, ugroženo je psihičko zdravlje i kvalitetan život pojedinaca, no vladajuće strukture mogu si priuštiti taj rizik budući da je društvo odavno premašilo stadij ekscesivnog kapitalizma.

Već desetljećima primjećujemo do koje je mjere konzumentska kultura vođena ekonomskim principa i S/M seksualnost „prodala“ kao proizvod putem masovnih marketingških umijeća, „prisvajajući“ njenu ikonografiju u svim sferama.

U postkapitalističkom društvu, kojeg nerazmjerni profit i pokreće i održava, i seksualnost je odavno postala izuzetno tražen i poželjan proizvod, a S/M seksualnost elegantno je promovirana kao skup i profinjen, haute couture proizvod za privilegirane konzumente visokog socijalnog statusa i rafiniranog ukusa.

Mainsova temeljna misao je komparacija urbane subkulture $\mathrm{s}$ aboridžinima i brojnim „primitivnim“ plemenima i kulturama te njihovim običajima, čime je nastojao što više približiti rituale i spiritualnu dimenziju S/M subkulture onom prirodnom, iskonskom:

„, Kultura u kojoj je nastao leather i koja samu sebe smatra sveznajućom, drži preskribirani pogled na ljudski um. Taj um je visoko strukturiran.

Svaki njegov dio je nezamjenjiv. A njegovo optimalno funkcioniranje je limitirano na jedan obrazac iskustva: racionalnu, uređenu percepciju i izražavanje.

To je vizija za koju smo usko vezani, usprkos suprotnim iskustvima antropologa.

Razlozi tomu su jasni, zapadno društvo smatra svoju formu mentalnog iskustva normalnom $i$ superiornom. Taj nefleksibilni pogled na um omogućuje i opravdanja za to uvjerenje i sredstva protiv kojih etiketira izmijenjene obrasce mentalnog iskustva, uključujuči leather kulturu, kao abnormalne i psihotične. "455

Za njega je $S / M$ leather subkultura bila pokret koji je nastojao praktikante sadomazohističke seksualnosti i aktere $\mathrm{S} / \mathrm{m}$ scene i istovjetnim seksualnim preferencama usmjeriti ostvarenju njihove prirodne seksualnosti i egzistencije, čime je ostavio naslijeđe svim budućim generacijama $\mathrm{S} / \mathrm{M}$ praktikanata, osobama $\mathrm{S} / \mathrm{M}$ orijentacije i brojnim teoretičarima te je bitno naglasiti njegov svojevrstan revolt S/M zajednica protiv kulture nasilja i represije.

455 Geoff Mains, Urban Aboriginals, Daedalus Press, Los angeles, 2002, str. 101, prev.a. 
U zapadnoj je kulturi, no i ostalima, represija S/M seksualnosti je potrebna da bi pojedinci bili sposobni provoditi nasilje u društvenoj sferi, gdje bi to, prema etičkim načelima, trebalo biti nedopustivo.

Ukoliko osobe svoje prirodno urođene nasilne porive manifestiraju i preusmjeravaju u razne, posebice sadomazohističke seksualne prakse, konzensualne prakse razmjene moći kojima je ultimativni cilj užitak, tada neće imati potrebe razviti potrebu za prakticiranjem nasilja u javnoj društvenoj sferi.

No zapadnoj je kulturi „potrebno“ nasilje i mnogi nezadovoljni pojedinci svoje „,nezadovoljstvo u kulturi“ „liječe“ maničnim ponašanjima, od pretjerane, opsesivne konzumacije proizvoda, čime postvaruju, ako i ne dokidaju ljudske odnose, a kao takvi su idealni za podilaženje svakoj manipulaciji, posebice uzmemo li u obzir današnju ovisnost o tehnologiji u zabavne svrhe, profit farmaceutskih kompanija od megaprodaje antidepresiva te sociopatiju eskalaciju nasilja među mlađom populacijom, jer svaka inhibirana seksualnost rezultira psihičkim poremećajima. To je upravo meritum onoga što istinski BDSM praktikanti i terapeuti, psiholozi i antropolozi žele naznačiti i poručiti svojim znanstvenim radovima, edukativnim i psihološkim radionicama i eksplicitnim manifestacijama poput performansa i $S / M$ prideova manifestacijama, individuum i partikularne zajednice, moraju biti na prvome mjestu, u svim društvenim znanostima, a tek potom cjelokupno društvo.

Mains i njegovi istomišljenici živjeli su upravo vođeni tim načelima, boreći se protiv društvenog nametanja normi, prakticirajući slobodu mišljenja i djelovanja u vlastitoj društvenoj i seksualnoj sferi.

Konstatirajući da je S/M kultura nastala u apolinijskom društvu vladanom supremacijom racionalnog uma te ne želi ili ne može razumjeti manifestacije emocija te zabranjuje izmijenjena stanja svijesti, Mains govori o sadomazohističkoj seksualnosti i njenom položaju u društvu svoga vremena, ironično zaključujući da nas „, uređenom zapadnom svijetu ekstaza čeka kao nagrada nakon smrti “. ${ }^{456}$

Međutim, S/M praktikanti žele i žive ekstazu sada i stoga Mains karakterizira tu subkulturu anarhističkom jer ona izlazi izvan okvira i restrikcija u kojima su pojedinci naučeni živjeti te jača njihovo samopouzdanje i osjećaj vrijednosti, pružajući im zadovoljenje njihovih „Zabranjenih“ želja te konačno prelazi kulturno zadane granice „dovodeći um na razinu spiritualnog kontakta“، ${ }^{457}$

\footnotetext{
456 Ibid, str. 167, prijev.a.

457 Ibid, 167, prijev.a.
} 
„Intenzitet osobnog iskustva nije lako oblikovan u velika društva i premda je leather kultura dionizijska, na neke je načine drugačije od ostalih dionizijskih kultura.

Leather kultura ne donosi samo transcendenciju već također i društvenu perspektivu. "458

Mains se zalaže za suvremeni, urbani hedonizam i dionizijsko načelo, inspirirano drevnim civilizacijama, on nastoji „stvoriti“ deskriptivnu teoriju urbane subkulture s utjecajima aboriđinskog - prirodnog i „divljeg“, no kulturnog - subkulturnog i time je njegovo djelo bilo i ostalo prihvaćeno kao originalno i inovativno psihologijsko - antropologijska studija ljudske prirode i sadomazohističke seksualnosti kao njenog eksplicitnog izraza te njene pozicije u relaciji s društvom.

Jack Rinella, američki autor brojnih kniga S/M tematike koje napisao kao član S/M leather scene u San Franciscu i iznimno uspješan psihoterapeut s bogatim iskustvom u edukaciji i radu s praktikantima i osobama $\mathrm{S} / \mathrm{M}$ sklonostima .

Uz knjige poput „Partners in Power/Living in Kinky Relationships“, na koju ću se ovdje referirati, najvažanija su mu djela „The Compleat Slave“, „The Master's Manual“, uz dugogodišnju kolumnističku karijeru u raznim S/M leather časopisima.

Najvažnije je ipak istaknuti njegov terapeutski pristup koji upravo u „Partners in Power“ iz 2003. najbolje dolazi do izražaja.

Kao svoj bitan utjecaj navodi Carla Gustava Junga, što ga uvelike razlikuje od ostalih autora iste tematike, te je kao pobornik Jungove psihologije postao inovativan autor $\mathrm{u}$ području prezasićenom brojnim neofreudovskim pristupima i tumačenjima.

On tumači BDSM seksualnost Jungovom teorijom arhetipa, čime je njegov pristup izuzetno interesantan i unikatan, diferencirajući ga od ostalih teoretičara i psihoterapeuta, jer on polazi od „arhetipa S/M odnosa“, na način da započinje analizu istih analizom tipova osoba koje formiraju raznolike odnose, no to mu je samo polazišna točka, jer Jungova mu je filozofija leitmotiv cijele knjige.

Prva i možda najvažnija njegova referenca na Junga za BDSM seksualnost je „Izuzetna je vrijednost imati bogat život fantazije: fantazija kultivira imaginaciju, koja zauzvrat donosi kreativnost u naše umove.“459, no Rinella dodaje da je „potrebno razlikovati fantaziju od realiteta. Realitet je ipak uvijek prisutan i vrhunac zdravog života. Moramo povući i distinkciju

\footnotetext{
458 Ibid, 167, prijev.a.

459 Jack Rinella, Partners in Power/Living in Kinky Relationships, Greenery Press, Oakland, California, 2003, str. 7 prev.a.
} 
između fantazije i laganja“ “460 jer on polaže veliki značaj iskrenosti i poštenju u svakom BDSM odnosu, iz razloga što se zdrav i zadovoljavajuć odnos može temeljiti jedino na tim kvalitetama i stoga je ,iskrenost teška vrijednost jer moramo živjeti s posljedicama svojih djela.“461

Najveći naglasak stavlja na spoznavanje sebe prethodno pronalaženju svoje istinske orijentacije i svoga mjesta u „BDSM svijetu“, dok su arhetipi samo uvod kao generalne reprezentacije, kojima se ne može opisati specifične pojedince, no oni su važni za temeljno razumijevanje određenog društvenog područja, ovdje konkretno S/M seksualnosti i scene, citirajući Junga :

„Velike odluke ljudskog života imaju u pravilu daleko više s instinktima i ostalim misterioznim nesvjesnim faktorima, nego sa svjesnom voljom i dobronamjernom razumnošću. "462

Rinella posebno naglašava ulogu $\mathrm{S} / \mathrm{M}$-a pri samospoznaji te u samome uvodu konstatira: „Naučio sam da je S/M vrijedno sredstvo za povećanje znanja o sebi, zajednica utjehe i podrške i put fizičkom, društvenom i duhovnom razvoju.

Bila je to i mnogo više, poznajem sebe bolje zbog događaja i odnosa iskustava koje mi je leather scena omogućila da doživim. " 463

U pogledu razvoja psihe i spoznavanja sebe, on dodaje:

„Leather scena je istraživanje, proces učenja i stoga ne postoji jedan ili najbolji način življenja tog lifestylea. Doista, mnogima to nije lifestyle, već diverzija, vrijeme daleko od uobičajenog da se jednostavno igraju i uživaju.

Ipak, leathersex je mnogo više od samo seksa,najpotpunije slavlje leathersexa je svakako orgazmičko, no jednako je toliko slavljenje zajednice, identiteta i osobne slobode...načini za kreiranje življenje potpuno održivog, zadovoljavaljućeg života, punog užitka sa i u leather subkulturi. "464

Kao iskusan i vrstan psihoterapeut, a istovremeno i praktikant BDSM - a, Rinella u potpunosti razumije kompleksnu psihološku pozadinu sadomazohističke seksualnosti i odnosa, te razlučiti onu istinsku i ispravnu od one uvjetovane raznim kompleksima iz djetinjstva i mladosti, osjećajem krivnje ili psihopatološkim stanjima, što je presudno razlikovati za dosljedno tumačenje S/M predispozicije, sklonosti i prakse.

Stoga i posvećuje nekoliko poglavlja knjige upoznavanju sebe kao osobe s ciljem spoznavanja vlastite seksualnosti i želja te naposljetku oblikovanju svoje ličnosti i izgradnji kvalitetnih

\footnotetext{
460 lbid, str. 7, prijev.a.

461 lbid, str. 15, prijev.a.

462 Ibid, str. 65, referenca na Carl Gustav Jung, Modern Man in Search of a Soul

463 Ibid, Preface, predgovor, prijev.a.

464 Ibid, prijev.a.
} 
odnosa, a njegovi opisi uloga analogno ličnostima i karakternim crtama pojedinaca temeljeni su i a njegovoj osobnom iskustvu i terapeutskoj praksi.

On prikazuje stručnu, generalnu elaboraciju BDSM uloga i odnosa, s najvećim naglaskom na Master/slave odnose, koji su za njega od najveće važnosti.

Master/slave vezu Rinella karakterizira kao najstrukturiraniju u čitavom spektru S/M odnosa, uključujući i D/s odnos, s naglaskom na kontrolu, vlasništvo i poslušnost. ${ }^{465}$

Dinamika moći je fundament takve veze, a gospodar i rob ulaze u takav odnos pregovaranjem i svojevrsnim ugovorom u kojem se rob predaje gospodaru postajući njegovo vlasništvo, potpuno konsenzualno, slobodan da uvijek prekine vezu. ${ }^{466}$

Kontrola, kao temeljan i neophodan dio S/M odnosa, provodi se dogovorenom, kodificiranom skupinom pravila, od kojih je najvažniji seksualni aspekt.

Rinella kao najuobičajenije načine seksualne kontrole u Master/slave vezama navodi zabranu seksualnog odnosa s drugima, premda su česti i slučajevi kada to biva naređeno, kontrolu orgazma, koja je psihologijski među najinteresantnijim S/M praksama, a podrazumijeva ili zabranu masturbacije ili „manipulaciju“ orgazmom ili pak, naredbu suprotnog. ${ }^{467}$

Pored seksualne kontrole, kontrola u S/M - u uključuje propisan ili arbitrarno naređen način odijevanja, ponašanja prema gospodaru, zadatka, igranja uloge, služenje i u pogledu scene, no i kućanskih poslova i ponašanja u društvenim situacijama. ${ }^{468}$

On napominje da je stupanj i tip kontrole vrlo specifičan u svakoj vezi, s ciljem da svaka strana nalazi u odnosu ispunjenje u svojem izražaju i aktivnostima, individualnim i zajedničkim te njihovim željama i dogovoru, ali moraju biti realne, a ne isključivo i samo fantazije. ${ }^{469}$

Poznato je da mnoge osobe imaju seksualne fantazije o raznim S/M scenarijima i aktivnostima, no nikada ne bi bile spremne učiniti nešto od istoga, ili zbog psihičke blokade uvjetovane nesigurnošću ili zbog straha uzrokovanog društvenim normama preskribirane seksualnosti, odnosno, straha od vlastite seksualnosti i osobnosti te je upravo to element koji razlikuje BDSM praktikante, koji fantazije i želje ostvaruju u realitetu, od osobe kojima želje ostaju fantazije.

Rinella piše jasno i otvoreno iz perspektive S/M leather praktikanta, no i iz pozicije terapeuta koji intenzivno radi s osobama $\mathrm{S} / \mathrm{M}$ orijentacije, što je velika prednost u njegovom tumačenje te iscrpnoj analizi S/M odnosa, subkulture i zajednice.

\footnotetext{
465 Ibid, str. 32, prijev.a.

466 Ibid, str. 33, prijev.a.

467 Ibid, str. 35

468 Ibid, str. 35

469 Ibid, str. 35 - 36
} 
S/M veza, Master/slave ili $D / s$, kao društveno - seksualni odnos, temelji se na međusobnom povjerenju i poštovanju, dominaciji i podređenosti, konstantnoj dinamici moći i boli da bi mogla biti ispunjenje želja i zadovoljstava obje strane.

Pravila BDSM - a, formulirana kao savjeti osobama s dilemama se ponajviše uvjeta, pregovaranja s potencijalnim partnerom te upoznavanja vlastitih želja, želja druge osobe i donošenja odluke žele li i mogu li se upustiti u odnos, kakvu vrstu odnosa zapravo žele te na što su sve uistinu spremni.

Rinella se dotiče i mogućih čestih problema u BDSM odnosima, vezanih prvenstveno za komunikaciju i (ne)kompatibilnosti različitih ličnosti, a sadizam i mazohizam o kojem Rinella govori su izvorne BDSM kategorije:

„Naša forma sadizma nije „perverzija postizanja seksualnog zadovoljstva nanošenjem boli drugima“ već postizanje užitka nanošenjem boli koja pruža užitak onima koji pristaju na tu aktivnost, izbjegavamo ozlijeđivanje naših partnera

Velika je grupa riječi unutar kontinuuma između dominacije i kontrole i njihovih suplemenata, submisivnosti i predaje.

Neke aktivnosti imaju površan privid dominacije, dok su zapravo fetiši.

Osoba može bičevati drugu bez kontrole i dominacije kao dio scenarija.

Radimo veliku distinkciju između boli i povrede. Nastojimo učiniti da se ljudi osjećaju dobro, ne ih povrijediti. Jednako tako, mazohisti ne uživaju u neerotskim povredama. “470

Bol, kao najvažnija komponenta S/M odnosa, pored kontrole, ,upravljana ispravno, pruža enormni endorfinsko uzdizanje mazohistu, čak i oni s niskom tolerancijom na bol mogu iskusiti vrhunac bez prelaženja njihovih osobnih granica.

Nanošenje boli, za sadista je jednako visoko uzbuđujuće i zadovoljavajuće iskustvo. "471

Moć u sadomazohističkom odnosu Rinella tumači razlikovno od odnosa moći u ostalim društvenim i međuljudskim odnosima kao „sposobnost ili kapacitet za efektivno djelovanje ili izvedbu “, dimenziju sebe u sebi “, neutralnu, o kojoj se ne može donijeti moralne prosudbe “, te je, pored užitka, erotizma i orgazma „razmjena moći sigurno jedan od ciljeva“ i, najvažnije „ono najneuobičajenije u $S / M$ - u je da mi mnogo češće prihvaćamo i raspravljamo razmjenu moći i mnogo je ugodnije priznajemo - činimo to svjesno."

U sadomazohističkoj seksualnosti najvažnija je recipročnost moći, moći koju gospodar ili dominant ima nad submisivnom osobom, primjerice u bondageu, ima mo da njome potpuno

\footnotetext{
470 Ibid, str. $3-6$, prijev.a.

471 Ibid, str. 25, prijev.a.
} 
gospodari, dok submisivna osoba, dozvoljavajući provođenje moći nad sobom, zadobiva vlastitu moć, ulaskom u izmijenjeno stanje svijesti koje dominantna traži i zahtjeva. ${ }^{472}$

$\mathrm{Na}$ taj se način i ostvaruje odnos primarne moći submisivne osobe, koji je detaljno razrađen kod svih relevantnih autora i stoga možemo zaključiti da je BDSM seksualnost utemeljena na uzajamnoj izmjeni moći i kontrole.

Kao subkultura ili zajednica izrazito etična, a u svom totalitetu namijenjena je isključivo psihički stabilnim i snažnim osobama, koje ekstremne prakse doživljavaju kao transcendentni užitak te u njima pobuđuje pozitivne emocije i čini ih još ustrajnijima, reflektirajući se na njihovu izdržljivost i izvan S/M scene.

Rinellina knjiga „Partners in Power“ je fascinantno iskrena psihološka studija sadomazohističke seksualnosti, s posebnim naglaskom na gay leather scenu, no jednako primjenjiva i na sve ostale BDSM odnose i scene te kao takva izuzetno edukativna elaboracija i S/M -a , no i ljudske psihe, namijenjena osobama S/M orijentacije, no i svima koji žele proučavati seksualnost, kulturu, ali i upoznati sebe.

Guy Baldwin, psihoterapeut i autor koji je posvetio čitav život, profesionalno i privatno, teoriji i praksi BDSM - a, daje, pored stručne razrade BDSM prakse, najbolji uvid u američku gay leather scenu, kao i veoma stručne i kvalitetne prikaze $\mathrm{S} / \mathrm{M}$ odnosa u svim njihovim aspektima svima zainteresiranima za tu tematiku kao predmet proučavanja ili kao način života. ${ }^{473}$

Baldwin polazi od elementarnog uvoda u BDSM odnose i scenu, način na koji bi dinamika odnosa optimalno funkcionirala te opisuje brojne primjere svojih pacijenata ili poznanika, da bi se konkretno razumjelo što je zapravo BDSM odnos i na koji način se prakticira te na koji se način zapravo ljudi međusobno odnose na BDSM sceni, prvenstveno gay leather sceni San Francisca, koja je oduvijek bila specifičan primjer.

Karakteristike i međusobne razlike submisivnih i dominantnih osoba, odnosno, top ili bottom, vrednuje na osnovi psihičke zrelosti i doraslosti osobe koja je neophodan uvjet za ulazak u bilo koju vrstu BDSM odnosa.

\footnotetext{
472 Ibid, str. 25

${ }^{473}$ Guy Baldwin, Ties That Bind, Daedalus Publishing Company, Los Angeles, 2003
} 
U svom pregledu Master/slave odnosa, on govori o pluralitetima mogućih veza submisivnih i dominantnih osoba, koje se odvijaju definiranjem autoriteta i odgovornosti između identificiranog gospodara i identificiranog roba koji se podređuje volji gospodara. ${ }^{474}$

Uvodeći u raznolikosti takvih odnosa, navodi kao primjere gospodare s više robova i situacije kad robovi imaju vlastite robove, a gospodari se podređuju drugim gospodarima, a također naglašava i razne stupnjeve submisivnosti koji su očekivani, od najblažih do najtežih, s namjerom prikaza neograničenost varijacija u BDSM seksualnosti i životnom stilu. ${ }^{475}$

Izuzetno je važna njegovo objašnjenje i podjela S/M ličnosti, pri čemu dominantna osoba ne mora biti sadist, niti submisivna mazohist, što je u njegovom terapeutskom iskustvu čest slučaj i stoga kao glavne psihološke i seksualne predispozicije i on razlikuje dominantnu i submisivnu, sadističku i mazohističku te agresivnu i pasivnu.

Osobe koje prakticiraju S/M obično su formirane kombinacijom ovih karakteristika i Baldwin navodi primjere agresivnih submisivnih, no nimalo sadističkih dominantnih mazohista, no uobičajeni stereotip je uvijek dominantni, agresivni sadist, a teški S/M, zasnovan na suprotnosti, jest između dominantnog agresivnog sadista i dominantnog agresivnog mazohista. ${ }^{476}$

Sklad, razumijevanje te međusobno zadovoljenje, zadatak su na kojem obje strane moraju raditi da bi odnos bio uspješan, a pored međusobne kompatibilnosti, osnovna na što Baldwin upućuje je sigurnost, zdravlje i konsenzualnost, odnosno općepoznati BDSM imperativ „Safe, Sane and Consensual“. Oba partnera moraju biti psihički zdrave i stabilne osobe, odnositi se primjereno sceni i znati poštivati granice, a tome je neophodan preduvjet njihovo vlastito poznavanje suštine BDSM - a i samih sebe, jer cilj nije da itko ostane fizički ili fizički povrijeđen, već da se oboje (ili više) nakon scene osjećaju emocionalno osvježeni. ${ }^{477}$

On se osvrće i na brojne probleme između BDSM partnera koji nastaju nesporazumima te veoma detaljno analizira manipulativne submisivne osobe, imenujući ih "killer bottoms", misleći pritom na osobe koje se podsvjesno ne žele podrediti ili očekuju da dominantna osoba preuzme svu inicijativu i odgovornost a potom je kritiziraju za neuspjeh scene. ${ }^{478}$

Najvažnije na što Baldwin apelira je da gospodar i rob mogu imati odličnu vezu kad kvalitetno provode zajedno mnogo vremena, što uključuje sve aktivnosti, od poslova do zabave, putovanja

\footnotetext{
474 Ibid. str. $71-75$

475 Ibid. str. $72-83$

476 Ibid. str. 59 - 63

477 Ibid. str. 203 - 207

478 Ibid. str. 181 - 184
} 
pa i zajedničko rješavanje problema, što će samo produbiti njihov odnos i uspostaviti sve veću mogućnost seksualne ravnoteže, jer isključivo fizičko zadovoljenje je kratkotrajno, i zato je u nalaženju adekvatnog partnera potrebno biti iskren u svojim očekivanjima i željama. ${ }^{479}$

Kvalitetan i korektan BDSM odnos mora tako biti zasnovan na odgovornosti i poštovanju i stoga je uloge i granice potrebno dogovoriti u samom početku.

On zato razrađuje SM ličnosti prema karakterima dominantni i submisivni, sadistički i mazohistički te agresivni i pasivni, a te se osobine i orijentacije često isprepliću, a kao primjer Baldwin navodi osobu koja je agresivna i submisivna, no nimalo mazohistična te submisivne, pasivne sadiste te agresivne dominantne mazohiste. ${ }^{480}$

U knjizi „SlaveCraft“, pisanu u koautorstvu s anonimnom osobom s BDSM scene, svojim bliskim suradnikom i prijateljem, Baldwin daleko detaljnjije pojašnjava temeljne razlike između submisivnih osoba ili bottoma i robova (slave), ulazeći u gotovo sve moguće životne situacije takvih veza.

Bivanje nečijim robom je stanje potpune poslušnosti i odricanja od svih svojih želja osim jedne - zadovoljenju gospodara, u seksualnim aktivnostima, svakodnevnim služenju, pri čemu on navodi kućanske poslove za koje priznaje da su submisivnim bottom osobama smiješne, primjerice „čišćenje kupaonice i laštenje čizama“481 te pokazuju mentalni sklop slave osoba i oprimjerujući to izjavom slave muškarca koji navodi da je :

„Ropstvo paradoksalni način za generiranje sreće predajom kontrole nad svojim ponašanjem drugome. Čin moje predaje se postiže slijedeći određene principe i primjenom načina submisivnosti impliciranih tim principima te razumijevanje principa i primjena načina je pravi posao ropstva. Jednom kad rob može učiniti te stari, čišćenje toaleta je sitnica" 482

Biti rob jest identitet i zato je između robova i submisivnih osoba enormna razlika jer submisivne osobe traže vlastito zadovoljstvo, a robovi žele samo zadovoljstvo gospodara - to je njihovo jedino zadovoljstvo.

Submisivne osobe vođene su vlastitom željom i svojim zadovoljenjem, dok su slave osobe orijentirane samo prema želji gospodara i čine samo ono što je njegov užitak.

\footnotetext{
479 lbid. str. $77-89$

480 Ibid. Str. 59 - 60

${ }^{481}$ Guy Baldwin, Slavecraft, Deadalus Publishing, Los Angeles, 2004, str. 57 - 58

${ }^{482}$ Ibid, str. 56, prijev.a.
} 
Baldwin parafrazira Buddhinu izreku „Da bi imao sve, moraš se prvo svega odreći“, naglašavajući da je osnovni moto BDSM „ropstva“ i time prikazuje bondage kao put do najvećeg zadovoljstva i oslobođenja, a to znači da se rob mora odreći svega i predati Gospodaru, a zauzvrat dobiva zadovoljstvo, sreću i blaženstvo. “ 483

To uvjerenje potkrepljuje izjavama koautora koji govori iz vlastitog iskustva:

„Ropstvo je sporazum koji činim prvo sa samim sobom. Odlučujem da će odluke o mom ponašanju biti stavljene pod kontrolu nekoga tko je je toga vrijedan i tko sam sebe dobro poznaje. Kad netko drugi ima kontrolu nad mojim ponašanjem, moj um doživljava transformaciju tijekom koje je otvoren za ekstatično blaženstvo koje nikako drugačije ne mogu postici. " 484

Pored identiteta, biti rob je umijeće, i to umijeće veoma hrabrih, a kao odrednica ličnosti se konstituira izrazito zahtjevnom praksom koja zahtjeva veliku psihičku snagu koju posjeduju malobrojni, a identitet mazohista, koliko god kompleksan, sasvim je drugačiji jer mazohist se podređuje vlastitoj želji, i premda je prema psihičkom ustrojstvu daleko snažniji od sadista, ne može biti robom jer ima sasvim suprotnu predispoziciju.

Osnovni principi BDSM ropstva su identitet, poslušnost, transparentnost i poniznost, no rob ipak, pored zadovoljenja gospodara misli i na vlastito:

„Ropstvo je paradoks. Dobivam što tražim davanjem svoje poslušnosti drugome.

Volim reći da je ropstvo izbor, ali u ovom trenutku svog života potalo je jasno da za mene nema uopće mnogo izbora. Da dišem, moram udahnuti.

Da osjetim svoje najdraže ushićenje, moram robovati. "485

No također naglašava ostvarenje sebstva i vlastitoga zadovoljstva:

„S tog gledišta, ropstvo je nešto što činim za sebe. To je moj način da budem sebičan jer se volim osjećati sretno i ushićeno. Mislim da smo svi rođeni da osjećamo ushićenje, a ropstvo je jednostavno način na koji ja to postižem. “

Ovim mislima izrečena je osnovna misao radikalnog BDSM - a, odnosno Master/slave odnosa, koji zvuči možda nepojmljiv, no participantima poput koautora „SlaveCrafta“ sasvim „,normalno“ i stoga su ovakvi iskreni nezaobilazni za razumijevanje ovako dubokih odnosa.

\footnotetext{
483 Ibid. str. $55-56$,

${ }^{484}$ Ibid. str. 55, prijev.a.

485 Ibid. str. 55, prijev.a.
} 
Princip identiteta je stoga temelj iz kojega proizlaze ostala tri i u njemu leži ontologijska odrednica i neizmjerna snaga individuuma:

„Idealno, rob je osoba koja uvijek zna tko i što jest-prvo rob, a svatko i sve ostalo drugo. Kad se bavim kompliciranim zanimanjem, ja sam rob i radim to prema naredbi Gospodara. Kad pišem, činim to po njegovoj naredbi i s njegovim dopuštenjem “486

Konstrukcija seksualne orijentacije i identiteta i roba i Gospodara je dugotrajan proces za koji je neophodno potpuno razumjeti svog partnera - razgovorom te konstantnim spoznavanjem i učenjem ,prodirati““ u psihu drugoga.

Baldwin govori o bezuvjetnoj poslušnosti i apsolutnom konsenzualnom ropstvu kao o BDSM u bez pravila, no shvaća da je to gotovo nemoguće ili moguće u veoma malom broju slučajeva kad se istinskim međusobnim razumijevanjem i razvijanjem poslušnosti, ekspanzijom dominacije i scenama koje ispunjavaju obje strane, tome se može maksimalno približiti ${ }^{487}$. Preduvjet je i pristanak oba partnera i njihova veza s realitetom, a istovremeno mogućnost isključenja iz stoga u vidu erotske eskstaze, koja mora biti jednako ispunjavajuća i gospodaru i robu, a to se postiže upravo „treningom“ poslušnosti, razvijanjem identiteta, ali prije svega svjesnim spoznavanjem vlastitih želja i ponašanjem u skladu s njima.

Moser i Kleinplatz u svojoj već spomenutoj eklatantnoj znanstvenoj studiji „Sadomasochism/Powerful Pleasures“, temeljenoj na istraživanjima ispitanika odlično prikazuju 24/7 BDSM odnose, koji su opravdano smatrani radikalnim i „najekstremnijim“ oblicima izmjene moći, odnosno, kao što sam već prikazala kod Baldwina, konsenzualni Master/slave odnosi potpunog predavanja i služenja i potpune dominacije.

Navedeni se odnosi nazivaju ,total power exchange“ i opisuju kao „konsenzualni nepristanak“ (consensual nonconsent), što na prvi pogled može zvučati kontradiktorno no radi se o uspostavnju uloga gospodara i roba ili vlasnika i roba i tada gospodar kontrolira sve, baš sve životne aktivnosti roba/inje, od seksualnosti do najjednostavnijih, poput slobodnog vremena, kućanskh poslova i ostalo.

Najvažnija su veoma striktna pravila koja obuhvaćaju pravila odijevanja, načina ponašanja, primjerice načina služenja, držanja, sjedenja, ophođenja, rituala, ukratko ,svakog pokreta submisivne osobe u ulozi roba.

\footnotetext{
486 Ibid. str. 71, prijev.a.

487 Ibid. str. 79 - 94
} 
Upravo iz tog razloga mnogi na takve odnose gledaju s neodobravanjem jer je velikoj većini ljudi, pa i S/M participanata teško pojmiti takav odnos i shvatiti na koji se način uopće tada mogu postaviti granice da bi submisivna osoba sačuvala svoj integritet.

Predavanje svoje slobode i egzistencije drugoj osobi uistinu nije jednostavna stvar, to je nešto što nadilazi sposobnosti većine i samo su malobrojni sposobni uistinu takav odnos provesti u djelo i održavati, obzirom na svoj identitet, poslovne obaveze, želje, vlastite dileme i probleme. No, stvar i jest upravo u tome - submisivna osoba uspostavlja identitet roba, kako nam je Guy Baldwin već pojasnio predaje svoje želje i potpuno povjerenje gospodaru i nalazi se sretna jedino kao rob svome gospodaru, koji, naravno, ima obavezu brinuti o dobrobiti „svog vlasništva“ kombinacijom stroge kontrole i velike pažnje i ljubavi i to dvoje moraju biti u potpunoj sinergiji.

Moser i Kleinplatz proveli su iscrpno istraživanje na osobama raznih dobnih, socijalnih i profesinalnih skupina, što je bitan indikator da Master ili slave osoba može biti bilo koje dobi, profesije, životnog stila, etničke pripadnosti, socijalne skupine. ${ }^{488}$

Naravno, najčešće su to osobe visoke inteligencije i obrazovanja, umjetničke profesije, što je i logično, jer je BDSM općenito seksualnost koja je za „posebne“ i ,drugačije“ ljude koji ne žive uobičajenim, mainstream životom, već ga nadilaze.

Apsolutni 24/7 odnosi su potpuno konsenzualni i partneri međusobno dogovaraju granice, osim u specifičnim odnosima gdje se granice ne postavljaju, kao niti safeword niti bilo kakav znak, drugim riječima, potpuna, bezgranična dominacija i submisivnost koja zahtjeva maksimalno povjerenje i određenu dozu rizika.

No svi 24/7 odnosi imaju zajedničke poveznice, a to slijedeće - ukoliko granice i postoje, one ne bi trebale biti konstantne već podložne promjenama razvitkom odnosa, takvi su odnosi nazivani, kao što je već spomenuto „nekonsenzualni pristanak“ jer esencija D/S odnosa i jest u tome da kompatibilnost partnera mora biti što veća da postavljene suviše limita ne bi bio potrebno i da submisivna osoba nema previše kontrole, kao što to često zna biti slučaj. ${ }^{489}$

Bitno je razlučiti privatnu od javne sfere u pogledu prakticiranja dominacije i submisivnosti. Naime, mnogi će ograničiti svoje aktivnosti na isključivo svoj zajednički život i neće svoj odnos iskazivati u javnosti, dok opet velik broj S/M praktikanata zaista živi svoj 24/7 odnos u svakome

\footnotetext{
${ }^{488}$ Charles Moser, Peggy Kleinplatz, Sadomasochism: Powerful Pleasures, Routledge, New York, 2006

489 Ibid. str. 86
} 
aspektu života, i privatno i javno, primjerice, rob dozvoljava Gospodaru da ga nadzire u svakom pogledu života, od ponašanja, izlazaka, posla, kućnih obaveza te da mu postavlja naredbe koje mora ispuniti, koliko god hirovite i besmislene bile.

Rob tada u potpunosti predaje kontrolu nad svojim životom tijelu i umu Drugog, Gospodara, bez propitkivanja i bez prava na prigovor, kojih se voljno odrekao:

„Ključan element S/M ropstva je želja roba da dozvoli drugom partneru (vlasniku) da kontrolira sve aspekte. Svakodnevna ponašanja kao biti u mogućnosti izići van sam, kada i što jesti, gdje sjediti i što nositi postaju začinjeni SM prizvucima vrlinom kontinuirane dinamike između participanata. " 490

Nadalje, autori napominju da je bitno razumjeti javnu i otvorenu reprezentaciju 24/7 odnosa, jer jedino se na taj način on može zaista konstantno održavati, jer jednostavno je prihvatiti uloge gospodara i roba kod kuće, no u javnosti oni mijenjaju svoje ponašanje i, premda njihov status roba i gospodara ostaje netaknut ${ }^{491}$, mnogima će to predstavljati poteškoću zbog održvanja privatnosti i osjećaja nelagode.

Međutim, brojni S/M praktikanti nalaze užitak upravo u javnom izražavanju i pokazivanju svojih uloga i identiteta i još će ih više seksualno uzbuđivati prakticiranje M/s uloga na javnim mjestima, pred drugima, neovisno o reakcijama sredine.

Fenomen „counter - behavioura“ ili u sociologiji i sociolingvistici „covert prestige“, postiže efekt normalizacije intimnog i seksualnog $u$ javnoj sferi putem „necenzuriranog“ $i$ time „subverzivnog“ ponašanja, ali prvenstveno riječima i naredbama kao performativima, kojima se S/M scene i prakse mogu javno izražavati i prakticirati kao manifestacija najeksplicitnijeg BDSM odnosa.

U privatnom okruženju, rob je vezan strogim pravilima, i nasamo s gospodarom/vlasnikom i u prisutstvu drugih koji ili sudjeluju ili su svjesni njihovog dogovora i prihvaćaju ga. ${ }^{492}$, dok u specijaliziranim privatnim S/M klubovima za članove ili zajednicu, pravila odijevanja, dress code i ponašanje sukladno ulozi su neophodni jer to je scena, kao ekstenzija privatnog.

Upravo se na taj način optimalno ostvaruje full time, 24/7, Master/slave odnos, koji je vjerojatno najdublji i najzahtjevniji od svih veza i općenito odnosa koje možemo zamisliti i stoga je

\footnotetext{
490 Ibid, str. 86 , prijev.a.

491 Ibid. str. 92

492 Ibid. str. 92 - 93
} 
„rezervirana“ samo za osobite, iznimne osobe, koje zaista nemaju nikakvih inhibicija te izrazito čvrsto izgrađenu psihičku ličnost.

Esencijalna je totalna izmjena moći uz poštivanje ili naslućivanje granica ukoliko su postavljene za gopodara, dok je robu imperativ bezuvjetno služenje i bivanje na raspolaganju 24 sata, konstantno, uz praksu moći, volje, te učenje, poštovanje dozvoljenog i zabranjenog, za koje slijedi ritualno kažnjavanje, kao što i za izvanredno služenje uvijek postoje razne vrste nagrada. Moser i Kleinplatz zaključuju da su ti odnosi slabo razumljivi među seksolozima jer im je nejasno zašto bi se netko potpuno podredio drugoj osobi i ostao u takvom odnosu ${ }^{493}$ i to je pokazatelj da jo i danas BDSM seksualnost nije u potpunosti shvaćena, no razumljivo je teško osobama, pa i znanstvenicima, koji sami nisu nikad iskusili takve tendencije, pojmiti užitak u takvom obliku života, koji nadilazi seksualnost u 24// Master/slave životu.

Konačna konstatacija koju autori iznose u svojoj studiji je pitanje ulaženja i izlaženja iz uloge, ovisno o mjestu i okruženju, privatnom i javnom na koje samouvjereni i istinski praktikanti odgovaraju: „Izvan uloge? Ovo nije role playing, to je 24/7!، “494

Zaključak o Master/slave odnosima bio da oni zaista nisu za većinu S/M praktikanata, već za malobrojne s tom urođenom ili razvijenom predispozicijom koju moraju oprezno i racionalno razvijati, dok ne dosegnu psihički stadij prijelaza u „konsenzualno iracionalno“ i ,ekstremno“, za užitak drugoga i vlastiti.

\footnotetext{
493 Ibid.str.86

${ }^{494}$ Ibid, str. 93, prev.a.
} 


\section{FEMINISTIČKE TEORIJE KAO ŽARIŠTA SUKOBA FEMINIZAM I SADOMAZOHIZAM - PRO ET CONTRA}

\subsection{RADIKALNI FEMINIZAM PROTIV SADOMAZOHIZMA}

U feminističkim strujama i teorijama razlike u shvaćanju sadomazohističke seksualnosti su značajne, te su kroz povijest feminizma bile predmet žustrih polemika i rezolutnih podjela feministkinja po pitanju sadomazohizma kao jedne od lezbijskih seksualnosti, a, s druge strane, kao negacije feminizma per se.

Sadomazohistička je seksualnost doživjela brojne osude radikalnih feministkinja, no i afirmativne stavove renomiranih feminističkih teoretičarki i članica S/M scene.

Feminizam i sadomazohizam kod mnogih su pro teoretičarki zajedno, u međusobnom odnosu samorazumljivi, dok je njihova veza kod drugih pak smatrani nemogućima, antifeminističkima, pa i „pervertiranim subverzijama feminizma“, što možemo iščitati iz djela najradikalnijih oponentica sadomazohističkog odnosa, kao što su Andrea Dworkin i Susan Griffith.

Njihova je elementarna materijalna teoretska greška bila u tome što nisu razumjele bit sadomazohističke prakse i decidirano nisu željele razlučiti realitet nasilja od svojevrsne ,igre“, kao života u imaginarnom, što sadomazohistički odnos upravo jest, u svojoj ontologiji, psihologiji i praksi.

„Feministički ratovi“ oko prakse sadomazohizma vodili se unutar feminističkih struja, od 60 ih godina dvadesetog stoljeća, do 1990 - ih, dok je danas centralno pitanje feminizma samog propitkivanje njegove suvremene opstojnosti, no u pitanjima seksualnosti i sadomazohizma najvažnije je istaknuti stavove i teze autorica zbornika „Against Sadomasochism “.

Spomenuti zbornik raznolikih tekstova, od znanstvenih do priča o osobnim iskustvima te replikama i kritikama pojedinim feminističkim S/M skupinama iz 1973. godine obuhvaća veoma različite i podijeljene pristupe feminizmu i sadomazohizmu.

Nakon čitanja pojedinih tekstova i uviđanja konfrontacije između stavova te stručnih i proznih, osobnih tekstova, jasno je da naslov nije opozicija praksi sadomazohizma unutar feminističkih i lezbijskih zajednica, već implicira mogućnosti propitkivanja sadomazohizma u feminističkim teorijama i strujama.

Judith Butler, u svom eseju „Lesbian S\&M : The Politics of Dis - Illusion“ zauzima, u odnosu na ostale autorice, izuzetno stručan i korektan, nimalo kritički stav spram sadomazohizma, s 
impliciranim pro S/M tendencijama, što je i čini svestranom i neprejudiciranom teoretičarkom rodne teorije i seksualnosti.

Butler se referira na Foucaultovu izjavu da „,ne smijemo misliti da kad kažemo da seksu, govorimo ne moći“, te naglašava njegovu važnost za tumačenje lezbijske seksualnosti i odnosa moći i time opoziciju sadomazohizmu, budući da su, žene otkrivale iznova lezbijsku seksualnost kao početak strasti, ranjivosti, uzajamnosti $i$ povjerenja“495, i ta je seksualnost nastojala proturiječiti, oponirati ideji moći kao dominaciji, uspostavljajući moć kao kreaciju novih oblika ljubavi. ${ }^{496}$

Foucaultova misao odražava određeno oslobođenje lezbijki od ukorijenjenih igri moći heteroseksualnosti, a lezbijski seks značio je afirmaciju novog oblika odnosa i negaciju „,heteroseksističke moći“ no za razliku od njega, „,većina S/M lezbijki ne dovode u pitanje da je ta intimna veza između moći i seksa naša historijska situacija, naslijeđe na kojem moramo raditi, napominje Butler, prihvaćajući tu tezu.

Referirajući se na radikalne pro S/M feministikinje poput Pata Califie i Gayle Rubin koje „,razumiju moralnu brigu o pornografiji i nasilja nad ženama kao dokazima represije ili prezira seksualnosti te govore o čudima fantazije, i dobivamo osjećaj da feministkinje s moralnim brigama imaju te brige zbog jedine svrhe potisnutog svijeta fantazije $S / M$ - a. “, te da je „ono centralno za lezbijke koje su prigrlile S/M oslobađanje fantazije, novih erotskih mogućnosti $i$ strasti i ponekad, animalnosti. “497, ona iznosi i svoje subjektivno stajalište o S/M seksualnosti, osvrtom na vlastita iskustva, želje i fantazije govoreći da je „osjećala strast $i$ intenzitet u skladu $s$ određenom dominantno - submisivnom dinamikom moći u svojim vlastitim odnosima sa ženama“ te se „uvijek osjećala ambivalentno u vezi neravnoteže moći koja ju je privlačila“ te je zbog tog mogla razumjeti jednake osjećaje kod pripadnica lezbijsko - feminističkog pokreta u kontekstu ,politički korektnog“, što je podrazumijevalo opoziciju sadomazohizmu i privatnom, koji je podržavao svijet fantazije. ${ }^{498}$

Butler uviđa problem koherencije javnog, političkog i osobnog, seksualnog, poredak u kojem se osobno podređivalo politici feminizma te stoga naglašava $S / M$ pokret kao život fantazije $u$ kojem javna sfera nestaje, a život je „libertinski“, ili „libertarijanski“, izvor zadovoljstva, sfera seksualnog, referirajući se pritom na Pata Califiu kao začetnicu „novog“ feminizma koji je protiv cenzure svakog oblika seksualnosti, za potpunu seksualnu slobodu i S/M seksualnost kao

\footnotetext{
495 Judith Butler, Lesbian S\&M : The Politics of Dis - Illusion,u Against Sadomasochism, Frog In the Well, East Palo Alto, California, 1982., str. 169, prev.a.

496 Ibid, str. 169

497 Ibid, str. 170, prev.a.

498 Ibid, str. 171, prev.a.
} 
ostvarenje slobodne seksualnosti i fantazije, u kojoj „politička kontrola“ anti S/M feminizma nema pristupa. ${ }^{499}$

Butler zaključuje svojim razumijevanjem glorifikacije egzistencije u privatnim fantazijama $u$ društvu te problematiku nastojanja feminističkih javnih politika u patrijarhalnom društvu, ali također postaje obeshrabrena lezbijsko - feminističkim pravilima koja joj nameću normu da svoja osobna iskustva prevodi u politički prihvatljive feminističke termine i prilagođava istima svoje ponašanje.

Njeno je propitkivanje feminističkog pokreta potpuno opravdano jer radikalne su feministkinje nametanjem svojih normi djelovale analogno patrijarhalnoj matrici, samo sa suprotnog polazište, dovodeći time u pitanju slobodu S/M seksualnosti, predstavljajući je kao nasilje.

Ona dovodi u pitanje i izbor konsenzualnog sadomazohizma, koji, kao slobodan izbor, nije nasilje, već sfera privatnog, no i inkluzivnog i javnog, dogovorenog, pristanka i odnosa moći koji su posve drugačije od društveno - političkih, jer su, kao i pristanak, stvoreni prema svojstvenoj logici i društveno - kulturnih utjecajima, što njoj nije sasvim razumljivo.

S/M je izraz seksualne želje te Butler dijalektički elaborira da S/M zauzima nerefleksivni stav prema seksualnoj želji, afirmirajući mišljenje „konsenzualnog izbora“ $i$ izuzimajući sebe iz stvarnog, dijeljenog svijeta, S/M lezbijke su ostavile iza sebe mogućnost za konkretne osobne $i$ političke izbore, a umjesto toga dobivaju igranje seksualnih fantazija kao da historijski $i$ politički svijet ne postoje začudo, izvire jasna slika dinamike moći karakterisitična za patrijarhalnu, historijsku stvarnost koju je S/M navodno ostavio iza sebe."500

Ona konstatira da S/M nije prevladao patrijarhalnu dinamiku moći, ali želja i pristanak ipak odražavaju slobodan izraz seksualnosti, bez moralističkog standarda, te su seks i moć nerazdvojno isprepleteni, a slobodan izbor temelji se na njihovom dijalektičkom odnosu jer:

„Naše želje mogu biti sigurne i slobodne koliko mi to jesmo. Tada to nije slobodan izraz želje, već je dijalektika izbora i želje presudna zadaća lezbijskog feminizma. “501

Otvoreno pitanje i poruka feministički praktikanticama sadomazohističke seksualnosti Butler formulira: „Kako učiniti naše želje zaista našim vlastitima, kako ih odabrati za sebe?

Kako učiniti ,, slobodan izraz seksualnosti“ istinski slobodnim “? "502

\footnotetext{
499 Ibid, str. 171 - 172

500 Ibid, str. 172, prev.a.

501 Ibid, str. 173, prev.a.

502 Ibid, str. 173, prev.a.
} 
S potpuno kontradiktornom stajališta, Susan Griffin, u svom eseju „,Sadomasochism and the Erosion of Self, a Critical Reading of Story of $O$ “, izlaže radikalnu, pa i agresivnu anti sadomazohističku teoriju svojeg čitanja dobro nam već poznatog romana.

Njenu kritiku istoga možemo shvatiti kao „blasfemičnu“ provokaciju sadomazohizma, posebice feminističke sadomazohističke prakse.

Za nju je sadomazohizam svojevrstan pandan totalitarnom, nacističkom režimu s kojim ona povlači neuspjele, diletantske paralele, ontološki i materijalno potpuno pogrešno tumačeći cjelokupni smisao i feminizma i sadomazohizma.

Njenoj antisadomazohističkoj i antifeminističkoj proizvoljnoj pseudoteoriji nije potrebno pridavati velike važnosti, no napominjem je kao još jedan primjer do koje su mjere radikalne anti S/M feministkinje nastojale diskreditirati sadomazohističku seksualnost.

Iz tog razloga ne mogu biti smatrane istinskim feministkinjama jer feminizam mora biti temeljen na jednakosti i poštovanju prava drugih i diverziteta seksualnosti, dok kod „radikalne feminističke struje“ nalazimo eksplicitne tendencije represiji i pokušajima „vrednovanju seksualnosti“" na vlastitom konzervativizmu.

Radikalne anti S/M feminističke teoretičarke pretjerano su politizirale sferu seksualnosti i iz tog razloga uspoređivale sadomazohizam čak i s totalitarističkim režimima, kao Griffin, nema nikakve opravdane utemeljene logike, .što je samo neupjeli subjektivan i arbitraran pokušaj diverzije slobodne seksualnosti.

Foucault ovu misao izražava mnogo blaže, objašnjavajući razliku poimanja seksualnosti kod homoseksualaca i lezbijki:

„Inventivni element, američki homoseksualci čine taj izazov svojim polazištem. Kao žene, počinju tražiti nove oblike zajednica, koegzistencije, užitka.

Ali, u kontrastu s pozicijom žena, fiksiranje homoseksulaca na njihovu seksualnu specifičnost je mnogo jača, oni reduciraju sve na poredak seksa.

Žene to ne čine. Homoseksualni pokret oslobođenja ostaje na razini zahtijeva za prava na seksualnost, na dimenziji seksološkog.

Žene, s druge strane, su sposobne imati mnogo šire ekonomske, političke i ostale objektive nego homoseksualci. ${ }^{\text {"503 }}$

\footnotetext{
${ }^{503}$ Michel Foucault, Colin Gordon Power/Knowlegde, Selected Interviews, Routledge, New York, 1980, str. 232,
} prijev..a. 
Čitajući radikalne anti - S/M teoretičarke, jasan je razlog zašto brojne feministkinje ne razumiju psihologiju i seksualnu praksu sadomazohizma.

Konstantnim eskalacijama devijantnih ponašanja i provođenja moći kao moći protiv u društvu, naizgled „nasilne“ seksualne prakse bude revolt i etičke sumnje, no potrebno se ispravno informirati te naučiti razumjeti razlike između „drugačije“ seksualnosti i nasilja jer S/M je izričito protiv nasilja.

Najeksplicitniji primjer, je komparativna konfrontacija teorije Andree Dworkin, opravdano smatrana potpuno pogrešnom interpretacijom sadomazohizma svojim nevjerodostojnim argumentima nasuprot pro S/M ideje lezbijsko/feminističku organizacije SAMOIS.

Kod Dworkin i istomišljenica, smatram da se radi o temeljnom nepoznavanju sadomazohizma u suvremenom kontekstu, koji je sve samo ne antifeministički, te o potpunom nerazumijevanju psiholoških, socioloških te filozofskih teorija, pojmova i međuljudskih odnosa, te apstraktnih pojmova psihoanalize i ontologije u kontekstu odnosa Ja - drugi, odnosa moći i naposljetku, nemogućnosti distinkcije i razgraničenja realiteta i imaginarnog, nasilja i fantazije:

“Teza o O je jednostavna. Žena je požudna, razvratna. Mora biti kažnjena, ukroćena, ponižena. Ona daje dar sebe, svoje tijelo, svoju dobrobit, svoj život, svom ljubavniku.

Tako bi trebalo biti - prirodno i dobro. Završava u njenoj anihilaciji, koja je isto prirodna $i$ dobra, kao i prekrasna, jer ona ispunjava svoju sudbinu. "504

U svojoj kontroverznoj knjizi „Woman Hating“, Dworkin inzistira na omniprezentnoj viktimizaciji žena, što i govori naslov najvažnijeg poglavlja „Woman as Victim“, u kojem analizira, između ostaloga kao i većina radikalnih feministikinja, roman „Story of $O$ “, iznoseći svoje radikalno stajalište, no ipak nešto opravdanije od Griffith.

"Story of O je više od jednostavne pornografije. Ona tvrdi da epistemološki definira što je žena, što ona treba, njene procese mišljenja i osjećanja, njeno odgovarajuće mjesto. Sado mazohistička složnost O nije trivijalna - ona je formulirana kao kozmički princip koji apsolutno artikulira feminini. ${ }^{505}$

Protagonisticu romana Dworkin prezentira kao paradigmu žene u falocentričkom društvu, kao podređenu žrtvu muškog nasilja, čiji je označitelj samo njen spolni organ, isključivo i samo u službi užitaka muškaraca.

"Iz tijeka priče o O izvire jasna mitološka figura :ona je žena, a imenujući je O, nulom, prazninom, govori sve. Njeno idealno stanje je ono potpune pasivnosti, ništavila, tako

\footnotetext{
504 Ibid, str. $57-5$, prev.a.

${ }^{505}$ Andre Dworkin, Woman Hating, Plume, Penguin Books, New York, 1974, str. 55, prijev.a.
} 
apsolutnoj submisivnosti da ona transcendira ljudsku formu (postajući sovom).” Samo rupa između njenih nogu ostaje da je definira i simbol te rupe mora siguno biti O. "506

Dworkin uporno nastoji prikazati S/M lezbijke kao žene kojima je seks u centru i time žele dominaciju muškaraca u svakome pogledu, a time djeluju protiv feminističkog i ženskog principa te uništavaju svoju vlastitu egzistenciju, što je, naravno, apsurdna ideja, zasnovana na arbitrarnim predrasudama i nesmislenim tezama.

“Kad rezimiramo, Story of $O$ je priča o psihičkom kanibalizmu, demonskom opsjednuću/ posjedovanju, zaposjednuću, priča koja smješta muškarce $i$ žene na suprotne polove svemirapreživljavanje jednog ovisno je o apsolutnom uništenju drugog. Pita se, kao mnoge price, tko je najmoćniji, i odgovor je : muškarci, doslovno preko mrtvih tijela žena."

Nepotrebno je napominjati da Dworkin ne razumije ispravno metaforiku i duboki smisao sadomazohističke seksualnosti te stoga ne može biti smatrana kompetentna za analizu istoga jer njene ,teorije“ nemaju znanstveno utemeljenje.

Njeno djelo može biti primjer radikalne feministkinje koja nastoji interpretirati feminizam analogno patrijarhalnom poretku jer koristi jednako validne argumente.

Lynda Hart (1953 - 2000), profesorica engleskog jezika i kazališne umjetnosti na Sveučilištu u Pennsylvaniji i aktivistkinja za LGTB prava u svojoj knjizi „Between the Body and the Flesh“, tumači postajanje lezbijkom sadomazohističkog identiteta dominantnom ili submisivnom, oslanjajući se na konstrukcije roda lezbijki kao žena ili pak izvan te kategorije, lezbijki kao jastva. Najvažnija je njena konstatacija da lezbijke sadomazohistkinje mijenjaju kategoriju lezbijki koje se definiraju kao žene, što je već ranije naznačeno i Hart zastupa poziciju da lezbijke zauzimaju jednako mjesto u sadomazohizmu, a kao što se rađaju kao žene, jednakom linijom rađaju se ujedno i kao submisivne i dominantne..$^{507}$

Hart uvodi termin "Nemoguće - Realno", preformulirano od "Realno - Nemogućeg" Slavoja Žižeka da bi prikazala arbitrarno postavljene razlike između heteroseksualnog i homoseksualnog BDSM - a, kao pretpostavke psihoanalize o ,ženskom prirodnom mazohizmu“ i tezu radikalnog feminizma da je ženski, feministički i lezbijski sadomazohizam nemoguć, i stoga ona postavlja razliku "Impossible - Real" i "Queer Real". 508

\footnotetext{
506 Ibid, str. 57, prijev.a.

507 Lynda Hart, Between the Body and the Flesh, Performing Sadomasochism, 1998, Columbia University Press, New York, str. 62 - 65

508 Ibid, str. 65, 84- 92
} 
Pritom se referira na Foucaultovu izjavu iz ranije spomenutog intervjua o superiornosti u muškoj homoseksualnosti u odnosu na žensku te $\mathrm{S} / \mathrm{M}$ još uvećava tu problematiku zbog mijenjanja uloga i asocijacije submisivnih muškarca s “ženskom” pozicijom.

Pod superiornošću on misli na "prisjećanje prije iščekivanja čina” jer je historijski muškarcima homoseksualnost lakše dostupna. ${ }^{509}$

Hart inzistira da je S/M odnos dviju žena, odnos butch i femme jednak bilo kojem top/bottom odnosu i time kvalitativno jednak heteroseksualnom te, pozivajući se na termin lezbijskog feminizma - "realesbians", i psihoanalizu, zaključuje da su u tom kontekstu lezbijke Realno ${ }^{510}$.

$\mathrm{U}$ djelu „Between the Body and the Flesh“ obuhvaćena je tematiku lezbijskog sadomazohističkog odnosa i tu je najvažnija njena interpretacija Lacanovih i Deleuzovih teorija, odnosno poveznice ženske seksualnosti i problematike rodne uloge žene sa suvremenim psihoanalitičkim teorijama.

Autorica isprva Deleuzovu teoriju naziva „obećavajućom“, argumentom da je model zasnovan na mazohizmu, ,jedini psihoanalički pristup koji dozvoljava“ i omogućuje sadomazohistički odnos dviju žena, jer je kao takav zapravo „odnos dvaju mazohista i time se trudi prevladati napetost Hegelovog dominantno - submisivnog modela“ “. 511 , obzirom da je hegelijanski pristup sadomazohizmu suviše površinski i može se primijeniti samo na osnovne odnose moći, dok je Deleuzeov sustav, kao primarno mazohistički, neprikladan feminističkoj teoriji.

Hart se stoga postavlja izrazito kritički spram Deleuzeove teorije sadomazohizma nakon elaboracije da njegov model mazohizma postavlja ženu kao ,fantazmički konstrukt mazohista“ te je time konstruiran na falocentričkoj seksualnosti te zaključuje da je pozicija žene unutar sadomazohističkog falocentrizma problematična, jer „ona“ nema ni konstrukciju tijela unutar diskursa niti realitet već samo fantazmičku egzistenciju u maskulinom Imaginarnom. ${ }^{512}$

Ona se pritom referira na Deleuzovu paradoksalnu tezu da su sadizam i mazohizam dvije odvojene perverzije te da se sadomazohistički odnos odvija, ne između sadista i mazohista, već između dva mazohista koji provode svoje seksualne fantazije kroz različitosti i sličnosti koje dijele kao potpuno jednaki. ${ }^{513}$

\footnotetext{
509 Ibid. str. $114-115$

510 lbid. 86 - 92

511 Lynda Hart, Between the Body and the Flesh, Performing Sadomasochism, 1998, Columbia University Press, New York, str. 68, prijev.a.

512 lbid. str. 72 - 73

513 Ibid. str. 68
} 
Hart konstatira da je unutar Lacanovog i Deleuzovog falocentričkih modela, od kojih prvi smješta ženu kao „tjelesnost prije konstrukcije tijela i izvan diskursa“, a drugi nameće poziciju dominantnog mazohista i definira ženu kao objekt njegove želje, konstrukciju mazohista referirajući se direktno na Lacana, naglašava neproduktivnu, preddiskurzivnu, želju za „tjelesnošću prije tijela u diskursu“, a ,žena, koja u u toj formuli ne postoji, je objekt te želje“. 514 Sadomazohizam, interpretiran kroz maskuliniziranu perspektivu psihoanalize je tako shvaćen kao mjesto dekonstrukcije identiteta žene i zato Hart ispituje poziciju S/M - a iz vlastite, feminističke, queer perspektive ${ }^{515}$, te u tom kontekstu lezbijski sadomazohizam smješta „,između tijela i tjelesnosti“ upravo stoga što je uvijek promatran kao „fantazmički konstrukt" i projekcija muškog rodnog identiteta i time je dekonstruiran, prestaje biti utjelovljen, već je „želja za željom“, još neutemeljen u Realnom i nastoji ontološki prevladati svoju poziciju „nemogućeg Realnog“. 516

Pritom misli na izričaj i vokabular koji ima deskriptivnu ulogu pravila i performativa $u$ lezbijskim S/M zajednicama, navodeći za primjer Pata Califiu koji strogom podjelom i ideološkim shvaćanjem S/M - a još produbljuje problematiku slobodnog izbora kao ideološki posredovanog, jer Hart ukazuje, ,postoji li način da mislimo o slobodi koja dozvoljava više od transgresija koje su neizbježno pretpostavljene i uistinu dozvoljene, ideologijom koja ih anticipira i inkorporira?“517

Svojim tezama ona nastoji ukazati na problem lezbijskom sadomazohizma kao kopije, reprodukcije opresivnog modela kao originalnog, mimesisa u Platonovu smislu, a istodobno je smješta u Realno budući da u takvom shvaćanju sadomazohizma vidi naznake mazohizma kao „queer“ čina, a naročito u Deleuzovom argumentu da su obje osobe subjekti koje traže elemente iste sklonosti ili, njegovim riječima, perverzije, a ne subjekt druge, suprotne perverzije. ${ }^{518}$

Time ona Deleuzovu teoriju smatra važnim doprinosom za lezbijski sadomazohizam, koji mijenja uspostavljenu kategoriju lezbijki kao „žena identificiranih kao žene“ te podsjeća da je suvremeni feminizam i naslijedio i konstruirao pojmove u konceptualizaciji seksualnih subjektivnosti i određenja. ${ }^{519}$

\footnotetext{
514 Ibid. str. $72-76$, prijev.a.

515 Ibid. str.

516 Ibid. str. 70 - 76

517 Ibid. str. 65, prev. a.

518 Ibid. str. 68 - 69

519 Ibid. str. 65
} 


\subsection{FEMINISTIČKA OBRANA MAZOHIZMA SADOMAZOHIZAM KAO FEMINISTIČKA SEKSUALNOST}

Sadomazohizam je neophodno sagledati i razumjeti i kao jednu od temeljnih feminističkih seksualnosti, upravo zbog praksi izmjene moći i time izjednačavanje s muškim rodom, ali i jačanju odnosa među mnogobrojnim feministkinjama koje prakticiraju istospolne $\mathrm{D} / \mathrm{s}$ odnose. Bitno je napomenuti da u brojnim S/M odnosima žena i muškaraca, upravo žene zauzimaju dominantnu ulogu, kao domine ili gospodarice, naravno, i prema vlastitoj želji, no najčešće i prema želji partnera i tome je slučaj i u privatnoj sferi, dok je u ,profesionalnoj“ gotovo ustaljeno pravilo, pored malobrojnih izuzetaka.

Elaborirala sam problematiku anti - sadomazohističkih feminističkih teorija, koje sadomazohističku seksualnost interpretiraju kao nasilnu antifeminističku praksu te ću sada predstaviti stajalište koje i osobno zastupam, sadomazohizam je, pored svih ostalih skupina i opredijeljenja i feministička seksualnost, budući da sve kontrateze nemaju objektivna niti znanstveno opravdana utemeljenja.

Prvim ,apologetskim“ djelom „feminističkog mazohizma“ možemo opravdano smatrati esej Simone de Beauvoir „,Must we Burn Sade“, izloženo u prvome poglavlju, kao jedan uvod u sve daljnje promjene i modifikacije feminizma.

Pravim „uvodom“ u feministički sadomazohizam kao zasebnu subkulturu neupitno je SAMOIS, feministkinje koje su svojim djelovanjem, i teoretskim i praktičnim učinile demonstrirale i provele manifest dotad nezamislivog ujedinjenja dviju pozicija, feminizma $i$ sadomazohizma, posebice mazohizma, koji se smatrao isključivo antifeminističkim, zbog nerazumijevanja želje i konsenzualnosti za istim.

SAMOIS je bila prominentna lezbijsko - feministička S/M organizacija u San Franciscu 1978. do 1983, koju su osnovale najistaknutije S/M orijentirane LGBTQ teoretičarke, prvenstveno Pat Califia i Gayle Rubin, a naziv organizacije dolazi od fiktivnog imanja u kojem je protagonistica „Histoire d'O“ boravila tokom svoje „obuke“ i inicijacije.

Intencija osnivačica i članica bila je demonstrirati da je ženska submisivnost, naročito kod lezbijki, sve osim nasilja, što u svome manifestu eksplicitno elaboriraju da bi prikazale dotad nezamisliv spoj feminizma i sadomazohizma, kao radikalan preokret i u feminističkom pokretu i u S/M seksualnosti i zajednicama, otvarajući poglavlje korelacije i koegzistencije sadomazohizma i feminizma. 
Njihov manifest od iznimnog značaja je knjiga „Coming to Power“, prvi put izdana 1981. godine, a ujedno je smatrana i platformom svih istomišljenica, čime je time ušla u povijest kao suvremeni klasik lezbijskog BDSM-a, kojim su dobile status „feminističke inačice“ gay leather scene San Francisca.

Djelo je zbirka teoretskih radova o povijesti ove zajednice, lezbijske S/M scene, uputa u ikonografiju i ponašanje unutar zajednice i scene, erotske S/M fikcije brojnih autorica, prigodno grafički popraćena crtežima i fotografija dotične tematike. ${ }^{520}$

Cilj SAMOIS - a je bio ,izaći van“, deklarirati se kao lezbijka S/M orijentacije, što je tada u svim ostalim dijelovima SAD-a predstavljalo dvostruki problem i izazivalo burne reakcije, $\mathrm{s}$ obzirom na konzervativne prilike i američke norme.

Nakon prekida rada SAMOIS - a, članice su osnovale razne slične grupe i organizacije od kojih su najvažnije The Outcasts (1984 - 1997), koju je osnovala Gayle Rubin te potom The Exiles koja još uvijek postoji od 2012. godine, a bitno je spomenuti antologiju Pata Califie i Robin Sweeny „The Second Coming:A Leatherdyke Reader“ iz 1996, koja govori o historijskom razvoju lezbijskih BDSM grupa sve od samih početaka SAMOIS - a.

Inicijalni manifestni zbornik grupe SAMOIS, „Coming to Power“ usredotočen je na osobna iskustva i ispovijesti S/M lezbijki i feministkinja, te legalističku problemtiku sadomazohističke prakse, usmjerenu na borbu za slobodu seksualnog opredijeljenja, protiv represije konzervativnog društva i stigmatizacije, za zaštitu seksualnosti kao privatne sfere i slobodnog izbora kao jednog od temeljnih ljudskih prava.

Najistaknutije aktivistkinje i teoretičarke SAMOIS pokreta bile su svakako Gayle Rubin i Pat Califia, koje su isticale neravnopravnost sadomazohističke prakse unutar feminističkih pokreta i inicijativa koje su ga oštro kritizirale kao „nasilje“ nad ženama, a feminističke S/M praktikantice bile su izložene etiketiranju kao protivnice feminizma zbog svoje seksualne orijentacije koja ,podilazi maskulinom poretku.“

Radikalni feministički anti S/M pokreti nastojali su tako, svim sredstvima diskreditirati SAMOIS svojom konzervativnom retorikom te izjednačavanjem S/M prakse i nasilja.

Feminizam je postao politika, bio je artikuliran i prakticiran kao seksualna i pravna politika, od 70 - ih godina 20. stoljeća, no oprijedjeljenja i ciljevi raznih skupina bili su veoma oprečni i stoga je nekadašnji pokret za prava i jednakost žena postalo žarište sukoba između feministkinja samih, između radikalnih anti S/M skupina s nultom tolerancijom prema drugačijim lez/fem

520 SAMOIS, Coming to Power, Alyson Publications, Boston, 1987 
aktericama i raznolikim seksualnostima i liberalnim, slobodnim, pro S/M feministkinja i sudionicama $\mathrm{S} / \mathrm{M}$ scene.

Feminizam može biti liberalna i egalitarna politika, inkluzivna i pacifistička, što joj i bila originalna, inicijalna ideja u samome početku, ali postoji i „radikalni feminizam“ kao konzervativno - opresivna struja, nasilna i ekskluzivna, u koju bismo svrstali teoretičarke poput Dworkin, Griffin, Ruth Linden, Dianu Russell i druge.

Isključivanje neke skupine ili pojedinca iz feminističkog diskursa zbog prakticiranja S/M seksualnosti tipičan je primjer takve opresije, koju je doživjela/o i Pat Califia i to dvostrukom ekskluzijom, kao S/M praktikantica, leather dyke te potom kao transseksualna osoba, što joj je pružilo iznimnu motivaciju da prikaže lezbijski pokret kakvim doista jest, kompleksan pokret različitih svjetonazora i dvostrukih standarda.

S/M orijentirane lezbijke ponosne su svojim identitetom koji je izgrađen na temeljnim ženskim pravima, slobodi izbora i seksualnosti kao jednakost svih žena jer model radikalnog feminizma daleko je opresivniji i izrazito diktatorski nastrojen od nekadašnjeg maskulinog poretka isljučivanja žena iz određenih društvenih sfera.

SAMOIS su svojom odlučnom politikom i manifestom zastupale osobnu i seksualnu slobodu u zakonu i društvenoj praksi, boreći se aktivistički u društvenim znanostima, psihoterapeutskom praksom, predavanjem na sveučilištima, pisanjem i objavljivanjem knjiga i radova i time pridonijele feminizmu u S/M zajednicama.

Pat Califia, jedna/dan ${ }^{521}$ od najvažnijih teoretičara i aktivista LGTBQ sadomazohističke seksualnosti, napravio/la je možda najveći breakthrough svojim brojnim radovima, člancima i knjigama na $\mathrm{S} / \mathrm{M}$ sceni te je visoko priznat u akademskoj zajednici društvenih znanosti sociologije i psihologije seksualnosti.

Započevši osobnim ispovijestima svog životnog puta transgender osobe, prijelazom u transseksualnu, vividno opisujući atmosferu S/M scene San Francisca te postavljajući vlastite retrospektivne uvide i teorije o sadomazohizmu, posebice dominaciji i Master/slave odnosima. Njegova knjiga „Public Sex, The Culture of Radical Sex“, sastavljena od radova iz raznih kolumni u časopisima te zasebnih radova i zbirki, pruža izvrstan i originalan pregled sadomazohističke seksualnosti i feminizma kroz prizmu osobe kompleksnog, višestrukog identiteta, osobe koja je doista proživjela sve stadije i feminizma, seksualnih oprijedijeljenje i

\footnotetext{
${ }^{521}$ Pat Califia, u početku transgender, a od 1990 i transeksualna osoba, objavljivala brojne radove kao pripadnica S/M scene i SAMOIS pokreta, prvo kao žena, lezbijka, a potom kao muškarac, op.a.
} 
roda te sve pozicije sadomazohističke seksualnosti te je stoga opravdano možemo smatrani kompetentnom za ovu temu.

Najrelevantnije su njegove deskriptivne teze o sadomazohizmu kao sinergiji i kontinuitetu društva, feminističke seksualnosti i politike, leather scene te naposljetku, sadomazohističke seksualnosti kao takve iz njegove vlastite perspektive.

Califia se argumentirano, ustrajno i odvažno „bori“ protiv pseudoteorija „radikalnih“ anti - S/M feministkinja, prvenstveno njihov proizvoljnih i apsurdnih ideja o sadomazohizmu kao „nasilju nad ženama“ i stoga „kontrafeminističkom“.

Nakon „ekskomunikacije“, prvo iz SAMOIS te ostalih feminističkih i lezbijskih zajednica, uslijed transgender orijentacije i tranzicije te zbog aktivnog sudjelovanja na S/M leather i S/M opredijeljenja per se, ustrajno nastavlja sa svojim radom, objavljujući brojne članke, studije i knjige o sadomazohizmu u korelaciji i kontekstu feminizma i roda te započinje karijeru u psihoterapeutsku praksu kao originalna, vjerodostojna i dosljedna teoretičar.

Califia je razvio originalnu teoriju semiotike za tumačenje rodno - seksualnog identiteta, temeljenu na odrednicama i varijacijama roda u sadomazohističkoj seksualnosti, prvo feminističkom, a potom gay leather $\mathrm{S} / \mathrm{M}$ seksualnosti.

Njegova semiotika seksualnosti specifična je terminologija izgrađena na inovativnoj rodnih identiteta, a kao svoj temelj ima vlastitu, duboko nijansiranu semantiku, koja pruža novi pogled na socijalnu hermeneutiku roda i S/M seksualnosti.

Terminologija s kojom se susrećemo u „Public Sex/The Culture of Radical Sex“ vođena je pitanjima oprijedijeljenja te problematikom osjećaja pripadnošću zajednici, sceni, no prvenstveno ontologijom sebstva, vlastitim osjećajem pripadnošću sebi, o čemu autor govori ponajviše iz vlastitog iskustva, putem naizgled kompleksne semantike i semiotičke strukture. On eksplicitno napominje svoju motivaciju za aktivizam i pisanje sadomazohističke teorije: „Opisujem svoje osjećaje jer se sadomazohizmom obično bavi na apstraktan, samoopravdavajući način, feminističke teoretičarke vjerujući je on epitom mizoginije, seksizma i nasilja. Motivirana sam svojom brigom za ljude koji su uplašeni ili posramljeni svojim erotskim podražajima na sadomazohističke fantazije. Ne želim čuti više tragičnih priča žena koje su potiskivale svoju seksualnost vjerujući da su njihove čežnje za bespooćnošću $i$ seksualnom kontrolom politički neprihvatljive. Ženski pokret postao je moralistička sila koja doprinosi samoprijeziru i jadu koji doživljavaju seksualne manjine. Mislim da je vrijeme da ženski pokret zauzme radikalnu poziciju u pitanjima seksualnosti. “522

522 Pat Califia, Public Sex : The Culture of Radical Sex, Cleis Press, San Francisco, California, 2000, str. 169, prev.a. 
Kod Califie nalazimo odlična, i objektivna i subjektivna objašnjenja sadomazohizma, i kao scenu i kao osobno psihoseksualno iskustvo, koje je bilo izuzetno teško opisati zbog osobnih barijera, no Califia je u svojim autobiografskim esejima pronašla i vlastitu psihoterapiju, i odgovore na mnoge dileme upućene čitateljima:

„Teško je raspravljati o sadomazohizmu u feminističkim terminima zato što je slang koji S/M osobe koriste govoreći o seksualnosti bio odgovarajući feminističkim agitatorima. Termini kao uloge, mazohizam, bondage, dominacija i submisivnost postale su krilatice. U feminističkom kontekstu njihova se značenje oštro razlikuju od značaja koje imaju S/M osobama. Feminističke teoretičarke inzistiraju na interpretaciji seksualnog ponašanja u skladu sa svojim vlastitim vrijednosnim sustavom. U svojoj sadašnjoj formi, feminizam nije najbolji teoretski okvir za razumijevanje seksualne devijacije. “ 523

Pitanje je koliko su u međuvremenu, posljednjih desetljeća, feministički pokreti promijenili svoje stavove prema sadomazohističkoj seksualnosti, no oprečne struje umjerenog pro S/M feminizma i radikalnog feminizma još uvijek postoje i Califia uviđa najvažniju problematiku razumijevanja sadomazohizma u kontekstu feminizma kao svjetonazora i feminističkih teorija. Njegov je rad izvrstan primjer da $\mathrm{S} / \mathrm{M}$ seksualnost nema granica $\mathrm{u}$ orijentacijama $\mathrm{i}$ preferencama, urođenim osobinama te izgradnji vlastitog identiteta te je inspirirala velik broj suvremenih teoretičara $\mathrm{u}$ čijim radovima nalazimo velike utjecaje prvog i drugog vala feminizma, terminologiju i teorije koje su započele 70 - ih i 80 - ih godina na u feminističkim strujama, BDSM sceni i akademskim krugovima Californije, prvenstveno San Francisca.

Califia napominje da je „,bitan dio opresije žena kontrola nad seksualnom ideologijom $i$ ponašanjem i ta seksualna kontrola pogađa seksualne nekonformiste, no i konformiste zato što su kazne za pobunu tako visoke da niti jedan individualac niti skupina nisu potpuno slobodni od erotske tiranije. "524

Time radikalno osuđuje feminističku opresiju sadomazohizma kao ,antifeminističkog“, svjestan da se takvo, nadasve pogrešno i pervertirano shvaćanje još dugo vremena neće promijeniti, no svojom originalnim promišljanjima, tezama i „revolucionarnom“ retorikom nastoji izmijeniti svijest istinskih feministkinja koje se zalažu za slobodnu seksualnost i jednako vrednovanje svih seksualnosti, posebice S/M, o kojem govori:

„Zbog toga što je sadomazohizam obično portretiran kao nasilna, opasna aktivnost, većina ljudi ne misli da postoji velika mjera razlike između silovatelja $i$ bondage entuzijasta. Ali sadomazohizam je konsenzualna aktivnost koja uključuje polarizirane uoge $i$ intenzivne

\footnotetext{
523 Ibid, str. 169, prijev.a.

524 Ibid, str. 170, prijev.a.
} 
senzacije. S/M scena je uvijek prethođena pregovaranjem, ključna riječ razumijevanju $S / M$ - a je fantazija. Uloge, dijalog, fetiš kostimi i seksualna aktivnost dio su drame ili rituala. "525

Navedena deskripcija iznosi bit sadomazohizma i put prema ispravnom razumijevanju, koje se tek recentno započelo razvijati ispravnim putem.

Califia je od svog početka definirao/la svoj identitet kao feministkinja, leather dyke lezbijka dominantne orijentacije, da bi naposljetku rodnom tranzicijom i naposljetku promjenom spola zadobila novi identitet, izjednačavanjem roda i spola, zadržavši svoju radikalnu sadomazohističku seksualnu orijentaciju:

„Istina je da društvo oblikuje seksualnost. Možemo donijeti bilo koju odluku o svom seksualnom ponašanju koju želimo, ali naša imaginacija i mogućnost da ih provedemo ograničeni su kulturom koja nas okružuje. Ali ne vjerujem da je sadomazohizam rezultat instituciolizirane nepravde, S/M subkultura je izložena seksizmu, rasizmu i ostalim otpadima sustava, ali dinamika između submisivne $i$ dominantne osobe uvelike je drugačije od dinamike između muškaraca $i$ žena, ili ljudima gornje $i$ srednje klase.

Tijekom S/M susreta, uloge su stečene i korištene na mnogo različitih načina, a najveća nagrada je seksualno zadovoljstvo. "526

Kao S/M praktikant, teoretičar i psihoterapeut, Califia je odličan primjer integracije profesije i životnog stila i upravo time stječe kompetenciju i stručnost u svome radu, i autorskoj i psihoterapeutskoj praksi, baveći se individualnim pravima i čvrsto oponirajući politizaciji seksualnosti te promičući ispravno tumačenje sadomazohističke prakse:

„S/M erotizam se fokusira na zabranjene osjećaje ili radnje te traži način da od njih postigne zadovoljstvo. S/M krši tabu očuvanja romantičnog seksa zato što je svaka uljučena bol namjerna. S/M ne uključuje nužno bol, izmjena moći esencijalna je prije nego disciplina $i$ kazna, bol je subjektivno iskustvo. “527

Britanska teoretičarka Anita Phillips svojoj obrani mazohizma pristupa veoma subjektivno no stručno, navodeći brojna vlastita iskustva i njena je knjiga „Defence of Masochism“ relevantna upravo zbog same feminističke pro BDSM pozicije.

Phillips brani mazohizam kao kontra anti - S/M feministkinja, zagovarajući seksualnost u kojoj se sve čini s pristankom, a sačinjena je od uživljenja u fantaziju, istraživanja sebe, kao više

\footnotetext{
525 Ibid, str. $171-72$, prijev.a.

526 Ibid, str. 173, prijev.a.

527 lbid, str. $174-5$, prijev.a.
} 
drugih sebstava i truda da se dogovor ili ugovor ispuni do kraja ${ }^{528}$ i kod nje nalazimo formulaciju vezanu za Deleuzovu teoriju - ,,nijedan sadist nije dobar za mazohista “529, jer ona također odvaja sadizam i mazohizam argumentima da su oni međusobno potpuno različiti i ne mogu biti kompatibilni i to je osnova specifične ekskluzivne mazohističke pozicije.

Ona konstatira da se sadist i mazohist jednostavno ne bi mogli razumjeti zbog svojih različitosti i karakternih osobina te bi zato kompatibilan par bili bi dva mazohista i njeni su argumenti za tu tezu, koju je originalno utemeljio Deleuze, a nalazimo je i kod Hart, interesantni i relevantni za promišljanje $\mathrm{S} / \mathrm{M}$ odnosa te pitanja mazohizma koje sam već ranije elaborirala $\mathrm{u}$ formi otvorenog pitanja i dileme, pri čemu Phillips svoje stajalište objašnjava tvrdnjama da ,sadist traži žrtvu i zgrožen je mazohistovim kapacitetom za užitkom, što umanjuje njegov vlastiti““. ${ }^{530}$

Ona sadizam karakterizira kao „ogorčenu apatiju obilježenu ispadima samosažaljujućeg bijesa“ , ,priču velikog patosa i čak neuspjeha u tome da nasilje nikad ne postiže svoj cilj u stvaranju prostora za akciju“ te ,prelazi odmah na stvar : zadovoljstvo se mora dobiti u nasilju protiv ili dominaciji nad drugom osobom". 531

S druge strane, mazohizam je velika sposobnost imaginacije, stvaranje ,atmosfere opasnog zavođenja, produbljeni kapacitet za fascinaciju “, a prije svega hrabrost i spremnost za suradnju i zajedništvo zbog rizika koje mazohist preuzima svojom submisivnošću, što zahtijeva dogovor i međusobno razumijevanje. ${ }^{532}$

Teza o simbiozi dvaju mazohista mogla bi se vrlo jednostavno protumačiti kao odnos dvije osobe koje obje vole užitak u boli, no jedna je dominantna nad drugom ili se povremeno izmjenjuju i bitno je naglasiti elementarnu materijalnu razliku pojmova sadist i mazohist, te dominantan i submisivan, koji nisu komplementarni, a i izvorno nikada ne mogu biti sinonimi jer submisivne osobe, kao što Phillips i govori, veoma često upravljaju scenom, uvjetuju sve aktivnosti svojim pristankom.

Osebujne karakterne crte mazohista koje ona primjećuje su taština i stav kojim traže partnera i žele privući sadista, jer i sami imaju sadističke sklonosti i prema sebi i drugome, što prikazuje $\mathrm{u}$ analizi odnosa u Masochovoj „Veneri $u$ krznu“.

\footnotetext{
${ }^{528}$ Anita Phillips, Defence of Masochism, Faber \& Faber, London, 1998 str. 25

529 Ibid. str. 12, prijev. a.

530 Ibid. str. 12, prijev. a.

531 Ibid. str. $12-13$, prijev. a.

532 lbid. str. 13 - 15
} 
Već je i Freud konstatirao da je sadist mazohistov seksualni objekt ${ }^{533}$, dakle, oni su jednaki jer jedan drugog objektiviraju i podređuju svome užitku, no, naravno, u suvremenom shvaćanju sadomazohizma, brinu i o užitku drugog.

Phillips u svojoj teoriji mazohizma, slično kao i mnogi drugi autori koji su ustanovili veliku moć mazohista, pripisuje mazohistu obilježje svjesnog manipulatora, onoga koji svojim fantazijama upravlja i usmjeruje odnos i scenu, i time podređuje sadista svojim željama, manipulirajući realitet. ${ }^{534}$

Tako, iz ontološke i etičke perspektive, ne bi smjelo biti, već bi trebalo, u smislu Kantovog „sollen“ uspostaviti egalitaran odnos koji isključuje svaku mogućnost manipulacije bilo dominantne, bilo submisivne osobe.

Ispravnije razumijevanje ove činjenice, bliže realitetu i praksi BDSM - a, uvjetovano ljudskom psihom, jest da mazohist jednostavno određuje, pa čak i „diktira“ dinamiku odnosa jer je taj koji se podređuje i pristaje, bilo dogovorno, bilo pismenim ugovorom i stoga je autoričino stajalište potpuno opravdano.

Phillips iz vlastitog i akademskog iskustva prikazuje mazohizam, i kroz brojne vividne opise scena i na samome kraju ponavlja najveću istinu mazohizma - „Konačna je, neočekivana poruka mazohizma zaboraviti sebe - teška disciplina. " ${ }^{335}$

Njen je rad veoma interesantna i promišljena psihologija mazohizma iz subjektivne, no i objektivne perspektive inspirativne autorice, koja jasno i elaborirano prikazuje ,paradoks mazohista“, izražavajući istovremenu vlastitu obranu i ironičnu „kritiku“ mazohista te je čije su teze utemeljene uvelike na osobnom iskustvu te doživljaju suvremene kulture.

Fokus $i$ teze navedene $u$ radovima $s$ feminističkim afirmativnim stavom prema sadomazohističkoj seksualnosti prikazuju sadomazohizam kao feministički, a taj mu atribut možemo dati zbog snage i samokontrole koju žena mora posjedovati da bi bila sposobna predati kontrolu nad sobom drugome, biti submisivna ili robinja.

Promišljanje žene u sadomazohističkoj seksualnosti mora biti i osobno, partikularno i univerzalno, jer feministkinju i istodobno S/M praktikanticu koja osobno i teoretski razumije komplementarnost feminizma i sadomazohizma odlikuje izvrsnost i jedinstvo ličnosti superiorne nadfeministkinje.

\footnotetext{
533 Sigmund Freud, Tri rasprave o seksualnoj teoriji, Matica Srpska, Beograd, 1981.

534 Ibid. str. 19 - 22

535 Ibid. str. 164
} 


\section{ZAKLJUČAK}

\section{Suvremeno filozofsko razumijevanje i vrednovanje sadomazohističke seksualnosti}

Socio - filozofsko tumačenje i vrednovanje sadomazohizma i njegova analiza kao seksualno sociološkog te (sub)kulturnog fenomena prikazala sam i protumačila od samih njegovih početaka u psihoanalizi, kontinentalnoj filozofije društva i seksualnosti te modernoj i suvremenoj psihologiji, postpsihoanalizi, S/M teoriji te feminističkim pristupima.

Suvremenu filozofsku interpretaciju sadomazohizma u odnosima psihe i seksualnosti, individuuma i društva bitno je sagledati kao cjelinu psihičkog, seksualnog i društvenog, putem konflikata afirmativnih teorija i kritički negativnih, pri čemu sam se usredotočila na najprikladniju afirmativnu opciju.

Svoje bih razumijevanje sadomazohističke seksualnosti, referencama na literaturu te detaljnim promišljanjem relevantnih teorija, okarakterizirala kao vlastitu „dekonstrukciju sadomazohizma“ utemeljenu na kontradikcijama u razumijevanju sadomazohističke seksualnosti u njenoj praksi, interakciji participanata, njihovom odnosu prema sebi i drugima te konačno u društvu kao „korektivnoj“ instanci provođenja moći i „moralističkih“ valoriziranja privatne sfere, pluralizma seksualnosti i alternativnog načina života.

Shvaćanje dekonstrukcije bih u tom smislu prikazala kao svojevrsnu subkulturno - seksualnu opoziciju regulativnim društvenim mehanizmima koji „oblikuju“, „stvaraju“ i „održavaju“ preskriptivnu, tradicionalnu seksualnost barem deklarativno, no još uvijek i represivnim društvenim praksama koje vremenom gube svoj značaj.

Sadomazohistička je seksualnost odavno također postala predmetom i instrumentom te društveno - političke prakse, nametanjem pogrešnih depikcija, masovnom pornografijom kao ekonomskim faktorom te vulgariziranom literaturom, bestselerima koji pružaju idealizirane no pogrešne ideje o sadomazohizmu.

Esencijalno je postaviti sadomazohističku seksualnost kao sasvim normalnu i zdravu koju ne možemo medicinski etiketirati, a ponajmanje etički ili moralistički valorizirati, budući da je konsenzualna, kao što je prikazano kod svih pro S/M autora zastupljenih u radu, od Foucaulta do suvremenih psihoterapeuta i S/M praktikanata. 
Lacanovoj "provokativnoj" izjavi "Il n'y a pas de rapport sexuel" cilj je potaknuti nas da shvatimo ne samo lingvistički poredak i odnose među označiteljima, već da promislimo međuljudske odnose, posebice onaj "najkompleksniji" - seksualni uz rodne odnose kao odnose moći u dijalektici submisivne i dominantne osobe.

Seksualni odnos Lacan tumači kao "nepostojeći" iz razloga što ga ne možemo misliti kao spolni odnos per se, obzirom da je seksualnost izuzetno kompleksan koncept kojeg je potrebno razumijeti putem odnosa nadređene i podređene osobe te odnosa osobe prema sebi, želji i jouissanceu te ga vlastitom analitičkom teorijom pokušava približiti i prikazati deskriptivno kao socijalno - lingvistički odnos utemeljen unutar područja Imaginarnog i Simboličkog.

Kad bi Realno bio "moguće", tada bi on bio „postojeći“, paradoks je i filozofska igra pojmovima koji sam zaključila iz Lacanove teorije komparacijom postpsihoanalitičkog i poststrukturalističkog prikaza sadomazohističkog odnosa.

On nam putem svojih odnosa stadija i odnosa ljubavi i seksualnog odnosa kao odnosa moći između označitelja koji predstavljaju osobe u različitim, suprotnim pozicijama objašnjava tjelesno - sublimnu prirodu sadomazohističkog odnosa, koji je obilježen relacijom submisivnog drugog i dominantnog Drugog.

S ciljem opisivanja sadomazohističkog odnosa iz vlastitog razumijevanja Lacana predstavila bih parafrazu „Il n'y a pas d'amour sans rapport sadomasochistique“ čime želim naglasiti da je, u interpretaciji Lacanove filozofije, svaki odnos „,sadomazohistički“ jer je odnos dominantne i submisivne osobe, Drugog i drugog.

Odnos prema sebi također je mazohistički jer se ja kao drugi identificira s Drugim kao zrcalnom slikom i refleksijom vlastitog fetišiziranog ideala, a interpersonalni odnos je uvijek odnos podređene i nadređene osobe, čak i kad su osobe jednake, budući da se i jednakost manifestira dinamikom izmjene moći, ne samo između sadista i mazohista već u svakom, a posebno seksualnom odnosu i u tom kontekstu možemo uvesti i parafrazu ,Il n'y a pas de rapport sadomasochistique“.

Lacan govori o ljubavi kao o apstrakciji koja egzistira u našem konceptualnom sustavu, o odnosu dvaju označitelja i na Imaginarnoj i Simboličkoj razini, ljubavni odnos je odnos moći, kao i sadomazohistički jer rapport, seksualni odnos, za njega ima simboličko značenje te su i ljubav i seks apstrakcije Imaginarnog, koje „postaju Realno“ samo prilikom posebne relacije označitelja, sadomazohističkog odnosa dviju osoba. 
Svaki interpersonalni odnos u ,realnom“, racionalnom životu je, preskriptivno, uzajamno poštovanje i povjerenje kao temelj, što se onda naziva ljubavlju, dok seksualni odnos sadrži ideje erotske privlačnosti, želje i užitka, iracionalnog jer simbolički, i ljubav i seks imaju ekstatične, romantične, irealne konotacije, koje su nam daleko estetski i psihički atraktivnije, pa se s onim Realnim ne želimo ili ne možemo suočiti - ne možemo ga živjeti.

Osvrnemo li se na istinski BDSM, uviđamo da se on upravo i temelji na bezuvjetnom i gotovo bezgraničnom međusobnom poštovanju i povjerenju, no s druge strane, zauzvrat, participanti dobivaju upravo sve one tjelesne i psihičke ekstatične emocije i senzacije, dakle, on je, naizgled nemoguća i neostvariva, poveznica Imaginarnog, Simboličkog i Realnog.

BDSM odnos pripada, prema svim svojim praksama, pravilima, načinu ophođenja i odnosu partnera, Simboličkom, nakon što je prevladao Imaginarno, dok je Realno isključio iz svoje sfere i Lacan ostavlja beskonačno mogućnosti za interpretacije raznih varijacija i mogućnosti sadomazohističkog odnosa, putem tumačenja želje te odnosa drugog kao sebstvu prema sebi i Drugome, te Drugoga prema sebi kao drugome.

Razmislimo li uvijek o tome da se svaka osoba ophodi i odnosi prvenstveno, ab initio sa i prema sebi, da bi bila sposobna uspostaviti i kreirati i odnos prema D/drugome, razumjet ćemo da je $\mathrm{i}$ BDSM odnos u početku konfliktna sinergija Imaginarnog i Realnog, da bi mogao doseći Simboličko, kao područje seksualnog zadovoljstva i užitka.

Zamislimo li odnos dominantne i submisivne osobe, kao odnos Drugog i drugog, uviđamo da je ustanovljen čvrsti imaginarni poredak između istih, te uloge moći se konstantno izmjenjuju, drugi transcendira u Drugog i vice versa no uvijek postoje te dvije pozicije, koje opet ne smijemo zamijeniti s pozicijama ili ulogama sadista i mazohista.

Foucault nas uvodi u potpuno realni socijalno - politički poredak seksa i moći, diskurs seksualnosti u kojem upravo sadomazohizam zauzima centralno mjesto i njegova teorija seksualnosti postavlja u centar odnos moći i žudnje, te nastoji prikazati na koji su način socijalno - politički definirani

Sagledamo li centralne teze i argumente njegove teorije, možemo jasno uvidjeti da znanje i moć, kao fundamentalne sile svih društvenih relacija i njihovih promjena, integriraju sadomazohističku seksualnost kao perpetualnu izmjenu moći i kontrole te multipliciranje drugačijih i raznolikih seksualnih odnosa. 
Temeljne poveznice Foucaulta s Lacanom nalazimo u njegovoj izuzetno detaljnoj analizi odnosa pojedinca, društva i seksualnosti, jer, premda je on bio svojevrsni oponent psihoanalize, svojom racionalnom perspektivom i historijskom teorijom društva, njegova je teorija seksualnosti ipak u mnogočemu bliska Lacanovoj.

Najbolje to možemo ilustrirati njegovom elaboracijom seksualnosti i mehanizama ili dispozitiva seksualnosti u odnosu na društvene odnose moći i zabrana, pri čemu je bitno razjasniti da pojam dispozitiv moramo odijeliti od pojma mehanizma, jer on sugerira svojevrsno raspolaganje seksualnošću, dok mehanizam označava način, tehniku i strukturu prema kojoj seksualnost funkcionira u društvenim i privatnim okvirima, kao istovremeno područje odnosa moći i kao sfera podložna moći.

Znanje, jezik, moć i želja temeljni su koncepti i za Lacana i Foucaulta, jedino su drugačije tumačeni i nadalje razrađeni u različitim terminima, no veoma sličnom logikom u gotovo jednakom smjeru promišljanja dinamike koju možemo direktno primijeniti na sadomazohističke odnose i logiku želje i moći u sadomazohističkom odnosu.

Argumentirano zastupam mišljenje te radikalno inzistiram na poziciji da je neophodno, $u$ današnjem vremenu i kulturi, ukloniti sve predrasude i stigme sa sadomazohističke seksualnosti, posebice u području psihijatrije i psihologije te u općem društvenom području, no ispravnim i prikladnim načinom, edukacijom i tolerancijom, umjesto komercijalizacije seksualnosti, koja je privid egalitarnosti i slika lažne slobode, u svrhu kontrole i konzumerizma. Vrednovanje seksualnosti i seksualnih opredijeljenja nije korektno niti etički ispravno, no nepristranosti i potpunu slobodu te mjere nisu još u potpunosti dosegle niti razvijene liberalne europske države, no bitna je razlika između sjeverne Europe i Skandinavije u odnosu na južne i istočne države ipak vidljiva već desetljećima i stoga je od neizmjerne važnosti stremiti prihvaćenosti BDSM seksualnosti jednako kao i svih ostalih koje se razlikuju od konzervativnog modela.

Znanstvenost teorija o sadomazohizmu - psiholoških, socioloških i filozofskih može se naizgled činiti upitnom, no one svoje znanstvene utemeljenje nalaze upravo u društvenim znanostima zbog širine koju obuhvaća - od antropologije do književnosti.

Razvojem pristupa i teorija brojnih psihoterapeuta, filozofa, sociologa i ostalih teoretičara koji su objavili iznimne studije navedene u ovome radu, sadomazohizam je postao predmet znanosti i samim time postoji znanost o sadomazohizmu. 
Kriterij znanstvenosti utemeljen je na istraživanjima, detaljnim bihevioralnim proučavanjima, studijama realnih slučajeva, intervjua i biografskih iskaza pojedinaca i zajednica prema modelu psihologije te najzad analizom kompetentnih psihoterapeuta i teoretičara koji su, od 70 -ih godina 20. stoljeća do danas, stvorili i konstantno stvaraju, novu znanost o sadomazohizmu, posve drugačiju od one primarne u počecima psihoanalize, koja je bila ustanovljena na konzervativnim i prilično netočnim medikalizacijama i psihopatologizacijama.

Današnja znanost opravdana je i moguća iskazima i podacima o osobnim doživjaljima $\mathrm{S} / \mathrm{M}$ praktikanata, no i filozofskim teorijama od kojih sam kao temeljne izdvojila Bataillevu teoriju nasilne seksualnosti, tjelesnosti i nagona, Lacanovu konceptualizaciju međuodnosa dominantne i submisivne osobe posredstvom želje te Foucaltovu teoriju odnosa moći i seksualnosti, koja, pored S/M seksualnosti, obuhvaća i sve društveno - političke disciplinarne odnose.

Sadomazohistička je seksualnost već pola stoljeća, neiscrpna inspiracija stvaranju novih znanstvenih interpretacija i inovativnih teza teoretičarima društva i filozofije te specijaliziranim psihoterapeutima i kao takva ontologijski i socio - filozofski znanstvena po sebi, znanost sama. Najrelevantniji su mehanizmi ili dispozitivi seksualnosti, koji umjesto „represije“ potiču diskurs kontrole nad seksualnošću nastoje manifestirati u društvenoj realnosti kao domeni istine i znanja o seksualnostima kao pluralitetu odnosa i diskursa koje društveni aparat mora upoznati, proučiti da bi njima ovladalo i nadziralo ih.

Svoju ključnu tezu o nepostojanju represije nad seksom Foucault potkrepljuje i konstatacijom da su je i psihoanalitičari osporili jer im se ,,misao o nekoj buntovnoj energiji koju bi trebalo zauzdati izgledala je neprimjereno za dgonetanje načina na koji se odgonetaju moć $i$ žudnja: pretpostavljaju da su povezane na složeniji i prvobitniji način od te igre između divlje, prirodne $i$ žive energije. " 536

Najvažnije njegove teze primjenjive na sadomazohističku seksualnost zasigurno su instanca pravila, diktiranje dozvoljene i zabranjene seksualnosti pravila kao preskriptivna seksualnost koja postavlja specifičnu moć i simbolički, pa nekad i realni binarni zakon zabranjene i dozvoljene sekualnosti i deklarativno zabranjuje svaku devijaciju, potom ciklus zabrane u smislu zabranjivanja svake senzualnosti i užitka te logika cenzure kao negacija određene seksualne prakse zabranom govora kao represivna praksa performativne moći. ${ }^{537}$

\footnotetext{
536 Ibid, str. 73

537 Michel Foucault, Povijest seksualnosti 1, Volja za znanjem, Domino, Zagreb, 2013, str. 73 - 77
} 
Seks ima svoju logiku žudnje i moći, Foucault nam konstantno raznolikim formulacijama ukazuje i opisuje raznolikost i multiplicitet odnosa moći, posebice relevantnih i neophodnih za tumačenje sadomazohizam i seksualnost općenito:

„Žudnju nije trebalo zamišljati potisnutom iz jednostavnog razloga što zakon ustanovljuje $i$ žudnju i nedostatak na kojem se ona temelji.

Odnos moći već bi bio ondje gdje je i žudnja : iluzija je dakle, prokazivati je u represiji koja se odvija naknadno, ali je isto tako i uzaludno poduzimanje potrage za žudnjom izvan moći. "538

Foucault nalazi i alternativu, residuum društvenoj strukturi moći i discipline provođene nad tijelima i osobama, njegova je ideja oslobođenja, slobode i etike od iznimne važnosti za sadomazohističku seksualnost jer je zasnovana na slobodi izbora i slobodi seksualnosti.

Sadomazohistička seksualnost najbolje nalazi svoj put i rezoluciju problematike svog statusa, misli i prakse i u njegovim tezama inspiriranim historijskim i filozofijskim teorijama korelacije seksualnosti i moći, no i vlastitim iskustvom, kao psihofizički određena, promatrana kroz prizmu ljudske prirode i razvoja društveno - seksualnih odnosa, doživljena kao konsenzualna praksa mnogima drugačijih i ekstremnih odnosa i užitaka, harmonija i korelacija, umjesto konflikta sadizma i mazohizma.

Nastojala sam izložiti i protumačiti filozofsko - psihologijske teza najprominentnijih autora socijalne filozofije i teorije seksualnosti te prikazala i subjektivno, i objektivno u vlastitom subjektivitetu, bitne zaključke o tumačenju, razumijevanju i valoriziranju sadomazohističke seksualnosti te zastupam mišljenje da je mazohizam primarni psihički i seksualni nagon.

Mazohizam kao primarna seksualnost najbolje je razumljiva iz psihologijsko - filozofske elaboracije svih dosad spomenutih postfreudovskih autora te suvremenih teoretičara sadomazohizma iz različitih perspektiva.

Ona može biti, kod nekih osoba u adolescenciji, manifestacija privlačenja osobne i seksualne pozornosti, i to na pozitivan, no i negativan način, a ta negativna i nezdrava faza mazohizma može rezultirati neseksualnim, patološkim sadizmom kao produktom nezadovoljenog mazohizma ili seksualne želje.

Kao primjere navela bih veoma često samoozlijeđivanje i suicidalnost mladih osoba zbog osjećaja manje vrijednosti, nezadovoljstvom sobom, manjka samopouzdanja zbog subjektivnog osjećaja potrebe za jubavlju i pažnjom kod labilnih, još neizgrađenih ličnosti, no dovoljno jake

538 Ibid, str. 73 
i zdrave osobe razriješit će te konflikte adekvatnom psihoterapijom te najzad autorefleksivnim promišljanjem, spoznavanjem sebe i svoje istinske seksualnosti.

U hipotetskim, zamišljenim i društveno poželjnim ,idealnim“ uvjetima, mazohistična će osoba svoj ,privremeni sadizam“, uslijed nesigurnosti u svoj identitet tijekom odrastanja izražavati na primjerenije i psihički zdrave načine, a inhibicije će, kad dosegne stupanj zrelosti i sigurnosti u sebe, osloboditi prijelazom u slijedeću fazu, u konsenzualni seksualni mazohizam ili će željeti eksperimentirati i sa svojom submisivnom i dominantnom stranom, te će formirati svoj osobni, društveni i seksualni identitet.

Taj identitet koji će nadalje konstantno razvijati, sadrži znanje o sebi te svijest o etičkim načelima prema sebi i drugima te razlikama sadizma i mazohizma, dominacije i submisivnosti u društvenom, javnoj i, u privatnoj sferi seksualne te stoga jedino samosvjesne, zdrave i društveno prilagođene osobe mogu biti $\mathrm{S} / \mathrm{M}$ praktikanti u pravome smislu, živjeti svoju urođenu, prirodnu seksualnost.

Mazohizam, shvaćen kao primarna seksualnost kod sadomazohistički orijentiranih osoba, nije konačno opredijeljenje ili praksa, budući da većina mazohističnih osoba, žele promijeniti svoju poziciju, kao i što submisivne osobe često, nakon izvjesnog vremena, postaju dominantne, no, jednako kao ne smijemo izjednačavati mazohizam i submisivnost, sadizam i dominaciju, tako ne možemo niti generalizirati promjene seksualne orijentacije ili pozicije, jer one su podložne psihoseksualnoj predispoziciji pojedinačne osobe, no često im je povod i samo dani trenutak želje za novim iskustvom i ekspanzijom vlastite seksualnosti.

Mazohizam je mnogo psihološki kompleksniji, pluriperspektivistički fenomen te ga je mnogo zahtjevnije, ako i moguće objasniti statističkim metodama, premda su mnogi suvremeni autori uspjeli izraditi odlične komparativne studije sadomazohizma upravo na način da su intervjuima ispitanika prikazali realitet prakse sadizma i mazohizma, no mogući zaključci uvijek ostaju otvoreni promišljanju čitatelja no i samoga autora kao istraživača.

Većina autora istraživalli su ponajviše oblike ekstremnog sadomazohizma, 24/7 Master/Slave $i$ $D / s$ odnosima, ostavljajući otvorena pitanja radi li se u takvim slučajevima o vezama dvaju mazohista, dvaju sadista ili zaista možda o naizgled "nemogućoj" vezi sadista i mazohista, budući da se radi o iznimnoj vrsti odnosa te su zaista sve vrste odnosa moguće.

Mazohističku ličnost i mazohistički odnos dominantne i submisivne osobe svaki bi participant $\mathrm{S} / \mathrm{m}$ seksualnosti mogao opisati subjektivnim poimanjem i stoga $u$ realitetu ne postoje prototipni sado - mazohistički odnosi niti jednake paradigmatske podjele uloga koje možemo 
okarakterizirati, samo one koje ostavljaju mogućnosti za potencijalni odnos sadista i mazohista koji su za mnoge teoretičare strogo psihološki i ontološki odvojeni.

Njihov odnos ne postoji u Lacanovu smislu, no zadržat ću se na Deleuzeu i mom vlastitom pokušaju suvremene interpretacije D/s odnosa, mazohističkog svijeta, sadističkog te izuzetno važnoj ideji kolizije i interrelacije sadističkog i mazohističkog svijeta, u psihologičkom smislu.

Osnovna ideja je što detaljnije i stručnije proučiti i upoznati neograničene varijacije BDSM odnosa, da bi se mogla obuhvatiti njihova problematika, pristup sadističkom i mazohističkom svijetu kao našoj “imaginarnoj realnosti”.

Obzirom da sam postavila mazohizam kao primarnu i daleko kompleksniju seksualnu orijentaciju, predispoziciju, neophodno je postaviti ontologijsko pitanje o njegovoj mogućnosti realne, imaginarne i simboličke egzistencije.

Mazohizam posjeduje svoj imaginarni bitak, no istovremeno i hiperrealni entitet, budući da se zasniva na fantaziji, a ozbiljuje hiperrealnim, ekstremnim tjelesnim i psihičkim praksama izmjene moći i intenzivne boli kao ultimativnom užitku.

Pozicija mazohizma nikada ne može biti unutar Realnom, jer Realno ga nastoji negirati i anihilirati, dok ga, nakon prvotnog razvoja, simboličko usmjerava i ostvaruje unutar poretka moći, no bitno pitanje je koje je njegovo istinsko, iskonsko porijeklo, njegovo uporište, možemo li sa sigurnošću tvrditi, kao za sadizam, da je on također prirodno urođen, navlastit pojedinim osobama ili razvijen putem sadizma kao „odvojen svijet“, sfera za sebe, psihološko bihevioralni fenomen koji svoje uzroke nalazi u nesvjesnom, inverzijom nasilnih poriva $\mathrm{i}$ urođene ili razvijene agresivne seksualne predispozicije.

Iz prizme filozofije tijela i socijalne filozofije, mazohizam je fenomen tijela i psihe kao jedinstva i samim je time užitak u senzacijama boli istovremeno tjelesan i psihički, psihofizičko - spiritualni doživljaj, što je jasno iz ranije izloženih teorija.

Osobe mazohističke predispozicije imaju konstantnu želju za istraživanjem sebe, granica svoga tijela i uma, no i nepoznatog drugog, što ih svojevremeno dovodi u neposredan odnos sa sadizmom, jer (in)dividuum je psihoseksualno podijeljen, jednako kao kod homo ili heteroseksualnosti.

Konceptualizacije mazohizma $u$ teorijama socijalne filozofije i filozofije tijela jasno nam ukazuju da su tjelesne senzacije i interpersonalni odnosi te zajednice BDSM praktikanata zasnovani na užitku svih pojedinaca koji u njima participiraju, a te strukture uključuju i 
mazohiste i sadiste, submisivne i dominantne osobe, pri čemu mazohistički svijet biva integriran u sadistički načelom želje i užitka, misaono i iskustveno, fantazijom, imaginacijom i ekstremnim tjelesnim i psihičkim praksama.

Mazohizam, kao fenomen imaginarnog i simboličkog, transcendentalno stanje uma i svijesti te ekstremna seksualna praksa možda je je najrelevantnija manifestacija psihoseksualne hiperrealnosti, a njegova realna pozicija pitanje je za promišljanje novih teorija i pristupa.

Možemo li to nazvati promjenom ili čak transcedencijom seksualnog identiteta budući da je seksualnost vođena samospoznajama i promjenama, osnovna su pitanja osobnosti i identiteta kao osnovnih psihoholoških karakteristika.

Ekstenzija seksualne orijentacije i preferenca je obilježje nove odrednice identiteta, njegovog procesa transformacije, no većina osoba BDSM orijentacije zadržavaju obje pozicije, i mazohističku i sadističku ili submisivnu i dominantnu, od kojih je uvijek jedna osnovna, dominantna i prevladava u njihovim željama i odnosima, i to je bitna teza ontologije kao filozofije tijela i seksualnosti.

Sadomazohizam kao psihofizički zdrava seksualnost može se prikazati empirijskim primjerima koji zastupaju ovu tezu i govore u prilog simultanog razvoja ličnosti i tjelesnog užitka, a tome su dokaz brojne osobe koje prakticiraju S/M, a profesionalno su renomirani psihoterapeuti ili znanstvenici raznih podučja, kao Baldwin, Rinella, Mains, Califia i mnogi drugi spomenuti.

Navedeni su samo nama poznati primjeri jer su ujedno i teoretičari sadomazohizma, no brojne su osobe izvan znanstvenog proučavanja S/M-a, izvrsne u svome radu, te u svojim raznolikim profesijama imaju iznimne karijere, $\mathrm{u}$ čemu im njihov diverzitet doprinosi ostvarenju njihovih originalnih umijeća i kreativnosti.

Možemo zaključiti da njihova seksualnost ima velik utjecaj ne samo na njihovu stabilizaciju ličnosti, već i na motivaciju potencijala, maksimalni razvitak profesionalnih talenata, znanja i stručnosti, otvorenosti svijetu i društvenim fenomenima i diverzitetima i time ima izuzetno pozitivan psihički učinak obzirom da osobe slobodne od inhibicija samosvjesno žive svoju seksualnost, te su osobno i socijalno motivirane u svojoj struci ili profesiji i društvenim odnosima te svojom egzistencijom i djelatnošću doprinose svojoj zajednici i širem društvu.

Seksualne diverzitete moramo stoga promatrati i razumjeti kao pozitivne i produktivne, foucaultovski rečeno, jer proizvode i kreiraju izuzetne individuume - znanstvenike, umjetnike, ali prvenstveno i najvažnij, psihički stabilne i zadovoljne osobe s osjećajem vlastite vrijednosti, 
odgovornosti prema sebi i drugima, koje mogu živjeti eksponirano u ekshibiciji seksualnosti ili odvojiti seksualnost od svoje karijere ili javno - socijalnog identiteta.

Sadomazohistička seksualnost mora biti promatrana kao specifični, sofisticirani oblik bitka, psihe i tjelesnosti zbog svoje unikatne erotsko - estetske dimenzije, ona je bit i identitet osobe, odnos osobe prema sebi i drugima, svome tijelu i tijelima drugih, obuhvaća psihičko, imaginarno, vizualno, taktilno, ekstatičko, a riječima Pata Califie:

„, S/M je strašan. Mi odabiremo najzastrašujuće, najodvratnije i najneprihvatljivije aktivnosti $i$ pretvaramo ih u u zadovoljstvo. S/M je namjerna, predumišljena, erotska blasfemija. To je forma seksualnog ekstremizma i seksualne disidencije. "539

Sveobuhvatnost ove nadseksualnosti izražena je međuuvjetovanosti Drugog i drugog kod Lacana, erotiziranom prirodnom nasilnom seksualnošću Bataillea te Foucaultovim odnosima moći u seksualnosti, samo su elementarne teorije kojima je istinski opisana, bez pretenzija, već u svom prirodnom iskonu i kulturno - seksualnoj suštini.

Identitet je varijabilan tijekom cijeloga života, no uvijek je dio istoga bitka, ali društveno psihološki i kulturološki, konstantno se mijenja, nadopunjuje i učvrščuje svoju poziciju ontološkim, epistemološkim i empirijskim napretkom.

Sadističko, a posebice mazohističko iskustvo i odnos kategorije su za sebe, kategorije su koje to nisu budući da su iznad i onkraj seksualnosti, a njihova im psihička konceptualizacija, sfera unije Imaginarnog i Simboličkog omogućuje da izbjegnu svaki sustav strukturalizacije, da budu realne u svojoj prividnoj apstrakciji.

Senzacije sadomazohističke tjelesne i psihičke prakse doživljaj su specifičnog momenta tjelesnih iskustava kao ontologijskog momenta koji je suviše realan da bi bio svjesno percipiran kao realan, one su hiperrealne u svojoj razini boli, transgresiji granica i svjesnom riziku kao uvjetu uzbuđenja, zadovoljenja te ultimativnog tjelesnost užitka i psihičke ispunjenosti.

Sadomazohizam je u svojoj esenciji hiperrealno ili „novo Imaginarno“, transcendentalno i sublimno, spiritualno i ritualno, a opet toliko ljudsko, „brutalno“ i ,nasilno“ i tom simulacijom nasilja, od flagelacije, asfikcijacije, hard bondagea do simulacije silovanja, nalazimo ono hiperrealno, iskonsko seksualno te tijek BDSM odnosa od tjelesnog prema konsenzualnom

\footnotetext{
539 Pat Califia, Public Sex/The Culture of Radical Sex, Cleis Press, San Francisco, California, 2000, str. 159, prijev.a.
} 
nasilnom, boli kao užitku te konačno transcendentalnom sublimnom čini sadomazhističku seksualnost hiperrealnom u Baudrillardovu smislu.

Tjelesne prakse sadomazohističke seksualnosti ekstremne su do mjere da osobe koje ih prakticiraju, s naglaskom na mazohističnu i submisivnu orijentaciju, doživljavaju ekstrapoziciju ili „napuštanje“ svog tijela, ,,izlazak iz sebstva“ i svijesti kao moment ultimativne ekstaze kojom transcendiraju tjelesnost i psihičko ustrojstvo, što sam opisala kao transcendenciju u sublimno, mislima i tezama u interpretaciji Nancyjevog djela.

Seksualno kao istovremeno nasilno, ritualno i transcendentalno, najbolje je prikazano $\mathrm{u}$ Bataillevoj misli, kao specifična shema antropologijskog razvoja seksualnosti i seksualnog odnosa, a najbolje je oprimjerena upravo u fenomenu sadomazohizma koji je obilježen nasilnim seksualnim porivima i faktorom nepredvidivosti te stoga ne može biti sveden isključivo na etabliranu shematsku paradigmu poput Lacanovog psihologičkog sustava.

Sfera i pozicija sadomazohizma obuhvaća cjelokupnu egzistenciju individuuma, njena se ekspanzija od simulacijskog do hiperrealnog manifestira tjelesno u surovoj i nasilnoj, naturalističkoj seksualnosti te potom u transcendentalnom, ritualnom, spiritualnom iskustvu.

Hiperrealnost sadomazohističke prakse njeni participanti, tijekom odvijanja odnosa samog, često ne mogu pojmiti ni zamisliti kao realnost, već doživljaju i percipiraju svoju fantaziju kao realno, osjećajući se pozicioniranima unutar simulacije prakticirajući razne aktivnosti koje, uslijed mijenjanja svijesti eksponiraju ono hiperrealno.

U takvim fenomenološkim momentima, individuum nije svjestan svoje uloge aktivnog subjekta u situaciji ili događaju, primjerice $\mathrm{S} / \mathrm{M}$ sessionu, što označava senzaciju interpolacije Imaginarnog i Realnog te simulacijskog kao svoje uloge i hiperrealnog kao nepojmljive fantazije koja se $u$ tom trenutku odvija i virtualnog koje percipira.

Sadomazohistička seksualnost je mjesto korelacije i inkluzije osobnog odnosa u interpersonalni te, finalno, u društvenu realnost i stoga je specifičan fenomen unije osobnog, interpersonalnog, socijalnog i univerzalnog, istovremeno je osobna i univerzalna, tjelesna i sublimna, prijelazima od osobnog unutar psihe individuuma do interpersonalnog, interpersonalnog do društvenog, te se naposljetku u društvenoj sferi realizira kao univerzalni socio - psihologijski fenomen.

Tjelesne prakse koje su isprva osobne i privatne svojom transcendencijom u sublimno postaju univerzalne, u ontologijskom smislu bitka osoba koje sudjeluju u sadomazohističkom odnosu i $\mathrm{u}$ sociologijskom smislu integracije određenih seksualnih orijentacija kao subkultura $\mathrm{u}$ zajednicama, umjetnosti i medijima. 
Realnost sadomazohističkog odnosa uvijek je u domeni i Imaginarnog i ultimativno, hiperrealnog koji u kontekstu psihičke strukture pojedinaca i društvene sfere odnosa postaju komplementarni kao dvije opozicije psihe i fantazije te hiperrealnosti koja je percipirana kao „nadogradnja“ $i$ ostvarenje fantazije jer prelazi sve granice Realnog.

Multidisciplinarni i pluriperspektivistički pristup sadomazohizmu prezentiran brojnim teorijama etablira i razvija hermeneutiku fenomena sadomazohizma kao psihičke realnosti, načina života i seksualnosti, a fenomenologiju sadomazohističke prakse prikazala sam i nastojala protumačiti kao transcendenciju tjelesnog i nasilnog u sublimno i ekstatički spritualno u smislu da osobno, vlastito i interpersonalno tjelesno iskustvo i užitak kreiraju seksualnost kao personalno - sublimnu, uzdižući je do univerzalno - sublimnog fenomena.

Uspostava autorefleksivnog odnosa prema sebi i spoznavanje vlastitog identiteta putem ostvarenja odnosa s drugom osobom osnovni su oblik samospoznaje i oblikovanja vlastite osobnosti i seksualnosti kao cjeloživotnog procesa.

Sadomazohistički odnos transcendira sve granice seksualnosti svojim tjelesnim praksama i psihičkim, spiritualnim iskustvom, hiperrealnim i sublimnim otkrivanjem razvijanjem i življenjem vlastitog, no uvijek novog identiteta.

Zaključak ontologije sadomazohizma trebao bi postaviti pitanja koja će implicirati odgovore o načinu razmišljanja unutar sadizma i mazohizma kao predispozicijama, orijentacijama, strukturama ličnosti, o prirodi njihovog odnosa, mogu li funkcionirati unutar istoga diskursa te na koji su način njihovi diskursi suprotstavljeni ili usklađeni.

Kao finalnu konkluziju postavit ću problematiku prvenstveno psihološkom ustrojstvu njegove pozicije i egzistencije unutar odnosa mazohizma i sadizma te otvoreno pitanja u smislu navedenog paradoksa mazohizma, filozofskog pitanja utemeljenosti njegove egzistencije.

U tom smislu doživljavamo i tumačimo sadomazohističku seksualnost, njenu transcendenciju na drugačiju, posve novu orijentaciju ili praksu, ili nadogradnju na postojeću stjecanjem novih iskustava i formiranjem drugačijeg, novog, no opet istog sebstva u sadomazohističkom kontekstu kao svojevrsnom ontološkom momentu.

Cjelokupan pregled i tumačenje teorija seksualnosti, zaključujem da je sadomazohizam sam po sebi bitan ontologijsko - socijalni fenomen, sa čvrsto utemeljenim statusom u društvenim teorijama, znanostima o seksualnosti i kulturnom kontekstu, čime moramo naglasiti i osvijestiti da je sadomazohizam fenomen koji zaslužuje neopisivo više od deskriptivne konceptualizacije seksualnosti, seksualnog eksperimentiranja ekstremnih praksi ili samoga načina života. 


\section{POPIS LITERATURE :}

Jean Baudrillard, Seduction, New world Perspectives, New York, 1990

Jean Baudrillard, Simulacija i zbilja, Jesenski i Turk, 2001, Zagreb

Jean Baudrillard, Cool Memories, 1980 - 1985, Verso, New York, 1990

Jean Baudrillard, The Transparency of Evil, Essays on Extreme Phenomena, Verso, New York, 1993

Jean Baudrillard, „Simulations and Simulacra“, University of Michigan Press, Michigan, 1995 Jean Baudrillard, Seduction, New World Perspectives, New York, 1990

Jean Baudrillard, Sylvere Lotringer, Forget Foucault, Semiotext(e), Los Angeles, 2007

Jean Michel Palmier, Wilhelm Reich, Ogled o rođenju frojdomarkizma, Beogradski izdavačko - grafički zavod, Beograd, 1977

Guy Baldwin, Ties That Bind, Daedalus Publishing Company, Los Angeles, 2003

Guy Baldwin, Slavecraft, Daedalus Publishing Company, Los Angeles, 2004

Georges Bataille, Eroticism, Marion Boyars Publisher, New York, 2008

Georges Bataille, The Absence of Myth, Verso, London, 2006

Roy Baumeister, Masochism and the Self, Psychology Press, New York, 2014

Simone de Beauvoir, Must We Burn Sade, Grove Press, New York, 1966

Frida Beckman, Between Desire and Pleasure - A Deleuzian Theory of Sexuality Ediburgh University Press, Edinburgh, 2013.

Frida Beckman, Charlie Blake, Visions of Cruelty, Shadows of Cruelty, Angelaki Journal, 2010 Jessica Benjamin, The Bonds of Love - Psychoanalysis, Feminism and the Problem of Domination Pantheon Books, New York, 1988

Pat Califia, Public Sex, The Culture of Radical Sex, Cleis Press, San Francisco, 2000

Lynn Chancer, Sadomasochism in Everyday Life : The Dynamics of Power and Powerlessness Rutgers University Press, New Brunswick, New Jersey, 1994.

Gilles Deleuze, Coldness and Cruelty, Zone Books, New York, 2013.

Gilles Deleuze, Foucault, University of Minnesota Press, Minneapolis, 1998

Gilles Deleuze, Felix Guattari, Anti-Oedipus, Continuum, London, 2004 
Molly Devon, Phillip Miller, Screw the Roses - Send Me the Thorns, the Romance and Sexual Sorcery of Sadomasochism, Mystic Rose Books, Connecticut, 2010

Andrea Dworkin, Woman Hating, Plume, Penguin Books, New York, 1974

Michel Foucault, Znanje i moć, Globus, Zagreb, 1994

Michel Foucault, The History of Sexuality 2, The Care of the Self, Vintage Books, New York, 1990

Michel Foucault, Essential Works Volume 1, New Press, New York, 1997

Michel Foucault, Essential Works Volume 2, New Press, New York, 1998

Michel Foucault, Povijest seksualnosti 1, Volja za znanjem, Domino, Zagreb, 2013

Michel Foucault, Colin Gordon, Power/Knowlegde, Selected Interviews, Pantheon Books, New York, 1980

Michel Foucault, Subjektivnost i istina, Sandorf \& Mizantrop, Zagreb, 2019

Michel Foucault, Colin Gordon, Power/Knowlegde, Selected Interviews, Pantheon Books, New York, 1980, str. 184 - 185

Michel Foucault, The History of Sexuality 2, The Care of the Self, Vintage Books, New York, 1990

Michel Foucault, History of Sexuality 2, The Care of the Self, Random House, New York, 1986.

Sigmund Freud,Tri rasprave o seksualnoj teoriji, Matica Srpska, Beograd,1981

Sigmund Freud Budućnost jedne iluzije i drugi spisi (1986, Naprijed, Zagreb)

Sigmund Freud, The Economic Problem of Masochism, "Essential Papers on Masochism", New York University Press, New York, 1995

Erich Fromm, Čovjek za sebe, Naprijed, Zagreb, 1984,

Lynda Hart, Between the Body and the Flesh - Performing Sadomasochism, Columbia University Press, New York, 1998

Georg Wilhelm Friedrich Hegel, Fenomenologija duha, Naprijed, Zagreb, 199..

Immanuel Kant, Metafizika ćudoređa, Matica Hrvatska, 1997

Richard von Krafft - Ebing, Psychopathia Sexualis, The F.A. Davis Company Publishers, London, 1894

Jacques Lacan, Ecrits, W.W. Norton and Company Ltd, London, 2006

Jacques Lacan, Seminar XX, On Feminine Sexuality, Norton and Company Ltd, London, 1998 Jacques Lacan, Četiri temeljna pojma psihoanalize, Naprijed, Zagreb, 198

Jacques Lacan, Desire and its Interpretation, lacaninireland.com, prijevod Cormack Gallagher Jacques Lacan, Seminar II, Ego in Freud's Theory and the Technique of Psychoanalysis, 1954 -55, lacaninireland.com, prijev Cormack Gallagher 
Jacques Lacan, Desire and its Interpretation, www. lacaninireland.com, prijev. Cormack Gallagher

Jacques Lacan, Seminar XX, On Feminine Sexuality, W. W. Norton \& Company, New York, 1998 ,

Jacques Lacan, Seminar 7, The Ethics of Psychoanalysis, prijev. C. Gallagher, lacaninireland.com,

Jacques Lacan, Seminar XX, Love And The Signifier, W.W. Norton \& Company, New York, 1998

Jacques Lacan, The Logic of Phantasy, lacaninireland.com, prijev. Cormac Gallagher, Jacques Lacan, Kant with Sade, Ecrits, 2006, W.W. Norton \& Company, New York, Ruth Linden, Linda Pagano, ur, Against Sadomasochism, Frog In the Well, East Palo Alto, California, 1982.

Sylvere Lotringer, Overexposed, Perverting Perversions, Semiotext(e), Los Angeles 2007,

Herbert Marcuse, Eros i civilizacija, Naprijed, Zagreb, 1985.

Herbert Marcuse, Čovjek jedne dimenzije, Naprijed, Zagreb, 1983,

Leopold von Sacher - Masoch, Venus in Furs, Zone Books, New York, 2013

Geoff Mains, Urban Aboriginals, Daedalus Press, Los Angeles, 2002

Charles Moser, JJ Madeson, Bound to Be Free, The S/M Experience, Continuum, New York, 1996

Charles Moser, Peggy Kleinplatz, Sadomasochism, Powerful Pleasures, Routledge, New York, 2006

Jean - Luc Nancy, Corpus, Fordham University Press, 2010

Jean - Luc Nancy, Corpus 2, Fordham University Press, 2013.

Friedrich Nietzsche, Uz genealogiju morala, AGM, Zagreb, 2004

Ingrid Olson, Abduction in Public Sphere : Sadomasochism, Surveillance and Governmentality, Conference Presentation, American Association of Geographers, 2016

Jean Michel Palmier, Wilhelm Reich, Ogled o rođenju frojdomarkizma, Beogradski izdavačko - grafički zavod, Beograd, 1977

Anita Phillips, Defence of Masochism, Faber and Faber Ltd, London, 1998

Pauline Reage, P. : The Story of O 1994, Corgi Books, London)

Wilhelm Reich, Analiza karaktera, Naprijed, Zagreb, 1982

Wilhelm Reich, Funkcija orgazma, Mladost, Beograd, 1990

Wilhelm Reich, Spolna revolucija, Naprijed, Zagreb, 1985

Jack Rinella, Partners in Power, Greenery Press, Oakland, California, 2003 
Sacher - Masoch, L. (2013, Zone Books, New York)

Donatien Alphonse Francois de Sade, Justine, Philosophy in the Bedroom and Other Writings, Grove Press, New York, 1994

Donatien Alphonse Francois de Sade, Juliette, Grove Press, New York, 1965

Donatien Alphonse Francois de Sade, The 120 Days of Sodom and Other Writings (1971, Grove Press, New York)

SAMOIS, Coming to Power, Alyson Publications, Boston, 1987 


\section{BIOGRAFIJA AUTORICE}

\section{Iva Šokičić}

Rođena 1984. godine u Zagrebu, Hrvatska.

Diplomirala na Odsjeku za anglistiku i Odsjeku za filozofiju engleski jezik i književnost i filozofiju uz dodatne dvogodišnje module norveškog i finskog jezika na Filozofskom fakultetu Sveučilišta u Zagrebu 2011. godine.

Izlagala na mnogim domaćim i međunarodnim konferencijama, s osnovnim područjima interesa i proučavanja socijalne filozofije, filozofija politike, ontologije, epistemologije, etike te filozofija tijela i seksualnosti .

Radi kao samostalna prevoditeljica i autorica s velikim afinitetom i aktivnim angažmanom za znanstveni rad u navedenim područjima filozofije.

Izvorni znanstveni radovi :

„Filozofsko promišljanje sadomazohizma“, Dijalog, 2018, Akademija nauka i umjetnosti Bosne i Hercegovine, Sarajevo

„,Ontologija sadomazohizma“, Filozofska istraživanja, Zagreb, 2020.

Izlaganja na skupovima i simpozijima:

1) Hrvatsko filozofsko društvo, Godišnji simpozij, 22 - 24. 11.2012

Godišnji simpozij

Hrvatskog filozofskog društva

,Priroda-društvo-politika“

Povodom 300. godišnjice rođenja

Jean-Jacquesa Rousseaua

„Ideja i kritika društva - od republikanizma do kritike civilizacijske represije“, 22.11.2010 
2) Hrvatsko filozofsko društvo

14 - 16.12. 2017.

„Revolucija protiv »novog svjetskog poretka«-

utopijska ideja ili realna opcija?“, 15.12.2012.

3) Hrvatsko filozofsko društvo

Simpozij "Čovjek u prostoru", 15 - 17. 12. 2016.

Pozicija rodnih identiteta i konceptualizacije

seksualnosti u društvu kao prostoru

4) Hrvatsko filozofsko društvo

Godišnji simpozij

„Filozofija i tjelesnost“

Zagreb, 27.-29. studenoga 2014.

„Tijelo kao iskonski instrument promišljanja i djelovanja“

\section{5) INSTITUT ZA FILOZOFIJU}

Znanstveni skup uz 40. obljetnicu časopisa Prilozi za

istraživanje hrvatske filozofske baštine

Znanstveni skup Hrvatska filozofska baština prigodom 40. obljetnice časopisa

Prilozi za istraživanje hrvatske filozofske baštine, Zagreb, Institut za filozofiju,

12-14. lipnja 2014.

„Rukopis Pedagogike Franje Markovića“

6) 16. LOŠINJSKI DANI BIOETIKE 
Mali Lošinj, Hrvatska, 14.-17. svibnja 2017.

Simpozij

„Integrativna bioetika i nova epoha“

15.-16. svibnja 2017.

„Eutanazija - pravo na život i smrt kao slobodan izbor / Euthanasia - the Right to Life and Death as a Free Choice“ 